\title{
MONOGRAPH
}

《(4)

MANAGEMENT, FINANCE,

INTERNATIONAL ECONOMICS: MODERN
PROBLEMS AND
WAYS OF THEIR SOLUTIONS

\section{SCIENCE GROUP}

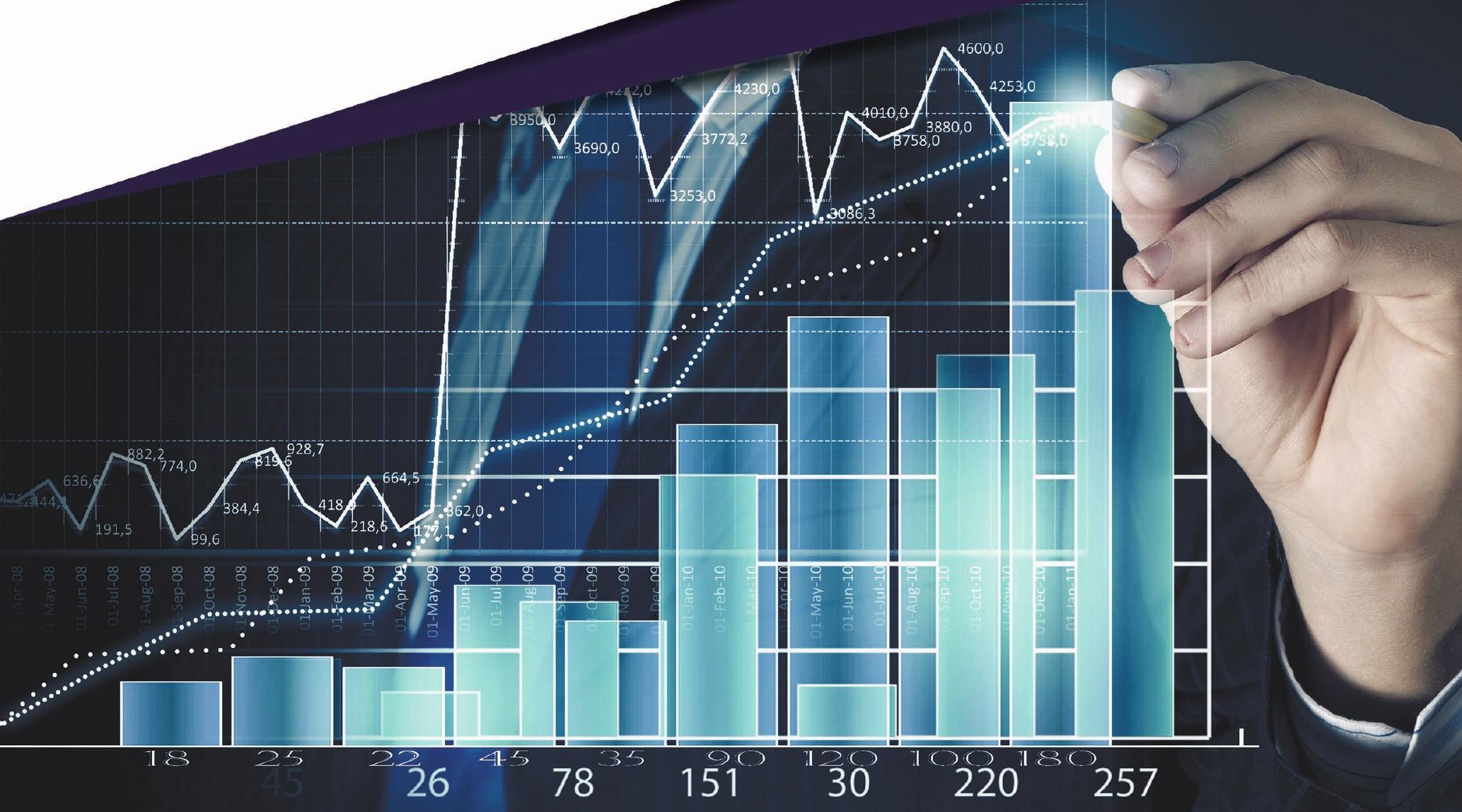

DOI 10.46299/ISG.2021.MONO.ECON.II ISBN 978-1-63848-667-1

BOSTON (USA) - 2021

ISG-KONF.COM 
ISBN - 978-1-63848-667-1

DOI - 10.46299/ISG.2021.MONO.ECON.II

\section{Management, finance,}

economics: modern problems and ways of their solutions

Gollective monograph 
Library of Congress Cataloging-in-Publication Data

ISBN - 978-1-63848-667-1

\section{DOI- 10.46299/ISG.2021.MONO.ECON.II}

Authors - Долбнєва Д., Косташ Т.В., Михалків А.А., Мишкович O., Golubkova I., Levinska T., Сухоставець А.І., Юрченко В., Яровий В., Абрамова М.В., Слюсаренко М.О., Васьківський Ю.П., Васьківська К.В., Денисенко М.П., Бреус С.В., Потетюєва М., Чизмар I., Шпортюк Н., Khoma I., Polova O., Voytsekhovska Y., Matviy I., Zaitseva V., Tsviliy S., Gurova D., Korniienko O., Mamotenko D., Блешмудт Д., Кирчата I.M., Напольських Х. Климчук М., Ільїна Т., Поляк О., Борохович Є., Кухарук А., Трусова Н., Сакун А., Пристемський O., Burdonos L., Oleynik O., Railianova V., Oleynik O., Striuk Y., Shmanatova A., Irchyshyna M., Sytnyk H., Olesenko I., Виноградня B.M., Квасницька P., Доценко I., Вітюк Л., Berezovskyi D., Farat O., Danko T., Yavorska N., Melnyk L., Dehtyarova I., Matsenko O., Kubatko O., Kharchenko M., Коненко В.В., Ніколаєнко I., Новохацька Г. Marekha I.S.,Гусенко О., Михайленко О., Краснікова Н., Prokudin G., Chupaylenko O., Kozlov A., Shuienkin V., Zakusylo P., Kharchenko V., Kozachuk V., Havrych H., Voronina A., Іваницька О.М., Ткачова Н.М., Казанська О.О., Живко З.Б., Родченко С.С., Руда I.I., Боруцька Ю.З., Бойко О.Т., Iukhno А., Волківська А., Семенюк Т., Борис В., Чечетова Н.Ф., Чечетова-Терашвілі Т.М., Лелюк Н.С., Бойко Т., Рой В., Сахненко О., Марчишинець О.

\section{REVIEWER}

Kvasnytska Raisa Doctor of Economics, Professor of Finance, Banking and Insurance, Khmelnytsky National University

Dovgal Olena Dr.Sc. of Economics, Professor (Full), Professor of the Department of International Economic Relations of V.N.Karazin Kharkiv National University.

Breus Svitlana Doctor of Economic Sciences, Associate Professor, Professor of the Department of Management and Public Administration, Kyiv National University of Technologies and Design.

Slavkova Olena Doctor of Economics, Professor, Head of the Department of Public Administration and Administration of Sumy National Agrarian University

Published by Primedia eLaunch https://primediaelaunch.com/ 
Text Copyright (C) 2021 by the International Science Group(isg-konf.com) and authors. Illustrations $\mathbb{C} 2021$ by the International Science Group and authors.

Cover design: International Science Group(isg-konf.com). (C)

Cover art: International Science Group(isg-konf.com). (C)

All rights reserved. Printed in the United States of America. No part of this publication may be reproduced, distributed, or transmitted, in any form or by any means, or stored in a data base or retrieval system, without the prior written permission of the publisher. The content and reliability of the articles are the responsibility of the authors. When using and borrowing materials reference to the publication is required.

The collection of scientific articles published is the scientific and practical publication, which contains scientific articles of students, graduate students, Candidates and Doctors of Sciences, research workers and practitioners from Europe and Ukraine. The articles contain the study, reflecting the processes and changes in the structure of modern science.

The recommended citation for this publication is:

Management, finance, economics: modern problems and ways of their solutions: collective monograph / Zhydovska N., - etc. - International Science Group. Boston : Primedia eLaunch, 2021. 615 p. Available at : DOI10.46299/ISG.2021.MONO.ECON.II 
TABLE OF CONTENTS

\begin{tabular}{|c|c|c|}
\hline 1. & ACCOUNTING REGION AND AUDIT & \\
\hline 1.1 & $\begin{array}{l}\text { Zhydovska N. } \\
\text { THE ECONOMIC ESSENCE OF THE COSTS, THEIR } \\
\text { RECOGNITION AND DISPLAYING THEM IN ACCOUNTING } \\
{ }^{1} \text { Department of Accounting and Taxation } \\
\text { Lviv National Agrarian University }\end{array}$ & 12 \\
\hline 1.2 & $\begin{array}{l}\text { Долбнєва Д. }^{1} \\
\text { СКЛАДАННЯ ТА ПОДАННЯ ФІНАНСОВОЇ ЗВІТНОСТІ } \\
\text { ПІДПРИСМСТВАМИ УКРАЇНИ НА ОСНОВІ ТАКСОНОМІЇ } \\
\text { ФІНАНСОВОЇ ЗВІТНОСТІ ЗА МІЖНАРОДНИМИ } \\
\text { СТАНДАРТАМИ } \\
{ }^{2} \text { Department of accounting, analysis and control, Ivan Franko National University of } \\
\text { Lviv }\end{array}$ & 18 \\
\hline 1.3 & $\begin{array}{l}\text { Косташ Т.В. }{ }^{1}, \text { Михалків А.А. }{ }^{1} \\
\text { ВЛАСНИЙ КАПІТАЛ ПІДПРИСМСТВА: СУТНІСТЬ, } \\
\text { СТРУКТУРИЗАЦІЯ ТА НАПРЯМИ УПРАВЛІННЯ ЯК } \\
\text { ОБ’ЄКТА ОБЛІКУ } \\
{ }^{1} \text { кафедра обліку, аналізу і аудиту, } \\
\text { Чернівецький національний університет імені Юрія Федьковича }\end{array}$ & 27 \\
\hline 2. & DEMOGRAPHY, ECONOMY, SOCIAL POLICY & \\
\hline 2.1 & $\begin{array}{l}\text { Мишкович О. } \\
\text { АНАЛІЗ СОЦІАЛЬНО-ЭКОНОМІЧНИХ ПРОБЛЕМ } \\
\text { ЗАБЕЗПЕЧЕННЯ БЕЗПЕКИ ДОРОЖНЬОГО РУХУ В УКРАЇНІ } \\
{ }^{1} \text { Ternopil Ivan Puluj National Technical University }\end{array}$ & 50 \\
\hline 3. & ECONOMICS OF INDUSTRIES & \\
\hline 3.1 & $\begin{array}{l}\text { Golubkova I. }{ }^{1} \text {, Levinska Т. } \\
\text { ОСОБЛИВОСТІ ФОРМУВАННЯ КОНТЕЙНЕРНИХ ПОТОКІВ } \\
\text { У ГЛОБАЛЬНОМУ РИНКУ МОРСЬКОЇ ТОРГІВЛІ } \\
\text { ' Department of Economic Theory and Business Undertakings on a Marine transport, } \\
\text { National University "Odessa Maritime Academy" }\end{array}$ & 57 \\
\hline
\end{tabular}




\begin{tabular}{|c|c|c|}
\hline 3.2 & $\begin{array}{l}\text { Сухоставець А.І. } \\
\text { ПІДПРИЄМНИЦЬКА ДІЯЛЬНІСТЬ В АГРАРНОМУ СЕКТОРІ } \\
\text { ' Кафедра економіки і підприємництва Сумський національний аграрний } \\
\text { університет }\end{array}$ & 65 \\
\hline 3.3 & $\begin{array}{l}\text { Юрченко В. }{ }^{1}, \text { Яровий В. }{ }^{1} \\
\text { ОРГАНІЗАЦІЙНО-ЕКОНОМІЧНІ МЕХАНІЗМИ УПРАВЛІННЯ } \\
\text { ІНФРАСТРУКТУРНИМ РОЗВИТКОМ ТУРИСТИЧНОЇ ГАЛУЗІ } \\
\text { РЕГІОНУ } \\
{ }^{1} \text { кафедра готельно-ресторанного та туристичного бізнесу, } \\
\text { Херсонський державний університет }\end{array}$ & 74 \\
\hline \multicolumn{3}{|c|}{ ECONOMY AND MANAGEMENT OF STATE GRATITUDE } \\
\hline 4.1 & $\begin{array}{l}\text { Абрамова М.В. }{ }^{1}, \text { Слюсаренко М.О. } \\
\text { ВАЖЛИВІСТЬ ОЦІНЮВАННЯ РИЗИКІВ ВОЕННО- } \\
\text { ЕКОНОМІЧНОГО ХАРАКТЕРУ ПІД ЧАС ДЕРЖАВНОГО } \\
\text { ПЛАНУВАННЯ } \\
{ }^{1} \text { Центральний науково-дослідний інститут Збройних Сил України }\end{array}$ & 82 \\
\hline 4.2 & $\begin{array}{l}\text { Васьківський Ю.П. }{ }^{1}, \text { Васьківська К.В. } \\
\text { ВЕДЕННЯ ІНФОРМАЦЙНОЇ ВІЙНИ ЯК КОНСТРУЮВАННЯ } \\
\text { НОВОЇ РЕАЛЬНОСТІ } \\
{ }^{1} \text { кафедра теорії і практики журналістики, } \\
\text { Львівський національний університет імені Івана Франка м. Львів, Україна } \\
\text { ² кафедра публічного адміністрування та управління бізнесом } \\
\text { Львівський національний університет імені Івана Франка, Україна; } \\
\text { Католицький університет Любельський Івана Павла ІІ, Люблін, Польща }\end{array}$ & 91 \\
\hline 4.3 & $\begin{array}{l}\text { Денисенко М.П. }{ }^{1}, \text { Бреус С.В. } \\
\\
\text { ОСНОВНІ АСПЕКТИ УПРАВЛІННЯ ЕКОНОМІЧНОЮ } \\
\text { БЕЗПЕКОЮ НА РІЗНИХ ІСРАРХІЧНИХ РІВНЯХ } \\
{ }^{1} \text { кафедра економіки та сфери обслуговування, } \\
\text { Київський національний університет технологій та дизайну } \\
{ }^{2} \text { кафедра менеджменту та публічного адміністрування, Київський національний } \\
\text { університет технологій та дизайну }\end{array}$ & 99 \\
\hline 4.4 & $\begin{array}{l}\text { Потетюєва М. } \\
\text { ОСОБЛИВОСТІ ОРГАНІЗАЦЇ МОБІЛІЗАЦІЙНӦ̈ } \\
\text { ПІДГОТОВКИ ЕКОНОМІКИ У КРАЇНАХ-ЧЛЕНАХ НАТО } \\
\text { ' Управління взаємодії з вищим органом та ревізійною комісією } \\
\text { Акціонерне товариство «Українська залізниця» }\end{array}$ & 106 \\
\hline
\end{tabular}




\begin{tabular}{|c|c|c|}
\hline 4.5 & $\begin{array}{l}\text { Чизмар І. } \\
\text { МЕТОДИ АНАЛІЗУ СИСТЕМОГЕНЕЗУ ТА ОНТОГЕНЕЗУ } \\
\text { РОЗВИТКУ КІБЕРСПОРТУ В УКРАЇНІ } \\
\text { '1 кафедра економіки та фінансів, Мукачівський державний університет, Мукачево }\end{array}$ & 115 \\
\hline 4.6 & $\begin{array}{l}\text { Шпортюк Н. }{ }^{1} \\
\text { ДИВЕРСИФІКАЦІЯ ОСНОВНИХ НАПРЯМКІВ ДЕРЖАВНОГО } \\
\text { РЕГУЛЮВАННЯ В АПК } \\
{ }^{1} \text { кафедра менеджменту і права Дніпровського державного аграрно-економічного } \\
\text { університету }\end{array}$ & 130 \\
\hline \multicolumn{3}{|c|}{$\begin{array}{l}\text { 5. ENTERPRISE ECONOMICS AND PRODUCTION } \\
\text { MANAGEMENT }\end{array}$} \\
\hline 5.1 & $\begin{array}{l}\text { Khoma I. }{ }^{1} \\
\text { FINANCIAL MODELLING OF AN IMPACT OF INVESTMENT } \\
\text { MAINTENANCE ON THE CONDITION AND DIAGNOSTICS OF } \\
\text { ECONOMIC PROTECTABILITY OF ENTERPRISES } \\
{ }^{1} \text { Department of Finance, Lviv Polytechnic National University }\end{array}$ & 136 \\
\hline 5.2 & $\begin{array}{l}\text { Polova } \mathrm{O}^{1} \\
\text { DIRECTIONS OF ECOLOGIZATION OF OIL AND FAT } \\
\text { INDUSTRY ENTERPRISES } \\
{ }^{1} \text { Department of Audit and State Control, Vinnytsia National Agrarian University }\end{array}$ & 147 \\
\hline 5.3 & 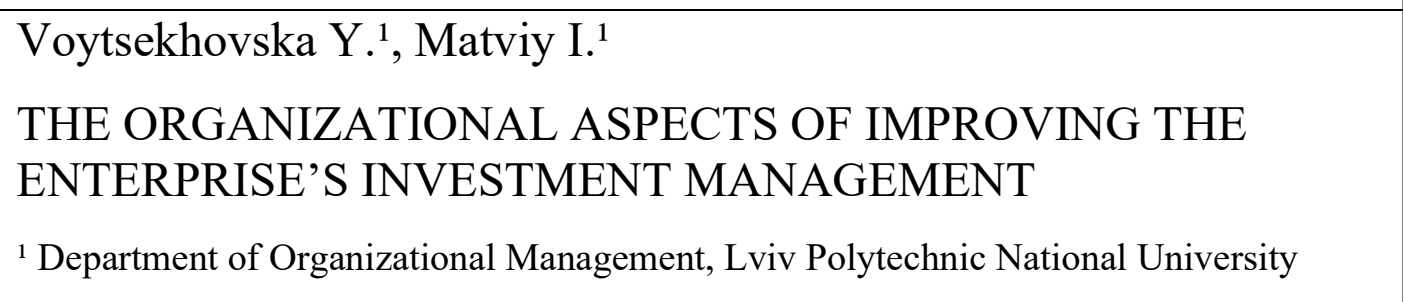 & 160 \\
\hline 5.4 & $\begin{array}{l}\text { Zaitseva V. }{ }^{1} \text {, Tsviliy S. }{ }^{1} \text {, Gurova D. }{ }^{1}, \text { Korniienko O. }{ }^{1} \text {, Mamotenko D. } \\
\\
\text { POSTCORONAVRUS FORMATION OF TOURIST MICRO- } \\
\text { BUSINESS OF THE REGION ON THE BASIS OF ECONOMIC } \\
\text { SECURITY } \\
{ }^{1} \text { Department of Tourism, Hotel and Restaurant Business, National University } \\
\text { «Zaporizhzhia Polytechnic» }\end{array}$ & 169 \\
\hline 5.4 .1 & $\begin{array}{l}\text { THEORETICAL ASPECTS OF } \text { THE } \text { FORMATION OF } \\
\text { POSTCORONAVIRUS BUSINESS SPACE IN THE REGIONAL } \\
\text { SPHERE OF TOURISM ON THE BASIS OF ECONOMIC } \\
\text { SECURITY }\end{array}$ & 169 \\
\hline 5.4 .2 & $\begin{array}{l}\text { POSTCORONAVIRUS RECOVERY OF BUSINESS ACTIVITY OF } \\
\text { MICRO-ENTERPRISES IN THE HOSPITALITY SECTOR OF THE } \\
\text { REGION }\end{array}$ & 177 \\
\hline
\end{tabular}




\begin{tabular}{|c|c|c|}
\hline 5.4 .3 & $\begin{array}{l}\text { POST-CORONAVIRUS MARKETING POLICY OF RETAINING } \\
\text { LOYAL CONSUMERS OF HOTEL AND RESTAURANT } \\
\text { PRODUCT }\end{array}$ & 185 \\
\hline 5.4 .4 & $\begin{array}{l}\text { DIRECTIONS AND ORGANIZATIONAL AND ECONOMIC } \\
\text { MEANS OF STRENGTHENING THE ECONOMIC SECURITY OF } \\
\text { TOURIST MICRO-ENTERPRISES IN THE POST-CORONAVIRUS } \\
\text { PERIOD }\end{array}$ & 192 \\
\hline 5.5 & $\begin{array}{l}\text { Sytnyk H. }{ }^{1} \text {, Olesenko I. }{ }^{2} \\
\text { METHOD OF ASSESING THE FINANCIAL STABILITY OF THE } \\
\text { ENTERPRISE } \\
{ }^{1} \text { Department of economics and business finance, Kyiv National University of Trade and } \\
\text { Economics } \\
{ }^{2} \text { Department of economics and international relations, Vinnytsia Institute of Trade and } \\
\text { Economics of Kyiv National University of Trade and Economics }\end{array}$ & 203 \\
\hline 5.6 & $\begin{array}{l}\text { Блешмудт Д. } \\
\text { ПІДХОДИ ДО ОЦІНКИ ЕФЕКТИВНОСТІ СТРАТЕГІЇ } \\
\text { РОЗВИТКУ ОРГАНІЗАЦЇ } \\
{ }^{1} \text { Кафедра маркетингу та управління бізнесом, Національний університет Києво- } \\
\text { Могилянська академія }\end{array}$ & 210 \\
\hline 5.7 & $\begin{array}{l}\text { Кирчата І.М. }{ }^{1} \text {, Напольських Х.1 } \\
\text { КАДРОВИЙ ПОТЕНЦІАЛ ЯК ОСНОВНИЙ ЕЛЕМЕНТ В } \\
\text { КАДРОВІЙ ПОЛІТИЦІ ПІДПРИСМСТВА } \\
{ }^{1} \text { Харківський національний автомобільно-дорожній університет }\end{array}$ & 223 \\
\hline 5.8 & $\begin{array}{l}\text { КЛИмчук М. }{ }^{1}, \text { Ільїна Т. }{ }^{1}, \text { Поляк О. }{ }^{1}, \text { Борохович С. }{ }^{1}, \text { Кухарук А. } \\
\text { КОГНІТИВНІ ТЕХНОЛОГІЇ В УПРАВЛІННІ } \\
\text { ПІДПРИСМСТВОМ: СТРАТЕГІЯ, РИЗИК-МЕНЕДЖМЕНТ, } \\
\text { ФІНАНСОВІ ІННОВАЦЇ } \\
{ }^{1} \text { Київський національний університет будівництва і архітектури } \\
\text { ² Національний технічний університет України } \\
\text { «Київський політехнічний інститут імені Ігоря Сікорського» }\end{array}$ & 230 \\
\hline 5.9 & $\begin{array}{l}\text { Трусова Н. }{ }^{1}, \text { Сакун А. }{ }^{2}, \text { Пристемський О. } \\
\text { РЕАЛІЗАЦІЯ ПЕРЕТВОРЕНЬ В УМОВАХ АНТИКРИЗОВОГО } \\
\text { УПРАВЛІННЯ АГРАРНИМИ ПІДПРИСМСТВАМИ } \\
{ }^{1} \text { Таврійський державний агротехнологічний університет ім. Дмитра Моторного } \\
\text { ² Херсонський державний аграрно-економічний університет }\end{array}$ & 236 \\
\hline
\end{tabular}




\begin{tabular}{|c|c|c|}
\hline 6. & FINANCE, PENNILESS AND CREDIT & \\
\hline 6.1 & $\begin{array}{l}\text { Burdonos L. }{ }^{1} \\
\text { РОЛЬ ВЕНЧУРНОГО ФІНАНСУВАННЯ ДЛЯ РОЗВИТКУ } \\
\text { НАУКОВО-ТЕХНІЧНОГО ПОТЕНЦІАЛУ КРАЇНИ } \\
{ }^{1} \text { SHЕЕ "Pereyaslav-Khmelnitsky GРU named Gregory Skovoroda" }\end{array}$ & 243 \\
\hline 6.2 & $\begin{array}{l}\text { Oleynik O. }{ }^{1} \text {, Railianova V. } \\
\text { FORMATION AND ANALYSIS OF PROJECT CASH FLOWS } \\
\text { FOR } \\
{ }^{1} \text { Dnepropetrovsk State University of Internal Affairs, Senior lecturer at Ukrainian } \\
\text { studies and foreign languages; }{ }^{2} \text { Dnepropetrovsk State University of Internal Affairs, } \\
\text { PhD, associate professor of social and humanitarian department }\end{array}$ & 250 \\
\hline 6.3 & $\begin{array}{l}\text { Oleynik O. }{ }^{1}, \text { Striuk Y. }{ }^{1}, \text { Shmanatova A. }{ }^{1}, \text { Irchyshyna M. }{ }^{1} \\
\text { THE GROWTH OF SOCIAL CONFIDENCE IN THE ECONOMIC } \\
\text { SPHERE IN CONNECTION WITH THE STATED PANDEMIC } \\
\text { SITUATION ALL OVER THE WORLD } \\
{ }^{1} \text { Dnepropetrovsk State University of Internal Affairs, Senior lecturer at Ukrainian } \\
\text { studies and foreign languages }\end{array}$ & 258 \\
\hline 6.4 & $\begin{array}{l}\text { Виноградня В.М. } \\
\text { ДІЯЛЬНІСТЬ БАНКІВ УКРАЇНИ НА СУЧАСНОМУ ЕТАПІ } \\
\text { ' кафедра фінансів, обліку і оподаткування } \\
\text { ДВНЗ «Переяслав-Хмельницький ДПУ імені Григорія Сковороди» }\end{array}$ & 264 \\
\hline 6.5 & $\begin{array}{l}\text { Квасницька Р.․, Доценко І. }{ }^{1}, \text { Вітюк Л. } \\
\text { СУЧАСНІ АСПЕКТИ ДІЯЛЬНОСТІ БЮРО КРЕДИТНИХ } \\
\text { ІСТОРІЙ В УКРАЇНІ } \\
\text { ' Кафедра фінансів, банківської справи та страхування, Хмельницький } \\
\text { національний університет }\end{array}$ & 279 \\
\hline 7. & INNOVATIVE ECONOMY & \\
\hline 7.1 & $\begin{array}{l}\text { Berezovskyi D. }{ }^{1} \\
\text { RESULT-BASED MANAGEMENT AS THE KEY CONCEPT FOR } \\
\text { THE DEVELOPMENT IN THE CONTEXT OF THE } \\
\text { DIGITALIZATION OF PUBLIC ADMINISTRATION } \\
{ }^{1} \text { Department of Management and Public Administration, «International Scientific and } \\
\text { Technical University» (ISTU) Kyiv. }\end{array}$ & 286 \\
\hline
\end{tabular}




\begin{tabular}{|c|c|c|}
\hline 7.2 & $\begin{array}{l}\text { Farat O. }{ }^{1} \text {, Danko T. }{ }^{1}, \text { Yavorska N. }{ }^{1} \\
\text { РЕАЛІЗАЦІЯ ОРГАНІЗАЦІЙНИХ РІШЕНЬ ІЗ ЗАБЕЗПЕЧЕННЯ } \\
\text { КОНКУРЕНТОСПРОМОЖНОСТІ ІННОВАЦІИНИХ } \\
\text { КЛАСТЕРІВ } \\
{ }^{1} \text { Department of Entrepreneurship and Expertise of Goods,Lviv Polytechnic National } \\
\text { University }\end{array}$ & 293 \\
\hline 7.3 & $\begin{array}{l}\text { Melnyk L. }{ }^{1} \text {, Dehtyarova I. }{ }^{1}, \text { Matsenko O. }{ }^{1}, \text { Kubatko O. }{ }^{1} \text {, } \\
\text { Kharchenko M. }{ }^{1} \\
\text { INNOVATIONS AS THE BASIS FOR SOCIO-ECONOMIC } \\
\text { TRENDS FORMATION IN THE DIGITAL ECONOMY } \\
{ }^{1} \text { Department of Economics, Entrepreneurship and Business Administration, Sumy State } \\
\text { University }\end{array}$ & 300 \\
\hline 7.4 & $\begin{array}{l}\text { Коненко В.В. } \\
\text { СТРАТЕГІЯ ПІДВИЩЕННЯ КОНКУРЕНТОСПРОМОЖНОСТІ } \\
\text { ПІДПРИСМСТВА } \\
{ }^{1} \text { кафедра "Підприємництва та бізнес-адміністрування" } \\
\text { Харківський національний університет міського господарства імені О. М. Бекетова }\end{array}$ & 307 \\
\hline 7.5 & $\begin{array}{l}\text { Ніколаєнко І. }{ }^{1}, \text { Новохацька Г. } \\
\text { КОМЕРЦІЙНА ДІЯЛЬНІСТЬ РОЗДРІБНОГО ІНТЕРНЕТ- } \\
\text { МАГАЗИНУ } \\
{ }^{1} \text { кафедра маркетингу } \\
\text { Навчально-наукового інститу економіки і управління } \\
\text { Національний університет харчових технологій }\end{array}$ & 315 \\
\hline \multicolumn{3}{|c|}{ INTERNATIONAL ECONOMIC RELATIONS } \\
\hline 8.1 & $\begin{array}{l}\text { Marekha I.S. }{ }^{1} \\
\text { INTERNATIONAL CORPORATIONS AS A STRONG FORCE } \\
\text { FOR ECONOMIC GLOBALIZATION } \\
{ }^{1} \text { department of International Economic Relations, Sumy State University }\end{array}$ & 326 \\
\hline 8.2 & 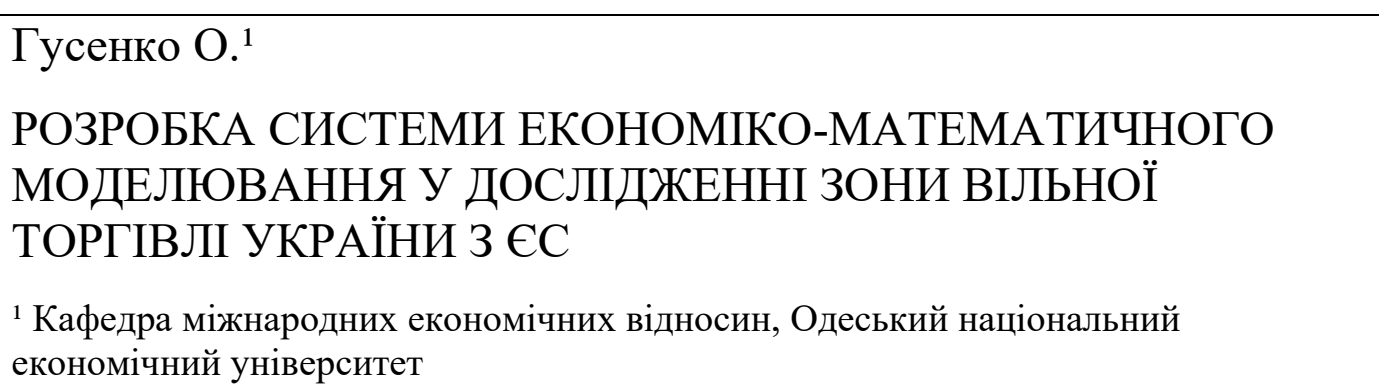 & 334 \\
\hline
\end{tabular}




\begin{tabular}{|c|c|c|}
\hline 8.3 & $\begin{array}{l}\text { Михайленко О. }{ }^{1}, \text { Краснікова Н. } \\
\text { РОЗВИТОК СВІТОВОГО ТА ВІТЧИЗНЯНОГО РИНКІВ } \\
\text { ЕЛЕКТРОННОЇ КОМЕРЦІІ В УМОВАХ ДІДЖИТАЛІЗАЦІЇ } \\
\text { СВІТОВОЇ ЕКОНОМІКИ } \\
{ }^{1} \text { Кафедра міжнародної економіки і світових фінансів, Дніпровський } \\
\text { національний університет імені Олеся Гончара }\end{array}$ & 352 \\
\hline 9. & MANAGEMENT & \\
\hline 9.1 & $\begin{array}{l}\text { Prokudin G. }{ }^{1} \text {, Chupaylenko O. }{ }^{1}, \text { Kozlov A. }^{1} \\
\text { NEW TECHNOLOGIES OF PERSONNEL MANAGEMENT IN } \\
\text { CUSTOMS AUTHORITIES } \\
{ }^{1} \text { Department of International Transportation and Customs Control, Kyiv, National } \\
\text { Transport University }\end{array}$ & 421 \\
\hline 9.2 & $\begin{array}{l}\text { Shuienkin V. }{ }^{1} \text {, Zakusylo P. }{ }^{1}, \text { Kharchenko V. }{ }^{1}, \text { Kozachuk V. }{ }^{1} \text {, } \\
\text { Havrych H. } \\
\text { THE DETERMINATION METHOD OF REQUIRED } \\
\text { MODERNIZATION LEVEL OF PRODUCTION'S TECHNICAL } \\
\text { MEANS AT AN ENTERPRISE } \\
{ }^{1} \text { Central Research Institute of the Armed Forces of Ukraine, Kyiv }\end{array}$ & 429 \\
\hline 9.3 & $\begin{array}{l}\text { Voronina A. }{ }^{1} \\
\text { THEORETICAL AND METHODOLOGICAL ASPECTS OF } \\
\text { RESEARCH AND DEVELOPMENT OF THE ENTERPRISE } \\
\text { MANAGEMENT SYSTEM } \\
{ }^{1} \text { Department of Organization Management and Administration, Dniprovsk State } \\
\text { Technical University }\end{array}$ & 437 \\
\hline 9.4 & 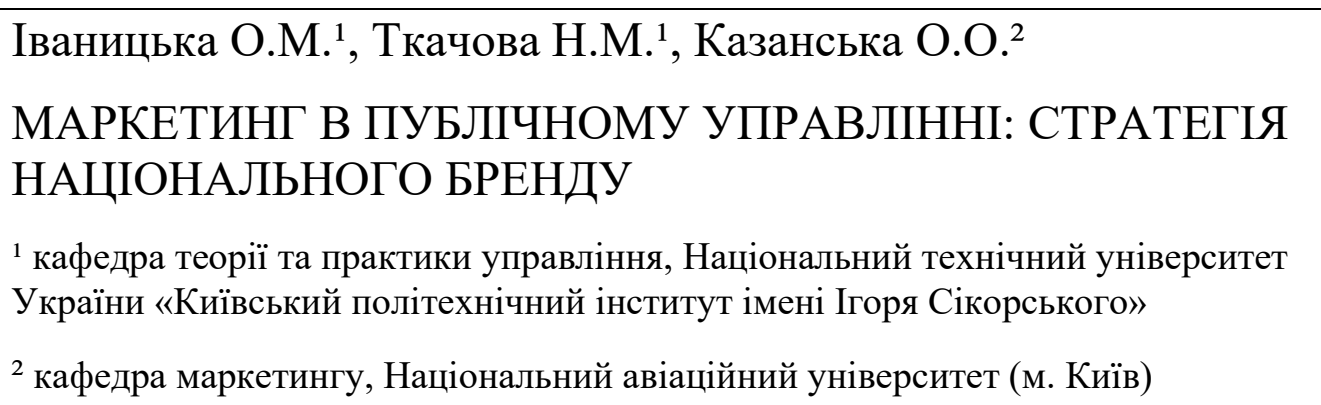 & 445 \\
\hline
\end{tabular}




\begin{tabular}{|c|c|c|}
\hline 9.5 & $\begin{array}{l}\text { Живко З.Б. }{ }^{1} \text {, Родченко С.С. }{ }^{2} \text {, Руда І.І. }{ }^{3}, \text { Боруцька Ю.З. } \\
\text { Бойко О.Т. } \\
\text { ТИПОЛОГІЯ ШАХРАЙСТВА У БАНКІВСЬКІЙ СФЕРІ: } \\
\text { СУТНІСТЬ, УМОВИ ВИНИКНЕННЯ ТА РОЗРОБКА ЗАХОДІВ } \\
\text { БОРОТЬБИ } \\
{ }^{1} \text { кафедра менеджменту, Львівський державний університет внутрішніх справ, } \\
{ }^{2} \text { кафедра фінансів та економічної безпеки, Харківський національний університет } \\
\text { міського господарства імені О.М. Бекетова, } \\
{ }^{3} \text { науковий відділ, Львівський державний університет внутрішніх справ, } \\
{ }^{4} \text { кафедра туризму, Львівський національний аграрний університет } \\
\text { s кафедра іноземних мов та культури мовлення, Львівський державний } \\
\text { університет внутрішніх справ }\end{array}$ & 453 \\
\hline \multicolumn{3}{|c|}{ MECHANISMS OF REGULATION OF THE ECONOMY } \\
\hline 10.1 & $\begin{array}{l}\text { Iukhno A. }{ }^{1} \\
\text { NORMATIVE MONETARY VALUATION OF INDUSTRIAL } \\
\text { LANDS UNDER INFLUENCE OF LOCATION FACTORS } \\
{ }^{1} \text { Department of Land Resources Management and Cadastre, Kharkiv National Agrarian } \\
\text { University named after V.V. Dokuchaiev }\end{array}$ & 468 \\
\hline 10.2 & $\begin{array}{l}\text { Волківська А. }{ }^{1}, \text { Семенюк Т. }{ }^{1}, \text { Борис В. }{ }^{1} \\
\text { СОЦІАЛЬНА ПОЛІТИКА ЯК ЕЛЕМЕНТ ІТЕГРАЛЬНОГО } \\
\text { МЕХАНІЗМУ ПОКРАЩЕННЯ ЯКОСТІ ЖИТТЯ НАСЕЛЕННЯ } \\
\text { УКРАЇНИ } \\
{ }^{1} \text { Житомирський інститут ПрАТ «ВНЗ «МАУП» }\end{array}$ & 476 \\
\hline \multicolumn{3}{|c|}{ 11. MICRO AND MACRO ECONOMY } \\
\hline 11.1 & $\begin{array}{l}\text { Чечетова Н.Ф. }{ }^{1}, \text { Чечетова-Терашвілі Т.М. }{ }^{2}, \text { Лелюк Н.С. } \\
\text { ДЕРЖАВНА ПІДТРИМКА СТРАТЕГІЧНИХ НАПРЯМІВ } \\
\text { РОЗВИТКУ МАЛОГО ТА СЕРЕДНЬОГО ПІДПРИСМНИЦТВА } \\
{ }^{1} \text { Харківський національний університет міського господарства ім. О.М. Бекетова } \\
{ }^{2} \text { Харківський національний економічний університет імені Семена Кузнеця }\end{array}$ & 552 \\
\hline \multicolumn{3}{|c|}{$\begin{array}{ll}12 . & \text { THEORY AND HISTORY } \\
\end{array}$} \\
\hline 12.1 & $\begin{array}{l}\text { Бойко Т. }{ }^{1}, \text { Рой В. }{ }^{1}, \text { Сахненко О. }{ }^{1}, \text { Марчишинець О. }{ }^{1} \\
\text { ТИМБІЛДИНГ ЯК ОДИН ІЗ ІННОВАЦІЙНИХ МЕТОДІВ } \\
\text { В УПРАВЛІНСЬКІЙ ДІЯЛЬНОСТІ КЕРІВНИКА } \\
{ }^{1} \text { Полтавський науково-дослідний експертно-криміналістичний центр МВС } \\
\text { України }\end{array}$ & 565 \\
\hline & REFERENCES & 571 \\
\hline
\end{tabular}




\section{SECTION 1. ACCOUNTING REGION AND AUDIT}

DOI 10.46299/ISG.2021.MONO.ECON.II-12-17

\subsection{The economic essence of the costs, their recognition and displaying them in accounting}

In order to effectively use the material, labor, money, information and other resources of the enterprise, and hence the implementation of a comprehensive analysis of processes and phenomena that negatively affect the economic process of the enterprise, the right approach is needed in the formation of production costs, their classification and accounting.

In the theory and practice of economic activity, the interpretation of the category of «costs» is ambiguous. This is primarily due to the use of different approaches to the valuation of economic resources used in the process of economic activity. Costs are an economic category. However, their origin and development are considered in the historical aspect. The costs arose with the advent of commodity production and trade. Therefore, the disclosure of the essence of costs at different times associated with the type of economy, economic structure, form of ownership of means of production, the functions of trade as a branch of the economy, as well as with the formation and development of economic thought [12].

According to A. Smith and D. Ricardo, costs meant social average costs per unit of output. In addition, costs were defined as the price of production, taking into account rent payments $[9$, c. 10$]$.

Marx's theory of production costs is based on two principal categories: production costs and circulation costs. If the cost of production is associated with the creation of goods, the cost of circulation - with their sale (purchase and sale) [5].

According to the Methodical recommendations № 132, the costs of the reporting period are recognized or a decrease in assets or an increase in liabilities, which leads to a decrease in equity, provided that these costs can be reliably estimated [6]. Expenses are also recognized as expenses of a certain period unambiguously with the definition of income for which they are incurred. Expenses that cannot be directly 
related to the income of a certain period are reflected in the expenses of the reporting period in which they were incurred.

The question of the nature, efficiency of costs and their regulation has been studied by many economists (table 1.1.1).

Table 1.1.1

Scientific approaches to the definition of «costs»

\begin{tabular}{|c|c|c|}
\hline № & Author & Essence \\
\hline 1. & Butynets F. [2] & $\begin{array}{l}\text { Costs are a decrease in economic benefits in the form of } \\
\text { disposal of assets or an increase in liabilities that lead to a } \\
\text { decrease in equity (except for a decrease in capital due to its } \\
\text { withdrawal or distribution by owners). }\end{array}$ \\
\hline 3. & $\begin{array}{c}\text { Drobiazko S. } \\
\text { [3] }\end{array}$ & $\begin{array}{l}\text { osts - a set of resources of all kinds, expressed in a single } \\
\text { onetary measure, grouped by appropriate characteristics } \\
\text { d used in key business processes to achieve the objectives. }\end{array}$ \\
\hline 4. & $\begin{array}{c}\text { Bondarenko } \mathrm{T} \text {. } \\
{[1]}\end{array}$ & $\begin{array}{l}\text { Costs are a reliably estimated amount of economic resources, } \\
\text { the consumption of which leads to changes in the composition } \\
\text { of assets and liabilities and contributes to the goals of the } \\
\text { enterprise, taking into account the resource nature of costs } \\
\text { and emphasizing efficiency as a prerequisite for their } \\
\text { implementation. }\end{array}$ \\
\hline 5. & $\begin{array}{l}\text { Chertkova N. } \\
\text { [12] }\end{array}$ & Costs are the cost of all materials and services spent. \\
\hline 6. & $\begin{array}{c}\text { Kostyakova A. } \\
\text { [4] }\end{array}$ & $\begin{array}{l}\text { Costs - the use of only those resources that in determining } \\
\text { the profit of the entity are considered in accordance with the } \\
\text { income for the reporting period. }\end{array}$ \\
\hline 7. & Suk L. [11] & $\begin{array}{l}\text { The process of converting money into resources has the } \\
\text { nature of spending and is called «costs». }\end{array}$ \\
\hline 8. & $\begin{array}{l}\text { Pogorelov Y. } \\
\text { [7] }\end{array}$ & $\begin{array}{l}\text { Costs from an accounting point of view indicate a change in } \\
\text { assets and increase liabilities of the enterprise and are focused } \\
\text { on the calculation of its financial result. }\end{array}$ \\
\hline
\end{tabular}

An important issue on the basis of which the methodology of the study of accounting for production costs in enterprises should be formed is their classification according to certain characteristics.

The broadest is the classification of costs according to such characteristics (Fig. 1.1.1). 


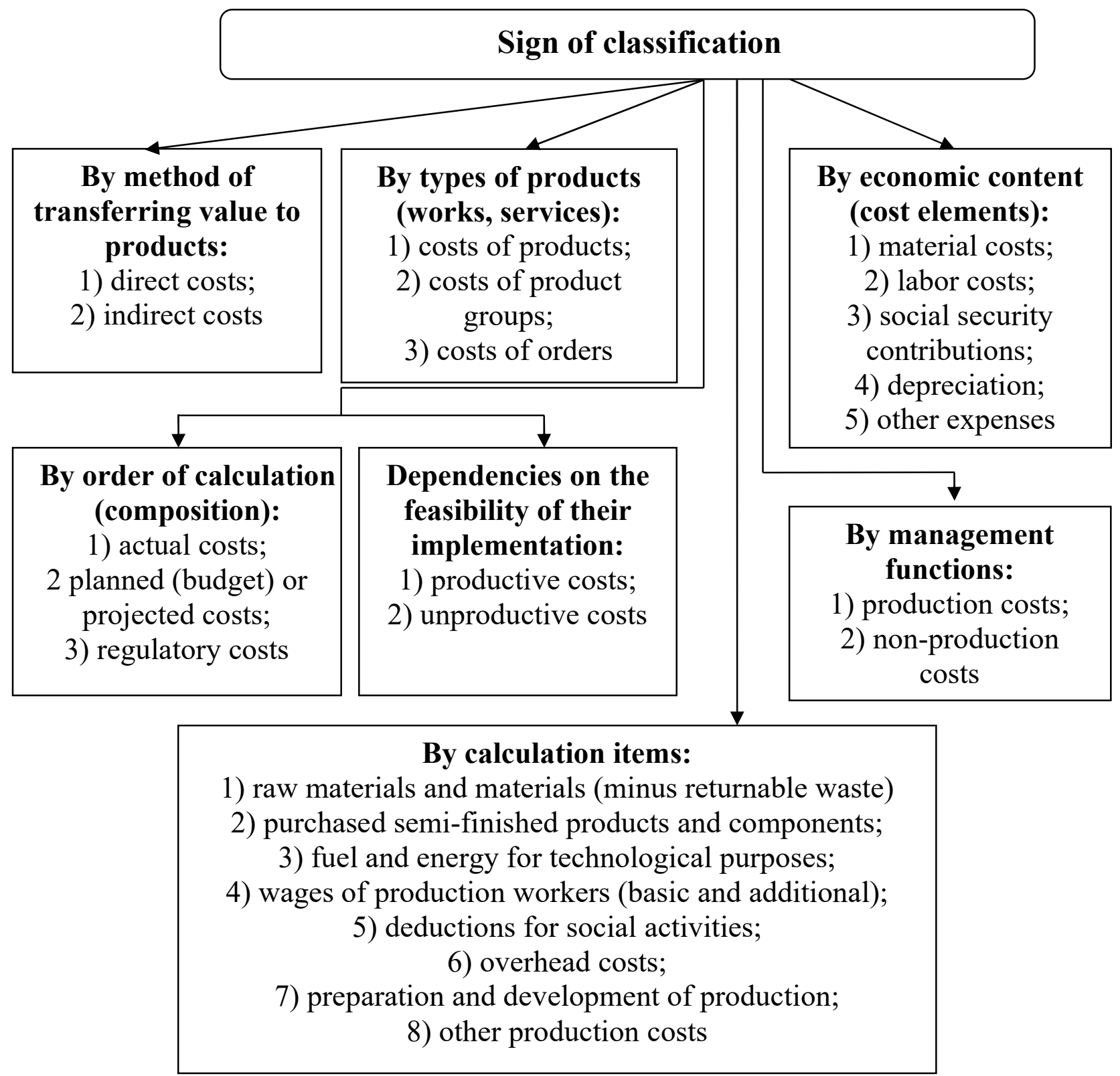

Fig. 1.1.1 Grouping costs by classification.

According to our analysis of scientific works, the concept of «costs» scientists interpret differently, but invest the same meaning in their interpretation, ie interpret the term as the use of economic resources, and the authors Kostyakova A. and Pogorelov Y. directly emphasize their compliance with the income for which they are incurred. In accordance with the principle of conformity of accrual of income and expenses in the financial statements [4, c. 7], costs as an economic category contained 
in the financial statements must correspond to the income for which they are incurred - so it is impossible to disagree.

Information on the costs of the enterprise and their disclosure in the financial statements is governed by the UAS 16 [8]. According to the Regulation, costs are reflected in the accounting at the same time as a decrease in economic benefits in the form of disposal of assets or an increase in liabilities that lead to a decrease in equity. In accordance with UAS 16, the conditions for recognizing costs are shown in Fig. 1.1.2.

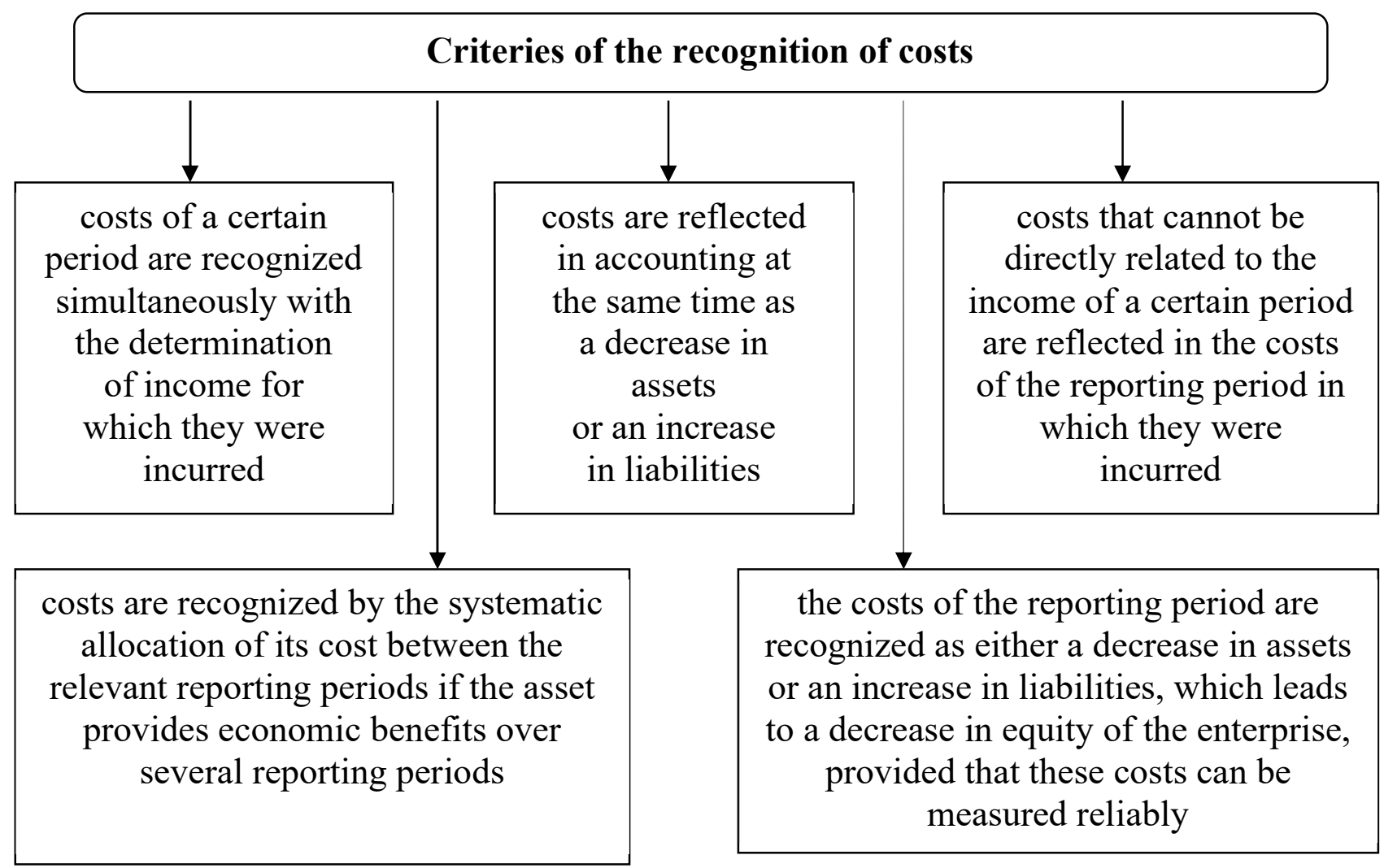

Fig. 1.1.2. Criteries of the recognition costs.*

* Source: [8].

It should also be noted that UAS, like IAS, do not specify the procedure for accounting. They describe the general rules for evaluating and presenting information in the financial statements. Therefore, it would be appropriate to show a comparative description of costs in accordance with UAS and IAS (Table 1.1.2) [8]. 
Table 1.1.2

\section{Comparative characteristics of costs in accordance with UAS and IAS}

\begin{tabular}{|c|c|c|}
\hline Characteristic & UAS & IAS \\
\hline $\begin{array}{l}\text { Standard that } \\
\text { regulates }\end{array}$ & UAS 16 & There is no single standard \\
\hline Definition & $\begin{array}{l}\text { Costs - a decrease in economic } \\
\text { benefits in the form of disposal of } \\
\text { assets or increase in liabilities that } \\
\text { lead to a decrease in equity }\end{array}$ & $\begin{array}{l}\text { Costs are a decrease in economic } \\
\text { benefits during the reporting } \\
\text { period that occurs in the form of an } \\
\text { outflow, a decrease in assets or an } \\
\text { increase in liabilities that results in } \\
\text { a decrease in equity unrelated to its } \\
\text { distribution among equity } \\
\text { participants }\end{array}$ \\
\hline $\begin{array}{l}\text { Classification } \\
\text { and grouping } \\
\text { of costs }\end{array}$ & $\begin{array}{l}\text { Costs are classified according to } \\
\text { the type of activity from which } \\
\text { they arose by economic elements } \\
\text { and cost items }\end{array}$ & $\begin{array}{l}\text { IAS are based on the generally } \\
\text { accepted practice of distinguishing } \\
\text { in the reporting of items of cost } \\
\text { that arise in the ordinary course of } \\
\text { business and items of cost that are } \\
\text { not related to ordinary activities }\end{array}$ \\
\hline $\begin{array}{l}\text { Determination } \\
\text { of costs }\end{array}$ & $\begin{array}{l}\text { Costs are recognized in the } \\
\text { reporting when the asset is } \\
\text { disposed of or the liability is } \\
\text { increased, which reduces the } \\
\text { equity of the enterprise, on the } \\
\text { basis of their systematic and } \\
\text { rational distribution during the } \\
\text { reporting periods when the } \\
\text { relevant economic benefits are } \\
\text { received }\end{array}$ & $\begin{array}{l}\text { Costs are recognized on the basis } \\
\text { of a comparison between incurred } \\
\text { expenses and income on specific } \\
\text { items of income, which involves } \\
\text { the simultaneous recognition of } \\
\text { income and costs arising directly } \\
\text { and jointly from the same } \\
\text { transactions or other events }\end{array}$ \\
\hline $\begin{array}{c}\text { Cost } \\
\text { estimation }\end{array}$ & $\begin{array}{l}\text { There are no special, set out in a } \\
\text { separate standard, rules for } \\
\text { estimating the costs of the } \\
\text { organization, but the standards } \\
\text { indicate some features of cost } \\
\text { estimation }\end{array}$ & $\begin{array}{l}\text { There are no rules specifically set } \\
\text { out in a separate standard for } \\
\text { estimating an entity's costs, but } \\
\text { some standards contain provisions } \\
\text { that determine the estimate of } \\
\text { related costs, which are determined } \\
\text { in the income statement }\end{array}$ \\
\hline
\end{tabular}

It is the level and dynamics of costs largely depend on the financial performance of enterprises and their structural units, so a very important tool in achieving high economic results in the enterprise is cost management. Effective cost management requires properly organized accounting.

In accounting, costs are reflected under certain conditions, which we have shown in Fig. 1.1.2. 


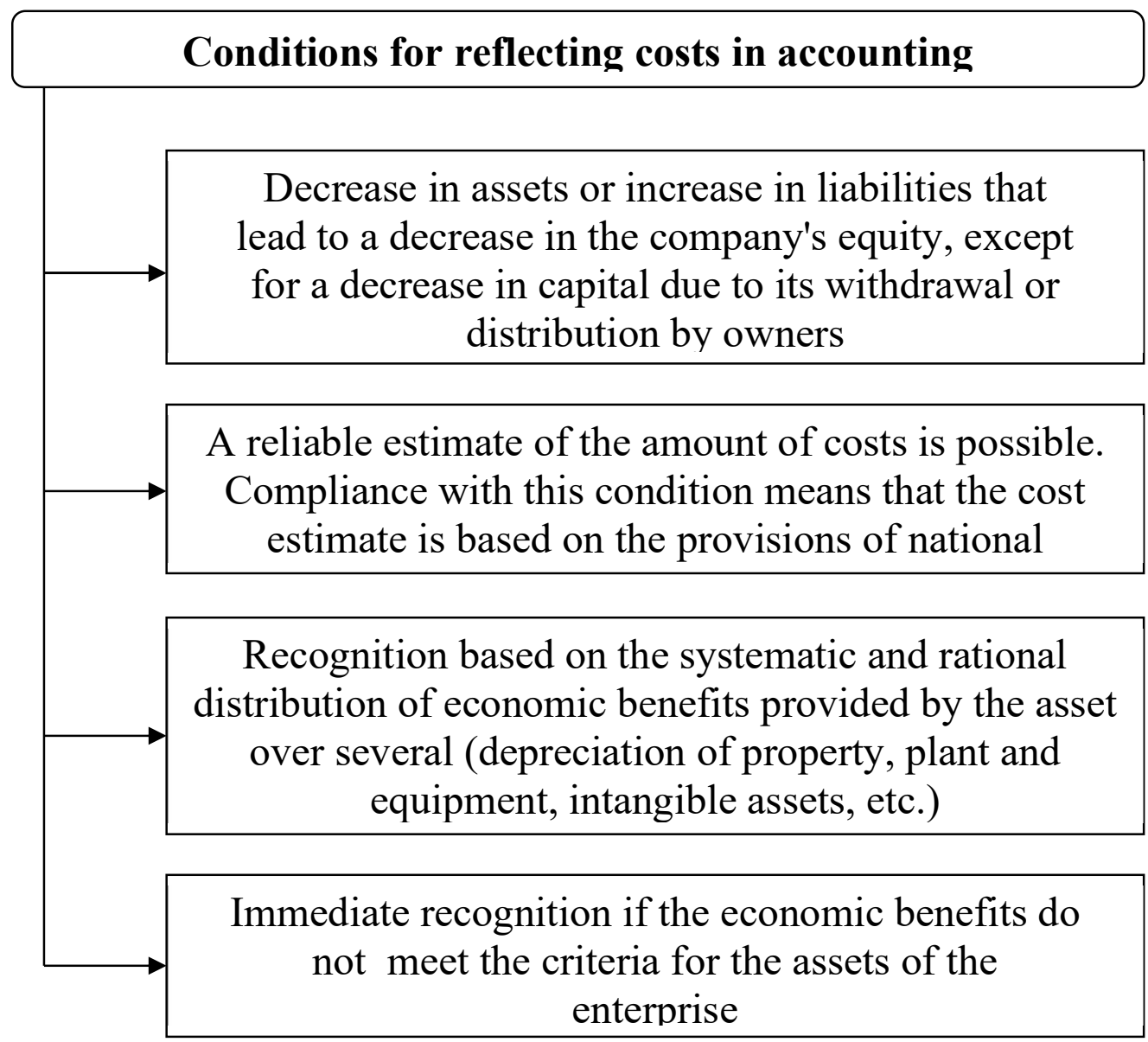

Fig. 1.1.2. Conditions for reflecting costs in accounting*

* Source: $[6$, c. 8$]$.

Thus, the role of costs in the economic activity of enterprises is undeniable. But only a well-established cost management system will give tangible results in the financial and economic activities of the enterprise. Careful consideration of the choice of cost classification will determine how well the cost management system is organized. Ultimately, the direct dependence of the company's profit on the level of costs in terms of finding reserves and reducing them will allow the company to grow faster. Eventually, the development of economic entities and this will be a competitive advantage in the market [13].

Thus, the classification of costs and our defined criteria for recognizing costs allow us to effectively manage them and keep a clear record of them. Because the quality of accounting work forms the image of the enterprise, and the efficiency and reliability of accounting information - the basis of modern effective management. 
DOI 10.46299/ISG.2021.MONO.ECON.II-18-26

\section{2 Складання та подання фінансової звітності підприсмствами України на основі таксономії фінансової звітності за міжнародними стандартами}

Обраний Україною курс на інтеграцію у європейську економічну спільноту вимагає від усіх вітчизняних учасників фінансово-економічних відносин рішучих дій у напрямку гармонізації і стандартизації ведення обліку, складання фінансової звітності та проведення аудиту.

Завершальним етапом ведення обліку на підприємстві $є$ складання фінансової звітності, яка містить необхідну інформацію про фінансовий стан підприємства, його фінансові результати, рух грошових коштів внаслідок здійснення різних видів діяльності, а також зміни у власному капіталі. Для того, щоб показники фінансової звітності українських підприємств були зрозумілі та інформативні не лише для вітчизняних, але і для іноземних користувачів інформації важливим $є$ відповідність iï складання вимогам міжнародних стандартів фінансової звітності (МСФЗ).

На сьогодні фінансову звітність та консолідовану фінансову звітність за МСФЗ складає ряд підприємств (дана вимога закріплена у Законі України «Про бухгалтерський облік та фінансову звітність в Україні» від 16.07.1999 р. № 996XIV), до яких належать:

1) підприємства, що становлять суспільний інтерес - це суб'єкти господарювання-емітенти цінних паперів, цінні папери яких котируються на фондових біржах або щодо даних цінних паперів здійснено публічну пропозицію; банківські установи; страхові компанії; недержавні пенсійні фонди; інші фінансові установи та підприємства, які відповідно до ст. 1 цього Закону належать до великих підприємств.

Великими підприємствами вважаються такі, показники яких на дату складання річної фінансової звітності відповідають щонайменше двом із наступних критеріїв:

- балансова вартість активів - понад 20 млн. євро; 
- чистий дохід від збуту продукції (товарів, робіт, послуг) - понад 40 млн. євро;

- чисельність працівників - понад 250 осіб;

2) публічні акціонерні товариства;

3) суб'єкти господарювання, які здійснюють діяльність у видобувних галузях;

4) підприємства, які провадять господарську діяльність за напрямками, перелік яких визначається Кабінетом Міністрів України:

- надання фінансових послуг, крім страхування та пенсійного страхування;

- недержавне пенсійне страхування;

- допоміжна діяльність у сферах фінансових послуг і страхування за винятком допоміжної діяльності у сфері страхування та пенсійного страхування [14].

Відповідно до вимог законодавства фінансова звітність вищевказаних підприємств України, повинна бути підготовлена згідно з таксономією, зокрема Таксономією UA XBRL міжнародних стандартів фінансової звітності, і подана в єдиному електронному форматі.

Розглянемо і більш детальніше розберемося в основних поняттях, які супроводжують даний процес.

Таксономія - це класифікаційна система, яка може бути використана для ідентифікації та структурування інформації з метою полегшення іiї пошуку та обробки користувачем [15].

Таксономія фінансової звітності - це склад статей і показників фінансової звітності та ії елементів, які підлягають розкриттю [15].

Система таксономії МСФЗ:

1) перераховує і визначає конкретні коди, якими можна скористатися для ідентифікації інформації, розкритої у фінансовій звітності за МСФЗ;

2) включає зміст, який описує значення елемента бухгалтерського обліку або допомагає користувачу знайти правильний елемент. 
Окрім цього, у таксономії містяться елементи розкриття інформації, які не вимагаються спеціально МСФЗ, але зазвичай розкриваються на практиці.

Таксономія UA XBRL MCФ3 - це таксономія фінансової звітності за міжнародними стандартами фінансової звітності в Україні, затверджена Міністерством фінансів України, яка адаптована до особливостей складання фінансової звітності в Україні та включає в себе також звіт аудитора і звіт про управління.

Для забезпечення виконання вимог Законів України «Про бухгалтерський облік та фінансову звітність в Україні» [14] і «Про внесення змін до Закону України «Про бухгалтерський облік та фінансову звітність в Україні» щодо удосконалення деяких положень» від 05.10 .2017 p. № 2164-VIII [18] Міністерство фінансів України відповідно до Договору з Фондом міжнародних стандартів фінансової звітності (м. Лондон, Велика Британія) отримує текст таксономії фінансової звітності за міжнародними стандартами мовою оригіналу, здійснює його переклад та оприлюднює на офіційному веб-сайті.

3 метою проведення підготовчих заходів щодо подання фінансової звітності на основі таксономії фінансової звітності за міжнародними стандартами в єдиному електронному форматі Міністерством фінансів України, Національною комісією з цінних паперів та фондового ринку, Національним банком України та Національною комісією, що здійснює державне регулювання у сфері ринків фінансових послуг у 2017 р. підписано Меморандум про взаєморозуміння щодо розробки і запровадження системи фінансової звітності [17]. У 2019 році до Меморандуму долучено Державну службу статистики України, Державну податкову службу України та Орган суспільного нагляду за аудиторською діяльністю. Згідно з Меморандумом [17] запроваджується єдина Система фінансової звітності (СФЗ) як інтегрована система, що дозволяє отримувати, перевіряти, обробляти та розкривати фінансову звітність суб'єктів звітування та ïx аудиторських звітів на основі використання документів у форматі Inline XBRL (iXBRL):

- в уніфікованому електронному форматі iXBRL; 
- підготовленої відповідно до таксономії UA XBRL MCФЗ;

- за принципом «єдиного вікна» [20].

iXBRL - це технологія, яка забезпечує механізм вбудовування тегів XBRL у документи HTML, що дозволяє отримати переваги відмічених (протегованих) XBRL-даних у поєднанні зі зручною для читання презентацією звіту [21].

Наказом Міністерства фінансів України «Про затвердження перекладу Таксономії фінансової звітності за міжнародними стандартами фінансової звітності» від 13.11.2020 р. № 709 [19] передбачено, що фінансова звітність на основі Таксономії фінансової звітності за МСФЗ складається і подається в єдиному електронному форматі із застосуванням розширюваної мови ділової звітності (XBRL).

Формат є XBRL (англ. eXtensibleBusiness Reporting Language «розширювана мова ділової звітності») - відкритий стандарт обміну діловою інформацією, який широко використовується в світовій практиці [20]. Використання формату XBRL несе численні переваги як для суб' єктів звітування, держави, так і для інвесторів (рис. 1.2.1).

Формат XBRL запроваджується у світі для посилення підзвітності та прозорості результатів діяльності підприємств, забезпечуючи відкритий стандарт обміну бізнес-інформацією.

Для того, щоб подавати фінансову звітність у форматі іXBRL підприємству необхідно здійснити такі кроки:

1. Зареєструватися на порталі СФЗ.

2. Скласти фінансову звітність відповідно до Таксономії МСФЗ у форматі iXBRL.

Таксономія UA XBRL MCФЗ надає можливість обрати один з двох варіантів складання фінансової звітності для суб'єктів господарювання (за виключенням банків) (рис. 1.2.3). 
Переваги застосування XBRL при складанні фінансової звітності

\section{для суб'сктів звітування}

1) коректне складання фінансової звітності;

2) виключення дублювання при поданні фінансової звітності регуляторам

3) сприяння залученню інвесторів

\section{для держави}

1) швидкість i автоматичність обробки та аналізу фінансової звітності;

2) своєчасне виявлення ризиків i оперативне реагування на них;

3) ефективний та економічний регуляторний процес

\section{для інвесторів}

1) якісне розкриття інформації за МСФ3;

2) швидкість та автоматичність обробки та аналізу фінансової звітності;

3) краще розуміння ризиків i перспектив бізнесу

Рис. 1.2.1. Переваги застосування XBRL при складанні фінансової звітності

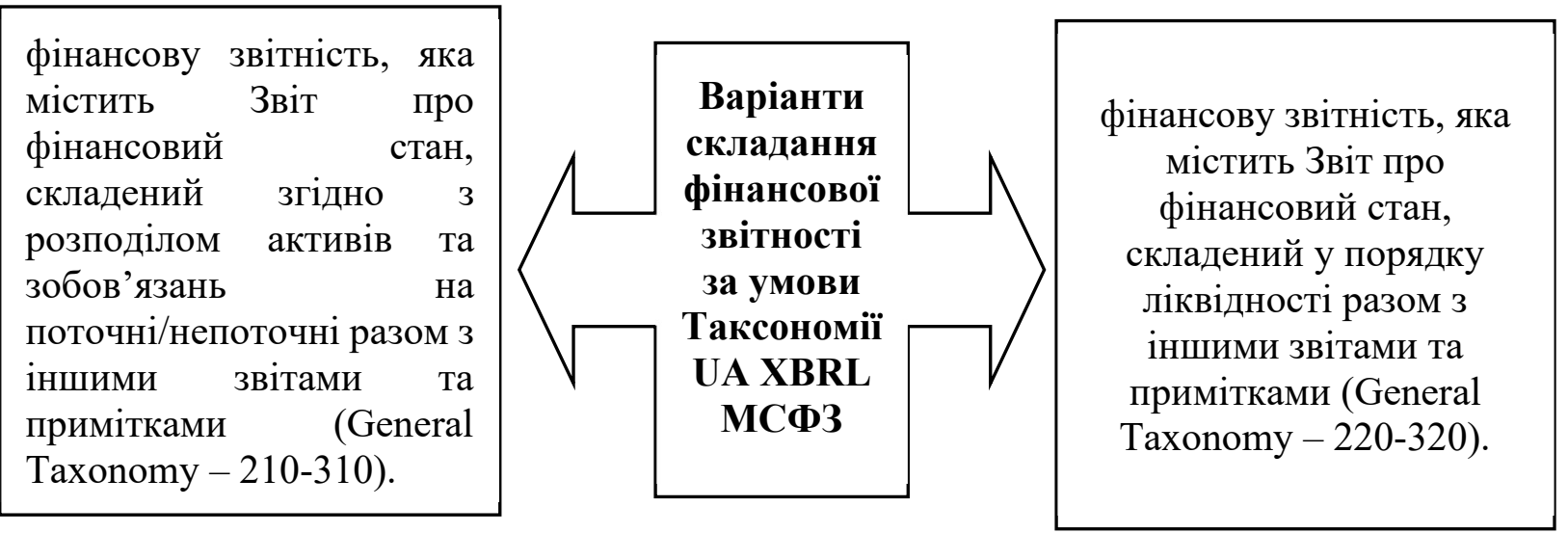

Рис. 1.2.3. Варіанти складання фінансової звітності для суб'єктів господарювання при застосуванні Таксономії UA XBRL MCФ3

3. Провести валідацію (перевірку) фінансової звітності у форматі iXBRL.

4. Підписати файл з фінансовою звітністю у форматі iXBRL.

Поряд 3 цим практикою виробилося два основні підходи до застосування таксономії UA XBRL MCФЗ та створення IXBRL-файлів:

1) підхід, що базується на заповненні стандартних таблиць;

2) підхід, що базується на тегуванні вже підготовленої фінансової звітності.

Сутність, переваги і недоліки цих підходів розглянемо у табл. 1.2.1 
Сутність, переваги і недоліки підходів застосування таксономії UA XBRL MCФЗ та створення iXBRL-файлів

\begin{tabular}{|c|c|c|}
\hline Підхід та його сутність & Переваги & Недоліки \\
\hline $\begin{array}{l}\text { 1. Підхід, що базується на } \\
\text { заповненні стандартних } \\
\text { таблиць передбачає ручне } \\
\text { заповнення тієї інформації, } \\
\text { яка підлягає розкриттю } \\
\text { згідно з вимогами МСФЗ, у } \\
\text { розробленій проформі } \\
\text { фінансової звітності. } \\
\text { Проформа є фіксованою, та } \\
\text { iї неможливо змінити }\end{array}$ & $\begin{array}{lr}\text { підхід } & \text { простий } \\
\text { застосуванні } & \text { д } \\
\text { компаній, } & \text { які } \\
\text { обмежену } & \text { мають } \\
\text { господарських } & \text { типологію } \\
\text { (наприклад, закупівля та } \\
\text { продаж } \\
\text { нескладне } \\
\text { обмежена виробництво, } \\
\text { простих } \\
\text { інструментів) } \\
\text { кількість } \\
\text { фінансових }\end{array}$ & 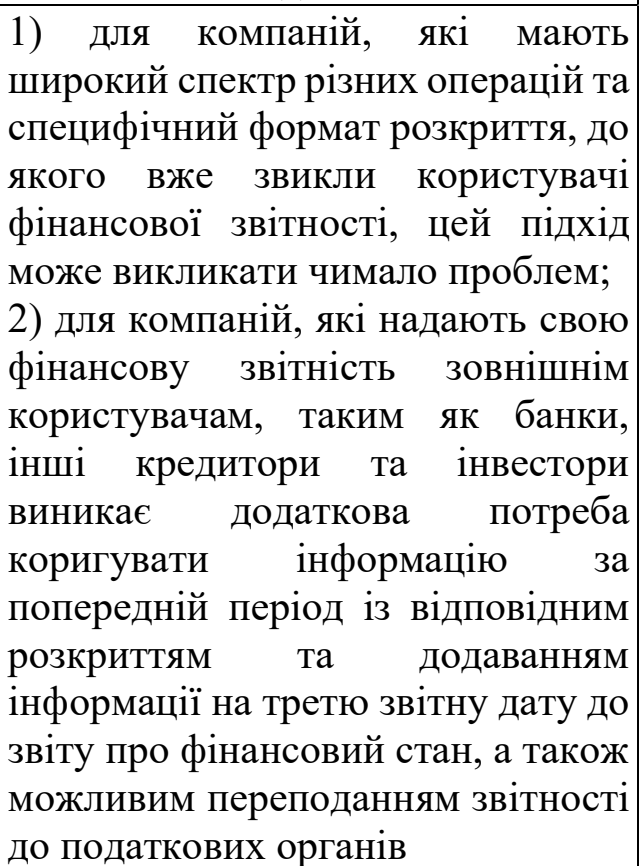 \\
\hline $\begin{array}{l}\text { 2. Підхід, що базується на } \\
\text { тегуванні вже підготовленої } \\
\text { фінансової звітності } \\
\text { передбачає присвоєння тегів } \\
\text { до певних цифр у фінансовій } \\
\text { звітності }\end{array}$ & $\begin{array}{l}\text { 1) дозволяє компанії } \\
\text { врахувати особливості та } \\
\text { специфіку їі операцій; } \\
\text { 2) можливість зробити } \\
\text { тегінг } \\
\text { звітності одинансової } \\
\text { використовувати й і } \\
\text { надалі для звітностей за } \\
\text { наступні роки } \\
\text { необхідними } \\
\text { оновленнями; } \\
\text { 3) немає необхідності } \\
\text { змінювати презентацію у } \\
\text { фінансовій звітності }\end{array}$ & $\begin{array}{l}\text { виникнення окремих труднощів, } \\
\text { зумовлені тим, що таксономія та } \\
\text { розкриті рядки фінансової } \\
\text { звітності можуть не збігатися }\end{array}$ \\
\hline
\end{tabular}

Джерело: складено на основі [21]

Ці підходи є принципово різними з точки зору процесу підготовки та вимагають різного програмного забезпечення, але їх застосування забезпечує один і той самий результат - iXBRL-файл, що є основним і необхідним при складанні фінансової звітності у форматі іXBRL.

Вибір того чи іншого підходу в першу чергу залежить від типу підприємства, специфіки його фінансово-господарської діяльності, характеру і искладності господарських операцій тощо. 
Підприємство може створити фінансову звітність у форматі iXBRL тільки за допомогою спеціального програмного забезпечення, яке воно може або розробити самостійно, або скористатися вже розробленими програмними продуктами (рис. 1.2.2).

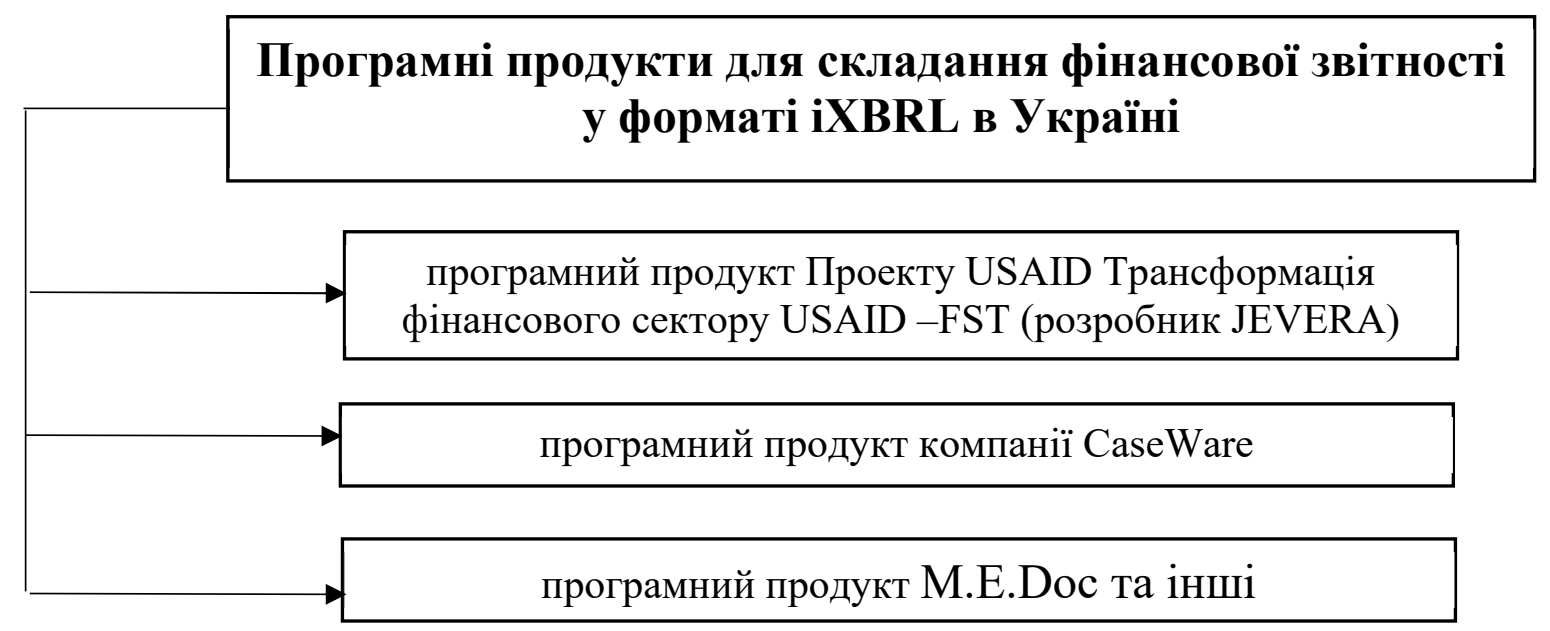

Рис. 1.2.2. Програмні продукти для складання фінансової звітності у форматі iXBRL в Україні

Основними функціями розглянутого програмного забезпечення є:

1) створення фінансового звіту;

2) редагування та видалення фінансового звіту;

3) управління формами звітності у звіті;

4) налаштування вмісту форми;

5) внесення даних до форми звітності;

6) очищення даних звіту та форми звітності;

7) імпорт даних у форматах CSV i JSON;

8) генерація звіту у форматі iXBRL;

9) імпорт даних з іXBRL.

Увесь процес складання фінансової звітності з використанням відповідного програмного забезпечення зводиться до таких етапів:

1. Внесення основної інформації про суб’єкт звітності.

2. Вибір типу звітності.

3. Вибір періоду, за який подається звітність. 
4. Вибір форм звітності, тобто звітів та приміток, що будуть включені до звіту.

При внесенні даних до форм фінансової звітності та під час роботи 3 формами, користувач має змогу переглядати інформацію про ту чи іншу статтю для кращого розуміння iї контексту.

Важливим у процесі підготовки фінансової звітності є їі валідація - перевірка правильності складання фінансової звітності і її відповідності правилам валідації, які закладені в Таксономії UA XBRL MCФ3. Вона здійснюється підприємством самостійно до моменту іï подання в СФЗ з використанням спеціалізованого програмного забезпечення. Одним з них є програмний продукт Arelle.

Arelle - це проект, який підтримується спільнотою XBRL має зручну платформу з відкритим кодом для XBRL. Програмне забезпечення підтримує XBRL та його функціональні розширення в розгорнутому вигляді [20]. Arelle використовується як настільний додаток із можливістю інтеграції 3 іншими програмами та мовами з використанням його веб-сервісів. Адже функціонал його програмного забезпечення $є$ простим і надійним.

У процесі валідації фінансової звітності доречно керуватися такими принципами:

1) заповнення звітів по одному;

2) перевірка кожного звіту окремо;

3) додавання кожного перевіреного звіту до основного i проведення повторної перевірки усього звіту.

Останнім етапом подання фінансової звітності у форматі iXBRL $є$ iï підписання з використанням діючого електронного цифрового підпису (ЕЦП).

Після того, як системою буде надіслано сповіщення користувачам щодо можливості подання фінансової звітності за відповідний звітний період відповідним суб'єктом звітування відбувається подання фінансової звітності шляхом завантаження підготовлених файлів фінансової звітності до Єдиної системи фінансової звітності. 
Першим звітним періодом для звітування за міжнародними стандартами на підставі таксономії за МСФЗ в електронній формі, є 2020 рік. Тобто підприємства, які подають звітність за МСФЗ, будуть звітувати на підставі таксономії за МСФ3 вперше у 2021 році за період 2020 року.

Нещодавно (9 квітня 2021 р.) на засіданні Комітету з управління системою фінансової звітності, створеного відповідно до Меморандуму [17] було схвалено електронний формат Таксономії UA XBRL MCФ3 2020 року (версія 1.2) для використання суб'єктами звітування при складанні фінансової звітності в електронному форматі за 2020 рік та проміжної фінансової звітності в 2021 році.

Для збору фінансової звітності, складеної на основі Таксономії UA XBRL МСФ3, а також з метою забезпечення доступу до неї органів державної влади, інших органів і користувачів створено Центр збору фінансової звітності, що є програмно-технічним комплексом (сукупністю апаратно-технічних і програмних засобів). Завдяки ньому забезпечується:

1) збір фінансової звітності, складеної на основі Таксономії UA XBRL MCФ3;

2) оприлюднення у публічній базі даних (на сайті https://frs.gov.ua) цієї фінансової звітності;

3) створення та підтримання функціонування «кабінетів користувачів» (зокрема, веб-застосунків для підприємств, які подають фінансову звітність);

4) доступ органів державної влади, інших органів і користувачів до поданої підприємствами фінансової звітності тощо [16].

Проведене дослідження дозволяє визначити, що перехід підприємств України на складання і подання звітності на основі Таксономії UA XBRL MCФ3 має багато переваг, основними з яких є посилення прозорості фінансової звітності та підвищення інвестиційної привабливості українських суб'єктів бізнесу шляхом подання ними структурованих фінансових даних в єдиному електронному форматі, який є порівнянним і сумісним із європейськими та міжнародними стандартами. Все це сприятиме пришвидшенню процесу гармонізації обліку, звітності та аудиту в Україні. 
DOI 10.46299/ISG.2021.MONO.ECON.II-27-49

\section{3 Власний капітал підприсмства: сутність, структуризація та напрями управління як об'єкта обліку}

У сучасних умовах ринку інформаційна база системи управління капіталом суб'єкта господарювання, незалежно від форми власності та виду діяльності, потребує детального обліково-аналітичного забезпечення процесу формування та розміщення власного капіталу. Важливо, щоб процедури аналізу ринкової та балансової вартості власного капіталу використовували сучасний інструментарій у контексті прийняття виважених управлінських рішень щодо ефективності діяльності підприємства, збільшення прибутку та підвищення його конкурентних переваг.

Сьогодні успішна діяльність підприємства зумовлена правильним вибором джерел формування, напрямів розподілу й використання власного капіталу. Відповідно, облікові та аналітичні концепції формування та управління власним капіталом підприємства повинні бути спрямовані на вирішення рішень, обумовлених видами господарської діяльності: операційних (структура i pyx капіталу), фінансових (особливості використання капіталу) та інвестиційних рішень (накопичення та розподіл капіталу).

Процес функціонування підприємства залежить від структури власного капіталу та ефективності його управління. Сформований власний капітал $€$ фінансовим підгрунтям діяльності кожного підприємства. Водночас, це один із найважливіших фінансових показників, адже $є$ безстроковою та початковою основою фінансування діяльності й, крім того, джерелом погашення збитків підприємства. Від величини власного капіталу залежить ступінь фінансової самостійності, фінансової потужності та кредитоспроможності підприємства.

Проблемні аспекти обліку та аналізу формування і зміни величини власного капіталу, а також питання обліково-аналітичного забезпечення управління власним капіталом завжди в центрі уваги економістів, зокрема: Ф. Ф. Бутинця, С. Ф. Голова, В. В. Ковальова, Я. Д. Крупки, Г. В. Нашкерської, О. І. Пилипенка, I. Р. Поліщук, М. С. Пушкаря, Ю. С. Цал-Цалка та ін. Попри 
значну кількість досліджень у цьому напрямі, потреба вдосконалення методології бухгалтерського обліку та аналізу власного капіталу є актуальною.

Величина власного капіталу дозволяє дати оцінку ефективності діяльності підприємства, його результативності, стабільності та відповідальності. Підприємство 3 ефективним управлінням структурою капіталу характеризується підвищенням дохідності та ділової активності, безперервним виробничим процесом, інтенсивним розвитком підприємства, високою швидкістю обороту капіталу, перевищенням рентабельності інвестованого капіталу над середньозваженою вартістю капіталу, балансом між рентабельністю капіталу та ризиками діяльності.

Проте, з кожним роком спостерігається тенденція зменшення питомої ваги власного капіталу у структурі пасивів підприємств України. Лише третина підприємств отримують прибутки. Власний капітал більшості підприємств має високий рівень ризику втрат, оскільки стає чутливим до «форс-мажорних» обставин. У зв'язку 3 цим дослідження питань обліково-аналітичного забезпечення управління власним капіталом підприємства має особливу актуальність, і потребує уваги управлінців підприємств.

Постійний розвиток економічних відносин України в умовах виходу суб'єктів господарювання на міжнародні ринки докорінно змінює умови їх стабільного та стійкого функціонування. Ефективне управління підприємством передусім полягає у якісному управлінні його капіталом, як важливим елементом у структурі фінансових ресурсів, на всіх етапах життєвого циклу підприємства. Оптимальна структура капіталу впливає на загальний фінансовий стан підприємства, його конкурентоспроможність та кредитоспроможність. Якісне управління власним капіталом підприємства дасть змогу його власнику сформувати такий склад активів підприємства, на які не впливають особи, не визначені як власники підприємства, що збільшує самостійність підприємства.

Для ефективного управління власним капіталом важливо розуміти його сутність, умови формування, структуризацію як об'єкта обліку. Питання 
сутності та теоретичної значущості поняття «власний капітал підприємства» у своїх працях піднімали такі науковці, як: О.В.Ареф’єва, І. М. Мягких, Т. Г. Росумака [22], Ф. Ф. Бутинець [23], О. Й. Вівчар [24], А. А. Горбатенко [25], Я. П. Іщенко [26], І .В. Олександренко [27], А. В. Хмелевська, Г. М. Незборецька [28], О. Д. Щербань [29] та ін. Незважаючи на значні напрацювання вчених та практиків, залишаються дискусійними питання щодо сутності та складу власного капіталу.

Дослідження теоретичних основ формування, використання та управління власним капіталом підприємства вимагає, перш за все, розкриття сутності власного капіталу.

Базуючись на фундаментальній балансовій моделі (Актив = Пасив), світова теорія і практика надала ряд модифікацій інформаційного подання капіталу в балансі підприємства. Найбільш розповсюдженою є формула, за якою активи дорівнюють сумі власного капіталу та залучених коштів.

Коли підприємство ще не має зовнішньої заборгованості і придбаває майно за рахунок лише коштів власників, то розмір активів відповідає розміру власного капіталу і фундаментальна облікова модель балансу підприємства має вигляд:

$$
\text { Активи (Assets) = Власний капітал (Equity) }
$$

У випадку залучення підприємством коштів із зовнішніх джерел, фундаментальна облікова модель балансу є такою:

Активи (Assets) = Власний капітал (Equity) + Зобов'язання (Liabilities) (2)

Згідно 3 вищенаведеними формулами, величина власного капіталу підприємства визначається за залишковим принципом (активи мінус залучений зі сторони капітал). Саме 3 такої позиції трактує поняття «власний капітал» НП(С)БО 1 «Загальні вимоги до фінансової звітності», згідно з яким «власний капітал $є$ часткою в активах підприємства, що залишається після вирахування його зобов'язань» [30].

Залишковий принцип відповідає й Міжнародним стандартам фінансової звітності, адже згідно з п. 4.4 Концептуальної основи фінансової звітності [31], 
власний капітал визначається як частка в активах підприємства, яка залишається після того, як будуть погашені всі його зобов’язання. Міжнародні стандарти, на відміну від вітчизняних, трактують власний капітал як чистий капітал або чисті активи суб’єкта господарювання, оскільки вони є базовим джерелом фінансування.

Визначаючи зміст власного капіталу 3 позиції власності, варто враховувати, що власний капітал - це основний ризиковий капітал, власність підприємства, який не дає гарантованого права на прибуток, дивіденди. Щодо нього не встановлено чіткого графіка повернення коштів учасникам, інвесторам. До того ж часткова або повна втрата інвестованого в підприємство капіталу не призводить до юридичної відповідальності останнього перед власниками, засновниками [32, с.119].

Розкриття категорії «власний капітал», наведеної у національних стандартах бухгалтерського обліку, поділяють та висвітлюють у своїх працях багато вітчизняних науковців, зокрема: Ф. Ф. Бутинець [23], Л. Г. Ловінська [33], Л. К. Сук [34], Р. Л. Хомяк [35] та інші. 3 наведеного випливає, що зазначені науковці здійснювали уніфікацію трактування поняття «власний капітал».

Водночас, інша група науковців вважає, що визначення власного капіталу, сформоване за залишковим підходом, не розкриває у повній мірі його економічну сутність. Огляд наукових праць свідчить, що існують різні бачення даного поняття.

Так, В. В. Сопко трактує поняття «власний капітал» як суму власних коштів підприємства, отримана в результаті його діяльності, або від власників (учасників) у вигляді внесків, придбаних акцій, паїв тощо, або залишена на підприємстві безоплатно [36, с.248]. У визначенні наведено джерела формування власного капіталу, проте власний капітал визначено винятково як сукупність грошових надходжень, отриманих із різних джерел.

Сутність власного капіталу як «модифіковану величину заборгованості підприємства його засновникам у розмірі вартості активів, які ним 
забезпечуються〉 трактують А. В. Хмелевська та Г. М. Незборецька [28, с.193]. У визначенні передбачено, що сформований розмір власного капіталу $\epsilon$ гарантією того, що зобов'язання перед засновниками будуть погашені. Проте, передані засновниками ресурси у господарську діяльність підприємства $є$ власністю емітента корпоративних прав і не можуть трактуватись як певний вид зобов'язань.

На нашу думку, таке визначення не повною мірою розкриває зміст власного капіталу, оскільки джерелом власного капіталу підприємства, крім внесків власників є результати діяльності, тобто чистий прибуток.

О. Й. Вівчар та В. М. Саварин, а також Л. В. Івченко та Н. Л. Удовик трактують власний капітал, як суму фінансових ресурсів, які вкладаються для організації та фінансування господарської діяльності [24, с.147; 37, с.56]. Визначення власного капіталу сформоване з врахуванням функції заснування господарського товариства. Проте, власний капітал охарактеризовано виключно $з$ точки зору реінвестування прибутку у господарську діяльність підприємства, що є вужчим поняттям, адже розкриває економічний зміст тільки накопиченого власного капіталу.

Інший підхід до визначення власного капіталу підприємства подає О. Д. Щербань, який під власним капіталом розуміє фінансові ресурси підприємства без визначення строку повернення його засновникам у грошовій, матеріальній i нематеріальній формах, які залучаються до економічного процесу діяльності суб'єкта господарювання [29, с.737]. Згідно із даним підходом, можна визначати власний капітал як усі блага, що є наявними на підприємстві, забезпечують прибутковість і термін їх використання необмежений.

І. Л. Цюцяк пропонує підхід до визначення власного капіталу, залежно від джерел його формування, а саме: вкладений, ефективний, інший накопичений та коригуючий власний капітал. Вкладений капітал автор трактує як суму внесків засновників підприємств. Ефективний капітал виступає як накопичена сума чистого прибутку, що включається до статті власного капіталу 
«нерозподілений прибуток». Під іншим накопиченим капіталом розуміється капітал утворений внаслідок приросту (дооцінки) майна, а під коригуючим капіталом - сума заборгованості власників, або сума вилучених коштів власниками зі статутного капіталу [38, с.276-277]. 3 врахуванням такого підходу можна визначити власний капітал як суму коштів, внесену власниками, накопичену в результаті прибуткової діяльності та приросту вартості майна підприємства і скориговану на вартість вилученого та неоплаченого капіталу.

У результаті оцінки підходів до визначення власного капіталу, можна погодитись із точкою зору І. В. Олександренко, який обгрунтовує, що власний капітал - це сукупність коштів, що внесені власниками, безоплатно отримані від інших осіб та накопичені у процесі прибуткової діяльності [27, с. 213].

Кожен з етапів розвитку економічної думки характеризує різні погляди на власний капітал, проте всі вони єдині в наступному: власний капітал асоціюється зі здатністю приносити дохід. Більшістю науковців розглядається саме грошова форма власного капіталу, а теоретичні визначення власного капіталу переважно характеризують його склад і структуру, відображаючи порядок розрахунку даної економічної категорії.

Оцінку поняття «власний капітал» підприємства за різними категоріями представлено на рис.1.3.1.

Категорія «актив» являє собою економічні ресурси підприємства, під час використання яких підприємство очікує отримати прибуток. Активи можуть мати фізичну форму (основні засоби та ін.) або її не мати (патенти, авторські права та ін.), але обов'язково повинні бути підконтрольними підприємству. Активи відображені в балансі підприємства.

Категорія «документ» сприяє оцінці інформації про рух власного капіталу на підприємстві, що спрощує вивчення динаміки змін його величини. 


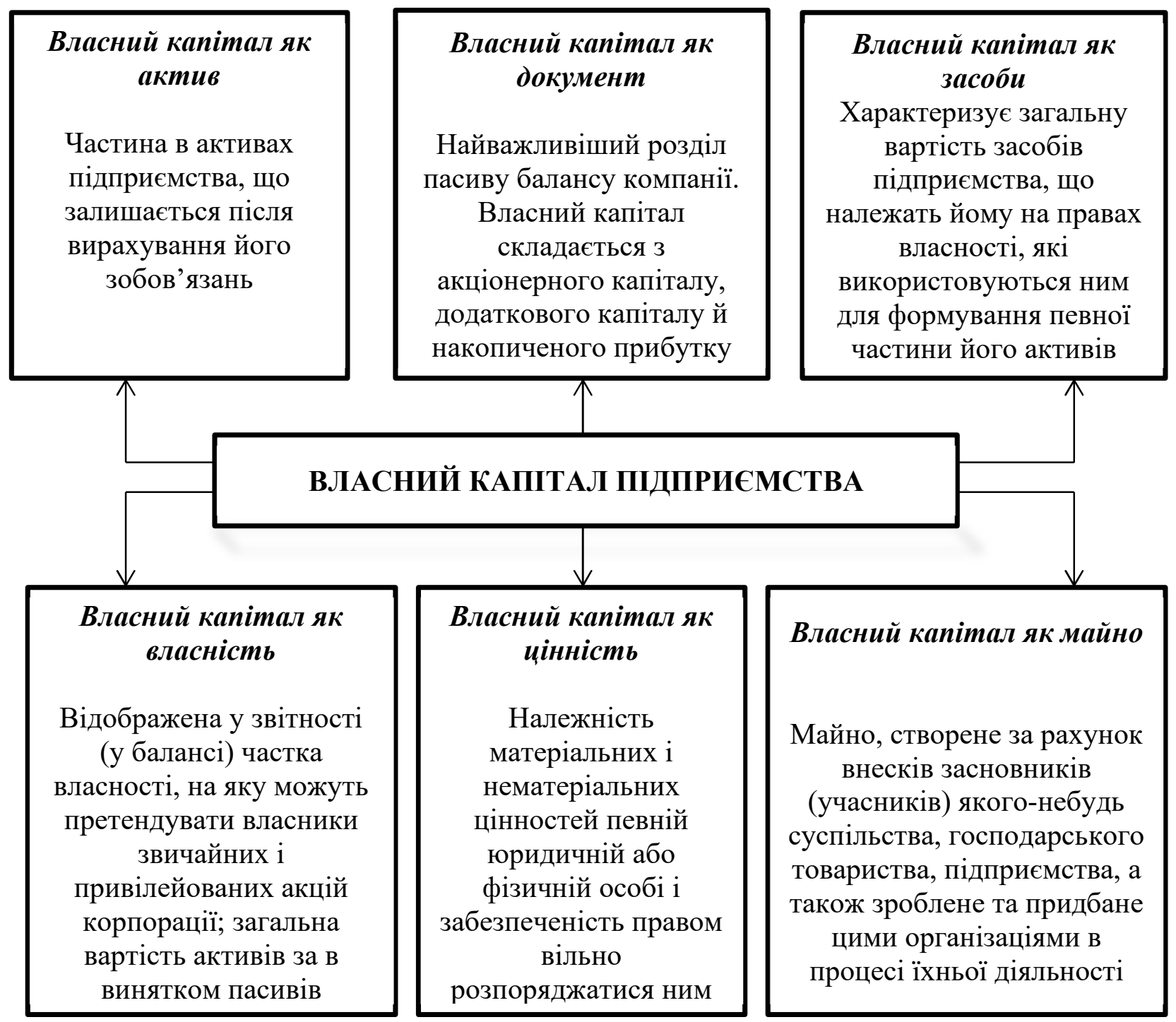

Рис. 1.3.1. Оцінка поняття «власний капітал підприємства» за різними категоріями [29, с.738]

Категорія «засоби» визначається за сукупністю матеріальних і фінансових ресурсів (кошти, основні засоби, засоби виробництва, тощо) для здійснення господарської діяльності.

Категорія «власність» акцентує увагу на економічних відносинах між власниками щодо часток активів підприємства.

Категорія «цінність» обумовлена матеріальними та нематеріальними цінностями, що мають вартість (ціну).

Під категорією «майно» розуміють сукупність матеріальних (основні засоби, сировина, тощо), нематеріальних (патенти, авторські права, тощо) i 
грошових цінностей, необхідних для задоволення потреб підприємства [39, с. $15]$.

Фінансовий стан суб'єкта господарювання вважається найкращим при умові превалювання частки власного капіталу в загальній структурі капіталу підприємства. Величина показника зумовлена як зовнішніми факторами середовища функціонування підприємства, так i видами його фінансовогосподарської діяльності.

Сутність капіталу також визначається його структурою. За чинним НП(С)БО 1 власний капітал поділяють на: зареєстрований (пайовий) капітал; капітал у дооцінках; додатковий капітал; резервний капітал; нерозподілений прибуток (непокритий збиток); неоплачений капітал; вилучений капітал [30].

Аналогічні складові виділяють й більшість вітчизняних науковців.

Зміст окремих складових власного капіталу, наведений у таблиці 1.3.1.

Таблиця 1.3.1

Характеристика складових власного капіталу підприємства

\begin{tabular}{|c|c|}
\hline $\begin{array}{l}\text { Складові } \\
\text { власного } \\
\text { капіталу }\end{array}$ & Зміст окремої складової \\
\hline $\begin{array}{l}\text { Зареєстрований } \\
\text { капітал }\end{array}$ & $\begin{array}{l}\text { Відображається зафіксована в установчих документах сума статутного } \\
\text { капіталу, іншого зареєстрованого капіталу, а також пайовий капітал у } \\
\text { сумі, яка формується відповідно до законодавства. }\end{array}$ \\
\hline $\begin{array}{l}\text { Капітал у } \\
\text { дооцінках }\end{array}$ & $\begin{array}{l}\text { Наводиться сума дооцінки необоротних активів } \mathrm{i} \text { фінансових } \\
\text { iнструментів }\end{array}$ \\
\hline $\begin{array}{l}\text { Додатковий } \\
\text { капітал }\end{array}$ & $\begin{array}{l}\text { Відображається емісійний дохід, вартість безкоштовно отриманих } \\
\text { необоротних активів, сума капіталу, який вкладено засновниками понад } \\
\text { статутний капітал, накопичені курсові різниці, які відповідно до } \\
\text { національних П(С)БО відображаються у складі власного капіталу та ін. }\end{array}$ \\
\hline $\begin{array}{l}\text { Резервний } \\
\text { капітал }\end{array}$ & $\begin{array}{l}\text { Наводиться сума резервів, створених відповідно до чинного } \\
\text { законодавства або установчих документів за рахунок чистого прибутку } \\
\text { підприємства }\end{array}$ \\
\hline $\begin{array}{l}\text { Нерозподілений } \\
\text { прибуток } \\
\text { (непокритий } \\
\text { збиток) }\end{array}$ & $\begin{array}{l}\text { Відображається накопичена сума чистого прибутку, що залишається на } \\
\text { підприємстві після розподілу або чистого збитку, в результаті отримання } \\
\text { негативного фінансового результату за звітний період }\end{array}$ \\
\hline $\begin{array}{l}\text { Неоплачений } \\
\text { капітал }\end{array}$ & $\begin{array}{l}\text { Відображається сума заборгованості власників (учасників) за внесками } \\
\text { до статутного капіталу. Ця сума наводиться в дужках і вираховується при } \\
\text { визначенні підсумку власного капіталу }\end{array}$ \\
\hline $\begin{array}{l}\text { Вилучений } \\
\text { капітал }\end{array}$ & $\begin{array}{l}\text { Господарські товариства відображають фактичну собівартість акцій } \\
\text { власної емісії або часток, викуплених товариством у його учасників. } \\
\text { Сума вилученого капіталу наводиться в дужках і підлягає вирахуванню } \\
\text { при визначенні підсумку власного капіталу }\end{array}$ \\
\hline
\end{tabular}


Що ж стосується міжнародної практики, то згідно 3 п. 4.20-4.23 Концептуальної основи фінансової звітності, до складу власного капіталу включаються:

- кошти, внесені акціонерами (зареєстрований або статутний капітал);

- нерозподілений прибуток;

- резерви, які відображають асигнування нерозподіленого прибутку (нормативні та ненормативні);

- резерви, які відображають коригування збереження капіталу [31].

Разом з тим, у міжнародній практиці структура власного капіталу залежить від національних стандартів кожної держави, політики іï розвитку та особливостей обліку. Ф. Ф. Бутинець зазначає, що у США, зокрема, до власного капіталу підприємств відносять: внесений (сплачений) капітал, нерозподілений дохід (накопичену суму доходу за вирахуванням усіх збитків та дивідендів, виплачених акціонерам), акціонерний капітал (суму інвестицій акціонерів $\mathrm{i}$ нерозподіленого доходу). Складовими власного капіталу підприємств Великобританії $\epsilon$ акціонерний капітал за звичайними акціями, резерви та довгострокова заборгованість. До власного капіталу на підприємствах Франції включають початковий внесок до акціонерного капіталу, який є постійною заборгованістю за відношенням до власника, а також фінансові результати та резерви. У Німеччині до складових власного капіталу відносять: статутний капітал, резервний капітал, передбачений прибуток (збиток) на наступний рік, річний прибуток (збиток). У Польщі власний капітал включає: статутний капітал, неоплачений капітал, додатковий капітал, резерви на переоцінку активів, інший резервний капітал, нерозподілений прибуток, чистий прибуток або збиток фінансового року [40, с.286-287]. А. М. Кадацька доповнює, що у Португалії, Туреччині та Фінляндії складові власного капіталу однакові, а саме: статутний капітал, додатковий капітал, нерозподілений прибуток (збиток), інший резервний капітал. Молдова, Естонія та Росія мають подібні до вітчизняних складові власного капіталу [41]. 
Отже, на підприємствах більшості зарубіжних країн складовими власного капіталу є: статутний (акціонерний) капітал, резервний капітал, нерозподілені прибутки. У міжнародній практиці складові власного капіталу визначаються рішенням власників щодо розподілу прибутку, створення певних фондових джерел (додаткового капіталу), операцій із власними акціями, тощо.

Важливо зазначити, що грунтуючись на класифікації власного капіталу формуються основні засади його обліку. Більшість науковців основною класифікаційною ознакою власного капіталу вважають джерела його утворення, проте певної однозначності щодо видів власного капіталу за цією ознакою немає. Нормативно-правовими актами чіткий розподіл власного капіталу за класифікаційними ознаками не проведений, тому доцільно розглянути точки зору науковців щодо ознак класифікації власного капіталу.

Так, С.Ф. Голов поділяє власний капітал на: вкладений (інвестиції акціонерів) та накопичений (нерозподілений прибуток акціонерів) [42]. Р. В. Варічева, дотримуючись аналогічної думки, до вкладеного відносить капітал, сформований як за рахунок внесків власників підприємства, так i внаслідок конвертування боргових зобов'язань підприємства в акції або частки (паї), а до накопиченого - капітал, сформований внаслідок господарської діяльності підприємства [43]. Аналогічно, О. В. Сфімова стверджує, що власний капітал можна розподілити на інвестований (вкладений власниками у фірму) i накопичений (створений понад той, що спочатку авансований власниками) [44].

У свою чергу, А. В. Хмелевська та Г. М. Незборецька структурними елементами власного капіталу підприємства виділяють зареєстрований та накопичений капітал. Автори вважають, що ці елементи змінюють величину власного капіталу, тобто модифікують величину заборгованості підприємства перед його засновниками, яка виникла у момент реєстрації суб'єкта господарювання у розмірі, що відповідає величині зареєстрованого капіталу [28].

В. В. Сопко пропонує розподіл власного капіталу здійснювати за іншим напрямом і поділяти його на:

- капітал власників (внесений засновниками), що складається 3 двох частин: зареєстрованого капіталу згідно з установчими документами за винятком 
неоплаченого i вилученого капіталу та незареєстрованого, тобто додатково вкладеного засновниками;

- капітал, створений у процесі діяльності, тобто отриманий у результаті діяльності суб’єкта (окрім результату від продажу акцій власної емісії), включає резервний капітал та нерозподілений прибуток (непокриті збитки);

- інший додатковий не вкладений власниками капітал, що формується за рахунок безоплатно отриманого майна, індексації майна тощо [36].

3 іншої точки зору до класифікації власного капіталу підходять Л. О. Бернадзіковська та І. В. Мукоїд, які поділяють власний капітал за формами фінансування на:

- інвестований (вкладений або сплачений капітал) - сума простих та привілейованих акцій за їхньою номінальною (оголошеною) вартістю, а також додатково вкладений капітал, який також може бути поділений за джерелами утворення;

- нерозподілений прибуток - частина чистого прибутку, що не була розподілена між акціонерами [45].

Дещо поглиблює вищенаведену класифікацію А. М. Кадацька, яка систематизує складові власного капіталу на:

- інвестований (вкладений або сплачений) капітал (сума простих та привілейованих акцій за їх номінальною вартістю, а також додатково вкладений капітал);

- дарчий капітал (додатковий капітал, отриманий підприємством від інших осіб у вигляді безоплатно одержаних активів);

- нерозподілений прибуток (частина прибутку, отриманого внаслідок ефективної діяльності підприємства, що була не розподілена між акціонерами, а знову інвестована у підприємство) [41].

Ф. Ф. Бутинець продовжує зазначений напрям класифікації, розширюючи його складові на:

- інвестований капітал (сума простих i привілейованих акцій за їх номінальною вартістю); 
- додатково вкладений капітал;

- подарований капітал (безоплатно отримані активи, безповоротна допомога);

- нерозподілений прибуток (частина прибутку, отриманого внаслідок ефективної діяльності підприємства, яка не була розподілена між акціонерами, власниками, а реінвестована у підприємство) [23].

Л. В. Коваль та В.В. Горбатюк стверджують, що підходи до поділу власного капіталу відповідно до джерел утворення залежать від того, чи здійснюються вони за вітчизняними, чи міжнародними стандартами. У вітчизняній практиці виділяють вкладений (інвестований) капітал, сформований за рахунок внесків власників підприємства та конвертування боргових зобов'язань в акції або частки (паї) та накопичений капітал, сформований внаслідок господарської діяльності підприємства. Своєю чергою, міжнародна практика передбачає поділ власного капіталу за джерелами утворення: вкладений (інвестований) капітал, тобто кошти, внесені власниками при організації підприємства (може змінюватися тільки за рахунок додаткових інвестицій або вилучень коштів власниками); зароблений капітал, тобто кошти, зароблені власниками і реінвестовані у діяльність підприємства (частина зароблених коштів може вилучатися власниками). Це спричиняє певні розбіжності у структуризації джерел формування капіталу, у компонентах фінансової звітності за МСФЗ та ПСБО [46].

О. Н. Коркушко теж вказує на невідповідність у систематизації власного капіталу за міжнародними та вітчизняними стандартами $\mathrm{i}$ пропонує, дотримуючись вимог МСФЗ, у структурі власного капіталу виділяти: інвестований капітал у складі статутного (зареєстрованого) і додаткового капіталу (емісійний дохід і курсові різниці, що виникли при інвестуванні капіталу); накопичений капітал у складі реінвестованого капіталу, нерозподіленого прибутку і набутого капіталу (приріст вартості майна від переоцінки основних засобів, безоплатне надходження майна, інвестиційні засоби власників, використані цільові кошти); резервний капітал у складі 
оцінних і витратних резервів; потенційний капітал - цільове фінансування, цільові надходження та доходи майбутніх періодів [47].

3 огляду на різні підходи вчених до структури та класифікації власного капіталу та враховуючи міжнародну практику його обліку узагальнена класифікація його складових наведена на рис. 1.3.2.

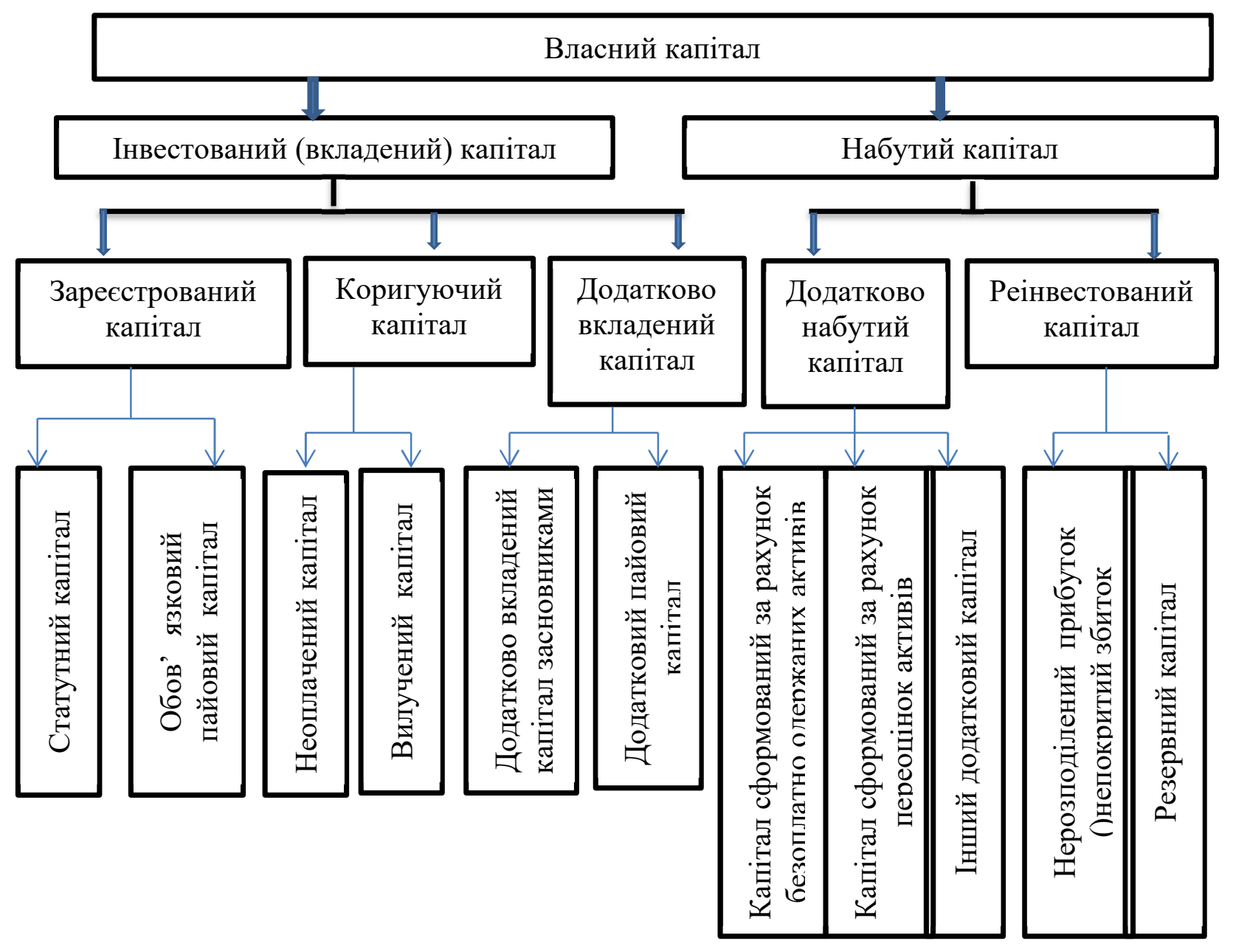

Рис. 1.3.2. Узагальнена структура власного капіталу [32, с.122].

Як зазначає I. Назарова, необхідність такої класифікації випливає з потреб збільшення інформативності фінансової звітності щодо відображення у ній власного капіталу. Зокрема, із фінансової звітності наразі важко зрозуміти, яку частку власного капіталу було реально внесено засновниками (власниками). Тому для відображення у звітності фактично внесеного (сплаченого) засновниками капіталу запропоновано використовувати показник «Інвестований (вкладений) капітал». Він має включати зареєстрований капітал, до якого 
входять суми статутного та обов'язкового пайового капіталу (відображення за даною статтею пайового капіталу загалом можна вважати нелогічним, оскільки він на даний час враховує й додатковий пайовий капітал, що не відповідає природі зареєстрованого капіталу) за виключенням коригуючого (негативного) неоплаченого та вилученого капіталу [32, с.123].

До інвестованого капіталу слід також відносити додатково вкладений капітал (капітал, інвестований власниками, засновниками, учасниками понад зареєстровану суму) та додатковий пайовий капітал.

Власний капітал слугує не лише основою створення підприємства, але й фактором його стабільної та ефективної діяльності, конкурентоспроможності та інвестиційної привабливості. Для вирішення питань, пов’язаних із формуванням та раціональним використанням власного капіталу першочерговим завданням $\epsilon$ визначення джерел створення власного капіталу та забезпечення його зростання. Збільшення власного капіталу забезпечується постійним моніторингом факторів його зміни, які є базою формування управлінських рішень і практичної їх реалізації.

Створення та ефективне функціонування суб'єкта господарювання неможливе без достатньої величини власного капіталу, який утворюється за рахунок внесків власників при його створенні. Проте, формування капіталу підприємства передбачає часткову втрату власником прямого зв’язку 3 капіталом, оскільки він фактично набуває статус власного капіталу підприємства, а не власника.

Оскільки власний капітал підприємства - кошти, які вкладаються для організації та фінансування господарської діяльності, то успішна, рентабельна робота підприємства, його висока конкурентоспроможність на ринку, фінансова стійкість забезпечуються при умові, коли власний капітал становить більшу частину його фінансових ресурсів.

Важливу роль в управлінні капіталом підприємства відіграє не тільки забезпечення ефективного використання вже накопиченої його частини, а й 
формування власних фінансових ресурсів, які є базою для майбутнього розвитку суб'єкта господарювання.

Власні фінансові ресурси класифікують за певними джерелами (табл. 1.3.2).

Таблиця 1.3.2

Джерела формування власних фінансових ресурсів підприємства

\begin{tabular}{|l|l|l|}
\hline $\begin{array}{l}\text { № } \\
3 / п\end{array}$ & Джерела & \multicolumn{1}{|c|}{ Склад джерел } \\
\hline 1. & Внутрішні & $\begin{array}{l}\text { 1. Прибуток, що залишається у розпорядженні підприємства. } \\
\text { 2. Амортизаційні відрахування від основних засобів і нематеріальних } \\
\text { активів. } \\
\text { 3. Інші внутрішні джерела формування власних фінансових ресурсів. }\end{array}$ \\
\hline 2. & Зовнішні & $\begin{array}{l}\text { 1. Залучення додаткового, пайового або акціонерного капіталу. } \\
\text { 2. Одержання підприємством безоплатної фінансової допомоги. } \\
\text { 3. Інші джерела формування власних фінансових ресурсів. }\end{array}$ \\
\hline
\end{tabular}

Основним внутрішнім джерелом формування власних фінансових ресурсів $\epsilon$ прибуток, що залишається в розпорядженні підприємства. Він забезпечує приріст власного капіталу i, відповідно, зростання ринкової вартості підприємства.

До складових внутрішніх джерел відносять і амортизаційні відрахування, особливо на підприємствах із значною вартістю власних основних засобів і нематеріальних активів. Потрібно зауважити, що на збільшення величини власного капіталу вони не впливають, а лише є засобом його реінвестування.

Інші внутрішні джерела не відіграють значної ролі у формуванні власних фінансових ресурсів підприємства.

Основним зовнішнім джерелом формування власних фінансових ресурсів підприємства $є$ залучення додаткового пайового капіталу (додаткові внески до зареєстрованого (пайового) капіталу) або акціонерного капіталу (додаткова емісія та реалізація акцій).

Для окремих державних підприємств зовнішнім джерелом формування власних фінансових ресурсів виступає надана їм безоплатна фінансова допомога. 
Іншими зовнішніми джерелами можуть бути безплатно передані підприємству матеріальні та нематеріальні активи, що включаються до складу майна і відносяться на баланс.

Фінансові ресурси підприємства формуються за рахунок власних та запозичених коштів i основними їх елементами $є$ : власний капітал, забезпечення майбутніх витрат та платежів, довгострокові i поточні зобов'язання.

Величина власного капіталу $є$ алгебраїчною сумою його складових елементів:

- зареєстрованого (пайового) капіталу, який показує зафіксовану в установчих документах загальну вартість активів, що $є$ внеском власників (учасників) до статутного й іншого зареєстрованого капіталу, пайового капіталу підприємства відповідно до законодавства й установчих документів, а також внесків до оголошеного, але ще незареєстрованого статутного капіталу;

- капіталу у дооцінках, який відображає суму дооцінки необоротних активів і фінансових інструментів;

- додаткового капіталу, як суми, на яку вартість реалізації випущених акцій перевищує їхню номінальну вартість;

- резервного капіталу, що показує суму резервів, створених відповідно до чинного законодавства або установчих документів за рахунок нерозподіленого прибутку підприємства;

- нерозподіленого прибутку (непокритого збитку), тобто суми прибутку, яка реінвестована у підприємство, або суми непокритого збитку;

- неоплаченого капіталу, як суми заборгованості власників (учасників) за внесками до капіталу;

- вилученого капіталу, який показує фактичну собівартість акцій власної емісії або часток, викуплених товариством у його учасників;

- забезпечень майбутніх витрат і платежів;

- цільового фінансування і цільових надходжень. 
Отже, початкове формування фінансових ресурсів відбувається при створенні підприємства за рахунок статутного капіталу. Внутрішнє фінансування здійснюється за рахунок коштів, одержаних у процесі діяльності підприємства, а зовнішнє фінансування - це кошти, не пов'язані $з$ його діяльністю. До них, зокрема, належать: кошти, які мобілізуються на фінансовому ринку (продаж акцій, облігацій, кредит; операції з валютою та дорогоцінними металами; проценти і дивіденди за цінними паперами інших емітентів); кошти, які підприємство одержує в порядку перерозподілу (державні бюджетні субсидії, страхові відшкодування, фінансові ресурси, що поступають від галузевих структур, асоціацій, концернів) [34, с. 431].

На думку І. В. Олександренко [27], власний капітал можна поділяти за джерелами формування на початковий і той, що створюється в результаті діяльності підприємства.

До джерел створення початкового власного капіталу автор відносить: внески засновників на період створення підприємства (формується зареєстрований капітал); вартість безкоштовно отриманого майна (формується додатковий капітал); суму перевищення ринкової вартості реалізованих акцій над їх номінальною вартістю у період створення підприємства (формується додатковий капітал); суму капіталу, вкладену засновниками початково понад суму статутного капіталу (формується додатковий капітал).

До джерел створення власного капіталу в результаті діяльності підприємства I. В. Олександренко відносить: чистий прибуток (формується нерозподілений прибуток та резервний капітал); вартість дооцінки майна (формується капітал у дооцінках); суму накопичених курсових різниць (формується додатковий капітал); вартість безоплатно отриманого майна (формується додатковий капітал); внески учасників в результаті додаткової емісії акцій чи збільшення статутного капіталу (формується зареєстрований капітал) [27, с.214-215].

Сутність будь-якої категорії проявляється через функції, які вона виконує, тому доцільно розглянути функції власного капіталу (рис.1.3.3). 


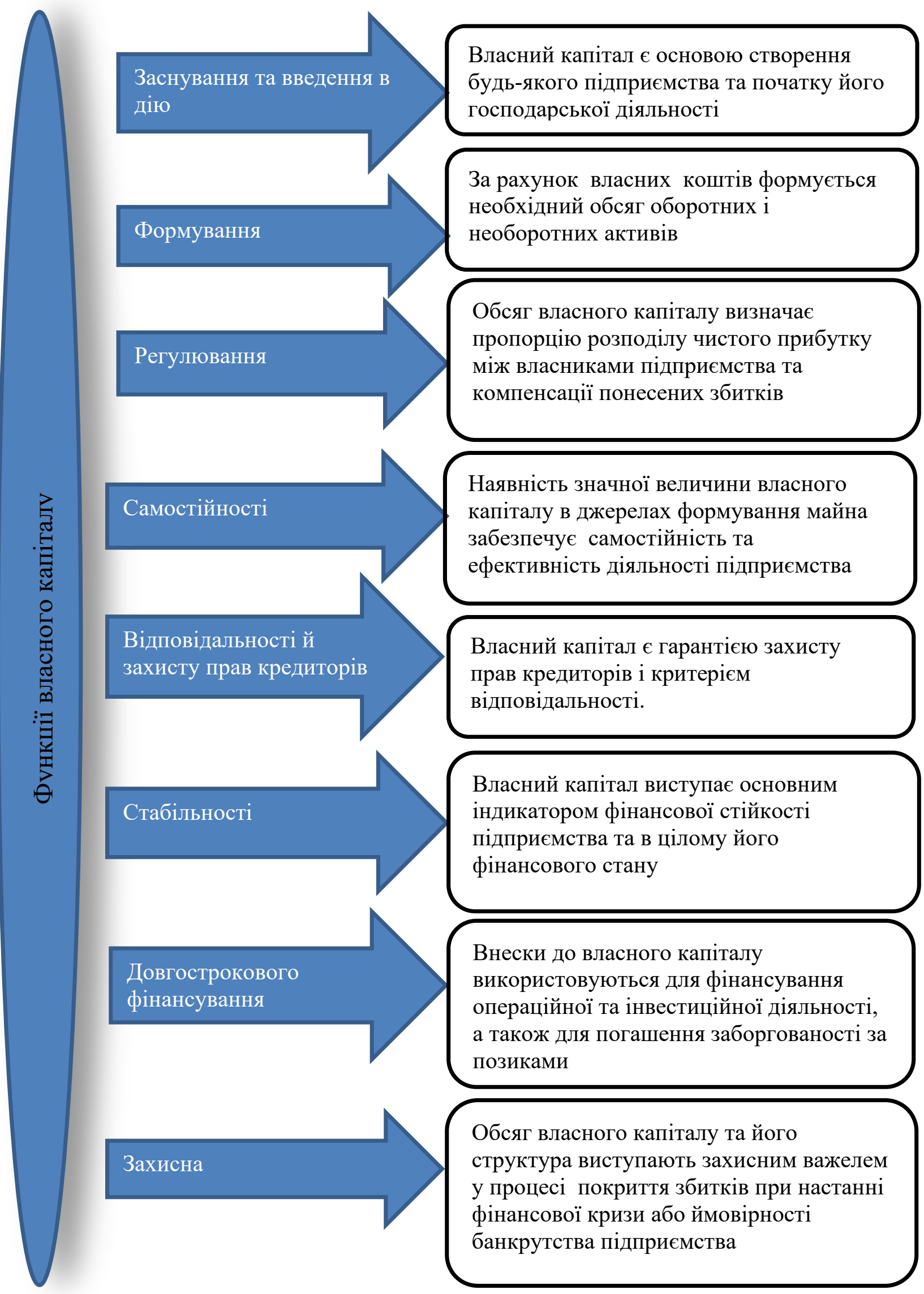

Рис. 1.3.3. Функції власного капіталу підприємства. 
Управління капіталом на підприємстві повинно грунтуватись на створенні інформаційної системи обліку, контролю капіталу, а також його аналізу відповідно до стратегії та оперативних завдань підприємства.

Управління власним капіталом - це система узгодження елементів, задач, принципів, які займаються регулюванням процесу розробки та реалізації управлінських рішень щодо руху власного капіталу в заданих параметрах [48, c.47].

Управління щодо формування та використання власного капіталу підприємства потребує постійного відстеження змін у його розмірі та структурі.

Це здійснюється шляхом ретельного ведення бухгалтерського обліку господарських операцій, що пов'язані зі змінами у розмірі та складі власного капіталу, і відображення відповідних даних в основних формах фінансової звітності підприємства: балансі (звіті про фінансовий стан), а також у звіті про власний капітал.

Метою управління власним капіталом є забезпечення формування власного капіталу, підтримка його достатності та ефективності використання [49, с. 98].

У широкому розумінні, система управління капіталом - це сукупність взаємопов'язаних та взаємодіючих елементів, до яких відносять підходи щодо управління капіталом, базові положення системи управління капіталом, забезпечення управління капіталом та складові системи управління капіталом $[48$, c.47].

Формування системи управління власним капіталом доцільно здійснювати згідно із сучасними концепціями побудови складних систем менеджменту, основу яких складають: комплексність охоплення напрямків впливів управління; розподіл управління; безперервність здійснення прогнозних і управлінських оцінок; послідовне застосування кількісних підходів для вирішення завдань аналізу та прогнозування; розвинене інформаційне забезпечення всіх або найважливіших етапів прийняття рішень.

Система управління капіталом підприємства складається із двох функціональних підсистем: управління щодо формування власного капіталу та 
управління щодо його використання. Під управлінням формуванням капіталу слід розуміти сукупність процесів підготовки й здійснення керуючих впливів, які спрямовані на досягнення оптимальної структури капіталу та обсягів оптимального співвідношення різних форм капіталу при прийнятному рівні ризиків. А під управлінням використання капіталу слід розуміти сукупність процесів підготовки й здійснення керуючих впливів, які спрямовані на максимально ефективний розподіл за пріоритетними напрямами складових власного капіталу.

Напрями управління власним капіталом підприємства подані на рис. 1.3.4.

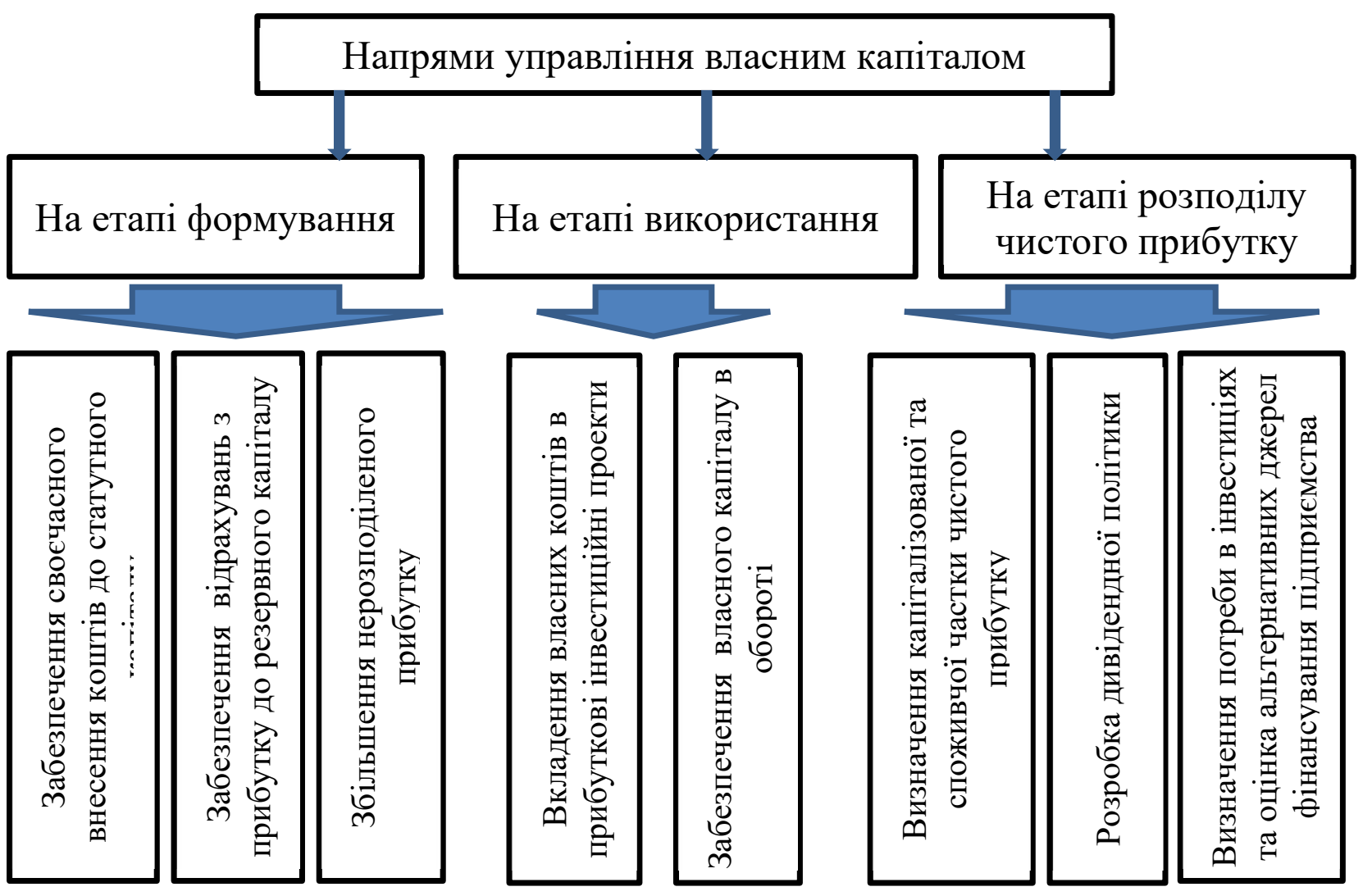

Рис. 1.3.4. Напрями управління власним капіталом підприємства

Для ефективного формування $\mathrm{i}$ використання власного капіталу підприємства, а також створення ефективної системи управління власним капіталом до ії підсистем, на думку Є. В. Міщука, можна віднести:

- оцінку реальної ринкової вартості підприємства та дієвості його фінансово-господарської діяльності; 
- визначення оптимальної частки власного капіталу у структурі капіталу підприємства.

Враховуючи функціональне призначення власного капіталу, на мікрорівні його позитивними рисами є: простота залучення й використання; висока дохідність та здатність генерувати прибуток; зростання конкурентоздатності підприємства.

Якщо підприємство використовує лише власний капітал, то негативними його рисами є:

- обсяг власного капіталу обмежений, тому підприємство може втратити можливість розширення діяльності та збільшення рентабельності за рахунок залучення позикових коштів за допомогою ефекту фінансового левериджу;

- часто власний капітал, залучений із зовнішніх джерел, має вищу вартість порівняно із позиковим капіталом [48, с.48-49].

Отже, одним із основних питань при управлінні власним капіталом має бути визначення його оптимальної структури. Оптимальна структура капіталу - це таке співвідношення використання власних i залучених джерел, за якого забезпечується найбільш ефективна пропорційність між коефіцієнтом фінансової рентабельності та коефіцієнтом фінансової стійкості, тобто максимізується його ринкова вартість.

На думку В.О. Подольської та О.В. Яріш, оптимізація структури капіталу передбачає співвідношення між власним i позиковим капіталом, за якого забезпечується найбільша ефективність пропорційність між дохідністю та фінансовою стійкістю підприємства [50, с. 355].

Процес визначення оптимальної структури повинен відбуватися безпосередньо перед початком етапу його формування, але аналіз його оптимальності повинен проводитись періодично, адже вибір раціонального співвідношення власних та позикових коштів залежить від внутрішніх та зовнішніх чинників.

Важливим моментом у створенні ефективної системи управління власним капіталом є розробка концепції збереження власного капіталу. 
Зважаючи на динаміку зовнішнього середовища та підвищення ринкової конкуренції, часто за основну мету підприємства ставлять збереження i примноження власного капіталу, що забезпечить фінансову стійкість підприємства на ринку. Необхідність забезпечення величини власного капіталу на певному рівні визначена міжнародними стандартами бухгалтерського обліку як концепція збереження власного капіталу, орієнтована на провадження безперервності господарської діяльності підприємства. Важливий показник збереження власного капіталу - це «чисті активи». Він розраховується як різниця між величиною активів підприємства та обсягом його зобов'язань.

Покращення системи менеджменту передбачає, зокрема, здійснення моніторингу системи управління власним капіталом.

Моніторинг системи управління власним капіталом - процес систематичного або безперервного збору інформації про параметри управління власним капіталом, яка може бути використана для поліпшення процесу прийняття рішення, а також як інструмент зворотного зв'язку 3 метою ефективного управління власним капіталом [48, с.48].

Постійний моніторинг системи управління власним капіталом дозволяє:

- виявляти проблеми навколишнього економічного середовища, вирішення яких передбачає вироблення напряму дій на майбутнє;

- забезпечувати зворотний зв'язок між попередніми успіхами і невдачами певної системи управління капіталом;

- встановлювати відповідність обраним критеріям ефективності.

Ефективне управління власним капіталом забезпечується своєчасним отриманням за допомогою сучасних програмних продуктів точних даних про темпи його зростання в результаті господарських операцій, спричинених певними факторами: рентабельністю обороту, оборотністю капіталу, мультиплікатором капіталу, часткою відрахувань чистого прибутку на розвиток виробництва, тощо, а також швидкістю обробки великих обсягів інформації та використанням складних алгоритмів розрахунків. 
Процес управління власним капіталом залежить від внутрішніх та зовнішніх особливостей ведення бізнесу та чіткого виокремлювання ризиків та можливостей.

До основних внутрішніх факторів, які впливають на процес управління власним капіталом відносять: специфіку виробництва, особливості збуту, обсяги та структуру майна підприємства, джерела формування позикового капіталу, наявність інноваційних технологій.

До факторів впливу зовнішнього середовища на ефективність управління власним капіталом підприємства належать: податкове регулювання держави; кредитна, цінова та валютна політика; рівень інфляції; експортний та конкурентоспроможний потенціал галузі та інші.

Кінцевим етапом управління капіталом на підприємстві повинна стати розроблена система показників стану i використання капіталу, зокрема: співвідношення власного, позиченого й залученого капіталу, норматив власного оборотного капіталу, плече фінансового важеля (фінансовий леверидж), тощо.

Отже, ефективне управління власним капіталом дозволить збільшувати його величину та сприяти зростанню ринкової вартості підприємства. У процесі прийняття управлінських рішень важливо більше уваги спрямовувати на фактори збільшення чистого прибутку, що дозволить у кінцевому підсумку збільшити нерозподілений прибуток та частку власних джерел у фінансуванні активів. 


\section{SECTION 2. DEMOGRAPHY, ECONOMY, SOCIAL POLICY}

DOI 10.46299/ISG.2021.MONO.ECON.II-50-56

\section{1 Аналіз соціально-экономічних проблем забезпечення безпеки дорожнього руху в Украӥні}

У 2011 p. році портал Autoblog опублікував інформацію про те, що кількість автомобілів у світі переступила позначку 1 млрд. У 2015p. ця цифра сягнула 1,2 млрд., а за прогнозами Navigant Research у 2035p. ця позначка досягне 2 млрд. В сучасних умовах автомобілізація розвивається над стрімкими темпами. Та проблема безпеки руху на дорогах існує ще з 1831 року, коли в Лондоні стався перший дорожньо-транспортний випадок. Його причиною стало використання возів 3 паровими двигунами в епоху кінного транспорту, а саме, водій об’іжджаючи дітей що гралися на дорозі, врізався в стіну будинку, в результаті чого загинув. I хоча сучасні автомобілі більш потужні, швидкісні, економічні і ергономічні, обладнані поясами та подушками безпеки, кількість ДТП щороку невпинно зростає.

Першість автомобільного парку за провідними розвинутими країнами світу, в середньому в країнах Західної Свропи на 1000 жителів зареєстровано від 400 до 700 легкових автомобілів. Для порівняння в Україні в 2016 році на 1000 жителів зареєстровано 202 легкових автомобілі, у 2019р. ця позначка уже становила 257 авто. При всьому цьому рівень аварійності та кількість постраждалих в Україні значно перевищують відповідні показники більшості світових країн. Так у США з кожної 1000 постраждалих гине 13 осіб, в Англії 17, в Німеччині - 22, а в Україні - 180. За прогнозами Всесвітньої організації охорони здоров'я і Світового банку, при неприйнятті ефективних попереджувальних заходів на державному рівні, смертність внаслідок ДТП в 2025 році займе третє місце серед причин смертності та інвалідності в країні.

Проблема безпеки дорожнього руху має велике народногосподарське значення, з одного боку - через надзвичайно великий розмір економічних втрат, викликаних аварійністю, а 3 іншого - складністю і багатоплановістю 
організаційних, матеріально-технічних, фінансових і багатьох інших задач щодо іiі вирішення.

Статистичні дані свідчать що причинами ДТП стають:

- помилкові дії людини (водія, пішохода) - 60-70\%;

- невідповідність дорожніх умов та характеру руху - 20-30\%;

- технічні несправності автомобіля 10-15\%.

23 грудня 2015p. Комітетом ВР з питань транспорту було ініційовано проведення парламентських слухань "Стан і перспективи забезпечення в Україні безпеки дорожнього руху" на яких було зазначено, що причиною високого травматизму та смерті людей внаслідок дорожньо-транспортних пригод в Україні $є$ відсутність комплексної державної політики у сфері безпеки дорожнього руху та ефективних механізмів іiі реалізації. По-перше, немає цілісного розуміння системи організації безпеки дорожнього руху, по-друге, не встановлена відповідальність за реалізацію програм та досягнення конкретних показників.

Під цілісним розумінням системи організації безпеки дорожнього руху слід розуміти постійну роботу з усіма учасниками дорожнього руху (пішоходи, велосипедисти, мотоциклісти, водії власного транспорту, водії комерційного транспорту, інші учасники) із застосуванням системного підходу за такими напрямами: вдосконалення системи управління безпекою дорожнього руху; будівництво безпечної дорожньої інфраструктури; вдосконалення механізмів активної та пасивної безпеки автомобілів; зміна поведінки учасників дорожнього руху; надання своєчасної і якісної медичної допомоги потерпілим у дорожньотранспортних пригодах [51,52] .

Та все ж незважаючи на рекордно низькі показники безпеки на дорогах, запровадження урядом різноманітних програм як на державному так і на місцевих рівнях спрямовані на підвищення безпеки дорожнього руху, регулювання транспортних потоків на дорогах, підвищення рівня безпеки але суттєвого покращення умов дорожнього руху не спостерігається. 
Варто зазначити, що $\mathrm{CC}$ та ООН приділяє надзвичайно багато уваги питанню регулювання дорожнього руху в країнах своїх членах та світу в цілому. Прийнято багато резолюцій та рекомендацій, які містять в собі комплексний підхід до забезпечення безпеки дорожнього руху в світі, який сформований на базі багаторічних досліджень, практик та набутого досвіду в цій сфері. Серед яких: прийнята 2010p. Резолюція Генеральної Асамблеї ООН 64/255 «Про проголошення Десятиліття дій з безпеки дорожнього руху на 2011-2020 роки». 11 травня 2011p. Україна офіційно приєдналась до даної Резолюції взявши на себе зобов'язання виконувати даний план на національному та регіональних рівнях [53]. КМ України у 2018р. схвалено Національну транспортну стратегію на період до 2030року. Основною метою якої $є$ розвиток безпечного та екологічного транспорту.

СС в свою чергу закликає проводити ефективну політику в галузі освіти учасників дорожнього руху. Наявність високих штрафів (від 250 до 1000 євро за керування автомобілем в стані алкогольного або наркотичного сп'яніння), камери відео спостереження, які фіксують перевищення швидкості мобілізують водіїв та зобов'язують дотримуватись правил дорожнього руху. Також, наприклад, у Німеччині вас можуть оштрафувати:

- за заниження швидкості на автобанах (за занадто повільну їзду);

- перетин білої суцільної лінії;

- незаконне паркування або паркування без оплати;

- розмова по мобільному телефону;

- не пристебнутий водій і пасажири в машині;

- відсутність крісла для дитини, при поїздці з дітьми;

- затоноване скло;

- викидання сміття з транспортного засобу;

- невідповідність гуми на шинах автомобіля погоднім умовам;

- самостійний ремонт автомобіля на автомагістралі.

Більшість перерахованих вище правил діють і в Україні, а підписавши угоду про вступ до ЄС ми прийняли на себе зобов'язання неухильно виконувати 
їх. Та все ж недосконалість системи штрафних санкцій, відсутність достатнього контролю дозволяють водіям дотримуватись правил БДР не в повній мірі.

Важливим $є$ те, що у всіх країнах $Є С$ на штрафи нараховується пеня (що також запроваджені і в Україні), наприклад у Греції при порушенні правил обгону водій зобов'язаний сплатити 350 євро, при не оплаті в десяти денний термін вказана сума зростає вдвічі.

У країнах Свропи системи автоматичної фіксації порушень Правил д орожнього руху використовуються десятиліттями і довели свою ефективніс ть. В Україні відповідний закон, який передбачає відповідальність водіїв за порушення ПДР, зафіксованих у автоматичному режимі, був ухвалений тільки на початку 2014року. I лише у липні 2016p. в Києві відбувся запуск пілотного проекту роботи системи автоматичної фіксації порушень правил дорожнього руху. Адже статистика говорить, що кожен другий водій нашої країни регулярно порушує правила дорожнього руху щодо швидкісного режиму [54,55]. Також, в Україні у 2020p. почили значно зростати штрафи за порушення ПДР у 2021р. вони стають ще жорсткіші. А саме:

- штраф за нетверезе керування 17 000грн.;

- штраф з водіїв які спричинили ДТП перебуваючи у нетверезому стані, що призвело до травмування людей 51000 грн. - 85000 грн. (раніше посилення відповідальності за такі дії не передбачалися);

- штраф за перевищення швидкості більше як 50 км/год. 1700 грн.

- за перебування в автомобілі не пристебнутим 510 грн.

Варто зазначити, що не лише водії а й пішоходи обкладаються штрафами за порушення правил дорожнього руху.

Остаточний соціально-економічний ефект від ведення нових штрафів і посилення відповідальності можна буде зрозуміти лише після перших судових справ в яких буде доведено вину водія та стягнено відповідні кошти. Зі збільшенням відповідальності водіїв має збільшитись уважність та відповідальність патрульних за правильну оцінку ситуації на дорогах та 
оформлення відповідних протоколів, адже від цього і залежить подальший розгляд справи у суді.

Як зазначає С. Товстуха державний потенціал із забезпечення безпеки дорожнього руху, наприклад у Німеччині, грунтується також на потужному потенціалі і діяльності громадських організацій та засобів масової інформації у цій сфері. Вагому роль виконує також Рада з безпеки дорожнього руху, яка об'єднує більше як 200 організацій є не комерційним об'єднанням. Фінансування Ради здійснюється частково за рахунок Федерального уряду, частково за рахунок Фонду соціального страхування від нещасних випадків, членських внесків та інших доходів. Рада безпеки дорожнього руху розробляє програми 3 підвищення безпеки дорожнього руху, орієнтовані на цільові групи населення, проводить тренінги для водіїв різних категорій транспортних засобів [56].

В Україні також існує достатньо розгалужена правова база в галузі транспорту та безпеки дорожнього руху. Втім, на нашу думку, ця база пот ребує суттєвого вдосконалення, насамперед, в частині адаптації внутрішньо го законодавства і правових актів до норм і стандартів СС. Не зважаючи на те, що ще у 2004 році було прийнято загальнодержавну програму адаптаці ї законодавства України до законодавства Європейського Союзу, на даний час ця програма повністю не виконана. Зокрема, у сфері автомобільного т ранспорту та безпеки дорожнього руху до внутрішнього законодавства досі не адаптовано низку важливих Деректив і Регламентів Ради ЄС. Як зазначає ВГО “Асоціація безпеки дорожнього руху” законодавство нашої країни настільки не досконале, що в ньому не міститься навіть базових визначень того, що в державі має розумітися під поняттями “безпека дорожнього руху” та “забезпечення безпеки дорожнього руху”. Також, відсутні визначення основних принципів забезпечення безпеки дорожнього руху, які повинні встановлювати загальні засади здійснення державного будівництва у сфері безпеки руху. Як наслідок, спостерігається розпорошення правового регулювання, що обумовлює прийняття суперечливих державницьких рішень [57,58]. 
В результаті неефективної державної політики в Україні в напрямку забезпечення безпеки дорожнього руху:

1. Відсутня ефективна взаємодія органів влади і громадських організацій в напрямку забезпечення безпеки дорожнього руху;

2. Корумпована система підготовки учасників дорожнього руху. Низький рівень водійської майстерності та дорожньої дисципліни;

3. Низький рівень інформаційно-технічного забезпечення безпеки дорожнього руху;

4. Не високі експлуатаційні показники автомобільних доріг та вулиць.

5. Негативна тенденція до щорічного збільшення кількості смертельних випадків на дорогах.

Отже з метою проведення ефективної державної політики в галузі забезпечення дорожнього руху рекомендуємо створення механізму реформування закоренілої системи, удосконалення адміністративного законодавства 3 залученням фахівців, експертів та аналітиків. А саме формування ефективних механізмів державного управління у сфері безпеки дорожнього руху, що адаптовані до сучасних викликів та загроз що виникають у цій сфері. І хоча система штрафних санкцій які ведені призводить до збільшення відповідальності за порушення правил дорожнього руху, зразу виникає потреба максимального виключення корупційної складової, ефективним на нашу думку $€$ реалізація проекту впровадження передових технологій та новітніх технічних засобів, комплексів та систем керування й нагляду за дорожнім рухом для забезпечення його безпеки. Зокрема, у Великобританії встановлено понад 6 тис. камер фіксації порушень, у Німеччині - 5 тис., у Франції - 3 тис., а в США - 4 тис. камер.

Варто зазначити, що в країнах Західної Європи не порушувати правила дорожнього руху є престижно, це є результатом ефективної державної політики. Мало хто з жителів наприклад Німеччини дозволить собі сісти п'яним за кермо. До того ж, якщо на протязі першого року після отримання прав водій порушив правила дорожнього руху, його знову відправляють на перенавчання. Тому 
важливо створити механізм розвитку інституту свідомого громадянського суспільства, де буде відбуватися популяризація дотримання правил дорожнього руху, а саме, проведення різноманітних заходів та компаній, лекцій і семінарів у школах та університетах. Формування свідомої молоді з заохоченням до того, що водіння за правилами це не лише менш травматично, але й модно. А тому одним із пріоритетів транспортної політики уряду має бути підвищення безпеки дорожнього руху.

Для кожного суспільства і окремої людини зокрема, велике значення має дотримання норм та правил і це стосується не лише дотримання правил дорожнього руху, а й взагалі виховання правильних етичних норм поведінки. А тому проява високої культури на дорозі, призведе до мінімізації дорожньотранспортних пригод та їх негативних соціальних наслідків. 


\section{SECTION 3. ECONOMICS OF INDUSTRIES}

DOI 10.46299/ISG.2021.MONO.ECON.II-57-64

\section{1 Особливості формування контейнерних потоків у глобальному ринку морської торгівлі}

Динаміка і структура основних параметрів глобального ринку морської торгівлі зумовлюється двома групами факторів. Перша група формується зі стратегії пріоритетів так званих розвинених країн у формуванні продукції 3 високою доданою вартістю при жорсткому обмеженні власних сировинних i енергетичних ресурсів. Ця умова обмеження і зумовлює імпортні вантажопотоки цих країн.

У свою чергу ця група країн виробляє товари з високою доданою вартістю, які формують їх експортний потенціал і забезпечують позитивний статус платіжного балансу. Висока вартість оборотного капіталу, закладеного в цій групі товарів, і вимагає транспортних технологій, що забезпечують необхідну швидкість доставки. Саме тому в 60-і роки минулого століття зародилася технологія доставки вантажів на основі великовантажних контейнерів. Вони в свою чергу скорочують витрати на тару і упаковку, на зберігання вантажів в закритих складах і забезпечують швидкість вантажно-розвантажувальних робіт. Якщо до контейнеризації навантаження генеральних вантажів не перевищувало кілька тон на годину, то перевантаження одного TEU коливається в залежності від порту від двох до п'яти хвилин. При цьому слід враховувати місткість контейнера до 15 тон вантажу.

Все це зумовило прискорене формування спеціалізованих суден в кінці 20 століття і перехід на суперконтейнери місткістю до 20 тисяч TEU на початку 20-x років 21-го століття.

Широко визнано, що існують міцні відносини між контейнерними перевезеннями і ланцюгами поставок, які призводять до появи значних кластерів логістичних фірм навколо великих контейнерних портів.

Аналіз стану сучасних закономірностей розвитку вантажопотоків світової торгівлі показує стійкі темпи зростання міжнародної торгівлі 3 
використанням транспортних суден. При цьому слід зазначити, що за останні 30 років загальний обсяг формування вантажопотоків в минулому столітті зріс в 2,3 рази, тоді як за період з 2000 р. по наш час приріст за темпами склав майже подвійний коефіцієнт, але фізично виріс з 5,9 мільярда тон до 12 мільярдів тон. При цьому істотно змінилася структура вантажопотоків. У 2000 році танкерним флотом було перевезено 2,2 мільярда тон і 2,6 мільярда тон суховантажів.

В даний час обсяги суховантажів перевищують обсяги перевезення енергетичних і сировинних вантажів, що і зумовлює вимогу щодо техніко економічного розвитку цієї групи суден.

Головними критеріями формування цього суднопотоку є мінімізація стоянки в торгових портах і більш висока швидкість доставки вантажів на маршруті.

Зазначена особливість структуризації вантажопотоків світової торгівлі зумовлює характер використання науково-технічного прогресу при виборі суден найбільш ефективного типорозмірного ряду. Фактично в даний час проведена стандартизація типів суден у відповідності до їх вантажопідйомності, що зумовлює оптимізацію розстановки за традиційними маршрутами. Одночасно підвищується частка великотоннажного флоту, чому сприяла реконструкція Панамського і Суецького каналів.

Певні зміни в структурі вантажопотоків, а також маршрутизації, зумовленої характером розміщення природних ресурсів, виробництвом продукції з високою доданою вартістю, відобразило характер формування обсягу транспортних робіт. З Рис.3.1.1 видно, що загальний обсяг вантажообігу з 2000 року зріс з 30 мільярдів тонна-миль до 60 мільярдів. При цьому збільшується складова частина транспортної роботи контейнеровозів [60]. 


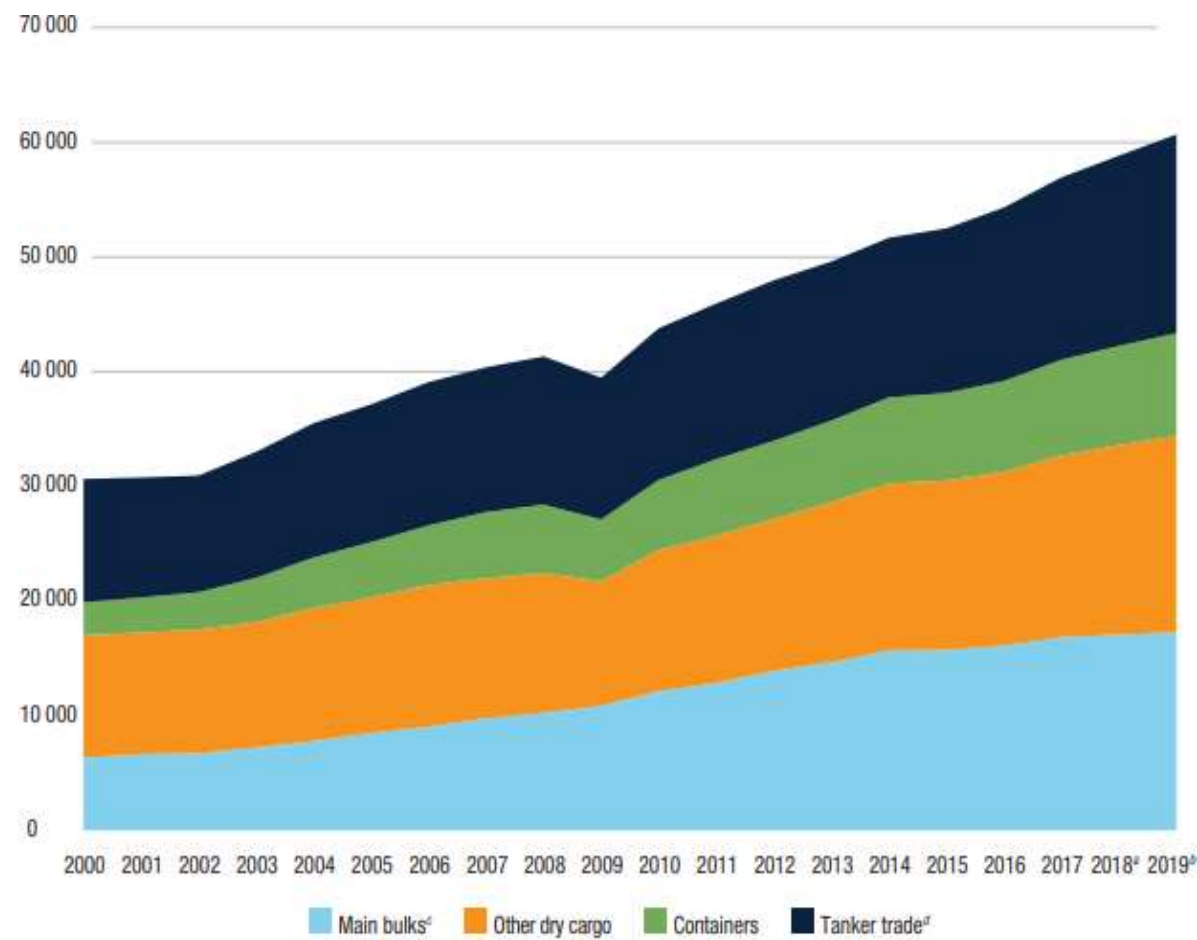

Рисунок 3.1.1. Вантажообіг світового торгового флоту за основними видами вантажів.

Джерело: Review of Maritime Transport 2019

Якщо загальний обсяг транспортної роботи виріс тільки в 2 рази, то обсяг цього показника по контейнерному вантажопотоку збільшився майже в 3 рази. Це в свою чергу зумовлює попит на провізну спроможність в цілому і на формування групи «суперконтейнеровозів».

Слід зазначити, що кількість портів для обробки таких суден обмежена їх розташуванням в основному на далекому сході, в меншій мірі в Західній Європі і обмежена в США. Тому глобальна контейнеризація при обмеженій кількості портів, здатних приймати певні судна, вимагає розширення стратегії доставки суден з портів хабів до місць споживання даної продукції. Особливо актуально ця проблема стає на Чорному морі, де обмежена кількість великих портів, здатних приймати контейнеровози в межах 10-12 тисяч TEU.

Такі порти, як Маріуполь, Ізмаїл в Україні, Батумі в Грузії, порти східної частини моря Туреччини, а також порти Болгарії грунтуються на використанні саме трансшипменту в стратегії інтермодальних перевезень.

Трансшипмент - це режим перевалки контейнерів, при якому контейнер не покидає територію порту: він перевантажується з одного судна на інше і йде в 
інший порт. При цьому слід враховувати особливості спеціалізації в регіональному аспекті операторської діяльності судноплавних компаній i зосередження перевізного процесу на певних видах вантажів світової торгівлі.

В таблиці 3.1.1 наведено характер структуризації світової торгівлі за трьома групами країн з різним рівнем науково-технічного прогресу, а також основних регіонів глобальної морської торгівлі. Анализ диференціації по навантаженню і вивантаженню генеральних вантажів по згаданим групам країн показує, що відвантаження продукції з високою доданою вартістю перевищує імпорт такої продукції через порти цих країн, що підкреслює їх економічний пріоритет.

Що стосується країн, що розвиваються, і країн з перехідною економікою, до яких належить i Україна, то проблеми надають пріоритет відвантаження навалювальних вантажів і надходження контейнерних вантажів. Саме це визначає вимогу до формування чіткої морської транспортної політики, що забезпечує фрахтову незалежність вантажопотоків.

Таблиця 3.1.1.

Особливості розподілу вантажопотоків світової торгівлі за напрямками

перевезення

\begin{tabular}{|c|c|c|c|c|c|c|c|c|c|}
\hline \multirow[b]{2}{*}{$\begin{array}{l}\text { Country } \\
\text { group }\end{array}$} & \multicolumn{5}{|c|}{ Goods loaded } & \multicolumn{4}{|c|}{ coods unloaded } \\
\hline & Vear & Tatal & Crude oil & $\begin{array}{l}\text { Other } \\
\text { tanker } \\
\text { trade }\end{array}$ & Dry cargo & Total & Crude ofl & $\begin{array}{l}\text { Other } \\
\text { tanker } \\
\text { trader }\end{array}$ & Dry cargo \\
\hline \multicolumn{10}{|c|}{ Millions of tonis } \\
\hline \multirow{2}{*}{ World } & 2017 & 10716.2 & 1874.6 & 1271.6 & 7570.1 & 10702.3 & 2033.7 & 1289.4 & 7379.2 \\
\hline & 2018 & 11005 & 1886.2 & 1308.1 & 7810.7 & 11002.2 & 2048.5 & 1321.8 & 7631.9 \\
\hline \multirow{2}{*}{$\begin{array}{l}\text { Developed } \\
\text { economies }\end{array}$} & 2017 & 3709 & 152.7 & 491.2 & 3065.1 & 3795 & 979.1 & 494.7 & 2321.2 \\
\hline & 2018 & 3821.7 & 157.7 & 511.2 & 3152.7 & 3822.9 & 946.5 & 495.8 & 2380.5 \\
\hline \multirow{2}{*}{$\begin{array}{l}\text { Transition } \\
\text { economies }\end{array}$} & 2017 & 694.4 & 206.8 & 41.6 & 445.9 & 81.4 & 0.3 & 4.6 & 76.4 \\
\hline & 2018 & 713.3 & 203.8 & 39.6 & 469.9 & 86.5 & 0.3 & 4.8 & 81.3 \\
\hline \multirow{2}{*}{$\begin{array}{l}\text { Developing } \\
\text { economies }\end{array}$} & 2017 & 6312.8 & 1515 & 738.8 & 4059 & 6825.9 & 1054.3 & 790 & 4981.6 \\
\hline & 2018 & 6469.9 & 1524.7 & 757.3 & 4188 & 7092.8 & 1101.6 & 821.2 & 5170 \\
\hline \multirow{2}{*}{ Africa } & 2017 & 740.9 & 291.3 & 70.4 & 379.1 & 496.8 & 40.5 & 93.8 & 362.6 \\
\hline & 2018 & 767.2 & 289.3 & 73.8 & 404 & 516.3 & 42.5 & 93.9 & 380 \\
\hline \multirow{2}{*}{ America } & 2017 & 1371.8 & 225.2 & 71.9 & 1074.7 & 617.2 & 47.5 & 141.4 & 428.2 \\
\hline & 2018 & 1403.7 & 219.3 & 78.3 & 1106.1 & 652.5 & 51.8 & 149 & 451.8 \\
\hline \multirow{2}{*}{ Asia } & 2017 & 4192 & 996.9 & 595.6 & 2599.5 & 5696.9 & 965.4 & 549.4 & 4182.1 \\
\hline & 2018 & 4290.7 & 1014.4 & 604.1 & 2672.1 & 5908.3 & 1006.5 & 572.5 & 4329.3 \\
\hline \multirow{2}{*}{ Oceania } & 2017 & 8.1 & 1.6 & 0.8 & 5.7 & 14.9 & 0.8 & 5.4 & 8.7 \\
\hline & 2018 & 8.4 & 1.6 & 1.0 & 5.8 & 15.6 & 0.8 & 5.8 & 9 \\
\hline
\end{tabular}

Джерело: Review of Maritime Transport 2019 
На Рис. 3.1.2 представлена діаграма зростання фізичного обсягу перевезень в мільйонах контейнерів розмірності $20 \mathrm{TEU}$, і середньорічні зміни темпів економічного зростання цього виду діяльності. При цьому якщо у 2000 році було переведено 60 мільйонів TEU, то в останньому році статистичного обліку цей рівень досяг 155 мільйонів.

На жаль, незважаючи на ініціативне формування дедвейту українського флоту підприємницькими структурами та доведення його до 3,8 мільйона тон дедвейту, в його структурі фактично відсутні контейнеровози необхідного класу.

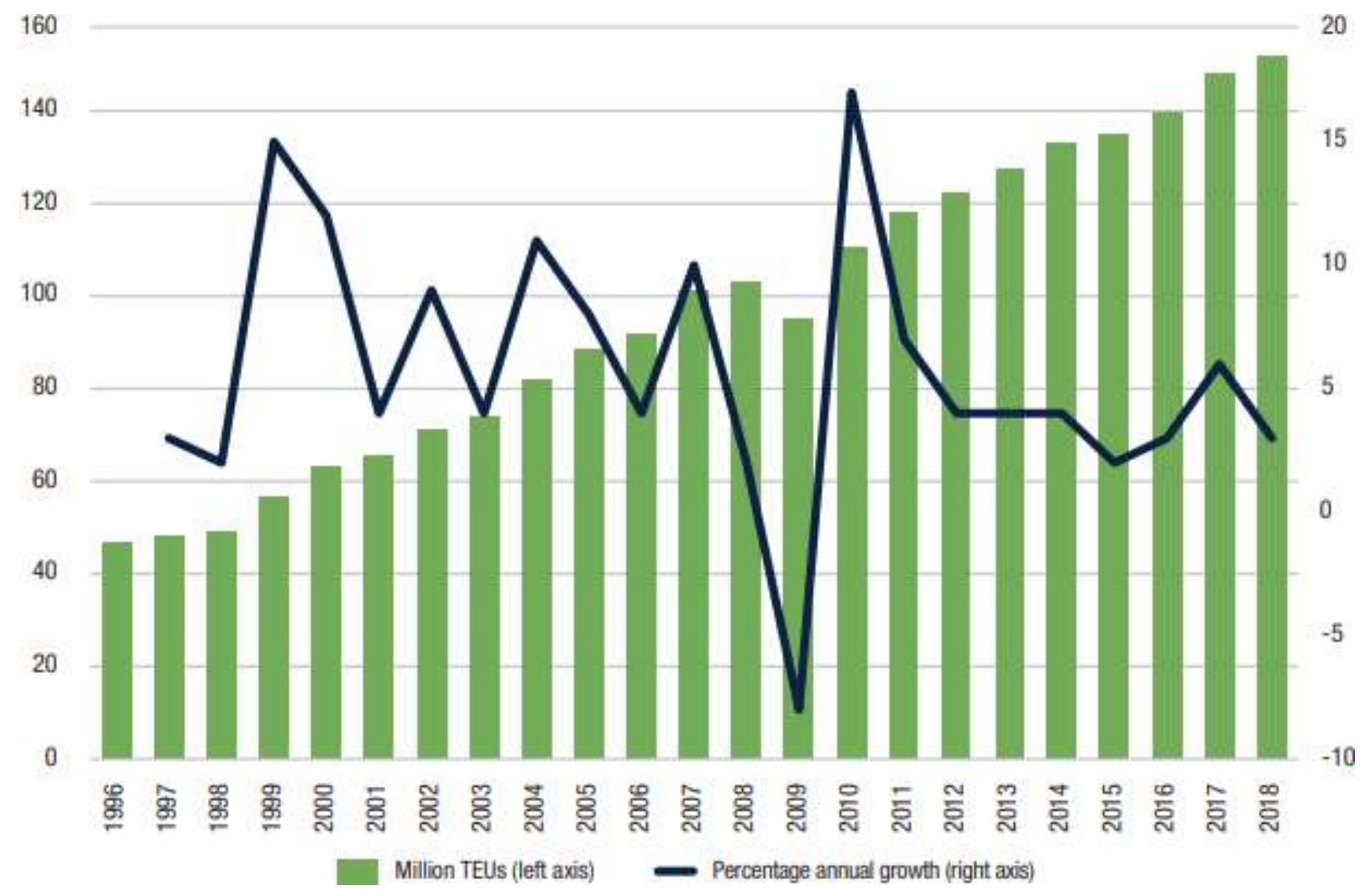

Рисунок 3.1.2. Динаміка параметрів розвитку контейнерного сегмента світової торгівлі

Джерело: Review of Maritime Transport 2019

Основним завданням для української морської транспортної індустрії, 3 урахуванням посилення ролі Китаю в поставках своєї продукції в Європу, в тому числі в Україну, є оцінка доцільності формування контейнерного флоту i розробка відповідної морської транспортної політики, а так як судна трансшипменту характеризуються контейнерної місткістю до $1000 \mathrm{TEU}$, то 
можливий розвиток і української суднобудівної індустрії.

Як показують дані розподілу глобального ринку морської торгівлі (Рис. 3.1.3) домінує сегмент Схід-Захід. Це пояснюється підвищенням ролі в світовому економічному розвитку Китаю і Індії в торгівлі з країнами Європи. Тому саме цей напрямок перевезення вантажів заснований на використанні суден великої місткості.

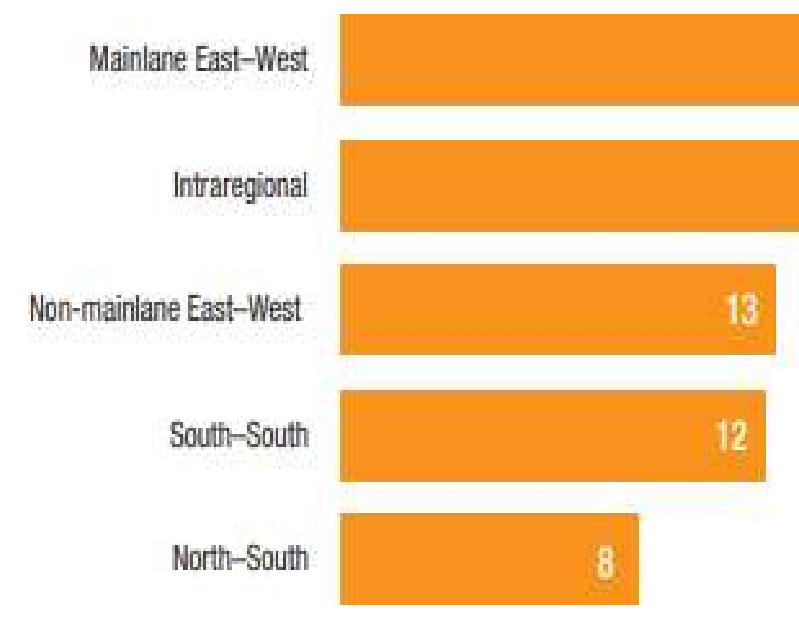

Рисунок 3.1.3. Глобальна маршрутизація контейнерних вантажопотоків, \% Джерело: Review of Maritime Transport 2019

Саме ця тенденція, перетворюючись фактично в закономірність, обумовлює розвиток технологій трансшипменту.

При цьому слід враховувати, що частина вантажопотоку піде по альтернативним коридорам «Одного поясу - одного шляху». Це і зумовлює підвищення фактору часу в доставці продукції, що перевозиться в контейнерах. Однак в остаточному підсумку перевезення морським шляхом обходиться значно швидше, ніж перевезення залізницею.

Аналіз структури контейнерних потоків на напрямку торгівлі Схід-Захід підтверджує об'єктивність формування стратегії «Один Пояс-Один Шлях», що враховує динамічність розвитку контейнерного потоку в торгівлі між країнами азіатсько-тихоокеанського регіону, Близьким Сходом і Західним регіоном. Одночасно слід враховувати негативну реакцію США, Японії і Австралії на концентрацію вантажопотоків Китай-Свропа в формі створення «трансіндотихоокеанського» морського маршруту. Однак варто зазначити, що на 
напрямку Північна Америка-Східна Азія вантажопотік виявляється в 2,5-3 рази менший, ніж потік контейнерних перевезень Східна Азія-Свропа. Одночасно якщо на американському напрямку вантажопотік за аналізований період зріс на 5 млн. TEU, то вантажопотік у напрямку Азія-Свропа виріс тільки на 2,6 млн. TEU. Це характеризує сформовану стійкість відносин, які потребують вдосконалення маршрутизації, що і реалізує китайська ініціатива.

Однак, слід звернути увагу на нестійкість параметрів маршрутів по роках, що і зумовлює ризики планування провізної здатності з одного боку і обмеження темпів будівництва суперконтейнеровозів для зниження поточних витрат судновласників і формування емерджентного ефекту для вантажовласників.

Це ж і зумовлює складність вибору параметрів і напрямків розвитку трансшипментських технологій обслуговування локальної частини вантажопотоків регіонів споживання.

Якщо проаналізувати динаміку формування пропускної здатності морських торговельних портів в основних регіонах зародження глобальної морської торгівлі товарами з високою доданою вартістю, то слід звернути увагу на два аспекти.

По-перше, це пріоритет азіатського континенту формування стійкості розвитку високотехнологічної економіки. По-друге, це жорстка відмінність ролі окремих регіонів і характеру їх впливу на глобальну економіку.

В кінцевому рахунку, в азіатському регіоні розташовано 63\% потужності контейнерних терміналів. На другому місці знаходиться Європа - близько 25\%. Третє місце займає Північна Америка.

Одночасно слід зазначити високі концентрації вантажопотоків в найбільших портах (середньорічні темпи приросту).

Вибір порту перевалки в основному залежить від конкурентоспроможності порту, що виражається у витратах, 3 якими стикаються перевізники при навантаженні і розвантаженні контейнерів, і від ефективності порту, яка визначається швидкістю завантаження і розвантаження контейнера [61]. 
Широко визнано, що існують міцні відносини між контейнерними перевезеннями і ланцюгами поставок, які призводять до появи значних кластерів логістичних фірм навколо великих портів [62].

Характер концентрації вантажопотоків зумовлює вимоги до інтенсивності вантажних робіт портів і вирішення питання ефективного обслуговування внутрішніх вантажопотоків. В цьому відношенні слід відзначити концентрацію уваги Свросоюзу на рішення цієї проблеми за технологією фідерних перевезень, а також створення внутрішніх каналів між Балтійським і Середземним морем і за рахунок розвитку технології «sea-motorway», фактично заснованої на принципах трансшипменту. Це підтверджує положення Білої і Блакитної книг Свросоюзу.

Сучасні світогосподарські тенденції, такі як розширення економічної інтеграції країн і регіонів, лібералізація світової торгівлі, зростання промислових і торгових центрів в Європі і Азії, збільшення між ними товарообігу ведуть до зміни географії наземних і морських перевезень, виникнення міжнародних транспортних коридорів, до реструктуризації світової транспортної системи . 
DOI 10.46299/ISG.2021.MONO.ECON.II-65-73

\section{2 Підприємницька діяльність в аграрному секторі}

Дослідження сутності категорії підприємницька діяльність завжди було полемічним питанням як в економічній теорії так і в економіці в цілому, його важливість визнають майже всі вчені, які працюють над такими дослідженнями. Як історично обумовлене явище, підприємницька діяльність проявляється через систему відносин у різних сферах життєдіяльності суспільства: на макрорівні як чинник суспільного виробництва та рушійна сила науково-технічного прогресу; на мікрорівні - як специфічна поведінкова стратегія взаємовідносин 3 учасниками ринку[63]. В понятійному плані підприємництво постійно еволюціонує, воно носить міждисциплінарний та метанауковий характер. Нормативне регулювання підприємницької діяльності викладено в Господарському кодексі України[64].

Водночас, уявлення про мету підприємницької діяльності тільки як про одержання прибутку, на думку Корольова В.І., веде до ототожнення підприємництва зі звичайним бізнесом [65]. Звичайно, бізнес і підприємництво мають багато загального. Їх характеризує самостійність, відповідальність, ризик, ініціатива. Однак, підприємництво характеризується ще і рядом специфічних рис, таких як: новаторство, творчий пошук рішень, комбінування різних факторів виробництва, одержання доходу внаслідок кращого використання факторів виробництва, тощо. Проте, деякі вчені поняття бізнесу та підприємництва не уточнюють і не завжди проводять між ними межу та не дають чіткого визначення відповідних понять. Однак твердження про рівнозначність понять «підприємництво» i «бізнес», на нашу думку, є недоцільним. А. Гальчинський визначає бізнес як більш широке поняття, ніж підприємництво, останнє є окремим випадком бізнесу [66]. Проведені дослідження свідчать, що для двох близьких понять «бізнес» і «підприємництв

Для кращого розуміння сутності підприємницької діяльності розглянемо еволюцію даного поняття в зарубіжній та вітчизняній літературі. У буржуазній політекономії поняття підприємництва з'явилось ще у ХІІІ ст. у Франції. Ранні 
теорії підприємництва базуються на роботах Й. Шумпетера та І. Кірцнера. Проте, сучасний еволюційний підхід включає в себе також деякі специфічні теорії, такі як теорія людського капіталу Шлютца, теорія соціальних мереж Грановеттера , теорія нео-Шумпетерської економіки. Першим вченим, який почав досліджувати роль підприємця в економіці був англійський вчений Р. Кантільйон? який класифікував економічних агентів на три групи: землевласники, підприємці та наймана робоча сила. В праці «Essai sur la nature du commerce en g'en'eral» $\mathrm{P}$. Кантільйон характеризував першу та третю групу як пасивних агентів, тоді як підприємцям відвів активну роль в економічній системі [67]. Відповідно до його концепції підприємці є координаторами, ланкою, яка з'єднує виробника із споживачем. При цьому він наголошував, що підприємець не завжди має бути власником капіталу. Великий внесок в дослідження підприємницької діяльності вніс А. Сміт, який визначав підприємця як власника капіталу, ціль діяльності якого - отримання підприємницького прибутку, який є компенсацією власника за ризик [68]. Таким чином, А. Сміт трактував підприємця як власника, пов'язував підприємницьку діяльність передусім із власним інтересом (особистим збагаченням), у процесі реалізації якого підприємець сприяє найефективнішому задоволенню потреб суспільства.

Іншою, скоріше капіталістичною точкою зору є теорія Ж. Тургота, згідно якої підприємець є результатом капіталістичного інвестиційного рішення. Так, власник капіталу може просто позичити свої гроші та бути капіталістом, або придбати земельну ділянку та стати землевласником, або придбати товари та вступити в бізнес, автоматично перетворившись в підприємця [69].

Варто зазначити, що більшість економістів до появи теорії Шумпетера працювали лише над теорією рівноваги. Концепція підприємництва Шумпетера стала відправною точкою для сучасних досліджень підприємництва. Всі теорії підприємництва, які з'явились після виходу в світ праці Шумпетера, базуються саме на його ідеях. До нього, ніхто не виділяв особливу, самостійну роль підприємця як одного з стимулюючих факторів економічного розвитку. Ним вперше була запропонована також послідовна теорія підприємництва. Таким 
чином, сучасне уявлення про підприємця та його ролі в господарській діяльності в значній мірі базується на концепції Й. Шумпетера. Цей видатний вчений в контексті підприємництва приділяв увагу інноваціям, він вважав, що це не тільки виготовлення нових продуктів та введення нових технологій, але й освоєння нових ринків збуту, джерел сировини, форм індустріальної організації. Підприємницька діяльність, за Шумпетером, - це не посада і не фах, а, скоріше, унікальна і рідкісна На його думку підприємницька функція полягає в реалізації організаційно-господарських нововведень, які відіграють головну роль в розвитку економіки, забезпечуючи іiі зростання. Тобто, підприємець-інноватор визнається однією з центральних фігур господарської діяльності. Водночас, підприємницьку функцію можуть виконувати як одна особа, так і група осіб. Основна мета підприємницької діяльності - це прибуток, і він важливий як критерій успіху, як оцінка якості реалізованого проекту. Окрім того Й. Шумпетер виділяє такі цілі як: потреба в пануванні, влади, впливі; радість творчості, яку дає самостійне ведення справ. Він не вважав важливою характеристикою підприємництва право власності на підприємство чи інше майно, навпаки, належність до конкретного підприємства він вважав навіть шкідливою для реалізації підприємницької функції. Також Шумпетер не надавав важливого значення функції несення ризик.

Представники неоавстрійської школи заснували новий напрямок в теорії підприємництва. Поведінка підприємця, залишаючись повністю раціональною, змінюється: це той, хто знаходить нові цілі та нові засоби, наявність яких ніким раніше не помічалися. Заслуговує на увагу висновок Ф. Хаєка про роль середовища, в якому діє підприємець. Незважаючи на наявність жорсткої ринкової конкуренції доля приватних осіб, які мають бажання випробувати нові можливості кругом практично однакова [71]. Сучасні західні економісти підприємницьку діяльність в першу чергу тісно пов’язують 3 інноваційним розвитком. Так, зокрема, Долан Е.Дж. та Ліндсей Д. підприємницьку діяльністю розглядають як процес пошуку нових можливостей, технологій та сфер вкладання капіталу, подолання старих стереотипів та меж [72]. 
Діяльність переважної більшості підприємців у розвинутих країнах підпорядковані дії основного економічного закону (виробництву і привласненню максимальної додаткової вартості у формі прибутку), тому інші виконувані ними функції (новаторська, організаційна, господарська, соціальна та особистісна) підпорядковані цій стратегічній меті. Виходячи із сутності підприємництва (новаторська, організуюча та ін.), попит на підприємців буде зростати, оскільки тенденції сучасного розвитку суспільства потребує породження нових, ефективних та раціональних способів організації використання дефіцитних та зникаючих ресурсів для більш повного задоволення кількісних та якісних потреб людства. Водночас, між підприємництвом та суспільством повинен бути встановлений прямий зв'язок. Амігуд М. та Ройтер А. зазначають в своїй статті, що життєздатність різних підприємницьких структур залежить від того, наскільки успішно вони виконують свою роль локомотиву економічного розвитку, а добробут суспільства прямо залежить від режиму сприяння бізнесу, від існування прибуткових та відповідальних суб'єктів господарювання підприємців. [73]. Таким чином, західна економічна наука дає нам уявлення про підприємництво як специфічну функцію, яка здійснюються не обов'язково власником капіталу, а й менеджером або структурним підрозділом фірми, як самостійна інноваційна діяльність, пов'язана 3 ризиком, спрямована на одержання підприємницького прибутку та яка забезпечує задоволення від досягнутого успіху, повноцінну реалізацію індивідуума, що можлива лише у відповідних соціально-економічних та правових умовах.

Проаналізувавши трактування підприємництва в західній науці, не можна не зупинитися на визначеннях даної категорії у працях вітчизняних науковців. Особистість ділової людини, мотивація його діяльності, роль в економічному житті суспільства значною мірою займали українську наукову думку на рубежі XIX - XX віків. Підтвердженням цього $\epsilon$, зокрема, роботи відомого економіста М. Туган-Барановского, що бачив у підприємці людину, яка працює заради високого прибутку і при цьому розумно ризикує. Те що історія вітчизняної теорії підприємництва продовжує залишатися маловивченою сферою не викликає 
сумніву. Це обумовлено тим, що донедавна багато робіт вітчизняних авторів, як дожовтневого періоду, так і перших післяреволюційних років були закриті і недоступні для українських вчених. Таким чином, специфіка сучасних досліджень в області підприємництва в Україні багато в чому визначається їхньою відірваністю від власних теоретичних джерел, а також припиненням традицій підприємництва.

Як зазначає професор Вороніна Л.І. підприємництвом вважається не будьяка діяльність виробника, банкіра, робітника торгівлі, сфери послуг, а лише діяльність власника, який самостійно (або із залученням найманої робочої сили) розпочинає і здійснює виробництво, надання послуг, торгівлю тощо [74]. За визначенням С. Мочерного, підприємництво є самостійним організаційногосподарським новаторством на основі використання різних можливостей для випуску нових або старих товарів новими методами, відкриття нових джерел сировини, ринків збуту тощо, з метою отримання прибутків і самореалізації власної мети.[75]

На думку Лагутіна В.Д. підприємництво - це ініціативна, пов'язана 3 ризиком, економічна діяльність $з$ ціллю здійснення інновацій і досягнення високого соціально-економічного ефекту розпочатої справи [76]. Динкін А. вважає підприємництво особливим, новаторським, антибюрократичним стилем господарської поведінки, в основі якої покладено постійний пошук сучасних можливостей $з$ орієнтацією на інноваційний розвиток, вміння залучати та долучати для вирішення поставлених завдань ресурси з різних джерел [77]. Кретов С.І. розуміє підприємництво не як прагнення одержати великі доходи, а як спосіб мислення ініціативної людини, що швидко мобілізує наявні в неї ресурси на організацію виробництва в якій-небудь надприбутковій сфері або галузі [78]. Це визначення дає нам уявлення скоріше про особистісні і потенційні можливості індивіда, які проявляються лише при наявності сприятливого економічного середовища. Найбільшого поширення одержало визначення підприємництва як особливого виду діяльності. При цьому слід зазначити, що багато авторів підходять до визначенню цього поняття досить широко. Як 
справедливо відзначає Гордєєва Ю., лідером в діловому світі стає той, у кого є вміння ризикнути та швидко впроваджувати інновації [79]. Професор Ніколенко Ю.В. стверджує, що підприємництво - це певний спосіб життя бізнесу, який базується на демократичних формах економічної діяльності та надає їм право ініціативи у виборі сфери, форм і методів управління, економічної, організаційної та технічної творчості та інновацій. В основі цієї системи лежить підприємець - грамотний менеджер, здатний організувати економіку на основі останніх подій в економіці та технологіях. [80].

Таким чином, при дослідженні суті підприємництва значна увага має приділятися також і характеристиці такого поняття як підприємець, оскільки підприємництво само по собі розуміє конкретну діяльність підприємця, як суб'єкта підприємницької діяльності. Підприємець взаємодіє зі споживачами як основними партнерами, а також з державою, яка може виступати помічником або опонентом у різних ситуаціях. До категорії суб' єктів підприємницької діяльності також потрапляють як споживач (суспільство), так і держава, а також працівник (якщо, звичайно, підприємець працює не один), та ділові партнери (якщо виробництво не відокремлено від суспільних відносин). 3 економічної точки зору, підприємець поєднує засоби виробництва, працю, матеріали, тощо так, що в процесі роботи їх сукупна вартість збільшується. При цьому він вносить певні зміни, здійснює інновації та змінюе установлений порядок на ринку. Підприємець в процесі своєї діяльності, використовуючи нове обладнання та технології у виробничому процесі, організовуючи роботу та виробничі процеси по-новому, отримує вигідний "товар найвищої якості". Надлишок, що генерується в процесі виробництва інноваційного ринку, є підприємницьким доходом. Процес отримання такого прибутку - глибока економічна сутність та суть підприємницької діяльності.

3 точки зору психології, підприємець - це людина, яка діє під впливом певних мотивів, наприклад, бажання досягти успіху в житті, спробувати започаткувати нову справу, самоутвердитися та ін. 3 політекономічної точки зору, підприємець - це людина, яка збільшує не тільки своє, а й національне 
багатство, знаходить способи ефективного використання ресурсів, зменшення збитків, створення робочих місць. Таким чином, підприємець $є$ основним суб' єктом господарювання, який завдяки наявності певної сукупності рис втілює у практику функції підприємництва і за свою працю отримує підприємницький дохід. Внесок підприємця часто розглядають в економічному аналізі фірми як самостійний фактор виробництва. Розбіжність між ним і виробничим ресурсом праці базується на результатах рішень, прийнятих підприємцем. Характер підприємницьких рішень відрізняється у різноманітних формах господарювання сучасних підприємств. Наприклад, в індивідуальних фірмах підприємець одночасно бере на себе фінансовий ризик підприємства i несе виняткову відповідальність за управління ним. У публічних компаніях ці дві функції розподілено між акціонерами, тобто власниками, які несуть фінансовий ризик, $\mathrm{i}$ радою директорів, яка здійснює фактичне керівництво політикою і прийняттям рішень, тобто управлінням фірмою. Часто стверджують, що такий поділ функцій $\epsilon$ джерелом змін ділової поведінки, особливо цілей, які переслідуються фірмою.

В сучасних умовах важливого значення набуває культура підприємницької діяльності в агарній сфері, яка повинна грунтуватися на принципах сталого розвитку.

На думку Лагутіна В.Д., підприємництво включає сукупність різних практичних також матеріальних $\mathrm{i}$ духовних надбань суспільства, які відтворюють досягнутий рівень підприємницької діяльності. У більш вузькому плані під культурою підприємництва розуміють процес обміну інформацією та ідеями, етику ділових відносин [81]. Малик М.Й. виділяє підприємництво як інститут інноваційного розвитку сільського господарства, економічний сектор, який виступає інструментом структурної перебудови, стимулює трансформаційні зміни економічних умов до ринкових. Однак, на думку автора сільськогосподарські підприємства, особливо малі, не стали економічно відповідальними, а надлишок економічної потужності дозволяє диктувати умови формування відносин, які насамперед пов'язані з перерозподілом ренти, а не на користь селянського власника [82]. 
На думку Охоти Ю. В. сільськогосподарське підприємство - це самостійна економічна одиниця, діяльність якої поєднує виробництво, першу переробку та продаж сільськогосподарської продукції. Доцільність подальшого розвитку та підтримки підприємництва в аграрному секторі залишається актуальною. Автор виділяє шляхи розвитку сільськогосподарського підприємництва: поліпшення інституційного середовища для форм малого бізнесу 3 метою створення середнього класу в сільській місцевості та підтримання конкуренції на сільськогосподарському та продовольчому ринках; забезпечення рівного доступу до ресурсів та державної допомоги для всіх бізнес-груп, незалежно від форм власності та розміру; вдосконалення структури сівозміни та впровадження використання органічних добрив у сільському господарстві. товаровиробники; вирішення кадрових проблем за рахунок збільшення кількості висококваліфікованого персоналу; оновлення матеріально-технічної бази; система управління та організація виробничих відносин.[83]. До думки щодо підтримки підприємницької діяльності в аграрному секторі приєднуються такі вчені як Сичова М. О. та Шевченко Н. О. Вони зазаначають, що підприємці потребують підтримки, особливо державної, оскільки навряд чи вони зможуть вирішити всі свої проблеми самостійно та подолати перешкоди, 3 якими стикаються. Але в сучасних умовах держава не зможе повною мірою сприяти розвитку підприємництва, зокрема сільського господарства. Тому підприємцям потрібно пам'ятати про функції підприємництва в суспільстві (ресурсні, організаційні та творчі) та якомога швидше адаптуватися до змін у зовнішньому середовищі, бути більш ініціативними та самостійними у вирішенні своїх проблем, зосереджуючись на забезпеченні ефективного розвитку бізнесу, подолання браку знань про здійснення підприємництва, використання всіх можливих способів залучення інвестицій, вдосконалення структури виробництва, диверсифікація видів підприємництва та інші речі, що є прерогативою самих підприємців.

Розглянувши та узагальнивши теоретико-методологічні підходи до визначення сутності підприємництва в агарному секторі, його функцій та 
соціально-економічного значення, можна зробити висновок, що підприємництво $\epsilon$ необхідною умовою економічного зростання країни, джерелом покращення добробуту пересічних громадян та їх соціальної захищеності.

Підсумовуючи вищенаведене на основі узагальнення результатів дослідження ми розуміємо категорію «підприємництво в аграрній сфері» як інноваційний вид діяльності, заснований на прагненні окремих індивідів або їхніх груп до самоствердження і підвищення суспільного статусу шляхом реалізації новаторських ідей, забезпечення високого комерційного ефекту підприємства та дотримання цілей сталого розвитку. Такий підхід підкреслює особливий характер підприємництва як одного з найбільш перспективних видів економічної діяльності в агарній сфері. 
DOI 10.46299/ISG.2021.MONO.ECON.II-74-81

\section{3 Організаційно-економічні механізми управління інфраструктурним розвитком туристичної галузі регіону}

В умовах посилення європейських та світових інтеграційних процесів туристична галузь набуває особливого стратегічного значення для соціальноекономічного розвитку України та ії регіонів. Вона сприяє становленню країни на світовому ринку товарів та послуг як повноправного партнера міжнародних відносин.

Розвиток туризму істотно впливає на такі інфраструктурні сектори економіки, як транспорт, торгівля, зв'язок, будівництво, сільське господарство, виробництво товарів широкого вжитку, і є одним 3 найбільш перспективних напрямів структурних змін.

У зв'язку з вищезазначеним виникає проблема вивчення та аналізу інфраструктури туристичної галузі, як стрімко зростаючого організаційноекономічного механізму національної та регіональної економік.

На думку Тридід О.М. організаційно-економічний механізм - це сукупність підсистем соціально-економічних i організаційно-економічних відносин, складених з блоків і відповідних їхньому змісту елементів, особливості наповнення яких відповідають розвитку суспільно-економічного устрою» [85].

В свою чергу Транченко Л. В. «під організаційно-економічним механізмом розуміє систему організації й управління, що включає певну сукупність взаємопов'язаних організаційно-правових, економічних та мотиваційних методів, які мають специфічні особливості у конкретних умовах суспільного виробництва» [86].

Малицький А.А. запропонував таке визначення організаційно-економічного механізму - це комплексна система, що складається з системи забезпечення, функціональної та цільової системи, які містять певну сукупність організаційних і економічних важелів, які впливають на економічні і організаційні параметри системи управління підприємством 3 метою забезпечення ефективності управління і отримання конкурентних переваг [87]. 
Потрібно відзначити, що за допомогою організаційно-економічного механізму формується інфраструктурна складова функціонування та розвитку туристичної сфери регіону та країни в цілому.

Інфраструктура туризму служить необхідною умовою освоєння рекреаційних ресурсів та функціонування туристичної індустрії. Її розвиток, 3 одного боку, сприяє туристичному освоєння території, а з іншого - покращує умови життя населення регіону, створюючи велику кількість робочих місць. I хоча поняття туристичної інфраструктури не є новим, у вітчизняній науковій літературі, однак немає його єдиного тлумачення. Неоднозначність і розмитість змістовного сенсу цього поняття пояснюється необгрунтованістю чітких ознак віднесення до інфраструктури туризму окремих видів господарської діяльності та невизначеністю кола їі об'єктів.

Зазначимо, що інфраструктуру туризму можна розглядати як комплекс видів діяльності щодо створення умов для реалізації туристичних послуг. Також існує і розуміння туристичної інфраструктури як сукупності різноманітних об'єктів, що використовуються для задоволення потреб туристів.

Так, наприклад, у Законі України «Про внесення змін і доповнень до Закону України «Про туризм» туристичну інфраструктуру визначають, як сукупність певних суб'єктів туристичної діяльності (індивідуальні та колективні засоби розміщення, заклади харчування, культури, розваг та спорту, медичних та оздоровчих послуг курортної сфери, торгівлі, земельні ділянки, транспортні засоби та транспортні підприємства (перевізники), інформаційні ресурси та інформаційні системи, а також інші матеріальні і нематеріальні блага, майно, майнові комплекси (підприємства), результати та продукти інтелектуальної діяльності), що належать суб'єктам туристичної діяльності. Отже, це різного призначення споруди, транспортні шляхи, засоби комунікації, які використовуються для виробництва та надання комплексних та/або окремих туристичних пакетів та туристичних послуг [88].

На думку Поступної О.В та Леоненко Н.А туристична інфраструктура - це сукупність підприємств, установ і закладів, діяльність яких спрямована на 
задоволення потреб людей, котрі беруть участь в оздоровленні або відпочинку, а також шляхів сполучення і транспорту та об’єктів розміщення туристів, що забезпечують умови стабільного функціонування туристичної галузі [89].

В свою чергу Мельниченко О.А. під інфраструктурою туризму розуміє комплекс споруд, інженерних i комунікаційних мереж, в тому числі телекомунікаційного зв'язку, доріг, суміжних індустрії туризму підприємств, що забезпечують нормальний доступ туристів до туристичних ресурсів і їх належне використання в цілях туризму, забезпечення життєдіяльності підприємств індустрії туризму і власне туристів [90].

Потрібно зазначити, що відповідно до призначення у суспільстві й економіці розрізняють виробничу та соціальну туристичну інфраструктуру. Такий умовний поділ пов'язаний з тим, що низка галузей і виробництв економіки обслуговують як потреби туристичних підприємств (організацій, установ, компаній), так і населення, як споживачів туристичних послуг. У свою чергу виробнича інфраструктура складається 3 транспортної, інформаційнокомунікативної та комунальної інфраструктур, екологічних об'єктів. Соціальна інфраструктура включає в себе такі елементи, як туроператори і турагенти, засоби розміщення, підприємства відпочинку та розваг, торгівля і громадське харчування, інфраструктура безпеки.

В цілому можна погодитися 3 думкою А. Гайдук, який представляє туристичну інфраструктуру у вигляді трьох складових: інституційної (транспорт, готелі, банки, страхові компанії, туристичні фірми, рекламні підприємства тощо), інформаційної (засоби розповсюдження інформації) та регламентуючої (нормативно-правові акти) [91].

Основною метою розвитку туристичної галузі Херсонської області $\epsilon$ створення досконалої інфраструктури та конкурентоспроможного туристичного продукту, поліпшення якості та доступності туристичних послуг, оскільки туризм підтвердив статус однієї 3 найбільш динамічних та перспективних галузей економіки регіону, яка позитивно впливає на динаміку росту соціально економічних показників та стимулювання розвитку суміжних галузей. 
Велика кількість територій та об'єктів туристичної та загальної інфраструктури потребують значних фінансових інвестицій. На заходи для їх залучення, у середньому, витрачається 5,4 \% коштів регіональних програм [92].

Важливою складовою формування будь-якого туристичного продукту є транспортне забезпечення. Тому, доцільно розглянути ситуацію зі станом транспорту та дорожнього господарства в регіоні.

Так, важливим інфраструктурним проектом, який реалізований в області $\epsilon$ міжнародний аеропорт «Херсон», де особлива увага приділяється підвищенню авіаційної безпеки, забезпеченню комфортних умов для пасажирів та залученню до роботи нових авіакомпаній. Кабінет Міністрів України затвердив Державну цільову програму розвитку аеропортів на період до 2023 року, до якої увійшли 17 аеропортів України, серед них і аеропорт «Херсон». Реалізація вказаної державної програми дасть змогу модернізувати до найсучасніших міжнародних стандартів інфраструктуру аеропорту, сприятиме розвитку авіаційних перевезень в області, забезпечить набуття Україною статусу транзитної держави з урахуванням іiі унікального географічного розташування [93].

В регіоні активно впроваджується та реалізується концепція розвитку автобусних перевезень в області, відповідно до якої додатково відкрито понад 30 щоденних сезонних автобусних маршрутів міжміського та міжобласного сполучення (Харків - Стрілкове; Нікополь - Скадовськ; Кам'янське - Скадовськ - Залізний Порт; Херсон - Щасливцеве, Стрілкове, Лазурне, Залізний Порт, Більшовик; Скадовськ - Київ, Генічеськ - Стрілкове. Відновлені регулярні автобусні міжнародні рейси до міст Варшава, Кельн, Прага, Варна, Кишинів та інших міст Європи, що в свою чергу, сприяє поїздкам іноземних громадян до курортних зон на узбережжях Чорного та Азовського морів [94].

Для створення безпеки автотуристів та приведення у належний стан автотранспортних шляхів, проводиться ремонт доріг, що ведуть до курортних населених пунктів Арабатської стрілки Генічеського району, селищ Залізний Порт і Приморське Голопристанського району, міста Скадовська та селища 
міського типу Лазурне Скадовського району, селища Хорли Каланчацького району [95].

Розвиток залізничної інфраструктури дає новий поштовх до розвитку курортів Херсонщини. На літній період щорічно запроваджується 11 потягів через залізничний вокзал станції «Херсон» до столиці та обласних центрів України: Київ, Львів, Харків. Через залізничні станції «Нова Олексіївка» i «Генічеськ» - запроваджено на літній період 19 пар нових потягів, 3 них 9 електричних. Швидкісне сполучення півдня України зі столицею сприяє збільшенню кількості пасажирів, які виявляють бажання відвідати курорти Херсонщини (їх кількість вже на сьогодні перевищує 3,5 млн. осіб) та зробить робочі і ділові візити більш оперативними [96].

Херсонський річковий порт (річковий вокзал) - це великий транспортний вузол, в якому здійснюється взаємодія річкового, морського, залізничного та автомобільного транспорту. Також приймаються річкові пасажирські судна пасажиромісткістю до 700 осіб. Пасажирські перевезення (зазвичай на місцевих лініях) здійснюються з 18 березня по 10 листопада. В цей період в середньому буває до 10 заходів суден на день [97]. Спільно з судноплавною компанією ТОВ СП «НІБУЛОН» проводиться масштабна робота відновлення пасажирських перевезень морським та річковим транспортом, запроваджується ефективна система екскурсійного супроводу і туристичних маршрутів [98].

Що стосується організації та розвитку закладів розміщення, то у 2019 році на відпочинок та оздоровлення туристів приймали 293 заклади відпочинку та оздоровлення, в тому числі 49 дитячих оздоровчих таборів. А також 700 офіційно зареєстрованих міні-готелів та пансіонатів, більше 50 готельних комплексів, 56 садиб сільського зеленого туризму. Загальна місткість ліжкового фонду понад 150 тис. місць [99].

Для підвищення рівня обслуговування в регіоні для готельєрів організовується низка тренінгів із залученням європейських фахівців-експертів 3 розвитку індустрії гостинності. 
Ще одним резервом підвищення привабливості вітчизняних туристичних продуктів $\epsilon$ реконструкція наявної туристичної та соціально-побутової інфраструктури. Санаторно-курортні заклади знаходяться в незадовільному стані і не становлять цінності як лікувальні здравниці. Одним із шляхів вирішення цього питання $є$ зниження кредитних ставок та встановлення відповідних пільг в оподаткуванні.

Розвиток масових комунікацій та інформаційно-комунікаційних технологій має вирішальне значення для формування ефективної туристичної інфраструктури. Значну роль відіграють сучасні електронні засоби інформації: створення інформаційних туристичних порталів в мережі Інтернет, інформаційних туристичних центрів і терміналів на основних туристичних маршрутах.

Так, наприклад, для створення привабливого туристичного іміджу Херсонщини, щорічно проводиться системна рекламно - іміджева кампанія «Херсонщина приваблива цілий рік». Презентацію туристичних та курортнорекреаційних можливостей регіону організовують на заходах національного та міжнародного значення в містах Одесі, Чернігові, Києві, Львові, європейських країнах, на національних та регіональних телеканалах, телевізійних проектах [100].

Кожен рік розповсюджується велика кількість друкованої рекламно інформаційної продукції, календар подій області (фестивалів та івент-заходів), електронний контент «літніх. осінніх, зимових туристичних пропозицій області», висвітлюється безліч відео сюжетів та статей про туристичний потенціал Херсонщини.

Одним з інструментів ефективного функціонування туристичної галузі та розбудова належної інфраструктури, створення належних умов для забезпечення якісного зростання рівня туристичних послуг, є регіональні програми розвитку туризму, які в свою чергу, враховують регіональні особливості та стимулюють інші види економічної діяльності. 
Регіональні програми виконують роль активного засобу регулювання ринкових процесів, інтеграції державних, регіональних інтересів та відносин у туристичній сфері, мобілізації ресурсів для забезпечення цілеспрямованого розвитку територіальної рекреаційної системи в господарському комплексі регіону.

Таким чином, успішне функціонування туристичної галузі та соціальноекономічний розвиток регіону повинні передбачати наступні складові:

1. Формування конкурентоздатного регіонального туристичного ринку (насамперед на основі раціонального використання туристичних ресурсів та сучасної туристичної інфраструктури), що сприятиме забезпеченню задоволення широких потреб вітчизняних та іноземних туристів у туристичних послугах.

2. Розвиток матеріально-технічної бази туристичної інфраструктури, яка набуває великої актуальності і потребує якомога скорішого вирішення. Цей напрям передбачає: розвиток інфраструктури на природно-заповідних територіях; облаштування місць для стоянок $\mathrm{i}$ короткочасних зупинок туристично-екскурсійних автобусів, автотуристів; створення додаткових об’єктів туристичних відвідувань, розширення переліку територій перспективних для запровадження нових туристичних маршрутів; збереження та реконструкція пам’яток архітектури.

3. Формування комплексної регіональної системи рекламноінформаційного забезпечення, що дасть змогу інформувати як внутрішнього так i зовнішнього споживача туристичного продукту (створення інформаційних туристичних центрів; підтримка й поповнення туристичного WEB-порталу; організація регіональних виставок, конференцій, фестивалів, семінарів та інших заходів; замовлення й придбання поліграфічної та відео-рекламнопрезентаційної продукції та сувенірів; популяризація туристичного бренду).

4. Залучення інвестицій, вивчення інвестиційно-привабливих об’єктів і надання консультативної допомоги в реалізації пріоритетних інноваційних проектів у туристичній галузі, участь у щорічних туристичних та економічних 
форумах та виставках; створення та видання туристично-інвестиційного довідника.

5. Одним з основних резервів підвищення привабливості вітчизняних національних та регіональних туристичних продуктів, що впливають на інфраструктуру i обсяг туристичного ринку, є встановлення відповідності параметрів пропонованого туристичного продукту обов'язковим регламентованим стандартам i нормам, що забезпечує його конкурентоспроможність та привабливість. 


\section{SECTION 4. ECONOMY AND MANAGEMENT OF STATE GRATITUDE}

DOI 10.46299/ISG.2021.MONO.ECON.II-82-90

\section{1 Важливість оцінювання ризиків воснно-економічного характеру під час державного планування}

Зацікавленість України у співпраці з Північноатлантичним альянсом (НАТО) зобов'язує до реформування принципів, підходів та методів прогнозування та планування обсягів ресурсної бази оборонного характеру. Останніми роками основою оборонного планування став принцип обгрунтування спроможностей Збройних Сил (3С), який $є$ невід’ємною складовою трансформаційних процесів у країнах НАТО. Так як визначення спроможностей 3С, зазвичай, проходить в умовах невизначеності, тому обгрунтування та врахування величини ризиків та загроз, що можуть мати вплив на їх стан $є$ одним із пріоритетів.

Методологічні основи розвитку спроможностей військ (сил), моделювання та основи класифікації спроможностей, планування розвитку спроможностей військ (сил), формування стандартного каталогу спроможностей типових структур військ (сил) розглянуто в монографії “Сектор безпеки і оборони України: теорія, стратегія, практика", підготовленій фахівцями Національного університету оборони України імені Івана Черняховського [101], остаточний їх перелік закріплено у Єдиному каталогу спроможностей міністерства оборони України та Збройних Сил [102]. Проблеми планування спроможностей в оборонному секторі України під різними кутами зору розглядалися в науковопрактичному середовищі в публікаціях В. Ю. Богдановича, А. І. Семенченка, О. О. Бортника, В. А. Мухи, Ю. В. Сгорова, В. П. Горбуліна, А. Б. Качинського та ін. Вивчення зарубіжного досвіду стратегічного планування на основі спроможностей з метою його творчого наукового розвитку та практичного застосування в контексті існуючих викликів та загроз знайшло висвітлення у публікаціях І. С. Романченка, В. Ю. Богдановича, М. М. Дєнєжкіна, П. М. Крикуна, О. В. Буняка, Р. Г. Бондаря, А. І. Поляєва, О. О. Суркова, Ф. В. Саганюка, В .С. Фролова, О. В. Устименко, М. М. Лобко, Ф. М. Сатанюка, 
В. М. Семененко, С. М. Овчаренко, М. Ю. Степанюка, Ю. В. Юрчина, Г. Ф. Костенко та ін.

У закордонних виданнях на удосконалення підходів та методів щодо підвищення ризик-менеджменту спроможностей $3 \mathrm{C}$ приділяється також достатня увага [103-109]. Вивчення поглядів вітчизняних авторів, а також думок іноземних фахівців дає змогу зробити висновок, що система оборонного планування на основі спроможностей здатна забезпечити ефективне реагування на зміни в середовищі національної безпеки за наявності реалістичної системи ризикменеджменту. Але недосконалість вітчизняних підходів до врахування впливу ризиків на стан спроможностей ЗС ( $\mathrm{CП}^{3 \mathrm{C}}$ ) призводить до похибок у оборонному та бюджетному плануванні, що не відповідає довгостроковим оборонним потребам. Тому метою данної роботи є розроблення рекомендацій щодо підвищення рівня спроможностей Збройних Сил з урахуванням скоригованого ризику.

Для виокремлення областей з вільними (наявними) ресурсами та - загрозами невиконання поставлених завдань доцільно визначити вплив сезонних коливань [110], а саме: внутрішньоквартальних коливань, зумовлених зміною тенденцій, що мають періодичний характер виникнення (ПХВ) протягом визначеного періоду.

До внутрішніх складових СП ${ }^{3 \mathrm{C}}$ (за основними групами), які мають ПХВ можна віднести (за напрямками наведеними на рис. 4.1.1):

1. Використання ресурсів на задоволення фінансових потреб технологічного забезпечення та функціонування оборонно-промислового комплексу (ОПК) (модернізація озброєння та військової техніки (ОВТ) на підприємствах обороннопромислового комплексу; збільшення випуску нових зразків ОВТ, що будуть прийняті на озброєння за рахунок виробничих потужностей підприємств ОПК, тощо). 


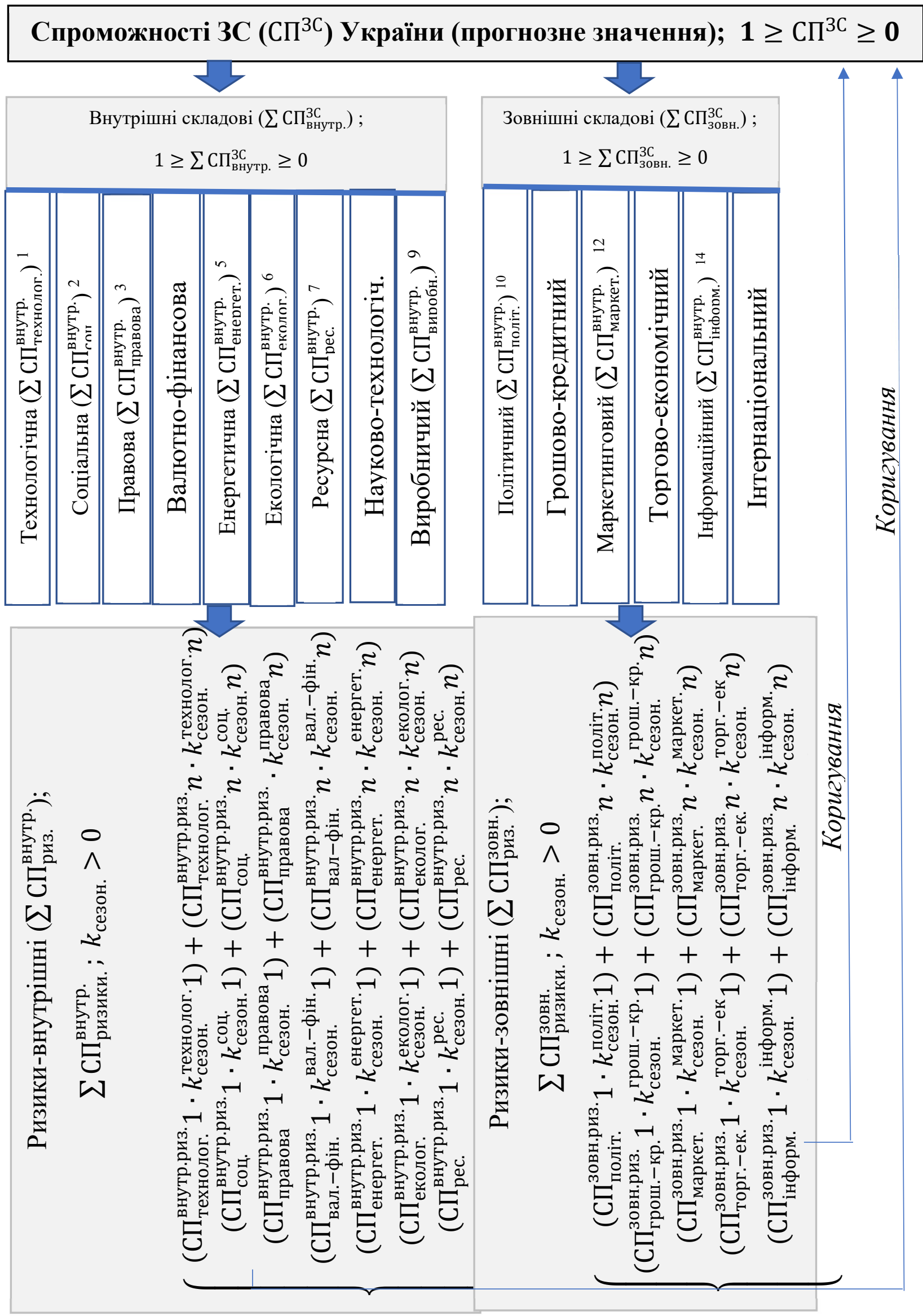

Рис. 4.1.1 Схематичне відображення впливу ПХВ виникнення ризиків на прогнозний стан спроможностей ЗС України 
2. Використання ресурсів на задоволення потреб соціально-економічного забезпечення ЗС України (розвитку медичного лікування, реабілітації та санаторного забезпечення особового складу ЗС України, тощо).

3. Використання ресурсів на підвищення рівня нормативно-правової бази у сфері (забезпечення воєнно-економічної діяльності поза межами України (міжнародні контракти), тощо).

4. Використання ресурсів у сфері для задоволення потреб оборонної сфери на макрорівні та потреб кредитно-інвестиційної діяльності (рівень інвестиційної активності в оборонної діяльності, тощо).

5. Використання ресурсів на задоволення потреб щодо (постачання природного газу; постачання вугілля та мазуту на потреби оборонного сектору, тощо).

6. Використання ресурсів на забезпечення утилізації, ліквідації та попередження наслідків воєнної діяльності (утилізація боєприпасів та рідинних компонентів ракетного палива, забезпечення живучості та вибухопожежобезпеки арсеналів, баз і складів ЗС України; ліквідація шкідливих викидів, скидів та твердих відходів підприємств, організацій, військових частин сфери оборони, тощо).

7. Відтворення ресурсів оборонного призначення (підготовка громадян на посади осіб офіцерського складу, підвищення кваліфікації, перепідготовка офіцерських кадрів та державних службовців, початкова військова підготовка молоді відносно чисельності ЗС України; визначення величини залежності потужностей ОПК від закордонного постачання енергоресурсів; вплив територіальної оборонної економіки регіону на оборонну економіку держави, тощо).

8. Використання ресурсів на забезпечення науково-технічної бази, наукового потенціалу оборонної сфери, кількісно-якісних характеристик міжнародного співробітництва (перепідготовка офіцерських кадрів та державних службовців; підготовка іноземних фахівців; прикладні дослідження у воєнно-теоретичній сфері - воєнна економіка, управління ЗС, теорія розвитку 3С; вплив фактора “тимчасової окупованості територій” на відтік науковотехнічної бази та кадрів; кількість миротворчих контингентів ЗС України; 
кількість візитів іноземних делегацій; кількість візитів за кордон; кількість іноземних інспекцій, тощо).

9. Використання ресурсів на підтримання виробничого потенціалу ОПК (конкурентоспроможність продукції оборонного призначення; стан виробничих потужностей підприємств ОПК 3 урахуванням фактора “тимчасової окупованості територій”, тощо).

До зовнішніх складових СП ${ }^{3 \mathrm{C}}$ (за основними групами), які мають ПХВ можна віднести (за напрямками наведеними на рис. 4.1.1):

10. Використання ресурсів на збереження обраного воєнно-економічного стратегічного курсу держави (зміна (щоквартальна) напрямів реформування 3С України, тощо).

11. Використання ресурсів щодо дебіторсько-кредиторської заборгованості в оборонній сфері (проведення мобілізаційної роботи і призову до 3С та інших військових формувань; будівництво і капітального ремонту військових об'єктів; забезпечення участі у міжнародних миротворчих операціях; забезпечення виконання міжнародних угод у військовій сфері; Погашення кредиторської та дебіторської заборгованостей за межами України (міжнародні контракти), тощо).

12. Використання ресурсів на забезпечення виконання своїх планових завдань центральним апаратом Міністерства оборони та генеральним штабом 3С України, тощо.

13. Використання ресурсів щодо торговельних операцій (експорт-імпорт товарів оборонного призначення, тощо).

14. Використання ресурсів на забезпечення захищеності інформаційних систем оборонної сфери (придбання одиниць апаратури зв’язку спеціального призначення, необхідні канали зв'язку відповідно до величини оплати послуг, тОщо).

15. Використання ресурсів на задоволення фінансових потреб забезпечення міжнародного співробітництва (забезпечення українських миротворчих контингентів, тощо). 
За допомогою методу експертних оцінок отримали наступну узагальнену ієрархію основних ризиків відповідно до їх ваги у сукупності (таблиця 4.1.1). Отже, найбільша імовірність виникнення ризиків присутня у сфері

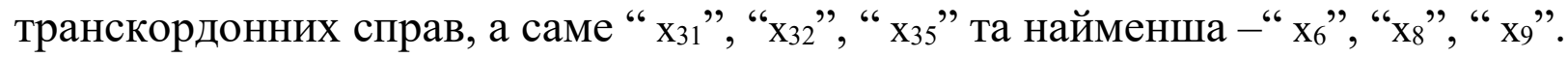

Таблиця 4.1.1

Узагальнена ієрархія основних груп ризиків відповідно до їх ваги у сукупності

(на 2021-2029 роки)

\begin{tabular}{|c|c|c|c|}
\hline П.н. & $\begin{array}{c}\text { Фактори } \\
\text { (умовні } \\
\text { позначення) }\end{array}$ & Опис & $\begin{array}{c}\text { Сума } \\
\text { рангів }\end{array}$ \\
\hline 1 & $\mathrm{x} 31$ & $\begin{array}{l}\text { створення, оснащення і підготовка на території інших держав збройних } \\
\text { формувань і груп з метою їх передислокації на території України або ії } \\
\text { союзників }\end{array}$ & 336,5 \\
\hline 2 & x32 & $\begin{array}{l}\text { діяльність прямо або побічно підтримуваних з-за кордону підривних } \\
\text { сепаратистських, націоналістичних або релігійних екстремістських } \\
\text { угрупувань, направлена на підрив конституційного ладу України, } \\
\text { створення загрози територіальній цілісності }\end{array}$ & 323 \\
\hline 3 & $\mathrm{x} 35$ & діяльність на території України міжнародних терористичних організацій & 313,5 \\
\hline 4 & $\mathrm{x} 26$ & $\begin{array}{l}\text { залежність процесу реформування воєнно-економічної складової України } \\
\text { від надання іноземних кредитів та іншої іноземної допомоги }\end{array}$ & 313,5 \\
\hline 5 & $\mathrm{x} 27$ & $\begin{array}{l}\text { зростання зовнішньої заборгованості, } \\
\text { іноземних кредитів }\end{array}$ & 303,5 \\
\hline 6 & $\mathrm{x} 29$ & $\begin{array}{l}\text { недосконала система збереження державної таємниці та захисту інформації } \\
\text { воєнно-економічного характеру }\end{array}$ & 295,5 \\
\hline 7 & $\mathrm{x} 34$ & $\begin{array}{l}\text { застосування сучасних інформаційно-мережевих технологій проти України } \\
\text { та її союзників }\end{array}$ & 285 \\
\hline 8 & $\mathrm{x} 33$ & $\begin{array}{l}\text { транскордонна злочинність, що включає контрабандну і іншу протизаконну } \\
\text { діяльність в масштабах, загрозливих безпеці України }\end{array}$ & 269,5 \\
\hline 9 & $\mathrm{x}_{2}$ & високий рівень зношеності основних фондів & 265 \\
\hline 10 & $\mathrm{X}_{19}$ & $\begin{array}{l}\text { непослідовність і безсистемність у здійсненні воєнно-економічних реформ, } \\
\text { відсутність власної моделі реформ та їхнього ідеологічного забезпечення }\end{array}$ & 264 \\
\hline 11 & $\mathrm{X}_{18}$ & $\begin{array}{l}\text { неефективність державного регулювання та керованості соціально- } \\
\text { економічними процесами }\end{array}$ & 257,5 \\
\hline 12 & $\mathrm{X}_{30}$ & некерований відтік за кордон інтелектуальних і трудових ресурсів & 247,5 \\
\hline 13 & $\mathrm{X}_{17}$ & $\begin{array}{l}\text { “консервування” здобутків науково-дослідної діяльності на заключному } \\
\text { етапі їх проектування }\end{array}$ & 228,5 \\
\hline 14 & $\mathrm{X}_{24}$ & витіснення України з частини зовнішніх ринків збуту продукції & 212 \\
\hline 15 & $\mathrm{x}_{10}$ & застарілі технології виробництва & 200 \\
\hline 16 & $\mathrm{x}_{3}$ & $\begin{array}{l}\text { деформована структура виробництва (відсутність науково-обгрунтованої } \\
\text { структурної перебудови економіки) }\end{array}$ & 192,5 \\
\hline 17 & $\mathrm{X}_{25}$ & $\begin{array}{l}\text { нерегульований приплив в Україну іноземного капіталу та надання йому } \\
\text { переваги порівняно з вітчизняним }\end{array}$ & 189,5 \\
\hline
\end{tabular}


Продовження таблиці 4.1.1

Узагальнена ієрархія основних груп ризиків відповідно до їх ваги у сукупності

(на 2021-2029 роки)

\begin{tabular}{|c|c|c|c|}
\hline П.н. & $\begin{array}{c}\text { Фактори } \\
\text { (умовні } \\
\text { позначення) }\end{array}$ & Опис & $\begin{array}{l}\text { Сума } \\
\text { рангів }\end{array}$ \\
\hline 18 & $\mathrm{x}_{21}$ & $\begin{array}{l}\text { недосконалість національного законодавства, пов'язаного з регулюванням } \\
\text { воєнно-економічних процесів }\end{array}$ & 187,5 \\
\hline 19 & $\mathrm{x}_{14}$ & низький рівень забезпечення військовослужбовців власним житлом & 179 \\
\hline 20 & $\mathrm{X}_{28}$ & $\begin{array}{l}\text { неспівпадання цілей іноземного капіталу } 3 \text { інтересами економічного } \\
\text { розвитку України }\end{array}$ & 166,5 \\
\hline 21 & $\mathrm{x}_{12}$ & застарілі технології & 162 \\
\hline 22 & $\mathrm{x}_{16}$ & зменшення кількості НДДКР та НДР & 131 \\
\hline 23 & $\mathrm{X}_{22}$ & відсутність експортно-імпортної збалансованості & 122 \\
\hline 24 & $\mathrm{X}_{11}$ & $\begin{array}{l}\text { низький рівень замкнених циклів виробництва стратегічно важливої } \\
\text { продукції, зокрема, військової техніки та озброєння }\end{array}$ & 106,5 \\
\hline 25 & $\mathrm{x}_{1}$ & високий рівень матеріаломісткості виробництва & 96,5 \\
\hline 26 & $\mathrm{X}_{4}$ & незадовільна орієнтація на виробництво продукції кінцевого споживання & 92 \\
\hline 27 & $\mathrm{x}_{13}$ & $\begin{array}{l}\text { недостатня розвіданість власної мінерально-сировинної бази, особливо тих } \\
\text { її компонентів, які Україна змушена імпортувати }\end{array}$ & 88 \\
\hline 28 & $\mathrm{x}_{20}$ & $\begin{array}{l}\text { недосконалість державного управління приватизаційними процесами, } \\
\text { зловживання у цій сфері }\end{array}$ & 87 \\
\hline 29 & $\mathrm{x}_{23}$ & 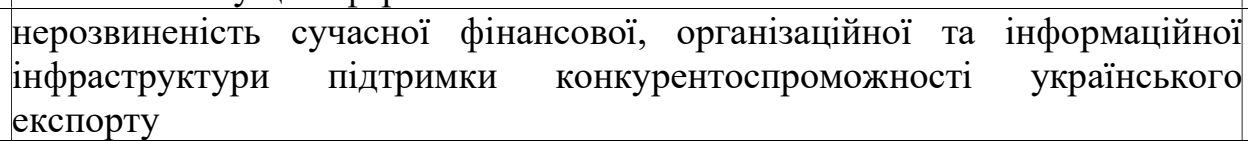 & 75,5 \\
\hline 30 & $\mathrm{X}_{5}$ & $\begin{array}{l}\begin{array}{l}\text { широкомасштабне i безсистемне } \\
\text { промислового комплексу }\end{array} \\
\text { проведення }\end{array}$ & 72 \\
\hline 31 & $\mathrm{x}_{7}$ & $\begin{array}{l}\text { низький рівень видобутку нафти, газу, вугілля для забезпечення власних } \\
\text { оборонних потреб }\end{array}$ & 63,5 \\
\hline 32 & $\mathrm{X}_{15}$ & $\begin{array}{l}\text { відсутність проведення робіт щодо психологічної адаптації новобранців } \\
\text { військовослужбовців звільнених в запас }\end{array}$ & 56 \\
\hline 33 & $\mathrm{X}_{8}$ & високий рівень енергомісткості виробництва & 55,5 \\
\hline 34 & $\mathrm{X}_{6}$ & монополізація економіки, низький рівень конкуренції & 48 \\
\hline 35 & $\mathrm{X}_{9}$ & $\begin{array}{l}\text { домінування видобувних і базових галузей з низьким ступенем переробки } \\
\text { сировини }\end{array}$ & 15 \\
\hline
\end{tabular}

За допомогою використання методу таксономії були розраховані рівні СП ${ }^{3 \mathrm{C}}$ (рис.4.1.2) на 2021-2029 рр.. Для визначення впливу динаміки ризиків на можливий стан спроможностей ЗС у майбутньому за умов невизначенності запропоновано розглядати їх зміну за 3-х сценаріїв (прогнозів), а саме: песимістичного $\left(\Pi_{1}\right)$, оптимістичного $\left(\Pi_{2}\right)$ та мінімального $\left(\Pi_{3}\right)$ (рис. 2 ). Умовою досягнення необхідного стану СП ${ }^{3 \mathrm{C}} \epsilon: \Delta \Pi_{n}^{m} \rightarrow 0$, за СП ${ }^{3 \mathrm{C}} \rightarrow \mathrm{C}_{\text {скореговані }}^{3 \mathrm{C}}$ Де $m$ - роки, $n$ - порядковий номер прогнозу. 


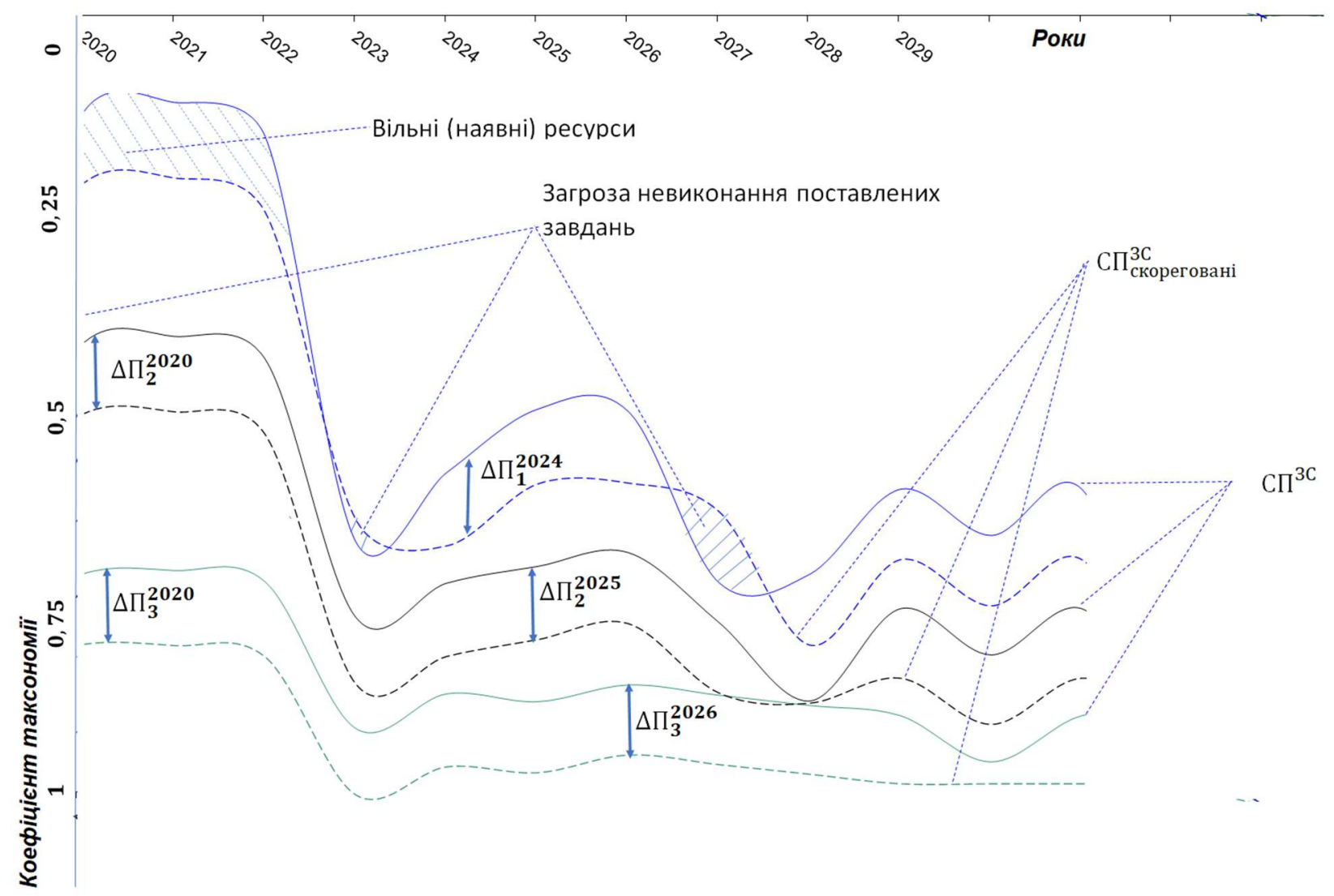

Рис. 4.1.2. Схематичне відображення динаміки спроможностей 3С з урахуванням скорегованого ризику, за трьох визначених сценаріїв до 2029 року включно.

Джерело: за результатами розрахунків авторів.

Врахування величини впливу можливих скорегованих ризиків є важливим елементом визначення рівня спроможностей ЗС на перспективу. За збільшення рівня (величини) ПХВ ризиків можуть виникати загрози невиконанню поставлених завдань. Така ситуація, може мати місце під час несвоєчасності поставки відповідних ресурсів, що мають високий рівень ПХВ із-зі чого позапланововивільнені ресурси призводять до корегування планування, а, в свою чергу, й спроможностей ЗС. Занижена величина ризику може провокувати появу вільних (наявних) ресурсів, наприклад, під час прогнозування необхідних ресурсів на відповідний період, адже ïх частина може вчасно не використовуватися та знаходитися у «стані простою» очікуючи на реалізацію, що зменшує ефективність використання узагальненої ресурсної бази. 
Тому, під час середньо- та довгострокового прогнозування спроможностей ЗС доцільно брати до уваги наступні рекомендації:

по-перше, є доцільним затвердити градацію можливих «сезонних» ризиків за кожним напрямом (складовою), що є частиною спроможностей 3С;

по-друге, розробити «карти-схеми» використання ресурсної бази 3 урахуванням впливу ПХВ ризиків на перспективу;

по-третє, розробити та затвердити Методику визначення рівня спроможностей 3С з урахуванням скорегованого ризику.

Отже, у роботі автороми висвітлена можливість врахування впливу скорегованого ризику на стан спроможностей Збройних Сил на довгострокову перспективу. Обгрунтування їх можливої динаміки, зазвичай, проходить в умовах невизначеності, тому дослідження величини ризиків та загроз, що можуть мати вплив на їх стан $є$ одним із пріоритетів. Зважаючи на наявні дослідження за цим напрямом підвищення їх рівня залишається невирішеною проблема щодо реалістичності моделей спроможностей Збройних Сил на перспективу. Тому модернізація алгоритму досліджень за цим напрямом потребує удосконалення. А саме у мажах визначення величини впливу закономірностей («сезонності») виникнення ризиків на ефективність використання ресурсної бази. Недосконалість визначення рівня спроможностей Збройних Сил на перспективу провокує удосконалення відповідних підходів. Урахування впливу скоригованого ризику дало можливість врахувати ПХВ ризиків під час прогнозування динаміки спроможностей Збройних Сил. Структурована ієрархія груп ризиків відповідно до їх ваги у сукупності надала можливість визначити найбільш та найменш- пріоритетні, щодо підвищення рівня спроможностей Збройних Сил. Для наочного сприйняття можливого впливу скорегованого ризику на прогнозний рівень спроможностей в роботі, iз використанням схематичних пояснень, наведено три можливих сценарії розвитку подій (песимістичний, оптимістичний та мінімальний) до 2029 року включно. Відповідно до отриманих результатів наведені рекомендації щодо підвищення рівня спроможностей Збройних Сил на перспективу. 
DOI 10.46299/ISG.2021.MONO.ECON.II-91-98

\section{2 Ведення інформаційної війни як конструювання нової реальності}

Уперше термін «інформаційна війна» вжив Томас Рон у звіті під назвою «Системи зброї та інформаційна війна» у 1976 році. Дослідник зазначає, що інформаційна сфера є невід'ємною складовою американської економіки та може бути вразливою у мирний та військовий час [113]. Саме поняття інформаційної війни (information war) почало широко застосовуватись в Америці ще з 1991 року. Але це не означає, що до цього часу світ не знав про дане явище. Можна навести декілька прикладів із Стародавньої історії, які доводять, що інформаційні війни завжди мали місце в суспільних протистояннях. Інформаційна війна це - такий спосіб подання інформації, який спрямований на дестабілізацію та сепарацію в середині суспільства. Найчастіше це відбувається прихованими методами, завдяки яким порушується колективна свідомість на психологічному рівні, що призводить до де конструкції суспільства та появи ворожої атмосфери в середині самої держави. Такий вплив здійснюються в першу чергу Засобами Масової Інформації. Грамотне ведення інформаційної війни дає можливість сформувати серед людей вигідну точку зору, систему поглядів чи навіть цілий світогляд. Адже за своєю природою індивід постійно перебуває в процесі пізнання. Тож така маніпуляція правдою, дає можливість дестабілізувати ситуацію ворога, розпалити внутрішньо державний конфлікт, особливо в сучасному світі. Будь які ЗМІ передбачають в першу чергу комунікацію групи людей між собою. Поширення в маси правди, що має місце на суспільному, політичному чи світовому рівнях. Проте, з ходом еволюції суспільство навчились використовувати іï у вигідних цілях, що не завжди $є$ позитивним. Тобто, з початком глобалізації світу, усі інформації процеси стали надто неоднозначними. Через це, громадянину важко самостійно осмислювати, фільтрувати та систематизувати отриману інформацію. Тож в сучасному світі інформація прирівнюється до зброї, а вміння подати iї у вигідному світлі - 3 мистецтвом ведення війни. 
Власне зомбування, яке виникло на зламі XX-XXI століть стало досить небезпечним явищем. Десятки років тому телебачення стало елементом повсякденності, без якого й не проходило дня у звичайного громадянина. Лише 3 появою Глобальної Мережі Інтернет, телебачення відійшло на задній план. Люди вірять усьому, що бачать на екрані свого телевізора. Вірять різним провокаціям з боку реклами чи телевізійного продукту. Суспільство стало настільки «чутливим», що контент телебачення легко може вороже налаштувати один народ проти іншого, посіяти егоїзм, розпорошити межі моральності. Найнебезпечніше - видавати брехню за правду і навпаки, шляхом підтасовки фактів, вириванням слів із контексту, посиланням до невідомого авторитету, що призвело до певного наслідування подій, що транслюють з боку користувачів медіа продукту [111, с. 402-404].

Часто маніпуляція ЗМІ спрямована не тільки проти країни суперника, але й використовуються владою задля впливу на власний народ. Сучасні політики давно усвідомили всю потужність медіа, тому й намагаються всіма силами переманити їх на свою сторону. Щоб заробити авторитет серед громадян, необхідно вміло маскувати свої недоліки, та висвітлювати власні переваги. Навіть, якщо доведеться перебільшити їх. Така «звітність» перед громадою здатна справити враження, створити певний образ та імідж того, кому це потрібно, і хто готовий за це заплатити. Наприклад, активне поширення інформації владою Росії про громадянську братовбивчу війну в Україні. I поширення серед населення того факту, що керівництво Кремля працює задля збереження народного спокою та не допущення національного конфлікту в середині держави. Таким чином, створюється ілюзія громадян про совісних політиків які працюють на благо країни. Всі кардинальні рішення влади приймаються задля безпеки громадян. I російський народ покірно $з$ цим погоджується, і не проявляє сильного інтересу до політичних рішень. Адже сутність людини полягає в потребі бути залученим до чогось, відчувати власну важливість. Саме емоції та психологічний аспект являють одним із найголовніших факторів впливу ЗMI, перед яким індивід постає майже 
беззахисним. Наприклад, агітація політиків перед виборами. Відбувається активна апеляція політика до особистості - «твій голос важливий», «ти сам обираєш своє майбутнє», «саме ти обираєш владу», « ти втомився жити в бідності - тому проголосуй і зміни ситуацію» і тому подібне. Таке спонукання до дій та активної громадянської позиції викликає певні емоції, якими людина керується при здійсненні політичного вибору. Отже, поняття «інформаційної війни» є набагато глибшим, ніж може здаватись на перший погляд. Оскільки мова йде про безліч технік, методів та різновидів прихованих впливів, під загрозою перебуває вся Світова спільнота. Існують мільйони людей які уявлення не мають про маніпуляції з боку ЗМІ, а є такі, які вміло ними користуються . Таким чином, створюється інший вимір, в якому розпорошується межа між реальним і віртуальним. Інформаційна війна не характеризується руйнуванням виключно інформаційного поля, вона несе і фізичну загрозу для держави. Зміна політичного клімату може вести за собою повстання як ворога, так і власного народу. Очевидно , що в сучасному світі виявлення суспільного невдоволення у вигляді страйків та протестів є звичним для керівництва країни. Дане явище чітко спостерігається як на прикладі України, так і сусідніх країн. Відтак, потрібно детальніше дослідити феномен гібридної війни, яка вражає як інформаційний , так і фізичний простір країни.

Гібридна війна стала одним із основних методом боротьби між державами. В першу чергу, вона покликана для послаблення когнітивних здібностей громадян та нав'язування вигідної точки зору, і як кінцевий результат абсолютне знищення державності. Визначення «гібридна війна» вперше було застосовано на саміті НАТО у Великобританії у вересні 2013 року. Воно характеризувалось як сукупність таємних бойових та інформаційних дій, здійснюваних злочинними угрупуваннями. Гібридна війна виходить за межі традиційного способу ведення війни та містить в собі низку інших явищ. Це не збройний конфлікт, а сукупність політичних інтриг, боротьба за домінування на всесвітньо-політичній арені. Росія бореться за можливість керувати політичноекономічними процесами в Україні, а також іï територією, торгівлею та 
соціокультурним середовищем. Якщо розглядати гібридну війну крізь призму військового конфлікту, то в Росії були створені цілі підрозділи збройних угрупувань, терористів, бойовиків та найманців, які оснащені найновішою зброєю та амуніцією. В поєднанні з інформаційним впливом, створюється потужний військовий сегмент, який застосовується для експансії іншої держави.

Можна виокремити основні принципи гібридної війни Росії проти України:

- ерешкоджання євроінтеграції України. Протидія співпраці з НАТО.

- здійснення заходів щодо послаблення економіки, сприяння внутрішньополітичній кризі України.

- повне підпорядкування України Російською Федерацією 3 метою реінтеграції до пострадянських структур.

- перешкоджання демократичних проявів в середині Росії, притаманних українському суспільству.

Потрібно визнати, що в добу глобалізації саме ЗМІ стали тим фактором, який конструює реальність, формує світогляд не лише особистий, але й національний. Сила медіа охоплює абсолютно усі сфери життедіяльності. Зникли межі приватності та публічності. 3 ходом еволюції інформація стала певним видом зброї, яка здатна впливати на політику, економіку, соціум як в світовому масштабі так і в середині країни. Здебільшого, це роками напрацьована система дій, де одна країна намагається контролювати соціально-політичне становище в іншій, за допомогою проплачених 3МI, у вигідних для неї цілях [112].

Агресія Російської Федерація проти України полягає в наступних діях:

- знищення інфраструктури та секторів промисловості через бойові дії, що завдає колосальний удар по економіці країни. ( Наприклад - руйнування Донецького міжнародного аеропорту)

- згубний інформаційний вплив Росії на український медіа простір.

- погіршення державного іміджу України на міжнародній політичній арені.

- перешкоджання зміцненню політичних інституцій, органів влади, держаної системи. 
- дискредитація України в проєвропейському та демократичному напрямку. Замилювання очей російському населенню 3 метою недопущення повстань.

- погіршення відносин України з іншими країнами світу.

- поступове загарбання українських територій та підпорядкування їх Російській Федерації. (Крим, Донецьк, Луганськ).

Основним завданням російської агресії є підірвати авторитет Свропи, Європейських цінностей, спотворення громадської думки, експансія держав та територій. Країна агресор різними способами перешкоджає будь який проєвропейський рух прилеглим до неї країнам ( Україна, Грузія). Так Росія намагається продемонструвати власні сили, залякати сусідні країни, деморалізувати людські цінності. Відтак, протягом останніх років стали частішими так звані «військові навчання» біля кордонів сусідніх країн, де активно демонструється повітряні та сухопутні збройні сили РФ. Це можна розцінювати як певного роду провокацію як інших держав, так і НАТО. Відомо, що з початку Незалежності України, ведеться гібридна війна з боку Росії. Проте, з настанням 2014 року, ситуація набирає все більших обертів, і як результат Революція Гідності, яка переросла в повномасштабну війну на Сході країни. Воєнний конфлікт триває вже 6 років, і з цього часу було прийнято велику кількість законів, проведено безліч переговорів, укладено мирні договори, які так і допомогли завершити війну або стабілізувати ситуацію.

На той час, в нашій державі не було дієздатного війська, належного його забезпечення та фінансування. Це стало перевагою для Російської Федерації, яка постійно нарощує сили, вкладає колосальні суми в розвиток армії та військової техніки. Варто визнати, що російський політико-економічний потенціал $\epsilon$ потужнішим за український. Саме це дало можливість агресору домінувати у веденні війни. Оскільки відомо, що військові дії - це в першу чергу витрати державних активів.

У постреволюційний період 2014 року в Україні були силові структури які могли моніторити інформаційний простір та проведення спецоперацій з боку 
Росії, проте в силу переорієнтації державних структур, все це функціонувало на примітивному рівні. Провокації на Сході давно перестали бути простим конфліктом, натомість перетворились в широкомасштабну війну, яка несе загрозу вже не тільки для України, але й як мінімум для Європи, СС надав підтримку для України. 10 червня 2015 року Свропарламент ухвалив Резолюцію «Про відносини між ЄС і Росією», де акцентується увага на тому, що Росія перестає бути їхнім стратегічним партнером. Відтак, Брюссель прийняв важливі рішення політичного, інформаційного, організаційного характеру з метою послабити натиск Росії. У липні 2016 року високопосадовці ЄС підписали 3 Генсеком НАТО декларацію про співпрацю та протидію «гібридному» впливу. 6 грудня 2016 року на саміті міністрів закордонних справ НАТО прийнято рішення про створення у 2017 році Європейського Центру протидії гібридним загрозам, також створений відповідний комплекс заходів зміцнення співпраці НATO і ЄС. Таким чином, було визнано той факт, що Російська Федерація $€$ країною-агресором та несе загрозу світового рівня [113].

Тривалий час, значна кількість російського медіа продукту була присутньою на українському телебаченні. Навіть український медіа контент транслювався російською мовою. Це призводить до популяризації російської мови та витіснення української. Проте, це стало лише початком катастрофи. Таким чином, готувався про надання статусу російській мові як державній та ще ціла низка інших негативних наслідків. Власне зомбування, яке виникло на зламі XX$\mathrm{XXI}$ століть стало досить небезпечним явищем. Десятки років тому телебачення стало елементом повсякденності, без якого не проходило й дня у звичайного громадянина. Лише з появою Глобальної Мережі Інтернет, телебачення відійшло на задній план. Люди довіряють всьому, що бачать на екрані свого телевізора.

Разом $з$ тим, настає криза медіа культури, оскільки суспільство все більше надає перевагу кількості інформації , а не якості. Адже, з психологічної точки зору , будучи в курсі подій, людина відчуває себе приналежною до чогось, що $є$ дуже важливим для неї. Так створюється «ефект присутності» - один із найпотужніших методів впливу та подання хибної інформації. Велике значення 
має те, як подається та чи інша інформація. Часто, задля досягнення максимального результату, потрібно проробити колосальну роботу, яка може тривати роками. Як приклад, можна навести «дружні» стосунки між Росією та Україною. Адже до 2014 року, як в Росії, так і в Україні активно пропагувалося те, що ми є братським народом з єдиною історією.

Сприйняття світу людством частково залежить від того, як його подають медіа. Поданий матеріал не перевіряється належним чином, це означає, що відповідальність 3МІ не є до кінця усвідомленою. Вплив медіа залишається не до кінця вивченим оскільки розвиток інформації, яка ототожнюється із знанням не можливо передбачити. А будь яка інтерпретація події є суб’єктивною i певною мірою нав'язує бачення автора. Отже, незалежно від обставин, потрібно зберігати автономію.

Соціальні мережі відіграють одну із ключових ролей повноцінного функціонування особистості у сучасному суспільстві:

- соцмережі сприяють збагаченню людей різним міжкультурним досвідом за допомогою споживання медіаповідомлень усіх типів (друкованого слова, зображень, аудіо та рухомих зображень).

- у країнах, що застосовують новітні технології, соціальні мережі допомагають громадянам представляти їхні інтереси, культуру та традиції на міжнародному рівні.

- соціальна мережа створює додаткові можливості людям у будь-якому суспільстві та уможливлює доступ до медіа людям з особливими потребами або економічно неспроможним верствам населення.

- соцмережі відіграють найважливішу роль у здатності людей оцінювати й реагувати на інформацію про соціальні та політичні конфлікти, війни, природні лиха, екологічні катастрофи тощо.

- соцмережі забезпечують миттєве розповсюдження інформації у всіх куточках світу, і відповідну миттєву реакцію громадян щодо подій, які відбулись. Тож вироблення критичного мислення детермінує всі сфери комунікації та робить доступними для людей принципи її роботи. 
Отже, інформаційні процеси є вирішальними на шляху побудови соціальнополітичних зв'язків. Саме тому, потрібно прискіпливо ставитись до усього, що публікується та виходить на всезагальний огляд. Оскільки в сучасному суспільстві інформація прирівнюється до знання, потрібно детальніше розібратися в іiі правдивості чи хибності. Захист інформації став однією 3 найбільших проблем XXI століття. Сукупність важливих даних про громадські, інфраструктурні, економічні та політичні ресурси стали зброєю в руках ворога, тому потребують належної протекції. Інформаційні процеси перетворились на потужний ресурс та стали інструментом в руках високопосадовців. У першу чергу, це пов'язано з впливом ЗМІ на психіку сучасної людини. Наплив інформації посилює відчуття вразливості та нестабільності в індивіда. Адже мозок людини не здатний сприймати та систематизувати весь потік знаків, символів чи образів, які продукують ЗМІ. Пересічний громадянин користується готовим набором інформації, його не хвилює достовірність знання, різко сприймає аргументовану критику. Так само можна охарактеризувати суспільство - воно не замислюється над своїм існуванням. 3 боку соціуму йде постійне нав'язування стереотипів та установок. Проблема кібернетичної безпеки стала широкомасштабною тоді, коли країни світу усвідомили можливі наслідки, що першочергово впливають на комп'ютерні системи. Таким чином через незначні зусилля можна паралізувати роботу усього державного апарату. Новітні технології застосовуються для автоматизації систем управління, створення цифрових державних ресурсів щодо діяльності міністерств, збереження інформації про органи виконавчої влади. Тому потрібен захист цих відомостей від несанкціонованого доступу до неї та її спотворення. Метою такого захисту $є$ зменшення інформаційного впливу на державні системи управління. 
DOI 10.46299/ISG.2021.MONO.ECON.II-99-105

\section{3 Основні аспекти управління економічною безпекою на різних ісрархічних рівнях}

При розгляді економічної безпеки кожне явище має вивчатися як певна система складових його елементів, як єдність взаємопов'язаних і взаємодіючих предметів, процесів, відносин. 3 позиції забезпечення економічної безпеки під цілим Ярочкин B.I [114] розуміє систему такого типу: «Суб’єкт - Об’єкт Система безпеки безпеки» для будь-яких об'єктів, рівнів і масштабів.

Економічній безпеці на різних ієрархічних рівнях притаманний інтегральний характер. Співвідношення частини i цілого вивчаються загальнонауковими методами аналізу та синтезу, що $\epsilon$ протилежно спрямованими й разом $з$ тим нерозривно пов'язаними способами пізнання. 3 тим або іншим ступенем конкретизації ці об’єкти підлягають захисту в економічній системі кожного інституціонального рівня. Об'єкти економічної безпеки розглядаються в інституціональному і функціональному аспектах [114].

Згідно з українським законодавством «поняття «національна безпека» зумовлює таку державну політику у цій сфері, яка має враховувати поточний стан і перспективи розвитку внутрішніх та зовнішніх чинників» [115, с. 42]. Зокрема Власюк О.С., досліджуючи національну безпеку України виділяє іiі базові принципи - комплексності та системності. Вони покладені в основу політики національної безпеки США (Закон про національну безпеку, 1947 р.) та на них базується й концепція національної безпеки України [115, с. 43]. При цьому комплексність державної стратегічної політики полягає у спільній участі не тільки представників різних гілок влади, господарсько-керівної та політичної еліт, але наряду з іншим й наукової спільноти.

Доцільним є розгляд державної політики національної безпеки на стратегічному рівні 3 використанням загальних підходів та методів задля уникнення зосередження уваги лише на іiї складниках та тактичних цілях, що можуть не на всіх рівнях збігатися із загальнонаціональними. «Дотримання 
принципу системності державної політики забезпечуватиме найвищу пї ефективність, гармонійне та взаємопов’язане функціонування іiі складників» [115, с. 42]. У результаті використання принципу системності збережеться загальна ефективність державної політики [115, с. 42].

Проте на законодавчому рівні, згідно зі ст. 2 та ст. 25 Закону України «Про національну безпеку України» [116], незважаючи на те, що економічна безпека є складовою національної безпеки, принципи розглянуто більшою мірою відносно її воєнної та політичної складових.

До основних принципів економічної безпеки доцільно віднести принципи, які грунтовно розкривають Ярочкин В.I. [114], Верхоглядова Н.I. та Олініченко І.В. [117], Шуршин В.О. [119].

1. Принцип системності. Він є основоположним принципом економічної безпеки. В його основі знаходиться співвідношення цілого (не є тотожним сумі частин, воно володіє новою якістю, відсутньою в частинах i виникає у результаті їх взаємодіiі) і частини (має відносну самостійність, властивими ій якісними особливостями і може, в свою чергу, розглядатися як ціле зі своїми складовими частинами, але вже меншого масштабу). За цим принципом здійснюється побудова економічної безпеки за ієрархічними рівнями. Будь-яке явище в сфері економічної безпеки доцільно вивчають як ціле, відносно самостійне, що включає ряд явищ меншого масштабу, воно є частиною більшого явища, відбиває його вплив на ціле та на нього впливає. За цього принципу, як розкрито в праці [117], відбувається облік внутрішніх взаємозв’язків і взаємозалежностей та зовнішніх чинників з позицій розгляду об’ єкту дослідження як елементу економічного простору більш високого рівня.

2. Принцип взаємозв'язку і взаємозалежності. Його сутність полягає в тому, що усі елементи системи нерозривно пов'язані між собою і одночасно впливають один на одного всередині системи.

3. Принцип визначальних чинників, його сутність полягає у виділенні істотних зв'язків та відносин, що мають вирішальний вплив на стан безпеки. Цей принцип дозволяє відсіяти другорядні чинники впливу, що не справляють 
значний вплив на функціонування економічної безпеки.

4. Комплексності. Він полягає у необхідності аналізу усіх сторін об'єкту дослідження (галузевої і територіальної, соціальною, технічної і екологічної складових).

5. Принцип варіантності (альтернативності). Сутність цього принципу полягає у виявленні та обгрунтованості кількох варіантів виходу з кризової ситуації, з одного боку та розрахунку траєкторії соціально-економічного розвитку на майбутнє, з іншого.

6. Принцип безумовного пріоритету економічної безпеки як найважливішого елементу якості життя i соціального прогресу, тобто пріоритетності рішення завдань i здійснення заходів, спрямованих на збереження здоров'я і життя людини, підтримку нормальних умов його існування.

7. Принцип прийнятного ризику, тобто виявлення і реалізації доступних заходів, спрямованих на захист людини в ринковому середовищі і недопущення кризових ситуацій.

8. Принцип сумісності технічної і соціальної складових економічної безпеки і безумовного пріоритету останньої.

9. Принцип компромісу між поколіннями з акцентом тяжкості подолання кризових ситуацій сьогодні.

Зокрема, на макрорівні Користін О.С., Барановський О.І. та Герасименко Л.В. [118], виділяють принципи забезпечення економічної безпеки держави [118], що, на відміну від принципів, визначених в Законі України «Про національну безпеку України» [116], незважаючи на схожість за змістом їх окремих положень, об'єднують макрорівень 3 мезо-, мікро- та рівнем сім'ї, особи, інакше кажучи дослідження економічної безпеки відбувається через призму національної безпеки. До таких принципів відносять:

- верховенства закону під час забезпечення економічної безпеки;

- додержання балансу економічних інтересів особи, сім’ї, суспільства, держави; 
- взаємної відповідальності особи, сім'ї, суспільства, держави щодо забезпечення економічної безпеки;

- своєчасності і адекватності заходів, пов'язаних із відверненням загроз і захистом національних економічних інтересів;

- пріоритетності договірних (мирних) заходів у вирішенні як внутрішніх, так і зовнішніх конфліктів економічного характеру;

- інтеграції національної економічної безпеки 3 міжнародною економічною безпекою.

Принципи економічної безпеки на мезорівні (рівні регіону) поділяються на загальні - комплексності, системності, варіантності (альтернативності), прийнятного ризику (Користін О.С., Барановський О.I. та Герасименко Л.В. [118], Шуршин В.О. [119], що можуть бути віднесені за своєю сутністю до основних та спеціальні - економії ресурсів, циркуляції інформації, балансу інтересів, «екватору» (Верхоглядова Н.І. та Олініченко І.В. [117]) - до підрядних. Ці принципи, як зазначено в працях [118-119] $є$ основою формування системи економічної безпеки регіону, оцінки ії загроз та їх наслідків.

До основних принципів функціонування систем Шнипко О.С. [120] відносить:

- принцип ефективного цілеформування (полягає у тому, що ціль ефективної поведінки системи задається над системою);

- принцип цілісності (стверджує, що ціле є більшим від суми складання його елементів, тобто система має властивості, які не виводяться із властивостей її елементів та способів їх поєднання);

- принцип детермінізму (його сутність полягає в тому, що причина зміни стану системи завжди знаходиться поза системою);

- принцип оптимальності (стверджує, що система повинна рухатися до мети за оптимальною траєкторією);

- принцип спеціалізації і кооперування (полягає в тому, що рухаючись до мети, система має тенденцію спеціалізуватись на виконанні своєї функції та 
кооперуватися з іншими системами);

- принцип ієрархічності (стверджує, що розвиток системи здійснюється ієрархічно).

Доцільно окремо виділити основні принципи забезпечення економічної безпеки регіону, до яких Користін О.С., Барановський О.І. та Герасименко Л.В. [118], Шуршин В.О. [119] відносять: принцип інтеграції з національною економічною безпекою; додержання балансу регіональних інтересів; чітке розмежування змісту діяльності, повноважень та відповідальності органів державної влади на державному та регіональному рівнях; чітке розмежування повноважень і відповідальності органів державної влади та місцевого самоврядування; прагнення до примноження національного багатства країни шляхом ефективного використання природно-ресурсного, науково-технічного, фінансового, інтелектуального трудового потенціалу регіону.

Також існує класифікація принципів організації та здійснення захисту у сфері економічної безпеки регіону (Головня Ю.І. [121]):

1. Системності. Передбачає розгляд проблем захисту з урахуванням усіх небезпечних каналів відпливу інформації та несанкціонованого доступу до неї, а також можливого часу та умов їх виникнення, комплексного застосування правових, організаційних та технічних заходів щодо захисту; при цьому має бути забезпечена спадкоємність та безперервність захисту.

2. Обгрунтованості. Оскільки складність завдань, що вирішуються, великий обсяг робіт, а також обмеженість ресурсів зумовлюють необхідність глибокого науково-технічного обгрунтування рішень, що приймаються, всебічної оцінки щодо їх реалізації.

3. Достатності. Означає необхідність пошуку ефективних та надійних заходів захисту, без зайвих витрат i забезпечується використанням найдосконаліших методів та засобів захисту. За характером впливу на загрозу серед способів захисту можна виділити узгодження, стримування, протидію та примушення.

4. Гнучкості в управлінні. Забезпечує здатність, залежно від умов захисту 
та важливості об’єктів, що захищаються, прогнозування загроз та запобігання їх нейтралізації, оперативну та ефективну ліквідацію наслідків цих загроз;

5. Своєчасності. Зумовлюється необхідністю завчасної розробки заходів захисту та контролю (у протилежному разі проведення заходів щодо захисту може не лише не дати ефекту, а й призвести до додаткових збитків).

У загальному вигляді на мікрорівні до принципів економічної безпеки Користін О.С., Барановський О.І. та Герасименко Л.В. [118] відносять: комплексність (системність); пріоритет заходів попередження; безперервність; законність; плановість; економність; взаємодія; компетентність; поєднання гласності та конфіденційності.

На мікрорівні зважаючи на предметну сферу дослідження здійснено поділ за групами на загальні та спеціальні принципи забезпечення економічної безпеки підприємства. Принципи комплексності, системності; безперервності [114, с. 5], обгрунтованості, достатності, гнучкості, своєчасності [122] за своєю сутністю є загальними, їх також можна віднести до основних. Принципи пріоритету заходів попередження; законності; плановості; економності; взаємодії; компетентності; поєднання гласності та конфіденційності; гнучкості; активності; законності; економічності; спеціалізації; взаємодії і координації; удосконалення; централізації управління [114, с. 5, с. 9] являються підрядними за змістом й можуть бути віднесені до спеціальних.

Зважаючи на сутність принципів та їх роль і значення задля забезпечення економічної безпеки та управління нею (вони є одночасно зведенням основних законів управління та правилами управлінської діяльності [123, с. 33, 124, с. 150]) на основі узагальнення наукових напрацювань у сфері управління економічною безпекою на макро-, мезо- та мікрорівні здійснено виокремлення принципів [125-129]. При цьому, окремо Ляшенко О.М. в праці [124, с. 149] виділяє принципи управління економічною безпекою підприємства, що виступають в якості правил, на основі яких здійснюється функціонування організацій, визначають поведінку суб'єкта й об’єкта в процесі управління та характер взаємовідносини організації 3 навколишнім середовищем. Вони 
відображають закономірності розвитку управлінських відносин, внаслідок чого $\epsilon$ логічним завершенням ланцюжка: «закони - закономірності - досвід управління - принципи» [124, с. 149].

Враховуючи вищенаведене слід зазначити, що реалізація на практиці виокремлених й систематизованих принципів управління економічною безпекою на різних ієрархічних рівнях дозволить приймати адекватні управлінські рішення в сучасних умовах господарювання з урахуванням ризику та невизначеності задля нівелювання чи принаймні зменшення негативного впливу загроз економічній безпеці. 
DOI 10.46299/ISG.2021.MONO.ECON.II-106-114

\section{4 Особливості організації мобілізаційної підготовки економіки у країнах- членах НАТО}

Мобілізація економіки - один з інструментів подолання екстремальних або кризових етапів історії будь-якої країни. Мобілізації економіки, як і будь-якого методу управління, відповідає група завдань, які необхідно вирішувати найбільш ефективно. У моделі національної економіки має бути враховано стабільний $\mathrm{i}$ мобілізаційний режими функціонування, які будуються відповідно до цілей розвитку держави та бачення іiі місця в майбутньому світі [130].

Щодо питання мобілізації економіки країн-членів НАТО, то перш за все необхідно зазначити, що головним завданням НАТО $є$ захист свободи й безпеки його членів в Свропі та Північній Америці відповідно до принципів Статуту ООН. Для досягнення цієї мети Альянс використовує як свій політичний вплив, так і військову потужність, залежно від характеру проблем безпеки, що постають перед країнами - членами НАТО. Відповідно до змін, що відбулися в стратегічному середовищі, змінилися й засоби реагування НАТО на нові проблеми безпеки. Нині Альянс забезпечує стабільність в євроатлантичній зоні і продовжує трансформуватися з метою адекватного реагування поза межами його традиційної зони відповідальності на нові ризики й загрози, такі як, тероризм і проблеми у сфері безпеки, що постають у країнах, які зазнали кризи державної влади [131].

У зв'язку з цим досвід організації мобілізаційної підготовки економіки у Франції є найбільш представницьким серед країн - членів НАТО.

У нормативно-правових актах визначено комплекс заходів, які мають проводитися для мобілізаційної підготовки країни (зокрема економіки) в мирний час, і встановлено порядок переходу на військовий стан. До основних 3 них належать такі: Закон від 11.07.1938 «Про загальну організацію нації на період війни», указ Президента Французької Республіки від 07.01.1959 № 59-63 «Про реквізиції майна і послуг», декрет Президента Французької Республіки від 29.06.1962 № 62-729 «Про мобілізаційну підготовку економіки» та інші [132]. 
Організація мобілізаційної підготовки економіки у Франції здійснюється на рівні центрального уряду і на територіальному рівні. На рівні центрального уряду управління мобілізаційною підготовкою економіки забезпечується за допомогою участі вищих посадових осіб держави в спеціалізованих державних органах з питань оборони і мобілізаційної готовності, а саме: у Вищій раді оборони і Комітеті оборони Франції. При цьому повноваження Вищої ради оборони полягають у дослідженні проблем оборони і розробки пропозицій щодо основних напрямів військової політики і військового будівництва. Відповідно Комітет оборони спеціалізується на прийнятті рішень із загальних і конкретних питань оборони і забезпечення координації та взаємодії центральних органів виконавчої влади.

Загальне керівництво обороною і відповідно мобілізаційною підготовкою економіки здійснює прем'єр-міністр країни, якому підпорядкований Генеральний секретар національної оборони, який координує підготовку оборонних заходів міністерств та відомств, а також готує міжвідомчі регламентні акти і здійснює безпосередній контроль їх виконання. Крім зазначених раніше двох колегіальних органів у Франції функціонує також Міжвідомча комісія 3 питань оборони, на засіданнях якої головує Генеральний секретар національної оборони.

Таким чином, аналіз організації мобілізаційної підготовки економіки у Франції показує, що фінансове забезпечення виконання робіт (послуг) здійснюється шляхом реалізації механізму критеріального відбору підприємств, серед яких територіальні органи розподіляють доведені до них відповідними міністерствами центрального уряду фінансові ресурси на конкурсній основі, що призводить до більш ефективного виконання заходів мобілізаційної підготовки економіки країни і відповідно до ефективного і раціонального проведення державних витрат, передбачених у державному бюджеті Франції на відповідні цілі.

Наступною доцільно розглянути організацію мобілізаційної підготовки економіки у Сполучених Штатах Америки. Організаційно-правові основи 
мобілізаційної підготовки економіки країни, а також порядок фінансового забезпечення виконання робіт (послуг) визначено у сукупності федеральних законів і указів президента країни.

Найбільш важливим нормативно-правовим актом виступає Президентський указ № 12742 «Мобілізаційна готовність економіки», який надає президенту країни необмежені можливості щодо залучення під час війни всіх економічних ресурсів країни для задоволення потреб національної оборони [133]. Іншими словами, президенту країни даються права і повноваження видавати будь-якій юридичній або фізичній особі замовлення на виготовлення $\mathrm{i}$ поставку тих зразків озброєння, військової техніки та військового майна, які ця особа виробляє або здатна виробляти 3 дотриманням позачергових вимог виконання цього замовлення за певними цінами. У разі відмови президенту надається право реквізувати відповідний виробничий об'єкт з подальшою виплатою власнику компенсації в розмірі, встановленої президентом. У разі незгоди із запропонованими умовами виплати компенсації законодавчо передбачено механізм оплати в розмірі 50 \% з наступним судовим розглядом в частині виплати суми, що залишилася. Відповідно президент може делегувати свої повноваження з розміщення пріоритетних замовлень так посадовим особам: міністру сільського господарства щодо всіх продовольчих ресурсів; міністру енергетики щодо всіх видів енергії; міністру транспорту щодо всіх видів цивільного транспорту; міністру економіки щодо всіх інших предметів i матеріалів. Делеговані повноваження можуть бути реалізовані вищеназваними міністрами тільки в разі винесення відповідних ухвал міністра оборони про негайну поставку конкретних предметів і матеріалів виключно для потреб збройних сил в інтересах національної безпеки, або ж міністром енергетики щодо ядерних енергетичних програм.

У законі про накопичення стратегічних і критичних матеріалів від 07.06.1939 передбачено здійснення закупівель і збереження запасів певних стратегічних і критичних матеріалів, а також розвідка та консервація джерел цих матеріалів на території США. Метою цього закону є зменшення та запобігання 
небезпечної і дорогої залежності країни від зарубіжних джерел поставки таких матеріалів у періоди надзвичайного стану. При цьому передбачено, що вироблене національне оборонне замовлення стратегічних i критичних матеріалів призначено для використання тільки в інтересах національної оборони і не може бути використано в бюджетних цілях. Крім того, законом передбачено повноваження щодо розмежування стратегічних $\mathrm{i}$ критичних матеріалів, їх характеристик, а також повноваження щодо закупівель і продажу матеріального національного оборонного замовлення і з управління запасами в частині встановлення вимог. Таким чином, закон про накопичення стратегічних і критичних матеріалів є комплексним законодавчим актом, що містить не тільки порядок і правила накопичення мобілізаційного резерву сировини і матеріалів, а й концептуальні положення, фактично визначає планування військовополітичним керівництвом США можливих масштабів мобілізації економіки для задоволення потреб забезпечення безпеки країни.

Безпосередньо пов’язаним 3 питанням мобілізаційної підготовки економіки країни є Закон про національну безпеку, згідно з яким передбачено певні повноваження директора Федерального агентства щодо дій у надзвичайних умовах, який є радником президента з координації мобілізації збройних сил, цивільних відомств і економіки. У кодексі США про військово-промисловий резерв передбачено збереження державних заводів, резерв верстатів та іншого виробничого обладнання, здатних у разі необхідності бути задіяними для забезпечення потреб збройних сил, але цей резерв має бути розраховано на мінімально необхідні потреби [134]. Важливо наголосити, що законодавчо передбачається забезпечення військового виробництва приватним сектором.

У США дуже складна система урядових органів, які займаються підготовкою економіки країни до задоволення потреб війни. Їх діяльність координується як «зверху вниз» - управління вищих органів підлеглими установами, так і «знизу вверх» - розробка нижчими установами пропозицій та подання їх на розгляд і затвердження керівним органам. 
Ще однією особливістю американської системи мобілізаційної підготовки промисловості (що підштовхувала до відмови від утримання резервних потужностей) $\in$ добровільний характер підтримання мобілізаційних потужностей з боку приватного сектора.

Головним є те, що в американській системі мобілізаційної підготовки промисловості США були величезні масштаби і високі темпи виробництва в період Другої світової війни деяких видів бойової техніки (наприклад, танків і літаків), завчасна розробка спеціальних так званих мобілізаційних зразків озброєння, технологічно орієнтованих на масовий випуск у разі мобілізації в цивільному секторі економіки. Завдання створення таких зразків було покладено на мобілізаційні органи армії (тобто сухопутні війська), ВМС і насамперед - на державні арсенали збройних сил [135].

Досвід мобілізаційної підготовки економіки Федеративної Республіки Німеччина не менш цікавий для проведеного аналізу. Питаннями мобілізаційної підготовки економіки в Німеччині займаються в тій чи іншій мірі всі органи різних рівнів влади. Федеральні міністерства координують діяльність щодо виконання рішень вищих органів законодавчої і виконавчої влади. Органи місцевого самоврядування земель, округів, районів і громад відповідають за практичну реалізацію мобілізаційних заходів. Формування законодавчої бази мобілізаційної підготовки здійснюється палатами федерального парламенту. На прийняття рішень президентом і парламентом країни з питань мобілізаційної підготовки економіки істотно впливає створена при Федеральному канцлерові Федеральна рада безпеки, яка є вищим консультативним органом з військових $\mathrm{i}$ військово-політичних питань, і в тому числі координує діяльність вищих військових і цивільних органів у сфері мобілізаційних заходів. Безпосередню роботу з планування та координації діяльності військових і цивільних органів щодо виконання прийнятих Федеральною радою безпеки рішень здійснює Відомство федерального канцлера, а керівництво здійсненням конкретних заходів з підготовки економіки до війни покладено на міністерство оборони $\mathrm{i}$ цивільні міністерства і відомства в зоні їх відповідальності [136]. 
Серед цивільних міністерств і відомств важливу роль в управлінні мобілізаційною підготовкою відіграє міністерство економіки, на яке покладено відповідальність за підготовку до війни обробної промисловості, тобто це міністерство відповідає за забезпечення військового виробництва необхідною сировиною і напівфабрикатами, а також за розширення виробничих потужностей у найбільш важливих для військового виробництва галузях промисловості. Міністерство фінансів забезпечує функціонування фінансової та грошовокредитної системи країни, здійснює фінансове забезпечення військовополітичних рішень, планування військових витрат, зміцнення національної валютної системи. У воєнний час у всіх федеральних міністерствах передбачено створення «кризових штабів» i виділення консультативних груп до складу робочого штабу військового кабінету, який координує діяльність органів військового та цивільного управління та організовує взаємодію між федеральними міністерствами і відомствами. Усі заходи 3 мобілізаційної підготовки економіки розробляються федеральними органами влади, на практиці здійснюються органами управління земель, округів, районів і громад.

Особливістю мобілізаційної підготовки економіки Німеччини є те, що використовується надзвичайне законодавство, згідно з яким держава організовує i координує проведення як мобілізаційної підготовки, так і мобілізаційних заходів у разі виникнення надзвичайної ситуації, контролює діяльність приватного сектора, перерозподіляє фінансові, матеріальні та трудові ресурси 3 метою забезпечення розгортання військового виробництва. У разі надзвичайної ситуації починають діяти положення Конституції країни, надзвичайні закони та урядові постанови. Мобілізаційну підготовку економіки країни регламентують такі закони: «Про функціонування промисловості і кредитно-грошової системи в надзвичайних умовах», «Про забезпечення продуктами харчової промисловості, сільського та лісового господарства» та інші. У звичайних умовах мирного часу ці закони діють лише частково і здійснюються в основному організаційно-підготовчі заходи. 
Переважання приватного сектора (в ньому зосереджено до $90 \%$ військового виробництва) вкрай обмежує можливості державного регулювання економіки. У цих умовах підготовка і здійснення економічної мобілізації в Німеччині неможливі без використання системи спеціальних взаємодоповнюючих законодавчих та фінансово-кредитних важелів, основа для використання яких у надзвичайних умовах створюється ще в мирний час. Характерною рисою законодавства Німеччини $є$ те, що всі закони містять положення про обов'язок підприємців і всіх громадян країни надавати до відповідних органів необхідну довідкову інформацію про виробничі потужності, обладнання, що випускається, транспортні засоби і об'єкти транспортної інфраструктури. Особливістю надзвичайного законодавства Німеччини $\epsilon$ наявність основ широкомасштабного державного регулювання економіки, без якого неможливе розгортання військового виробництва. Іншими словами, згідно 3 цим законодавством можна у разі потреби використовувати заборонені в мирний час адміністративні методи впливу на економіку країни. Відповідно до законів про завчасну підготовку економіки передбачено прийняття необхідних постанов уряду в частині регулювання, наприклад, щодо обсягів і номенклатури товарів, щодо проведення банківських і біржових операцій, щодо порядку отримання і використання фінансових ресурсів.

Також у Німеччині діє закон «Про військові обов'язки», який може застосовуватися після відповідного рішення федерального уряду [137]. Зокрема, він може повністю набрати чинності в мирний час під час командно-штабних навчань НАТО, під прикриттям яких можливе здійснення досить широкого комплексу мобілізаційних заходів в економіці. Згідно з цим законом передбачено можливість конфіскації у приватного сектора на користь держави рухомого майна, виробничих потужностей, ділянок землі. Крім закону «Про військові обов'язки» міністр оборони ухвалив «Основні принципи процесу підготовки до задоволення потреб військової і цивільної оборони». Тобто в цьому документі містяться основи визначення потреб країни в матеріальних ресурсах і величини запасів у разі війни. Таким чином, усі федеральні міністерства зобов'язані 
визначати свої потреби в матеріальних засобах і послугах, які знадобляться додатково для забезпечення виконання збройними силами бойових завдань. Галузеві відомства, які відповідають за ці кошти і послуги, визначають можливості щодо задоволення зазначених потреб. Потім узгоджуються потреби і можливості спочатку на рівні районів, потім - на рівні федерації. У всіх надзвичайних законах Німеччини передбачено порядок і розміри відшкодування приватному сектору збитків і шкоди, пов'язаних із здійсненням мобілізаційних заходів, а також форми покарання за невиконання урядових розпоряджень. У цілому досвід мобілізаційної підготовки економіки в Німеччині дуже показовий у частині розроблення відповідного надзвичайного законодавства, що охоплює великий спектр питань, зокрема фінансового забезпечення заходів мобілізаційної підготовки економіки. Досвід Німеччини цікавий також щодо залучення до заходів мобілізаційної підготовки приватного сектора i розроблення механізму фінансового забезпечення витрат і збитків підприємців в умовах воєнного виробництва.

Таким чином, якщо правильно оптимально організувати мобілізацію економіки будь-якої країни, яка веде війну або готується до неї, то їі можна не тільки не програти, але і виграти.

Виходячи $з$ досвіду країн-членів НАТО та з урахуванням проведеного аналізу можна виокремити наступні заходи для вдосконалення системи мобілізації економіки:

визначення показників та критеріїв, які впливають на діяльність системи мобілізаційної підготовки;

розробка мобілізаційних планів економіки в частині визначення обсягів постачань озброєння та військової техніки, майна і продовольства з урахуванням невідкладних потреб економіки вцілому;

створення і розвиток мобілізаційних потужностей для виробництва озброєння та військової техніки;

формування державних та мобілізаційних матеріальних резервів; 
удосконалення організації мобілізаційної підготовки економіки, включаючи мобілізаційне планування і проведення науково-дослідних робіт із мобілізаційної тематики;

забезпечення фінансування заходів щодо мобілізаційної підготовки економіки тощо;

організація взаємодії з державними громадськими інститутами, що вирішують завдання організації мобілізації (громадські або комерційні структури, які виконують частину функцій мобілізації під керівництвом держави (у США і Великобританії в період Другої світової війни));

забезпечення адміністративного спрямування ресурсів приватних осіб і організацій програми, які визнані пріоритетними під час організації мобілізації економіки;

формування громадської думки на підтримку мобілізації, включаючи волонтерський рух;

залучення наукового співтовариства до розробки і виробництва проривних технологій. Це дозволить сформувати нову парадигму стратегічного управління на мезо- і макрорівнях російської економіки, що виражається в залученні синергетичного взаємозв'язку мікро-, мезо- і макропроцесів економічного розвитку інноваційного типу. 
DOI 10.46299/ISG.2021.MONO.ECON.II-115-129

\section{5 Методи аналізу системогенезу та онтогенезу розвитку кіберспорту в Україні}

Базисом систематизованої сукупності кроків, які потрібно здійснити для розвитку кіберспорту $\epsilon$ аналіз розвитку кіберспортивних організацій, орієнтований на виділення:

- системогенезу функціональних систем (а саме загального відбиття стану сукупності уподібнення різновекторних процесів виробничо-господарської діяльності кіберспортивних організацій всередині цільових формальних груп видавця/розробника кіберспортивної гри);

- онтогенезу їх внутрішнього розвитку (через ідентифікацію еволюції спорідненості кіберспортивних організацій за цими процесами 3 моменту їх утворення до зникнення).

Такі потреби обумовлені тим, що саме виробничо-господарські процеси всередині цільових формальних груп видавця/розробника кіберспортивної гри пов’язані між собою та впливають на якість кіберспортивної гри (як продукту) i якості організації подій (що проходять в віртуальному просторі).

Важливим для видавця/розробника такої гри є досягнення максимальної спорідненості таких процесів, оскільки це формує уніфіковане середовище взаємодії кіберспортсменів у грі та рівні умови змагань.

Щодо процесів ідентифікації системогенезу та онтогенезу у науковій літературі майже відсутні методичні підходи, що містять алгоритми дій, які пристосовані під специфіку розвитку спорідненості кіберспортивних організацій [152, с. 16, с. 18]. Це пов'язане з відносно недовгою генезою їх розвитку. Крім того, за даними видавців/розробників така спорідненість полягає у координованості дій 3 виробництва, постачання, організації споживання нематеріальних благ, що $є$ кіберспортивною дисципліною (а саме тих, що за цільовими форматами орієнтовані на потреби видавця/розробника конкретної кіберспортивної гри) починаючи від ігрових спільнот, командних складів, команд, клубів, ліг (що поділяють почуття спільності, щодо їх діяльності) гри до 
операторів кіберспортивних подій $[152$, с. 16, с. 18]. Зміст основних процесів виробничо-господарської діяльності кіберспортивні організації $\epsilon$ наступним $[152$, с. 16, c. 18$]$ :

- процеси виробництва це створення специфічних благ, яке забезпечуються технічними можливостями систем, що у загальному сенсі створюють різноманітні програмні коди, які набувають різноманітної форми та можуть узагальнювати: режим роботи 3 комп'ютерною програмою, інтерфейс користувача, насиченість ігрового процесу; пришвидшена робота 3 комп’ютерною грою; перетворення роботи з комп'ютерною грою на конкретні кіберспортивні послуги.

- процеси постачання, які охоплюють закупівлю, генерування потужностей реплікації та масштабування, що призначені для постачання продуктів та послуг різного виду (на вимогу споживачів) за цільовими формальними групами видавця/розробника кіберспортивної гри;

- процесів 3 організації споживання нематеріальних продуктів та потужностей сервісів, необхідне для їх існування та розвитку.

Специфічним є те, що всі процеси виробничо-господарської діяльності кіберспортивних організацій, всередині цільових формальних груп видавця/розробника кіберспортивної гри, мають відбуватися у єдиних умовах, сформованих багатофункціональними кіберспортивними майданчиками (аренами) та їх глобальним мережами, представленими одноформатними спеціалізованими клубами, базами 3 домашніми аренами для локальних кіберспортивних подій, навчально-тренувальними базами для кіберспортсменів.

Враховуючи зміст таких процесів важливим є їх дослідження коштом різних методів цілеспрямованих дій або їх поєднання, що мають не просто представляються у числових величинах та напрямках, інтерпретованих у багатокрокових ітераціях (повтореннях), а ідентифікуватися як множинні математичні моделі, які надають опис рис спорідненості, уподібнення.

Науковцями нарізі пропонуються до використання різні підходи, що присвячені особливостям ідентифікації у математичних моделях окреслених 
процесів, які можуть трансформуватися відповідно до [140]: специфіки функціонування різнотипових організацій (у т.ч. індустрії розваг); індивідуальної тотожності процесів та тих їх рис, які значущі для набуття стану пов'язаності.

Всі математичні моделі, в залежності від систематизованої сукупності кроків, що ними використовуються, мають властивості до унікалізування (із врахуванням особливостей діяльності конкретної організації). Зокрема, кожна модель містить виняткові змінні рішення: які впливають на ці цілі, враховує обмеження, що існують; які впливають на феноменологію, що визначає субпроцеси, що представлені окремими моделями, вихідні величини яких $є$ вхідними для інших (наступних) субпроцесів.

Хоча ці властивості різняться за ступенем набуття унікальних властивостей, підходи застосовувані для ідентифікації системогенезу функціональних систем та онтогенезу їх розвитку для кіберспортивних організацій, що діють у межах цільових формальних груп видавця/розробника кіберспортивної гри.

Серед методичних підходів, що визначаються, як такі, що придатні для такої ідентифікації, науковцями пропонуються ті, що передбачають створення математичних моделей стану процесів виробничо-господарської діяльності організацій та їх еволюції, а саме ті, що грунтується на засобах:

- лінійного програмування або ЛП (Г. І. Карімов, Амрін Г., Річі Дж., Моді I., Дзюбан І. Ю., Листопад В.В);

-лінійного програмування із використанням транспортних матриць (Гетьман О.О., О.В. Іваницька, Н. В. Рощина, Р.С. Сербул);

- динамічного програмування (Соколовська 3.М., Яценко Н. В., Хортюк М. В., Бхондекар, Мол, П., \& Виг, Р.);

- теорії масового обслуговування (Ложковський А. Г., Штрік Дж., Тютюнник Ю.М.;

- теорії ігор (Льюс Р., Райфа Х., Олешко Т.І., Лобанов М.О.). 
Розглянемо сутність кожного 3 виділених підходів, їх особливості, доцільність застосування для ідентифікації стану спорідненості процесів виробничо-господарської діяльності та напрямів їх еволюції.

Підхід, що грунтується на засобах лінійного програмування або ЛП (Г. I. Карімов [145], Амрін Г., Річі Дж., Моді I. [138], Дзюбан I. Ю.[142], Листопад В.В.[146]) передбачає, що за процесами виробничо-господарської діяльності організацій формується система лінійних нерівностей, що визначають стан спорідненості та напрямки іï еволюції за безліччю рішень (це здійснюється за системою обмежень задач лінійного програмування). Закономірно, лінійна функція $\mathrm{f}(\mathrm{x}) \epsilon$ цільовою функцією, що придатна для ідентифікації розвитку спорідненості за цільовими формальними групами видавця/розробника кіберспортивної гри. При цьому підхід має ряд недоліків, що обмежують можливості його застосування для кіберспортивних організацій. Зокрема, відмічена відсутність усталеного підходу до систематизованої сукупності кроків з ідентифікації системогенезу та онтогенезу процесів виробничо-господарської діяльності. Для реалізації цих задач пропонуються до використання: графічного методу рішення, симплекс-методу, двоїстого симплекс-методу (Р-метод), методу Гоморі; параметричного програмування; дрібно-лінійного програмування [145, c. 5]. Крім того, за описом особливостей ідентифікації ситемогенезу функціональних систем організацій та онтогенезу їх розвитку за сукупністю методів ЛП (табл. 4.5.1), можна констатувати, що:

1) за будь-яким з цих кроків складно чітко ідентифікувати реальний зміст еволюції різновекторних процесів у середні споріднених кіберспортивних організацій, якщо змінюється лише одна змінна. Наприклад, якщо кіберспортивні організації, за результатами генерування потужностей реплікації та масштабування, подвоять продажі окремого кіберспортивного продукту, а все інше залишається незмінним, рівняння покаже подвоєння доходу;

2) неможливо ідентифікувати уподібнення та зміст еволюції різновекторних процесів у середні споріднених кіберспортивних організацій, якщо ряд таких процесів (або X відносно Y) будуть знаходяться у нелінійних залежностях. 
Наприклад, якщо подвоюється бюджет на оновлення технічних можливостей забезпечення контенту та ігрового процесу, це не означає, що еволюція виробничого процесу збільшить прибуток кіберспортивних організацій;

3) рівняння формуються грунтуючись з певних припущень, обмежень, що $є$ елементами ідентифікації природньої течії еволюції, щодо спорідненості процесів виробничо-господарської діяльності кіберспортивних організацій 3 моменту їх утворення до зникнення. Припущення та обмеження можуть бути невірними (наприклад, припускається, прискорення виробництва програмних кодів потроїть продажі кіберспортивного продукту (користуючись зі збільшення кількості кіберспортсменів на кіберспортивних подіях), але насправді воно насичує ринок.

4) рівняння щодо процесів виробничо-господарської діяльності мають занадто багато можливостей, щоб вписатися у формулу лінійного програмування (оскільки умови реалізації цих процесів можуть потребувати феноменології).

Недоліки підходу, що грунтується на засобах лінійного програмування, також виділяються у фундаментальних працях, присвячених дослідженню операцій, серед яких: Беллман Р.[139], Вентцель Е.С.[140].

\section{Таблиця 4.5.1}

Особливості ідентифікації ситемогенезу функціональних систем організацій та онтогенезу їх розвитку за сукупністю метолів ЛП*

\begin{tabular}{|c|c|c|}
\hline $\begin{array}{l}\text { Методи } \\
\text { рішення }\end{array}$ & $\begin{array}{l}\text { Особливості } \\
\text { методу Ллг }\end{array}$ & Специфіка застосування ЛП \\
\hline Графічний & 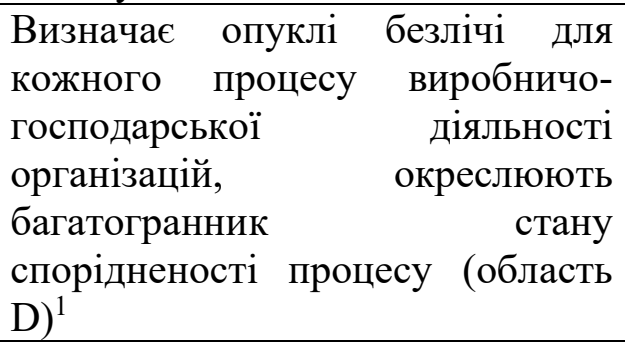 & $\begin{array}{l}\text { Побудова області D; знаходження gradF i } \\
\text { його побудови; знаходження екстремуму } \\
\text { функції по першій і останній точках області } \\
\text { D }\end{array}$ \\
\hline Симплекс & \multirow[t]{2}{*}{$\begin{array}{l}\text { Визначає специфіку послідовної } \\
\text { еволюції кожного процесу } \\
\text { виробничо-господарської } \\
\text { діяльності } 2\end{array}$} & $\begin{array}{l}\text { Визначає за конкретне число кроків } \\
\text { оптимістичний } \\
\text { спорідненості по ЛП і зант відповідними } \\
\text { окремим процесом. }\end{array}$ \\
\hline Гоморі & & 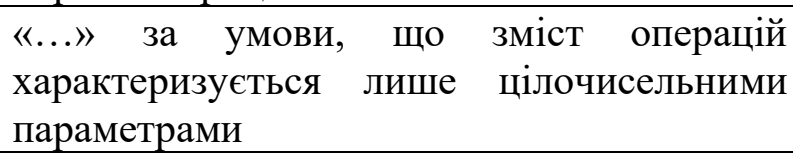 \\
\hline
\end{tabular}




\begin{tabular}{|c|c|c|}
\hline $\begin{array}{l}\text { Параметричн } \\
\text { ого } \\
\text { програмуванн } \\
\text { я }\end{array}$ & $\begin{array}{l}\text { Визначає специфіку послідовної } \\
\text { еволюції кожного процесу } \\
\text { виробничо-господарської } \\
\text { діяльності з урахуванням системи } \\
\text { обмежень що залежать від певних } \\
\text { параметрів } 2\end{array}$ & $\begin{array}{l}\text { Дозволяє за конкретне число кроків } \\
\text { отримати різні оптимальні варіанти } \\
\text { еволюції спорідненості по ЛП за окремим } \\
\text { процесом, за умови, що результат еволюції } \\
\text { (цільова функція) має обмеження, що } \\
\text { залежать від одного або декількох } \\
\text { параметрів t. }\end{array}$ \\
\hline $\begin{array}{l}\text { Двоїстий } \\
\text { симплекс (Р- } \\
\text { метод) }\end{array}$ & $\begin{array}{l}\text { Визначає специфіку послідовної } \\
\text { еволюції кожного процесу } \\
\text { виробничо-господарської } \\
\text { діяльності із можливим } \\
\text { дослідженням варіаторіки }\end{array}$ & 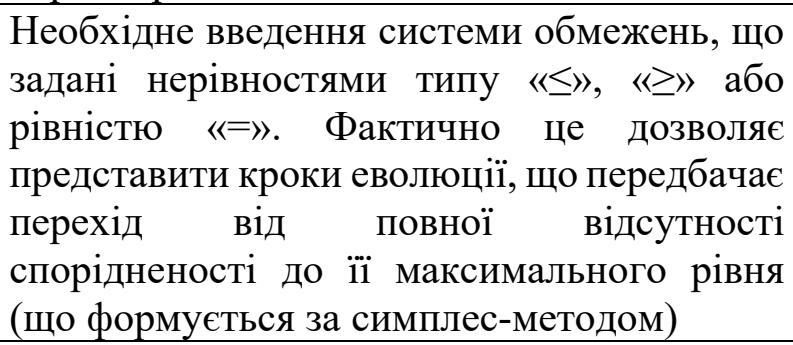 \\
\hline $\begin{array}{l}\text { Дрібно- } \\
\text { лінійне } \\
\text { програмуванн } \\
\text { я }\end{array}$ & $\begin{array}{l}\text { Визначає специфіку послідовної } \\
\text { еволюції процесу виробничо- } \\
\text { господарської діяльності, якщо } \\
\text { потрібно оптимізувати цей } \\
\text { процес } 3 \text { урахуванням системи } \\
\text { обмежень що залежать від певних } \\
\text { параметрів }\end{array}$ & $\begin{array}{l}\text { Необхідне отримання цільової функції } \\
\text { природної еволюції за змінними, що є } \\
\text { відношеннями двох лінійних функцій. Така } \\
\text { особливість значно ускладнює процес } \\
\text { ідентифікації онтогенезу та потребує } \\
\text { застосування спеціалізованих методів } \\
\text { обробки даних Знаменник цільової функції } \\
\text { еволюції має бути виключно позитивним, } \\
\text { та не може дорівнювати нулю в області D }\end{array}$ \\
\hline
\end{tabular}

Примітка

* Результат застосування методу ЛП: 1 математичний опис спорідненості процесів у поточний момент; 2 побудова тренду еволюції спорідненості організацій; 3 побудова трендів еволюції спорідненості організацій, що трансформуються коштом вільних членів bi, що можуть приймати будь-які значення; 4 побудова трендів еволюції спорідненості організацій, що будуються за змінними дрібно-лінійного виду. При цьому системи обмежень для функцій залишаються лінійними

Джерело: сформовано на основі [138-141]

\section{Підхід, що грунтусться на засобах лінійного програмування із} застосуванням транспортних матриць (Гетьман О.О. [141], О. В. Іваницька, Н. В. Рощина, Р. С. Сербул, [144]) специфічний тим, що орієнтується на процеси виробничо-господарських операцій організацій мають формуватися транспорті матриці (за цією логікою для формальних груп кіберспортивних організацій ці матриці мають узагальнювати деталізовані змінні, щодо вартості цифрових кіберспортивних продуктів, можливостей із перетворення цих продуктів на кіберспортивні послуги (що потрібно розподілити за ігровими спільнотами) та командними склади, команди, клуби, ліги, за якими їх необхідно розподілити). Підхід має ряд недоліків, що обмежують можливості його застосування для кіберспортивних організацій. Зокрема, відмічена відсутність усталеного підходу до систематизованої сукупності кроків з ідентифікації еволюції спорідненості 
кіберспортивних організацій за наявними процесами, оскільки, окрім класичної транспортної матриці (або матриці Хітчкок-Купманса), до використання пропонуються методи: диференціальних рент або метод призначення). Крім того, наявна відсутність усталеного підходу до ідентифікації уподібнення процесів виробничо-господарської діяльності, відтак у середні цільових формальних груп видавця/розробника кіберспортивної гри до використання пропонуються методи мінімального елемента, північно-західного кута, апроксимації Фогеля, подвійної переваги (особливості застосування та переваги яких не вказуються).

Також за описом особливостей застосування наявних методів програмування із застосуванням транспортних матриць (табл. 4.5.2) можна зробити висновок, що базовою умовою застосування підходу є контрольованість еволюції спорідненості кіберспортивних організацій, що можливе лише для тих видавців/розробників кіберспортивної гри, що мають закриті бізнес-екосистеми, які не набули значного поширення.

Таблиця 4.5.2

Особливості ідентифікації ситемогенезу функціональних систем організацій та онтогенезу їх розвитку за сукупністю метолів ЛП із застосуванням транспортних матриць

\begin{tabular}{|c|c|c|}
\hline & $\begin{array}{l}\text { Особливості алгоритму дій методу ЛП із } \\
\text { застосуванням транспортних матриць }\end{array}$ & $\begin{array}{l}\text { Специфіка, застосування ЛП із } \\
\text { транспортними матрицями }\end{array}$ \\
\hline $\begin{array}{l}\text { класична } \\
\text { транспортна } \\
\text { матриця } \\
\text { (або } \\
\text { матриця } \\
\text { Хітчкок- } \\
\text { Купманса) }\end{array}$ & $\begin{array}{l}\text { Формування опорної транспортної матриці за } \\
\text { змінними, що обмежені на пропускну } \\
\text { здатність** (наприклад. щодо перетворення } \\
\text { цифрового продукту на кіберспортивні } \\
\text { послуги). Ця матриця визначає поточний стан } \\
\text { виробничо-господарських процесів, щодо яких } \\
\text { досліджується можливість оптимістичного } \\
\text { варіанту еволюції }\end{array}$ & $\begin{array}{lr}\text { Ідентифікація } & \text { еволюції } \\
\text { спорідненості } & \\
\text { кіберспортивних організацій } \\
\text { за кожним окремим продуктом } \\
\text { чи послугою, за умови, що є } \\
\text { обмеження на розвиток } \\
\text { формальних } \\
\text { кіберспортивних організацій }\end{array}$ \\
\hline $\begin{array}{l}\text { диференціал } \\
\text { ьних рент }\end{array}$ & $\begin{array}{l}\text { Формування опорної транспортної матриці за } \\
\text { змінними, що обмежені за розподілом } \\
\text { інформаційних продуктів та послуг**. У } \\
\text { стовпцях вказується мінімальний тариф на } \\
\text { доведення нематеріального продукту до } \\
\text { споживача / або максимальний прибуток від } \\
\text { цього. Знайдені числа позначають колом, а } \\
\text { клітини, в яких стоять ці числа, заповнюють. У } \\
\text { них записують максимально можливі числа. }\end{array}$ & 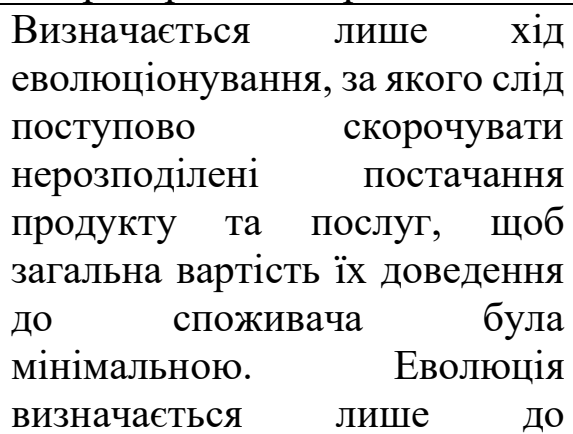 \\
\hline
\end{tabular}




\begin{tabular}{|c|c|c|}
\hline & $\begin{array}{l}\text { Формується розподіл, що не задовольняє } \\
\text { обмеженням вихідної транспортної задачі. В } \\
\text { результаті подальших кроків ідентифікується } \\
\text { хід еволюціонування. Для визначення ходу } \\
\text { еволюціонування мають бути визначені } \\
\text { надлишкові/недостатні рядки* }\end{array}$ & $\begin{array}{l}\text { моменту, нерозподілений } \\
\text { залишок ресурсів стане рівним } \\
\text { нулю }\end{array}$ \\
\hline призначення & $\begin{array}{l}\text { Формування опорної транспортної матриці за } \\
\text { змінними та за розподілом виробничих і } \\
\text { господарських робіт у межах формальних } \\
\text { груп**. Вважається, що є деяке число робіт і } \\
\text { деяке число виконавців. Потрібно розподілити } \\
\text { роботи так, щоб виконати їх } 3 \text { мінімальними } \\
\text { витратами для видавця/розробника конкретної } \\
\text { кіберспортивної гри.. }\end{array}$ & $\begin{array}{l}\text { Будь-який виконавець може } \\
\text { бути призначений } \\
\text { виконання будь-якої (але } \\
\text { тільки однієї) роботи } 3 \\
\text { неоднаковими витратами. Це } \\
\text { не можливо, оскільки } \\
\text { виконавець може виконувати } \\
\text { кілька або всі роботи. }\end{array}$ \\
\hline
\end{tabular}

Примітка

* рядки, що відповідають сервісам та продуктам видавця/розробника кіберспортивної гри, ресурси яких повністю розподілені, а потреби пунктів призначення, пов'язаних з даними споживачами та запланованими постачаннями, не задоволені або недостатні. Рядки, ресурси яких вичерпані не повністю, є надмірними.

**здійснюється методами мінімального елемента, північно-західного кута; апроксимації Фогеля; подвійної переваги.

Джерело: сформовано на основі [141, с. 7]

Підхід фактично орієнтує на ідентифікацію уподібнення процесів виробничо-господарської діяльності та їх еволюцію за кожним окремим цифровим продуктом видавців/розробників, сервісною чи іншою послугою. За значної кількості сервісів та послуг формується громіздка система матриць, що має велику кількість змінних та продукує громіздкі розрахунки.

Підхід, що грунтусться на засобах теорії масового обслуговування (Ложковський А. Г. [147], Штрік Дж. [156], Тютюнник Ю.М. [150]) передбачає кількісну оцінку процесів обслуговування вимог споживачів продукції, товарів, послуг у системі масового обслуговування (CMO), коштом ймовірностей та математичних методів масового обслуговування. При цьому СМО - це система, яка виконує обслуговування вимог споживачів, що надходять до неї [156]. Відповідно до змісту теорії, кількісну оцінку таких процесів, у межах цільових формальних груп видавця/розробника кіберспортивної гри, необхідно реалізувати за систематизованими кроками, які придатні для кількісної оцінки процесів багатоканальних систем, кількість пристроїв обслуговування $\mathrm{n}$ (кількість робочих, сервісів та ін.) у яких більше одного. За описом особливостей застосування методу кількісної оцінки багатоканальних систем, наявних у 
підході, що грунтується на теорії масового обслуговування (табл. 4.5.3) можна зробити висновок, що підхід має ряд недоліків, що обмежують можливості його застосування для кіберспортивних організацій. Зокрема, кількісна оцінка ідентифікує лише стан процесів обслуговування вимог ігрових спільнот, командних складів, команд, клубів, ліг. Мова йде про стан процесів обслуговуванням вимог споживачів, щодо завантаження ігор на жорсткий диск ігрового комп’ютера, черга на отримання цифрового ключа (при поширенні ігор за спеціальною схемою). У той час як їх зміст та зміст процесів виробничогосподарської діяльності організацій цільових формальних груп видавця/розробника кіберспортивної гри ширший ніж просте обслуговування вимог ігрових спільнот, командних складів, команд, клубів, ліг. Методи рішення не враховують багатоступеневості структуру процесу, а лише ідентифікують їі можливу конфігурацію.

Таблиця 4.5.3

Особливості ідентифікації ситемогенезу функціональних систем організацій та онтогенезу їх розвитку за сукупністю методів теорії масового обслуговування

\begin{tabular}{|c|c|c|c|}
\hline $\begin{array}{l}\text { Методи } \\
\text { рішення }\end{array}$ & $\begin{array}{lr}\text { Особливості } & \\
\text { алгоритму } & \text { дій } \\
\text { методу } & \text { теорії } \\
\text { масового } & \\
\text { обслуговування } & \end{array}$ & Варіації застосування методу & $\begin{array}{l}\text { Специфіка, } \\
\text { застосування методу. } \\
\text { теорії масового } \\
\text { обслуговування }\end{array}$ \\
\hline \multirow[t]{2}{*}{$\begin{array}{l}\text { Кількісна } \\
\text { оцінка } \\
\text { багатоканал } \\
\text { ьних систем }\end{array}$} & \multirow{2}{*}{ 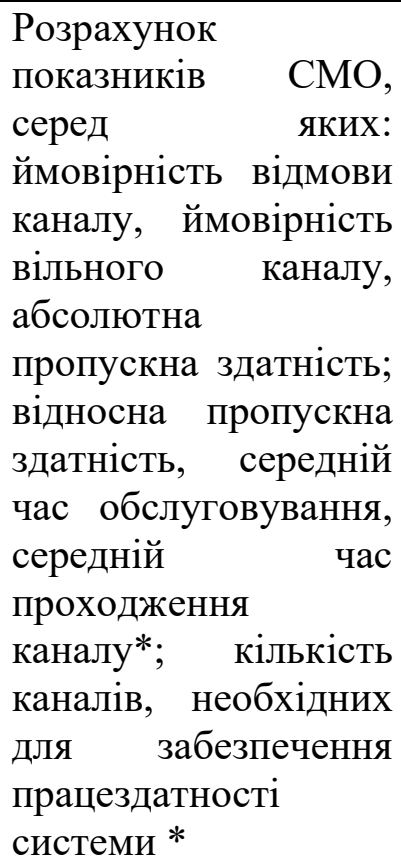 } & $\begin{array}{l}\text { Багатоканальна СМО } \\
\text { відмовами у обслуговуванні } \\
\text { вимог споживачів. Ідентифікує } \\
\text { ситуації за яких запит отримує } \\
\text { відмову (зазвичай це ситуація, } \\
\text { за якої всі канали } \\
\text { обслуговування зайняті) }\end{array}$ & \multirow{2}{*}{$\begin{array}{l}\text { Метод, за будь-якою з } \\
\text { варіацій застосування, } \\
\text { ідентифікує лише: } \\
\text { - стан процесів } \\
\text { обслуговуванням } \\
\text { вимог споживачів, } \\
\text { щодо завантаження } \\
\text { ігор, поширення ігор } \\
\text { за спеціальною } \\
\text { схемою,; } \\
\text { - конфігурацію такої } \\
\text { системи. } \\
\text { Метод не визначає } \\
\text { еволюцію даного } \\
\text { процесу. }\end{array}$} \\
\hline & & $\begin{array}{l}\text { Багатоканальна СМО } \\
\text { обмеженою довжиною черги. } \\
\text { Ідентифікує ситуації за яких } \\
\text { запит знаходиться у режимі } \\
\text { очікування поки не звільниться } \\
\text { канал обслуговування (разом } 3 \\
\text { тим у черзі може передувати } 1 \\
\text { запит). }\end{array}$ & \\
\hline
\end{tabular}




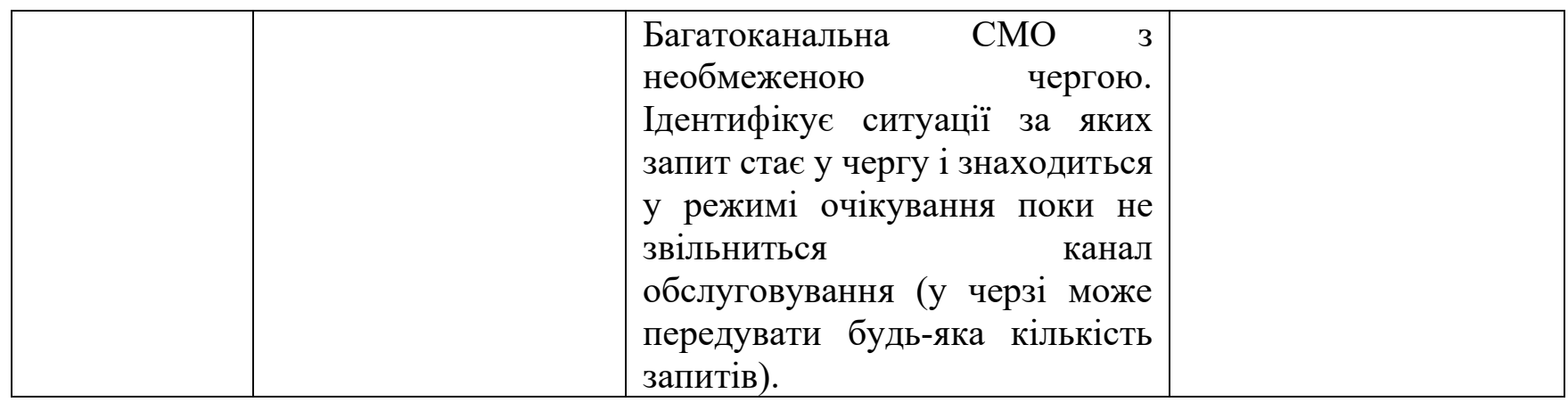

Примітка

*вхідними даними $є$ інтенсивність потоку замовлень, інтенсивність потоку обслуговування, кількість каналів обслуговування.

Джерело: сформовано на основі $[147$, с. 13, с. 19]

Підхід, що грунтується на засобах теорії ігор (Льюс Р., Райфа Х. [148], Олешко Т.І., Лобанов М.О. [149]) передбачає, що всі процеси оцінюються як такі, що реалізуються в умовах невизначеності або конфлікту сторін цільових формальних груп видавця/розробника кіберспортивної гри. У цьому випадку дійсно видавець/розробник кіберспортивної гри та його ігрові спільноти (включаючи людей, які не обов'язково $є$ покупцями зараз, але точно стануть ними в майбутньому), командних складів, команд, клубів, ліг мають різні інтереси. Так, видавець/розробник прагне до максимального розширення організацій, що об’єднанні почуттям спільності, щодо їх діяльності (оскільки це гарантує сталість доходів від цифрової гри). Учасники ігрових спільнот, командних складів, команд, клубів, ліг діють кожен у своїх фінансових інтересах, за виключенням випадків їх переходу на франшизну систему, коли ліги ділять доходи з командами-учасниками. Специфічними, щодо підходу є те, що за сукупністю кроків підхід націлений на вивчення оптимальної еволюції процесів виробничо-господарської діяльності, ідентифікуючи їх як множинні ситуації ігрового характеру. До них відносяться:

1) ситуації, пов'язані з вибором найвигідніших виробничих рішень (видавця / розробника кіберспортивної гри, кіберспортивних арен видавця/ розробника, клубів і тренувальних центів);

2) ситуації, пов'язані з вибором найвигідніших збутових рішень видавця/ розробника, кіберспортивних арен; 
3) ситуації, пов’язані з вибором найвигідніших рішень, щодо розподілу ресурсів.

Специфічним $є$ те, що ідентифікуючи ситуації ігрового характеру математично, представники підходу прагнуть формалізувати їх стан та онтогенез. Вони представляються у множинній грі двох, трьох або більшої кількості гравців, кожен з яких переслідує ціль з максимізації вигоди, коштом іншого. У межах підходу пропонуються різні методи та варіації рішення гри гравців (щодо застосування яких немає усталеного підходу). Особливості ідентифікації ситуації ігрового характеру для виробничих та господарських рішень за сукупністю методів теорії ігор систематизовані у табл. 4.5.4.

Таблиця 4.5.4

Особливості ідентифікації ситуації ігрового характеру для виробничих та господарських рішень за сукупністю методів теорії ігор

\begin{tabular}{|c|c|c|c|}
\hline $\begin{array}{l}\text { Методи } \\
\text { рішення }\end{array}$ & варіації рішення гри гравців & $\begin{array}{l}\text { Особливості } \\
\text { алгоритму дій методу } \\
\text { теорії ігор }\end{array}$ & $\begin{array}{l}\text { Специфіка, } \\
\text { застосування } \\
\text { теорії ігор* }\end{array}$ \\
\hline \multirow{4}{*}{$\begin{array}{l}\text { ідентифікаці } \\
\text { я } \\
\text { оптимальної } \\
\text { ігрової } \\
\text { ситуації }\end{array}$} & $\begin{array}{l}\text { Мінімакс (пошук чистої стратегії } \\
\text { гравців або точок рівноваги) }\end{array}$ & \multirow{4}{*}{$\begin{array}{l}\text { Задаються платіжні } \\
\text { матриці. у межах } \\
\text { кроків здійснюється } \\
\text { пошук чистих або } \\
\text { змішаних стратегій } \\
\text { гравців i, ціни гри. }\end{array}$} & \multirow{7}{*}{$\begin{array}{l}\text { Еволюція } \\
\text { спрямована на } \\
\text { ідентифікацію } \\
\text { конфліктних } \\
\text { ситуацій між } \\
\text { учасниками гри. } \\
\text { стан виробничих } \\
\text { та господарських } \\
\text { процесів чітко не } \\
\text { ідентифікується; } \\
\text { ідентифікації } \\
\text { еволюції можливо } \\
\text { тільки якщо по } \\
\text { кожному з гравців } \\
\text { відомі всі його } \\
\text { можливі дії, щодо } \\
\text { виробничо- } \\
\text { господарської } \\
\text { діяльності }\end{array}$} \\
\hline & $\begin{array}{lcc}\text { Симплекс } & \text { (пошук } & \text { змішаних } \\
\text { стратегій } & \text { методами } & \text { лінійного } \\
\text { програмування) } & \end{array}$ & & \\
\hline & $\begin{array}{l}\text { Графічний (пошук змішаних } \\
\text { стратегій до точки рівноваги) }\end{array}$ & & \\
\hline & $\begin{array}{l}\text { Iтераційний } \frac{\text { Брауна-Робінсона }}{\text { (пошук наближеного значення ціни }} \\
\text { гри, причому істинне значення } \\
\text { можна отримати } 3 \text { будь-яким } \\
\text { ступенем точності). }\end{array}$ & & \\
\hline $\begin{array}{l}\text { біматрична } \\
\text { гра }\end{array}$ & $\begin{array}{l}\text { Варіації рішення гри гравців не } \\
\text { передбачені }\end{array}$ & 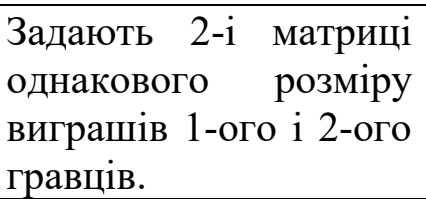 & \\
\hline \multirow[t]{2}{*}{$\begin{array}{ll}\text { гра } & 3 \\
\text { природою }\end{array}$} & $\begin{array}{l}\text { Максимакса, Байєса, Лапласа } \\
\text { (обираються шляхи еволюції, що } \\
\text { забезпечують } \\
\text { виграш) } \\
\text { максимальний }\end{array}$ & \multirow{2}{*}{$\begin{array}{l}\text { Здентифікуються } \\
\text { напрямки еволюції за } \\
\text { критеріями } \\
\text { Максимакс, Байєса, } \\
\text { Лапласа, Вальда, } \\
\text { Севіджа, Гурвіца. }\end{array}$} & \\
\hline & $\begin{array}{l}\text { Вальда } \quad \text { (обираються } \quad \text { шляхи } \\
\text { еволюції, } \\
\begin{array}{l}\text { максимальний виграш за найгірших } \\
\text { ситуацій) }\end{array}\end{array}$ & & \\
\hline
\end{tabular}




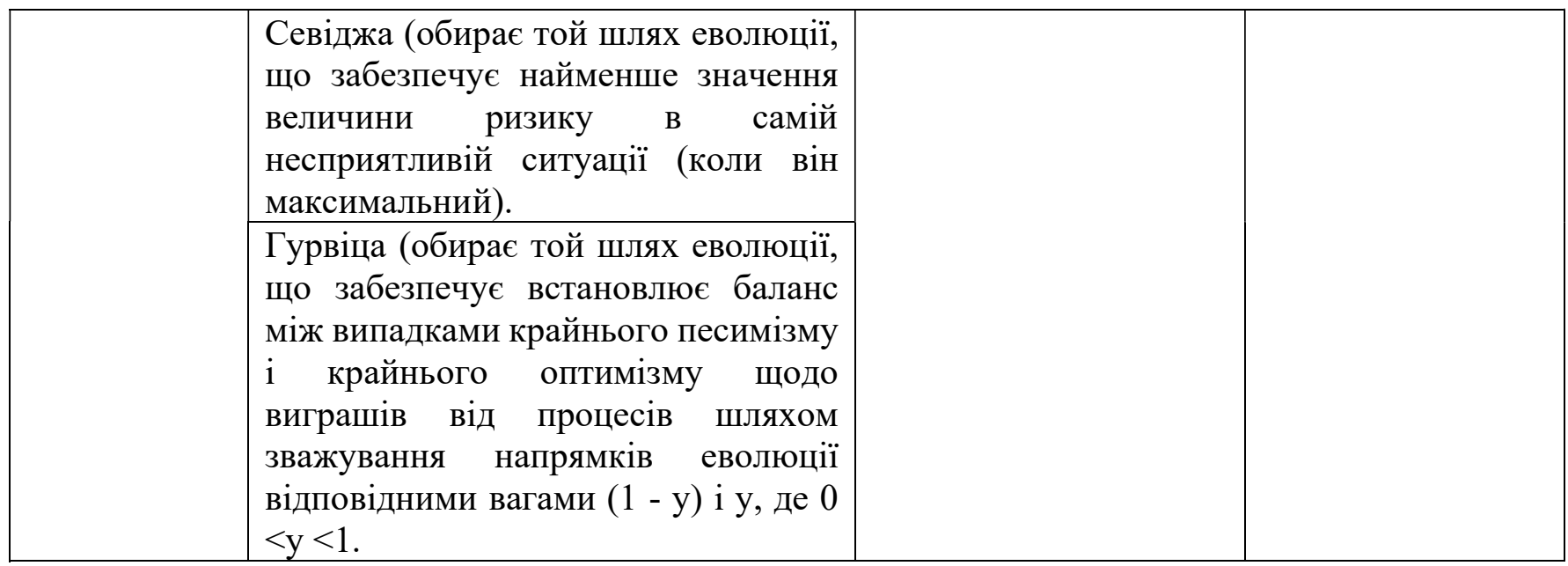

Примітка

* значення у від 0 до 1 може визначатися за схильністю гравців, що приймають рішення, до песимізму або оптимізму. За відсутності яскраво вираженої схильності представляється найбільш розумним значення $\mathrm{y}=0,5$.

Джерело: сформовано на основі [147, с. 13, с. 19]

За розглядом їх особливостей можна зробити висновок, що підхід має ряд недоліків, що обмежують можливості його застосування для кіберспортивних організацій, зокрема: 1) еволюція спрямована на ідентифікацію конфліктних ситуацій між учасниками гри., а сам стан виробничих та господарських процесів чітко не ідентифікується; 2) можливе застосування тільки якщо по кожному 3 гравців відомі всі його можливі дії, щодо виробничо-господарської діяльності (за виключенням того, якими з них він скористається).

Підхід, що грунтується на засобах динамічного програмування (Соколовська 3.М., Яценко Н. В., Хортюк М. В. [154]) передбачає, що за всіма процесами виробничо-господарської діяльності організацій здійснюється відтворення їх первинного стану, ідентифікація можливих напрямків еволюції спорідненості (шляхом пошуку розв'язків, отриманих розбиттям змін на послідовні проміжки часу). Це виражається у відзначенні послідовності змін множинних значень функцій V1, V2, ..., Vn, з аргументом у, котрі позначають стан всіх або окремого процесу в моменти часу і від 1 до n. На відміну від інших підходів, у межах окресленого наявна чітка структурованість та уніфікованість кроків. Основні методи ДП, на яких грунтується підхід виділені у табл. 4.5.5. 
Особливості ідентифікації ситемогенезу функціональних систем організацій та онтогенезу їх розвитку за сукупністю методів ДП

\begin{tabular}{|c|c|c|}
\hline & Особливості алгоритму дій методу ДП & $\begin{array}{l}\text { Специфіка, } \\
\text { застосування ДП* }\end{array}$ \\
\hline $\begin{array}{l}\text { Ідентифікаці } \\
\text { i } \quad \text { стану } \\
\text { розподілу } \\
\text { ресурсів }\end{array}$ & $\begin{array}{l}\text { Формується рівняння стану розподілу ресурсів } \\
\left(x_{k}+y_{k}=a_{k}\right) \text {, яке щодо сфери кіберспорту } \\
\text { відрізняються такими базовими параметрами* як: } \\
\text { кількість ресурсів, що виділяються для відтворення } \\
\text { кожного виду нематеріальних продуктів та } \\
\text { потужностей сервісів на кожному кроці. Еволюцію } \\
\text { процесу розподілу ресурсів визначаємо шляхом } \\
\text { рекурсії* та розбиваємо на етапи по роках (нумеруючи } \\
\text { починаючи від першого), що спрямовуються дією } \\
\text { змінної управління. }\end{array}$ & 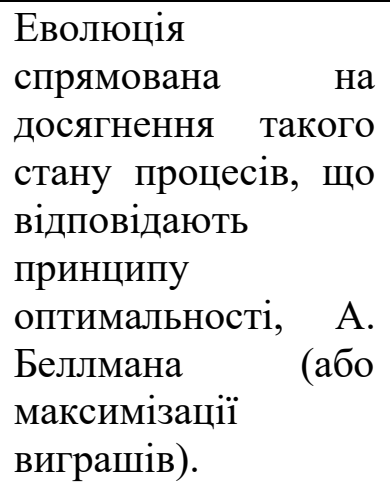 \\
\hline $\begin{array}{l}\text { Ідентифікаці } \\
\text { ï } \\
\text { постачання }\end{array}$ & $\begin{array}{l}\text { Формується рівняння стану процесів постачання }\left(y_{t-1}=\right. \\
\left.y_{t}-x_{t}+d_{t}, t=1, \ldots, n\right) \text {, яке щодо сфери кіберспорту } \\
\text { відрізняються такими базовими параметрами** як: } \\
\text { число продуктів та послуг, виготовлених в t-му місяці } \\
\text { (етапі); рівень здатностей до реплікації та } \\
\text { масштабування на кінець t-го місяця; попит на } \\
\text { продукти та послуги в t-му місяці; витрати на } \\
\text { масштабування та реплікацію продукції та послуг в t- } \\
\text { му місяці. Еволюцію процесу стану постачання } \\
\text { розбиваємо визначаємо шляхом рекурсії* та на етапи, } \\
\text { що спрямовуються дією змінної управління. }\end{array}$ & $\begin{array}{l}\text { Змінна управління } \\
\text { обирається так, щоб } \\
\text { вона приводила до } \\
\text { виграшу, як на } \\
\text { даному етапі, так і } \\
\text { на всіх наступних } \\
\text { до кінця операції; } \\
\text { - за рівнянням стану } \\
\text { виробництва } \\
\text { найбільш бажаним є } \\
\text { вид рівняння } 3\end{array}$ \\
\hline $\begin{array}{l}\text { Ідентифікаці } \\
\ddot{1} \quad \text { стану } \\
\text { виробництва }\end{array}$ & 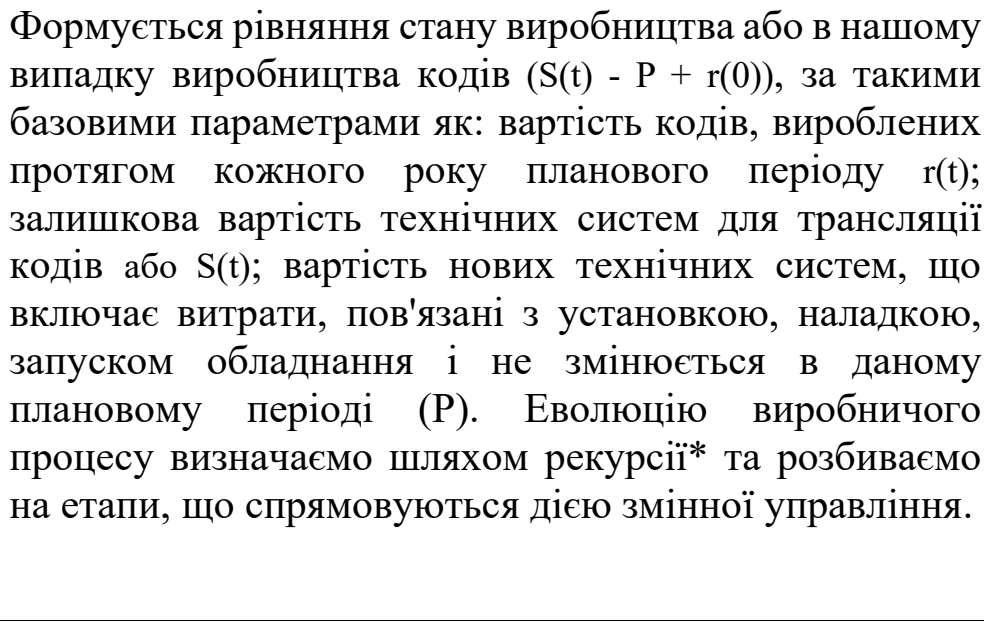 & $\begin{array}{l}\text { параметрами } \\
\text { збереження } \\
\text { виробничої системи } \\
\mathrm{Fk} \mathrm{(t)} \mathrm{для} \mathrm{k}= \\
5,4,3,2,1 \text {. } \\
\text { Спрощення пошуку } \\
\text { розв'язку складної } \\
\text { задачі, розбиттям iї } \\
\text { на простіші } \\
\text { підзадачі; } \\
\text { вибір числа та умов } \\
\text { еволюції стану } \\
\text { процесів }\end{array}$ \\
\hline
\end{tabular}

\section{Примітка}

* $x_{k}, y_{k}$ кількість коштів, що виділяються на відтворення кожного виробі, продукту чи послуги; $a_{k}$ - дохід, який отримується від виробів, продуктів, послуг на k-му i всіх наступних.

** у класичному варіанті параметри є наступними: (xt) число виробів, виготовлених в $\mathrm{t}-$ му місяці (етапі); (yt ) рівень запасів на кінець t-го місяця; (dt) попит на виріб в t-му місяці; (ft $(\mathrm{xt}, \mathrm{yt}))$ - витрати на виробництво і зберігання виробів в t-му місяці.

** у класичному варіанті параметри є наступними: річний дохід $\mathrm{r}(\mathrm{t})$ і залишкова вартість $\mathrm{S}(\mathrm{t})$; вартість нової виробничої системи (Р). При обрахунку параметрів враховуються витрати на ремонт і подальшу експлуатацію виробничої системи; кількість одиниць обладнання, що формують виробничу систему; P (t) - щорічні витрати, пов'язані із заміною одиниць обладнання, що формують виробничу систему.

Джерело: сформовано на основі [154] 
Зокрема, за описом особливостей ДП, констатовано, що для ідентифікації стану процесів та їх еволюції пропонуються систематизовані кроки, орієнтовані на часткове їх визначення через себе або через використання раніше визначених станів:

1) ідентифікації стану розподілу ресурсів. Щодо цільових формальних груп видавця/розробника кіберспортивної гри важливий стан та еволюція ресурсів, що можуть бути використані для відтворення нематеріальних продуктів та потужностей сервісів, необхідних для їх існування і розвитку. Це ресурси ігрового аскета, інфраструктурні, обчислювальні (як значення кількості операцій з числа з плавучою комою в секунду);

2) ідентифікації стану постачання за цільовими формальними групами видавця/розробника кіберспортивної гри (зокрема, щодо доставляння власницького контенту, поширення ігор за стандартною схемою та за передплатою через спеціальний клієнт; щодо завантаження ігор);

3) ідентифікації стану виробництва. У цільових формальних групах важливим є створення технічно розвинених клубів і тренувальних центів, для команд, які представлятимуть свій регіон, і за які будуть вболівати мешканці цих регіонів. Виробництво відрізняються нематеріальним характером, орієнтованим на програмні коди, а ідентифікація їх стану та еволюції має зводитись до визначення можливостей, щодо створення кодів у багатофункціональних кіберспортивних майданчиках (аренах) та їх глобальних мережах, представлених одноформатними спеціалізованими клубами, базами з домашніми аренами для кіберспортсменів, навчально-тренувальними базами.

Відповідно до аналізу оптимальним, 3 точки зору унікалізування математичної моделі, є підхід до ідентифікації стану процесів виробничогосподарської діяльності кіберспортивних організацій та еволюції їх розвитку, що грунтується на методах динамічного програмування. Перевагою $є$ те, що унікалізування моделі реалізується паралельно із: 
- спрощенням пошуку спорідненості процесів, що вона відбиває, шляхом розбиття система математичних співвідношень на простіші підзадачі методом рекурсії;

- можливостями вибору числа та умов проведення дослідів, щодо еволюції стану процесів виробничо-господарської діяльності кіберспортивних організацій всередині цільових формальних груп видавця/розробника кіберспортивної гри. 
DOI 10.46299/ISG.2021.MONO.ECON.II-130-135

\section{6 Диверсифікація основних напрямків державного регулювання в АПК}

У зв'язку з посиленням конкурентних засад в сільському господарстві країни на провідний план виходять стійкість положення підприємства на ринку сільгосппродуктів, конкурентоспроможність, економічна ефективність i ефективність. Постійний пошук раціональної моделі виживання і подальшого розвитку сільськогосподарського підприємства в умовах мінливості кон'юнктури в частині купівельного попиту i освоєння вигідних товарних ніш на ринку сільгосппродуктів обумовлює зростання ролі диверсифікації виробництва як фактору протистояння ринковим катаклізмам, коливаням купівельного попиту.

Правильне формування стратегії i тактики сільськогосподарського підприємства визначає тип диверсифікації, особливості спеціалізації, концентрації та інтенсифікації виробництва. Разом з тим у вітчизняній теорії управління та економіки проблеми диверсифікації поки ще залишаються недостатньо дослідженими, що не дозволяє в максимальному ступені реалізувати резерви їі ефективності в аграрному виробництві.

У статті аналізуються переваги стратегій диверсифікації для зниження ризиків, зокрема, агропідприємств в умовах дії правил i в цілому висока нестабільність сучасної економічної ситуації в Україні. Запропоновано заходи щодо посилення ефектів диверсифікації.

Одним 3 пріоритетних напрямків економічних досліджень в зв'язку 3 необхідністю адаптації агропромислового комплексу в світовому господарстві $є$ осмислення взаємозв'язку конкурентоспроможності, стратегії інноваційної диверсифікації, інституційного регулювання. Методи посилення конкурентних переваг та інституційної підтримки повинні бути адаптовані до умов функціонування України в COT 3 використанням традиційних i нових методологічних підходів: аналізу, синтезу, моделювання, інформатизації, експертних оцінок та ін.

Стратегія диверсифікації є найбільш ефективною для розвитку інноваційних бізнесів в рамках агропромислового комплексу. В умовах економічної 
модернізації економіки в зв'язку з необхідністю іï перекладу на інноваційний шлях розвитку найбільш доцільне використання стратегії диверсифікації з метою забезпечення стійкості до оновлення сучасних агропромислових комплексів. Диверсифіковані напрямки інноваційної діяльності забезпечують конкурентні переваги на світових ринках: зниження інноваційних ризиків, економічне зростання, скорочення витрат при диверсифікації галузі. Досвід стратегічного управління диверсифікованими структурами в інших країнах показав, що він цілком може бути застосовний в умовах модернізації українського сільського господарства інноваційним шляхом розвитку. [158]

Необхідність та перспективність впровадження диверсифікації як альтернативної стратегічної орієнтації підприємств обгрунтували такі зарубіжні науковці, як М. Портер, Ф. Котлер, Г. Амстронг, А. Кукарцева.

Потенціал економічного зростання аграрної сфери за рахунок диверсифікованого виробництва є об’єктом досліджень І. Гришової, В. Ткачука, О. Томіліна, Н. Степаненко.

Переваги та можливі загрози диверсифікації підприємств, зокрема аграрних, описані в працях Д. Дея, Н. Маслак, О. Лемішко, А. Семенов, І. Іщенко, Ф. Важинського, М. Корінько, Л. Лозовського, В. Лебедевої, Т. Панюк.

Проте означені питання не можна вважати вичерпаними та достатньо розкритими, тому пошук ефективних механізмів і методів їх розв'язання й надалі становить неабиякий інтерес для аграрної науки та господарської практики.

Диверсифікація як форма економічних зв'язків економічних суб'єктів $є$ закономірністю існування та інноваційного розвитку агропромислових систем.

У свою чергу, диверсифікація має свої закономірності розвитку:

- вирівнювання галузевої рентабельності,

- усунення диспропорцій аграрного відтворення,

- трансформація і динамічна стійкість.

Ефект диверсифікації виражається в появі нових видів продукції і послуг, зміні галузевих, міжгалузевих та регіональних пропорцій. Диверсифікація може 
здійснюватися з метою отримання ефекту масштабу виробництва та розширення видів діяльності.

В АПК диверсифікація здійснюється шляхом вертикальної інтеграції сільськогосподарських товаровиробників та підприємств промислової переробки, організацій, що надають фінансові послуги - виробниче i інвестиційне спрямування, розуміється як розширення масштабів діяльності. У сільському господарстві поширені: горизонтальна, конгломератна диверсифікація. Основними видами стратегії диверсифікації в АПК є диверсифікація по продукту і по регіону [160].

Для кількісної оцінки диверсифікації використовуються показники: широта диверсифікації, коефіцієнт пов'язаної диверсифікації, масштаб диверсифікації. Ефект диверсифікації виходить за межі аграрного сектора економіки. Необхідність модернізації економіки в умовах кризи сільського господарства, функціонування в СОТ вимагає посилення конкурентних позицій агропромислового комплексу України на шляху його інноваційного розвитку. Низька інноваційна сприйнятливість АПК, втрата значної частини науковотехнічного потенціалу, негативні аспекти стану світової економіки вимагають здійснення заходів щодо вдосконалення управління в аграрному секторі, принципово нового підходу, що відображає вплив зовнішніх i внутрішніх факторів інноваційного розвитку, їх взаємодії з державним регулюванням.

Стратегія інноваційної диверсифікації є ефективною для великих структур. Різноманіття видів даної стратегії дозволяє кожній компанії знайти таку модель розвитку, яка підходить саме їй, сприяє стійкості до оновлення. Диверсифіковані напрямки інноваційної діяльності забезпечують конкурентні переваги. Інноваційної формою диверсифікації $\epsilon$ кластери, що складаються 3 конкурентоспроможних економічних суб'єктів в рамках окремих галузей i локальних утворень. Однак розвиток ефективних диверсифікованих кластерів можливий тільки при наявності ефективної регіональної стратегії, оскільки їх розвиток у відриві від регіону неефективний. 
Кластер являє собою комплекс на базі галузевої або територіальної концентрації і диверсифікації мереж виробників, постачальників і споживачів, пов'язаних єдиним технологічним ланцюжком. У кластер входять також інфраструктурні організації, забезпечують сервісні, логістичні, науково-дослідні послуги [161].

Управління в інноваційних кластерах забезпечує ефективність диверсифікації відтворювальних процесів у сільському господарстві, що означає створення оптимальних відтворювальних пропорцій, безпосередньо залежить від ефективності диверсифікації мікроекономічних систем. Синергетичний ефект диверсифікації полягає в отриманні більшого чистого прибутку диверсифікованою системою, ніж сума чистих прибутків, що входять до їі складу окремих господарських систем, які діють самостійно. Складовими синергічного ефекту є: економія інвестицій, економія витрат, економія часу відтворювального процесу.

Особливостями функціонування агропромислового комплексу полягає в низькому рівні диверсифікаційних процесів, локалізації виробництв, недостатній фінансовій підтримці інновацій. Дія сукупності зазначених факторів і особливостей обумовлює специфіку заходів посилення конкурентних позицій АПК на макро, мезо і мікрорівні.

Серед заходів важливе значення мають: підтримка олігопольних ринків, підтримка експорту вітчизняного продовольства, високотехнологічних виробництв, вдосконалення діяльності територіальних торгових палат по сертифікації і стандартизації сільськогосподарської продукції, стимулювання диверсифікації сільськогосподарського і продовольчого ринків за рахунок розвитку середнього і малого підприємництва, ринкової інфраструктури банківських, страхових, рекламних, транспортних, торговельних послуг, імпортозамещенія.

Підтримуючі заходи повинні бути спрямовані інституційними структурами на формування необхідних умов для подолання інноваційної паузи, розвитку цивілізованої конкуренції, зниження підприємницьких ризиків. Важливо 
встановити заборону на контракти з продажу та лізингу основних фондів і товарів, якщо їх умови про обмеження взаємопов'язаних продажів послаблюють конкуренцію. Особливо актуальними $є$ заходи 3 розвитку інформаційноаналітичної та інноваційної інфраструктур, створенню умов для взаємодії інфраструктурних та підприємницьких виробничих компонентів. Для цього необхідна диверсифікація програм інфраструктурного забезпечення підприємництва в АПК [158].

Виявлення сучасних тенденцій диверсифікації, що супроводжується зміною структури організації виробництва, сприяє методика встановлення кількісної залежності в родинних і неспоріднених галузях сільськогосподарського виробництва, в якій міститься розрахунок інтегрального показника, значення якого свідчить про структурні зміни всередині галузі. Показник допомагає оцінити характер структурних зрушень між виробничими, але непов'язаними галузями - рослинництвом і тваринництвом, між профільними і непрофільними видами діяльності. Розрахунки інтегральних показників підтверджують наявність різних рівнів диверсифікації, причому переваги подальшого розвитку мають регіони з більш високим показником. Поєднання в одній господарській системі декількох видів діяльності неминуче призводить до інституційної диверсифікації - в сфері державної підтримки та надання фінансових послуг. Диверсифікація реалізується шляхом надання кредитних ресурсів для різних видів діяльності, використання бюджетних коштів на фінансування заходів держпідтримки сільськогосподарських товаровиробників.

Необхідні диверсифікація в сфері надання держпідтримки і кредитних ресурсів в АПК з різних видів діяльності, використання бюджетних коштів на фінансування вищезазначених заходів, зокрема, на продукцію, придбану сільськогосподарськими виробниками на умовах лізингу.

Держпідтримка повинна бути спрямована на поглиблення внутрішньогалузевої спеціалізації і спорідненої диверсифікації, стимулювання розвитку малих форм господарювання 3 метою посилення функціональної диверсифікації. 
В сучасних умовах звужується диверсифікація в результаті концентрації кредитних ресурсів, виданих великим сільгосппідприємствам у формі ТОВ - 7385\% від загального обсягу виданих кредитів, підвищується концентрація i поглиблюється спеціалізація кредитних послуг банками. Необхідно стимулювати диверсифікацію банківських послуг з метою розширення доступу сільських товаровиробників до кредитно фінансових ресурсів на основі розширення банківської мережі і кредитних кооперативів в сільській місцевості. У переліку послуг сільським виробникам, включеним в систему державних стандартів, розробка якої передбачена в Концепції сталого розвитку сільських територій, слід передбачити надання банківських послуг на стаціонарній основі в залежності від кількості сільського населення в регіонах, що може бути забезпечено шляхом державного замовлення на послугу серед кредитних організацій на конкурсній основі. Посилення конкурентних позицій агропромислового комплексу на основі кластеризації як інноваційного варіанта диверсифікації пов'язано з кон'юнктурою конкретного ринку, рівнем взаємозв'язку зовнішніх і внутрішніх факторів і їх впливів на попит, взаємодією чинників державного регулювання та інституційної підтримки.

У зв'язку з цим надзвичайно важливо встановлення ієрархічної зв'язку між конкурентним позиціонуванням, інституційним регулюванням, диверсифікацією діяльності, інтеграцією інноваційних програм технологічної модернізації агропромислового комплексу.

Елементи i структурно-організаційні зв'язки механізму посилення конкурентних позицій сільськогосподарських товаровиробників незалежно від ієрархічності ланок світового сільськогосподарського ринку повинні бути модифіковані для реалізації стратегії інноваційної диверсифікації діяльності у вигляді освіти інноваційних кластерів 3 метою модернізації економіки інноваційним шляхом розвитку. 


\section{SECTION 5. ENTERPRISE ECONOMICS AND PRODUCTION MANAGEMENT}

DOI 10.46299/ISG.2021.MONO.ECON.II-136-146

\subsection{Financial modelling of an impact of investment maintenance on the condition and diagnostics of economic protectability of enterprises}

Under the conditions of changing market environment processes of investing are not subjected to sufficiently precise prediction due to the fact that any investments by their nature of inflows are uneven both by time and by volume. This makes quantitative measurement-forecast of investments axiomatically subordinate to the law of probability distribution of the random value. However, the volume of investment inflow has always had a direct impact on the general level of investment maintenance of a number of business entities that needed them, since investment funds replenish working capital and are reflected on the condition of the economic protection of the given enterprise.

In this connection there arises the necessity to conduct a financial modelling of an impact of investment maintenance on the quality of economic protectability of the business entity for implementation of effective management and control over investment processes and their profitability in the system of high-grade safety of entrepreneurship.

In most countries in recent years there has developed an uneasy economic situation in which the necessity to review the possibility of additional involvement of foreign direct investments in order to restore financial stability and to save sufficient level of economic protectability of industry that noticeably staggered in crisis conditions of world scale has become the urgent need for the real sector of the economics. In particular, in Ukraine the current situation on inflow of investments is cardinally distorted - some outflow of foreign funds from the industry has been fixed. The reason lies in both improper attention of the state to ensuring of the realization of statutory guarantees for foreign investors and in the deterioration of a number of economic parameters of strategically important domestic branches of industry that previously attracted investors by big dividends. 
As is known, financial investments ensure investing of capital in various financial instruments of investment primarily in securities to receive income. They are independent kind of economic activities for enterprises and primary means of realization of external investing [162].

Analyzing in general financial-credit policy in the post-crisis period in the conditions of Covid-19, we can conclude that some production and economic structures stopped to prefer foreign investments due to the difficult financial condition and cover all their needs from their own savings, reserve funds and domestic bank loans. However, these funds are not enough and under the rules of the market economy at this stage the preference should be given to namely external investments as to the main instrument of government maintenance of such financially unstable industrial enterprises that can become significant substitutes for insufficient domestic sources concerning profit earning and for efficient cost management.

It is necessary to understand that financial-credit and investment maintenance at crisis enterprises in full is impossible without primary activization at them of investment and innovation activities and increase of their investment attractiveness that requires the search of appropriate opportunities of acceleration of their economic growth on their own reproductive basis and improvement of the regulatory framework concerning regulation of economic activities. The problem of choice of sources of raising funds in a lack of own financial resources to ensure sufficient economic protection of enterprise is typical for crisis condition of economics, when production and economic structures are forced to turn to external resources, but do not get them themselves due to unstable financial condition, since the risk of not returning of investments and their ineffective use increases.

Rational combination of financing sources and strategic decisions relating to various projects of development of enterprises forms its financial-credit and investment strategy that has the direct impact on the economic protectability of the last ones. According to [163], financial and credit and investment strategies can be based on a resource or targeted basis. Depending on the structure of the financing sources of the activities and development of enterprise as well as on effectiveness of objectives and 
scopes of investment projects the following variants of selection of strategy are pointed out: use preferably own funds to invest limited number of small investment project; receive state investments and loans; receive financing from various sources on the basis of partnerships; use simultaneously all investment sources for the realization of one strategic project or only one kind of financial resources of all possible. In other words economic development of industrial enterprises is always caused by the choice of a particular strategy of financing that is the basis of investment maintenance and is evaluated by the ultimate effectiveness of the process of functioning and profitability of investment program.

For most of industrial enterprises additional investments inflow is particularly necessary for renewal of the basic production assets, since production assets is a limitative factor for them that determines the production of finished products.

The experience of the developed countries of the world shows that the reproductive processes occur solely on the basis of investing. The more active it is, the faster paces of reproduction are and the more effective innovation transformations are. There is a wide range of methods to stimulate attraction of investments: accelerated depreciation, rational tax system, soft loans, the introduction of mechanisms of regulation of bank interest rates, encouragement of leasing [164]. As a rule, nowadays enterprises try to give preference to independent investing without intermediaries and to introduce rational policy of attraction of external resources, including favorable foreign investments $[165,166]$. Preference is given to foreign direct investments among other external sources of financing, since they do not increase the indebtedness of the country that receives them, but quite the contrary stimulate export revenues and create conditions for further decrease of debt.

In general, estimation of cost of investments is affected by: valuation of their payback period; accounting rate of income on securities; net current value; internal rate of profitability and correlation coefficient of costs and incomes. In the period of significant inflation long-term capital investments will not be preferred because to provide loans and to invest money in securities for a long period of time is unprofitable because of the high risk of unstable economic situation, depreciation of money that will 
outstrip incomes, and because of the difficulties to predict interest rates in the future. Such capital investments usually have target character and may be preferential and connected with the financing of national programs. In such a case bank institutions should use the mechanism of allocation of loan not for the whole number of years and under mixed interests. In this situation, the payment amount or accreting amount will be calculated:

$$
S=S_{0} \times(1+i)^{t \times l} \times(1+\Delta t \times i)
$$

where: $t=t \times l+\Delta t, S-$ the payment amount or accreting amount, hrn; $S_{0_{-}}$initial loan amount, received by the borrower, hrn; $i$ - interest rate; $t \times l-$ the whole number of years; $\Delta t$ - fractional residue; $t$ - term of crediting of the enterprise, years.

If an increase of interest rate is expected, the following options are available: 1) the rate under the agreement varies according to the growth of the average market rate, which, in its turn, changes depending on inflation; 2) the rate changes according to the terms of the loan agreement. Then the amount of repayment $(\mathrm{S})$ will be calculated by the formula:

$$
S=S_{0} \times\left(1+i_{1}\right)^{t_{1}} \times\left(1+i_{2}\right)^{t_{2}} \ldots\left(1+i_{k}\right)^{t_{k}},
$$

where: $i_{1}, i_{2}, \ldots i_{k}$ - successive values of interest rates; $t_{1}, t_{2}, \ldots t_{k}$ - periods during which the corresponding rates are valid.

A special place concerning correction of investment activities today belongs to the issues concerning the optimality of portfolio of securities, estimation of cost of bonds and shares and determination of factors that influence their price and yield, and can be implemented in daily financial and economic activities of industrial enterprise to ensure the necessary their economic protectability now and for the future. The best option is such when investor has an optimal portfolio of securities, that is, there is established an optimal correlation between risk and yield on dividends of securities. Although researches showed that the degree of risk of optimal portfolio will anyway be growing with increase of efficiency that is required and expected. If there is present borrowed capital, it is possible to form a portfolio with any expected efficiency, but herewith the risk will be increasing indefinitely. If at some moment of time it is 
impossible to borrow money, then utmost expected efficiency of portfolio will match the efficiency at that moment of the most efficient security, all cash will be invested exactly in it. Most often portfolio of investor is diversified, that means that it represents a variety of securities that is why both capital and risk will be allocated among all types of securities. Accordingly, the effectiveness of such optimal portfolio $\left(E_{o p t}^{L I I}\right)$ can be expressed through the random magnitude:

$$
E_{\text {opt }}^{\text {LII }}=k_{0} \times g_{0}+\sum_{i=1}^{n} G_{i} \times k^{*},
$$

where $k_{0}$ - share of investments with guaranteed efficiency $g_{0} ; G_{i}$-random efficiency of the $i$-th risky security; $k^{*}$-scalar multiplier.

Particular attention simultaneously should be paid to estimation of cost of a wide range of securities that are in circulation in the market, since their cost has also a direct impact on the security of economic protectability of business entities that own them. For bonds, for example, it is a must to take into account: coefficient of long-term debt to own capital, coefficient of profitability, coefficient of interest income taking into account dividends on preferred shares, the coefficient of relation of working capital to short-term obligations, conditions of ensuring of bonds by mortgage, conditions of guarantees, maturity date etcetera.

As for mechanism of valuation of shares, valuation is carried out separately both for preferred and ordinary shares. Evaluation of ordinary shares is much more difficult in comparison with the valuation of bonds or preferred shares because the investor not always can be sure about the amount of income, time limits of his payments and rate of profit. For bonds and preferred shares the only unknown variable is the accepted rate of profit. This approach is also suitable to determine the investment value of ordinary shares. But it is possible to give preference also to profit for discounting or to discount incomes which will receive dividends.

The most appropriate method that is used to determine the cost of ordinary shares is:

$$
V_{0}=\frac{D_{1}}{(1+g)^{1}}+\frac{D_{2}}{(1+g)^{2}}+\ldots+\frac{V_{n}}{(1+g)^{n}},
$$


where $V_{0}$ - discounted value of shares; $D_{1}, D_{2}, \ldots$ - expected annual dividend payment to the n-th year; $g$ - expected rate of profit; $n$ - last year of holding period of investment; $V_{n}$ - expected cost of the shares at the end of the year $n$.

An important criterion of estimation of the portfolio of securities is the general expected rate of profit on a portfolio. This indicator can be expressed as follows:

$$
P^{N}=\sum_{i=1}^{n} a_{i} N_{i}^{a}+\sum_{j=1}^{k} o_{j} N_{j}^{o},
$$

where $P^{N-}$ total expected rate of profit on a portfolio of securities; $N_{i}^{a}, N_{j}^{o}$ - expected rates of profit on shares and bonds; $a_{i}, o_{j}$ - percentage (or proportion) of shares (bonds) in the portfolio of securities; $n$-number of shares in portfolio; $k$ - number of bonds in portfolio.

However, much attention now is paid to option contracts and the opportunity to use them at industrial enterprises to manage at them financial and economic protectability. In general, option on a security is characterized by a certain maturity and exercise price. Option to purchase gives its owner the right to purchase a security at an exercise price, option for sale - the right to sell a security at an exercise price. The problem of efficient granting of premiums for option is one of the most difficult in the theory of development of the securities market. As for the European option, it is based on some assumptions that are taken from the experience of developed countries and are applied in practice. Firstly, the effectiveness of risk-free investments is determined by permanent force of growth so that the price of the investment will change in time according to the equation:

$$
\frac{d S_{0}(t)}{S_{0}(t)}=Z d t
$$

where $S_{0}(t)$ - price of investment; $Z$ - force of growth of effective risk-free investments.

Secondly, the effectiveness of investment in any securities option is issued on will always be a random value and the price of security will change according to the stochastic equation:

$$
\frac{d S(t)}{S(t)}=v d t+R^{1},
$$


where $S(t)$ - price of a security that is set at the moment of payment of premiums; $v$ - growth rate of the expected value of the efficiency of investment; $R^{l}$ - standard process with unit intensity.

If to denote as $P_{p}^{0}$ a premium for option for sale, as $P_{k}^{0}$ a premium for option to purchase, as $P$ - exercise price after time interval $T$ after the release of option, then according to the theorem of parity of options [167] there is established such a dependency between the premium for option to purchase and sale:

$$
P_{p}^{0}=P_{\kappa}^{0}+P \times e^{-Z T}-S(t)
$$

From this we can conclude: the higher the price of a security, industrial enterprise owns, that is established at the time of payment of premiums is, the lower the premium amount for option for sale is.

Option contracts allow you to limit the risk with a certain amount that is lost in the event of adverse development of events at business entity in the development of which funds are invested and their gaining herewith potentially is unlimited. Various assets are the basis of options contracts. In practice, option contracts can be concluded on shares, indices, interest securities, currencies, futures contracts, goods and more.

As is known, the contents of option lies in the fact that it provides one of the parties of the agreement a right of choice in execution of the contract or rejection of its execution, if it is disadvantageous and thus significantly destabilizes condition of economic protectability of the corresponding business entity if its actual costs significantly exceed the planned ones.

The problem of modelling of prices of options is to determine the price that must be demanded for the purchase (or sale) of option. Resolution of this problem can greatly simplify the mechanism of management of the condition of economic protectiveness of the owner of this option or of that production and economic structure which wants to purchase it from an investor. Since the cost of the option at the moment of his expiry is impossible to predict accurately in advance, its use can be either beneficial or not.

Theoretically to evaluate option is much easier than to simulate a situation that 
will be responsible for the condition of economic protectability of business entity that is interested in the contract. In practice it is difficult to assess the value of American option since American options, unlike the European ones are characterized by the right of premature execution, that means that to predict the their ending date is impossible. Therefore, let us review a European option with pre-known ending date. Let us consider that shares are its basis and dynamics of change the share price during the validity of option is a random process. In order to more precisely evaluate the random event, in practice, we turn to the Bernoulli process [168]. With its help it is possible to evaluate the dynamics of the price of shares during the validity of option which either increases with the probability $q$ or decreases with the probability $(1-q)$. This mechanism is the basis of binominal process.

If to denote share price at the moment of conclusion of option as $A_{0}$, then after some period of time in case of increase of dynamics of price the new share price will be $A_{1}=A_{0} \times k_{1} \uparrow k_{0} \downarrow$ and in case of decrease $-A_{1}=A_{0} \times k_{0} \uparrow k_{1} \downarrow$, where $A_{0}$ - initial share price; $A_{1}$ - share price in one time interval; $k \uparrow$ - growth of share price; $k \downarrow$-falling of share price. According to the binomial process period of validity of the option is divided into sub periods where each period is characterized by possible growth or falling of share price and can be considered as a classical Bernoulli process.

Having conducted modelling of binomial process of change of share price for the duration of the option contract that is owned by enterprise for the period $t$ you can establish additional control over the process of management of its level of economic protectability. Moreover, if we assume that during the validity of European option on shares it is affected by a large number of factors: time of conclusion and end of option, dynamics of change of share price during this period, the presence of capital on the market except shares and other financial instruments, the presence of a continuous process of functioning of the capital market, the lack of opportunities of arbitrageur and taking into account the fact that the capital market is competitive, then, according to $[168,169]$, the magnitude of the cash flows that are expected on option for sale at time $t$, will be equal to:

$$
G_{k \uparrow}=\max \left(A_{0} k \uparrow-P, 0\right) \text { i } G_{k \downarrow}=\max \left(A_{0} k \downarrow-P, 0\right),
$$


where $P$ - option exercise fee.

Accordingly for European option for sale magnitude of cash flows will be evaluated by the following equations:

$$
\begin{aligned}
& P_{k \uparrow}=\max \left(P-A_{0} k \uparrow, 0\right), \text { якщо } A_{1}=A_{0} \mathrm{i} \\
& P_{k \downarrow}=\max \left(P-A_{0} k \downarrow, 0\right), \text { якщо } A_{1}=A_{0} k \downarrow .
\end{aligned}
$$

For more precise valuation of options in practice it is suggested to calculate profitability of shares $\left(r_{k \uparrow}, r_{\downarrow \downarrow}\right)$, which are the part of option and affect change of share price, so:

$$
k \uparrow=1+r_{k \uparrow} ; \quad k \downarrow=1+r_{k \downarrow}
$$

For valuation model of European option for sale, also using the binomial model, we can calculate the magnitude of cash flows that would directly affect the characteristics of option for sale after $m$ growth of share price:

$$
P^{m}=\max \left(P-A_{0} k \uparrow^{m} k \downarrow^{n-m}, 0\right) .
$$

By controlling this process, it is possible to more efficiently determine the impact of the investment maintenance on condition of economic protectability of industrial enterprises, modeling forecasted dynamics of the rate of individual securities within the option contract.

Besides that the problem of valuation of European options will be more complex, the more increased will be the number of shares in the portfolio. This will lead to a variety of changes in the rate of securities and will affect the price of options to purchase and for sale, which will lead to either losses or extra profitability of industrial enterprise.

Also building of generalization of criteria of evaluation of investment projects at production and economic entities in the sphere of general investment activities which affects the general level of their economic protectability becomes also of a big importance.

Condition of economic protectability always correlates with a satisfactory or unsatisfactory financial state of an enterprise that is reflected in the degree or level of its economic protection. Like any other property of business entity, "economic 
protectability" being dynamic in time requires constant necessary diagnostics that is the development each time of the system of more innovation evaluative measures aimed at absolutely precise determination of the value of deviation of fixed current protection from permitted level of general condition of economic protectability of an enterprise under conditions of its normal further existence. In general, diagnostics is the process of recognition and determination of negative (crisis) phenomena in the activity of an enterprise on the basis of noticed local changes, established dependences as well as especially notable phenomena of current entrepreneurial activity.

The structure of generalized phased innovation process of diagnostics of economic protectability at an enterprise is shown in Fig. 5.1.1.

When it is necessary to choose an investment project, it is recommended first of all to answer the question: what is the required amount of financial resources for enterprise; where to find additional sources in the necessary amount and what their price is; to determine whether the investment incomes pays off.

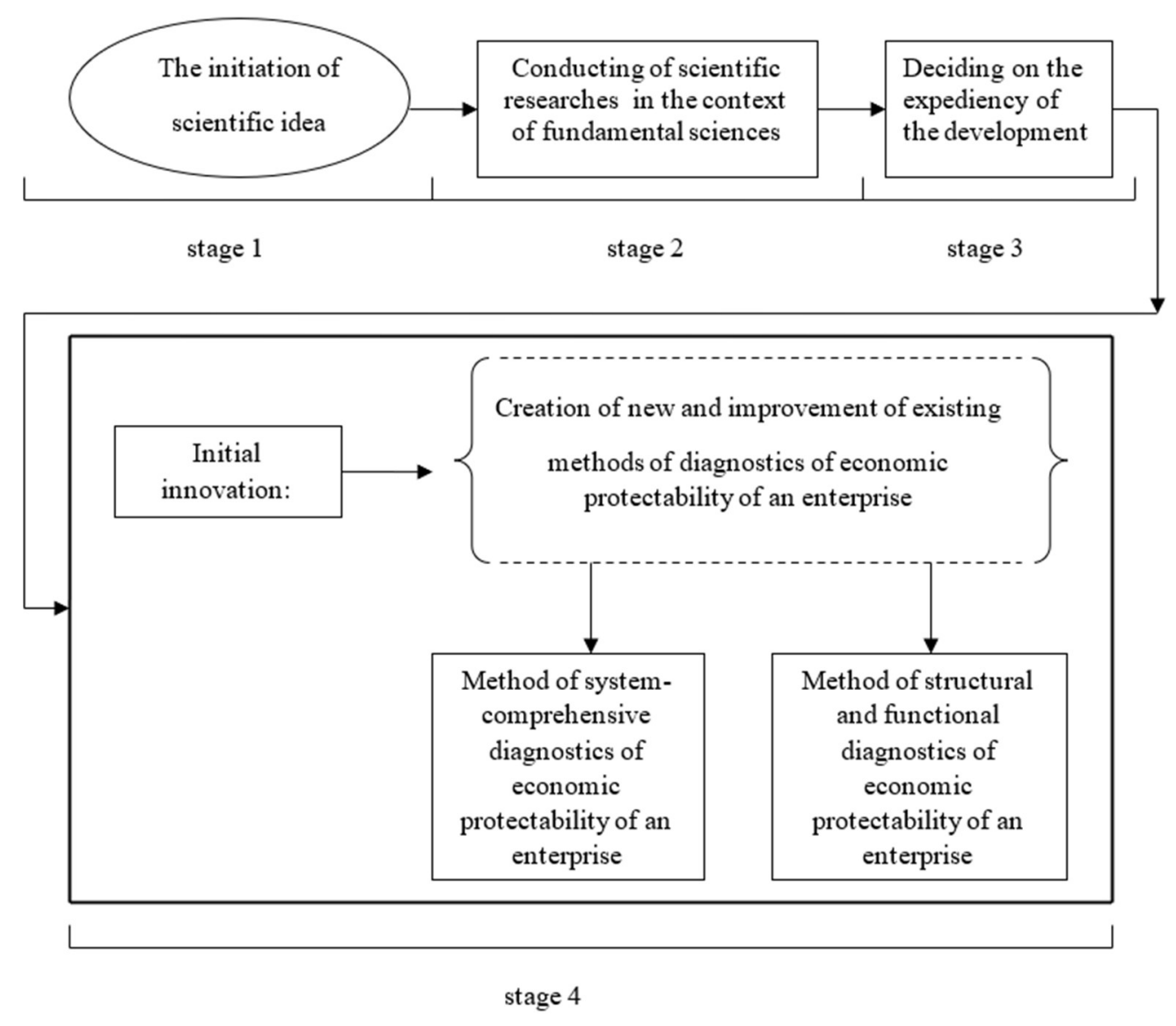

Figure 5.1.1. The structure of phased innovation process when developing diagnostics of economic protectability of an enterprise 
Thus, management in the sphere of the investment activities of enterprises and integration of rational investment policy with scientific-research, production and commercial activities must become an essential element to ensure economic security at them. In other words to successfully develop a mechanism to ensure economic protectability at enterprise an objective and precise financial and economic evaluation of its investment projects is necessary. It is found that an investment project that is owned by industrial enterprise and which affects the investment maintenance of its activities - is a complex mechanism that operates according to a number of factors and parameters which constantly dynamically change and correct through its effectiveness or ineffectiveness the condition of its economic protectability, that directly complicates the process of financial modelling of this effect. 
DOI 10.46299/ISG.2021.MONO.ECON.II-147-159

\subsection{Directions of ecologization of oil and fat industry enterprises}

The oil and fat industry of Ukraine is one of the branches of the food complex, which consists of interconnected production of oil, fats, margarine, edible oil and sales. As a raw material, the oil and fat industry uses oilseeds: sunflower, soybean, rapeseed, flax, peanuts, hemp, etc. The seeds of these crops contain an average of 35-40, and in the best varieties - more than $50 \%$ oil. And in macus and sprat and most of them contain $30-35 \%$ protein and up to $10 \%$ oil, which makes them a concentrated high-value animal feed. In a relatively short period of time, the oil and fat complex of Ukraine has significantly restored and increased its production potential. Ukraine is the largest producer of sunflower oil in the world, its share in world production is $23 \%$, and the share of exports is $51 \%$. But Ukraine has gained the status of a leader in the production of unrefined sunflower oil in the world relatively recently. To stimulate the growth of sunflower oil production in Ukraine, an export duty on sunflower seeds was introduced.

For the proper and active development of the agro-industrial complex, it is necessary to support the active mutual development of the state and business. Among the main tasks for both structures should be, first, to improve the existing legislation in order to adapt as easily as possible to the global principles of corporate governance. Second, international standards must be introduced on a mandatory basis, not voluntary ones, and compliance with them must be clearly monitored. Particular attention should be paid to creating preconditions for institutional support, agrarian business, development of agricultural advisory system in the form of information and consulting assistance to agricultural producers and rural population, development of small-scale agricultural production, agricultural cooperation to ensure integration of personal farms into the market. [171].

The main problems of the oil and fat industry are as follows. High level of monopolization of the industry. Thus, the industry is represented by more than 1.2 thousand enterprises, but the nine largest companies in 2013 accounted for $85 \%$ of production of unrefined sunflower oil, $66 \%$ of production of refined sunflower oil and $82 \%$ of production of margarine products from the corresponding volumes of their total 
production in Ukraine. Another consequence of the monopolization of the oil and fat industry is the underutilization of production capacity of enterprises, due to the logical desire of large enterprises to use their monopoly power - to produce and sell even a smaller amount of products, but at a higher price.

Insufficient innovation and investment orientation of oil and fat enterprises. At first glance, the oil and fat industry is one of the most innovation-oriented sectors of the domestic economy. The innovative activity of the enterprises of the oil and fat industry is carried out through the introduction of complex equipment to ensure the full cycle of production of oil and derived products; application of new types of catalysts in oil and fat production technologies; improvement of oil extraction technology and margarine production; use of waste oil and fat production to create new products.

Poorly developed system of storage and transportation of oil and fat products in Ukraine. The development of the storage system in Ukraine is carried out through storage in agro-holdings, storage in small and medium-sized agricultural producers, the development of port and river grain terminals. The basis of the storage system are elevators of different types, which are a set of structures and mechanisms designed to receive grain, its post-harvest processing (cleaning, drying), storage and shipment to various modes of transport, however, the current system of storage of oil products in Ukraine does not meet modern requirements globalization space and the existing export orientation of the industry. The latter is confirmed by the fact that despite the investment orientation of the industry, the construction of the storage system remains the prerogative of large enterprises and is almost unattainable for medium and small enterprises in the industry in the absolute absence of state support in this area.

The highest growth rate of production and exports in the world is due to soybean oil. Thus, the production of sunflower oil from 15.45 million tons in 2019 increased to 17.72 million tons in 2019, an increase of $114 \%$. In turn, palm and soybean oil showed an increase of 117 and $123 \%$, respectively. Palm oil is cheap to produce because it provides 5-8 times higher yields than other oil sources, and palm tree does not require special care. Of course, in contrast to sunflower and soybeans, the care and nutrition of which will directly affect the quantity and quality of the final product [172]. 
In Ukraine, the production of oilseeds accounts for a large share of crops grown in general. Of the almost 95 million tons of crops grown in the 2018-2019 marketing year, more than 22 million tons fell on soybeans, soybeans and rapeseed together. This figure is growing every year. Soybean processing capacity reached 5.44 million tons per year, rapeseed - more than 2 million tons per year.

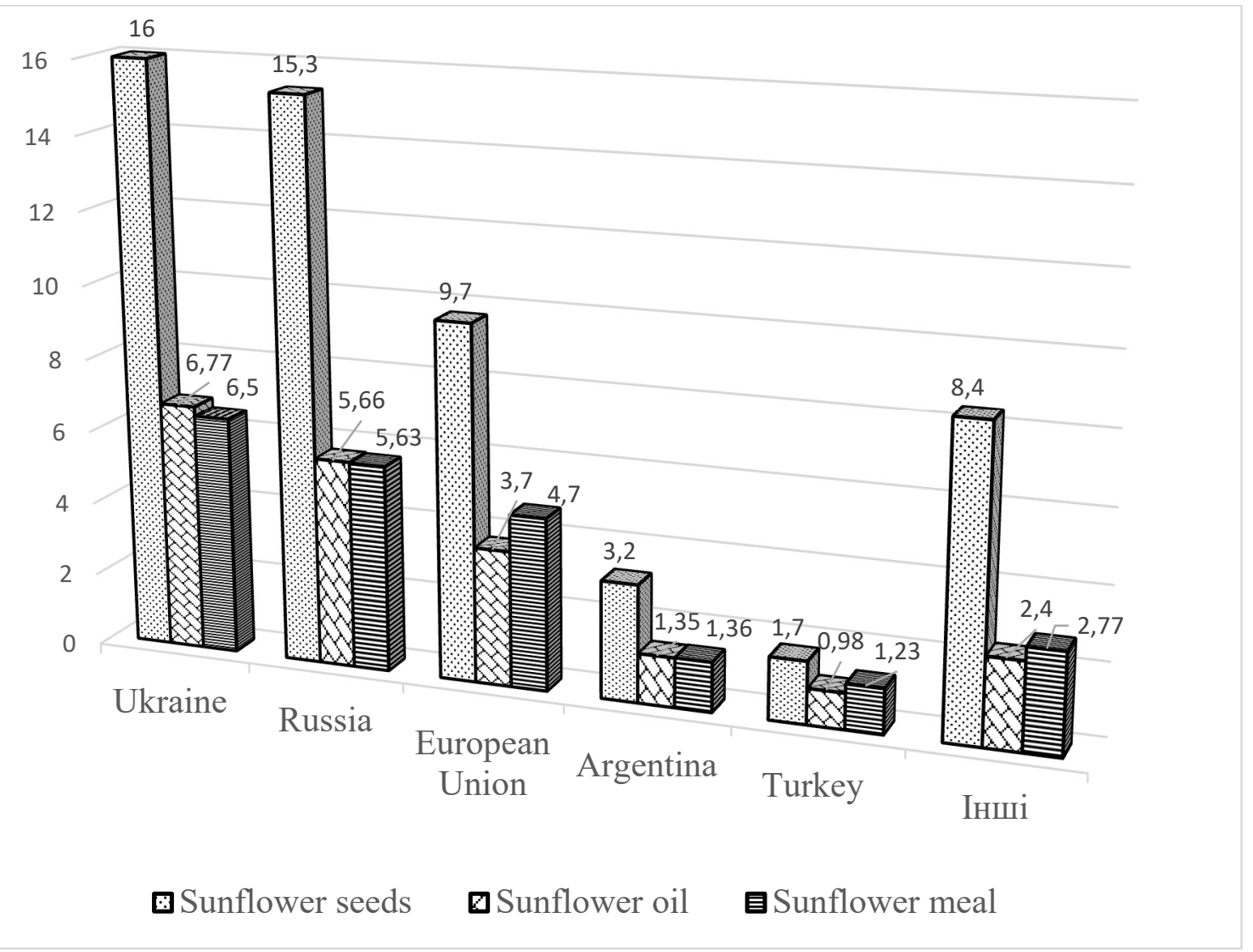

Fig. 5.2.1 The largest producers of sunflower, oil and meal in the world, million tons Source: constructed by the author according to [173]

However, due to mass exports of soybeans and rapeseed, they are loaded by only $16 \%$, despite the fact that Ukrainian-produced oil (soybean and rapeseed), as well as meal are in demand on the world market, especially in the EU. Our producers and exporters of oil and meal can satisfy all orders for their products in both domestic and foreign markets. In the 2018-2019 marketing year, 54.4 million tons of sunflower were harvested in the world, the leader was Ukraine, growing more than 15.5 million tons of this crop. In second place - Russia, collecting 15.3 tons, in third place - the EU, with a gross collection of 9.7 million tons.

The Organization for Economic Cooperation and Development in its forecast of 
agricultural development, sees the following trends for the next few years in the development of the market of vegetable oils: per capita consumption will continue to grow, the price will remain at 700-760 dollars. per metric ton, the growth in the use of vegetable oils in biodiesel will be quite slow. The main trend in the market of vegetable oils and oilseeds in the world is the growth of supply and this trend has been going on for more than ten years. In Ukraine, the oil and fat complex is developing similarly, domestic processing is growing, and exports are growing every year. In addition to the positive impact of increased foreign exchange earnings in the country and, there is another side to this process. World vegetable oil prices are falling and are currently at their lowest level in a decade.

Ukraine ranks first in the export of sunflower oil, placing about 6 million tons of products on foreign markets last marketing year. That is, of the total exports, 6.6 million tons of vegetable oils, 6 million tons - sunflower. Only 600,000 tons are other vegetable oils, despite the fact that processing capacity is underutilized by almost $30 \%$. Oilseed processing can be considered an almost waste-free production. For example, obtained in the process of aqueous hydration of oil (one of the types of refining) phosphatide concentrate has a high biological value and is used in the baking industry. The oil obtained in the process of extraction - extraction of oil from the cake or petals with a solvent, is used for the production of drying oils. Granulated sunflower husk is widely used in the world as an alternative fuel. Meal as a valuable biological additive is one of the components for the production of compound feeds for animal fattening.

The production base of enterprises allows to process different types of oilseeds: sunflower, rapeseed, soybeans, and the investment leads investors to pursue a prudent pricing policy for oilseeds, which encourages them to grow oilseeds. The outstripping increase in processing capacity causes fierce competition between processing enterprises in the domestic market of oilseeds and is a factor in maintaining the level of purchase prices for oilseeds. The oil market of Ukraine is one of the promising sectors of agricultural production. Oil products are in great demand on the world market due to two main factors: the growing reorientation in the structure of human nutrition to oils and fats of vegetable origin due to their physiological advantages and 
more affordable prices compared to animal fats and the dynamic growth of biodiesel production worldwide. based on vegetable oils against the background of progressive growth of prices for mineral energy resources and reduction of their natural reserves.

Today the issue of greening of production becomes especially important and relevant for all enterprises of the processing industry. Greening of production is understood as the expanded reproduction of natural resources through the introduction of new and improvement of existing technologies, optimization of the organization of material production, increasing labor efficiency in the field of environmental protection. The issue of environmental safety is now of paramount importance directly related to the preservation of human existence, as never before, the state of the environment is rapidly deteriorating due to the expansion of industrial production in all countries, as a result - it is important to constantly develop, improve and the implementation of strategies and models of greening of production, which is reflected in the environmental characteristics of the product of production, and, as a consequence, its competitive position in the market.

The introduction of ecological innovations will increase the efficiency of production, improve its ecological level, improve living conditions and human existence, which will be the basis for consolidating competitiveness through the greening of innovative development. Oil and fat industry - having a strong export potential, enterprises in this industry must also change the vector of work. This is primarily due to the significant depletion of natural resources, increasing anthropogenic impact and technological load on the environment. The need to green production is due to several important factors. The manufacture of products on obsolete equipment leads to the production of low-quality products, the accumulation of production waste, which creates the problem of utilization, reduced productivity, as well as too high resource and energy consumption [174].

Studies of a set of measures to prevent or stop the negative impact of economic processes on the environment, allow us to identify the main directions of greening of production, which coincide with the main applied tasks of eco-biotechnology.

1. Preparation and substantiation of effective solutions, methods and means for 
wastewater treatment from industry, rationalization of water resources of the country, reduction of emissions from stationary and mobile sources (industrial and transport). The implementation of these measures will help to prevent environmental pollution, of course, in part.

2. Measures aimed at reducing or completely eliminating hazardous waste that pollutes the environment are relevant and promising for implementation. The main direction recognized in the world is the transition to the use of closed technologies, a special feature of which is the lack of metabolism with the environment, ie, a process in which there are no emissions of solids, discharges of liquids and gases of gaseous waste. A promising direction here is the development of new, created on an alternative basis of technology in energy, new materials, possibly "nano-materials", the development of new technologies based on natural (environmental) processes, possibly the transition to biotechnology.

3. The principles of economics of nature generate such a modern direction of greening as recycling or reuse of waste. A separate type of reuse of the resource is the regeneration of primary waste. Regeneration is understood as additional processing of primary waste left in the production cycle and removal of compound elements that remained after that. The state of the environment largely depends on the creation and implementation of practical activities of effective mechanisms for managing industrial enterprises. Recently, a mechanism for improving production processes on the basis of greening is being developed. As the territory of Ukraine is recognized as a zone of ecological crisis, the solution of this issue is not only the need for integration into the European space, but, first of all, the goal is the physical survival of the population.

Achieving this, of course, as is generally accepted, is possible only through the pursuit and adherence to the principles of sustainable economic development. If we consider greening as a process, today it is more common to understand it as a process of gradual and consistent implementation of interconnected sound organizational, technological, technical, managerial and other solutions that help increase the efficiency of natural conditions and resources, while maintaining, and preferably b, improved the quality of the natural environment. In the context of the global 
environmental crisis, this can be defined as the main requirement of today. In the socioeconomic aspect, the basis of greening should be considered the transition to such methods and principles of management that would provide optimal resource use, and technically - the introduction of innovative eco-technologies of production and nature management [175].

Innovative theoretical developments in the direction of greening of modern production indicate the ways in which it should be implemented in practice. The greening movement, in turn, requires feedback from society in the form of not only theoretical agreement but also practical support for the transition to green production. According to some scientists, the solution of global environmental problems is associated with the transition to the bioeconomy as a new economic system. In particular, the development of biotechnology is often seen as one of the engines of environmentally sustainable production and the creation of a variety of innovative products that can mitigate or even solve some global problems of mankind.

Greening based on the use of living organisms in the production process is fully consistent with its essence. This applies, first of all, to such a branch of modern production as biotechnology, the development of which has been quite rapid recently. The use of new biotechnologies is primarily envisaged in such sectors of the economy as agriculture, medicine, pharmacology, chemical industry, and energy. In this case, these industries are considered as end producers of bioeconomy products Sustainable development of oilseeds production provides high yields without compromising natural resources and systems. Businesses that adopt this method of work and fully implement it, have more effective cooperation with the environment, do not ignore its needs and use the best of modern knowledge and technology, avoid the unpredictable consequences of industrial and chemical pollution. An important result of sustainable production is that businesses can minimize the use of pesticides, thus saving money and protecting future productivity and the environment, of course.

The oil and fat industry of Ukraine is characterized by a tendency to increase production, which is reflected in the environment. The generated fat-containing waste, getting into the environment, causes a negative impact, first of all, on the state of water 
sources. The grease contamination systems used in most oil and fat enterprises are inefficient and require the introduction of new technological solutions. Moreover, the oil production process itself requires a significant amount of water for oil production, the processes of chemical neutralization, subsequent washing and deodorization.

As the requirements for product quality and safety increase, it is important for every company that accepts the finished product to be able to track the entire production, processing and distribution so that if necessary to recall the product from the market, the seller could do it without error, in full and properly notify all other companies. The bidder must take all appropriate measures to ensure that the processed products can be traced at all stages. That is, there must be a register with relevant data on purchases, production and sales. The formation of an effective control system should be based primarily on the certification of the manufacturer and only then on the quality control of the products he produces. This practice is used in developed countries. Soils where raw materials are grown must be certified, as well as raw materials, equipment, technological equipment, personnel, vehicles, trade network and many other aspects of the enterprise. Thus, there is effective control throughout the chain from production to sale.

The issue of product quality of the enterprises of the oil and fat complex of Ukraine is one of the important problems of its development today. The peculiarity of the current system of state regulation of quality and safety of food products is the presence of several state institutions responsible for this direction; State Inspectorate of Ukraine for Consumer Protection; State Veterinary and Phytosanitary Service of Ukraine; State Sanitary and Epidemiological Service of Ukraine; Ukrainian Research and Training Center for Standardization, Certification and Quality, as well as a number of public organizations for the protection of protection.

For the harmonization of national standards in accordance with EU legislation in the field of safety and quality of food products in 2014. came into force in Ukraine conference Zakon "Pro osnovni principles ta ta vymohy till the bezpechnosti yakosti harchovyh produktiv" maye chto nA meti zabezpechennya vysokoho level zahystu interests spozhyvachiv, a takozh stvorennya prozoryh umov driving hospodarskoyi 
diyalnosti, increasing konkurentospromozh-nosti vitchyznyanoyi produktsiyi harchovoyi promyslovosti. The law provides for the introduction in Ukraine of the European model of the system of guaranteeing the safety and quality of food products, which is based on the procedures of the HACCP; clarification of terminology, types of offenses and adequacy of the measure of punishment; creation of a single controlling body in the field of food safety; abolition of permits and procedures that are absent in the EU; implementation of European principles of GMO regulation, especially in the part of registration of GMO sources, and not products made from them.

The implementation of procedures based on the principles of HACCP in the capacity of processing enterprises is an extremely important method, because without these principles it is impossible to ensure that the product is manufactured in compliance with all standards for product quality and safety. According to the author, no processing enterprise can operate without the HACCP system today. Almost all modern standards of the food safety system are created on the basis of HACCP: ISO 22000, FSSC 22000, BRC, IFS, Global Gap, SQF and others. HACCP (Hazard Analysis and Critical Control Points) is a quality control system. It makes it possible to identify threats and apply control measures throughout the production chain. The HACCP concept meets the requirements of the Codex Alimentarius Commission, established by the World Health Organization and the Food and Agriculture Authority of the United Nations, to bring together international food standards, regulations and codes to ensure fair trade. There are seven principles that formed the basis of the HACCP system and are mandatory when creating a system for a particular enterprise - a food producer [176].

The first principle is to conduct a thorough risk analysis. This is done through the process of assessing the significance of potentially dangerous factors at all stages of the life cycle of food products, controlled by the manufacturer. The probability of any risks is also assessed, and general preventive measures are taken to prevent, eliminate and minimize the identified hazards. The second principle is the definition of critical control points, as well as technological stages and procedures in which strict control makes it possible to prevent, prevent potential danger or through certain 
measures to eliminate the possibility of risks. The third principle is to set critical limits for each control point. Here, criteria are defined that show that the process is under control. The developers of the system form tolerances and limits, which must be adhered to so that the situation does not get out of control at critical control points.

The fourth principle is the establishment of procedures for monitoring critical control points. To do this, surveillance systems are installed at critical points, and various inspections are created through regular analysis, testing and other types of production supervision. The fifth principle concerns the development of corrective actions to be taken in cases where inspections and surveillance indicate that the situation may be out of, out of control or out of control. The sixth principle is the establishment of accounting procedures and record keeping, which fixes the necessary parameters. The documentation will be a clear indication that the production processes at critical points are under control, all deviations are corrected, and the developed HACCP system for this company as a whole functions effectively. The last, seventh, principle is the establishment of procedures for checking the set of documentation, which must be constantly maintained in working order, reflect all measures for the implementation, enforcement and compliance with all the principles of HACCP. In other words, this set of documents will reflect the fact of viability of the developed HACCP system for this enterprise - a food producer.

The main idea of HACCP is to focus on critical points. The system is a warning method and is used in the food industry as a guarantee of product safety. The primary advantage of this system is the guarantee of the quality of manufactured products, the assessment of all weaknesses in doing business, the possibility of leveling them, and thus increase profits. Other benefits include the following: - Optimization of control of production processes; - Reducing damage and increasing shelf life; - Increasing the stability of the product; - Reducing costs by reducing the volume of defective products; - Consolidation of market positions. The development of Ukraine's market economy and access to world markets should determine new priorities for the development of production. This is, firstly, increasing the competitiveness of manufactured products. And here we are not talking about a specific system, HACCP is one way to achieve 
this goal, and if you follow all the principles of the system, which were discussed above, the chances of improving the image are quite high. Secondly, an important stage is the transition from mining to processing. Third, the creation of a system for ensuring the safety of consumed products should be an equally important part of increasing competitiveness.

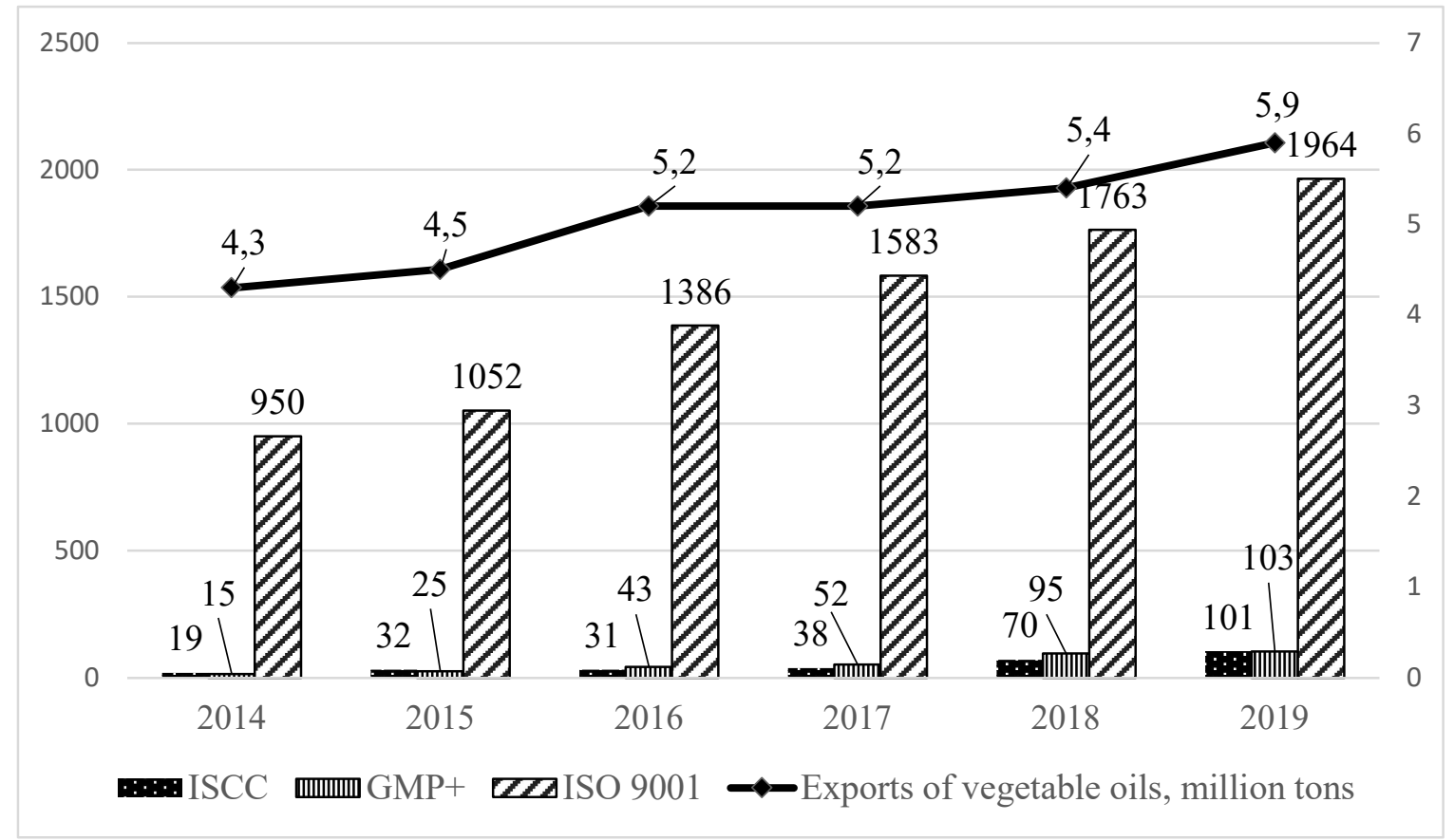

Fig. 5.2.2. Number of certificates and increase in vegetable oil exports to Ukraine in 20142019 Source: built by the author on the basis of [177].

Among the systems that have helped to increase and expand the range of exported products in recent years: ISCC for the export of rapeseed oil for biodiesel production, GMP + for the export of processed products for feed purposes, ISO 22000 to confirm food safety. ISO 9001 certification, an enterprise quality management system, helps to improve the company's image, and the processing companies themselves have the opportunity to increase the efficiency of production processes, as well as to achieve a stable result on an ongoing basis.

The introduction of international systems is the first step towards the greening of production, as they can neutralize biological, physical and chemical risks, reduce costs and increase competitiveness in both foreign and domestic markets. Businesses that have certificates of compliance with quality and food safety standards with 
international accreditation receive many competitive advantages. First, it is an opportunity to enter international markets where there are generally accepted world standards and trade rules. Secondly, it is an opportunity to participate in important tenders. Third, such companies have the opportunity to attract foreign investment, as an enterprise that has streamlined production processes and has a mechanism for analysis, control and improvement, and hence increase the efficiency of enterprise management. Fourth, obtaining the status of a reliable supplier that produces quality and safe product.

In addition to competitive advantages, companies also receive internal benefits that companies receive as a result of the introduction of the HACCP system: Management receives documented assurance about the safety of the product, which is especially important when analyzing complaints and possibly lawsuits. - Significant savings due to the reduction of the share of defective products, as preventive measures for the management of hazardous factors and the early warning system come to the fore, rather than delayed actions for already produced defective products. - Staff motivation increases, there is an opportunity to attract more qualified staff. Moreover, the company's plants are subject to GMP + B1 certification, trucking companies - GMP + B4, and transshipment facilities - GMP + B3. The laboratories of the enterprises are licensed according to the ISO 17025 standard, which allowed to expand the range of analyzes. The production of raw materials is also subject to certification. In particular, the cultivation and processing of corn is certified according to the ISCC EU standard. In addition, Kernel has been certified according to the EU ISCC standard for soybeans, rapeseed and wheat [178].

Given the factors of influence inherent in the oil and fat industry of our country, which characterize the state of the market of sunflower seeds and products of its processing, at all stages of a market economy, it is necessary to combine with a free pricing system and elements of government regulation. This principle should be used primarily to ensure price parity for agricultural products and means of production coming into this industry from industry. The state must have a realistic concept of prices, which would reflect the objective economic processes and limit the role of 
subjective factors in pricing. Given the possibility of industry development, prices for sunflower seeds should be set on the market under the law of supply and demand.

Analyzing the state and prospects of the oil and fat industry, it is safe to say that this industry has significant prospects in terms of providing the domestic market with quality and healthy products, and in terms of entering foreign markets a wider range of reliable products. The oil and fat industry has a number of problems, the main of which are: high level of concentration in the industry leads to loss of independence of smaller enterprises and leads to the disappearance of competition, monopoly in the industry, fluctuations in prices for both oil and oil; close dependence of the industry on the raw material base, which is affected by agriculture with seasonal, climatic problems; low quality of raw materials and oils that are exported leads to a decrease in export potential; insufficient use of energy-saving technologies; lack of state support. [179].

The expediency of greening the oil and fat industry should not be underestimated. First of all, all companies that are actively involved in improving the work through the introduction of energy-saving technologies are expanding the list of potential buyers. Second, such companies can be confident in the quality of their products and claim a higher price in the market. Third, the process of greening oil and fat enterprises will encourage business management to take the right approach in decision-making and to determine the vector of activities aimed at improving both the financial situation and the environmental and social component. Successful management decisions and effective control include the following: environmental performance assessment, environmental impact assessment, life cycle assessment, ecoaudit. 
DOI 10.46299/ISG.2021.MONO.ECON.II-160-168

\subsection{The organizational aspects of improving the enterprise's investment management}

In contemporary economic conditions, an important way to increase production efficiency is the formation of a mechanism for active investment policy. It is known, that investments are all types of property and intellectual values that are invested in objects of production, business and other activities, as a result of which the profit (income) is created, or a social effect is achieved.

The total amount of investments is investment potential. Capital investments are funds that the company sends for reimbursement, as well as the accumulation of fixed assets for production and non-production purposes. When assessing the effectiveness of capital investments, it should be borne in mind that in economic practice they are repaid not by the growth of gross domestic product or profit, but by depreciation.

The growth of gross domestic product and profit - indicators of efficiency not only of capital investments, but of all social production: labor productivity, the general level of its social organization, fixed assets efficiency, etc. Between the investments and income there is an intermediate link - production, the result of which crucially shapes the efficiency of capital investment.

In the investment-reproduction cycle, the efficiency of capital investments is determined by a system of local indicators. Own sources of financing of capital investments are called to provide first of all simple reproduction of the basic means of production. The exception is the replacement of equipment that has fallen out as a result of accidents, as well as its replacement in the event of a sharp reorientation of production. Extended reproduction in most cases is also carried out at the expense of own sources of financing of capital investments. In turn, own sources of financing of capital investments are formed at the expense of profit, depreciation deductions and funds received from the sale of surplus equipment. According to many economists, the simple reproduction of fixed assets can be fully secured by depreciation, and the expanded reproduction by the profit that goes to the production development fund. 
Statistics show that in recent years there has been a variable trend in the share of depreciation deductions in both production costs and capital investments. Table 5.3.1 presents the cost of production in industry and the share of depreciation and wages.

The cost of production (goods and services) of enterprises in 2012-2019

\begin{tabular}{|c|c|c|c|c|c|}
\hline \multirow[t]{3}{*}{ Years } & \multirow{3}{*}{$\begin{array}{l}\text { Cost of production } \\
\text { (goods and } \\
\text { services), } \\
\text { thst.UAN }\end{array}$} & \multicolumn{4}{|c|}{ Of these, the component costs } \\
\hline & & \multicolumn{2}{|c|}{ Amortization } & \multicolumn{2}{|c|}{ Wages and salaries } \\
\hline & & thst.UAN & $\begin{array}{l}\text { in } \% \text { to } \\
\text { the total }\end{array}$ & thst.UAN & $\begin{array}{l}\text { in } \% \text { to } \\
\text { the total }\end{array}$ \\
\hline 2012 & 1155360086,9 & 62509214,5 & 5,4 & 123478442,0 & 10,7 \\
\hline 2013 & 1105414502,9 & 68176839,4 & 6,2 & 127880241,8 & 11,6 \\
\hline 2014 & 1084722077,3 & 71833903,2 & 6,6 & 115242030,3 & 10,6 \\
\hline 2015 & 1351983391,3 & 80332058,4 & 6,0 & 126115009,3 & 9,3 \\
\hline 2016 & 1498586798,6 & 93983179,4 & 6,3 & 150162035,1 & 10,0 \\
\hline 2017 & 1879666066,9 & 100314932,9 & 5,4 & 190349354,2 & 10,1 \\
\hline 2018 & 2242650422,7 & 120166382,7 & 5,4 & 238331691,4 & 10,6 \\
\hline 2019 & 2313033556,9 & 145098611,7 & 6,3 & 282339101,4 & 12,2 \\
\hline
\end{tabular}

Source: is developed based on [180]

The growing share of depreciation in production costs reflects the general trend of replacing labor by capital. At the same time, today in many enterprises the share of wages in production costs is growing very slowly or even decreasing.

The share of depreciation in capital investments may increase due to several reasons. First, the change in depreciation rates, an increase in the structure of fixed assets, the share of their active part. Second, the decline in the growth rate of funds is due to a slowdown in the growth of net investment, and as a consequence, a decrease in their share in gross capital investment. The constant increase in the share of depreciation in capital investments makes such issues of depreciation theory as: - the use of depreciation not only for simple but also for extended reproduction; 
- taking into account both physical and moral depreciation in depreciation deductions; - use of regressive and accelerated depreciation in business practice.

The analysis of depreciation policy, as well as the economic practice of reimbursing worn-out funds, show that the latter did not provide optimal proportions between reimbursement and accumulation of means of labor. This discrepancy is manifested in the incomplete implementation of the renovation. To a large extent, the practice of not meeting the needs for renovation is due to the depreciation policy and the current depreciation system. The latter is characterized by: "bifurcation" of the flow of accrued depreciation for major repairs and renovations with a disproportionately large share of its first part; lack of mechanisms for under-depreciation and redepreciation (when depreciation is accrued during the entire period of use of equipment in accordance with regulations); not taking into account in depreciation deductions the decrease in consumer value of fixed assets as they depreciate (uniformity of depreciation); high degree of differentiation of depreciation rates depending on industry specifics, types of equipment and conditions of its operation.

With regard to external sources of investment for the company, it should be noted that high investment properties have securities, the issue of which with the development of joint-stock management is constantly expanding. Under the securities of enterprises, joint-stock companies understand the certificates of equity ownership, which give its owner the right to a share of profit (income) of the enterprise, as well as the right to vote in management decisions.

The international practice has extensive experience in the use of securities in business. In the United States, corporate securities fall into three main categories: corporate bonds, corporate stocks, and commercial paper. Corporate bonds have maturities and fixed interest payments, and the yield on them at maturity varies depending on changes in their price. The set maturity is in the range of ten to thirty years. Shares of a corporation mean that their owner has ownership of the relevant portion of the corporation's capital. The shares have no maturity and are not subject to mandatory periodic payments to their owners. The shareholder receives dividends only if the company's directors declare profits and dividends. Shareholders have the right to 
vote in resolving issues related to the management of the enterprise. Commercial securities are short-term securities that represent unsecured debt. Therefore, only corporations with a solid credit standing can raise funds in this way. To increase their funds in this way, some firms have to secure their obligations with bank letters of credit, and sometimes with guarantees from insurance companies. Commercial papers are mainly issued by industrial corporations, financial firms and bank holdings. Often, small companies combine to issue commercial paper in order to obtain cash at a lower cost than bank interest. Typically, commercial papers are repaid forty-five days after issue, or earlier. Commercial papers have denominations often ranging from fifty thousand to a million dollars.

The issuance and sale of securities - is a loan of funds from employees of enterprises, members of joint stock companies (investors). Among the main requirements that interest investors, should be considered profitability - the ability to receive dividends and the interest on securities. A specific quantitative expression of the yield from securities indicates the dividend rates on them. Forecasting these indicators is an objective element of the feasibility study for the issue of securities in the formation of joint stock companies. The dividend mass is the part of the net profit of a joint-stock company that can be used to pay dividends on shares. When forecasting the dividend mass, it is necessary to determine the net profit based on sales revenue (taking into account the dynamics of prices under the influence of market conditions), its cost, balance sheet profit, the amount of taxes and fees payable.

The distribution of net income is a controversial and complex process. In the distribution of net profit there are certain objective contradictions between members of joint stock company. This concerns, in particular, the share of the dividend fund in net profit. Ordinary shareholders are interested in increasing the share of profits that goes to pay dividends, while for shareholders who own a controlling stake, high dividends are less interesting because they care about the strategic development of the corporation. The rational solution of the problem of distribution of net profit should be based on the prospects of development of the joint-stock company, which in turn 
should take into account trends in demand for products, their competitiveness, market capacity and so on.

The dividend policy of the management of the joint-stock company includes the definition of the dividend fund, as well as the regime of dividend payment to shareholders. Dividend policy is developed by the general meeting of shareholders, which decides on what part of the net profit is paid in the form of dividends, which is directed to the development of the company and the reserve fund, how to stimulate managers for the company's results and more.

When distributing net profit as a guide, it is advisable to use the minimum permissible in world practice annual excess of the company's net profit over dividends: for industrial companies - 3 times, for state-owned enterprises in the field of utilities 2 times. Corporate statistics show that deviations from these indicators in the direction of increasing dividend payments can lead to a crisis in the company or even its bankruptcy.

The projected value of the dividend rate is used to determine for investors the feasibility of investing in securities compared to other objects of investment. The dividend rate or the yield of securities is determined by the ratio of the mass of the dividend to the authorized capital (nominal value of the issued shares) of the jointstock company. To determine the feasibility of investing, it is recommended, first of all, to compare the estimated dividend rate (DR) with bank interest rates (BR) on longterm retail deposits and corporate deposits. Fulfillment of the condition DR $\geq B R$ indicates a sufficient level of security of return of securities, their investment attractiveness for shareholders. Otherwise (ie when DR $<$ BR) the yield of securities should be considered insufficient and therefore the company needs to develop specific recommendations to increase it in order to attract investment.

In the context of an active investment policy, the development of investment scenarios and strategic management is becoming increasingly important. One of the priority tasks of strategic management is to find ways to reduce the vulnerability of the enterprise, ie to protect the capital that has already been obtained and formed. The next tasks may already be the development of measures to increase and develop it. 
Increase in return on invested capital $(\Delta E)$ in economic literature is recommended to calculate by equation:

$$
\Delta E=\frac{G+\Delta G}{K+\Delta K}-\frac{G}{K}
$$

where $\mathrm{G}$ - the amount of profit provided while the existing position is maintained;

$\mathrm{K}$ - the amount of current capital investment of the enterprise in the strategic management area;

$\Delta K$ - increase in investments required to ensure an optimal position; $\Delta G$-profit growth [181].

With the existence of a more or less stable economic system, the future development of the enterprise can be determined by the method of extrapolation of past trends and planned production targets. In modern conditions, when companies do not have a clear and stable growth prospects, there is a need for a differentiated assessment of external conditions for the company by limiting trends, ie all that is called in the economic literature "strategic management areas". The mechanism of technical renewal of enterprises is based on the formation at the expense of profit (income) of funds for various purposes (production development fund, social sphere fund, material incentive fund, etc.). The pace and effectiveness of technical renewal is largely determined by the ratio between these funds. As a link not of macro- but of microeconomic economic mechanism, the process of making appropriate contributions to the funds of specialpurpose enterprises directly affects the interests of enterprises for the technical renewal of existing production. However, currently these processes are significantly influenced by the mechanisms of market regulation of the economy.

The analysis of the current order of enterprise's management of investment processes shows, that they are usually almost unmanageable, resulting in reduced efficiency of capital investments in general. This applies primarily to the renewal of fixed assets, which is the main area of investment. Therefore the processes of renewal of fixed assets require proper and purposeful regulation.

An industrial enterprise acts as a socio-economic system, which is an organically integral and dynamic set of objectively determined elements, the interaction of which 
creates the possibility of systematic and rational updating of tools, taking into account external and internal factors. This is an organizational prerequisite for the rational construction and efficient operation of subsystems for managing the renewal of fixed assets at the enterprise, and especially the fleet of equipment. Modern business practice does not single out the issue of organizing the management of the renewal of the equipment park of the enterprise from the general management function. These issues are resolved by various departments - technical and technological departments, design department, production department, production development department, etc. However, the diversity and complexity of the tasks of managing the renewal of fixed assets determines the feasibility of allocating it to a separate subsystem, which has a certain independence and organizational autonomy. Its managerial influence will be aimed at organizing the renewal of physically and morally obsolete equipment. However, the object of management will not be individual means of labor, and production teams of shops, services, departments and individual performers, directly engaged in the renewal of fixed assets.

The organization of equipment fleet renewal at the enterprise is carried out by management services of different hierarchical level: special management units (departments of chief engineer, technologist, capital construction; design and technology departments, production managers, etc.); management units that perform general management functions on the enterprise (planning and economic department, accounting, finance department, etc.); units of line management and service units (main production shops and sections, repair and mechanical shop, etc.). Such a dispersion of functions and the lack of objective conditions for comprehensive coordination of services and departments do not allow for a purposeful implementation of a single technical policy in the renewal and in turn reduces its effectiveness.

In the process of renewal of fixed assets, many organizational, economic, technical and social problems are solved. In modern conditions, the range of these tasks is expanding, and their complexity is growing. Therefore, the specifics of modern industrial production requires constant and clear regulation and coordination of all services and departments that are engaged in updating equipment at the enterprise. 
The problem of integrated management of the equipment park renewal of existing enterprises is not sufficiently developed both in theoretical terms and in practice. At the same time, the processes of renewal are objectively characterized by regulated, planned and purposeful principles. Therefore, the renewal of fixed assets should have a clear organizational structure, characterized by the unity of purpose, formed by the autonomy of the processes occurring in it, and the circle of necessary information. The process of equipment renewal management is reduced to solving a certain range of management tasks, the synthesis of which should be the basis for the formation of the subsystem management upgrade of the equipment for existing enterprises. From this point of view, each task qualitatively and quantitatively shows its specific relation to the subsystem of equipment fleet update management. On the other hand, a prerequisite for solving each problem is the presence of the subject, ie employees who organize and carry out the renewal process, and the object in relation to which the solution of this problem is directed.

Tasks of updating fixed assets differ in content and direction of actions associated with their solution. As well as any production activity, they are characterized by existence of exclusively executive (production) acts and acts of preparation and acceptance of administrative decisions. Therefore, the whole set of tasks of the equipment upgrade management subsystem can be divided into production and technological and management tasks. Production and technological tasks that are solved in the process of upgrading equipment, mainly form the managed part of the subsystem, as in most cases are regulated by special documentation - a system of planned and preventive repairs for major repairs, technical tasks for equipment upgrades, etc.

In the most general form, the function of managing the renewal of fixed assets can include planning, regulation, accounting, analysis and control. The basis of the organization of the equipment upgrade management subsystem is the formation of its internal structure. The formation of the internal structure of the control subsystem should be carried out in the following sequence: - substantiation of the composition and content of management functions, their grouping by type of activity; - construction of the scheme of interconnection of functions and definition of the enlarged administrative links in the 
directions: the account of a condition and movement of the equipment, planning of updating, realization of capital repairs, modernization and replacement; - distribution of management functions, administrative rights and responsibilities of departments at the enterprise; - creation of a specialized unit to manage the renewal of fixed assets, the formation of its organizational structure.

The formation of the equipment upgrade management subsystem and the mechanism of its operation should provide the following basic requirements: 1) efficiency, ie ensuring a high level of productivity of employees of services engaged in the renewal of fixed assets, quality performance of the planned volume of work; 2) efficiency, ie coordination in time of processes of updating and changes in a technical condition of the equipment; 3 ) reliability - a reliable reflection of the state of fixed assets and their updating in the analytical and reporting information; 4) optimality - the choice of the most effective forms of renewal: overhaul, modernization, replacement.

The full coverage of all tasks is an important prerequisite for the formation of a rational organizational structure for managing the renewal of the equipment fleet on enterprises. It should be borne in mind that the range of problems and tasks does not remain unchanged. With the development of production, improvement of forms and methods of management, new management tasks appear, which can make adjustments to the existing management structure of equipment upgrades. Experience shows that the creation of special services at enterprises that would deal with the management of fixed assets, in mechanical engineering is not practiced. At the same time, at some enterprises the services which administrative task is the organization of technical re-equipment of production are created. The practice of their work shows that they do not fully cover the whole complex of works on the renewal of the equipment fleet, but only occasionally deal with current issues of modernization and replacement of certain types of equipment.

Summarizing the above, it should be emphasized that in modern business conditions an important way to increase production efficiency is to improve the management of investment processes and the implementation of active investment policy. 
DOI 10.46299/ISG.2021.MONO.ECON.II-169-202

\subsection{Postcoronavrus formation of tourist micro-business of the region on the basis of economic security}

\subsubsection{Theoretical aspects of the formation of postcoronavirus business} space in the regional sphere of tourism on the basis of economic security

Post-coronavirus formation in Ukraine of a modern highly efficient and competitive tourist complex requires solving a number of tasks, namely: improving the regulatory framework and system of public regulation of tourism, creating a modern tourism market on the basis of competition, deepening specialization and cooperation in tourism micro-companies development of various types of domestic and inbound tourism, introduction of public-private partnership mechanism, stabilization of microbusiness, modernization and transformation of regional tourism infrastructure to global standards, digital integration of Ukraine into the world tourist space, sustainable development of international cooperation in tourism to realize domestic interests business, protectionist policies to promote the creation of tourist destinations. In general, meeting the needs and demand for tourism implies the need to provide a large number of tourist services. From the point of view of economic activity, tangible and intangible tourist services are of interest to micro-business. The subjects of postcoronavirus relations in the context of tourism are the organizers and sellers (tour operators and travel agents) of the tourist product, their contractors (service providers: hotels, restaurants, carriers, operators) and buyers, both complex tourist product and separate tourist services. Thus, the business of tourism micro-enterprises is an organized work, which uses capital, recreational resources, means of production, staff, digital space for the production and sale of tourism products [187].

In the post-coronavirus business space of tourism important stages of microenterprise activity should be: adequate planning of tourist services and quality control of tourist product: preparation of tours, their methodological support, preparation of contractual documentation, work with insurance and other interested organizations (1); determination of the method of realization of a tourist product taking into account 
technological, information achievements and experience of the global tourism industry: independent realization or through other firms, commission sale through intermediaries or creation of an extensive dealer network (2); innovative ways to stimulate sales: virtual fairs, exhibitions, competitions, auctions, travel lotteries, seasonal benefits, loyalty programs for regular customers, children, promotional tours, etc. (3); selection by competencies and implementation of smart-personnel management of a travel company: calculation of the number of employees, formation of staff smart-schedule, development of digital-instructions, entrepreneurial innovative forms of remuneration, introduction of smart-regulations of micro-enterprises (4). The system of micro-enterprises in the tourism business of the region is presented in Fig. 5.4.1.

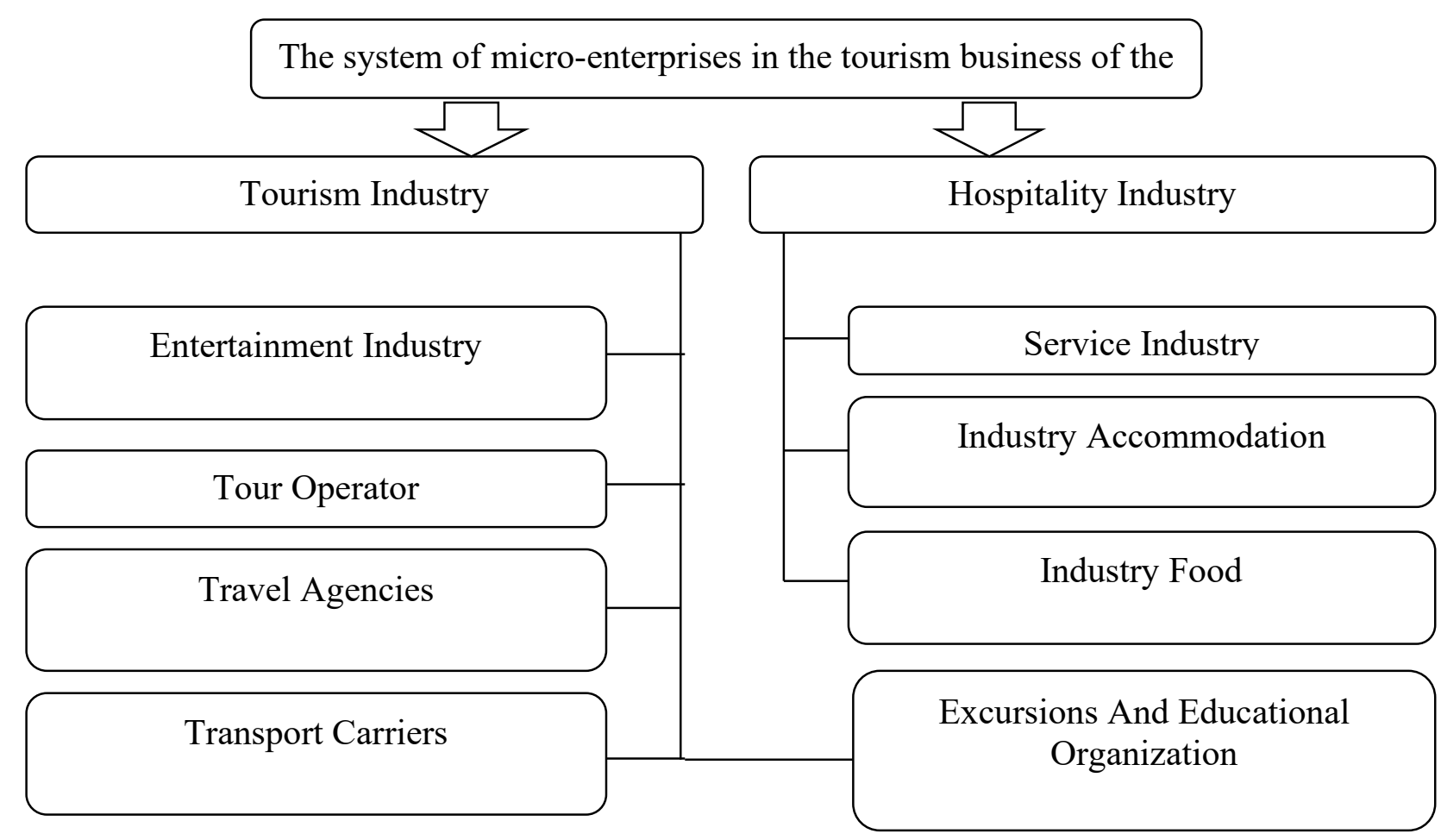

Figure 5.4.1. The system of micro-enterprises in the tourism business of the region

The transformation of the regional tourism economy to the post-coronavirus era is accompanied by the emergence of management problems that are extremely complex in content, their solution must be found by combining the efforts of leading scientific schools using the results of retrospective analysis of economic tourism systems in the conditions of COVID-19, both nationally and internationally. It should be assumed that 
the creation of a new paradigm of regional tourism economy is becoming an additional factor in its globalization. The search for a vision of development during and after the COVID-19 pandemic is gradually transforming the region's tourism sector into an effective mechanism for developing optimal steps towards a systematic vision of a comprehensive strategy, taking into account the interests of firms. However, microenterprises in the region often find themselves at a disadvantage in the market, as largescale competitors have much stronger capital, an attractive brand and strong leverage. The operators of the regional market have an additional organizational, legal and economic burden. From this point of view, the traditional approach to the use of classical tools to combat competitors is ineffective and requires immediate review, as well as the entire management system of the micro-enterprise on the specifics of the business. Therefore, it is necessary to approach the formation of post-coronavirus business space in the regional sphere of tourism on the basis of economic security.

Significant experience of scientific research on economic security has been accumulated in foreign and domestic science and practice, among which the works of D. Lambert, V. McMack, V. Muntian, G. Pasternak-Taranushchenko, V. Yarochkin should be noted. Among the authors who consider the principles of economic security, the formation of mechanisms for ensuring, assessing the economic security of the enterprise should be distinguished works: M. Bendikova, N. Vashchenko, S. Glushchenko, L. Donets, N. Kapustina, T. Kovaleva, G. Kozachenko, L. Korchevska, M. Kurkina, O. Lyashenko, E. Oleynikov, O. Razdin, V. Tambovtsev, L. Shemayev, V. Shlykov. The achievements of such well-known specialists as V. Gulyaev, I. Zinoviev, I. Zorin, V. Kvartalny, V. Kozyrev, M. Marinin, H. Savina, A. Taksanov, V. Tkach, S. Tsokhly, O. Chudnovsky are devoted to the problems of economic security management in the field of tourism. Some aspects related to the functioning and development of the world tourism industry are covered in the works of such foreign scholars as R. Barton, P. Bernecker, A. Bull, J. Ingram, C. Robinson, G. Harris, J. Holloway [188]. Despite the significant amount of research on this issue, the intensive changes in tourism caused by the factors of COVID-19, lead to the development of a comprehensive vision of post-coronavirus development in this area 
and the need to improve the management of economic security of microenterprises. Researchers from the Department of Tourism, Hotel and Restaurant Business of the National University "Zaporizhzhia Polytechnic" (leading Institute of higher education of the region) in the research work "Tourism industry of Ukraine in the period of European integration: theoretical aspect" explored the concept of "safety in tourism" modern content (Table 5.4.1).

Table 5.4.1.

Definition of "security in tourism"

\begin{tabular}{|l|l|}
\hline \multicolumn{1}{|c|}{ Authors } & \multicolumn{1}{c|}{ Contents of the concept of "safety in tourism" } \\
\hline $\begin{array}{l}\text { Zaitseva } \\
\text { V.M. }\end{array}$ & $\begin{array}{l}\text { A system of comprehensive measures that provide an adequate mechanism to } \\
\text { protect the individual from trouble and conflict during travel. }\end{array}$ \\
\hline $\begin{array}{l}\text { Tsviliy } \\
\text { S.M. }\end{array}$ & $\begin{array}{l}\text { Covers the personal and private safety of tourists, the preservation of their property } \\
\text { and care for the environment when traveling. }\end{array}$ \\
\hline $\begin{array}{l}\text { Gurova } \\
\text { D.D. }\end{array}$ & $\begin{array}{l}\text { A complex and multifaceted concept that cannot be limited to the protection of } \\
\text { tourist facilities and private security of tourists, but should be considered on many } \\
\text { levels: from national security to security of accommodation, transport, hotel, } \\
\text { recreational complexes, tourism centers. }\end{array}$ \\
\hline $\begin{array}{l}\text { Korniienko } \\
\text { O.M. }\end{array}$ & $\begin{array}{l}\text { Emphasis on the negative and dangerous factors faced by the domestic market of } \\
\text { tourist services, namely: pollution of water, air, garbage, noise, damage to wildlife. }\end{array}$ \\
\hline $\begin{array}{l}\text { Mamotenko } \\
\text { D.Yu. }\end{array}$ & $\begin{array}{l}\text { With the development of tourism, the problem of travel safety is exacerbated, and } \\
\text { since the participants of the trips face the corresponding risks, it is necessary to } \\
\text { provide the necessary measures to reduce the level of danger to tourists. }\end{array}$ \\
\hline $\begin{array}{l}\text { Vindyk } \\
\text { A.V. }\end{array}$ & $\begin{array}{l}\text { Physical and social security should be taken into account by the tourism industry, } \\
\text { whose task is to minimize and prevent threats. }\end{array}$ \\
\hline
\end{tabular}

According to table 1 concluded that within the concept of "safety in tourism" should distinguish between the safety of tourists, the safety of tourism entities and the state, the safety of the environment. Each of these concepts is multifaceted and requires specific analysis and understanding. In a general sense, the category of "security" can be interpreted as a state of protection of vital interests of all security objects (state, society, individual) from real or potential, different in origin, external and internal dangers: political, economic, military, information, environmental. According to the authors, the economic security of a tourism enterprise is a state of protection of the company's activities in the field of tourism from the negative effects of external and internal environment, as well as its ability to quickly eliminate various threats [189]. The content of this concept includes a comprehensive system of means of ensuring 
sustainable competitiveness and economic stability of the tourism enterprise, and the main purpose of its economic security system is to ensure sustainable and effective development for the realization of tourism potential in the post-coronavirus business space. It is worth noting that in the post-coronavirus period of tourism there is a need to review approaches to the formation and provision of economic security in order to maintain a stable position of enterprises in domestic and international markets, both in real and digital environment. Based on this, the structure of economic security of the tourism sector of the region will have the following components: environmental, financial, investment, social, innovation, as well as functional components. In turn, the composition of the system of economic security of the tourist micro-enterprise is logically expressed by the components: tourist, technical and economic; financial, personnel, information. The success of the enterprise in the conditions of transformation will depend on the constant monitoring of its positions, research of the strengths and weaknesses of its own business and competitors, the ability to adapt to the changing regional business space. Thus, the concept of "safety in tourism" includes: safety of tourists; safety of tourism entities and the state; safety of the environment.

At the present stage of development of the tourism economy of the regions, a large number of domestic micro-enterprises are in crisis and that is why the management faces the urgent task of forming an effective strategy for economic security of micro-companies in this area to counter external and internal threats, protect economic interests, ensuring the economic security of the micro-company in this area in order to counter external and internal threats, protect the economic interests of the enterprise, ensure stable development, increase efficiency. Depending on the size and production capacity of the enterprise, the availability of resources, scale and specifics of the problems to be solved, different approaches should be used to form a strategy to ensure its economic security [190].

In recent years, domestic tourism companies are creating special units in the structure, the main task of which is to ensure economic security. However, most of these units do not have an effectively functioning system of economic security and this aspect significantly reduces the efficiency of their business and necessitates the 
development of this strategy. At the same time, the creation of such units is a positive vector for the development of modern micro-enterprises in the region and shows the understanding of tourism market participants of the main tasks of economic security of the travel company (Fig. 5.4.2).

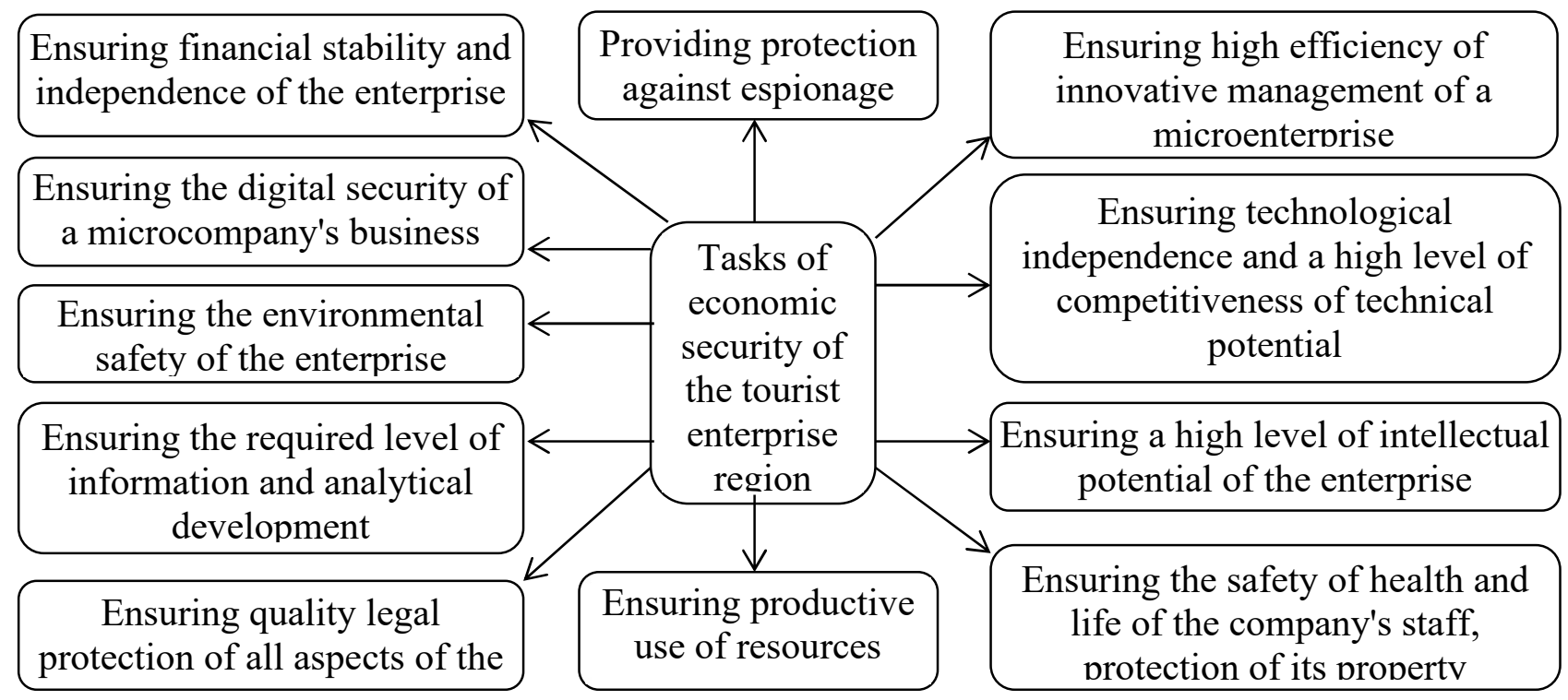

Figure 5.4.2. Problems of economic security of the tourist enterprise of the region

Given the limited budget of domestic micro-companies in the regions and the unpreparedness of a significant number of them to restructure the organizational structure, a slightly different approach to economic security can be used, the essence of which is the maximum delegation of economic security to existing units. In this case, it will not be necessary to radically reform the organizational structure, but will only need to create the position of "director of security" with the authority to lead the process of economic security of the tourist micro-enterprise. This way of solving the problem will ensure an appropriate level of economic security with minimal costs for reforming the organizational structure. However, it should be emphasized that this approach is appropriate only for innovative micro-enterprises, as it has been tested against large and medium-sized tourism companies and requires some adaptation.

It is clear that the most significant influence on the activities of micro-enterprises is exerted by the state. However, a retrospective study of the areas of state regulation of micro-business in the region showed that it aims to pursue certain interests that do 
not always coincide with the interests of enterprises. Due to the discrepancy between state interests and the interests of enterprises in a number of cases, state regulation has a negative impact on the economic security of the enterprise. Under these conditions, tourism micro-enterprises should intensify efforts to develop a post-coronavirus mechanism for economic security, which the authors propose to understand a set of managerial, economic, organizational, legal, motivational ways to harmonize the interests of the firm with the interests of the environment. The specific of the microcompany in the field of tourism business ensures a sufficient level of profit, the amount of which will be justified (at least) for the company to be in economic security [191]. As a result, the concept of creating a mechanism of economic security of a microbusiness in tourism should provide that the basis of the mechanism is the formation of a system of priority interests of the enterprise with their subsequent harmonization with the interests of the environment interacting with the micro-firm. Thus, the precondition for the post-coronavirus transformation of the concept of economic security of a microcompany is the growing negative impact of environmental factors, outdated forms and methods of state regulation of micro-business.

The method of forming the system of economic security of a micro-enterprise in the regional sphere of tourism in the post-coronavirus business space includes the following stages: studying the specifics of the micro-enterprise's business, its market segment, staffing, staff, etc. (1); analysis of external and internal threats to the economic security of the enterprise and the study of information about crisis situations, causes and ways of settlement (2); audit of available security tools, as well as analysis of their compliance with the identified threats (3); modeling of the company's postcoronavirus economic security system (4); development of a plan to eliminate the shortcomings identified during the audit (5); preparation of proposals for improving the economic security system (including the creation of a security service at the enterprise, if such did not exist, or a security system based on it, defining mechanisms for its provision and development of organizational structure of system management) and calculation of all necessary resources (6 ); planning of monthly expenses for ensuring the functioning of the system of economic security of the tourist micro-firm 
(7); approval by the management of the model of the modernized system of economic security and the budget for its maintenance (8); organizational procedures for the formation of a new system of economic security (9); evaluation of the efficiency of the formed system and vectors of its improvement (10).

The given technique of formation of system of economic safety of the tourist micro-enterprise provides realization of constant control (during and after realization of each stage), adjustment and improvement of directions of formation of system of safety for the purpose of optimum adaptation and reaction to changes in external and internal environments, the nature of risks and threats, changes in the legal field, the appearance on the market of unfair competitors, changes in the forms and methods of illegal activities, lists of confidential information and other factors. At the same time, all approaches to the development of technology for assessing the economic security of a micro-enterprise are divided into three groups: a combination of well-known proven techniques (1); independent method of assessing economic security with miscalculations of its functional components (2); comprehensive assessment of the levels of key indicators of business functioning and their ranks (3).

It should be noted that the formation of the system of economic security and the creation of entities depend on the size of the enterprise and capabilities. Practice has shown that micro-business, small firms use the services of external specialized private agencies (consulting, security, detective). Medium-sized businesses can use a combined system of economic security, relying on the capabilities and resources of their own units with partial involvement of the potential of external firms. It makes sense for large companies to create a full-fledged system of economic security with their own powerful service. It should be added that the concept of economic security of a travel micro-company involves the efficient use of resources for stable operation in the post-coronavirus business space at the operational stage and the stage of sustainable strategic development [192]. To ensure the economic security of the microcompany, it is necessary to use a set of business resources (business factors in tourism, which are used by the owners and managers of the firm to achieve goals).

Modern economic literature has a wide arsenal of methods and techniques for 
studying the economic security of micro-entrepreneurship in the region. However, given the complexity of this economic category, its dependence on economic, social, political, historical, religious, technological, psychological and other factors of society, the purpose, objectives, principles and indicators of tourism micro-entrepreneurship in the region depend on the existing system of government and are based on methodological approaches, methods, evaluation methodology that is acceptable for its evaluation. In any case, the micro-company must fully and effectively use theoretical and methodological approaches to ensure economic security in forming its own position in the post-coronavirus business space of the regional tourism sector in order to quickly restore business activity.

\subsubsection{Postcoronavirus recovery of business activity of micro-enterprises in}

\section{the hospitality sector of the region}

Under the conditions of COVID-19 factors, many issues related to the organization of business of micro-enterprises in the field of hospitality, which were previously in the status of promising and perceived by the management of microcompanies of this type quite inert. These issues include: product range and quality, additional services for guests, the company's competitiveness, consumer safety, partnerships, environmental friendliness of business, participation in targeted programs, preferential taxation, etc. It is clear that today the global and domestic tourism sector (including the regional hospitality sector) is suffering as a result of measures to counter the COVID-19 pandemic. At the same time, the current crisis situation should be considered not only as a problem, but also as an opportunity to bring the hospitality sector of Ukraine to a new level of development. The state of the regional hospitality sector and related industries and areas of regional business needs to be reviewed and adapted to the conditions of the circular economy. The basis of the transition to the structure of the regional economy of a new type is the restoration of business activity of micro-enterprises in the industry on such principles as: postcoronavirus increase in the role of micro-enterprises in the development of territories, 
destinations, regions; introduction of contemporary practices and world experience in business management of companies; implementation of public-private partnership tools; intensification of innovation and investment mechanisms at the regional level; digitalization of business processes in business. That is why the chosen direction of research is relevant and timely for companies.

The study of the state and development of the tourism industry was devoted to the works of domestic and foreign scientists, namely: Horban H., Herasimenko V., Vorotina L., Dyachenko L., Kifyak V., Kravchuk I., Lyubitseva O., Teobald U., and others. A significant contribution to the development of the hospitality industry has been made in the research of such scientists as: Azar V., Bowen J., Vindyk A., Durovich A., Karpova H., Mackenz D., Rieger A., Rogov H., Saunders D., others. Specific features of hospitality micro-company management are occasionally covered in the works of researchers, namely: Alekseeva Yu., Zaitseva V., Kuklina T., Pavlyuk K., Sklyar H., Udovychenko V., Harrod R., others. Some practical aspects of business of micro-companies of the region in the conditions of COVID-19 are considered in scientific works of Vasilichev D., Hres S., Gurova D., Zhuravlyova S., Mamotenko D. and other well-known scientists. However, in the presence of a significant number of scientific ideas today there are almost no comprehensive studies on the formation of effective approaches to identify ways to restore business activity of domestic hospitality micro-companies in the post-coronavirus economy of Ukraine [193]. That is, it is important to study the current realities of hospitality in the region and based on the study of the experience of micro-enterprises in the context of the COVID-19 pandemic to develop effective and efficient recommendations for postcoronavirus business recovery of companies of this type.

The generalization of domestic and foreign experience in determining the essential characteristics of the hospitality industry has stated that it covers business forms in the field of services related to customer service, namely: 1) types of service based on hospitality and reproducing generosity and friendliness to customers and consumers; 2) it is a set of micro-business entities (travel agencies, hotels, motels, facilities, etc.), for which the commonality lies in the complexity of physical, social, 
emotional components of the product; 3) companies in the hospitality industry (restaurants, hotels, resorts, etc.) participate in the creation of an invisible product suitable for consumption only at the time of offer to the consumer. Thus, hospitality companies are rightly identified with micro-business. COVID-19 in Ukraine has been significantly affected by micro-business enterprises in the hospitality sector in the regions, as they are the main sellers of a comprehensive product to guests.

Table 5.4.2.

Factors of negative impact on the regional hospitality sphere

\begin{tabular}{|l|l|}
\hline \multicolumn{1}{|c|}{ Factor } & \multicolumn{1}{c|}{ The essence of negative influence } \\
\hline $\begin{array}{l}\text { World economic } \\
\text { crisis }\end{array}$ & $\begin{array}{l}\text { The crisis due to the factors COVID-19 and the global economic recession, } \\
\text { which automatically affected the domestic regional hospitality sector of } \\
\text { Ukraine. }\end{array}$ \\
\hline $\begin{array}{l}\text { Military and } \\
\text { political risk }\end{array}$ & $\begin{array}{l}\text { High degree of uncertainty of future prospects of the temporarily occupied } \\
\text { Autonomous Republic of Crimea and the territory of ORDLO, which has an } \\
\text { impact on the safety of travel. }\end{array}$ \\
\hline $\begin{array}{l}\text { Recovery and } \\
\text { development plan }\end{array}$ & $\begin{array}{l}\text { Lack of a real strategy to restore business activity at the level of the state and } \\
\text { its regions, a clear plan and stages of specific economic support measures. }\end{array}$ \\
\hline $\begin{array}{l}\text { Service quality } \\
\text { standards }\end{array}$ & $\begin{array}{l}\text { Non-compliance of most domestic infrastructure facilities in the regions with } \\
\text { international standards of quality of customer service. }\end{array}$ \\
\hline $\begin{array}{l}\text { Investment } \\
\text { processes }\end{array}$ & $\begin{array}{l}\text { Inertia of the processes of investing in the restoration and development of the } \\
\text { material base of tourist facilities and the development of the transport } \\
\text { network and logistics of the regions. }\end{array}$ \\
\hline $\begin{array}{l}\text { Innovative } \\
\text { activity }\end{array}$ & $\begin{array}{l}\text { Insufficient research, research, scientific support of the industry; low } \\
\text { technical and technological level of service facilities for guest service. }\end{array}$ \\
\hline $\begin{array}{l}\text { The policy of } \\
\text { protectionism }\end{array}$ & $\begin{array}{l}\text { Lack of modern effective mechanisms to ensure business preferences at the } \\
\text { level of micro-enterprises in the region to increase their level of } \\
\text { competitiveness. }\end{array}$ \\
\hline $\begin{array}{l}\text { Business } \\
\text { regionalization }\end{array}$ & $\begin{array}{l}\text { Insufficient development of the structure of business process organization } \\
\text { and partnership in the business environment at the level of locations, } \\
\text { destinations, regions, regions. }\end{array}$ \\
\hline $\begin{array}{l}\text { Product } \\
\text { promotion }\end{array}$ & $\begin{array}{l}\text { Lack of a unified policy to promote a comprehensive product of micro- } \\
\text { enterprises in the hospitality sector of the region in the domestic and } \\
\text { international tourism markets. }\end{array}$ \\
\hline $\begin{array}{l}\text { Digitalization of } \\
\text { business }\end{array}$ & $\begin{array}{l}\text { Low level of use of digital technologies for modernization of the process of } \\
\text { complex product development and service of foreign and domestic tourists. }\end{array}$ \\
\hline
\end{tabular}

Thus, the practice of their operation in 2020-2021 confirms the large number of claims regarding violations of consumer rights and complaints from them about the insignificance of products and cases of abandonment of travel plans due to medical restrictions. Given the loss of customers, coronavirus barriers to business, and the lack 
of real assistance from public authorities, regional micro-companies suffered unjustified losses and were forced to reduce their business activity.

The study of the state of the regional hospitality sector has identified a number of factors that have a negative impact on its micro-business (Table 5.4.2).

According to table 2, seven out of ten factors are external to micro-enterprises; reduction of the negative impact of the factors "business regionalization" and "product promotion" can be achieved through the implementation of the mechanism of publicprivate partnership ; "Digitalization of business" is an internal threat to the company, which must be eliminated immediately.

It is clear that the resumption of business activity of micro-enterprises in the hospitality region in the post-coronavirus perspective should begin with a strategic analysis of their own potential and the development of an appropriate strategy taking into account the updated environmental factors. The table 3 presents the structure of micro-business of Zaporizhzhia region by type of economic activity.

According to table 3, the structure of micro-enterprises for the period 2015-2019 has not undergone significant changes. With such a division (by type of economic activity), it is advisable to group them in terms of integration into the hospitality of the region. Thus, it makes sense to include 1 group (high integration): temporary accommodation and catering; health care and social assistance; arts, sports, entertainment and recreation; (in 2019, their total share is 4.08\%). Group 2 (average integration) should include: wholesale and retail trade; repair of motor vehicles, motorcycles; transport, warehousing, postal and courier activities; information and telecommunications (34.81\%). The 3rd group (low integration) includes: agriculture, forestry and fisheries; financial and insurance activities; real estate transactions $(30.86 \%)$. That is, $69.75 \%$ of micro-enterprises in the region directly or indirectly need to resume business activity. 
Table 5.4.3.

The share of micro-enterprises of Zaporizhzhia region by types of economic activity in $2015-2019 \mathrm{in} \%$ to their total number [194]

\begin{tabular}{|l|r|r|r|r|r|}
\hline Types of activity $\backslash$ years & 2015 & 2016 & \multicolumn{1}{|c|}{2017} & 2018 & \multicolumn{1}{|c|}{2019} \\
\hline Total & 100 & 100 & 100 & 100 & 100 \\
\hline agriculture, forestry and fisheries & 18,71 & 19,97 & 20,18 & 19,39 & 18,43 \\
\hline industry & 10,44 & 10,61 & 10,75 & 11,25 & 11,69 \\
\hline construction & 7,58 & 7,13 & 7,09 & 7,18 & 7,31 \\
\hline $\begin{array}{l}\text { wholesale and retail trade; repair of motor vehicles and } \\
\text { motorcycles }\end{array}$ & 29,43 & 29,03 & 28,44 & 27,99 & 28,04 \\
\hline transport, warehousing, postal and courier activities & 3,35 & 3,15 & 3,20 & 3,32 & 3,48 \\
\hline temporary accommodation and catering & 2,41 & 2,21 & 2,34 & 2,38 & 2,43 \\
\hline information and telecommunications & 2,86 & 2,95 & 2,87 & 3,08 & 3,29 \\
\hline financial and insurance activities & 0,57 & 0,63 & 0,51 & 0,46 & 0,43 \\
\hline real estate transactions & 10,96 & 11,55 & 11,88 & 11,99 & 12,00 \\
\hline professional, scientific and technical activities & 7,20 & 6,60 & 6,34 & 6,31 & 6,11 \\
\hline $\begin{array}{l}\text { activities in the field of administrative and support } \\
\text { services }\end{array}$ & 3,21 & 3,04 & 3,32 & 3,49 & 3,57 \\
\hline education & 0,47 & 0,46 & 0,45 & 0,49 & 0,56 \\
\hline health care and social assistance & 1,22 & 1,16 & 1,14 & 1,28 & 1,18 \\
\hline arts, sports, entertainment and recreation & 0,48 & 0,45 & 0,46 & 0,43 & 0,47 \\
\hline provision of other types of services & 1,10 & 1,06 & 1,03 & 1,03 & 1,00 \\
\hline
\end{tabular}

The opinion of the owners of 50 micro-enterprises with a high degree of integration into the hospitality sector of Zaporizhzhia region regarding the prospects of rapid recovery of business activity (Google-form was filled out) was studied and based on their answers a fragment of SWOT-analysis matrix was compiled (Table 5.5.4).

Also, according to the owners of the specified number of micro-enterprises in the region, the resumption of business activity depends entirely on the realization of the internal potential of companies. From this position, recommendations have been developed for companies to choose a vector of post-coronavirus business recovery, which provides for innovative development based on a customer-oriented approach. Under the innovative development of micro-enterprises in the hospitality industry in the post-coronavirus state of the environment should be considered the trajectory of its movement, which provides external efficiency through the implementation of a system of changes of various forms, due to a combination of factors, namely: 1) new 
technologies; 2) their use in the form of new services, products and processes; 3) new markets or individual segments; 4) new organizational management structures, organizational design; 5) new approaches in management. Changes are implemented in parallel and are a product of the knowledge system [195].

Table 5.4.4.

Fragment of the matrix of SWOT-analysis (study of the prospects of post-coronavirus recovery of business activity of micro-enterprises)

\begin{tabular}{|c|c|}
\hline Strengths (S) & Weaknesses (W) \\
\hline $\begin{array}{l}\text { 1. Readiness of companies to serve guests at a } \\
\text { higher level of quality. } \\
\text { 2. Compliance with the requirements of the } \\
\text { Ministry of Health of Ukraine on health and } \\
\text { safety of institutions. } \\
\text { 3. A large number of operators providing } \\
\text { hospitality services in the region. } \\
\text { 4. Mobility and flexibility in adapting to changing } \\
\text { market and consumer requirements. } \\
\text { 5. Ease of management and control of processes } \\
\text { due to the optimal size of the company. }\end{array}$ & $\begin{array}{l}\text { 1. Low level of digitalization of microbusiness } \\
\text { and lack of a single digital platform. } \\
\text { 2. Rising prices for products, services, services } \\
\text { due to market shrinkage. } \\
\text { 3. Insufficient working capital hinders rapid } \\
\text { recovery and development. } \\
\text { 4. Lack of brand information in comparison } \\
\text { with medium and large enterprises. } \\
\text { 5. Difficulty in processing a significant amount } \\
\text { of operational marketing information. }\end{array}$ \\
\hline \begin{tabular}{|c|} 
Opportunities $(\mathrm{O})$ \\
\end{tabular} & \\
\hline $\begin{array}{l}\text { 1. The transport network of the region is developed } \\
\text { and the structure of city transport is restored. } \\
\text { 2. Growing interest of domestic tourists in the } \\
\text { organization of domestic travel. } \\
\text { 3. Respectful, polite, loyal, friendly attitude to } \\
\text { foreign tourists. } \\
\text { 4. Growth of activity on creation of information- } \\
\text { consulting hubs. } \\
\text { 5. Development guidelines are defined (Tourism } \\
\text { Development Strategy for } 2021-2027 \text { ) }\end{array}$ & $\begin{array}{l}\text { 1. Lack of a unified philosophy in the region } \\
\text { regarding the presentation of cultural heritage. } \\
\text { 2. Seasonality of demand for summer vacation } \\
\text { and weak alternative supply. } \\
\text { 3. High competition from domestic hospitality } \\
\text { spheres of other regions and cities. } \\
\text { 4. Low level of economic, financial and legal } \\
\text { and business security. } \\
\text { 5. A large number of tourist infrastructure } \\
\text { facilities need to be modernized. }\end{array}$ \\
\hline
\end{tabular}

In turn, the customer-oriented approach in the management of innovative development in the process of restoring the business activity of the microfirm involves: providing a unique service: the final product is differentiated, unique in its kind, which brings additional benefits to the consumer (1); providing a global concept of the product: the idea, design and development of goods and services must first focus on world quality standards (2); ensuring the marketing orientation of the studied processes (3); intensive primary analysis: resources should be spent on in-depth substantiation of forecast changes prior to development (3); implementation of a new product strategy: 
action plan for project implementation, list of tasks, market selection, set of properties for its positioning (4); attitude to information as a resource that is not limited by barriers and on the basis of creating a common information platform to ensure the coordination of actions of individuals with the results of micro-enterprises (5); providing crossfunctional synergy within the company's unified philosophy regarding a new product based on the organization of an information network on the vector "research production - marketing - finance - personnel" (6); ensuring the unity of the processes of updating the archive and knowledge models with other functional business processes and administration processes (7); management on the basis of a structured plan for the development of innovations: the transition from the planned positioning of the product in the minds of consumers to the plan of operational marketing in time, prices, sales channels, communications (8); support of ideas and innovations by the management of a micro-enterprise in the field of hospitality (refusal of direct intervention and interested support) (9); ensuring economic, technological, consumer, image impact of innovations (connection of all to obtain a combined effect) (10); development of a mechanism for pre-selection of innovative projects (11); control over the implementation of an innovative project, as well as timely rejection of the project when changing situational factors (12); ensuring access to resources: for success, human and financial resources should be formed for consideration as an investment, not as an expense (13); taking into account the time factor as a priority in the competitiveness of the business: rapid entry into the market with a quality product offer to the customer (14); implementation of a multi-stage procedure for evaluating future innovations (15).

It should be borne in mind that in the process of operational management it is unacceptable to combine the principles of different approaches to managing the company's innovations and focus on long-term planning and strategic management. The philosophy of post-coronavirus business, which aims to ensure the quality of sustainable consumption of services, should focus exclusively on the innovation of the organizational and economic system of the micro-enterprise [196]. Post-coronavirus management principles in a particular company must be clearly defined and 
implemented by management in procedures, regulations, organizational design, corporate culture, information system, consumer code [197].

According to the proposed approach in the post-coronavirus recovery of business activity of micro-enterprises in the hospitality sector, the mobilization of internal potential for certain components is of great importance (Table 5.4.5).

Table 5.4.5.

Mobilization of the potential of a micro-enterprise by components of the profile of its internal environment

\begin{tabular}{|l|l|}
\hline \multicolumn{1}{|c|}{ Component } & \multicolumn{1}{|c|}{ Meaningful readiness for post-coronavirus innovation } \\
\hline Production & $\begin{array}{l}\text { technology, engineering, vertical integration, procurement, quality, stocks, } \\
\text { ideas, innovations, patents, licenses, research, energy, premises, etc. }\end{array}$ \\
\hline Finances & $\begin{array}{l}\text { short- and long-term capital, flexibility of capital structure, accounting, the } \\
\text { possibility of reducing costs, taxation, the level of shadowing, etc. }\end{array}$ \\
\hline Marketing & $\begin{array}{l}\text { products, services, services, market share, promotion, sales channels, sales, } \\
\text { image, reputation, trade, communications, customers, consumers, etc. }\end{array}$ \\
\hline Personnel & $\begin{array}{l}\text { managerial staff, standard of work, morale, fluidity, competencies, } \\
\text { qualifications, motivation, incentives, income, personnel policy, etc. }\end{array}$ \\
\hline Management & $\begin{array}{l}\text { business goal, values, structure, organizational culture, corporate ethics, } \\
\text { strategic planning, synergy, internal communications, etc. }\end{array}$ \\
\hline
\end{tabular}

It is also expedient to mobilize the internal potential of the micro-company to implement a process approach in its management system based on the post-coronavirus need to ensure survival, economic security, a certain level of competitiveness, reduce the time of transformation of ideas to new market requirements, acquisition of modernized competencies by staff, strengthening positions in the field of hospitality of a particular domestic region [198].

Today, domestic micro-companies in the hospitality sector are experiencing a time of enormous financial difficulties. The paradox of the crisis period is that in the conditions of COVID-19 intensive work is carried out at the level of micro-firms and business structures to develop an effective mechanism for post-coronavirus recovery of their business activity. To ensure the competitiveness of the regional hospitality sector in the post-coronavirus space, the authors consider the adoption of emergency measures to preserve the economic potential of micro-enterprises, the development of their intellectual potential, entrepreneurial spirit and culture. Also extremely important 
is the role of informatization of business processes in the effective functioning of the micro-firm. The successful experience of transformation and adaptation to new global conditions of micro-firms from other locations, tourist destinations, regions and countries should be a useful help of micro-business. Also, the efforts of companies should be useful in developing a marketing policy to retain loyal customers of a comprehensive tourism product.

\subsubsection{Post-coronavirus marketing policy of retaining loyal consumers of hotel and restaurant product}

Changes in the political, economic, social spheres of life in Ukraine, the country's integration into the European Community, the introduction of innovative technologies determine the feasibility of improving all areas of management of hotel and restaurant companies. Global factors of the crisis, including the action of factors COVID-19 and the transformation of the tourism economy, influenced the intensification of competition, identified vectors of crisis management, intensified diversification of elements of post-coronavirus strategy, proved the inevitability of qualitatively new approaches to managing marketing activities of hotel and restaurant enterprises. These companies, unfortunately, rarely turn to scientific approaches, methods, marketing tools to reduce the level of crisis risk; practically do not implement important for their own successful development functions, such as digital monitoring of environmental factors, including audit of priority consumer needs, forecasting the post-coronavirus market, strategic trends in individual segments, etc. [199]. However, the growing level of competition and globalization, digitalization of activities have led to the introduction into practice of companies the latest marketing solutions. That is why the chosen direction is also relevant and timely.

Consideration of various scientific opinions has made it possible to understand that analysts consciously identify the reasons for the progressive recovery and further development of the market of hotel and restaurant services: the loss of the vast majority of firms dynamism in the global coronavirus economic crisis; the material component 
in the creation of a complex hotel and restaurant product is becoming less and less effective element of consumer value in the process of satisfying the basic interests of customers; marketing crisis of service production; loss of loyalty from regular customers. In general, the specifics of hotel and restaurant marketing are revealed in the works of scientists such as: Azar V., Durovich A., Karpova H., Kotler F., Mackenz D., Rozanova T., Saunders D., and others. Problems of regulating the development of marketing management systems of hotel and restaurant companies in a crisis are occasionally covered in the scientific works of famous scientists, namely: Zaitseva V., Kifyak V., Pavlyuk K., Porter M., Sklyar H., Harrod R., presentation of opinions which added a significant contribution to the classical knowledge of the issue. Practical aspects of marketing policy implementation in companies in this industry in the conditions of the COVID-19 pandemic are considered in the studies of A. Vindyk, S. Zhuravlyova, T. Kuklina, D. Mamotenko, V. Pruss, others. However, with a significant number of scientific ideas of domestic and foreign scientists today there are almost no comprehensive studies on the formation of approaches, tools, mechanisms for determining the marketing policy of consumers of complex products of hotel and restaurant companies, taking into account the realities of post-coronavirus business space . An important area of research is to study the conditions, specific features and feasibility of maintaining a segment of loyal consumers of hotel and restaurant product in the conditions of COVID-19 factors and based on the interests of the company and the client to develop post-coronavirus marketing policy.

It should be noted that the complex hotel and restaurant product is the end product of the micro-enterprise of the hotel and restaurant industry, which covers the processes of production, sales, organization of consumption in accordance with the theory of marketing services [200]. The concept of modern consumption of hotel and restaurant product is characterized by specific features: 1) complexity (goods, services, services); 2) short process of promotion (integration of production, sales and consumption); 3) continuous improvement of the customer service model; 4) innovative principles of sales; 5) mobile architecture of relations with consumers; 6) flexible dependence on modern development of branch and related technologies; 7) a 
high degree of dependence on the loyalty of a particular segment of customers [201]. The scheme of a complex hotel and restaurant product is presented in Fig. 5.4.3. It is clear that when positioning a hotel and restaurant product in the context of postcoronavirus development of the company's market should be studied in detail the updated needs of the segment of loyal customers, which, in turn, contributes to an effective strategy and marketing policy for their content. That is, the resumption of business activity and economic feasibility of the hotel and restaurant company on the market today directly depends on this segment.

\begin{tabular}{|c|c|c|}
\hline Hotel goods units & Hotel service units & Hotel additional service units \\
\hline$\vee$ & $\downarrow$ & $\vee$ \\
\hline $\begin{array}{l}\text { An integrated range of hotel } \\
\text { products }\end{array}$ & $\begin{array}{c}\text { An integrated range of hotel } \\
\text { services }\end{array}$ & $\begin{array}{l}\text { Integrated range of hotel } \\
\text { additional services }\end{array}$ \\
\hline$\downarrow$ & $\downarrow$ & $\downarrow$ \\
\hline \multicolumn{3}{|c|}{ Complex hotel product (hotel nomenclature) } \\
\hline \multicolumn{3}{|c|}{$\downarrow$} \\
\hline \multicolumn{3}{|c|}{ Complex hotel and restaurant product } \\
\hline \multicolumn{3}{|c|}{$\uparrow$} \\
\hline \multicolumn{3}{|c|}{ Complex restaurant product (restaurant nomenclature) } \\
\hline$\uparrow$ & $\uparrow$ & $\uparrow$ \\
\hline $\begin{array}{l}\text { An integrated range of } \\
\text { restaurant products }\end{array}$ & $\begin{array}{l}\text { An integrated range of } \\
\text { restaurant services }\end{array}$ & $\begin{array}{l}\text { An integrated range of } \\
\text { restaurant additional services }\end{array}$ \\
\hline$\uparrow$ & $\uparrow$ & $\uparrow$ \\
\hline Units of restaurant goods & Restaurant service units & Restaurant additional service \\
\hline
\end{tabular}

Figure 5.4.3. Scheme of a complex hotel and restaurant product

Recently, marketers have often made significant efforts to attract new customers, but this business policy is not always the most profitable [202]. In the context of the COVID-19 pandemic, domestic companies have found that attracting a new customer costs the hotel and restaurant company five to six times more than implementing the existing maintenance policy. Customer retention policy provides a set of marketing activities aimed at establishing a long-term, low-cost relationship between customers and the company for mutual benefit of both parties. Regarding the segment of loyal consumers, it is worth noting that they: 1) much longer prefer a particular institution; 
2) interested in buying a comprehensive hotel and restaurant product; 3) ready for partial self-service; 4) show resistance to small price fluctuations; 5) participate in product evaluation and promote the dissemination of information in the digital space.

In general, the definition of "loyal consumer" should be understood as a certain segment of the market of buyers of complex hotel and restaurant product, which chose the rational range of goods, services of hotel and restaurant company, formed the appropriate and justified by their own decisions and impressions has a stable positive emotional attitude to it, demonstrates the rejection of alternative competitors. From this position, the relevant criteria for the formation of loyalty to the consumer are: 1) giving preference to a particular hotel and restaurant product of a certain institution; 2) feeling of comfort when buying goods, services, service of the companies; 3 ) inclusion for a long time in the diversification of sales records on the treatment of other products and market offers from competitors; 4) the need for long-term use of a complex hotel and restaurant product; 5) acquiring a sense of satisfaction and desire to disseminate this information. Insanely, knowledge of the loyal customer's requests allows the company to influence its real and potential consumers, passing from the category of "dependent" on the market conditions to the category of the hotel and restaurant company, which regulates the product according to the customer's preferences.

It makes sense to distinguish the main benefits of retaining loyal consumers as a target market segment in the post-coronavirus perspective for the hotel and restaurant company: 1) effective marketing communication through the "consumer firm"; 2) the multiplicity of repeated purchases of various goods, services, services of the enterprise by one consumer; 3 ) the cost of creating a network of supporters and loyal customers partially reimburse the cost of developing a set of incentives and promotion systems for new customer groups (savings); 4) formation with their help of organizational culture of harmonious organization; 5) the use of the segment of loyal consumers as a tool to attract additional consumers and buyers of a complex product of the enterprise [203]. In turn, the basic requirements to the enterprise-manufacturer of a complex hotel and restaurant product from loyal consumers are: 1) constant modernization of product components; 2) creation of uniqueness and introduction of value system of 
consumption of hotel and restaurant product (image, quality, prestige, rationality, etc.); 3) providing up-to-date and complete information about new, updated, improved products, services, services of the company; 4) creation of digital space for the purpose of full-fledged communication of consumers of this segment in social networks, product evaluation, announcement of opinions; 5) providing opportunities for selfservice within the digital space of the firm.

The management of the hotel and restaurant company in the formation of postcoronavirus marketing policy to retain consumers should realize the priority of the following vectors: 1) a more favorable market model is monopolistic competition; 2) the consumer value of the product is the basis for maintaining the market segment of loyal customers; 3) consumer loyalty in a COVID-19 pandemic is a rather unstable criterion for assessing marketing policy; 4) the quality of goods, services, services of the firm is an important criterion for retaining the consumer and giving him the status of a supporter; 5) re-sale of the product to the target segment of consumers requires constant updating of the marketing complex.

The process of developing this policy should be preceded by an analysis of: 1) the presence of a sustainable segment of consumers of a complex hotel and restaurant product; 2) competitors with a market offer of an analogue product; 3 ) the volume of sales of a particular type of goods, services, services for a certain period; 4) innovative activity of competitors according to various criteria; 5) key success factors of the complex product (uniqueness, quality, image, price, technological level of customer service, digital service); 6) the stability of post-coronavirus forecast demand for certain units of goods, services, services of the enterprise.

The main purpose of the post-coronavirus policy of retaining loyal consumers of hotel and restaurant product is to establish long-term partnerships between producers and consumers on the basis of mutually beneficial interests of the parties. The basic objectives of this policy should be: 1) to ensure friendly relations between consumers, the company and business partners who supply related products and perform ancillary and service functions; 2) creation and proper support of modern digital space for digitalization of relations with the segment of loyal customers; 3 ) introduction of a 
transparent policy of communications and informing consumers about changes in the activities of the enterprise for the production of a comprehensive hotel and restaurant product; 4) encouraging consumers to take certain actions to realize the interests of the company; 5) involvement of customers in the process of dissemination of positive information about the product and the company; 6) formation of a favorable image and attractiveness of a complex hotel and restaurant product; 7) connecting customers to the "club" sales system.

To overcome obstacles to the implementation of post-coronavirus policy of retaining loyal consumers of hotel and restaurant product, the domestic company should completely reform the organizational structure of marketing and identify units that are functionally responsible for the market segment of loyal consumers [204]. In the post-coronavirus environment, only those hotel and restaurant companies that have gained experience in retaining this segment of customers during the period of COVID19 will be able to secure a stable position in customer relations. The functions of the company's marketing department must also change. Post-coronavirus areas of formation of a set of marketing functions for interaction with the segment of supporters of the company's product are presented in Table 5.4.6.

For effective interaction and management of a certain micro-segment of the loyal consumer market, it is necessary to: 1) know, study, analyze the facts related to a certain segment of consumers of complex hotel and restaurant product (regularly conduct retrospective analysis, establish the logic of events in this segment to establish effective interaction with clients, to introduce a mechanism for diagnosing problems in the process of satisfying their interests); 2) to predict the future goals of postcoronavirus development of the segment, and the goals and objectives should be the objects of constant monitoring and control, develop and update a strategic concept, action strategy aimed at realizing the potential of the innovative product to meet needs; 3) organize, provide, combine resources, sales technologies for their rational use in managing the development of the segment of loyal consumers; 
Table 5.4.6.

The directions for the formation of a set of marketing functions

\begin{tabular}{|c|c|}
\hline & Contents of a set of post-coronavirus marketing functions \\
\hline $\begin{array}{l}\text { Development of } \\
\text { post-coronavirus } \\
\text { marketing } \\
\text { strategies }\end{array}$ & $\begin{array}{l}\text { analysis of the strengths and weaknesses of the hotel and restaurant company; } \\
\text { monitoring the potential of the loyal customers segment; industry audit; } \\
\text { assessment of micro-segment potential; analysis of competitors; study of } \\
\text { relations with clients and partners; environmental impact assessment; } \\
\text { marketing audit; marketing audit of the internal environment; assessment of } \\
\text { ways to modernize the traditional and develop an innovative product; } \\
\text { development of a marketing plan; control of marketing activities }\end{array}$ \\
\hline $\begin{array}{l}\text { n of } \\
\text { aurant }\end{array}$ & $\begin{array}{l}\text { nalysis of trade flows; analysis of the effectiveness of sales channels; } \\
\text { nethods of stimulating demand; development of effective channels of } \\
\text { nteraction; specifics of conducting virtual demonstrations; organization of } \\
\text { ligital presentations; development of advertising policy }\end{array}$ \\
\hline $\begin{array}{l}\text { Post-coronavirus } \\
\text { segmentation of } \\
\text { the market of } \\
\text { loyal consumers }\end{array}$ & $\begin{array}{l}\text { ographical, demographic, psycho } \\
\text { oproaches to the division of market } \\
\text { egments; scientific synthesis of worl }\end{array}$ \\
\hline el & $\begin{array}{l}\text { rtain } \\
\text { arket } \\
\text { hess, } \\
\text { ons }\end{array}$ \\
\hline $\begin{array}{l}\text { Pricing for } \\
\text { and restau } \\
\text { services }\end{array}$ & $\begin{array}{l}\text { oyal } \\
\text { tors' } \\
\text { ount }\end{array}$ \\
\hline $\begin{array}{l}\text { Analysis of the } \\
\text { specifics of the } \\
\text { segment of loyal } \\
\text { consumers }\end{array}$ & $\begin{array}{l}\text { frequency } \\
\text { structure } \\
\text { in groups } \\
\text { cs on the }\end{array}$ \\
\hline & $\begin{array}{l}\text { search of foreign market segments of loyal customers; analysis of the } \\
\text { pediency of post-coronavirus retention of clients from the foreign market; } \\
\text { oviding opportunities for target groups to access digital services of the hotel } \\
\text { id restaurant company; large-scale digitalization of the company's } \\
\text { ternational business }\end{array}$ \\
\hline of & t-coronavirus policy of formatic \\
\hline $\begin{array}{l}\text { Improving the } \\
\text { technique of } \\
\text { marketing staff of } \\
\text { the company }\end{array}$ & $\begin{array}{l}\text { gnostics of the system of technological support of working conditions; } \\
\text { it of staff competencies; assessment of competencies; organization of } \\
\text { nings, seminars, webinars for employees of the marketing department; } \\
\text { entation of staff in the digital space }\end{array}$ \\
\hline $\begin{array}{l}\text { Organization of } \\
\text { effective } \\
\text { communication } \\
\text { policy }\end{array}$ & $\begin{array}{l}\text { ssessment of the level of digitalization of communication channels; } \\
\text { onducting effective marketing research of micro-segments of the market of } \\
\text { oyal consumers; introduction of innovative communication technologies; } \\
\text { xing feedback in digital space }\end{array}$ \\
\hline
\end{tabular}


4) create adequate marketing structures to ensure the implementation of strategic, tactical, operational goals for customer retention of the segment; 5) to provide coordination and integration of actions of divisions and experts who take part in creation of consumer value of a complex product.

Thus, the post-coronavirus policy of retaining loyal consumers of hotel and restaurant product: can be used as an effective tool for determining the economic development and directions of structural adjustment of the hotel and restaurant company with limited resources; help accelerate the transformation of economic and social systems, while helping to control changes in supply and demand; will help promote innovative ideas for the transformation of goods, services, services of the company through their perception by the segment of loyal consumers; should define a digital path for the possibility of adequate presentation of the hotel and restaurant product in the digital space; will create the potential for diversification of goods, services, services of the company, growth of their sales. Further research is promising in the direction of creating a favorable safe regional business space for tourism microenterprises.

\subsubsection{Directions and organizational and economic means of strengthening} the economic security of tourist micro-enterprises in the post-coronavirus period

Now, especially when the micro-business of the regional sphere of tourism operates in the conditions of COVID-19 factors, the idea of obligatory creation of a system of economic security at a certain enterprise is practically unquestionable. Today, both in the literature and in economic practice, there are different understandings of the system of economic security of the enterprise [205].

Tactics to ensure the security of a micro-enterprise involves the application of specific procedures and specific actions to ensure its economic security in the postcoronavirus business space of the region in tourism. Thus, we are talking about such procedures and actions as: expansion of the legal service of the enterprise (1); taking additional measures to preserve trade secrets (2); creation of a computer security unit 
(3); filing claims against the infringing counterparty (4); appeal to the courts (5); appeal to law enforcement agencies (6); digital security control in digital space (7), etc. Thus, a comprehensive system of economic security of the tourist micro-enterprise should include a structured certain amount of interdependent elements that ensure the security of the enterprise in achieving its main business goals. There is also an interdependence between strengthening the economic security of the tourism microenterprise sectors of certain regions of Ukraine and ensuring the national security of the state, including its components such as financial, social, innovation and technological, food, foreign economic, demographic, energy, environmental security, digital. In turn, the development of micro-entrepreneurship is a necessary prerequisite for socio-economic growth, democratization of society, increasing the level of digital transformation, ensuring the European vector of territorial development, modernization of infrastructure of locations, cities, districts, etc.

Priority areas for strengthening the economic security of tourism microentrepreneurship in the region should include: policy tools at the macro-level of the economic management hierarchy (1), and policy tools at the meso-level of the economic management hierarchy (2). In turn, it is expedient to include in the means of policy at the macro-level the hierarchy of economic management: first, strengthening of program-normative regulation of economic security of tourist activity of microenterprises; secondly, promoting the level of motivation of local governments to implement measures to strengthen the economic security of tourism. By means of policy at the meso-level hierarchy of economic management it makes sense to understand the activation of management functions of local authorities in the direction of creating a safe environment for tourism in a particular region. The structure of these management functions is presented in detail in Fig. 5.4.4.

Today, under the influence of COVID-19 factors, mainly the state and small and medium-sized local entrepreneurs contribute to tourism [206]. In addition, the transformational and systemic changes taking place in the economy of Ukraine, institutional transformations of the subject-object structure, as well as the digitalization of business and public authorities define the process of entrepreneurship as a 
phenomenon that becomes the foundation of post-coronavirus economy which under the creation of appropriate favorable conditions will have broad prospects for development (as evidenced by the experience of developed countries, in which indicators of development and the role of the micro-enterprise sector in the economy occupy a stable and important position), will ensure socio-economic growth of regions and countries.

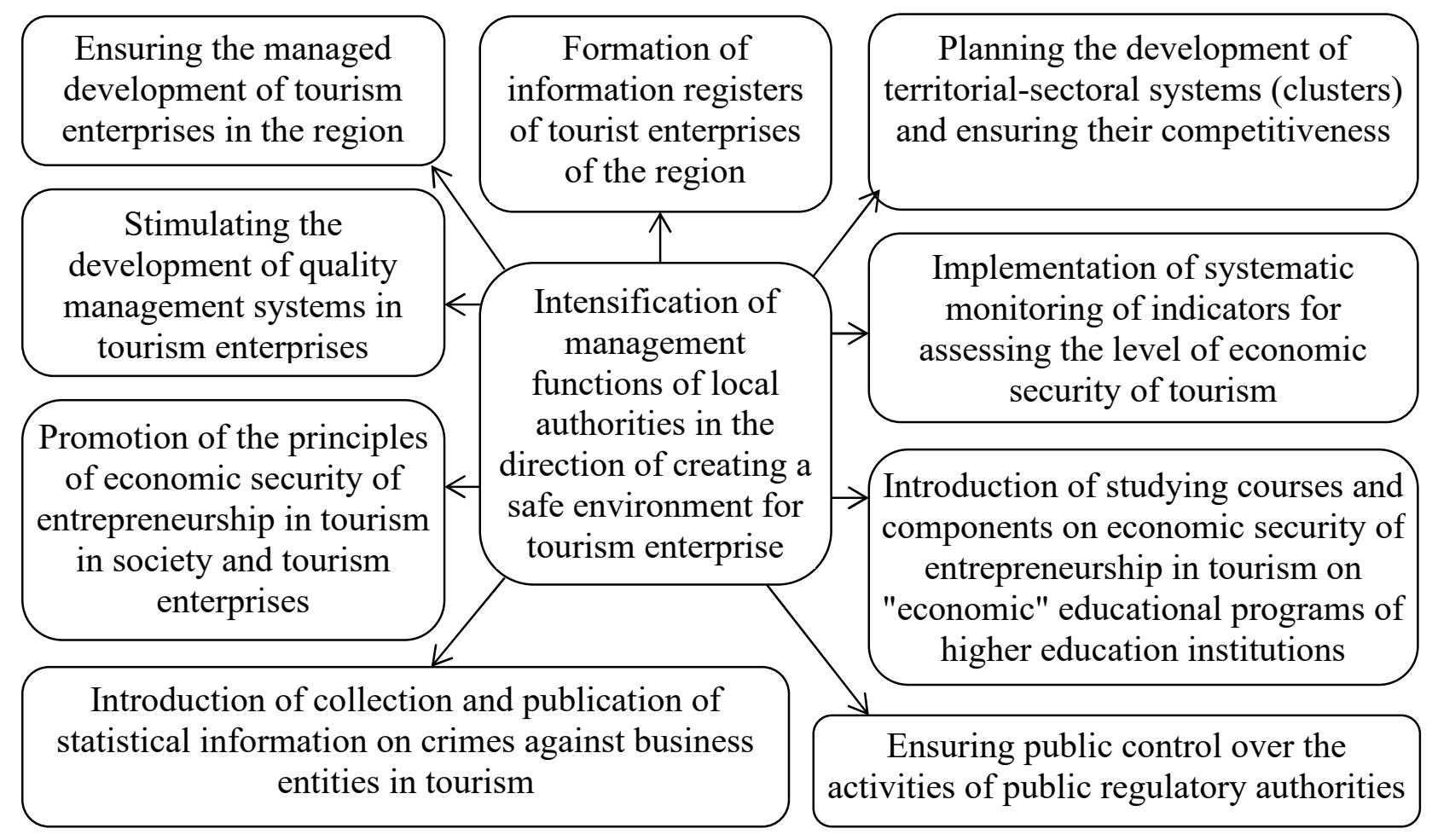

Figure 5.4.4. Activation of management functions of local authorities in the direction of creating a safe environment for tourism (structure)

It is expedient to emphasize that to these prerequisites the authors include: changes directly in the nature of the economic space and business relations, which are implemented within it (1); transformation on the latest post-coronavirus principles of economic principles of the system of social division of labor in the region (2); formation of the social stratum of owners, i.e. subjects of entrepreneurial (production, commercial) activity (3); legal protection of property rights, their inviolability and freedom to choose the sphere of transparent capital investment (4); variety of forms of product production, management structures, property in the multilevel economy of the region of the post-coronavirus period (5); openness of domestic markets and the 
national economy for the establishment of world economic relations (6); liberalization of economic processes (7). Thus, the strategic interests of public authorities in ensuring the economic security of micro-enterprises in tourism are directly determined by the desire to achieve social and economic development of the system, to form a democratic sphere of hospitality and ensure its development on European tourism principles. In this context, it is more important to outline the directions, goals, objectives and measures of public policy to ensure the strengthening of economic security of this sector of the regional economy [207].

When developing a strategy and a specific policy, according to the authors, it is necessary to identify a range of problems or factors of negative impact, which will be addressed by the developed measures. In addition to the negative impact of COVID19 factors, as well as existing preconditions and factors in the regions of Ukraine that hinder the development of micro-entrepreneurship and hinder market-reform transformations and post-coronavirus transformations, significant deterrents are also: credit system, tax policy, lack of favorable investment and investment climate. At the same time, the subjects of the tourism sector of micro-entrepreneurship do not have the opportunity in the regions to attract available financial and credit resources for entrepreneurial business for investment, innovation, modernization of production facilities. It remains a problem for the micro-enterprises of the region the home system of taxation that reduces business activity of population substantially, stipulates negative attitude of business-environment toward public government bodies. That is, the complex nature of these influences leads to the fact that the financial system of the country, which is a significant investment resource, prefers the speculative nature of circulation in the financial sector (capital accumulation), which almost does not pass into the real (production) sphere of the because the "last" level of profitability is much lower, and the payback period is longer.

According to this situation, it should be added that these conditions do not correspond to the nature of a favorable environment for doing business and until they are changed, the prospect of creating appropriate conditions for business development in the micro-enterprise sector in most regions of Ukraine is rather limited [208]. Also 
a problem for domestic tourism micro-enterprises and a characteristic feature of the modern business environment is the lack of an adequate civilized market for buying and selling businesses, which: significantly constrains investment activity (1); contributes to the illegal actions of certain "shadow" structures (2); leads to a decrease in the level of liquidity of domestic micro-enterprises (3); "freezing" of the funds invested in them (4); lack of incentives for owners to capitalize their own microenterprise and often to economically and organizationally unjustified creation (registration) of new legal entities, which, in turn, complicates the activities of registration, tax, law enforcement and other public bodies, creates a fictitious ballast of legal entities and eliminates reliability statistics on the increase in the number of microenterprises and their share in the tourism economy of the regions.

Given the systemic nature of these reasons, the solution of these problems is impossible due to the implementation of individual or a whole set of measures. Today it is necessary to develop and implement a strategy to change the relationship "government - tourism micro-business - society" on the basis of post-coronavirus phased implementation of a set of measures of regulatory, organizational, administrative, economic and law enforcement nature. The strategic goal of this set of measures, relevant decisions should be the need to form a viable competitive environment and favorable conditions for the development of legitimate business activities. It should be recognized that the public policy in the field of support for tourism micro-companies in the region is not systematic and coordinated and is not fully implemented to achieve its goals, which are set by public authorities. Therefore, the policy of supporting micro-entrepreneurship in Ukraine needs to be adjusted.

Based on the outlined trends, first of all it is necessary to ensure the recognition by regional socio-political groups of the ideology of obtaining less intensive, but longterm economic return from the limited resources invested. To do this, all socio-political groups should be aware of the connection between investing in less profitable areas of tourism (innovation, scientific and technological development, education, social sphere, etc.) and providing a qualitatively new and more efficient business space of the country and individual regions. It is expedient to develop and ensure public recognition 
of the fundamental priorities of post-coronavirus economic and tourist development of the region. First of all, it concerns the need to outline the basic principles of economic policy, which should be linked to the relevant system of moral values, form the basis for an effective model of tourism development in the region and micro-entrepreneurial environment and to ensure the elimination of existing contradictions, especially those that have a negative impact on the deepening of disintegration trends in the tourism environment. Among the priority principles it is expedient to fix: reduction of the distributive function of public administration bodies; ensuring the proportionality of economic and social growth; reducing the level of monopolization of the economy and its industries.

The main principles for ensuring the development of micro-entrepreneurship in the post-coronavirus economy of tourism in the region should be: emphasis on the development of tourism subsectors that have comparative and competitive advantages in the global economy of regional and global scale (1); high level of internal integration of the domestic tourism economy of the region, creation of a strong national tourism market as a fundamental basis for conquering and securing relevant niches in highly competitive and efficient global markets for integrated tourism goods and services (2); taking into account the different factor intensity of national tourism subsectors and industries, their capital and employment compared to other countries, taking into account the relevant domestic prices and their world counterparts (3); creation of a post-coronavirus system of incentives for public legitimization of shadow income from tourism activities and ownership of tourism infrastructure (4); ensuring investment in innovation, scientific and technological development, education and social sphere of regional tourism, which will ensure the development of these less profitable areas of tourism, including by amnesty "shadow" income from business activities invested in these areas (5).

In the post-coronavirus perspective, ensuring the liberalization of state economic policy by limiting the institution of public power, hypertrophied functions and financial levers of influence that allow easy manipulation of economic processes in tourism and make political activity an extremely attractive "business area" for various monopolistic 
associations and political and financial groups can be achieved through the following measures: a significant reduction in taxes while limiting the amount of other financial resources accumulated in the budget, the harmonization of customs tariffs and fees to the level required by the requirements of global business (1); elimination of "informal" benefits, preferences, subsidies paid from state and local budgets to large enterprises (2); significant simplification of the procedure for creating new micro-enterprises and liquidation of existing ones, passing of permitting and approval procedures (3); strengthening the antimonopoly legislation of Ukraine while increasing the role and increasing the weight and functions of the Antimonopoly Committee (4); judicial reform (strengthening the institutional support of the judicial system, increasing the openness and transparency of the judiciary, the introduction of the institute of case law in judicial practice) (5); separating power from micro-business by banning entrepreneurs from running for representative, executive or judicial positions until their business at the regional level is sold at an open auction with appropriate media coverage (6).

Based on the results of studying scientific works and research materials, which substantiate the strategic interests of public administration bodies in the field of national and regional economic security in tourism, the following approaches are considered: approaches to establishing a permanent system of economic security monitoring of microenterprise sector at different levels of public administration (1); measures aimed at strengthening the competitive position of the subjects of this sector of the economy, as well as the search for organizational and economic mechanisms to strengthen the economic security of microenterprises and individual micro-businesses in the region (2): functions to ensure economic and social security growth and competitiveness and a number of requirements for the system of public management of micro-entrepreneurship in the region. Based on the study of scientific opinions and experience of public authority in tourist regions and the function of regulating the development of micro-entrepreneurship, the main requirements are presented, which, according to the authors, are determined by the concept of economic security of microentrepreneurship in tourism (Fig. 5.4.5). 


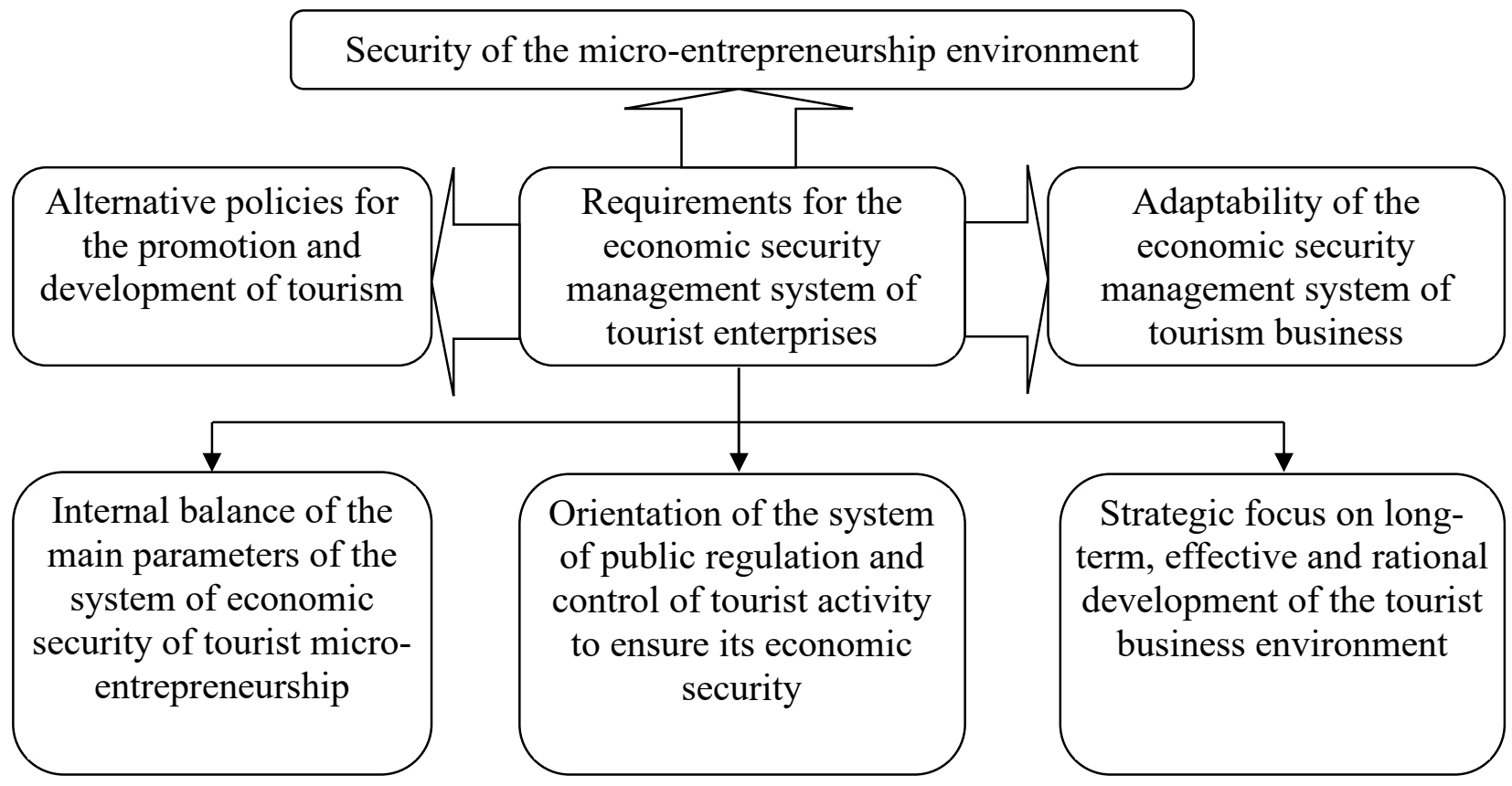

Figure 5.4.5. Requirements for effective public policy in ensuring the economic security of tourism micro-enterprises

From this point of view, the orientation of the system of public regulation of tourism in the regional sector of micro-entrepreneurship to ensure its economic security implies that management decisions made in any area of public regulation of the economy and have an impact on micro-entrepreneurship must be considered and evaluated in terms of their impact on the economic security of the micro-enterprise sector, both during the effects of the COVID-19 pandemic and in the post-coronavirus perspective. Implementation of the requirement of alternative management decisions implies that the preparation of a specific regulatory act or decision within the system of public regulation of micro-entrepreneurship should take into account options for influencing the possible development of tourism enterprises in the region, structure and key indicators of economic security [209]. The requirement of adaptability of the economic security management system of tourist micro-enterprises means that this system must take into account the current state and future post-coronavirus changes in the resource provision of the micro-entrepreneurial environment, environmental factors, regional economic structure, competitiveness and financial stability of microenterprises and other parameters of transformation.

The strategic orientation in the management of economic security of the tourist 
micro-enterprise of the region on long-term and rational sustainable development obliges public administration to make management decisions taking into account not only the set of external and internal business environment, but also measures to protect the interests of tourism. Under the conditions of realization of target complex programs of economic safety of tourist microenterprises of the region it is possible to reduce risks and a threshold of their economic safety by means of external factors: target projects. When drafting the target program for the development of the domestic tourist region for the post-coronavirus perspective, the following areas should be covered: recreational and tourist nature management of the region, protection and restoration of recreational and tourist resources (1); economic development of territories, change of proportions in placement of productive forces, clustering of non-mass forms of tourism, formation of recreational and tourist system on the basis of modern infrastructure (2); financing of projected activities (3); improving the system of legal support for the management of micro-entrepreneurship (4).

At the same time, as directions and tasks of formation of a competitive regional tourist product within the framework of the target program of development of recreational and tourist region, it is expedient to allocate the following: in the direction of "providing conditions for the development of recreation and tourism by local governments": the creation of a coordination council at the local administration to perform coordination functions and conduct business operations, implementation of decision-making procedures in recreational and tourist activities in a municipality (1); within the direction of "regional management of recreational and tourist sphere": creation of new institutes of tourism management and restructuring of existing in accordance with the goals and objectives of recreation and tourism in the region (2); within the direction of "modern marketing strategy for the promotion of recreational and tourist product in the domestic and international markets": development of a calendar of events taking place in the region; expansion of the sales network; joint promotion of a regional recreational and tourist product, development of international cooperation; formation of the image of the region (3); within the direction of "formation of the legal framework for the development of recreation and tourism": 
definition of legal documents to be adopted at the regional level and development of recommendations for the adoption of national documents or change their provisions to improve the efficiency of recreational tourism (4); within the direction of "financial support for the development of recreation and tourism": search for sources of funding for the development of recreational and tourist sphere and compiling a list of possible recipients of resources and structures to decide on the provision of funds to microenterprises (5); within the direction of "staffing the development of recreation and tourism": ensuring cooperation between micro-enterprises and educational institutions to improve the quality of education and better consideration of market requirements in training professionals and entrepreneurs, organization of branches of educational institutions, courses for residents of recreational and tourist areas local employment; development of a system of interaction with employment services of different levels (6); within the direction of "accounting for environmental, political and other risks": development of measures to reduce natural risks in recreational and tourist activities, their compensation; formation of a special program of natural risk management in recreational and tourist regions; development of measures for operational crisis management (7); within the direction of "formation of conditions for the development of recreation and tourism within specially protected natural areas": initiation of projects to create specially protected natural areas of regional and local importance; promoting the investment attractiveness of infrastructure in specially protected natural areas; development of norms of recreational and tourist loads for different types of specially protected natural territories, destinations and locations of the region; formation of bases of the organization of natural parks in a zone of establishments of a resort and sanatorium profile for the purpose of preservation of a recreational and tourist resource (8).

In general, strategic preparation for post-coronavirus economic conditions at the level of a separate domestic tourist region, destination, location requires not only the definition of directions and organizational and economic means of strengthening economic security of tourist microenterprises, but also procedures for developing and implementing a comprehensive balanced system of socio-economic, legal and 
administrative and managerial nature, which aims to create conditions for the development of a qualitatively new level of tourism potential and ensure the formation of sustainable competitive advantages of tourism micro-entrepreneurship in a particular area while ensuring stable diversified employment and opportunities to participate in projects by business structures. Thus, the post-coronavirus formation of the tourist micro-business of the region on the basis of economic security in Ukraine, as a condition of guaranteeing the sustainable development of the tourist destination, region, location in the global post-coronavirus world is only possible due to the synergy of interests and needs of all participants. In particular, investors must be confident in return on investment, as tourism innovation ideas have a significant degree of risk, which is caused by the high capital intensity of infrastructure projects for the tourism business and too long payback periods with an unknown end result. Therefore, along with the development of infrastructure, public authorities must share the risks of private investors and provide long-term post-coronary guarantees of fulfillment of obligations: favorable lease of land, tax benefits, long-term loans at low interest rates, opportunities to attract foreign personnel. Further scientific interest is required to investigate the activation of tourism micro-business forces in the region in the direction of full-cycle digitalization of processes through the use of the leading experience of professionals and companies. 
DOI 10.46299/ISG.2021.MONO.ECON.II-203-209

\subsection{Method of assesing the financial stability of the enterprise}

Stability in modern scientific and reference sources is mostly interpreted as the ability of a system to keep certain properties and characteristics unchanged or almost unchanged, or as the ability of the system to restore the previous (or close to) state after some disturbance, which is manifested in deviation of system parameters from nominal value. In a broader sense, this term means the ability of a system to perform its functions despite the influence of endogenous and exogenous factors [267]. If we apply this term to financial activities, then in the most generalized form, financial stability can be interpreted as the ability to maintain/restore the desired (target) parameters of the financial condition. However, in modern research there is no single interpretation of this concept, which sometimes leads to misunderstandings, variability in the identification of its parameters, and, accordingly, the ambiguity of approaches. O. Pavlovskaya, N. Prytulyak and N. Nevmerzhytska consider financial stability from the standpoint of the company's ability to provide inventories and expenses at its own expense, to prevent unjustified receivables and payables and to settle liabilities on time [268, p.189]. In our opinion, the presented approach is somewhat narrow and considers only the so-called current financial stability. However, this is not enough to ensure the sustainable development of the enterprise, which is achieved by long-term capital investment and compliance with certain proportions between the types of long-term capital. G. Kramarenko understands financial stability as a financial and economic condition of the enterprise, in which solvency maintains a tendency to stability, i.e., it is constant over time, and the ratio of equity and debt capital is within the limits that ensure this solvency [269]. In fact, the author identifies the concepts of solvency and financial stability. M. Bilyk believes that financial stability is a state of financial resources of the enterprise, in which the rational disposal of them is a guarantee of own funds availability, stable profitability, and ensuring the process of expanded reproduction [270, p.302].

Based on the etymology of the concept of "sustainability" and the generalization and development of existing scientific approaches, the financial stability of the 
enterprise can be considered as the ability to restore and maintain target volumes and proportions of financial resources, which allows the company to maintain a stable financial position over time: to avoid excessive financial risks, to maintain a sufficient level of self-financing, to avoid bankruptcy, to form financial support for the development of operating activities, to compensate for the negative environmental factors impact. Thus, we can identify the main parameters of financial stability (figure 5.5.1).

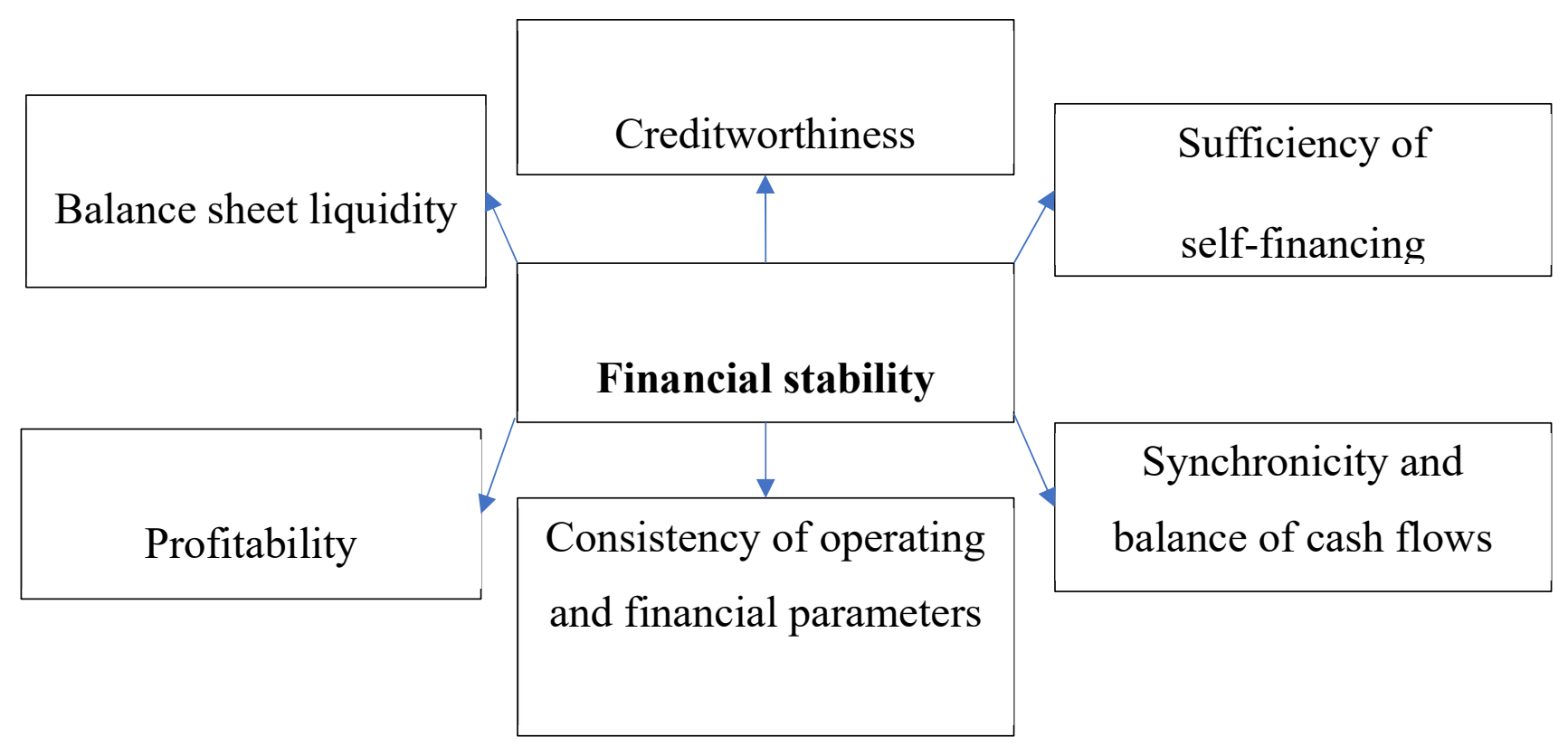

Figure 5.5.1. Parameters of financial stability of the enterprise Source: compiled by the authors for [267-272]

Based on the parameters of financial stability, it can be understood that the assessment and management should be carried out on all control circuits in accordance with the defined tasks with the choice of special diagnostic methods (Table 5.5.1). 
Table 5.5.1

Management system of financial stability of the enterprise

\begin{tabular}{|c|c|c|c|}
\hline \multirow{2}{*}{ Subsystems } & \multicolumn{3}{|c|}{ Management contour } \\
\hline & Operational & Current & Strategic \\
\hline 1 & 2 & 3 & 4 \\
\hline Task & $\begin{array}{l}\text { Ensure } \\
\text { synchronicity of } \\
\text { cash flows, } \\
\text { sufficient } \\
\text { liquidity and net } \\
\text { working capital }\end{array}$ & $\begin{array}{l}\text { Ensure balanced cash } \\
\text { flows, sufficient self- } \\
\text { financing } \\
\text { creditworthiness }\end{array}$ & $\begin{array}{l}\text { Ensure a sufficient } \\
\text { level of self- } \\
\text { financing } \\
\text { investment } \\
\text { activities and } \\
\text { compliance with a } \\
\text { sustainable growth } \\
\text { rate }\end{array}$ \\
\hline $\begin{array}{l}\text { Methods } \\
\text { analysis }\end{array}$ & $\begin{array}{l}\text { - coefficient; } \\
\text { - balance; } \\
\text { - statistical. }\end{array}$ & $\begin{array}{l}\text { - coefficient; } \\
\text { - discriminant analysis. }\end{array}$ & $\begin{array}{l}\text { - methods of } \\
\text { integrated analysis. }\end{array}$ \\
\hline $\begin{array}{l}\text { Principles of } \\
\text { management }\end{array}$ & \multicolumn{3}{|c|}{$\begin{array}{l}\text { Target orientation; integration into the financial decision-making } \\
\text { system; dynamism; responsibility; scientific validity }\end{array}$} \\
\hline $\begin{array}{l}\text { Information } \\
\text { support }\end{array}$ & \multicolumn{3}{|c|}{$\begin{array}{l}\text { External: information on the state of the financial market, } \\
\text { macroeconomic parameters, information on the state and working } \\
\text { conditions of the main counterparties in financial activities; } \\
\text { Internal: financial report; management reporting; analytical } \\
\text { accounting data; forecast of financial activity of the enterprise. }\end{array}$} \\
\hline
\end{tabular}

Source: developed by the authors

In the available research, the vast majority of proposals for assessing financial stability are reduced to recommendations for the application of the coefficient method and balance sheet models. Among the main ratios, it is proposed to use liquidity ratios, capital structure ratios and the current asset provision with net working capital. Among the balance sheet methods, it is proposed to apply the identification model of financial 
stability type by sources of financing stocks; various analytical balances, etc. Namely, we can say that the vast majority of methods for assessing financial stability: 1) is limited to the analysis of the balance sheet, i.e., it is static. Balance sheet data are instantaneous and therefore do not always objectively reflect the level of financial stability, especially characteristics such as absolute liquidity. Of course, the study of balance ratios in the dynamics partially solve this problem. However, often such an analysis is purely retrospective in nature, allows you to identify trends and their causes, taking this into account when planning financial, investment and operating activities. However, such an analysis has questionable analytical value for making operational financial decisions; 2) mainly focused on the current management contour and do not take into account the needs of operational and strategic levels of government.

Based on this, it becomes clear the need to improve existing approaches to assessing financial stability, expanding the use of analytical tools and structuring the evaluation process in accordance with the management contours with the choice of appropriate analytical methods and tools (Figure 5.5.2).

Operational management contour

Stage 1. Assessing the level of synchronicity of the enterprise cash flows

Stage 2. Assessing the adequacy of the average cash reserve

Stage 3. Estimation of the level of the enterprise net working capital

\section{Current management contour}

Stage 4. Estimation of current liquidity ratios dynamics and level of working capital

Stage 5. Estimation of the current financial stability type by sources of stock financing

Stage 6. Assessing the level of the enterprise cash flow balance

Stage 7. Estimation of the enterprise capital structure

Stage 8 . Assessing the enterprise debt capacity 
Strategic management contour

Stage 9. Estimation of growth stability

Stage 10. Assessing the adequacy of reinvestment of net cash flow from operating activities

Stage 11. Forecast assessment of prospects for the development of the proportions of financial resources of the enterprise

Figure 5.5.2. Structural and logical sequence of assessing the enterprise financial stability

Source: developed by the authors

Thus, within the operational management contour, the emphasis is on assessing the enterprise operational solvency on static and dynamic indicators. Thus, at the first stage, the level of uniformity and synchronicity of cash flows according to analytical accounting data, or operational management reports on cash flows is investigated.

In the process of such analysis, standard statistical tools are used: standard deviations, coefficients of incoming and outgoing cash flows variation, the correlation coefficient between incoming and outgoing cash flow are calculated. Also, the facts of deferred spending (deferred payments) are investigated and recorded, which presence is an indicator of payments inconsistency over time. The reasons for payments transfers are determined in order to identify technical cash gaps, or deeper causes of cash shortages.

The second stage estimates the share of monetary assets in the structure of current assets, their ratio to the volume of current liabilities. In combination with dynamic indicators, this enables to assess the level of funds adequacy in the accounts better, change the policy of their planning, identify opportunities for coordination of payments. 
In the third stage, the amount of net working capital is identified. Its absence imposes stricter requirements for cash flow planning and payment discipline control. Its presence indicates a certain "airbag" in ensuring financial stability.

The results of operational analysis are significantly deepened within the current assessment. Thus, at the fourth stage, the dynamics of the total, intermediate coverage coefficients the level of net working capital is studied.

The fifth step identifies the type of current financial stability depending on the sources of stock funding. Since inventories are the least liquid part of current assets, they must be covered by so-called normal sources of financing, which include net working capital, current accounts payable for goods, works and services and bank loans used to finance inventories. An unstable or critical financial situation indicates problems in ensuring current financial stability, which require finding reserves for net working capital growth.

At the sixth stage, the level of cash flow balance is studied, that is, dynamic indicators are evaluated. Within the framework of such analysis, the cash flow coefficients from operating activities, the level of cash flow efficiency, the quality level of net cash flow from operating activities, the cash flows liquidity ratio are assessed. The insufficient level of these indicators indicates disparities in operating activities, in the formation of credit policy and the policy of attracting commodity credit. First of all, it requires finding ways to optimize operating costs, increase revenue.

At the seventh stage, the main indicators of capital structure are evaluated: the financial stability coefficient, financial leverage, debt, equity maneuverability. Based on the results of such an analysis, decisions can be made to change the target capital structure and ways to ensure it.

At the eighth stage, the debt capacity of the enterprise is assessed. To assess it, the ratio of interest on the loan due to EBIT, the ratio of interest on the loan and shortterm loans due to net cash flow from operating activities are calculated. These indicators are important markers of the enterprise creditworthiness. 
Within the strategic management contour, the parameters of sustainable growth, the ability to finance investment programs and prospects for improving or maintaining the proportions of financial resources are studied.

Thus, the ninth stage evaluates the company's compliance with sustainable growth, that is, the actual growth rate of activity is compared with a stable one, which is determined by multiplying the return level on equity by the capitalization ratio of net profit. Exceeding the actual growth rate of net revenue over stable indicates the inconsistency of the financial parameters of the enterprise tasks and operating activities rates. Such a disparity often leads to the bankruptcy of profitable growing enterprises. Its identification requires a review of functional financial policies in order to avoid a shortage of financial resources.

Therefore, at the tenth stage, such important indicators as the net profit capitalization ratio and the net cash flow reinvestment ratio are analyzed. The low capitalization ratio of net income indicates large volumes of net profit consumption, which in combination with the active growth of operating activities and investment often causes a shortage of resources. A similar analytical function is performed by the reinvestment ratio of net cash flow from operating activities, which is estimated for a period of 3-5 years.

At the eleventh stage, the prospects for improving or maintaining the proportions of financial resources in the future are assessed. This analysis is based on the enterprise forecasts and the macro environment development, financial market and legislation using SWOT-analysis and involves assessing the threats and opportunities generated by environmental factors and identifying strengths and weaknesses of the enterprise (its internal environment). The result of such an analysis is a revision of existing financial policies and their adjustment in the process of developing a financial strategy. 
DOI 10.46299/ISG.2021.MONO.ECON.II-210-222

\section{6 Підходи до оцінки ефективності стратегії розвитку організації}

Постановка проблеми. У сучасних умовах формування ринкових економічних відносин бізнес відіграє важливу роль як у зарубіжних країнах, так i в Україні. Саме підприємництво надає можливості здійснити структурну перебудову економіки і наситити всі види ринків товарами чи послугами в короткі терміни. Тенденція зростання складності та невизначеності зовнішнього та внутрішнього середовища функціонування суб'єктів господарювання стає однією з ключових проблем ритмічного та стійкого розвитку бізнесу. Рішення проблеми розробки інструментів стратегічного планування $\epsilon$ особливо важливим. Рішення, яке приймається менеджерами частіше в такій ситуації, обмежується підвищенням ефективності фінансової діяльності, і воно має ефект, але на короткий термін. Довгострокове планування змушує менеджерів розробляти більш гнучкі цілі та формулювати проблему під впливом змін внутрішніх та зовнішніх умов функціонування. У той же час, стикаючись із жорсткою ринковою конкуренцією, підприємства повинні оптимізувати стратегічну роботу, посилюючи синергію всіх сфер своєї діяльності. За таких обставин керівництво підприємств має сформувати набір цілей розвитку для кожної діяльності, яка буде спрямована на досягнення спільної стратегічної ефективності, а також виявити синергічні зв'язки між підрозділами та розвивати ïx. Рішення проблеми вимагає створення незалежної системи підтримки прийняття рішень для координації та контролю діяльності всіх структурних підрозділів. Створення та підтримка такої координації між стратегічними ресурсами організації та постійно мінливим зовнішнім середовищем вимагає розуміння та врахування ключових факторів, що визначають успіх організації. Після того, як визначено найважливіші компетенції, вам потрібно зосередитись на них для постійного вдосконалення роботи організації в цій галузі. Для цього потрібні системи аналізу та обліку показників ефективності, які повинні бути найбільш точними та об'єктивними. 
Мета статті - дослідити підходи до діагностики ефективності стратегії, беручи до уваги взаємозв'язок параметрів, що характеризують різні сфери діяльності підприємства.

Результати дослідження: Провідним підходом до вивчення цієї проблеми був системний підхід, що застосовується при розробці методів оцінки ефективності стратегічного розвитку, що дозволяє визначити пріоритетні фактори стратегічного розвитку компанії. У статті обгрунтовано використання ціннісного підходу в управлінні як методичної основ діагностики ефективності стратегічного розвитку підприємства.

Практична значущість. Результати дослідницької роботи можуть бути корисними для оцінки ефективності стратегічного розвитку підприємства та для визначення пріоритетних факторів стратегічного розвитку та вироблення рекомендацій щодо підвищення вартості бізнесу.

Ключові слова: ефективність, продуктивність, value-based management, підприємництво, стратегії розвитку; ринковий підхід, фінансовий підхід, бізнес.

У сучасних умовах формування ринкових економічних відносин бізнес відіграє важливу роль як у зарубіжних країнах, так і в Україні. Саме підприємництво надає можливості здійснити структурну перебудову економіки і наситити всі види ринків товарами чи послугами в короткі терміни.

Підприємництво - це особливий вид діяльності, і особливість полягає самостійній діяльності за власний рахунок, творчій, систематичній діяльності на власний ризик з метою одержання прибутку або власного доходу.

Згідно чинного законодавства України, підприємництво - це безпосередня самостійна, систематична, здійснювана на власний ризик діяльність 3 виробництва продукції, виконання робіт, надання послуг для отримання прибутку, що здійснюється фізичними та юридичними особами, зареєстрованими як суб'єкти підприємництва у порядку, встановленому законодавством [210]. 
Варто зазначити, що у господарській діяльності підприємництво і бізнес зазвичай використовують як тотожні поняття, але, насправді, «бізнес» - поняття ширше за «підприємництво», адже:

- по-перше: бізнесом вважається здійснення як одноразових бізнесоперацій, так і регулярних комерційних угод в будь-якій сфері діяльності, що націлені на отримання прибутку;

- по-друге: кількість учасників у комерційних операціях перевищує кількість учасників в підприємницькій діяльності, адже остання обмежена кількістю зареєстрованих суб'єктів;

- по-третє: на відміну від підприємництва у бізнесі пряме керівництво не обов'язкове, можлива тільки форма участі, наприклад, через засоби виробництва або гроші.

Отже, можна дійти висновку, що підприємництво та бізнес мають деякі відмінності, але загалом це синонімічні поняття.

Доброва Н.В. зазначає, що “На практиці підприємництво виступає як підприємницький бізнес і залучає тільки свого суб'єкта, а не усіх учасників ринку. Бізнес без підприємництва не існує. Підприємництво - не тільки елемент систему бізнесу, але і фактор його розвитку.” [212, с. 13].

Визначивши деякі відмінності бізнесу від підприємництва, слід навести визначення терміну «бізнес».

Бізнес - це економічна діяльність приватних осіб чи підприємств щодо користування природними ресурсами, виготовлення, купівлі і продажу товарів чи надання послуг в обмін на інші послуги чи гроші для взаємної вигоди декількох сторін.

У науковій літературі виділяють підприємницький, державний та споживчий бізнес. Система бізнесу зображена на мал. 5.6.1. 


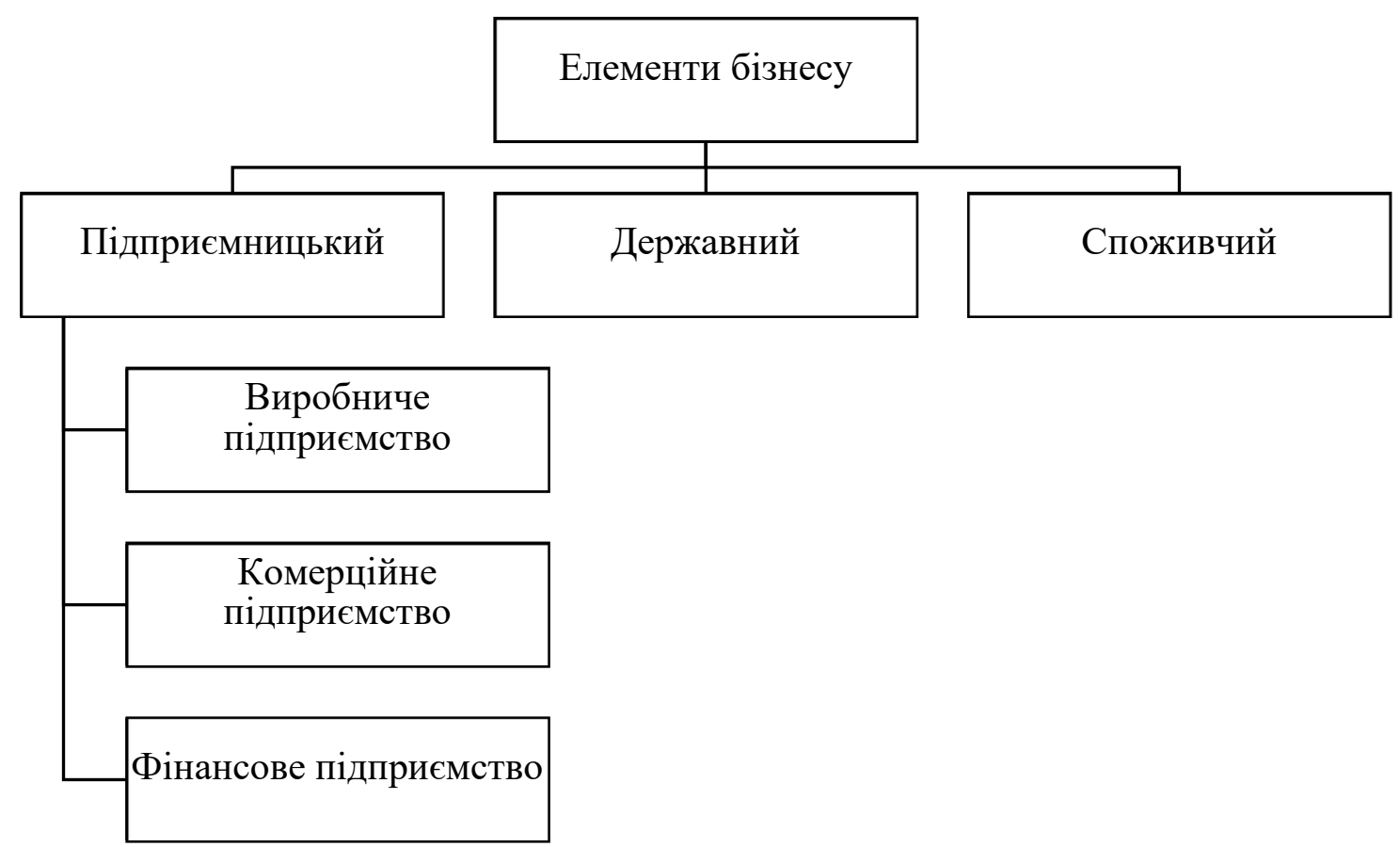

Малюнок 5.6.1. Системи бізнесу як система господарювання Джерело: розроблено автором на основі [215]

Підприємницький бізнес базується на самостійній ініціативі, відповідальності та ініціативній підприємницькій ідеї підприємця. Він поділяється на:

- виробниче підприємство (створення та реалізація товарів чи послуг),

- комерційне підприємство (обмін товарів, послуг через торговельні заклади),

- фінансове підприємництво (обмін вартості через фінансові установи).

Державний бізнес означає вирішення головних загальнодержавних наукових, виробничих, технічних і інших проблем, що мають задовольняти інтереси національної економіки загалом.

Споживчий бізнес - це діяльність громадян 3 метою отримання товарів $\mathrm{i}$ послуг через самостійний пошук постачальників і покупців для одержання максимальної вигоди.

Необхідно вказати, що єдиний підхід до класифікації підприємств на малі, середні та великі на сьогодні відсутній, у кожній країні такі підходи розрізняються. Напевно, що основним критерієм належності підприємств до тієї 
чи іншої категорії є чисельність робітників та обсяги обороту, але при необхідності визначення розміру підприємства можуть враховуватися й інші показники, які коригують і доповнюють вищеназвані критерії. За даними Світового банку існує більше ніж 50 різних критеріїв, за якими розмежовують суб'єктів господарської діяльності на малий, середній та великий бізнес.

Загалом, роль бізнесу полягає у стабільності розвитку економіки держави. Він забезпечує значну частину зайнятості, а звідси і благополуччя населення. Бізнес формує середній клас, беручи участь у поглибленні i розвитку конкуренції.

Як правило, великий бізнес - це трансформація малого бізнесу. Можна навести низку відомих підприємців, що побудували бізнес-імперії з незначних накопичень і геніальних бізнес-ідей. Тому зосередимо свою увагу на малому $\mathrm{i}$ середньому бізнесі 3 позиції значення у вирішені соціально-економічних питань держави.

Бізнес $є$ пріоритетом та рушійною ланкою розвитку будь-якої держави 3 перехідною економікою, як найбільш динамічний елемент ії структури, що оперативно реагує на зміни кон'юнктури ринку й надає ринковій економіці необхідної гнучкості та стійкості.

Значення бізнесу для економіки держави розкривається в таких функціях [214, с.8]:

- формування конкурентного середовища;

- швидко реагуючи на зміни ринкову мінливість, надає ринковій економіці необхідної гнучкості;

- значний внесок бізнесу у науково-технічний прогрес;

- вирішення проблеми зайнятості;

- пом'якшення соціальної напруги і демократизації ринкових відносин.

Рушійною силою відновлення позитивних темпів економічного зростання $\epsilon$ підприємництво, функціонування якого не можливо без фінансових ресурсів. Сьогодні особливо складно початкуючим підприємцям, які роблять перші невпевнені кроки в незнайомому для них середовищі і в умовах несприятливої 
економічної ситуації. Фінансове забезпечення стартового етапу підприємництва повністю забезпечується внутрішніми ресурсами самого підприємця, оскільки інші джерела важкодоступні, за винятком дуже дорогих і ризикованих позик від фізичних осіб або кредитних кооперативів. Створити успішний бізнес в Україні - це і виклик і можливість одночасно. Отже, новостворені малі підприємства проходять декілька етапів фінансування таких як бутстрепінг, фінансування «бізнес-ангелами», венчурне фінансування, фінансування кредитними кооперативами, банківське кредитування. Для вирішення проблеми фінансової підтримки новостворених підприємств необхідно удосконалити механізм фінансово-кредитного сприяння розвитку підприємництва. Одними із основних напрямів цієї підтримки $є$ фінансова допомога міжнародних та українських фінансових організацій та фондів, позики комерційних банків та кредитних спілок, лізинг [213, с. 35].

На основі переваг відриття бізнесу, враховуючи недоліки та можливі ризики обирається з наявних або розробляється унікальна стратегія розвитку бізнесу. Найпоширенішими стратегіями в економічній літературі прийнято вважати базисні або еталонні.

За визначенням Боярської М.О. “Вони відбивають підходи до зростання підприємства та пов'язані зі зміною стану одного чи кількох елементів: продукту, ринку, галузі, положення підприємства всередині галузі, технологію” [211, с. 307].

Стратегії концентрованого зростання полягають у зростанні через модифікацію продукту, не змінюючи галузь чи пошук нового ринку збуту, сподіваючись поліпшити власне положення. Розрізняють такі типи:

- стратегія посилення позицій - маркетингові рішення мають покращити позиції компанії;

- стратегія розвитку ринку - покращення позицій компаній, змінивши ринок, на якому вона буде функціонувати;

- стратегія розвитку продукту - розробка і реалізація товару, не змінюючи ринок. 
Стратегії інтегрованого зростання - зростання компанії за рахунок створення нових структур або придбання власності. Компанія може застосовувати таку стратегію, якщо знаходиться в достатньо міцному бізнесі. Розрізняють такі типи:

- стратегія зворотної вертикальної інтеграції - зростання внаслідок створення дочірніх структур, що здійснюють постачання, або ж приєднання компаній, які вже здійснюють постачання. Це зменшує залежність від встановлення цін постачальниками;

- стратегія прямої вертикальної інтеграції - розширення компанії через створення систем розподілу та продажу. Це підвищує якість роботи з клієнтами.

Стратегія диверсифікованого зростання - це стратегія, яка здійснюється в разі, коли компанія більше не має можливостей для розвитку на освоєному ринку 3 виробленим продуктом. Розрізняються такі види [211, с. 308]:

- стратегія центрованої диверсифікованості (пошук та використання способів модифікації продукту, не змінюючи ринку);

- стратегія горизонтальної диверсифікованості (зміна якості продукту, його модифікація або зміна продукту не змінюючи галузі);

- стратегія конгломеративної диверсифікованості (розширення бізнесу на основі виробництва нового продукту за новими технологіями, реалізуючи на новому ринку).

Стратегію поліпшення якісних показників за рахунок скорочення витрат використовують для пошуку способів заходів, що мають знизити планові витрати підприємства. Розглянемо детальніше дані стратегії в табл.5.6.1

Таблиия 5.6.1. Базові (еталонні) стратегії розвитку бізнесу

\begin{tabular}{|c|c|c|c|}
\hline Стратегіï & Продукти & Ринки & Розвиток \\
\hline \multicolumn{4}{|c|}{ Стратегії концентрованого зростання } \\
\hline Посилення позицій & Без змін & Без змін & $\begin{array}{c}\text { Ресегментування й } \\
\text { репозиціювання }\end{array}$ \\
\hline Розвиток продукту & Новий & Без змін & Інноваційні розробки \\
\hline Розвиток ринку & Без змін & Новий & Маркетинг нових ринків \\
\hline \multicolumn{4}{|c|}{ Стратегії інтегрованого розвитку } \\
\hline $\begin{array}{c}\text { Зворотна вертикальна } \\
\text { інтеграція }\end{array}$ & Новий & Без змін & $\begin{array}{c}\text { Інтеграція } 3 \\
\text { постачальниками }\end{array}$ \\
\hline $\begin{array}{c}\text { Пряма вертикальна } \\
\text { інтеграція }\end{array}$ & Новий & Без змін & $\begin{array}{c}\text { Інтеграція } 3 \\
\text { торговельними } \\
\text { постачальниками }\end{array}$ \\
\hline
\end{tabular}




\begin{tabular}{|c|c|c|c|}
\hline \multicolumn{4}{|c|}{ Стратегії диверсифікованого зростання } \\
\hline $\begin{array}{c}\text { Горизонтальна } \\
\text { диверсифікованість }\end{array}$ & Новий & Без змін & $\begin{array}{c}\text { Освоєння нової } \\
\text { технології на старому } \\
\text { виробництві для нового } \\
\text { продукту }\end{array}$ \\
\hline $\begin{array}{c}\text { Конгломератна } \\
\text { диверсифікованість }\end{array}$ & Новий & Новий & $\begin{array}{c}\text { Нові технології на } \\
\text { новому виробництві для } \\
\text { нового продукту й } \\
\text { нового ринку } \\
\end{array}$ \\
\hline $\begin{array}{c}\text { Центрована } \\
\text { диверсифікованість }\end{array}$ & Новий & Без змін & $\begin{array}{c}\text { Розширення старого } \\
\text { виробництва для } \\
\text { випуску нового } \\
\text { продукту } \\
\end{array}$ \\
\hline \multicolumn{4}{|c|}{ Стратегія поліпшення якісних показників } \\
\hline $\begin{array}{c}\text { Стратегія поліпшення } \\
\text { якісних показників за } \\
\text { рахунок скорочення витрат }\end{array}$ & Освоєниї & Освоєний & $\begin{array}{c}\text { Реалізація стратегії } \\
\text { лідерство за витратами }\end{array}$ \\
\hline
\end{tabular}

Джерело: складено автором

Отже, головна мета стратегій розвитку бізнесу - це забезпечення впровадження нових технологій i змін в діяльності підприємства шляхом впровадження заходів розподілу ресурсів, зменшення витрат, адаптування до мінливості оточуючого середовища, i плануванні проведення змін у господарській діяльності у майбутньому.

Стратегія розвитку бізнесу обирається на основі аналізу зовнішнього середовища та внутрішніх перспектив компанії, враховуючи непередбачені ринкові зміни. Вона має складатися не тільки виконання визначеного плану, а також із реакції на зміни в оточуючому іiі середовищі.

Перш за все, хочеться наголосити, що саме вибір стратегій для розвитку кожного бізнесу підприємства є основою стратегічного менеджменту. Звернемо увагу на підхід, який оцінює стратегії базуючись на визначенні ряду нормативних та фактичних показників і встановленні співвідношення між ними для виробничих підприємств, діяльність яких проходить на ринках 3 інтенсивною конкуренцією, який передбачає реалізацію наступних етапів:

- формування переліку показників визначення економічного зростання;

- встановлення нормативних співвідношень між темпами зростання цих показників, тобто побудову нормативної структури показників відповідно до конкретних умов; 
- вибір нормативної структури показників відповідно до особливостей ситуації;

- визначення фактичної структури показників, що відображає реальний стан організації;

- оцінку відповідності між фактичною та нормативною структурою показників;

- виявлення зовнішніх і внутрішніх чинників, які визначають фактичну структуру показників і ступінь їхнього впливу;

- формулювання висновків про результативність діючих у минулому стратегій і доцільність розроблення нової стратегії.

Здійснивши аналіз плюсів та мінусів основних підходів, що було розглянуто вище, до оцінки обраної стратегії, можна дійти висновку, що кожен 3 таких підходів може застосовуватися тільки за конкретних умов і має ряд значних обмежень. Більшість підходів дають можливість провести не тільки кількісну, а й якісну оцінку однієї з обраних стратегій, що являється достатньо суб'єктивною.

3 усіх проаналізованих підходів до оцінювання стратегії можна виділити як найбільш доцільний та повноцінний останній підхід, а саме - оцінка, що заснована на визначенні ряду показників фактичних та нормативних i встановлення співвідношення між ними, через те що у порівнянні з іншими підходами він має набагато більше суттєвих переваг. В цей же час не можна ігнорувати ряд виділених недоліків обраного підходу. Проаналізовані мінуси цього підходу були взяті до основи пропозицій автора щодо його вдосконалення. Можна виділити критерії оцінки стратегії іншим чином відповідно до двох підходів - фінансового та ринкового (мал. 5.6.2). 


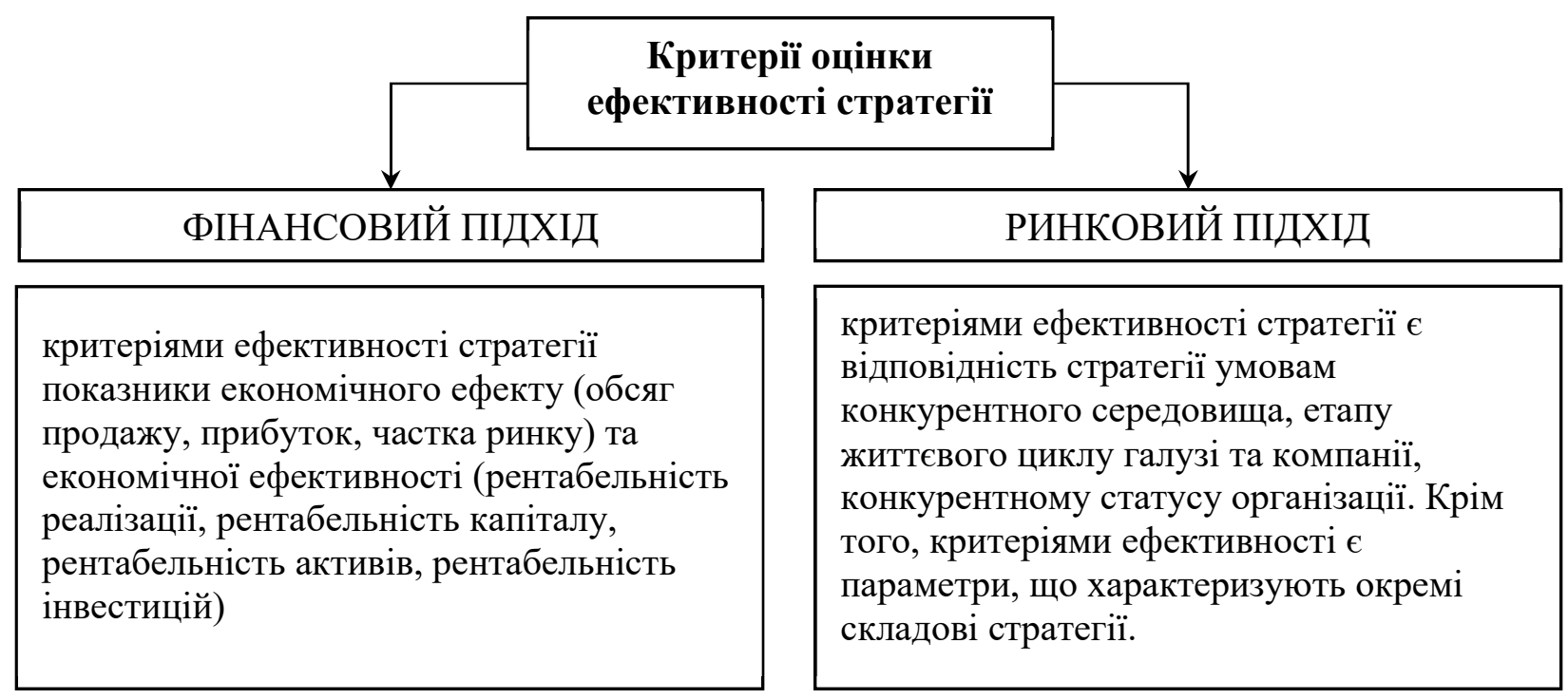

Малюнок. 5.6.2. Критерії оцінки ефективності стратегії підприємства

Джерело: [216, с. 112]

Так, бачимо, що перший підхід, в більшості базується на розрахунку внутрішніх показників діяльності підприємства 3 метою їхнього подальшого аналізу та оцінки, щодо другого - то такий підхід $є$ ширшим за перший, та охоплює аналіз конкурентного середовища, що має на увазі оцінку всіх найбільших конкурентів компанії та їх діяльності.

Однак, на нашу думку, ринковий підхід не є досконалим. Він може лише порівняти ефективність діяльності підприємства 3 іншими на ринку, однак повністю оцінити ефективність самого підприємства та його подальший розвиток, за допомогою ринкового підходу неможливо.

Цільовий підхід, підхід, заснований на теорії систем, багатопараметричний підхід до оцінки можна виділити серед підходів, спрямованих на оцінку ефективності діяльності підприємства (включаючи його стратегічну ефективність),

Цільовий підхід - це погляд на ефективність, який підкреслює центральну роль цілі як критерію оцінки результативності. Відповідно до цього підходу організація існує для досягнення певних цілей, а ступінь реалізації завдань відображає ступінь іiі ефективності. Підхід до оцінки ефективності систем, заснований на теорії, передбачає аналіз організаційної поведінки, передбачаючи 
розподіл основних елементів ("вхід", "процес", "вихід") у системі та іiі адаптацію до високого рівня системних умов. Теорія систем акцентує увагу на тому, що виживання організації залежить від іiі здатності адаптуватися до вимог навколишнього середовища. Виконання цих вимог залежить від того, чи знаходиться повний цикл "вхід - процес - вихід" в центрі уваги керівництва. Отже, критерії повинні відображати стратегічну ефективність цих положень. Цей підхід пояснює, чому ресурси слід використовувати для діяльності, яка не пов'язана безпосередньо з досягненням організаційних цілей.

Багатопараметричний підхід передбачає оцінку задоволеності працівників та груп, що беруть участь в організації.

Використання традиційної фінансової моделі для оцінки ефективності ринку базується на типі економічного мислення, згідно з яким на ефективність компанії впливають фактори внутрішнього середовища (цілі, організаційна структура, завдання, використовувана технологія та людські ресурси). Отже, ефективність роботи досягається шляхом прийняття стратегічних та оперативних рішень на основі поточних можливостей організації.

Вартість фінансової моделі відрізняється від традиційної, враховуючи існуючі альтернативи та пов'язані $з$ цим ризики. Ця модель являє собою інтегровану оцінку всіх аспектів організації вартості бізнесу через результативність.

Таким чином, ми можемо зробити висновок, що в якості методичних основ оцінки ефективності стратегії доцільно використовувати концепцію управління на основі вартості (VBM), що орієнтується на забезпечення стійкого розвитку підприємства в довгостроковому періоді.

Відповідно до концепції VBM критерієм ефективності управління підприємством є підвищення ринкової вартості підприємств. Приріст вартості бізнесу надає бізнесу можливість створювати економічні вигоди. У цьому випадку економічний прибуток створюється шляхом злиття капіталу (функція фінансування) та їх вкладення в механізми отримання певного прибутку бізнесу 
(функція інвестування). Компанію в цілому можна розглядати як сукупність механізмів створення вартості.

Економічний прибуток - найпоширеніший показник ефективності організації, який представляє величину прибутку після покриття всіх витрат організації, як операційних, так i фінансових, пов'язаних із виконанням зобов'язань перед кредиторами та власниками. Також включаються фінансові витрати, пов'язані з обслуговуванням власного капіталу, у сумі, що відповідає вимогам власників повернути вкладений капітал, незалежно від розміру фактично виплачених дивідендів.

Для визначення ефективності процесу додавання вартості до основних характеристик стратегічної ефективності можуть бути використані: ефективність та продуктивність. У цьому випадку результативність може бути виражена як здатність ефективно створювати додану вартість у процесі основної та інвестиційної діяльності (ROIC), а продуктивність - через оцінку здатності генерувати позитивні фінансові результати, як здатність ефективно використовувати вкладений капітал (ROIC-WACC).

Таким чином, ефективність визначає рівень досягнення цілей i запланованих результатів у виробничо-господарській, маркетинговій, фінансовій, соціальній, інноваційній та інших видах діяльності підприємства.

Ефективність може бути підвищена за рахунок вдосконалення продуктів або послуг (результатів), які компанія пропонує ринку. Залежно від ситуації ефективність може бути покращена шляхом переробки процесів або переробки продуктів (послуг) відповідно до вимог до продуктивності, визначених зовнішніми та / або внутрішніми замовниками та споживачами.

Продуктивність - це інтегрований багатофакторний індекс, який поєднує навички та інтереси персоналу, рівень технологій, якість продукції, якість управління, маркетинг, соціальне та економічне середовище. Найкраще поєднання факторів виробництва визначає найкраще використання ресурсів, їх найкращі показники. На продуктивність праці в першу чергу впливають внутрішні фактори: технологія, організація виробництва та управління. Таким 
чином, необхідно враховувати макроекономічні фактори, які можуть сприяти або перешкоджати поліпшенню результативності. Це включає державну політику, економічну та соціальну стратегію та напрямок їх реалізації, діловий цикл та міжнародну конкуренцію, природне середовище, географічні та кліматичні особливості, демографічні (структурні та соціальні) зміни.

Продуктивність як кількісний параметр оцінки бізнес-процесу, це відношення обсягу вироблених товарів або послуг, що продаються організацією, до витрат на їх створення. Він відображає ефективне використання ресурсів (праці, капіталу, матеріалів, енергії, інформації) у бізнес-процесах організації.

Компанії різних галузей працюють у надзвичайно складних, невизначених та динамічних сучасних соціальних та економічних умовах. Формування глобального інформаційного ринку, де ви можете отримати майже миттєвий доступ до інформації про будь-які товари від будь-якого постачальника у всіх регіонах світу, спричинило різке посилення конкуренції між суб'сктами господарювання. Інерційна організація управління бізнесом 3 жорсткою структурою не дозволяє швидко реагувати на постійно мінливі вимоги ринку. Основною умовою сталого розвитку в конкурентній боротьбі є здатність суб'єкта господарювання до довгострокового бачення та послідовного впровадження різноманітних інновацій в асортименті товарів та послуг, менеджменті, технологіях тощо. Для досягнення конкурентної переваги підприємство повинно бути кращим за своїх конкурентів не лише з точки зору всіх бізнес-процесів, але й загальної ефективності. Чітка стратегія, виражена в цілях та показниках бізнеспроцесів, повинна бути спрямована на задоволення очікувань споживачів та акціонерів (інвесторів). Цей підхід від загального до конкретного (зверху вниз) виявляє абсолютно нові бізнес-процеси, в яких, і завдяки яким компанія зможе досягти досконалості. 
DOI 10.46299/ISG.2021.MONO.ECON.II-223-229

\section{7 Кадровий потенціал як основний елемент в кадровій політиці підприсмства}

В ринкових умовах важливо забезпечити організацію кадрами в необхідній кількості і потрібної кваліфікації, що передбачає її орієнтацію на зміни вимог до співробітників, інноваційні здібності керівників до вирішення конфліктів, вмінню створювати згуртовану команду і організовувати групову роботу. Управління персоналом починається з залучення людей на роботу. Кадровий потенціал доцільно формувати, розвивати і реалізовувати відповідно до цілей і завдань організації. При цьому кадрові служби повинні враховувати мотиваційні установки особистості і спиратися на дослідницьку базу, консультативну допомогу, управлінську інфраструктуру.

Проблемам кадрового забезпечення та мотивації праці присвячені дослідження М.І. Воєйкова, Ю.П. Кокіна, Н.Е. Титової, Т.Я. Четверняної, Л.С. Шаховської, Р.А. Яковлева. Окремі елементи мотивації персоналу докладно описані в працях С.А. Агапцова, В.В. Адамчука, Б.М. Генкіна, В.М. Соколинського, О.В. Ромашова та інших авторів.

Актуальність розвитку і удосконалення мотивації праці та пї механізму постійно зростає, хоча реалії сьогодення створюють не однозначне ставлення до вирішення цих питань. Багато теоретичних питань мотивації трудової діяльності залишаються дискусійними й малодослідженими, а пропоновані практичні заходи є розрізненими й часто не пов'язаними між собою.

Основною метою роботи є дослідження основних теоретичних положень мотивації та стимулювання праці працівників підприємств в сучасних умовах їх функціонування, як головної складової кадрової політики.

Задоволенню потреби організації в трудових ресурсах на довготривалий період сприяє маркетинг персоналу, що включає дослідження і сегментування ринку робочої сили, вивчення якостей кандидатів і їх потреб, рекламу вакансій, виявлення і формування потенційних кандидатів в резерв всередині організації. 
Маркетинг персоналу може виступати в різних ролях: як головний принцип управління, орієнтований на ринок; в якості способу пошуку рішень відповідно до певної системою; як засіб досягнення переваг в конкурентній боротьбі; в якості напрямку стратегічного і оперативного планування персоналу.

Посередники здійснюють конфіденційний пошук працівників, надають професійне консультування, що полегшує роботу власного відділу кадрів. Крім того, завдяки компетентності посередника звужується сфера відбору з числа претендентів, кваліфікація яких заздалегідь відома.

Кадрова політика - сукупність способів впливу на персонал для досягнення цілей підприємства.

Кадрова політика повинна повністю відповідати концепції розвитку підприємства і в першу чергу передбачати формування стратегії управління персоналом, яка будується на систематичному аналізі внутрішнього i зовнішнього середовища.

Коли організація має в своєму розпорядженні засоби впливу на ситуацію $і$ здатна розробити антикризові кадрові програми, то вона проводить активну кадрову політику (якщо на підставі діагностування і прогнозування розвитку ситуації керівництво має можливість вплинути на неї, то дотримується раціональної політики; коли підприємство в програму розвитку включає плани кадрової роботи, не проаналізувавши ї з точки зору зміни ситуації (через відсутність коштів), то дотримується авантюристичної політики).

Робота 3 кадрами може зводитися до ліквідації негативних наслідків (пасивна політика). При цьому в організації відсутній прогноз потреб в працівниках, засобів оцінки праці і персоналу, діагностики кадрової ситуації в цілому.

Реактивна кадрова політика передбачає контроль симптом негативного стану в роботі з персоналом: виникнення конфліктних ситуацій, відсутність достатньо кваліфікованої робочої сили і мотивації до високопродуктивної праці. Превентивна політика спрямована на розробку програм розвитку організації, де відображаються короткостроковий і середньостроковий прогнози потреби в 
персоналі. У той же час через відсутність коштів керівництво не може вплинути на ситуацію, що склалася з кадрами.

Отже, кадрова політика повинна бути тісно пов'язана зі стратегією розвитку підприємства, враховувати його реальні фінансові можливості і зміни, що відбуваються в економіці. Стратегічний напрямок роботи кадрових служб полягає в забезпеченні умов конкурентоспроможності i довгострокового розвитку організації на основі регулювання відносин між адміністрацією та працівниками. Організації потрібно постійно відслідковувати зміни попиту на робочу силу з боку власних структурних підрозділів.

Кадрові служби повинні надавати допомогу в розвитку бізнесу за допомогою наймання висококваліфікованих працівників, планування кар'єри, оцінки виробничої діяльності, вдосконалення оплати праці.

Аналіз плинності кадрів необхідний для встановлення тенденцій призначень визначення попиту на нових співробітників, складання персональних графіків їх просування по службі, планування кар'єри, вирішення інших важливих питань. 3 числа співробітників, які пройшли навчання і тестування, необхідно відібрати тих працівників, які займуть вакантні посади.

Для підбору та розстановки кадрів використовується профільний метод, основу якого складає каталог характеристик (вимог), що пред'являються до конкретного працівника з урахуванням займаної ним посади. При цьому вимоги до посад включають спеціальні знання: освіту, професійний досвід, володіння іноземною мовою. У числі інших характеристик можуть бути управлінські якості, здатність до спільної роботи, відповідальність, цілеспрямованість, енергійність, підприємливість і т. п. Отже, профіль вимог призначений для визначення ступеня відповідності кваліфікаційних ознак співробітників певним посадам.

На практиці дуже важливо встановити ступінь відповідності якісних характеристик працівника вимогам займаної посади або робочого місця, для чого проводиться ділова оцінка персоналу. Разом 3 тим вона не обмежується тільки цим. Ділова оцінка персоналу реалізує три основні функції: адміністративну 
(прийняття керівництвом обгрунтованих рішень про підвищення заробітної плати, просуванні співробітника на посаді або про його звільнення), мотивуючу (стимулювання працівника до підвищення кваліфікації); інформаційну (інформування працівника про сильні і слабкі сторони його діяльності).

Систематична, продумана оцінка є важливим інструментом розвитку співробітників, підвищення ефективності роботи всієї організації, вирішення важливих виробничих завдань і конфліктних ситуацій. Ключовим питанням ділової оцінки співробітників організації $є$ розробка стандартів, 3 якими порівнюється їх діяльність. При цьому, як правило, оцінюються результативність праці, професійна поведінка і особисті якості.

В сучасних умовах кадрові служби повинні сприяти розвитку ділової активності організації, мобілізуючи резерви особистості кожного співробітника і акцентуючи увагу на самоосвіті і техніці групової роботи, тим самим надаючи допомогу керівникам вищої ланки управління у вирішенні ряду питань. При цьому основними напрямами кадрової політики повинні стати: проведення маркетингової діяльності в області персоналу, створення нових робочих місць 3 урахуванням впровадження сучасних технологій, підбір і розстановка кадрів, раціоналізація витрат на персонал, розробка програм зайнятості і т. п.

Організація буде досягати успіху, коли кадрові служби будуть краще вивчати ринок робочої сили і внутрішні джерела вибору з числа претендентів, займатися формуванням реального кадрового резерву i професійним просуванням співробітників, планувати витрати на персонал, сприяти забезпеченню соціально-психологічних умов в підрозділах.

Задоволенню потреби підприємства в трудових ресурсах на довготривалий період сприяє маркетинг персоналу, що включає дослідження і сегментацію ринку робочої сили, вивчення якостей кандидатів і їх потреб, рекламу вакансій, виявлення i формування резерву потенційних кандидатів. Саме тому в ринкових умовах важливо забезпечити підприємство кадрами у необхідній кількості і потрібної якості.

Кадровий потенціал будь-якого підприємства може істотно впливати на 
конкурентоспроможність підприємства тільки за умови, що всі основні складові технології роботи з персоналом - набір, адаптація, оцінка результатів праці, сучасні форми мотивації та організація праці, об’єднані в єдину програму.

Від кількісної і якісної збалансованості та рівня використання кадрового потенціалу значною мірою залежать високі кінцеві показники господарської діяльності, досягнення конкурентних переваг, можливості забезпечення сталого конкурентоспроможного розвитку підприємства та економічного зростання.

В свою чергу кадрова політика повинна повністю відповідати концепції розвитку підприємства і в першу чергу передбачати формування стратегії управління персоналом, яка будується на систематичному аналізі внутрішнього $\mathrm{i}$ зовнішнього середовища. Кадрова політика повинна бути тісно пов'язана iз стратегією розвитку підприємства, враховувати його реальні фінансові можливості і зміни, що відбуваються в економіці. Стратегічний напрям роботи кадрових служб полягає в забезпеченні умов конкурентоспроможності і довгострокового розвитку організації на основі регулювання відносин між адміністрацією і працівниками.

В сучасних умовах кадрові служби повинні сприяти розвитку ділової активності підприємства, мобілізуючи резерви особи кожного співробітника $\mathrm{i}$ акцентуючи увагу на самонавчанні і техніці групової роботи, тим самим надаючи допомоги керівникам вищої ланки управління в рішенні ряду питань. При цьому основними напрямами кадрової політики повинні стати: проведення маркетингової діяльності у області персоналу, створення нових робочих місць 3 урахуванням упровадження сучасних технологій, підбір і розстановка кадрів, раціоналізація витрат на персонал, розробка програм зайнятості і т.п.

Через відсутність методичної бази для детального дослідження якісних показників кадрового потенціалу та з метою виконання функцій у ринкових умовах господарювання, їхнього подальшого кількісного оцінювання $\epsilon$ необхідність розгляду таких показників (табл.5.7.1). 
Таблиця 5.7.1

Показники для аналізу кадрового потенціалу

\begin{tabular}{|c|c|c|c|}
\hline Показник & $\begin{array}{l}\text { Умовне } \\
\text { позначення }\end{array}$ & $\begin{array}{l}\text { Формула для } \\
\text { розрахунку }\end{array}$ & Примітка \\
\hline $\begin{array}{l}\text { Продуктивність } \\
\text { праці }\end{array}$ & $\Pi$ & $\frac{B P}{Y_{c p}}$ & $\begin{array}{l}\text { ВР - виручка від реалізації виробленої } \\
\text { продукції, тис. чол.; }\end{array}$ \\
\hline $\begin{array}{l}\text { Коефіцієнт } \\
\text { кадрового } \\
\text { забезпечення } \\
\end{array}$ & $K_{\text {кадр.забез }}$ & $\frac{\Psi_{\text {факт }}}{\Psi_{\text {nomp }}}$ & $\begin{array}{l}\text { Чср - середньоспискова чисельність } \\
\text { працівників, чол.; } \\
\text { Ч }_{\text {факт }- \text { фактична чисельність працюючих }}\end{array}$ \\
\hline $\begin{array}{lr}\text { Динаміка тастки } \\
\text { працівників } \\
\text { вищою освітою, } \\
\text { науковим } \\
\text { ступенем }\end{array}$ & $\Delta q_{B O}$ & $q_{B o}=\frac{\Psi_{B o}}{\Psi_{c p}}$ & 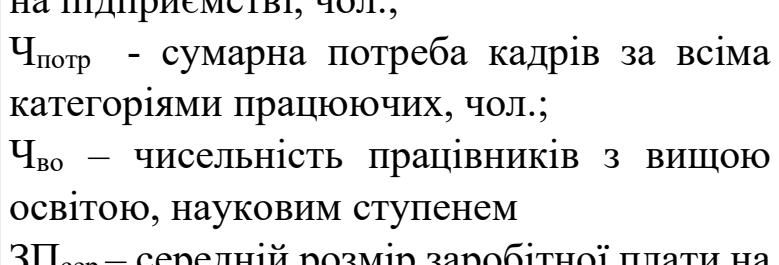 \\
\hline $\begin{array}{l}\text { Коефіцієнт } \\
\text { соціальної } \\
\text { захищеності кадрів }\end{array}$ & $K_{\text {сои.зах. }}$ & $\frac{3 \Pi_{c е p}}{3 \Pi_{\text {гал }}}$ & $\begin{array}{l}\text { 311 сер - середн1и розмір зароо1тно1 плати на } \\
\text { підприємстві, грн; } \\
\text { ЗП гал - середній розмір заробітної плати в }\end{array}$ \\
\hline $\begin{array}{l}\text { Коефіцієнт } \\
\text { стабільності кадрів }\end{array}$ & $K_{\text {стаб }}$ & $1-\frac{\Psi_{38}}{\Psi_{c p}}$ & $\begin{array}{l}\text { Ч }_{\text {зв }} \text { ч чисельність працівників, що } \\
\text { звільнились за аналізований період, чол.; }\end{array}$ \\
\hline $\begin{array}{l}\text { Коефіцієнт } \\
\text { мотивації } \\
\text { працівників }\end{array}$ & $K_{\text {мот }}$ & $\frac{\Phi_{\text {мom }}}{\Phi_{3 n}}$ & $\begin{array}{l}\Phi_{\text {зп }}-\text { фонд заробітної плати працівників, } \\
\text { тис. грн; } \\
\Phi_{\text {мот }}-\text { фонд матеріального стимулювання } \\
\text { працівників, тис. грн }\end{array}$ \\
\hline
\end{tabular}

Розглядаючи показник продуктивності праці, зокрема темпи його зміни, можна безпосередньо визначати зміну кадрового потенціалу.

Що стосується коефіцієнту стабільності кадрів, то низьке його значення свідчить про несприятливе внутрішнє середовище підприємства, про наявність негативних факторів, але водночас значення близьке до 1, може бути ознакою застою та відсутності конкуренції між працівниками.

Особливу увагу доцільно приділити рівню кваліфікації та мотивації працівників, а тому до переліку показників було включено: коефіцієнт соціальної захищеності кадрів, динаміка частки працівників з вищою освітою, науковим ступенем.

Як слідство, необхідно відзначити, що кадровий потенціал впливає на всі елементи структури конкурентного потенціалу підприємства шляхом:

визначення кількісних та якісних параметрів структури управління; зниження витрат на підготовку чи залучення висококваліфікованого 
персоналу;

забезпечення здатності виробити високотехнологічну продукцію; удосконалення механізмів мотивації праці, розробки об'єктивного маркетингового плану дій.

При цьому основними напрямами кадрової політики повинні стати: проведення маркетингової діяльності у області персоналу, створення нових робочих місць 3 урахуванням упровадження сучасних технологій, підбір i розстановка кадрів, раціоналізація витрат на персонал, розробка програм зайнятості і т.п. 
DOI 10.46299/ISG.2021.MONO.ECON.II-230-235

\section{8 Когнітивні технології в управлінні підприсмством: стратегія, ризик- менеджмент, фінансові інновації}

Актуальність теми дослідження. Традиційні системи ризик-менеджменту призначені для забезпечення ефективності фінансового та операційного контролю відповідно до пріоритетів організаційної стратегії. На відміну від них, когнітивний підхід фокусує увагу на редизайні людського мислення, оскільки не конкурує 3 класичними інструментами управління, а навпаки, доповнює їх основні функції. Цифрова трансформація виробничо-комерційної діяльності потребує інноваційного підходу щодо розвитку управлінських структур, інструментів й нового мислення про природу ризику. Когнітивні технології та наявність величезного обсягу інформації надають можливість більш детальному аналізу ризикових ситуацій, але розуміння недоліків в роботі персоналу компанії обумовлює своєрідний ефект мультиплікатора.

Виклад основного матеріалу. Thomson Reuter's оприлюднив звіт «Cost of Compliance 2021» [228], де зазначено, що зміни в роботі компаній обумовлені низкою факторів, зокрема i пандемією Covid-19. Оскільки деякі компанії змінюють свої стратегічні пріоритети, у звіті наголошується на доцільності реалізації ефективної кадрової політики для залучення інвестиційних ресурсів.

3 метою уникнення ризиків $34 \%$ респондентів, що взяли участь в дослідженні делегують повністю або частково свої функції для оптимізації затрат та максимізації доходу. Ефективна система управління ризиками є цінним активом, який компанія може розвинути, особливо в динамічних умовах сьогодення. Як зазначили респонденти опитування, що формування такої системи залишається головним стратегічним пріоритетом компаній [228].

Концепція Cognitive Risks Framework (CRFC) пропонує тривимірну структуру захисту від потенційних загроз, з допомогою наукових методів $\mathrm{i}$ налагодження комунікацій зі стейкхолдерами. Концепція «CRFC» - це еволюційний крок від інтуїції та припущень до кількісного аналізу й оцінювання ризику. Структура когнітивного управління включає 5 елементів: 
-Управління ризиками досліджується в контексті оцінювання потенційних загроз;

-Когнітивне сприйняття ризику орієнтоване на уточнення розрізнених поглядів про загрози, які перешкоджають їх ефективному управлінню;

-Редизайн людського мислення враховує когнітивне навантаження, ситуаційну обізнаність і взаємодію з цифровими технологіями персоналу компанії;

-Елементи штучного інтелекту і моделювання непередбачуваних ситуацій орієнтовані на ефективне формування системи ризик-менеджменту;

- Середньозважена вартість капіталу чинить вплив на систему ризикменеджменту, що показує середню дохідність, яку очікують стейкхолдери компанії.

Отже, розглянута структура «Cognitive Risks Framework» розширює природу ризику за допомогою концепцій поведінкової науки, щоб сформувати взаємозв'язок методології прийняття рішень та технологій управління ризиками.

Когнітивні технології $\epsilon$ складовою кластера конвергентних NBICтехнологій (nano-bio-info-cognitive), які розглядаються як основа економічного прогресу. Спеціальні програми соціального розвитку на основі NBIC-технологій запроваджені в Америці та країнах Свропи (американська програма «Converging Technologies for Improving Human Performances, 2002», програма Євросоюзу «Converging Technologies for European Knowledge Society»). Мета цих програм поліпшення якості життя людей.

Окрім сучасних концепцій ризик-менеджменту варто розглянути питання стандартизації. 3 метою регламентації процесу управління ризиками в компанії розроблені та діють низка стандартів різного рівня. Ці документи описують загальне бачення процесного управління ризиками $\mathrm{i}$, як правило, розробляються визнаними міжнародними органами стандартизації або галузевими групами.

Світова практика демонструє останнім десятиліттям активний розвиток процесів стандартизації в галузі управління ризиками як на національному, так i міжнародному рівнях. Підтвердженням тому є національні стандарти Австралії та 
Нової Зеландії, Великобританії, Канади і багатьох інших країн, а також стандарт Федерації європейських асоціацій ризик-менеджерів, стандарт, розроблений Комітетом спонсорських організацій Комісії Тредвея (COSO, США), i, нарешті, група міжнародних стандартів по управління ризиками ISO 310004. Дані документи є загальними методичними рекомендаціями для застосування всіма організаціями незалежно від специфіки роботи і ризикових ситуацій.

Як показує практика, для більшості вітчизняних підприємств характерна реактивна форма управління фінансовими ризиками, коли процес прийняття управлінських рішень це реакція на поточні проблеми підприємства, а управлінські рішення $є$ фрагментарними. При такому підході до ризикменеджменту виникає низка проблем як всередині самого підприємства, так і за його межами у вигляді розбіжностей цілей та інтересів стейкхолдерів, які мають пряме або опосередковане відношення до підприємства (акціонери, управлінський персонал, контрагенти, органи державної влади).

Пропонуємо розглянути можливість імплементації інтегративноконвергентного підходу до діагностики управління фінансовими ризиками підприємства в умовах розвитку когнітивних технологій, оскільки вони $є$ складовою конвергентного NBIC- кластера. Запропонований підхід призначений для упорядкування тактичних і стратегічних цілей з метою їх структурування, визначення взаємозв'язків i виявлення чинників, що впливають на їх імплементацію.

Правомірність застосування інтегративно-конвергентного підходу до процесу управління ризиками на підприємстві обумовлено системністю представлення самого об'єкта дослідження і всіх його структурних компонентів, яким характерні нові властивості, що не притаманні жодному з них. Можна визначити інтегративно-конвергентний підхід в контексті управління ризиками підприємства, як складну систему, що характеризується насамперед різноманітністю і неоднорідністю складових елементів, численними внутрішніми і зовнішніми зв'язками, що обумовлює їх взаємодію, зміну іiї структури [225-227]. 
Перевагами інтегративно-конвергентного підходу, як одного 3 проявів діалектичного методу дослідження управління ризиками підприємства, є синкретизм різних концепцій менеджменту. На системність діагностики управління фінансовою діяльністю підприємства вказує і наявність таких специфічних елементів, як об'єкт, суб'єкт і методи аналізу управління ризиками.

Об'єкт діагностики - сукупність взаємопов'язаних підсистем підприємства 3 урахуванням існуючої компоненти управління ризиками. Така апологія структурування не випадкова, оскільки основним i найбільш важливим принципом проведення ефективної діагностики є правильне виокремлення окремих, але взаємопов'язаних між собою підсистем, складових в сукупності системи управління фінансовими ризиками.

Функціонування кожної підсистеми безпосередньо впливає на діяльність всієї системи, продукуючи тим самим позитивний ефект синергії. Таким чином, процес діагностування має здійснюватися не тільки 3 позицій кожної окремої iï підсистеми, а й всієї фінансової діяльності підприємства в цілому, враховуючи складні взаємозв'язки, що існують усередині виробничо-економічної системи.

Результативність діагностики управління фінансовими ризиками підприємства невід'ємно пов'язана з регламентацією цілей самої системи, а також кожної підсистеми, оскільки мета є системоутворюючим, інтегруючим чинником, що об'єднує окремі елементи й процеси в цілісність, спрямовану на результат.

Головною метою пропонованої системи є підвищення рівня ефективності управління фінансовими ризиками шляхом комплексного виявлення недоліків на основі їх структурування і впорядкування, а також вибору оптимального рішення прогалин і прогнозування можливості їх появи при розробці заходів, спрямованих на упередження відповідних проблем в перспективному функціонуванні підприємства для забезпечення стабільного, динамічного і сталого економічного зростання [223-225].

Для підсистеми діагностики управління фінансовими ризиками підприємства характерні наступні основні властивості системності: підсистема виконує свої, тільки їй властиві функції, які не повторюються іншими 
підсистемами даної системи; вона має здатність взаємодіяти 3 іншими підсистемами; підсистема взаємопов'язана з іншими елементами своєї системи.

Наведені властивості функціональних підсистем вказують на їх прагнення до забезпечення стійкості системи діагностики управління фінансовими ризиками підприємства в цілому, а не окремих іiі підсистем. Пропонуємо в системі діагностики управління фінансовими ризиками підприємства виокремити такі предиктори:

1. Наукова обгрунтованість діагностики, що базується на положеннях діалектичної теорії пізнання, вимогах економічних законів, використанні досягнень науково-технічного прогресу i новітніх методів економічних досліджень.

2. Комплексність діагностики, яка полягає в детальному дослідженні напрямів і функцій управління фінансовими ризиками підприємства в контексті функціональних підсистем; у всебічному вивченні причинно-наслідкових зв'язків в економіці підприємства; в забезпеченні проведення всіх видів фінансового аналізу (ретроспективного, поточного й перспективного); в комплексній оцінці впливу кількісно-якісних факторів на управління фінансовими ризиками підприємства.

3. Спрямованість діагностики на перспективу, яка полягає в прогнозуванні розвитку управління фінансовими ризиками і визначенні можливих передумов виникнення проблем для прийняття ефективних управлінських рішень.

4. Динамічність і ситуаційність діагностики, націлені на безперервне дослідження причинно-наслідкового механізму виникнення недоліків в роботі системи управління ризиками підприємства.

5. Дієвість діагностики, що припускає активізацію ऑii впливу на процес управління фінансовими ризиками та полягає в своєчасному розпізнаванні й аналізі проблем, а також в розробці й прийнятті управлінських рішень по їх усуненню (зниження ступеня впливу). 
6. Гнучкість фінансової діагностики, спрямована на можливість швидкого прийняття нововведень по адаптації параметрів внутрішнього стану управління фінансовими ризиками до нових умов функціонування.

7. Безперервність діагностики управління фінансовими ризиками, яка полягає в проведенні ії на постійній основі.

8. Когнітивне управління ризиками - оптимізація процесу та інструментарію ризик-менеджменту таким чином, щоб робота функції управління ризиками все більше грунтувалася на використанні даних i когнітивних технологій в контексті прогнозування ризиків і реагування на них з превентивною метою, що обумовлено цифровою трансформацією підприємства.

Розробка концепції діагностики управління ризиками підприємства на основі запропонованих предикторів формує її як систему економічних поглядів 3 позицій основних напрямів управлінського циклу і функціональних підсистем.

Висновки. Функціонування системи діагностики управління фінансовими ризиками підприємства грунтується на використанні різних методів іiі реалізації, вибір яких залежить від стану об'єкта, що діагностується, виокремлених підприємством цілей i завдань, а також впливу факторів зовнішнього та внутрішнього середовища. Всі методи діагностики спрямовані на досягнення однієї спільної мети - своєчасного виявлення й вирішення прогалин в системі управління ризиками підприємства.

В науковому дослідженні ми розглядаємо когнітивне управління ризиками орієнтоване на міждисциплінарний підхід. Оскільки когнітивні технології надають змогу виявити аномалії і помилкову логіку в системі ризик-менеджменту підприємства, а також систематизують інформацію на основі фактичних даних, дозволяючи аналітикам оцінювати альтернативні результати та покращувати процес прийняття рішень. Когнітивне управління призначене для виявлення недоліків в роботі компанії, які розглядають систему ризик-менеджменту як окреме завдання, відмінне від основної бізнес-стратегії. 
DOI 10.46299/ISG.2021.MONO.ECON.II-236-242

\section{9 Реалізація перетворень в умовах антикризового управління аграрними підприсмствами}

У ситуації кризи більшість власників та менеджерів думають лише про те, як елементарно вижити. В складні часи їм це здається єдино можливою стратегією. Необхідно зазначити, що більшість керівників навіть не змогли вести бізнес в інших, жорсткіших умовах. Вони виявилися не лише не готові до кризи, а й не реагували на неї, допоки не впали обсяги продажу, контрагенти перестали виконувати свої зобов'язання, а гроші не зависали на банківських рахунках.

В різних літературних джерелах науковці виділяють багато значень терміну «криза», зокрема, що фінансова криза - це глибокий розлад державної фінансової системи, що проявляється у нестабільності і падінні валютного курсу національної грошової одиниці, інфляції, нестійкістю курсів цінних паперів, що проявляється в різкій невідповідності доходів бюджету їх видаткам; періодичне перевиробництво товарів, що призводить до різкого загострення всіх суперечностей економіки країни: скорочення виробництва, розладу кредитних $\mathrm{i}$ грошових відносин, банкрутства фірм, масового безробіття [233].

Виникнення кризи на підприємствах аграрного сектору обумовлено об'єктивною особливістю умов його функціонування: невизначеністю зовнішнього середовища і нестабільністю його внутрішнього середовища, а також суб'єктивною стороною: особливістю сприйняття i переробки менеджментом підприємства інформації про зміни, що відбуваються.

Кожне підприємство в тій чи іншій мірі у своїй господарській діяльності відчуває на собі кризові явища, економічні та фінансові проблеми, що нерідко призводять до банкрутства.

Криза на агровиробничих підприємствах - це загострення протиріч, що загрожує його життєстійкості. Агропідприємство вважається кризовим, як і всякий виробничий процес, коли воно перестає отримувати прибуток або коли отриманий прибуток не забезпечує в якості джерела фінансових ресурсів можливість покриття поточних витрат і необхідних потреб [234]. Криза може бути обумовлена браком власного капіталу, що призводить до росту боргових 
зобов'язань, некомпетентністю керівництва, впливом несприятливих зовнішніх факторів. Протиріччя між виробництвом і споживанням - головна, але не єдина причина економічних криз.

Подолання кризи - це побудована система управління, націлена на виявлення ознак кризових явищ та створення відповідних передумов для їх своєчасного подолання, забезпечення виживання і відновлення життєздатності сільгосппідприємства i недопущення банкрутства. Система управління підприємством припускає принципову зміну функцій учасників бізнес-процесів, механізмів їх взаємодії, а так само організації матеріальних, фінансових, інформаційних та інших потоків [235].

Антикризове управління сільгосппідприємством враховує галузеві особливості аграрного сектору. Вибір правильної стратегії антикризового управління дає можливість вчасно розпізнати кризову ситуацію i, з огляду на особливість, знизити гостроту. Антикризове управління в умовах зростаючої динамічності підприємницького аграрного середовища вимагає перебудови традиційних поглядів на стратегічне планування в сільгосппідприємстві. Застосування періодичного стратегічного планування дозволяє здійснювати перехід від виконання кризового плану до реалізації актуалізованого стратегічного курсу. Незалежно від причин виникнення і розвитку типів кризи підприємств сільського господарства, існує ряд принципів стратегії виходу 3 кризи, які виробляються на основі досліджень і вивчення досвіду антикризового управління [236].

1. Принцип адаптивності стратегії, управління будується на принципах системного та ситуаційного підходу.

2. Принцип концентрації зусиль на напрямках основної діяльності сільгосппідприємства, які дають основний внесок в кінцевий результат.

3. Принцип диференційованого підходу до стратегії антикризового управління, виходячи з виду кризи, в якому знаходиться аграрне підприємство.

4. Принцип відповідності масштабу i швидкості змін всередині сільгосппідприємства. 
Iз зазначеного вище випливає, що основними завданнями антикризового управління в сільськогосподарських підприємствах є: зміна функціонування господарських механізмів; трансформація критеріїв прийняття управлінських рішень; розробка і реалізація стратегії і тактики управління в нових умовах; активне використання нових можливостей управління; застосування всіх легальних методів господарського маневрування [237].

Саме чітке визначення процесу антикризового управління дозволить не лише своєчасно й ефективно виявити кризи, мінімізувати їх негативні наслідки, але й попередити виникнення кризових явищ у майбутньому. 3 метою забезпечення ефективної протидії кризовим явищам процес антикризового управління необхідно здійснювати поетапно: 1-й етап - створення спеціалізованої робочої групи (антикризової команди); 2-й етап - проведення діагностики та оцінка параметрів кризи; 3-й етап - визначення мети і завдань антикризового управління, пошук способів виходу підприємства 3 кризи, визначення необхідних ресурсів, перевірка можливості досягнення поставлених цілей; 4-й етап - оцінка ресурсного потенціалу та часових обмежень антикризового управління; 5-й етап - розробка антикризової програми; 6-й етап - створення системи реалізації антикризової програми виходу підприємства 3 кризової ситуації; 7-й етап - організація впровадження антикризової програми та контроль за її виконанням; 8-й етап - аналіз доцільності подальшого проведення заходів щодо виходу підприємства 3 кризової ситуації; 9-й етап - розробка заходів щодо прогнозування і профілактики майбутніх кризових ситуацій [239].

Як інструмент в процесі антикризового управління в сільськогосподарських організаціях використовується найбільш радикальний спосіб перетворень реструктурування сільгосппідприємства. Під реструктурування в аграрному секторі розуміються фундаментальні комплексні зміни, в основі яких лежить трансформація структури бізнесу i способу функціонування сільгосппідприємства, що охоплює практично всі аспекти його діяльності, кінцевою метою якої $\epsilon$ підвищення ефективної роботи i конкурентоспроможності, збільшення прибутковості. Реструктурування, що 
припускає оновлення всіх сфер діяльності, необхідно аграрним виробникам для адаптації в нових умовах господарювання.

Існуючі розробки з описом окремих варіантів реструктурування на основі створення системи бізнес-одиниць і на основі створення малих підприємств на базі великих через процедуру поділу та виділення недостатньо ефективних $\mathrm{i}$ вимагають концентрації зусиль на всіх етапах процесу реструктурування. В якості практичного засобу, що сприяє підвищенню ефективності перетворення структури сільгосппідприємства, проведеного в рамках стратегічного реструктурування, розроблена комплексна технологія, що включає п'ять елементів і представляє собою процедуру вибору стратегії, адаптації структурних параметрів, планування та реалізації структурних перетворень в умовах антикризового управління в сільськогосподарських підприємствах.

Перший етап - аналіз причин кризи сільгосппідприємства і оцінка можливості реструктурування. Дослідження внутрішніх і зовнішніх причин кризи, встановлення сильних і слабких сторін сільгосппідприємства. Аналіз проводиться за напрямками структури макро- і мікроумов, які характеризують зовнішні причини кризи та ймовірні загрози [240].

Другий етап - це визначення цілей і стратегічної концепції перетворень. Розробка стратегічного бачення і місії в сільськогосподарських підприємствах, встановлення цілей переводить стратегічне бачення його розвитку в конкретні завдання, пов'язані з сільгоспвиробництвом і результатами його діяльності. До результатів цього етапу відносяться - більш швидке зростання доходів, збільшення прибутку на вкладений капітал, визнання міцного фінансового становища сільгосппідприємства; стратегічні цілі - більш високе і надійне становище в аграрній галузі, зниження витрат сільськогосподарського виробництва, підвищення якості сільгосппродукції.

Третій етап - визначення варіантів структурної перебудови і вибір організаційної стратегії сільгосппідприємства. Критерієм вибору стратегії перетворень сільгосппідприємства є вартісний розрив між вартістю, якою володіє підприємство сільського господарства в даний час, потенційної $\mathrm{i}$ 
вартістю його після реструктуризації [241]. Вартісний розрив, тобто межа між поточною вартістю сільгосппідприємства при існуючих умовах і поточною вартістю нового сільгосппідприємства після реструктуризації, являє собою чисту поточну вартість ефекту реструктуризації.

Четвертий етап передбачає координацію структурних параметрів. Після визначення варіанта організаційної стратегії і встановлення стратегічних господарських регіонів для сільгосппідприємства необхідна координація його структурних параметрів. Найважливішими структурними параметрами сільгосппідприємства є стратегічні види бізнесу, організаційно-правова форма i загальна організація.

П'ятий етап - це планування і реалізація нових структур. Проблематику цього етапу становить часовий графік змін, так як потрібно поступовий підхід.

Особливість такої програми реструктурування сільгосппідприємства є те, що за умови іiі повного здійснення вона дає шанс, навіть якщо і були допущені помилки при виробленні стратегії. Керуючись методологічними принципами системного підходу до реструктуризації, наприклад, принципом інтеграції, використовують наступні моделі:

1. Поділ підприємств аграрного виробництва.

2. Створення спільних підприємств сільського господарства.

3. Створення на базі сільгосппідприємства асоціації фермерських господарств.

4. Створення на базі сільськогосподарського підприємства особистих підсобних господарств (ОПХ).

Застосування цих моделей здійснювалося на підставі результатів аналізу фінансового стану суб'єктів аграрного сектору. Видно, що суть моделі поділу підприємства полягає в тому, що існуюче підприємство ділиться на два і більше самостійних юридичних осіб, які стають його правонаступниками та особливість цього варіанту - одні новостворені підприємства взяли собі тільки ліквідне, а інші - все невикористане майно. У даній моделі кожне новостворене підприємство бере на себе борги пропорційно частці переданого майна. 
Розглядаючи суть другої моделі - створення нового підприємства на базі ліквідної частини активів старого сільгосппідприємства. Модель реалізовувалася за кількома варіантами:

а) суб'єкт створено за участю сторонніх підприємств при наявності інших, які бажали створити спільне підприємство;

б) суб'єкт створено за участю сторонніх підприємств і працівників господарства, готових вкласти кошти в розвиток спільного підприємства;

в) підприємство створено за участю працівників господарства, в разі відсутності підприємства - інвестора і на базі земельної власності громадян господарства. Створення самостійних фермерських господарств на базі сільськогосподарського підприємства, які потім об'єдналися в асоціацію фермерських господарств, основа третин моделі реформування. Ця модель більш ефективна, як визначилося, для підприємств 3 великою кредиторською заборгованістю і низьким виробничим потенціалом, що дало шанс збереження виробництва і вихід на беззбитковий рівень господарювання. Об'єднання особистих підсобних господарств має свої відмінності, метою якого $є$ самозабезпечення учасників особистих підсобних господарств та прилеглих населених пунктів продукцією сільського господарства. Важкий фінансовий стан можливо подолати, якщо створити на базі ОПГ нові комерційні сільськогосппідприємства.

Таким чином, концепція антикризового управління виходить 3 того, що вирішальними для відновлення сільськогосподарського виробництва доведення його до допустимого в сучасній економіці світової спільноти рівня $є$ дві компоненти: аграрна політика держави та ефективний менеджмент в самих сільськогосподарських підприємствах.

Система антикризового регулювання включає основні напрями забезпечення сталого (безкризового) розвитку сільськогосподарських підприємств, це: формування багатоукладного аграрного виробництва; формування ефективної аграрної політики (ціноутворення, кредитування, антимонопольна політика, податкова політика, страхування і т. п.); захист 
інтересів вітчизняного товаровиробника; формування кадрового потенціалу; розвиток науки і здійснення наукової діяльності; розвиток соціальної сфери села; реформування земельних відносин; формування i функціонування ринку сільськогосподарської продукції, сировини і продовольства [242].

Отже, можна зробити висновок, що активізація процесів банкрутства в сільському господарстві призводить до зменшення забезпеченості засобами виробництва сільськогосподарських товаровиробників і деградації галузі. У зв'язку з цим нагальною потребою $є$ запобігання або подолання неспроможності аграрних підприємств при наявності такої можливості. Тому необхідно здійснити глибоку і всебічну діагностику кризових явищ, оцінити їх масштаби, виявити можливість запобігання неспроможності підприємств через реалізацію перетворень в умовах антикризового управління ними. 


\section{SECTION 6. FINANCE, PENNILESS AND CREDIT}

DOI 10.46299/ISG.2021.MONO.ECON.II-243-249

\section{1 Роль венчурного фінансування для розвитку науково-технічного потенціалу країни}

Конкурентоспроможність національної економіки в сучасній глобалізованій системі світового господарства залежить від рівня розвитку національної науки та науково-технічного потенціалу країни. Тому достатній рівень асигнувань на науку - одна із основних умов ефективного використання наукового потенціалу, як провідного фактора економічного розвитку. В економіці знань державне фінансування науки розглядається як капіталовкладення в майбутнє, що, у кінцевому підсумку, принесе високі дивіденди всьому суспільству.

Важливою також є роль університетської науки. Університет сьогодні являє багатофункціональну систему, в якій здійснюється не лише підготовка фахівців, перепідготовка та підвищення кваліфікації, а реалізуються функції підготовки наукових кадрів (аспірантура та докторантура), проведення наукових досліджень і впровадження наукових розробок у практику (кафедри, наукові лабораторіï), вирішується триєдине завдання: перше, поєднання якості підготовки фахівців; друге, проведення наукових досліджень; третє, впровадження їх результатів в економіку України, функціонують науково-виробничі комплекси, технопарки, бізнес-інкубатори, кластери.

Структура наукових та науково-технічних робіт, виконаних в університетах України за видами робіт в цілому, представляється таким чином: питома вага фундаментальних досліджень складає 36\%, прикладних досліджень - 37,5\%, наукових розробок $-15,8 \%$, науково-технічних послуг - 10,7\%. Одним 3 головних чинників, що визначають структуру НДР в університеті, є обсяг фінансування. Фінансування наукових досліджень в університетах України здійснюється за рахунок: державного бюджету; місцевих бюджетів; позабюджетних фондів; власних коштів вищих навчальних закладів; коштів замовників (підприємств, організацій України, іноземних держав), інших джерел. 
Новою для України, але достатньо відомою у світі формою інвестування $є$ венчурне фінансування, яке має деякі відмінності порівняно із традиційними формами фінансування. Іноземні інвестори венчурного капіталу досліджують довгострокові перспективи підприємства, в яке вкладають кошти. Практика венчурного фінансування передбачає інвестування як шляхом придбання акцій (паїв) компаній, так і шляхом кредитування підприємств. Процес інвестування передбачає залучення інвесторів у безпосереднє управління виробничим процесом, прийняття стратегічно важливих рішень. Фірма, що отримує венчурне фінансування, стає акціонерною компанією закритого типу, акції якої належать вузькому колу осіб - iї засновникам та інвесторам венчурного капіталу.

Переваги венчурного фінансування полягають у тому, що створювані невеликі фірми мають доступ до фінансових ресурсів, а також можливість консультацій з питань виробництва, фінансів, управління персоналом, чим забезпечуються гнучкість в управлінні та швидкість прийняття рішень. Венчурний капітал традиційно орієнтується на малі та середні підприємства, віддаючи перевагу приватним компаніям і спільним підприємствам. Пріоритетними для венчурного капіталу є галузі, продукція яких має значний внутрішній ринок збуту, та такі, що не залежать від імпорту. Наявність експортного потенціалу підвищує привабливість підприємства, але не є суттєвим чинником інвестицій. Існує безліч визначень того, що таке венчурне фінансування, але усі вони так чи інакше зводяться до його функціональної задачі: сприяти росту конкретного бізнесу шляхом надання визначеної суми коштів в обмін на частку в статутному чи капіталі деякий пакет акцій.

За визначенням Національної асоціації венчурного капіталу США, венчурний капітал - це довгостроковий, ризиковий капітал, який інвестується в акції нових та швидко зростаючих компаній з метою отримання високих прибутків після реєстрації даних компаній на фондовій біржі [243,c.2].

Особливість венчурного механізму полягає у поетапному фінансуванні підприємницьких проектів. Розподіл грошових потоків на окремі транші зумовлений, з одного боку, прагненням мінімізувати інвестиційний ризик на 
початкових стадіях інноваційного процесу, а з іншого - забезпеченням можливості залучення додаткових коштів у разі зміни початкового плану проекту в ході його реалізації. Як правило, виділяють шість етапів венчурного інвестування ризикованих бізнес-ініціатив: достартовий (“посівний”); пусковий; рання стадія розвитку фірми; швидке розширення; етап придбання та етап фінансування викупу $[244$, c.30].

До появи венчурного капіталу в світі були відомі кілька джерел фінансування малого та середнього бізнесу: банківський капітал, великі корпорації і компанії та заможні люди, що готові вкладати значні кошти в ризикову справу. Перший венчурний фонд, заснований Артуром Роком в 1961 р., був розміром 5 млн дол США, 3 яких інвестовано було всього 3 млн. Але результати роботи фонду виявилися приголомшливими: витративши всього 3 млн, А. Рок через нетривалий час повернув інвесторам майже 90 млн. дол.. США. Після цього у нього були проекти, що призвели до появи таких відомих сьогодні імен, як «Intel» і «Apple Computer». Перші кроки у розвитку венчурного бізнесу в Європі зробила Великобританія. Якщо в 1979 р. загальний обсяг венчурних інвестицій у цій країні становив всього 20 млн. фунтів, то в 1987 р. він уже перевищував 6 млрд фунтів $[245$, c. 74$]$.

Участь венчурного капіталу в інноваційному процесі являється принципово важливим фактором в розвитку будь-якої національної економіки. В Україні тенденції абсолютно інші - кошти венчурних фондів інвестуються в будівництво і нерухомість і поки слабо орієнтовані на «хай-тек» технології. Це свідчить, що орієнтація класичних венчурних фондів на інноваційні проекти, технопарки та технополіси поки що не притаманна українському венчурному капіталу. Все таки він схильний, не надто диверсифікуючи активи, реалізовувати середньоризикові інвестиційні проекти з використанням операцій з фінансовими активами та нерухомістю.

За сучасних умов в Україні, коли ринок в науково-технічній сфері тільки формується, держава повинна узяти на себе ініціативу створення мережі інноваційних фондів за участю власних коштів із залученням на правах 
партнерів або акціонерів широкого кола приватних інвесторів. Участь держави у створенні мережі інноваційних науково-технічних фондів у якості співзасновника дозволить їй набувати і реалізовувати особисті й майнові права на об’єкти промислової та інтелектуальної власності, виконувати делеговані їй функції фінансового забезпечення і комерційної реалізації нововведень. Реалізація державою прав управління та майнових прав на нематеріальні активи через інноваційні фонди робить іiї суб'єктом ринкової економіки, який вкладає капітал у початкові стадії нових напрямків розвитку інноваційного процесу по мірі їх економічної реалізації і створює умови для венчурних інвестицій в інноваційний процес. Це дуже важливо, оскільки політика передбачення бюджетних видатків на інноваційну діяльність коштами позабюджетних інноваційних фондів, які діють на принципах венчурного фінансування, для розвитку науково-технічного потенціалу країни необхідна і виправдана [247, с. 246]. Очевидним є те, що ефективно конкурувати як на внутрішніх, так і на зовнішніх ринках зможуть лише ті вітчизняні підприємства, які дотримуватимуться інноваційного типу розвитку. Однак, згідно статистичних даних, кількість інноваційно-активних підприємств в Україні, у порівнянні з розвинутими країнами світу, є мізерною. Однією з вагомих причин цього $\epsilon$, як було зазначено, відсутність фінансів у вітчизняних підприємств. Державна політика в сфері інноваційної діяльності повинна сприяти зростанню кількості впроваджених у виробництво нових видів продукції та технологій шляхом інвестування венчурного капіталу в підприємства. Нововведення виступають головним джерелом конкурентних переваг підприємства в сучасних умовах. А зростання рівня конкурентоспроможності сприяє, як відомо, зростанню вартості бізнесу.

Історія розвинених країн свідчить, що малі підприємства, які досягли значного успіху в бізнесі, використовували венчурний капітал. Зокрема, фірми, які були лідерами в комп'ютерній галузі, в кожному наступному поколінні, були профінансовані безпосередньо венчурним капіталом.

Сьогодні венчурні фонди $є$ локомотивом інвестиційного бізнесу, який пов'язує реальний сектор вітчизняної економіки 3 фінансовим ринком. При 
використанні механізму венчурного інвестування важливим є те, що гроші не виходять із економіки України. Навіть якщо це нерезидент, податки будуть сплачені в Україні як під час реалізації проекту (податки і збори, заробітна платня, робочі місця), так і при завершенні і виході з інвестицій. Венчурні фонди дають механізм роботи в Україні грошей із оффшорів.

Одним із таких фондів в Україні, що успішно розвивається є Western NIS Enterprise Fund. Сумарні інвестиції фонду становлять приблизно 77 млн дол. США. Вони розміщені у 24 компаніях, які $\epsilon$ лідерами у своїх галузях (кондитерська

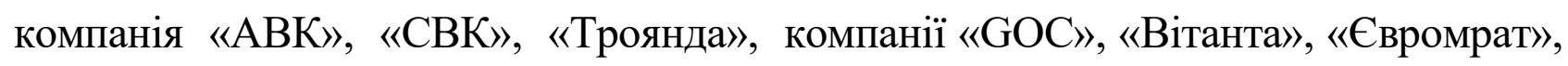
«Світанок» і ін.). Фонд дає компаніям капітал, для того, щоб виділитися і змінити форму управління на корпоративну. Його основним напрямом є орієнтація на довгостроковий приріст акціонерного капіталу і високу якість продукції [247, с.257]. Останнім часом на вітчизняному венчурному ринку спостерігаються значні позитивні зрушення: одна із зареєстрованих компаній в Україні - ТЕХIHВЕСТ - внаслідок добре продуманої стратегії успішно вийшла на міжнародний ринок венчурного капіталу. Ця компанія планує такі найважливіші заходи з розвитку інноваційного підприємництва в Україні:

- підготовка і проведення Всеукраїнського конкурсу високих технологій;

- створення разом із Тімом Дрейпером Технологічного венчурного фонду DFJ Nexus $з$ бюджетом 100-150 млн. дол. для фінансування високотехнологічних компаній на ранніх стадіях розвитку;

- організація разом із провідною технологічною установою (ВНЗ чи інститутом НАН України) Технологічного центру на 1 тис. робочих місць для інженерів та науковців;

- проведення щорічних презентацій українських наукомістких технологій в США.

Так, в 2005 р. сім проектів вітчизняних хай-тек-компаній у сфері ITтехнологій, нанотехнологій та енергетики, відібраних на Всеукраїнському конкурсі високих технологій, викликали значний інтерес серед американських венчурних інвесторів [246, с.39]. 
В Україні можливість державно-приватного партнерства у сфері венчурного фінансування формально з'явилася 3 моменту створення Державного інноваційного фонду, який виявився недієздатним. Однією $з$ істотних причин цього була нестача державних коштів, відсутність відповідної тактики формування фонду, опрацьованого плану дій з його використання як результату постійної зміни урядів, що не визнають наступність у виконанні прийнятих державних рішень. Сьогодні, коли завдання переходу до економіки, заснованої на знаннях, $є$ одним із пріоритетних, для запуску венчурної системи фінансування механізм державно-приватного партнерства $€$ найбільш прийнятним і актуальним [247, с. 149].

Стримують активний розвиток ринку венчурного фінансування в Україні такі чинники [246]: економічна і політична нестабільність; орієнтація економіки на інвестування розвитку виробництв, а не на активізацію інноваційної діяльності; відсутність чіткої інноваційної політики держави; відсутність розвиненої інноваційної інфраструктури; орієнтація на імпорт високотехнологічного устаткування, недостатня увага до розвитку власного науково-технічного потенціалу; недосконалість інструментів правового регулювання венчурних структур; відсутність економічної зацікавленості господарських суб'єктів у нових розробках, інноваціях.

На нашу думку, для активізації венчурного підприємництва в Україні необхідно здійснити такі заходи:

1. Формування економіко-правової бази для забезпечення інноваційної діяльності шляхом розробки нових та внесення доповнень у чинні законодавчі акти для створення привабливих умов для інноваційної діяльності на державному i регіональному рівнях.

2. Формування i ефективний розвиток системи інформаційного забезпечення інноваційної діяльності підприємств.

3. Розробка i впровадження системи підготовки та перепідготовки спеціалістів для роботи в сфері інноваційної діяльності. 
4. Забезпечення розвитку міжнародного співробітництва в сфері інноваційної діяльності шляхом участі в міжнародних ярмарках, виставках, організації і проведення конференцій 3 інноваційної тематики, обміну інформацією, трансферу і тиражування інноваційних проектів.

5. Розробка та реалізація заходів щодо ефективного розвитку інноваційних інститутів, таких як технопарки, інноваційні агентства і центри, інноваційні інкубатори, активізації взаємодії науки і виробництва, підвищення якості розробки інвестиційних та інноваційних проектів, залучення в регіон інвестицій завдяки створенню ринку проектів.

Реалізація цих пропозицій в Україні забезпечить формування налагодженої і ефективної системи венчурного інвестування, об'єктивним доказом цього буде підвищення рівня України у міжнародних рейтингових оцінках.

Розвиток ринку венчурного капіталу $є$ невід'ємною частиною інноваційного розвитку економіки держави, він добре рекомендував себе як ефективне джерело інвестування в інноваційні підприємства не лише у країнах, що належать до високотехнологічних за структурою своєї економіки, але й у країнах, які лише починають здійснювати перехід до моделі економіки побудованої на знаннях. життєвого циклу залежно від інноваційної та науково-технічної діяльності. Очевидним $є$ те, що ефективно конкурувати як на внутрішніх, так і на зовнішніх ринках зможуть лише ті вітчизняні підприємства, які дотримуватимуться інноваційного типу розвитку. Однак, згідно статистичних даних, кількість інноваційно-активних підприємств в Україні, у порівнянні з розвинутими країнами світу, $\epsilon$ мізерною. Однією з вагомих причин цього $\epsilon$, як було зазначено, відсутність фінансів у вітчизняних підприємств. Державна політика в сфері інноваційної діяльності повинна сприяти зростанню кількості впроваджених у виробництво нових видів продукції та технологій шляхом інвестування венчурного капіталу в підприємства. 
DOI 10.46299/ISG.2021.MONO.ECON.II-250-257

\subsection{Formation and analysis of project cash flows}

The orientation of economic systems mainly towards market methods of management becomes the reason for the active interest of economists and practitioners in monetary factors when organizing new projects. Nowadays, especially in crisis conditions of non-payments, consideration of the most important aspects of the content of the project's cash turnover acquires special relevance.

Non-profit assets, namely cash, are required to purchase equipment, materials and raw materials, payment for transportation and other services, wages, and repayment of creditors.

The chosen topic is relevant since the existence and profitability of the project depends on the establishment of a lower limit for the balance of funds in national and foreign currencies, which will be sufficient to:

- timely pay suppliers' bills, which will allow discounts on the price of goods;

- maintain creditworthiness;

- pay for unforeseen expenses that may arise in the process.

To solve this problem, it is necessary to take into account that when immobilizing monetary resources as an irreducible balance of money on the account, it is associated with some losses for the project; with a certain degree of convention, their value can be estimated by the amount of lost benefits. Thus, it is advisable to take into account two circumstances: maintaining the current solvency and obtaining additional profit from the investment of free funds.

The main purpose of the work is to analyze cash flows using the example of an operating enterprise, for which the tasks of assessing cash flows using direct and indirect methods, the method of coefficients are set.

A number of factors affect the decision-making on how much cash you need to have at your disposal, taking into account the liquid assets of the enterprise, financial risk, the volume of debt obligations and the timing of their repayment, the ability to obtain bank loans in a short time and for favorable conditions. First-class borrowers in terms of creditworthiness, who are able to obtain loans at favorable interest rates, can 
afford a lower level of funds than firms with a high proportion of leveraged funds in the balance sheet liabilities or with a higher credit risk. In order to reveal the real cash flow at the enterprise, to assess the safety of their receipts and expenditures, as well as to link the size of the financial result with the availability of money at the enterprise, it is advisable to analyze all directions of the inflow and outflow of cash resources.

In order to carry out its expenses, the project needs to ensure an adequate inflow of money supply and revenues. Roofing felts from the sale of manufactured products, goods (services, works), receipt of temporary borrowed funds, it is possible to receive dividends on the invested capital. Which means that the activity of the project is an objective prerequisite for the emergence of cash flow.

Cash flow is created by the movement of project funds over time and is an ongoing process.

Cash flow is the aggregate of the volumes of cash outflows and inflows distributed over time in the course of the economic activity of the project. A positive cash flow is a cash inflow or inflow.

The disposal or outflow of cash is called negative cash flow. Net cash flow is the difference between negative and positive cash flows for each type of activity or economic activity of the project as a whole. The concept of cash flow is generalized and contains a large number of different types of cash flows that arise during the operation of the project. In order to provide a comprehensive, in-depth analysis, the cash flows of the project must be classified according to a number of such basic characteristics:

I. By type of activity: operating; investment; financial.

2. For participation in the business process: for the project as a whole; by the types of his economic activities; by project directions; for individual business transactions

3. Direction: negative cash flow; positive cash flow.

4. By the level of optimality: scarce cash flow; excess cash flow.

5. By time: planned cash flow; operational cash flow.

6. At the moment of valuation of cash: future and present value of cash flows. 
7. By the nature of the formation: periodic or regular cash flow; episodic or discrete cash flow.

8. By time intervals: cash flow with regular and irregular intervals.

In order to carry out the normal life of the project, it must have the optimal amount of funds. Lack of funds can negatively affect the activities of the project and lead to unprofitability, loss-making, decrease in liquidity and even the winding down of the project.

Excess cash can also have a negative impact on the project. Surplus funds or money supply that are not involved in production and commercial turnover does not increase income. Inflationary processes affect the real value of money, by devaluing them over time. To make optimal management decisions related to the movement of funds, in order to achieve the best effect of economic activity, the project management needs constant awareness of the state of funds. From which it follows that both a systematic detailed analysis and an assessment of the project's cash flows are needed. The role of cash flow analysis is very important because the analysis creates the basis for the formation of an effective and correct policy for making managerial decisions by the project management, its significance is due to a number of reasons:

- the project, in almost all aspects of its activity, cash flows serve its functioning;

- financial stability and solvency of the project ensure optimal cash flows;

- the rationalization of cash flows contributes to the achievement of the rhythm of the production and commercial process of the project;

- the project's need for attracting borrowed capital is reduced through effective cash flow management;

- a prerequisite for accelerating the turnover of the project's capital as a whole is the optimization of cash flows;

- expansion of the scale of production and growth of proceeds from the sale of products, goods (services, works), the receipt of additional income is ensured through the rational use of freed up funds as a result of optimization of cash flows. The purpose of the analysis of cash flows is to obtain the required volume of their parameters, which give objective, reliable, accurate and timely characteristics of the directions of receipts and 
expenditures of funds, composition, volumes, structure, both objective and subjective, both external and internal factors that have a different effect on the change in cash flows.

Tasks of the analysis of project cash flows:

- assessment of cash flows by type of economic activity;

- assessment of the optimality of the organization's cash flows

- assessment of both the composition and the structure, including the directions of cash flow;

- assessment of the dynamics of cash flows;

- identification and measurement of the degree of influence of various factors on the formation of cash flows;

- both identification and assessment of reserves for improving the operation of cash;

- development of offers for the sale of reserves to improve the efficiency of the operation of funds.

Substantiation of the degree of sufficiency or insufficiency of the formation of the volume of money supply as a whole, including by type of activity, the balance of both positive and negative cash flows in terms of volume and time is one of the main directions of the analysis of cash flows. Together with the analysis of cash flows as a whole for the project, it is advisable to carry it out in separate areas. The first stage of the analysis includes consideration of the dynamics of the volume of formation of the positive cash flow of the project (i.e., cash flow) from the point of view of individual sources. It would be advisable to compare the growth rate of positive cash flow with the growth rate of assets, sales, revenue volumes, with different profit indicators. It is necessary to pay special attention to the ratio of the sources of formation of a positive cash flow of its internal (sales proceeds) and external (such as received loans, credits), determining the degree of dependence on external sources.

At the second stage, the dynamics of the volume of the negative cash flow of the project is studied, which is the outflow of funds, including its structure in the direction of spending money. 
The third stage is the analysis of the balance of negative and positive cash flows in terms of their total volume. The dynamics of the net cash flow is analyzed and makes it possible to assess the result of the project, since the net cash flow is almost the most important indicator of the balance of production and financial activities. During the fourth stage, the analysis determines the role and place of the net profit indicator for the formation of net cash flow, the influence on it of various factors: accounts receivable and payable, changes in the amount of inventory balances, created reserves, accrued depreciation during the analyzed period. A special place is given to the characteristic of the quality of the net cash flow, namely to the indicators of the structure of the sources of its formation. A high level of quality of net cash flow is characterized by an increase in the proportion of net profit received due to an increase in sales proceeds and a decrease in costs.

Low quality is characterized by net cash flow, in which a significant part is obtained due to the increase in sales prices, income from non-sales operations associated with inflationary processes, extraordinary income.

Coefficient analysis, where the necessary indicators are calculated, which characterize the efficiency of the use of the project's funds, are carried out at the fifth stage. With the help of various coefficients, the modeling of factor systems is carried out in order to identify and quantitatively measure the reserves for the growth of the efficiency of cash flow management. There is a very significant drawback in the direct method of analyzing cash flows: it will not allow analyzing the influence of various factors on the subject of changes in the balance of funds in conjunction with changes in those indicators that form the financial results of the project. For this purpose, it uses an indirect method.

In this regard, it is necessary to carry out a number of adjustments, as a result of which the value of the net profit of the reporting period becomes equal to the increase in cash. Such adjustments are conventionally divided into three groups according to the nature of business operations:

Adjustments related to the discrepancy between the time of reflection of income and expenses in accounting with the inflow and outflow of funds for these operations. 
An example of such operations is the reflection in the accounting of proceeds from the sale of goods, products (works, services) with the provision of deferred payment to buyers. In this case, the accounting reflects the amount of revenue, but the corresponding cash inflow in this reporting period may not occur. Consequently, it is necessary to adjust the net profit indicator towards its decrease by the amount of growth in the balance of accounts receivable. And vice versa, with an increase in the amount of advances received in the form of an advance payment for future deliveries of goods, products (works, services), it is necessary to increase the amount of net profit of the reporting period by this amount.

Adjustments related to business transactions that do not directly affect the calculation of net income, but generate cash flows. In particular, the payment for the purchase of raw materials and materials and the adequate growth of the balances of tangible current assets in the analyzed period necessitates adjustments to the amount of net profit. With an increase in the balances of tangible current assets, the amount of net profit should be reduced by this amount, and with a decrease, it should be increased. Another example of this group of adjustments can be business transactions that cause a change in the short-term and long-term obligations of the organization. So, the inflow or outflow of funds in connection with the attraction or return of borrowed funds (loans, borrowings) does not cause a similar change in the financial result. Therefore, if the balances of the corresponding accounts change, the amount of net profit of the reporting period is also subject to adjustment: with their growth, the profit should be increased, with a decrease, it should be reduced.

Adjustments related to transactions that have a direct impact on the calculation of the profit indicator, but do not cause cash flows. An example of such a transaction is the accrual of depreciation of fixed assets, intangible assets, low-value and wearing out items. The amount of net profit should be adjusted upwards by the amount of accrued depreciation; for the reporting period. Correction procedures affect the overwhelming part of balance sheet accounts, and calculations should be made based on the proposed general rule: in order to achieve a correspondence between the amount of the increase in cash balances and the adjusted amount of net profit, it is necessary to 
increase the net profit by the amount of capital gains (equity and borrowed sources). $\neg$ nikov funds) and reduce by the amount of the increment of assets (non-circulating, circulating). Moreover, it should be borne in mind that the amount of the increment can be both positive and negative.

Based on the results of direct and indirect analysis of cash flows, the management of the organization can adjust its financial policy in relations with debtors and creditors, make decisions on the formation of the necessary volumes of inventories, create reserves, reinvest profits, distribute and consume them, taking into account available financial capabilities and the level of security with monetary resources.

Ratio analysis is an integral part of cash flow analysis. With its help, the levels and their deviations from the planned and baseline values of various relative indicators characterizing cash flows are studied, and the coefficients of the efficiency of using the organization's funds are calculated.

An important point in the coefficient method of analysis is the study of the dynamics of various coefficients, which makes it possible to establish positive and negative trends reflecting the quality of the organization's cash flow management, as well as to develop the necessary measures to make appropriate adjustments to optimize management decisions in business process.

An important point in the analysis of cash flows is the assessment of their balance in time, deviations of multidirectional cash flows in separate time intervals. In this case, it is necessary to proceed from the criterion of minimization of possible deviations (fluctuations) in the values of the inflow and outflow of funds.

To establish the degree of synchronicity (balance) of cash flows for the analyzed period, the correlation coefficient of positive and negative cash flows is used.

The closer the value of the correlation coefficient of cash flows to one, the less the variation of fluctuations between the values of positive and negative cash flows, therefore, the less the risk of a situation of insolvency, on the one hand (in periods of excess of the values of negative cash flows over positive), and the excess of the money supply - on the other hand, testifying to the lost profit of placing surplus funds and the financial losses of the organization from the depreciation of funds in conditions of 
inflation (in periods of significant excess of the values of positive cash flows over negative ones)

Cash flow forecasting is the most poorly understood problem in financial science. It is closely related to both the strategic planning of the development of the enterprise in the future, and with the implementation of long-term financial planning.

Cash flow forecast consists in determining the possible sources of income and directions of spending money. Proceeding from the fact that most of the indicators are rather difficult to predict with great accuracy, cash flow planning comes down to drawing up a budget for cash in the forecast period, taking into account only the most important flow parameters: sales volume, share of proceeds from sales in cash, forecast of accounts payable ... The forecast is carried out for a certain period: for a year (with a breakdown by quarters); per quarter (broken down by months); per month (broken down by decade). 
DOI 10.46299/ISG.2021.MONO.ECON.II-258-263

\subsection{The growth of social confidence in the economic sphere in connection with the stated pandemic situation all over the world}

A necessary condition for the viability of the political system and the most important aspect of civil society is trust, the existence of trust as a socio-cultural phenomenon, this is well argued "a solidary community of citizens, who take part in politics and are loyal to the government, bound by strong bonds, could not exist without horizontal trust, as citizens mutually bestow each other, as well as vertical trust in public institutions "'[254].

Taking this circumstance into account, it can be concluded that the problem of citizens' trust in civil servants gains the status of one of the most important in both the political and socio-economic life of society in any country. Also, because the objects of special attention from society are civil servants in various directions of development of state systems focused on the development of capitalism, socialism or even a totalitarian system, the level of public confidence in these systems and officials representing them through their activities determines the the highest degree of social stability of society (subject to high indicators, the above-mentioned index) and its readiness for serious actions, collectively aimed at improving the quality of life of the population of the countries, reforms.

A high level of trust, which is manifested by the population in relation to the state and to civil servants, as representatives of it, also contributes to a stable socio-political situation, increases the level of interaction between state structures and civil society, has a positive effect on the quality of work of the state apparatus and, in general, becomes the basis for the formation of a favorable climate of trusting relationships in society. However, the civil service is considered the most important element of transformations in such spheres of the state's life as: power, economy, social sphere, in the sphere of national security, according to many experts, today it is not adapted and is not able to solve many strategic tasks. One of the problems, which can be called one of the key ones, regarding the functioning of the modern state, the state apparatus is that the interaction of the state and society, at the moment, does not meet the social 
needs of citizens, today there are no mechanisms on the part of the civil society of the social control over the activities of public authorities, which can and does lead to both the spread of corruption and abuse in the public service.

As a result, in the last decade in many countries there has been, with varying degrees of intensity, a significant drop in the level of trust on the part of the population in relation to the authorities. This fact is due to the growing and continuing to grow demand on the part of society for the efficiency of the work of the state and civil servants, as its representatives, for the quality of services they provide, and most importantly, for their moral character, when we talk about intolerance in relation to immoral acts, bureaucracy, corruption. actions, isolation from the interests of the population, etc.

To date, a variety of approaches have been developed for trust research. As separate scientific directions, those that study trust, both some components of public and political consciousness, and, to a large extent, its influence, can be distinguished. Many scientific studies, this indicator, which affects the economy (V.P. Zinchenko, A.V. Belyanin, V.E.Bodyul, I.K. Vladykina and S.N. Plesovskikh, D.M.Dankin, V.V. P. Goryainov, V. N. Dakhin, K. F. Zachinsky, A. V. Komina, G. L. Kertman, Yu. N. Kopylova, Yu. V. Levada, D. W. Lovell, N. N. Lobanov, V.N. Lukin, V.N. Minina, B.Z. Milner, T.M. Mozgovaya, V.A.Miroshnichenko, D.V. Olshansky, G.U. Soldatova, T.P. Skripkina, N.Yu. Tishkova, N.N. Yamko and many others). Namely, the works of D.M. Dankin. As the subject of analysis, Yu.N. Kopylova advocates the confidence of the population and is considered as a factor in increasing the social status of the authorities in the state. According to the research of A.V. Comina analyzes such factors as responsibility, authority, trust in the role of imperatives of power. In relation to the institutions of state power and management, the factors of mistrust were studied by V.N. Minina. Trust and distrust as a social and social problem are considered by T. Govir, Yu.A. Levada, T.A. Pravorotova, A.B. Ruzanov and others. Foreign studies are also devoted to the problem of political and public trust (P. Brown, D. Lewis and A. Weigert, J. Capella and K. Jamison, D. Carnevale, S. Mitchell, K. Parks and S. Comorita, A. Seligman, F. Fukuyama, M. Hezirington, R. Abramson, etc.). To assess 
the level of trust today, both foreign and Russian researchers have developed and widely used "one-dimensional" trust indices. For example, in 2008, the Levada Center created an updated methodology for calculating the Index of Social Sentiments, in accordance with which assessments of the level of public confidence in basic government institutions began to be taken into account. The TI trust index is calculated as the sum of the percentage of those who "fully trust" T, Half of those who "partially trust" NT gk.c 100:

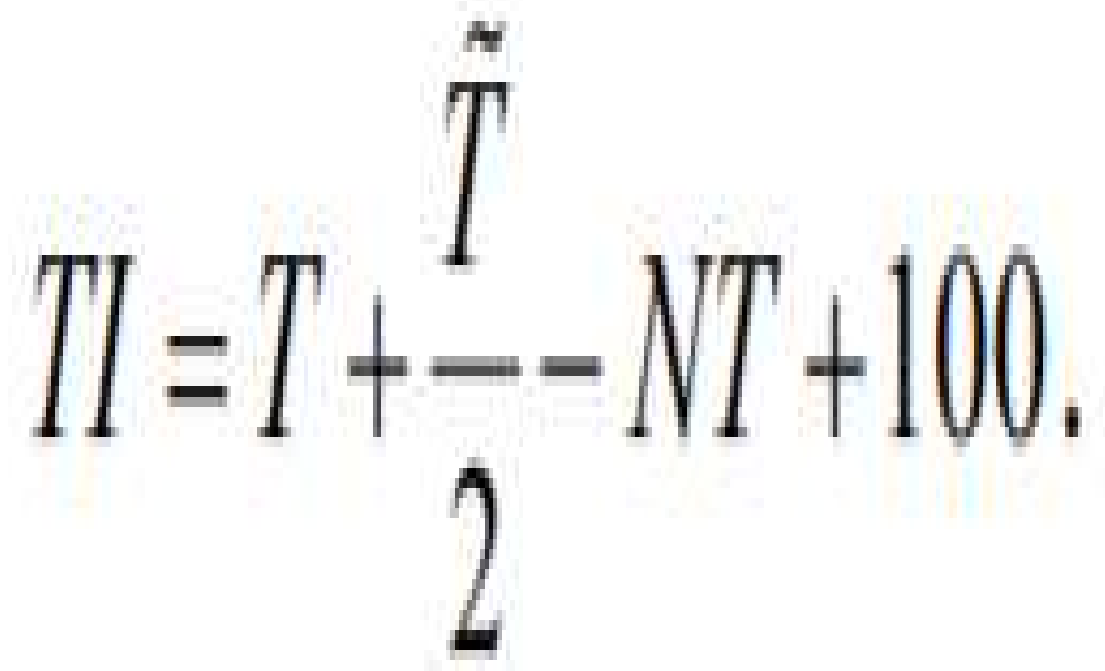

[256].

Tracking the sentiments of citizens regarding trust in the instruments of power, as its embodiment, is a very interesting and informative process.

According to the data provided by the portal of the electronic edition "NONEWS", which can be seen in more detail in Table 6.3.1, the confidence index varies significantly from country to country. The World Economic Forum annually, in its large report, The Global Competitiveness Report, includes a separate study that examines the level of citizens' trust in politicians in the country. Based on the results of the study, a list of countries is compiled by the level of public trust in politicians. [255]

Table 6.3.1.

Confidence index by countries of the world

\begin{tabular}{|l|l|l|}
\hline № & Country & Index \\
\hline 1. & Singapore & 6.4 \\
\hline 2. & UAE & 6.3 \\
\hline 3. & New Zealand & 6.1 \\
\hline
\end{tabular}




\begin{tabular}{|l|l|l|}
\hline 4 & Qatar & 5.9 \\
\hline 5. & Finland & 5.8 \\
\hline 6. & Norway & 5.7 \\
\hline 7. & Netherlands & 5.6 \\
\hline 8. & Luxembourg & 5.6 \\
\hline 9. & Switzerland & 5.5 \\
\hline 10. & Rwanda & 5.4 \\
\hline 11. & Sweden & 5.2 \\
\hline 12. & Saudi Arabia & 5.2 \\
\hline 13. & Germany & 5.1 \\
\hline 14. & Denmark & 5.1 \\
\hline 15. & Canada & 5.0 \\
\hline 16. & USA & 4.8 \\
\hline 17. & United Kingdom & 4.8 \\
\hline 18. & Hong Kong & 4.8 \\
\hline 19. & Oman & 4.7 \\
\hline 20. & Azerbaijan & 4.7 \\
\hline 21. & Ireland & 4.6 \\
\hline 22. & Australia & 4.6 \\
\hline 23. & Iceland & 4.6 \\
\hline
\end{tabular}

Although many scientists have studied the institution of trust (among them:

Fukuyama F., Kupreychenko V.A., Obosov N.N. and many others), we see that this issue has not been sufficiently studied for many reasons, and one of them is the lack of a simple and accurate way its calculation and its features of manifestation in various spheres of economic, legal, not to mention linguistic (connotations and their influence on mutual understanding between agents of a particular sphere of economic activity and the above.

Along with this, it is worth noting that it is trust, as a marketing and financial tool, that is most often used by companies to attract their customers, and when this idea is widely used to the maximum, primarily by institutions such as banks, security system manufacturers and others (trading companies, any that have social interaction).

The rational approach is based on evidence, calculations, statistics.

The purpose of this study: to establish the existence of an interdependence between the index of the level of trust in power and the economic indicators of countries, or to refute the existence of such a relationship; substantiate the results of the study; suggest possible ways and directions for further research in this area. 
To fulfill the goal set in this study and substantiate the results, we use statistical data and the calculation of the correlation coefficient.

In this study, we take into account only 2 variables, which, of course, can lead to inaccuracies.

Many conduct the research in a one-dimensional way, which obligatory leads to not only inaccuracies, but even absolute mislead in the direction of research. For instance when researching trust as an influential tool for economy we should view not only index of trust from society to the government, but from government to society as well. As this is the two way road. We should view and track the changes and the shift of balance in these to parallel and simultaneous processes to see how this living organism behaves. And we are to admit that both directions of the research and study of trust gives different outcomes because the move in different directions, but at the same time they move towards each other. As there is no other way to interact and enjoy the benefits of it.

In most of the cases these directions of movement are preconditioned with the goals, means of reaching these goals, set of resources and many more. But what make them harmonize their movement and move towards each other is the interconnection and interdependence between these two motions that actually precondition the level of life of this or that country.

And taking into account the above mentioned, facts we can conclude that these motions can be acting synergically with a very strong probability.

In this direction we are going to develop our research and for this aim we will have to take into account many more indices.

Still with the obvious need to involve many more indices we realize the risk that occure when scientist neglect such tool as astrogating.

Below is a table with an array of data, on the basis of which we tried to establish the relationship between the index of confidence in the countries listed in the table in the authorities of these countries and the relationship between the level of gross domestic income per capita in these countries by calculating the correlation coefficient. 
Table 6.3.2.

Correlation coefficient - the degree of interdependence of the index of public confidence in the authorities and the GDP of their countries.

\begin{tabular}{|c|c|c|}
\hline & GDP, USA dollars & Index of trust \\
\hline USA & 20574972485307 & 83,7 \\
\hline China & 22526559322400 & 73,9 \\
\hline Japan & 5231066130915 & 82,3 \\
\hline Germany & 4473821954811 & 81,8 \\
\hline Sweden & 547238102912 & 81,2 \\
\hline Russia & 3968180465310 & 66,7 \\
\hline Hong Kong & 449639702214 & 83,1 \\
\hline Great Britain & 3121120096107 & 81,2 \\
\hline Canada & 1843053386835 & 79,6 \\
\hline France & 3097061752487 & 78,8 \\
\hline Australia & 1262034238485 & 78,7 \\
\hline New Zealand & 210877926824 & 76,7 \\
\hline \multirow[t]{2}{*}{ Israel } & 363597897494 & 76,7 \\
\hline & & $-0,036291995$ \\
\hline
\end{tabular}

So, the correlation coefficient is -0.036291995 , based on the analysis of the data set indicated above in table 1 . What allows us, at first glance, to conclude that these indicators are not at all interconnected, BUT !, what we can really conclude is that with such a rough and abstracted calculation of the correlation coefficient, and therefore the relationship between the investigated factors less than zero.

To talk about more or less reliable conclusions, it is necessary to take into account many more indicators, such as: population, traditions, culture, immigration processes, the specifics of national production, the co-relativity of the resource potential of countries, at least.

Thus, at this stage, we can only conclude that the topic of research is very deep and requires further research. 
DOI 10.46299/ISG.2021.MONO.ECON.II-264-278

\section{4 Діяльність банків України на сучасному етапі}

Функціональний банківський сектор в Україні $\epsilon$ необхідною умовою створення ефективної ринкової економіки та сприяє завоюванню міцних позицій на світовому ринку. Для належного функціонування банківської системи в Україні розроблено нормативну базу, впроваджені принципи діяльності банків, методи та інструменти грошово-кредитної політики тощо. Однак швидкий розвиток фінансових глобалізаційних процесів ставить перед банківською системою щоразу більше завдань. За останні роки в умовах серйозних економічних та політичних кризових явищ в Україні питання щодо нинішнього стану розвитку банківської системи є вкрай актуальними.

Напрямам удосконалення функціонування банківської системи присвячено наукові праці В. Ворочек, М. Звєрякова, Е. Карлетті, В. Кротюк, О. Марианні, В. Міщенка, С. Міщенко, С. Науменкової, В. Шпачука, про те в сучасних умовах дана тематика потребує постійного дослідження та удосконалення.

Комерційні банки на сучасному етапі є найважливішою ланкою ринкової економіки. У процесі їх діяльності відбувається залучення і накопичення вільних грошей, що приносять дохід своїм власникам i одночасно $є$ джерелом формування ресурсів банків. При цьому комерційні банки забезпечують посередництво в кредитуванні через перерозподіл тимчасово вільних грошових коштів підприємств, організацій, населення, держави на умовах повернення грошового капіталу зі сфер накопичення у сфери використання. Завдяки комерційним банкам діє механізм перерозподілу капіталу за сферами і галузями виробництва. Таким чином банки мобілізують капітали, що є необхідними для розвитку економіки, а саме: розширення виробництва, інвестування, запровадження інновацій та інше. Вагомим в банківській діяльності $\epsilon$ посередництво при розрахунках, що сприяло розвитку електронних безготівкових платежів і появи найрізноманітніших форм розрахунків, зокрема платіжних карток, чеків тощо. 
Протягом останніх років розпочався активний процес інтеграції банківської системи України у світову фінансову систему на основі іiі адаптації до міжнародних вимог функціонування та регулювання банківських систем. Тому в нинішніх умовах стратегічним завданням Національного банку України $\epsilon$ розбудова стійкої, ефективної, конкурентоспроможної банківської системи, яка б сприяла довгостроковому економічному зростанню країни, іiі фінансовій безпеці, що можливо через забезпечення стійкості банківської системи, іiі прозорості та високого рівня конкурентоспроможності [273].

Банківська сфера $є$ однією $з$ провідних ланок фінансової системи, від стабільності якої залежить подальший розвиток економіки України, можливість виходу на міжнародні ринки та активної участі у глобалізаційних процесах. Останніми роками відбулися значні зміни щодо напрямів реформування банківської системи спрямовани на ії оздоровлення та розвиток. Програма реформ оздоровлення банківської системи [282], запропонована Національним банком України, призвела до суттєвого зменшення кількості банківських установі та до радикальних змін у функціонуванні системних банків.

Станом на 1 січня 2021 р. ліцензію Національного банку України отримали 74 банківських установ (зокрема 33 банки з іноземним капіталом, з них 23 з 100\% іноземним капіталом). 3 початку 2014 р. кількість функціонуючих банківських установ скоротилася на 106 (зокрема на 13 банків з іноземним капіталом). Кількість банків з 100\% іноземним капіталом збільшилась на 4. Як бачимо, в Україні спостерігається тенденція до скорочення кількості банківських установ вітчизняних власників, причому, банки 3 100\% іноземним капіталом мають тенденцію до підвищення кількості. (Таб. 6.4.1).

Чинниками, що показали накопичені проблеми банківської системи України останніми роками були економічна та політична кризи. При цьому деякі банки відмовлялися повертити кошти своїм вкладникам, інші-були не в змозі виконувати нормативи та вимоги Національного банку, а також розраховуватись за кредитами рефінансування. Декілька банків опинились на захопленій 
зовнішнім агресором території. Тому очищення банківської системи від проблемних банків було неминучим.[280]

Зростання частки іноземного банківського капіталу сприяє залученню іноземних інвестицій в країну, збільшенню обсягів кредитування населення, росту рівня рентабельності банків, підвищенню гарантування вкладів, Підвищенню якості системи управління банківськими ризиками; зростання обсягу банківських ресурсів і посилення стабільності їхніх джерел; розширення спектру банківських продуктів, комплексний підхід до обслуговування різних клієнтів; запровадження міжнародного досвіду фінансового оздоровлення, може принести в країну новітні банківські технології та фінансові продукти.

До основних негативних наслідків функціонування іноземних банків в Україні можна віднести те, що їхня присутність може послабити позиції ще недостатньо розвиненої банківської системи нашої країни. [286]

Однак в загальній кількості діючих банків в Україні спостерігається збільшення питомої ваги банків з участю держави в капіталі («Приватбанк», «Ощадбанк», «Укрексімбанк», «Укргазбанк»). Відповідні банки витримали вимоги НБУ щодо капіталізації та втримали конкурентні позиції виконуючи вимоги регулятора.

Таблиця 6.4.1.

Кількість комерційних банків в Україні з 2008 по 2020 рр.

\begin{tabular}{|c|c|c|c|}
\hline Рік & $\begin{array}{c}\text { Кількість діючих } \\
\text { банків }\end{array}$ & $\begin{array}{c}\text { 3 них з іноземним } \\
\text { капіталом }\end{array}$ & $\begin{array}{c}\text { У т. із 100\% іноземним } \\
\text { капіталом }\end{array}$ \\
\hline 01.01 .2011 & 176 & 55 & 20 \\
\hline 01.01 .2012 & 176 & 53 & 22 \\
\hline 01.01 .2013 & 176 & 53 & 22 \\
\hline 01.01 .2014 & 180 & 49 & 19 \\
\hline 01.01 .2015 & 163 & 51 & 17 \\
\hline 01.01 .2016 & 117 & 41 & 17 \\
\hline 01.01 .2017 & 96 & 38 & 18 \\
\hline 01.01 .2018 & 82 & 38 & 23 \\
\hline 01.01 .2019 & 77 & 37 & 23 \\
\hline 01.01 .2020 & 75 & 35 & 33 \\
\hline 01.01 .2021 & 74 & & \\
\hline
\end{tabular}

*3а даними [281]

Основиними причинами ліквідації банків був: незадовільний фінансовий стан та невиконання нормативів, виявлення незаконних дій після фінмоніторингів, непрозора структура власності, добровільний вихід з ринку. 
Та найбільшою проблемою була неплатоспроможність багатьох банків, тому у 2014 р. особливо гостро постало питання обов'язкового збільшення статутних капіталів (докапіталізації) банківських установ. Цей захід було спрямовано на зміцнення стійкості українських банків до різноманітних негативних впливів і ризиків, забезпечення їхньої здатності виконувати свою основну функцію фінансових посередників у процесі розвитку національної економіки.

Результатом очищення банківської системи повинне стати ефективне функціонування механізму реалізації монетарної політики Національним банком України; впевненість вкладників у вчасному та повному обсязі їхніх коштів; спрямування залучених банками коштів на кредитування бізнесу, зокрема малого та середнього, а не на фінансову підтримку компаній, що належали акціонерам банку; зниження вартості кредитів; збільшення обсягів кредитних ресурсів доступних для підприємств; підвищення стійкості банків до макроекономічних шоків підвищилася, банки матимуть достатній запас ліквідності та капіталу, щоб стабільно працювати навіть в умовах рецесії.[280]

Відповідно до цпередбачені такі групи банків:

-банки 3 державною часткою - банки, в яких держава прямо чи опосередковано володіє часткою понад 75\% статутного капіталу банку;

- банки іноземних банківських груп - банки, контрольні пакети акцій яких належать іноземним банкам або іноземним фінансово-банківським групам;

- банки $з$ приватним капіталом - банки, в яких серед кінцевих власників істотної участі $є$ один чи кілька приватних інвесторів, що прямо та/або опосередковано володіють не менше ніж 50\% статутного капіталу банку.[283]

Ліквідація проблемних банків, з одного боку, позитивно впливає на прозорість банківської системи, але разом з тим різке скорочення кількості банків, може призвести до погіршення конкурентного середовища на ринку банківских послуг та умов надання банківських продуктів, що може нести негативні наслідки для розвитку економіки в цілому. 
Слід зазначити, що для кожної країни необхідним є така кількість банківських установ котра збільшила б проникнення фінансових послуг, враховувала б реальні проблеми суб'єктів господарювання залежно від специфіки їх діяльності. Тому першочерговим завданням держави $\epsilon$ забезпечення належної банківської конкуренції, а не скорочення кількості банків. Відповідно до даних Свропейської банківської федерації на кінець 2017 року в Австрії функціонувало 572 банки, в Іспанії-206, у Франції - 422, в Італії 546, в Німеччині - 1632 установи. [293]

Аналіз сучасного стану банківської системи України дозволяє визначити найбільш гострі проблеми сучасної банківської системи до яких слід віднести негативний вплив політичних процесів, недовіра до банків, девальвація національної грошової одиниці, низький рівень ризик менеджменту банків, суперечливість механізму рефінансування українських банків; невисока якість кредитного портфеля банків тощо.

Девальвація національної грошової одиниці значно вплинула на вітчизняну банківську систему. Протягом 2014-2017 років гривня девальвувало по відношення до долара США більше ніж у три рази, що спричинило зростанню проблемної заборгованості клієнтів банків та валютних активів і зобов’язань

Основні показники банківської діяльності за останні 6 років зображено в таблиці 6.4.2.

Таблиця 6.4.2.

Основні показники банківської діяльності в Україні (млн.грн).

\begin{tabular}{|c|c|c|c|c|c|c|}
\hline Показники & 01.01 .2016 & 01.01.2017 & 01.01.2018 & 01.01.2019 & 01.01 .2020 & 01.01 .2021 \\
\hline 1. Активи банків & 1254385 & 1256299 & 1336358 & 1360764 & 1494460 & 1822814 \\
\hline 1.1.Надані кредити & 1009768 & 1005923 & 1042798 & 1118618 & 1033539 & 963664 \\
\hline $\begin{array}{lcc}\text { У } & \text { т.ч. } & \text { кредити } \\
\text { субєктам господарі }\end{array}$ & 830632 & 847092 & 870302 & 919054 & 822020 & 752503 \\
\hline $\begin{array}{lrl}\text { У } & \text { т.ч. } \\
\text { особедам } & & \\
\end{array}$ & 175711 & 157385 & 170938 & 196634 & 206761 & 199556 \\
\hline $\begin{array}{ll}\text { 2. } & \text { Зобовязання банків } \\
& \text { (млн. грн) }\end{array}$ & 1150672 & 1132515 & 1172761 & 1205114 & 1293606 & 1612474 \\
\hline $\begin{array}{lcc}\text { У } & \text { т.ч. } \quad \text { кошти } \\
\text { господарювання } & \end{array}$ & 318568 & 369913 & 403927 & 406166 & 498156 & 646491 \\
\hline У т.ч. кошти фізичних огсіб & 402137 & 437152 & 478656 & 508869 & 552592 & 682029 \\
\hline
\end{tabular}

*3а даними [285] 
Слід підкреслити, що незважаючи на зменшення кількості банків та труднощі у їх діяльності, спостерігається збільшення активів банків України, що дозволяє зробити висновок про підвищення їх потужності та стабільності. Найбільшу питому вагу в структурі активів банків посідають кредити.

Банківські кредити господарюючих суб'єктів $є$ домінуючою складовою кредитного портфелю банківської системи України. Питома вага цих кредитів у загальній сумі кредитного портфелю українських банків мала стійку тенденцію до зростання: значення цього показника становило 69\% на кінець 2019p. Але для економіки країни розвиток банківського кредитування суб'єктів господарювання є надто повільним

Основними причинами недостатнього розвитку у сфері кредитування суб'єктів господарювання в Україні є: повільне відновлення економіки після іiі падіння у 2014-2015 рр.; повільне зниження рівня інфляції; незадовільна якість вже сформованого кредитного портфелю; комплекс проблем банківської системи; інструментів безпечного та надійного інвестування вільних ресурсів банків.

Зв'язок між динамікою виробництва у базових галузях економіки та динамікою корпоративного кредитування $\epsilon$ тісним, тому що кредитні ресурси $\epsilon$ джерелом активізації виробництва та економічного зростання держави, але банки уникають кредитування збиткових, недостатньо прозорих та неплатоспроможних підприємств, фінансовий стан яких гальмує надання кредитів банками.

Ситуацію у сфері корпоративного кредитування в Україні ускладнює також значна частка підприємств, що працюють в «тіні», адже процедура надання та супроводження корпоративних кредитів передбачає всебічний аналіз балансових та інших фінансових показників підприємств, перерахунок чергових кредитних траншів на рахунки юридичних осіб у безготівковій формі, що входить у суперечність з особливостями функціонування таких підприємств.[292]

В цілому банківська система України має достатній обсяг ресурсів для кредитування. Значна частина ресурсів банків останніми роками були задіяними 
в міжбанківському кредитуванні, придбанні ОВДП та депозитних сертифікатів НБУ. Ці ресурси при сприятливих умовах могли б працювати як довгострокові кредити субєктів господарювання, однак обираючи між ризиковим кредитуванням корпоративних позичальників та значно безпечнішим кредитуванням дефіциту державного бюджету (ОВДП) чи короткостроковим кредитуванням НБУ (депозитні сертифікати) банки обирають більш надійний для себе шлях кредитування держави. Так станом на 01.01.2021року вкладення банками в цінні папери склали 791345 млн.грн., або 43\% від загальної кількості активів.

Починаючи 3 травня 2017 p. НБУ почав публікувати статистику непрацюючих кредитів (NPL), розрахованих за новими правилами на основі загальноприйнятих у світі стандартів. Частка непрацюючих кредитів (NPL) в Україні становила $41 \%$ на початок 2021 року в той час як на початок 2020 року вона становила $48 \%$, а на початок 2019 року - 53\%

У 2020 році державні банки: за рік списали 30,6 млрд у гривні та 3,1 млрд у доларовому еквіваленті. Це дозволило знизити частку непрацюючих кредитів.. У результаті загальна частка NPL у банківському секторі знизилася за 2020 рік на 7,4 в.п.

На даний час всі непрацюючі кредити визнані банками, рівень покриття їх резервами становить приблизно 98\%. ,Проте все ще велика їх частка є тягарем для банківського сектору, особливо для держбанків, у яких сконцентровано понад 70\% NPL сектору (близько 42\% припадає на Приватбанк).

Висока частка NPL - результат кредитної експансії минулих років, коли стандарти оцінювання платоспроможності позичальників були низькими, а права кредиторів недостатньо захищеними. [291]

За останні роки помітно і зріс попит на кредити серед населення. Утім, у структурі кредитування населення України поки переважають короткострокові позики (.

Банківська система на даному етапі все ще не може бути джерелом дешевих i довгострокових кредитних ресурсів. Саме високі кредитні ставки є вагомою 
перешкодою для отримання довготермінових кредитів і обмежують прагнення бізнесу позичати необхідні йому кошти в українських банках.

Позитивни в діяльності банків є зростання депозитних ресурсів банків

Також населення доволі поступово збільшує терміни зберігання своїх коштів на депозитних рахунках. При цьому в 2020 році ставки за депозитами знизилися майже вдвічі. Якщо на початку року індекс UIRD за депозитами на 12 місяців у гривні становив $15,18 \%$ річних, в доларах $-2,54 \%$, а в євро - 1,09\%, то наприкінці 2020-го - 8,63\%, 1,21\% і 0,56\% відповідно. Збільшення обсягів коштів на депозитних рахунках у вітчизняних банках передбачає зростання довіри бізнесу і населення до української банківської системи.

У загальній структурі депозитів фізичних і юридичних осіб все ще лідируючу позицію займають депозити на вимогу.

Вагомим фактором, який зупиняє клієнтів банків від відкриття строкових депозитів є неможливість скористатися достроково своїми коштами в разі потреби.

Тому банки надають деякі супутні послуги, для залучення сторокових вкладів, наприклад, відкривають кредитну лінію аж до 80\% суми депозиту на доволі вигідних умовах,.тому навіть в разі непередбачених ситуацій вклад продовжує працювати, а клієнт не втрачає прибутковість за попередній період

3 останній рік, під час карантину, спостерігалося загальне зниження бізнесактивності та падіння попиту на кредити й банківські послуги, а також наявність неплатежів за кредитами, що негативно позначається на доходах банків (Таблиця 6.4.3.).

Коронакриза погіршила фінансовий стан банків, однак кількість збиткових банків не зросла. У 2020 році з 73 платоспроможних банків 65 банків були прибутковими.

При зниженні вартості фондування та спаду ділової активності банківський сектор України залишається прибутковим. Однак прибуток банківського сектору дуже концентрований, так,ПриватБанк сформував $61 \%$ усього прибутку (25,3 млрд грн), а п'ять найприбутковіших банків - 89\% прибутку.[279] 
Таблиця 6.4.3.

\section{Доходи і витрати банків України у 2013-2020 рр.,}

Млн грн. *

\begin{tabular}{|c|c|c|c|c|c|}
\hline Показники & 2016* & $\begin{array}{c}2017^{*} \\
\text { (A4) }\end{array}$ & $\begin{array}{r}\text { 2018* } \\
(\mathbf{A 4})\end{array}$ & $\begin{array}{l}2019 \\
\text { (A4) }\end{array}$ & $2020^{*}$ \\
\hline ДОХОДИ & 190691 & 178054 & 204554 & 243102 & 249745 \\
\hline Процентні доходи & 135807 & 124009 & 140803 & 152954 & 147312 \\
\hline Комісійні доходи & 31362 & 37138 & 50969 & 62057 & 70640 \\
\hline $\begin{array}{c}\text { Результат від переоцінки та } \\
\text { від операцій купівлі- } \\
\text { продажу }\end{array}$ & 8243 & 7224 & 1853 & 16225 & 21433 \\
\hline Інші операційні доходи & 9605 & 7264 & 8589 & 8147 & 6940 \\
\hline Інші доходи & 3946 & 1349 & 1809 & 2809 & 2657 \\
\hline $\begin{array}{c}\text { Повернення } \\
\text { списаних активів }\end{array}$ & 1728 & 1070 & 532 & 909 & 763 \\
\hline ВИТРАТИ & 350078 & 204545 & 182215 & 184746 & 208449 \\
\hline Процентні витрати & 91638 & 70971 & 67760 & 74062 & 62888 \\
\hline Комісійні витрати & 7182 & 9650 & 13159 & 18096 & 24111 \\
\hline $\begin{array}{l}\text { Інші операційні } \\
\text { витрати }\end{array}$ & 10920 & 11719 & 16800 & 11790 & 16049 \\
\hline $\begin{array}{c}\text { Загальні адміністративні } \\
\text { витрати }\end{array}$ & 39356 & 44202 & 53670 & 62936 & 69302 \\
\hline Інші витрати & 3089 & 15116 & 2011 & 2379 & 2683 \\
\hline Відрахування в резерви & 198310 & 49206 & 23758 & 10714 & 29878 \\
\hline Податок на прибуток & -418 & 3681 & 5057 & 4769 & 3538 \\
\hline $\begin{array}{c}\text { Чистий прибуток } \\
\text { (збиток) }\end{array}$ & -159388 & -26491 & 22339 & 58356 & 41296 \\
\hline
\end{tabular}

*Без урахування неплатоспроможних банків. За даними: [278]

Основною причиною погіршення фінансового результату у 2020 році стало формування резервів під очікувані збитки „Витрати на резерви за кредитами у 2020 році зросли на 91\% до 20.8 млрд грн проти 10.9 млрд грн у 2019 році через визнання низки банків щодо погіршення якості активів через фінансові труднощі позичальникіів.[279]

Вагомим для подальшого розвитку банківської системи України є чіткий та налагоджений механізм ризик менеджменту банків.

Банківський ризик слід розглядати як ймовірність недоотримання доходів або зменшення ринкової вартості капіталу банку внаслідок несприятливого впливу зовнішніх чи внутрішніх чинників, стану корпоративного управління, а також потенційну можливість отримати додатковий прибуток у разі реалізації певних, прийнятних для банку, фінансових ризиків.[287] 
Для діяльності банківських установ характерними $є$ наступні ризики: кредитний ризик, ризик ліквідності, ризик зміни процентної ставки, ринковий ризик, валютний ризик, операційно-технологічний ризик, ризик репутації, юридичний ризик, стратегічний ризик . Банківська установа, проводячи різноманітні операції, свідомо бере на себе всі відповідні ризики.

Після змін, що відбулися в банківській системі останніми роками ,менеджерам довелося змінити підхід до ризик менеджменту банку, закрема до методик вимірювання ризику, стрес-тестування та корективів планів на випадок непередбачених обставин. Прозорість у роботі банків дає можливість більш чітко сформувати вимоги контролюючих органів щодо управління ризиками.

3 метою підвищення якості управління кредитним ризиком НБУ запровадив вимоги щодо контролю за оцінкою майна, що отримується в заставу за наданими кредитами. Зокрема передбачається здійснення верифікації вартості майна; ротації оцінювачів майна; моніторингу незалежності процесу відбору зовнішнього оцінювача; бек-тестування вартості майна (аналізу зіставності вартості продажу майна з його вартістю, визначеною під час останньої оцінки)

3 урахуванням результатів аналізу практичного впровадження банками та банківськими групами вимог про організацію системи управління ризиками, яке завершилось у поточному році, а також у тісній співпраці з банківською спільнотою Національний банк у змінах до зазначеного положення: передбачив право відповідальної особи банківської групи організовувати систему управління ризиками без урахування учасників банківської групи, які не мають суттєвого впливу на діяльність банків-учасників банківської групи, що сприятиме забезпеченню співставності величини ризиків та витрат на управління ними; уточнив визначення посад головного ризик-менеджера та головного комплаєнс-менеджера, що враховує різну організаційну структуру банків; спростив процедуру автоматичного ухвалення кредитних рішень для стандартизованих кредитних продуктів, що сприятиме оперативності прийняття кредитних рішень; збільшив періодичність звітування про операційний ризик перед правлінням банку та періодичність проведення стрес-тестування 
операційного ризику, що зменшить навантаження на банки під час підготовки ними управлінської звітності. [284]

У кожному банку необхідним є розробка індивідуальних програм щодо управління ризиками відповідно до складу клієнтської бази та банківських операцій відповідно до наступних принципів: рівні ризиків постійно змінюються відповідно до зовнішніх чи внутрішніх умов; ризики банків безпосередньо пов’язані з ризиками їх клієнтів; всі ризики є взаємопов'язаними.

Процес управління ризиками для банківських установ передбачає наступні етапи: визначення причин виникнення ризиків; оцінка величини ризиків; вибір методів управління ризиками для їх мінімізації; здійснення безперервного контролю за рівнем ризиків.

При управлінні ризиками банк повинен оцінити, які ризики і в якій мірі може прийняти на себе банк та проаналізувати їх на якісному та кількісному рівні.

Для ефективної діяльності банків України в сучасних умовах все більшу роль відіграють банківські асоціації, що приймають активну участь в координації діяльності комерційних банків, а також в розробці та аналізі банківського законодавства. Для підвищення ефективності роботи банківським установам необхідно постійно співпрацювати між собою, тому для захисту своїх інтересів банкам важливо об'єднуватися.

В сучасних умовах, значну увагу банкам необхідно приділяти розробленню та постійному оновленню веб-сайтів, що забезпечують надання інформації про банк та конкретні його послуги та продукти, рекламу, можливість здійснювати банківські операції клієнтами цілодобово не відходячи від комп'ютера та підтримку клієнтів. Правильно розроблений веб-сайт банку сприяє збільшенню клієнтів банку та ефективному здійсненню їх обслуговування. Головною умовою при цьому $\epsilon$ представлення банківських продуктів 3 якомога більшою зрозумілістю для клієнтів. Для цього банки застосовують різні нововведення, наприклад представляють на сайтах відое-помічники щодо надання своїх послуг у вигляді цікавих роз’яснювальних відеоролеків. 
Реалізація заходів щодо підвищення конкурентоспроможності банківських послуг комерційного банку повинна супроводжуватись коригуванням кадрової політики і орієнтації іiї на безперервність інноваційної діяльності.

Кадрова політика комерційного банку повинна включати в себе: створення умов для ефективної роботи, навчання персоналу, систему мотивації, вдосконалення та зміцнення корпоративної культури, формування колективу високопрофесійних фахівців.

Банки також здійснюють постійний контроль за роботою працівників через дослідження задоволення клієнтів методами телефонного опитування анкетування на сайтах, а також через анонімних клієнтів, що дозволяє перевірити результати роботи персоналу.

Важливими факторами в якості обслуговування клієнтів є також кількість відділень банку та зручність їх графіка роботи для клієнтів, зокрема, продовженість робочого дня, робота у вихідні дні, без перерви на обід. . Для банків дані фактори вимагають значних витрат, але в майбутньому це призводить до збільшення кількості клієнтів та підвищення рівня їх задоволеності.

Якість обслуговування в банку залежить від доступної для клієнтів системи звернень. Банки, що зацікавлені в довготривалих відносинах з клієнтами та в партнерських відносини з ними, мають створити зручну систему звернутися до керівництва банку з приводу будь-якого питання щодо діяльності банківської установи. Для цього комерційними банками можуть застосовуватись різні прийоми, зокрема безкоштовні цілодобові контактні номер телефонів.

Банківські асоціації - добровільні об'єднання банків, створене як неприбуткова організація з метою захисту та представлення інтересів своїх членів, координації роботи у сфері спільних інтересів, співпраці з органами влади у правовій сфері, розвитку міжрегіональних та міжнародних зв'язків, забезпечення наукового та інформаційного обміну і професійних інтересів, розробки рекомендацій щодо банківської діяльності.

Слід зазначити, що НБУ постійно взаємодіє із банківськими асоціаціями через консультування при прийнятті важливих рішень в банківському 
законодавстві, надає необхідні роз'яснення, розглядає пропозиції щодо питань регулювання банківської діяльності. В Україні зареєстровані і працюють наступні загальнонаціональні банківські асоціації: Асоціація українських банків (АУБ), Український кредитно-банківський союз (УКБС), Незалежна асоціація банків України (НАБУ), Українська міжбанківська асоціація членів платіжних систем "СМА", Асоціація «Українська спілка учасників платіжного ринку», Асоціація "Українська національна група членів та користувачів СВІФТ" (УкрСВІФТ).

Основними принципами створення банківських асоціацій повині бути: встановлення небхіних принципів належності до асоціації, визнання асоціації державними ораними влади, розробка правил взаємодії безпосередньо членами асоціації, встановлення чіткого контролю за виконанням правил асоціації та визначення санкцій за їх порушення.[274, С.335]

Всі банківські асоціації $є$ самоврядними громадськими неприбутковими організаціями і покривають свої операційні витрати за рахунок членських внесків. В Україні більшість банків є членами трьох основних універсальних асоціацій: АУБ, УКБС та НАБУ.

Роль банківських асоціацій для розвитку банківської системи України є значною, адже вони виявляють загальні проблеми діяльності комерційних банків та захищають їх інтереси на державному рівні. Банківські асоціації виконують вкрай важливу роль при розробці банківського законодавства а також його удосконалення та підвищенні престижу банківської діяльності.

Таким чином, на даному етапі українська банківська система розвивається, поступово долаючи кризові наслідки. Аналіз діяльності основних банківських показників засвідчив, що банківська система України подолала кризовий стан і в цілому стабілізувала свою роботу, хоча банки-поки що не в повній мірі виконують функцію ефективних фінансових посередників у частині кредитування розвитку вітчизняної економіки. Щодо простроченої заборгованості за кредитами, то банки повинні інтенсивніше розчищати баланси, при цьому непрацюючі кредити слід реструктурувати, продавати чи списувати. 
Для банківських установ в сучасних умовах необхідним є удосконалення правової бази регулювання банківської діяльності, а також більш фундаментальна оцінка їх діяльності на перспективу для прийняття швидких та ефективних рішень.

Для успішного розвитку банкам в сучасних умовах необхідним $є$ розробка заходів спрямованих на підвищення якості обслуговування клієнтів, а також модернізацію та оптимізацію банківських операцій та послуг. При цьому банкам слід звернути увагу на диверсифікацію банківських активів; впровадження нових депозитних програм; виконання та дотримання нормативів НБУ, що регулюють діяльність комерційних банків; та реалізацію нових продуктів, що не створюватимуть суттєвих ризиків.

Банкам необхідно приділяти значну увагу до пошуку шляхів щодо удосконалення напрямів управління ризиками, що сприятиме вчасному їх виявленню, оцінці та контролю. Важливим є розробка комплексної системи ризик-менеджменту банку та створення окремих банківських відділів чи комітетів 3 управління ризиками із залученням висококваліфікованих спеціалістів, що зможуть не лише оцінювати ризики, а й впроваджувати незалежну, інтегровану систему управління ними.

Реалізація даних заходів в майбутньому дозволить мінімізувати вплив негативних факторів на банківську діяльність у короткостроковій перспективі та створить умови для прискореного розвитку банківської системи України.

Роль банківських асоціацій для розвитку банківської системи України є значною, адже вони виявляють загальні проблеми діяльності комерційних банків та захищають їх інтереси на державному рівні. Банківські асоціації виконують вкрай важливу роль при розробці банківського законодавства а також його удосконалення та підвищенні престижу банківської діяльності.

Швидкість реакції банку в створенні нових технологічних продуктів $є$ важливим для обслуговування максимальної кількості клієнтів. Саме тому вітчизняним банкам доцільно постійно розвивати нові та удосконалювати традиційні канали збуту своїх продуктів та послуг 3 використанням 
високотехнологічних систем. При здійсненні операцій щодо залучення та розміщення грошових коштів банкам слід розробляти інноваційні продукти та залучати клієнтів можливістю отримання певного набору додаткових послуг та програм лояльності.

Значну увагу необхідно приділяти кадровій політиці банку шляхом запровадження мотивацій та постійного контролю за роботою персоналу. Запроваджувати більші можливості безпосереднього спілкування з клієнтами щодо здійснених операцій та консультаційних послуг.

Також слід розробити відповідні процедури контролю для кожної складової якості окремо 3 метою швидкого реагування і зміни тактики конкурентної боротьби, що в майбутньому сприятиме зростанню іміджу банку. 
DOI 10.46299/ISG.2021.MONO.ECON.II-279-285

\section{5 Сучасні аспекти діяльності бюро кредитних історій в Україні}

Бюро кредитних історій розпочинають свою діяльність 3 моменту отримання ліцензії, яку надає НБУ відповідно до Ліцензійних умов на підставі заяви бюро і документів за умови відповідності бюро кредитних історій організаційним, технологічним та кваліфікаційним вимогам.

В Україні отримали ліцензії і здійснюють профільну діяльність вісім бюро кредитних історій [294]:

- ПрАТ «ПЕРШЕ ВСЕУКРАЇНСЬКЕ БЮРО КРЕДИТНИХ ІСТОРІЙ»;

- П ПРАТ «МІЖНАРОДНЕ БЮРО КРЕДИТНИХ ІСТОРІЙ»;

- ТЗОВ «УКРАЇНСЬКЕ БЮРО КРЕДИТНИХ ІСТОРІЙ»;

- ТзОВ «УНІВЕРСАЛЬНЕ БЮРО КРЕДИТНИХ ІСТОРІЙ»;

- ТЗОВ «НЕЗАЛЕЖНЕ БЮРО КРЕДИТНИХ ІСТОРІЙ»;

- ТзОВ «БЮРО КРЕДИТНИХ ІСТОРІЙ «УКРАЇНСЬКЕ КРЕДИТНЕ БЮРО»;

- ТЗОВ «РОЗДРІБНЕ БЮРО КРЕДИТНИХ ІСТОРІЙ»;

- ТзОВ «ОНЛАЙН БЮРО КРЕДИТНИХ ІСТОРІЙ».

Однак, варто зазначити, що хоча в Сдиному реєстрі бюро кредитних історій, станом на 01.01.2021 р. зареєстровано вісім бюро, значною базою даних володіють чотири бюро: Українське бюро кредитних історій; Міжнародне бюро кредитних історій; Перше Всеукраїнське бюро кредитних історій; Бюро кредитних історій «Українське кредитне бюро», і 85\% банків зазвичай користуються послугами двох або трьох приватних кредитних бюро, що свідчить про незрілість ринку. Водночас банки більше довіряють приватним кредитним бюро з незалежним акціонерним капіталом.

Усі функціонуючі бюро кредитних історій володіють певним сегментом інформації, а тому в Україні єдиної бази кредитних історій, з якою банкам було б зручно працювати, не існує (частково формування такої бази здійснюється на рівні держави через Кредитний реєстр НБУ). Особливістю діяльності кредитних бюро в Україні є те, що на 97\% бази даних вони формують за рахунок надходження 
інформації із банків. Коефіцієнт ефективності пошуку становить близько $61 \%$ у кожного з трьох найбільших приватних кредитних бюро. За суміщення їх роботи рівень ефективності підвищується до 85\%, і якщо три бюро працюють одночасно, це дає практично повне покриття ринку. При цьому, кожне кредитне бюро має власні тарифи, що відрізняються в залежності від типу та кількості звітів.

За кількістю партнерів лідером серед бюро кредитних історій в Україні є Українське бюро кредитних історій - бюро налічує 4031 партнерів [295]. Друге місце займає Перше Всеукраїнське бюро кредитних історій, партнерами якого є 82 банки, 196 фінансових компаній та 90 кредитних спілок [296].

Українське бюро кредитних історій є також лідером щодо бази кредитних історій, в арсеналі якого 90,8 млн кредитних історій та більше 435,1 млн запитів до бюро [295] (табл.6.5.1).

Таблиця 6.5.1.

Основні показники діяльності бюро кредитних історій України

\begin{tabular}{|l|l|l|l|}
\hline $\begin{array}{l}\text { Назва бюро } \\
\text { кредитних історій }\end{array}$ & $\begin{array}{l}\text { Кількість кредитних } \\
\text { історій }\end{array}$ & Кількість партнерів & Кількість запитів \\
\hline $\begin{array}{l}\text { Перше Всеукраїнське } \\
\begin{array}{l}\text { бюро кредитних } \\
\text { історій }\end{array}\end{array}$ & 31,5 млн & 368 & 203,3 млн \\
\hline $\begin{array}{l}\text { Українське бюро } \\
\text { кредитних історій }\end{array}$ & 90,8 млн & 4031 & 435,1 млн \\
\hline $\begin{array}{l}\text { Міжнародне бюро } \\
\text { кредитних історій }\end{array}$ & 20,0 млн & 292 & 150,7 млн \\
\hline $\begin{array}{l}\text { Бюро кредитних } \\
\text { історій «Українське } \\
\text { кредитне бюро» }\end{array}$ & 15,5 млн & 81 & 8,4 млн \\
\hline
\end{tabular}

Складено за даними джерел [295, с. 3, с. 4, с. 5]

Як свідчать дані табл. 6.5.1, не всі бюро кредитних історій надають інформацію про свою діяльність щодо переліку та кількості партнерів, кількості кредитних історій тощо. Однак, навіть проаналізувавши показники чотирьох наведених у табл. 6.5.1 бюро кредитних історій, можна відмітити, що хоча кількість банків-партнерів бюро дуже різниться, насправді не можна сказати, що якесь бюро більш поінформоване, а інше - менш. Всі діючі бюро кредитних історій на сьогодні мають свої переваги - це і технологічність сервісу, і повнота інформації, і набір учасників бюро. Однозначного лідера по всіх параметрах на ринку бюро виділити 
складно. Крім цього, цінність бази визначається не тільки кількісним наповненням, а й якісним. Так часто буває, коли позичальник платить одному банку, але при цьому не платить іншому. Відповідно, такий позичальник буде цінним клієнтом для першого і стресовим для іншого банку.

У кожного бюро кредитних історій $є$ партнери серед банків. Якщо фінустанова значиться в списку партнерів, вона може запитувати інформацію про позичальників, а також передає його дані в це бюро. Якщо ж банку в списку партнерів немає, то він, відповідно, не може дізнатися інформацію про позичальника, яка доступна в бюро. Раніше кредитних бюро було більше, i, лавіруючи між різними банками-партнерами, можна було отримати позику і 3 радикально зіпсованою кредитною історією - якщо підібрати банк, який не перетинається через бюро з фінустановою, де недобросовісно погашався кредит.

Сьогодні це вже майже неможливо. На практиці банки, які видають споживчі кредити фізичним особам, $є$ учасниками будь-якого чинного бюро кредитних історій. Отримання кредиту в іншому банку за поганої кредитної історії було можливо, так як деякі банки вважали за краще економити на платних запитах кредитної історії. Але в нинішніх умовах це стає практично неможливим (банки підключаються до більш, ніж одного бюро), так як відомості про позичальника та його кредитну репутацію стають відомі всім учасникам бюро.

Звичайно банківську діяльність не можливо уявити без ризику, оскільки ризик $є$ складовою частиною функціонування банківських установ. Зважаючи на те, що кредити є найбільш прибутковими та найбільш масштабними банківськими активами (питома вага кредитів, наданих банками України у загальній величині їх активів становила у 2018 р. - 61,69\%, у 2019 р. - 55,39\% та у 2020 р. - 47,58\%), то логічно припустити, що найвагоміше значення в системі банківських ризиків належить саме кредитному ризику [299, с. 7]. Аналіз тенденцій кредитування в Україні (табл. 6.6.2) свідчить про те, що:

- за 2018-2020 роки обсяг кредитного портфеля банків України щороку зменшувався (у 2019 р. порівняно із 2018 р. обсяг кредитів зменшився на 95963 млн 
грн, тобто на 8,04\%, а у 2020 р. порівняно із 2019 р. зменшення склало 48016 млн грн, тобто 4,37\%);

- обсяг наданих кредитів корпоративному сектору також щороку зменшувався (у 2019 р. порівняно із 2018 р. обсяг кредитів зменшився на 112342 млн грн, тобто на 11,71\%, а у 2020 р. порівняно із 2019 р. зменшення склало 51854 млн грн, тобто 6,12\%);

- обсяг наданих кредитів фізичним особам у 2019 р. порівняно із 2018 р. зріс на 12050 млн грн, тобто на 5,96\%, а у 2020 р. порівняно із 2019 р. відзначається його зменшення на 100409 млн грн, тобто на 18,92\%;

- обсяг непрацюючих кредитів значно скоротився за 2018-2020 роки ( у 2019 р. порівняно із 2018 р. він зменшився на 99987 млн грн, тобто на 15,85\%, а у 2020 р. порівняно із 2019 р. зменшення склало 100409 млн грн, тобто 18,92\%);

- обсяг сформованих резервів під кредитні ризики у 2019 р. порівняно із 2018 р. зменшився на 75184,5 млн грн, тобто на 13,76\%, а у 2020 р. порівняно із 2019 р. відзначається подальше його зменшення на 106553,1 млн грн, тобто на 22,61\%, що свідчить про покращення стану кредитного портфеля банків України.

Таблиця 6.5.2.

Аналіз динаміки обсягів кредитного портфеля, проблемної заборгованості та сформованих резервів під кредитні ризики банків України за 2018-2020 роки У мільйонах гривень

\begin{tabular}{|l|l|l|l|l|l|}
\hline Роки & $\begin{array}{l}\text { Обсяг } \\
\text { кредитного } \\
\text { портфеля } \\
\text { банків }\end{array}$ & $\begin{array}{l}\text { Обсяг наданих кредитів } \\
\text { у сектору }\end{array}$ & $\begin{array}{l}\text { Обсяг } \\
\text { непрацюючих } \\
\text { кредитів }\end{array}$ & $\begin{array}{l}\text { Обсяг } \\
\text { сформованих } \\
\text { резервів під } \\
\text { кредитні } \\
\text { ризики }\end{array}$ \\
\hline 2018 р. & 1193558 & 959601 & 202202 & 630767 & 546453,1 \\
\hline 2019 р. & 1097595 & 847259 & 214252 & 530780 & 471268,6 \\
\hline Відхилення & & & & & \\
\hline абсолютне & -95963 & -112342 & +12050 & -99987 & $-75184,5$ \\
\hline Відносне, \% & $-8,04$ & $-11,71$ & $+5,96$ & $-15,85$ & $-13,76$ \\
\hline $\begin{array}{l}\text { Темп } \\
\text { приросту, \% }\end{array}$ & 91,96 & 88,29 & 105,96 & 84,15 & 86,24 \\
\hline 2020 р. & 1049579 & 795405 & 208383 & 430371 & 364715,5 \\
\hline Відхилення & & & & & $-106553,1$ \\
\hline абсолютне & -48016 & -51854 & -5869 & -100409 & $-22,61$ \\
\hline Відносне, \% & $-4,37$ & $-6,12$ & $-2,74$ & $-18,92$ & 77,39 \\
\hline $\begin{array}{l}\text { Темп } \\
\text { приросту, \% }\end{array}$ & 95,63 & 93,88 & 97,26 & 81,08 & \\
\hline
\end{tabular}

Складено за даними джерела [299, с. 7] 
Варто зауважити, що за період, який аналізується, частка непрацюючих кредитів у загальному обсязі наданих кредитів банками України з року в рік зменшується (у на 01.01.2019 р. вона становила 52,85\%; на 01.01.2020 р. - 48,36\%; на 01.01.2021 p. - 41,0\%). Така позитивна динаміка зменшення частки непрацюючих кредитів спостерігається і за кредитами наданими корпоративному сектору економіки, і наданими кредитами фізичним особам (в т.ч. і фізичним особам-підприємцям), про що свідчать дані рис. 6.5.1.

Однак, варто зазначити, що частка непрацюючих кредитів залишається досить значною, що обумовлено дією багатьох чинників, серед яких суттєве місце займає недостатність інформації про кредитну історію позичальників, наявний стан виконання позичальниками заборгованості перед іншими кредиторами та рівень кредитного навантаження на них на момент отримання кредиту у певного банку.

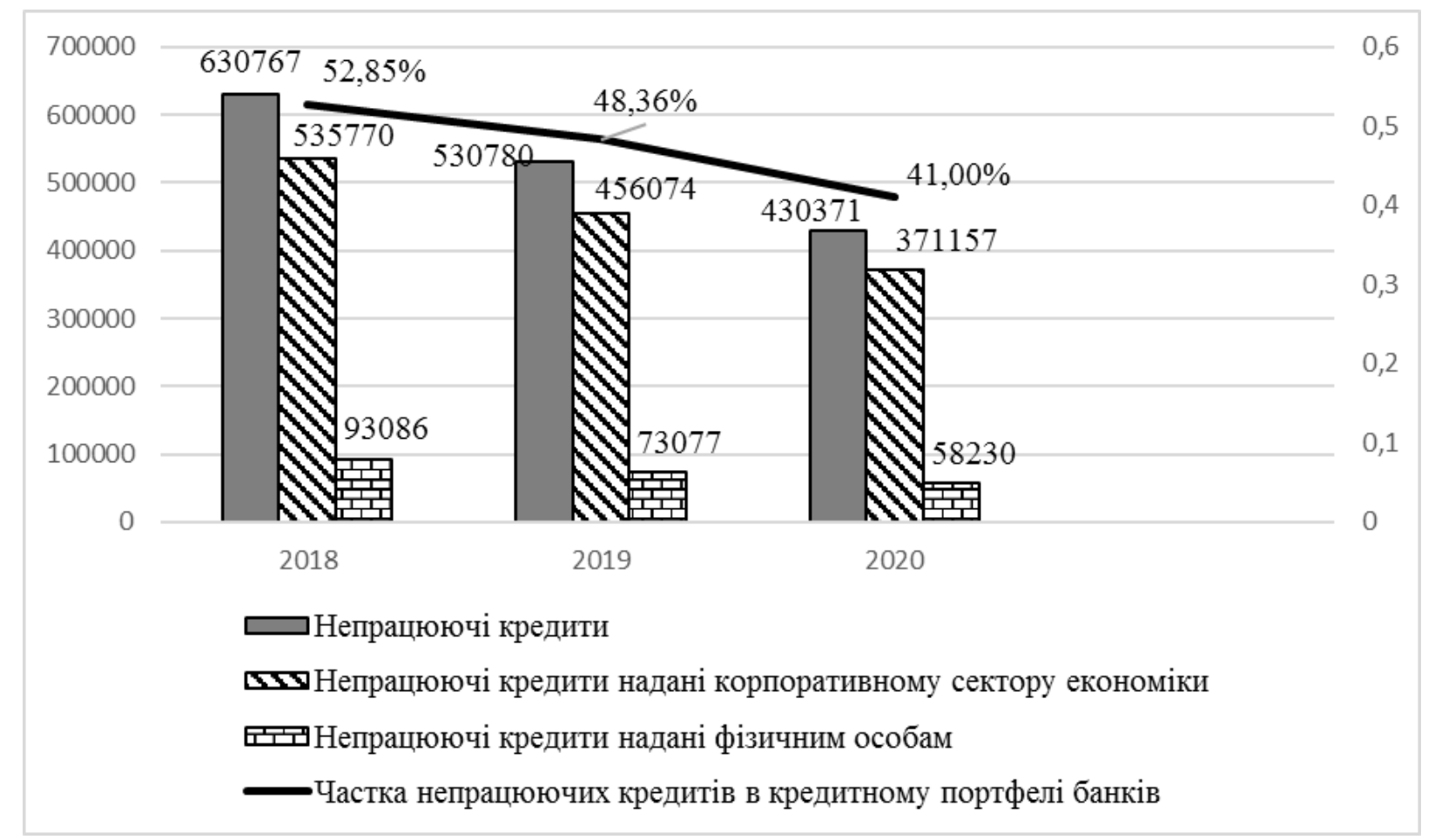

Рис. 6.5.1. Динаміка непрацюючих кредитів наданих банками України та їх частки в їх кредитному портфелі у 2018-2020 роках

Сформовано за даними джерела [299]

Адже банк бачить тільки ту інформацію, яку їм надає сам клієнт, або ту, що вже є у банку, якщо цей клієнт отримував кредит у цьому банку раніше. 
Проте, на момент звертання до банку за позикою клієнт уже може мати кредити в іншому(их) банку(ах), і невідомо, як він виконує свої боргові зобов'язання за отриманим(и) кредитом(ами), чи платить взагалі і чи буде він погашати новий кредит сумлінно.

Так, наразі, фізичні особи мають можливість одночасно брати кредити в різних банках та кредитних спілках, користуватися кредитними картками, купувати товари з розстрочкою платежу, а банки не мають можливості оцінити та проаналізувати всю заборгованість позичальників, тому позбавлені можливості достовірно оцінити їх платоспроможність, в наслідок чого зростає ризик неповернення кредитів. А відтак, неповернення кредитів як фізичними, так і юридичними особами є одною $з$ основних проблем подальшого розвитку кредитної діяльності банків і посилення їх кредитної підтримки розвитку реального сектору економіки України вирішення важливих соціальних завдань суспільства.

Слід мати на увазі, що за браком достовірної, повної і прозорої інформації про позичальника банки змушені встановлювати однаково високі ставки відсотків за кредитами для всіх позичальників, а відтак сумлінні позичальники змушені платити підвищену надбавку банку за ризик. Тобто, за недобросовісних позичальників розраховуються сумлінні позичальники. Для банків це також не вигідно, оскільки висока вартість кредитів обмежує доступ до них потенційних споживачів банківських кредитів, в наслідок чого скорочуються обороти за кредитами, доходи і прибутки від кредитної діяльності банківських установ. При цьому втрачається певна частка клієнтів. А відтак, в умовах асиметрії інформації про кредитоспроможність і платоспроможність потенційних позичальників стримується темпи зростання обсягів банківського кредитування, що негативно позначається на соціально-економічних показниках країни.

Спектр напрямів діяльності, які здійснюються бюро кредитних історій $\epsilon$ досить варіативним як в окремих бюро, так і в цій складовій інфраструктури функціонуючого кредитного ринку загалом. Першочергово ці напрями поділяються на: 
1) продукти та послуги, що надаються позичальникам;

2) продукти та послуги, що надаються партнерам бюро кредитних історій.

Так, за першим напрямом діяльності бюро кредитних історій щодо надання інформації позичальникам, надають можливість кожній особі перевіряти інформацію щодо наявності в базі даних бюро тї кредитної історії та контролювати достовірність інформації, що міститься в ній. При цьому бюро кредитних історій дбають про фінансову безпеку громадян та забезпечує зручність користування своїми інформаційними сервісами.

За другим напрямом діяльності бюро кредитних історій надають послуги i продукти своїм партнерам, вони пропонують повнофункціональний інструментарій для кредитного ризик-менеджменту. Продукти та послуги бюро можуть бути ефективно використані на всіх етапах кредитного циклу - від аплікаційної стадії до стадії стягнення.

Зазначений перелік продуктів та послуг, що надаються бюро кредитних історій постійно розширюється, а самі види послуг та продуктів удосконалюються під потреби споживачів інформації. Так, сьогодні для банківпартнерів бюро кредитних історій вкрай важливим $є$ питання ймовірності дефолту позичальника. Така послуга, яка має назву «Кредитний бал», сьогодні надається лише одним бюро кредитних історій - Українським бюро кредитних історій. Завдяки цій послузі банки можуть: швидко отримувати уявлення про потенційного позичальника - фізичну особу, підприємця, юридичну особу; поліпшити якість кредитів, що видаються; підтримувати обраний рівень якості свого кредитного портфеля; співпрацювати тільки з перевіреними та надійними партнерами та клієнтами. 


\section{SECTION 7. INNOVATIVE ECONOMY}

DOI 10.46299/ISG.2021.MONO.ECON.II-286-292

\subsection{Result-based management as the key concept for the development in the context of the digitalization of public administration}

The effective development of any region of Ukraine depends on how the functions of management are performed at different levels of management. Control is a set of tools and methods by which one object affects another, while necessarily changing its properties, state, and so on. [301]

The problem of good governance has recently become increasingly relevant at the regional level in connection with the decentralization reform in Ukraine. Modern management processes are under the influence of constant changes and need to adapt quickly to the latest conditions. The manager of the new model should be flexible and adaptable, which will help to quickly navigate the new plans for economic development. Focusing on an effective outcome in training a modern civil servant is becoming an important challenge for Ukraine.

Recent years in Ukraine can be characterized as a stage of comprehensive reforms, rethinking management and the role of a manager in general. Therefore, it is not surprising that in the context of the digitalization of public administration, attention is paid to the concepts of good governance. The use of digital technologies in the field of public administration is an important stage in the development of a competitive economy in Ukraine and will help advance the course towards digitalization of management processes.

In the context of digitalization for the development of public administration in Ukraine, one of the leading concepts can be considered the concept of "result-based management". It is worth noting results-based management (RBM) is another phrase for management by objectives (MBO), which was spearheaded by the famous scientist Peter Drucker in 1954. It was first mentioned in his book "The Practice of Management" a method of improving the efficiency of an organization, where an employee performing his duties is assessed not by the process, but by the result. It has 
also come to be known by other names such as performance based management (PBM). $\mathrm{MBO}$ - is a considered a systematic and comprehensive management approach, with a clear focus on the effective and efficient achievement of goals, including in public administration.

In the sense of results-based management, it is the emphasis on results that is essential, which has both fundamental and functional significance. In performancebased management, organizations' capabilities are used in such a way that performance plans extend from their strategic level to individual employee time-use plans. At the planning stage, the use of the will and thinking of all members of the organization has already been activated. [301]

Some of the main provisions of this concept are:

- The development of goals is needed not only for a specific organization; they must also be developed for workers. The main point is that the goals of the workers must flow from the goals of the organization itself.

- The development of goals is spoken from top to bottom to communicate with the main strategy and from the bottom up to achieve understanding with the employee.

- Taking part in decision-making. The process of developing a goal for the worker is a stage in the creative process between him and the manager. In this concept, the goals should be developed by the manager and the employee together. In this case, the boss and the worker during the discussion period have a much better understanding of what needs to be done and how to achieve the goal.

- Constant feedback and evaluation of the work performed.

What is the difference between conventional management and results-based management? The answer to this question can be found in Table 7.1.1, which shows the most characteristic features of conventional management from results-based management. 
Table. 7.1.1

Distinctive features of conventional and results-based management

\begin{tabular}{|c|c|c|}
\hline & $\begin{array}{l}\text { Conventional } \\
\text { management }\end{array}$ & Results-based management \\
\hline General characteristics & $\begin{array}{l}\text { Unclear or inaccurate } \\
\text { management system } \\
\text { aimed at achieving a } \\
\text { result. }\end{array}$ & $\begin{array}{l}\text { Management is the process of } \\
\text { finding a result (determination of } \\
\text { the result, operational } \\
\text { management, and control of } \\
\text { results). }\end{array}$ \\
\hline Planning & $\begin{array}{l}\text { Employee initiatives } \\
\text { are discouraged; there is } \\
\text { no clear connection } \\
\text { between groups and } \\
\text { individual workers. }\end{array}$ & $\begin{array}{l}\text { Clarity of the end result; position } \\
\text { of strategic management; } \\
\text { employees' initiatives are taken } \\
\text { into account; plans of activities are } \\
\text { drawn up in a calendar form; } \\
\text { budget planning. }\end{array}$ \\
\hline $\begin{array}{l}\text { Operational } \\
\text { management }\end{array}$ & $\begin{array}{l}\text { The results are due to } \\
\text { the work of the staff; } \\
\text { there is no clear link } \\
\text { between planning and } \\
\text { results. }\end{array}$ & $\begin{array}{l}\text { Management is based on linkage } \\
\text { to results; constant operational } \\
\text { control; providing assistance and } \\
\text { support in the work of staff. }\end{array}$ \\
\hline The control & $\begin{array}{l}\text { Narrow market focus; } \\
\text { no analysis, only } \\
\text { explanations. }\end{array}$ & $\begin{array}{lcr}\text { Conclusions } & \text { are made on } \\
\text { successes } & \text { and failures; } \\
\text { performance } & \text { analysis is } \\
\text { appreciated. } & & \end{array}$ \\
\hline
\end{tabular}

The process of democratization in Ukraine, its course on decentralization of the system of public administration, propaganda of involvement of citizens in public discussion and adoption of socially significant decision forces various institutions to respond effectively to the demands of society and technological progress. After all, more and more innovations are reflected in the sphere of service to citizens. This 
testifies to the spread of Technological progress and the best innovations of its market to society, to which state policy must react in a timely manner.[302]

As you know, the results-based management methodology is based on a concept called the "balanced scorecard" (BSC), which was developed in the 1980s. David Norton and Robert Kaplan. It can be noted that this approach is most successfully applied in the USA and EU countries. [303]

Monitoring the achievement of goals and monitoring the implementation of activities aimed at achieving them must be carried out using measurable indicators. The developed indicators should meet the following requirements to the greatest extent:

- adequacy: an indicator (group of indicators) should characterize progress in achieving the goal and cover all significant aspects of achieving the goal;

- accuracy: this requirement is aimed at preventing errors and ensuring such a measurement of the indicator that forms an objective view of the progress of the process of achieving the goal;

- objectivity: the use of indicators, the improvement of which leads to a aggravation in the real state of affairs, is not allowed, the indicators used should, to the least extent, create incentives for managers to carry out this kind of activity;

- reliability: the method of collecting and processing the initial information should allow the accuracy of the data obtained in the process of independent monitoring and assessment of the achievement of the goal;

- unambiguity: the definition of the indicator should provide the same understanding of the essence of the measured;

- cost-effectiveness: obtaining reporting data should be carried out at the lowest possible cost; the indicators used should be based to the maximum extent on existing information collection programs;

- comparability: the choice of indicators should be based on the need for continuous accumulation of data and the possibility of their comparison, both for separate periods, and with indicators used to assess progress in achieving similar goals, as well as with indicators used in international practice; 
- timeliness and regularity: reporting data should be received with a strictly defined frequency and with a small time lag between the time of information collection and the term of its use. For use in monitoring purposes, reporting data should be provided at least once a year and, as a rule, no more than 2-3 months after the end of the reporting period;

- uniqueness: indicators of goal achievement should not be a combination (weighted sum or product) of several indicators characterizing the solution of individual tasks related to this goal. [303]

The resulting system of indicators is the BSC, the use of which in the management process provides the foundation for building results-oriented management procedures. Thus, the BSC is a tool, the skillful application of which provides new opportunities for effective management. [303]

Ukraine's policy of digitalization will also affect monitoring in the field of public administration. For example, electronic surveys of citizens about their satisfaction with the work of local self-government will simplify further monitoring of this information.

Ukraine has taken important steps towards digitalization in public administration. The Ministry of Digital Transformation of Ukraine was established to ensure the formation and implementation of state policy in the areas of: digitalization, digital development, digital economy, digital innovations and technologies, e-government and e-democracy, information society development, informatization; in the field of electronic document management; in the field of development of digital skills and digital rights of citizens; in the areas of open data, development of national electronic information resources and interoperability, development of broadband Internet and telecommunications infrastructure, e-commerce and business; in the field of electronic and administrative services; in the areas of electronic trust services and electronic identification; in the field of IT industry development. [304]

This undoubtedly indicates that the state policy of Ukraine is focused on effective results.

Thus, in the modern sense, "result-based" has a number of characteristics that distinguish it from other forms of management activity. First, when using results-based 
management, it is imperative to set goals and objectives, as well as to understand the expected result. Results-based management is a complete cycle of activities, in which there are stages of preparation and planning, implementation and evaluation. Secondly, the scheme of work represents the relationship "goals - results", and when setting the following goals provides for attention to previous results. [305]

If we assume a complete rejection of bureaucracy and giving more flexibility to the management system through digitalization, we will get an acceleration of the process of adopting innovations in the work of organizations and changing directions of work in the case of global transformations, which cannot be ruled out. [306, 307, 308, 309, 310, 311]

The process of digitalization of services can be a great example of synergetic action of institutions of the state and civil society in the direction of state formation with a view to the socially just nature of their public. It is impossible to ignore another positive consequence of the introduction of digital technologies - the possibility to significantly simplify the mechanism of communication between citizens and state institutions, heads of various institutions, government agencies, civil servants, social workers, etc. And finally, this process has the goal of overcoming such a shameful phenomenon in Ukrainian society as corruption. [312]

Everything goes to the fact that the dominance of digital services in Ukraine is not far away. Leading states of the world, the European Union are boldly testing various programs of digital social security, launching ambitious projects of public service, stimulating public institutions to provide a wide range of administrative services. In this respect, the experience of neighboring Poland, which only a few years ago chose the path of digitalization of public services and accelerates this process every year, can be valuable for Ukraine. In particular, the fact that the "electronic platform" of public administration services has been introduced testifies to the perception of managerial innovations and IT technologies at the highest state level, and its policy envisages control and transparency of this process by representatives of various institutions and public organizations. The most important lesson to be learned from this 
is universal assistance for citizen participation in public administration and a socially responsible attitude to socially important decisions. [312]

Conclusions: Public administration in Ukraine has changed significantly and now focuses on methods that emphasize the implementation of activities. Today, the Ukrainian government faces challenges that require much greater accountability and transparency. Citizens of Ukraine, public organizations, volunteers and activists demand detailed reports on the use of budget funds and other state resources. Against the background of a decrease in confidence in political leadership, there is a need for changes that will be aimed at more transparent management that can provide an effective result. The course of Ukraine towards digitalization maximally contributes to the implementation of the concept of results-based management. This concept can become a universal tool in the management of Ukraine regarding the fight against resource leakage, inefficiency and bureaucracy of the management system. Implementation will require a radical change in the approach of civil servants to management. The digitalization process will reduce the burden on civil servants and allow them to focus on regularly and objectively measuring performance and make adjustments to improve the efficiency and effectiveness of their decisions to achieve the desired result. The application of this concept in Ukraine will increase the level of citizens' confidence in public administration, as well as increase the level of government accountability, improve the work of the management system, improve the qualifications of employees and create high-quality conditions for transparency and openness in public administration. 
DOI 10.46299/ISG.2021.MONO.ECON.II-293-299

\section{2 Реалізація організаційних рішень із забезпечення конкурентоспроможності інноваційних кластерів}

Процес розвитку інноваційних кластерів характеризується відсутністю чіткого нормативно-правового поля, яке б надавало можливість ідентифікувати інноваційні кластери у загальній сукупності господарюючих суб’єктів, та визначало можливі механізми їхнього створення та розвитку. Це ускладнює координацію взаємодії учасників кластерного процесу, а також процесів пов'язаних зі створенням та розвитком інших інноваційно-орієнтованих підприємницьких структур (індустріальні парки, бізнес-інкубатори тощо) задля забезпечення конкурентоспроможності суб'єктів підприємництва як на внутрішньому, так та зовнішніх ринках. Вагомий вплив чинить наявність надзвичайно слабкого інформаційного поля, завданням якого є налагодження ділових комунікацій між державою та бізнесом стосовно питань забезпечення максимально можливої реалізації наявного інноваційного потенціалу, зокрема шляхом комерціалізації прогресивних інноваційних розробок. Тому питання побудови структурованого інституційного середовища, яке б визначало чіткі механізми розвитку саме інноваційних підприємницьких структур в Україні є одним із ключових пріоритетів стратегічного бачення забезпечення конкурентоспроможності суб'єктів підприємництва, які є учасниками інноваційних кластерів.

Динаміка життя в сучасному світі пояснює особливий інтерес суспільства до інновацій та креативно-інноваційної діяльності. Практичне застосування нових ідей у вигляді нових товарів та технологій став потужною рушійною силою економічного та соціального розвитку. Креативно-інноваційна діяльність призвела людство до нового, вищого ступеня розвитку. Це, у свою чергу, посилило процеси глобалізації суспільства, що призвело до швидких змін технологій, а також постійного пошуку нових підходів до управління суб'єктами господарювання. Для України це важливо для продовження інтеграції у світовий економічний простір, тому активізація інновацій набуває стратегічного державного значення. Реалізація інноваційного потенціалу передбачає комплексну модернізацію національної 
економіки України. Досягнення цієї мети можливо шляхом взаємної інтеграції таких соціально-економічних зв'язків, як «наука-освіта-виробництво» [318].

Стосовно України, то для більш точного оцінювання сучасного стану вітчизняної економіки, проаналізовано місце України у наступних світових рейтингах: глобальний індекс інновацій (Global Innovation Index), глобальний індекс конкурентоспроможності (Global Competitiveness Index) та індекс легкості ведення бізнесу (Doing Business) (табл. 7.2.1).

Таблиця 7.2.1

Місця України в глобальних рейтингах у 2017-2020 pp.

\begin{tabular}{|c|c|c|}
\hline Роки & $\begin{array}{c}\text { Місця України в рейтингах/ Загальна кількість оцінюваних } \\
\text { держав }\end{array}$ & $\begin{array}{c}\text { Значення } \\
\text { індексів }\end{array}$ \\
\hline \multicolumn{3}{|c|}{ Глобальний індекс інновацій } \\
\hline 2017 & $56 / 128$ & 35,72 \\
\hline 2018 & $50 / 127$ & 37,62 \\
\hline 2019 & $43 / 126$ & 38,50 \\
\hline 2020 & $47 / 129$ & 37,4 \\
\hline \multicolumn{3}{|c|}{ Індекс легкості ведення бізнесу } \\
\hline 2017 & $143 / 190$ & 63,90 \\
\hline 2018 & $80 / 190$ & 65,75 \\
\hline 2019 & $76 / 190$ & 68,28 \\
\hline 2020 & $64 / 190$ & 4,03 \\
\hline \multicolumn{3}{|c|}{ Глобальний індекс конкурентоспроможності } \\
\hline 2017 & $79 / 140$ & 4,0 \\
\hline 2018 & $85 / 138$ & 4,11 \\
\hline 2019 & $81 / 137$ & 4,11 \\
\hline 2020 & $85 / 141$ &
\end{tabular}

Джерело: побудовано на основі [314,315,316]

Дані табл.7.2.1 свідчать, що за показником Глобального індексу інновацій Україна займає опосередковані позиції, однак спостерігається тенденція до його покращення, тобто наявне незначне посилення оцінки інноваційного розвитку саме в глобальному економічному просторі протягом досліджуваного періоду.

У 2020 році Україну за оцінками експертів GII, які представляють Корнелльський університет (США), міжнародну бізнесшколу INSEAD, а також Світову організацію інтелектуальної власності (WIPO), за рівнем інноваційності економіки Україну поставили на 45 місце серед 131 країни. Серед країн із рівнем доходу економіки нижче середнього Україна посіла за цим індексом другу позицію. Першою тут визначено В’єтнам, третьою - Індію. До першої десятки за 
глобальним інноваційним індексом у 2020 році увійшли Швейцарія, Швеція США, Велика Британія, Нідерланди, Данія, Фінляндія, Сінгапур, Німеччина та Республіка Корея. Останньою, 131-ю за інноваціями кваліфіковано Смен.

Пандемія коронавірусу спричинила значний вплив на цьогорічну інноваційну діяльність та спричинила значне падіння світових економік. Водночас, уражаючи одні галузі, COVID-19 стимулює розвиток та фінансування інновацій в інших, особливо у сфері охорони здоров'я.

Вказані значення проаналізованих показників вказують на низький рівень зацікавленості держави у створенні, внутрішній комерціалізації та просуванні на зовнішній ринок власних інноваційних технологій, та у розвитку саме інноваційного підприємництва, що своєю чергою відображається на здатності суб'єктів підприємництва розвивати свій інноваційний потенціал. Вітчизняне законодавство не визначає дієвих механізмів податкового стимулювання розвитку інноваційного підприємництва, чинні програми стимулювання розвитку підприємництва не є системно орієнтованими, цільове фінансування в межах діючих програм не завжди є достатнім та не дозволяє задовольнити потреби господарюючих суб'єктів в повному обсязі. Наявна значна кількість бюрократичних перепон від процесів реєстрації до закриття підприємств.

Аби пришвидшити поступ у цьому напрямі, Кабмін запустив роботу Ради інновацій, покликаної стати ефективним інструментом взаємодії уряду, бізнесу та представників наукових кіл, а також майданчиком напрацювання важливих рішень у цій сфері. Проте вже й сьогодні можна говорити про значний інноваційний внесок України, винаходи й започаткування в різних галузях економіки, науки, культури, які стали відомими у світі:

1. ІT-індустрія. Згідно 3 даними платіжного балансу України, експорт комп'ютерних послуг у 2020 році зріс на 30,2\% порівняно з попереднім роком i склав 4,17 млрд дол. Відповідно обсяг сплачених до держбюджету України податків та зборів збільшився на 28\% і становив 16,7 млрд грн. Експорт комп'ютерних технологій стає одним із головних джерел надходжень бюджету i піднімає Україну у світових рейтингах. 
2. Літакобудування. Флагман українського літакобудування ДП «АНТОНОВ» розробляє чимало інноваційних програм, щоб передбачити нові потреби клієнтів, забезпечити технології, продукти та послуги, необхідні для завтрашнього аерокосмічного та оборонного ринків.

3. Ракетно-космічна галузь. Новітні технології, які роблять необов'язковим перебування людей на майданчику під час підготовки носія до запуску, взяті за зразок багатьма виробниками новітньої ракетно-космічної техніки. Провідним центром космічної галузі $\epsilon$ конструкторське бюро «Південне» та виробниче об'єднання «Південний машинобудівний завод» у м. Дніпро. Там створюють та серійно виробляють ракети-носії, космічні апарати, а також системи управління, орієнтації і траєкторних вимірювань. Великим досягненням українських фахівців стало створення космічних апаратів: «Січ-1», «Океан-О», «АУОС» та «Мікрон», ракет-носіїв «Зеніт-3SL», «Зеніт-3SLБ» та «Циклон-3».

4. Культуран сфера. У серпні 2019 року розпочав роботу Офіс культурних інновацій, який заснували громадські організації в партнерстві $з$ державними та приватними інституціями. Ключове завдання Офісу - відкрити потенціал української культури й науки за посередництва інноваційної платформимаркетплейсу «Український національний інтелект» UNI.ua.

6.Банківська сфера. 3 серпня 2020 року СЕП запрацювала в режимі 24 години на добу 7 днів на тиждень. Така новація дасть можливість проводити чутливі до часу платежі, а також сприятиме розширенню доступу клієнтів до фінансових послуг та зростанню частки безготівкових розрахунків.

За версією видання «Власть денег» наприкінці 2019 року список 20 найбільш інноваційних компаній України очолили компанії Сільпо, Нова Пошта, WOG, DATA Group, Moneweo. У свою чергу, за рейтингом журналу «ТОП-100» (Новостной портал Украины Delo.ua, 2020), що формувався за підсумками 2019 року лідерами 50-ти інноваційних компаній в Україні стали такі: Метінвест (вид діяльності - промисловість), Сільпо (вид діяльності - рітейл), ДТЕК «Нафтогаз» (вид діяльності - енергетика та нафтогаз), АВК (вид діяльності - FMCG), MХП (вид діяльності - АПК), Альфа-Банк України (вид діяльності - фінанси), Taruan 
Group (вид діяльності - будівництво), Київстар (вид діяльності - IT та телеком), Фармак (вид діяльності - фармацевтика) та Нова Пошта (вид діяльності транспорт та логістика) [313].

Отже, можна прослідкувати, що найбільша частка інноваційних компаній в припадає на сферу технологій, фармацевтику, машинобудування, альтернативну енергетику, фінанси, вантажоперевезення, паливно-енергетичний комплекс тощо.

В Україні сьогодні інституційного середовища для кластерних об'єднань підприємств немає, так як кластери навіть не ідентифікуються у вітчизняному господарському законодавстві як самостійна господарська одиниця, що відображається на відсутності офіційної статистичної інформації щодо стану та динаміки їхнього розвитку у регіонах. Тому запропонований приклад механізму інформаційно-комунікаційного супроводу розвитку інноваційних кластерів в Україні, який спрямований на системне удосконалення інстутуційноорганізаційних основ розвитку інноваційного підприємництва шляхом встановлення чітких алгоритмів створення та ідентифікації інноваційних кластерів. У рамках запропонованої структури інституційно-організаційного середовища розвитку кластерів та із урахуванням попередніх досліджень, виділено можливі технології створення кластерів (кластерний сценарій - технологія створення кластера (кластерний сценарій) - сукупність нормативно-правових, інвестиційних, фінансових, інформаційних та інших організаційних рішень, що є результатом компатибільних дій усіх зацікавлених учасників спрямованих на створення нових та розвиток існуючих кластерів), які є об’єднаними у два блоки: технології у секторі державного підприємництва - вихідним джерелом стимулювання є державні інституції та технології у секторі приватного підприємництва - джерелом вихідного стимулювання є самі суб'єкти підприємництва. Визначено, що у секторі державного підприємництва можливі наступні сценарії створення кластерів: сценарій «верхньої ланки» та «регіональний сценарій». На рис. 7.2.1 представлено графічну модель технології реалізації організаційних рішень із забезпечення інноваційних кластерів в системі національної економіки. 


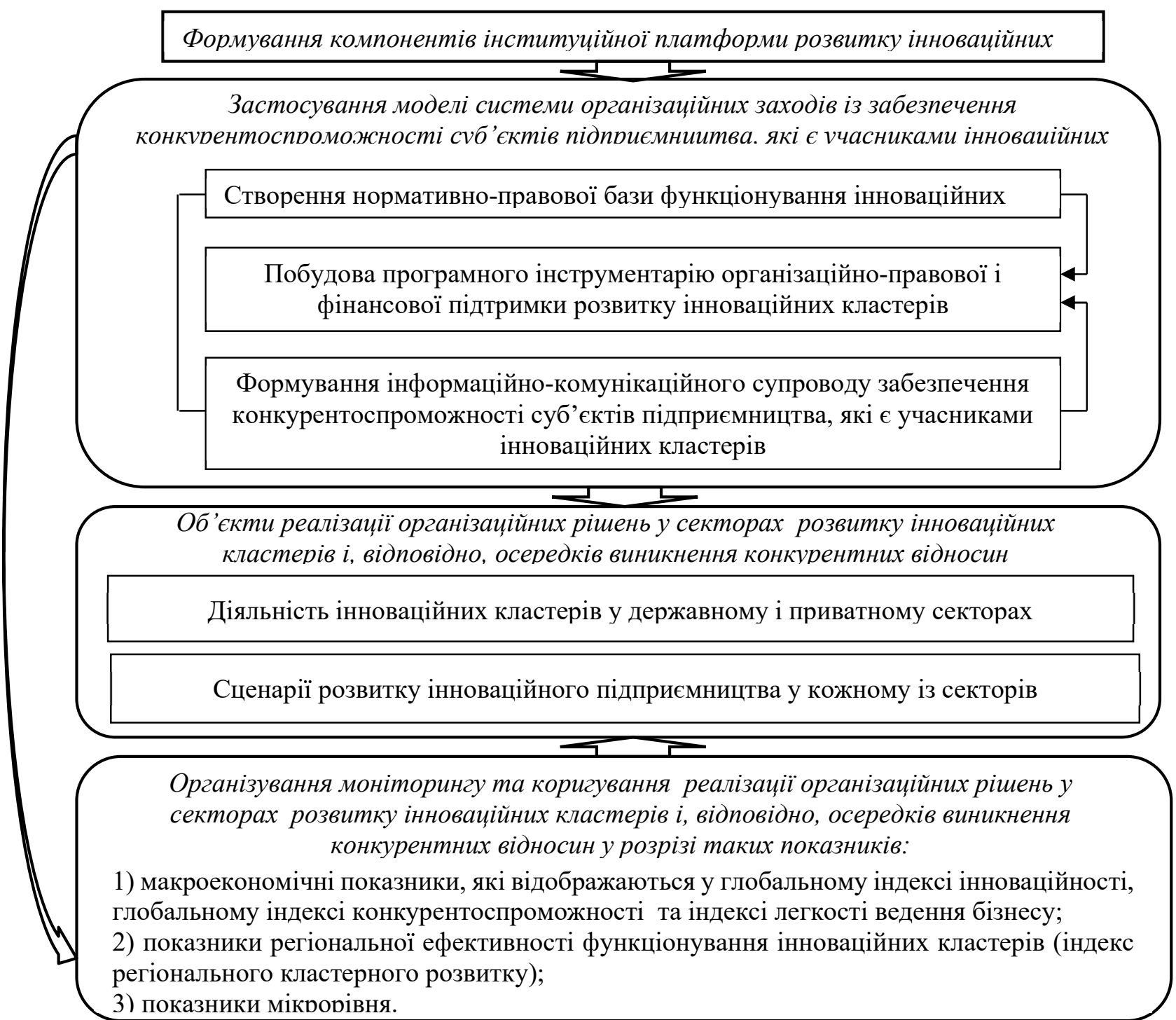

Рис. 7.2.1. Запропонована процесно-структурна модель технології реалізації організаційних рішень із забезпечення конкурентоспроможності інноваційних кластерів національної економіки

У теорії сучасного менеджменту організаційні заходи передбачають формування та переформування організаційних структур, розподіл та перерозподіл повноважень та обов'язків між суб'єктами управління, створення та коригування правил та процедур. У наведеній на рис. 1 процесно-структурній моделі технології реалізації організаційних заходів із забезпечення конкурентоспроможності інноваційних кластерів у системі національної економіки передбачено не лише формування компонентів інституційної платформи розвитку інноваційних кластерів, але й моніторинг та регулювання наслідків впроваджених рішень. Варта зазначити, що етапи представленої моделі застосовуватимуться на різних фазах управлінського процесу під час виконання функцій організування, контролювання 
та регулювання діяльності інноваційних кластерів в системі національної економіки.

Важливою сполучною ланкою між етапами застосування представленої моделі системи організаційних заходів та їхнім регулюванням $є$ моніторинг об’єктів реалізації організаційних рішень у секторах розвитку інноваційних кластерів та осередків виникнення конкурентних відносин. Його інформативність значною мірою залежить від методів та джерел акумулювання та обробки управлінської інформації, а також повноти охоплення факторів, які впливають на ефективність організаційних рішень із забезпечення конкурентоспроможності суб’єктів підприємництва, які є учасниками інноваційних кластерів в системі національної економіки. За результатами проведених досліджень, повноту відомостей, які необхідні для забезпечення інформативності моніторингу, відображатиме комплекс показників: макроекономічні показники, які відображаються у глобальному індексі інноваційності, глобальному індексі конкурентоспроможності та індексі легкості ведення бізнесу; показників регіональної ефективності функціонування інноваційних кластерів (індекс регіонального кластерного розвитку); показників мікрорівня.

Процес ефективної кластеризації з урахуванням сучасних економічних реалій потребує глибинного системного підходу спрямованого на повну трансформацію наявного інституційного середовища шляхом його функціональної структуризації. Така функціональна структуризація повинна передбачати чітке виокремлення всіх необхідних для ефективного розвитку кластерної парадигми процесів: правового забезпечення - необхідного для чіткої ідентифікації інноваційних кластерів серед інших господарюючих суб'єктів, програмного забезпечення - необхідного для стимулювання та зацікавлення суб'єктів підприємництва у створенні інноваційних кластерів, інформаційного забезпечення - необхідного для організації ефективної взаємодії всіх учасників процесу створення інноваційних кластерів та надання інструментарію аналітичного оцінювання їхньої практичної корисності економіки держави в цілому. 
DOI 10.46299/ISG.2021.MONO.ECON.II-300-306

\subsection{Innovations as the basis for socio-economic trends formation in the digital economy}

Today humanity is experiencing extremely rapid changes in innovation and the state of socio-economic systems. In such periods, the ability to control the direction of transformation processes begins to play a significant role. In the scientific literature, this direction is characterized by "trend" and "tendency". It is no coincidence that more and more attention is being drawn to such concepts in the economic literature.

Recently, the word "trend" is one of the most used terms, especially in publicistic literature. Ratings of the most relevant trends in socio-economic and sociocultural development are published annually. Each area of public life has its own top 5, 10, 20 , etc. - the hottest innovation trends at the current time.

There are significantly fewer scientific works that analyze the content and mechanisms of trend formation. In this regard, we should mention S. Atkinson's works (Atkinson, 2016). He studied the dynamics of global megatrends of socioeconomic development. A team of German scientists from the Institute for Future Studies (Horx, 2020) proposed approaches to classify various types of socioeconomic trends. C. Efrat (2014) analyzed the impact of the future state of systems,

The authors of the book "Megatrends of Tomorrow's World" (Klein et al., 2017) analyzed the dependence of the trends of the highest level on the processes of the formation of trends of the lower classes. M. Dufva (Dufva, 2020b) analyzed the patterns of the formation of trends at various levels.

At the same time, in the scientific literature on the problems of trends, little attention is paid to systemic views on the dynamics of the formation of trends; in particular, there is no analysis of the specifics of modern mega- and metatrends, which form the channel of the epoch-making trend of the phase transition to a new socio-economic formation.

This research presents a systematic analysis of the dynamics of the formation of socio-economic trends. Particular attention is paid to the analysis of the content of 
modern industrial revolutions and the role they play in the formation of the epochmaking trend of the phase transition to a new socio-economic formation.

Most researchers agree that in the first approximation, the concept of trend means a specific dynamic characteristic of the system's behavior. As soon as this characteristic is active, it characterizes the features of the process in time. To be precise, it represents the patterns (algorithm, program, and recurring characteristic periods) in the system's behavior and the change in its parameters, which is ultimately embodied in the development of the system.

The concept of a trend is associated primarily with such informational characteristics as direction, direction, and vector. However, the trend characterizes the informative parameters of changes in the state of the system and the dynamics of its energy. The trend of changing the state of the system is implemented along the trajectories on which the system seeks to function in its most effective modes for a given period and given socio-economic conditions.

The trends of socio-economic development differ in the sphere where the corresponding processes take place and in the scale of the impact on society and nature.

Scientists from the German Institute for Future Research (Zukunftsinstitut) proposed a classification of trends, depending on the areas of activity (measurements), which can conditionally be included in the sphere of influence of a particular trend.

First, one smooth line (straight or curved) cannot convey the nature of an event in the future. It always has a turbulent nature, including due to bifurcation transformations. Therefore, any trends can only approximately convey the specifics of the future state of systems. Secondly, as a rule, trends have a wave character, which causes the rise and fall of their conditional energy, that is, the forces of influence on the spheres of society in different periods. Sooner or later, any trend loses its potential and gives way to other trends. Thirdly, in the operation of trends, one can observe a specific spiral-like behavior as a rule. This means that after an inevitable extinction of their influence on society, they can eventually, relatively speaking, return in a new 
quality and new forms. As the authors of the study above note: "each trend has its counter-trend, which emits the power of the" retro"(Horx, 2020).

The primary reason for the formation of a megatrend can be various events or phenomena that arise in the sociocultural sphere (for example, an increase in the level of education or urbanization of the population), in economy (industrialization, informatization, economic crisis, etc.), in scientific research.

So far, there are no clear generally recognized formal signs of assigning specific trends to the category of "mega" or "meta". Some researchers use typically only one of the named terms, ignoring the other; some use them as synonymous words.

For a megatrend to become a metatrend, it must affect qualitative changes in a person's lifestyle (have a manifestation in the civilizational dimension) and begin to significantly influence a person's relationship with nature (electrification, automation trends, etc.).

The megatrend can be defined as a large-scale, long-term trend of social development, which causes a change in the qualitative parameters of socio-economic systems. S. Efrat details the concept of a megatrend, defining it as global stable macroeconomic forces of development that affect business, economy, society, cultures, and personal life, thereby determining our future world and its growing pace changes (Efrat, 2020). M. Esposito emphasizes the ability of megatrends to influence the future development of systems. It defines megatrends as the trajectories of largescale events that occur today but affect future changes in demographics, natural resource use, climate change or inequality (Bhasin, 2018).

Despite the different formulations, these definitions have standard definitional features. First, they assume the large-scale nature of the changes associated with the megatrend; secondly, they imply a comprehensive coverage of the spheres of public life.

Some authors even talk about a "sea" of trends (Klein et al., 2017). And this is not far from the truth. Any spheres of human activity have their own trends: scientific, economic, business (business), engineering, agricultural and others. And in each of them, there are sub-trends in narrower divisions. 
Different authors call their own "fives", "tens", "twenty," and other "twenty" critical trends of our time. They differ in content, form, scale and even the order of formation. To show the degree of diversification of modern trends, we will cite as examples just a few megatrends belonging to various fields of activity (Efrat, 2020; Mitchell, 2020). Consider an example when a megatrend is formed based on disruptive technologies. These include, in particular, the development of a personal computer, mobile phone, efficient solar panel or 3D printer.

If successful, innovations are deployed in pioneering basic industrial plants, and new products enter the market in the form of the first commercial prototypes of serial products. In the sociocultural environment, information about a new product begins to circulate (advertising, promotions, consumer reviews). This is how a megatrend is formed for adherence to new technology and innovation and (most often) to a new type of product associated with it.

The consequences of the megatrend as a primary wave are: sociocultural trend when new products find their supporters among the population and entrepreneurs; product trend - when consumers begin to switch to new types of products massively; business trend - when the use of new technologies for the production of a new kind of product turns into a profitable business platform.

As the scale of the megatrend increases, it begins to influence the relationship between humans and nature. Under the influence of the trend, qualitative changes occur in a person (in particular, his worldview, level of education, ethical principles and attitudes towards social change), which can be interpreted as civilizational transformations. In such a situation, we can say that this socio-economic trend has acquired signs of a metatrend.

The trends of individual products, born from a certain disruptive technology, like streams from a source, can, uniting with the trends of other products, gain the strength of megatrends, influencing various spheres of public life: the sociocultural environment, the economy, and business. The trends of electrification, motorization, telephony, radio, television broadcasting, computerization, the use of mobile phones, GPS, 3D printers and other social phenomena have gone this way. 
Metatrends are more significant than megatrends. They cover the relationship between man and nature and lead to civilizational transformations in society. These metatrends have been associated with the inventions of the steam engine and the internal combustion engine. Each of these events initiated changes in the use of basic types of natural resources, the average level of education of a person and his way of life. It was associated with the formation of a large number of other trends that we mentioned above. The same can be said about the formation of a number of metatrends in the 20th and 21 st centuries. These trends were associated with the development of aviation, the development of global communications (radio, television, telephone, Internet), mass computerization of the population, informatization of the economy, digitalization of information systems, the development of alternative energy sources, the development of 3D printers and other social phenomena.

To have some idea of the content of individual metatrends, we suggest that you familiarize yourself with some of the results of S. Atkinson's research on forecasting the socio-economic development of humanity (Atkinson, 2016).

Socio-economic trends - from not very noticeable trends in the development of individual products to large-scale mega- and metatrends have their characteristics that refer them as social phenomena.

The nature of the dynamics of the formation of socio-economic trends is complex. It can be assumed that metatrends are formed by the flows of megatrends, like the rivers that feed them (Dufva, 2020b). In particular, such a metatrend in innovations as the spread of additive technologies depends on developing many megatrends (computerization, digitalization, development of new materials, etc.).

At the same time, it should be noted that, once formed, the flow of the metatrend begins to influence the configuration of the megatrends that form it, dictating their requests to them. In particular, in the metatrend of the development of additive technologies, the needs of $3 \mathrm{D}$ printing begin to determine the requirements for the development of the necessary computer programs, the properties of new materials, 
digital platforms, and the like. At the same time, these indicated directions of socioeconomic progress in other spheres act as independent metatrends.

As Mikko Dufva observed: "Megatrends are influenced by metatrends that lag behind the megatrends" (Dufva, 2020a). There are periods in the history of humanity when socio-economic trends acquire the features of phase transitions to a new socioeconomic formation. Then all conditions of the person's environment change and radical changes occur in the essential foundations of the person himself. Such trends are called socio-economic revolutions.

Now humanity is experiencing a new epochal trend - a phase transition to the future socio-economic formation. Its peculiarity is that it develops in three industrial revolutions at once - the Third, Fourth and Fifth, which act as a kind of general metatrends.

Any revolution brings radical changes to society. The third, fourth, and fifth industrial revolutions (the industrial revolution, the industrial revolution, the industrial revolution), which humanity is now experiencing, promise to become the basis of the phase transition. They change all spheres of human civilization, including the means of production, institutions, lifestyle, basic needs and occupations, and many other attributes of life.

Without pretending to be a full-scale study of the topic touched upon, we will only consider the formation of socio-economic trends in the coming transition period.

Economic and business are the two critical spheres of society that ensure the production and consumption of products. Therefore, they entirely depend on the essential technologies for the production of material resources and energy.

The third industrial revolution is the phenomenon of a radical qualitative transformation of socio-economic systems, which is characterized by the following processes: the transition to renewable energy sources and raw materials, the massive introduction of additive technologies and networked production systems, a digital basis for recording and transferring information, the formation of horizontal production and consumer structures and corresponding to them solidary forms of economic relations. 
The fourth industrial revolution is the phenomenon of the introduction of cyberphysical systems into the production and consumption of products, in which fully automated networks (in particular, the Internet of Things) appear, capable of operating without direct human participation (Rifkin, 2015; Shahan, 2016; Melnyk et al, 2019). The fifth industrial revolution is a phenomenon of human adaptation to a cyberized environment, in which the personal basis of a person develops, including synergistic integration of human cognitive abilities and artificial intelligence and human biological nature and technical means.

This research was funded by a grant from the state budget of the Ukraine, "Fundamentals of the phase transition to the additive economy: from disruptive technologies to institutional sociologization of decisions" (No. 0121U109557). 
DOI 10.46299/ISG.2021.MONO.ECON.II-307-314

\section{4 Стратегія підвищення конкурентоспроможності підприємства}

В сучасних умовах активізації глобалізаційних процесів основним показником оцінки економічних позицій підприємств $\epsilon$ конкурентоспроможність. Даний критерій дозволяє оцінити лідируючі позиції на ринку, виявити сильні та слабкі сторони, можливості і загрози та сформувати стратегічні напрямки розвитку.

Вчені пропонують розглядати конкурентоспроможність підприємства як мінливу величину під впливом факторів внутрішнього i зовнішнього середовища. Під конкурентоспроможною системою управління підприємством варто розуміти сукупність чинників, що реалізують місію і цілі діяльності, виходячи з вимог зовнішнього та навколишнього середовища та потенційних можливостей підприємства.

Система управління не може існувати поза сферою виробництва i споживання різних матеріальних цінностей. У той же час вона володіє своїми трудовими, матеріальними, енергетичними, інформаційними, фінансовими та іншими ресурсами, за допомогою яких здійснює управлінські рішення i організовує випуск конкурентоздатної продукції. Таким чином, конкурентоспроможність підприємства можна назвати адаптивною системою, так як вона пов'язана 3 мінливим ринковим середовищем і зростаючими потребами суспільства.

Ступінь конкурентоспроможності підприємства, іншими словами, характер його конкурентної переваги у порівнянні з іншими підприємствами, перш за все, залежить від того, як воно організовує і виконує всі види своєї діяльності.

В табл. 7.4.1-7.4.2 наведена класифікація рівнів управління конкурентоспроможності 3 позиції двох факторів: залежно від масштабів конкуренції та рівня управління процесами підприємства. 
Таблиця 7.4.1

Рівні управління конкурентоспроможністю підприємства залежно від масштабності конкуренції

\begin{tabular}{|c|c|c|}
\hline $\begin{array}{l}\text { Рівень управління } \\
\text { конкурентоздатні } \\
\text { стю підприємства }\end{array}$ & $\begin{array}{c}\text { Основні об'єкти } \\
\text { управління }\end{array}$ & Основні результати управління \\
\hline 1 & 2 & 3 \\
\hline Нанорівень & $\begin{array}{l}\text { Конкурентоспроможність } \\
\text { продукції підприємства }\end{array}$ & $\begin{array}{lr}\text { Прибутковість, } & \text { платоспроможність, } \\
\text { забезпечення } & \text { конкурентного } \\
\text { маневрування та ін. } & \end{array}$ \\
\hline \multirow[t]{2}{*}{ Мікрорівень } & $\begin{array}{l}\text { Конкурентні переваги } \\
\text { підприємства та } \\
\text { конкурентоспроможність } \\
\text { підприємства }\end{array}$ & 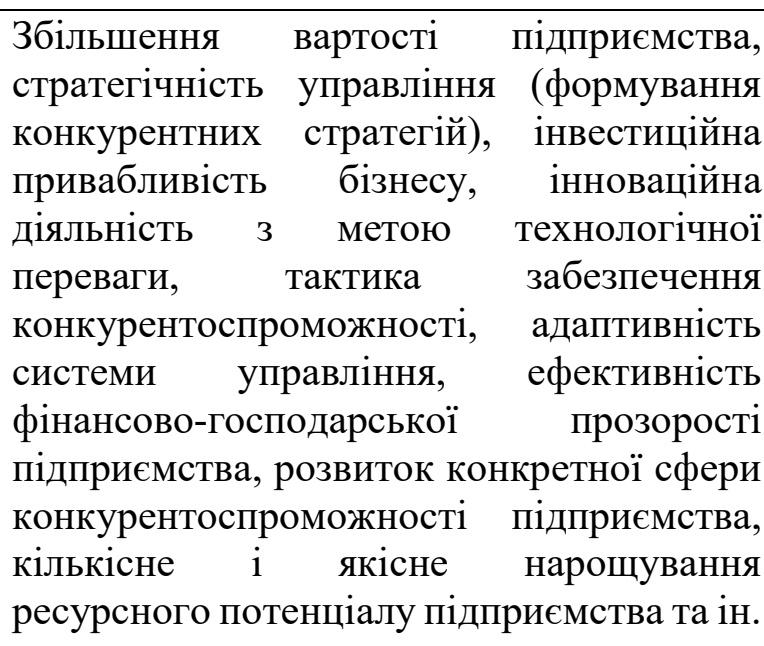 \\
\hline & $\begin{array}{l}\text { Конкурентоспроможність } \\
\text { диверсифікації мережевих } \\
\text { структур } \quad \text { (кластери, } \\
\text { технопарки і т.п.) }\end{array}$ & $\begin{array}{l}\text { Конкурентні та партнерські відносини } \\
\text { підприємства } 3 \text { іншими підприємствами, } \\
\text { приватними підприємцями, розвиток } \\
\text { кластерних структур як інструменту } \\
\text { захисту вітчизняних товаровиробників і } \\
\text { збереження його ефективності діяльності } \\
\text { та конкурентоспроможності }\end{array}$ \\
\hline \multirow[t]{2}{*}{ Мезорівень } & $\begin{array}{l}\text { Конкурентоспроможність } \\
\text { галузі }\end{array}$ & $\begin{array}{l}\text { Здатність підприємств створювати обсяг } \\
\text { доданої вартості конкретної галузі, } \\
\text { підвищення ефективності використання } \\
\text { факторів виробництва, забезпечення } \\
\text { інвестиційної привабливості галузі, } \\
\text { освоєння нових ринків підприємствами } \\
\text { галузі }\end{array}$ \\
\hline & $\begin{array}{l}\text { Конкурентоспроможність } \\
\text { регіону, міжрегіональних і } \\
\text { міжгалузевих об'єднань }\end{array}$ & $\begin{array}{l}\text { Підвищення } \\
\text { підприємстввності діяльності } \\
\text { систем }\end{array}$ \\
\hline
\end{tabular}


Продовження табл. 7.4.1

\begin{tabular}{|c|c|c|}
\hline 1 & 2 & 3 \\
\hline Макрорівень & $\begin{array}{l}\text { Конкурентоспроможність } \\
\text { країни }\end{array}$ & $\begin{array}{l}\text { Здатність країни конкурувати } 3 \text { іншими } \\
\text { країнами, рівень ії комплексного } \\
\text { розвитку, яке визначається якістю життя } \\
\text { населення, збільшення частки продукції } \\
\text { нових високотехнологічних } \\
\text { наукомістких галузей у валовому } \\
\text { внутрішньому продукті, якістю товарів, } \\
\text { робіт і послуг, ступенем інтегрованості } \\
\text { країни у світове співтовариство, зрілістю } \\
\text { політичної та економічної систем і ін. }\end{array}$ \\
\hline Мегарівень & $\begin{array}{l}\text { Міжнародна конкуренція, } \\
\text { що носить } \\
\text { інтернаціональний } \\
\text { характер }\end{array}$ & $\begin{array}{l}\text { Розвиток діяльності найбільших ТНК, } \\
\text { крупних експортерів продукції } \\
\text { імпортерів сировини, обладнання та ін. }\end{array}$ \\
\hline
\end{tabular}

Таблиця 7.4.2

Рівні управління конкурентоспроможністю підприємства залежно від рівня управління процесами підприємства

\begin{tabular}{|c|c|c|}
\hline $\begin{array}{c}\text { Рівень управління } \\
\text { конкурентоздатністю } \\
\text { підприємства } \\
\end{array}$ & $\begin{array}{c}\text { Основні об'єкти } \\
\text { управління }\end{array}$ & Основні результати управління \\
\hline Оперативний & $\begin{array}{l}\text { Конкурентоспроможні } \\
\text { сть } \quad \text { продукції } \\
\text { підприємства } \\
\end{array}$ & $\begin{array}{lr}\text { Прибутковість, } & \text { платоспроможність, } \\
\text { забезпечення } & \text { конкурентного } \\
\text { маневрування та ін. } & \\
\end{array}$ \\
\hline Тактичний & $\begin{array}{l}\text { Конкурентні переваги } \\
\text { підприємства за } \\
\text { тактичний } \\
\text { конкурентний період }\end{array}$ & $\begin{array}{lc}\text { Tактика } & \text { забезпечення } \\
\text { конкурентоспроможності, } & \text { адаптивність } \\
\text { системи управління, } & \text { ефективність } \\
\text { фінансово-господарської } & \text { прозорості } \\
\text { підприємства, керованість бізнесу }\end{array}$ \\
\hline Стратегічний & $\begin{array}{l}\text { Конкурентоспроможні } \\
\text { сть підприємства }\end{array}$ & $\begin{array}{llr}\text { Збільшення } & \text { вартості } & \text { підприємства, } \\
\text { стратегічність } & \text { управління } & \text { (формування } \\
\text { конкурентних } & \text { стратегій), інвестиційна } \\
\text { привабливість } & \text { бізнесу, } \\
\text { діяльність } 3 & \text { метою } & \text { техноцоційна } \\
\text { переваги та ін. } & & \end{array}$ \\
\hline
\end{tabular}

Досягнення конкурентоспроможності підприємства неможливе без впровадження системних інновацій, що є запорукою їх успішного розвитку.

Під стратегічної стійкістю конкурентних переваг підприємства розуміється здатність конкурентних переваг забезпечувати стратегічну технологічну конкурентоздатність виробничої системи при мінливому впливі зовнішнього і 
внутрішнього середовища.

Для довгострокового розвитку підприємства на основі процесу формування i / або підвищення його конкурентоспроможності необхідно конкретизувати складові (мал. 7.4.1), від яких найбільшою мірою залежить розглянута категорія.

В довгостроковому періоді підвищення стратегічної технологічної конкурентоспроможності можливе за рахунок вирішення наступних завдань:

- реорганізації виробничих процесів і освоєння нових технологій;

- підвищення рівня розвитку науково-дослідних і дослідноконструкторських робіт;

- підвищення якості продукції, що виробляється;

- підвищення ефективності за рахунок змін реорганізації мотиваційноконтрольних аспектів функціональної діяльності персоналу підприємства;

- підвищення якості навчання і залучення кадрів, особливо виробничого персоналу і менеджменту у виробничій системі підприємства;

- зміни підходів до управління підприємством, зокрема, оцінки поточного рівня і перспектив розвитку підприємства.

В якості основи для формування конкурентоспроможності підприємства як ключового інноваційного чинника його довгострокового розвитку, пропонується використовувати такі основні складові:

1) інноваційні технології основних та допоміжних процесів виробництва продукції;

2) інноваційні технології управління персоналом, обслуговуючим виробництво продукції;

3) інноваційні технології інфраструктурних зв'язків підприємства.

Деталізуючи представлену на малюнку 1 схему, необхідно зауважити, що під інноваційно-конкурентними технологіями процесів розуміються нові методологічні підходи організації виробничого процесу на підприємстві, що включають в себе інноваційні технології використання економічних ресурсів усіх видів, а також інноваційні технології засобів праці та інтелектуальні технології. 


\begin{tabular}{|c|c|c|}
\hline \multicolumn{3}{|c|}{ Стратегічна конкурентоспроможність підприємства } \\
\hline$\nabla$ & $\downarrow$ & $\nabla$ \\
\hline Технологія & Персонал & Інфраструктура \\
\hline$\nabla$ & $\downarrow$ & $\nabla$ \\
\hline $\begin{array}{l}\text { 1. Удосконалення та } \\
\text { інтенсифікація основних } \\
\text { виробничих процесів. } \\
\text { 2. Удосконалення та } \\
\text { інтенсифікація } \\
\text { допоміжних виробничих } \\
\text { процесів } \\
\text { 3. Скорочення тривалості } \\
\text { виробничого циклу. } \\
\text { 4. Раціоналізація системи } \\
\text { матеріально-технічного } \\
\text { забезпечення }\end{array}$ & $\begin{array}{l}\text { 1) Ліквідація різниці в планах при } \\
\text { задоволенні потреби в людських } \\
\text { ресурсах. } \\
\text { 2) Оптимальна величина набору } \\
\text { персоналу залежно від потреб. } \\
\text { 3) Застосування мотиваційних } \\
\text { заходів у вигляді коригування } \\
\text { розміру заробітної плати і } \\
\text { компенсацій. } \\
\text { 4) Профоріснтація та адаптація } \\
\text { управлінського і управлінсько- } \\
\text { технічного персоналу, які } \\
\text { обслуговують виробничі процеси } \\
\text { підприємства }\end{array}$ & $\begin{array}{l}1 \text { ) Зміни } \\
\text { інфраструктурних } \\
\text { зв'язків у вигляді } \\
\text { зміни розвитку } \\
\text { процесів інтеграції } \\
\text { підприємства } \\
\text { 2) Оптимізація } \\
\text { логістичної складової } \\
\text { інфраструктурних } \\
\text { зав'язків } \\
\text { підприємства. }\end{array}$ \\
\hline
\end{tabular}

Малюнок 7.4.1. Складові формування стратегічної технологічної конкурентоспроможності підприємства

Розглянемо кожну із складових процесу формування конкурентоспроможності підприємства докладніше.

1. Подолання виявленої різниці між фактичним і гранично можливим результатом виробничого процесу, рівнем використання технічного оснащення виробничих систем, що може бути досягнуте за рахунок удосконалення та інтенсифікації основних виробничих технологічних процесів підприємства (що забезпечить підвищення продуктивності праці i призведе до зниження собівартості виробленої продукції) шляхом:

1.1 Удосконалення виробництва і його організації в кількісних і якісних показниках; ліквідації недостатності комп'ютеризації виробництва, наприклад, впровадження більшої кількості мікропроцесів, кожен з яких орієнтований на виконання не однієї, а декількох завдань.

1.2 Удосконалення та інтенсифікації допоміжних виробничо-технологічних процесів підприємства (що забезпечить підвищення продуктивності праці i, призведе до зниження собівартості виробленої продукції) за рахунок: 
- розробки та впровадження вдосконалених способів використання контрольно-вимірювальних та інших засобів визначення якості і правильності роботи обладнання;

- розробки та впровадження удосконалених методів діагностики і усунення несправностей, регулювання, налагодження, настройки машин, механізмів, приладів, інших технічних пристроїв і об'єктів;

- дослідженнями i їх аналізом кількісних i якісних залежностей між величинами, параметрами, характеристиками технічних об'єктів.

1.3 Скорочення тривалості виробничого циклу (що забезпечить збільшення продуктивності праці і, в наслідку, зниження собівартості виробленої продукції) шляхом:

- організації ритмічної роботи відповідно до графіка;

- ліквідації простоїв в процесах обробки сировини і напівфабрикатів;

- переходом від періодичних процесів виробництві продукції до безперервних;

- раціоналізації розміщення високопродуктивного обладнання;

- раціоналізації системи планово-попереджувального ремонту обладнання;

- комплексної автоматизації та комп'ютеризації виробництва продукції;

- безперервністю транспортних операцій, збільшенням швидкостей переміщення предметів праці;

1.4. Раціоналізацією матеріально-технічного обладнання (задоволення виявленої потреби підприємства в матеріальних ресурсах рекомендується проводити на основі балансу МТО підприємства при обліку залишків i внутрішніх джерел забезпечення), тобто обсягу необхідних матеріальних ресурсів, необхідних:

- для впровадження нової техніки;

- для виготовлення оснащення та інструменту;

- на експлуатаційні і технологічні потреби;

- на створення необхідного заділу незавершеного виробництва;

- на утворення перехідних запасів. 
2. Розвитку підприємства за рахунок подолання різниці між існуючим i максимально можливим ефектом діяльності персоналу підприємства, що обслуговує технологічний і управлінсько-технологічний процеси, що може бути досягнуто за рахунок:

2.1 Ліквідації різниці в планах при задоволенні потреби в людських pecypcax.

2.2 Оптимальної величини набору персоналу в залежності від визначеної різниці.

2.3 Застосуванні мотиваційних заходів у вигляді коригування заробітної плати та компенсацій: зміна структури заробітної плати; зміна в розробках компенсацій і пільг з метою мотивації персоналу при виявленні необхідності і можливостей підприємства.

2.4 Проведення профорієнтаційних заходів та адаптація управлінського та управлінсько-технічного персоналу, які обслуговують виробничі процеси підприємства, при виявленні необхідності і можливостей підприємства, шляхом:

- розробки та впровадження програм навчання персоналу;

- розробки та впровадження скоригованих методів просування працівників на інші посади зі зміною ступеня персоніфікованої відповідальності;

- розробки та впровадження програм, спрямованих на необхідний розвиток здібностей та управлінського персоналу і т.д.

3. Розвитком підприємства за рахунок подолання різниці між потенційно ефективною кількістю інфраструктурних зв'язків підприємства та їх фактичною кількістю, в тому числі логістичних, що може бути досягнуто за рахунок:

3.1 Зміни підходів до управління підприємством, зокрема, оцінки поточного рівня і перспектив розвитку з точки конфігурації інфраструктурних зв'язків, тобто у вигляді зміни розвитку процесів інтеграції підприємства 3 різними агентами економічного середовища.

3.2 Оптимізації логістичної складової інфраструктурних зв'язків підприємства в розмірі виявлених необхідних змін, шляхом:

- оптимізації транспортних витрат (спрямованих на коригування виявленої 
різниці шляхом мінімізації транспортних витрат у вигляді раціоналізації транспортних і пов'язаних потоків;

- оптимізації логістики постачання;

- оптимізації складських витрат;

- оптимізації трансакційних витрат.

Таким чином, стратегічну конкурентоспроможність підприємства варто розглядати як узагальнену характери існуючого і потенційно можливого рівнів розвитку в конкурентному середовищі за рахунок виділення груп ресурсів, які використовуються не повною мірою, і можливостей оптимізації їх використання в довгостроковій перспективі за допомогою впровадження комплексу концептуально нових методик мобілізації резервів підприємства. 
DOI 10.46299/ISG.2021.MONO.ECON.II-315-325

\section{5 Комерційна діяльність роздрібного інтернет-магазину}

Останнім часом, зручність інтернет-покупок отримала прихильність майже всього світу. Людина може придбати товар онлайн будь-коли та будь-де, зекономивши свій час. Все більшого значення набуває комерційна діяльність, яка спрямована на здійснення купівлі-продажу товарів, та $є$ неодмінною умовою ефективної діяльності та розвитку інтернет-магазину.

Цілями даної статті є дослідження поняття «комерційна діяльність» та визначення важливості даного показника для роздрібної онлайн-торгівлі.

На сьогоднішній день переваг інтернет-торгівлі стає все більше і більше, а отже популярність покупок онлайн досить стрімко зростає. Через раптовий наплив замовлень, можливий варіант занепаду цієї сфери. На допомогу досвідченим фахівцям та виробникам приходить розумне ведення комерційної діяльності, яка зможе внести чималий розвиток у бізнес.

Комерційна діяльність - це сукупність елементів торгівельної діяльності, що направлена на отримання доходів [335].

Комерційна діяльність представляє собою сукупність послідовно виконуємих торгово-організаційних операцій, які здійснюються в процесі купівлі-продажу товарів та надання торгових послуг 3 метою одержання прибутку [336].

Для того, щоб акт купівлі-продажу пройшов успішно, торговому підприємцю потрібно провести низку оперативно-організаційних та господарських операцій, враховуючи попит населення і ринку збуту товарів, перебування покупців та постачальників продукції, налагодження 3 ними надійних відносин та господарських зв'язків, рекламно-інформаційну роботу зі збуту товарів та їхнє транспортування, організацію торгового обслуговування тощо.

Комерційною діяльністю можна визнати всі покупки товарів, що здійснюються або з метою їх подальшого продажу в тому ж вигляді або після їх 
обробки і доведення до необхідних властивостей, кондицій, якості, або навіть просто з метою здачі їх в оренду, напрокат.

В якості суб'єктів комерційної діяльності виступають і юридичні, і фізичні особи, що наділені правом іiі здійснення. Об'єктами комерційної діяльності на споживчому ринку є товари та послуги.

Основними принципами комерційної діяльності є:

- дотримання чинного законодавства;

• висока культура обслуговування покупців;

• оптимальність комерційних рішень;

• дохідність, прибутковість.

Комерційна діяльність повинна забезпечити виконання важливої функції торгівлі - товарно-грошового обігу. Для налагодження грошово-торгового обміну необхідно використовувати величезний перелік таких комерційних засобів та методів, як оптимізація цін, стимулювання збуту, прискорення оборотності коштів, диверсифікація діяльності в торгівельній сфері.

Комерційна діяльність полягає у дотриманні та виконанні низки завдань (рис. 7.5.1).

Комерційні служби підприємств повинні формувати свої зв'язки 3 партнерами на взаємовигідній основі, тобто, залучаючи до товарообігу продукцію виробників та інших постачальників різних форм власності, а також громадян, які займаються індивідуальною трудовою діяльністю, закордонних постачальників, задля розширення цільової аудиторії.

Цілі комерційної діяльності визначають її основний зміст:

• встановлення партнерських та господарських відносин із суб'єктами ринку;

- аналіз та вивчення джерел закупівлі товарів; 


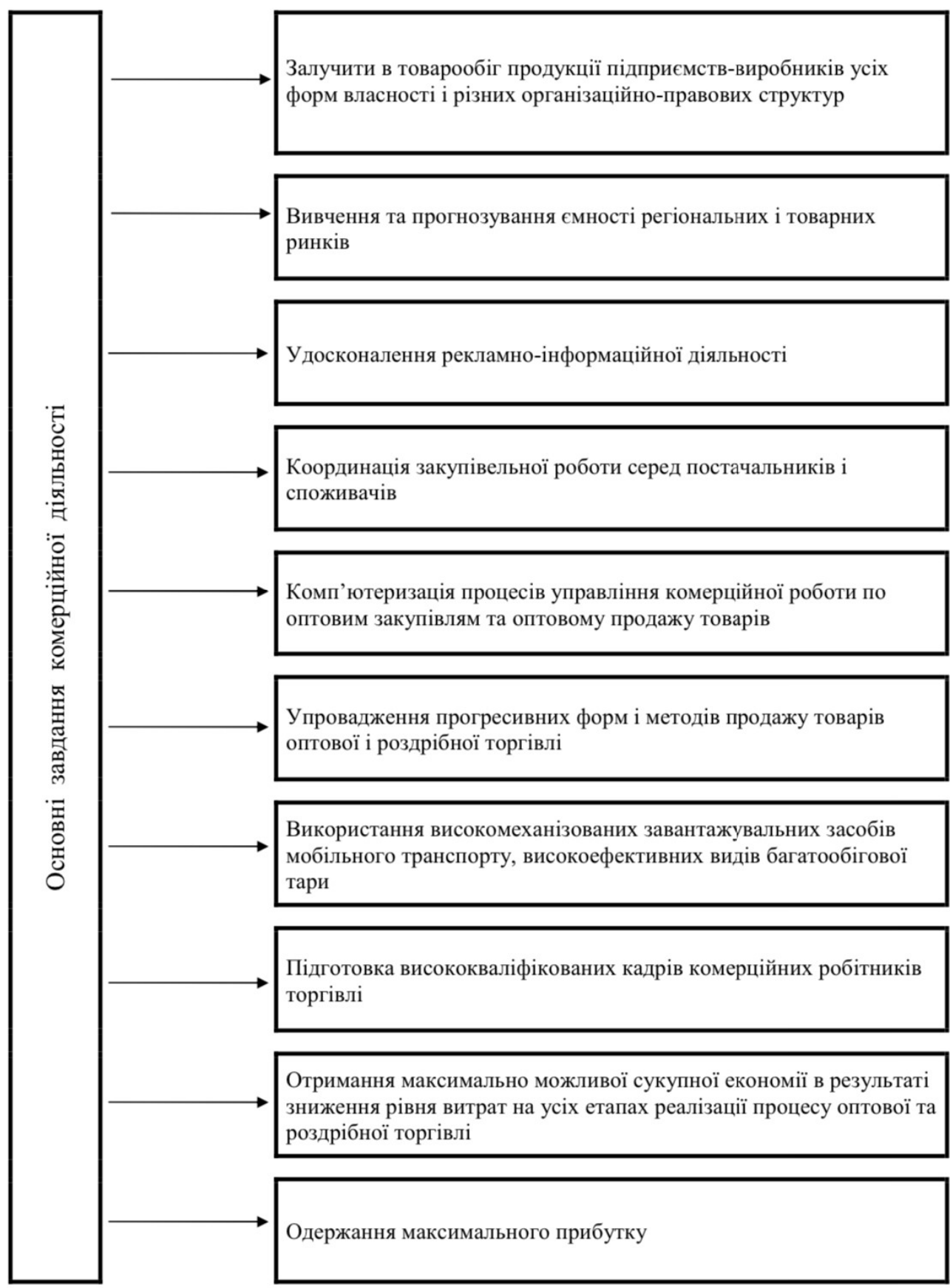

Рис. 7.5.1. Основні завдання комерційної діяльності

• узгодження зв'язку виробництва зі споживанням товарів, орієнтованих на попит покупців (обсяг і обгрунтування своєї продукції, асортимент);

• здійснення купівлі-продажу товарів з урахуванням ринкового середовища;

• розширення існуючих і перспективний розвиток цільових ринків збуту товарів;

• скорочення витрат обігу товарів. 
Діяльність роздрібного торговельного підприємства пов'язана з реалізацією продукції кінцевому споживачеві, що є останнім етапом її просування зі сфери виробництва. Предметом роздрібної торгівлі $\epsilon$ як продаж товарів, так i торговельне обслуговування та надання додаткових послуг клієнтам. Для покупців торговельне обслуговування визначається зручністю та мінімальними витратами часу на здійснення покупки та іміджем підприємства. Надані послуги супроводжуються покупкою продукції і, крім того, післяпродажним сервісним обслуговуванням реалізованих товарів. Отже, процес роздрібної торгівлі складається 3 цілеспрямованої продажу товарів, обслуговування покупців, торгових і післяпродажних послуг.

Функції роздрібної торгівлі визначаються ii сутністю і полягають у наступному:

• задоволення потреб населення за допомогою різноманітних товарів;

- доведення товарів до покупців шляхом організації просторового їх переміщення та подачі до місць продажу;

- утримання балансу між попитом та пропозицією;

• вплив на виробництво з метою розширення асортименту та збільшення обсягу продажів;

• вдосконалення процесу торгівлі та поліпшення обслуговування споживачів.

У роздрібній торгівлі комерційні операції мають свою специфіку, що в першу чергу стосується операцій, наступних за оптовими закупівлями товарів, управління товарними запасами та управління асортиментом товарів. Свою специфіку мають послуги підприємств роздрібної торгівлі та їхня рекламно-інформаційна діяльність.

Оскільки в роздрібній торговельній мережі завершується процес доведення товарів від виробництва до споживача, то комерційна діяльність, пов'язана 3 роздрібним продажем товарів, є найбільш відповідальною, тому що на цьому етапі доводиться мати справу 3 кінцевим споживачем товару. Тому дуже важливо не тільки запропонувати роздрібному покупцеві широкий вибір 
високоякісних товарів, великий перелік послуг, але і використовувати при цьому сучасні, зручні для покупця методи продажу, прогресивні системи розрахунку за покупки тощо.

Розробка Інтернет-магазину та його використання є поширеним питанням на сьогоднішній день, оскільки мільйони людей щодня, не виходячи 3 дому, купують різні товари в електронних магазинах. У світі, а особливо в Україні, величезними темпами зростає кількість користувачів Інтернету і, як наслідок, кількість «електронних» покупців.

Інтернет зближує покупців, реакція на будь-яку подію виникає практично негайно, а відстані зникають. Інтернет-магазини істотно зменшують витрати виробника, заощадивши на утриманні звичайного магазина, розширюють ринки збуту, так само як і розширює можливість покупця - купувати будь-який товар у будь-який час в будь-якій країні, в будь-якому місті, у будь-який час доби. Це дає інтернет-магазинам перевагу перед звичайними магазинами. Цей момент $є$ істотним під час переходу виробників із «звичайної» торгівлі на «електронну».

Онлайн-магазин (електронний магазин) - це комплекс, який дозволяє продавати товари чи послуги через віртуальну мережу «Інтернет» та автоматизувати управління бізнес-процесами. Інтернет-магазини об'єднують елементи традиційної торгівлі та прямого маркетингу. Основними відмінностями інтернет-магазину від традиційного $\epsilon$ інтерактивність, велика кількість інформації та асортименту продукції і персоналізований підхід до кожного покупця. Найбільшим недоліком електронних магазинів є те, що не можна доторкнутися до товару та оцінити його візуально. Але, даний недолік 3 успіхом компенсується великою кількістю інформації, яку не зможе надати продавець в традиційному магазині.

Основними функціями онлайн-магазину є:

- надання насиченої інформації про представлені товари та послуги;

- прийом та обробка замовлень;

- персоналізація споживачів;

- проведення платежів; 
- збір та аналіз статистичної інформації.

Електронний магазин - це сайт, оснащений онлайн-вітриною, що дозволяє приймати замовлення не тільки по телефону, але і через сайт на електронну пошту.

Інтернет-магазин дозволяє оформляти взаєморозрахунки з покупцями, як за готівку, так і за безготівковим розрахунком з можливістю отримання рахункуфактури і вибором «з ПДВ» або «без ПДВ».

Онлайн-магазин також включає всі функції вирішення корпоративного сайту, що дозволяє в рамках цього рішення об'єднати повноцінний корпоративний сайт з роздрібним або оптовим електронним магазином.

Даний онлайн-магазин підійде для тих споживачів, які планують ефективно почати продавати, швидко і недорого організовувати онлайн-вітрину з функцією замовлення товарів за допомогою інтернету.

До переваг онлайн-покупок можна віднести:

•Економія часу. В інтернеті $\epsilon$ можливість вибрати i порівняти характеристики товарів серед декількох магазинів. Дана процедура займе лічені хвилини, на відміну від походів традиційними магазинами. Покупка потрібного товару через інтернет зекономить такий вельми дорогий час для людства. Інтернет-магазин доступний 24 години в добу, 7 днів на тиждень, 365 днів на рік. Працює без свят і вихідних, черги відсутні. Покупець може у будь-який час відірватися від вибору товару, якщо в даний момент у нього немає часу, i повернутися до вибору навіть через декілька діб (всі дані по вибраних позиціях залишаються в аккаунті користувача). Продовжити вибір можна у вільний час на робочому місці або удома, увечері або вночі.

-Низькі ціни. Більшість товарів у віртуальній мережі, можна придбати за нижчу ціну, аніж у звичайному супермаркеті. Чим це зумовлено? По-перше, в інтернет-магазині немає необхідності орендувати торгову площу, по-друге, відсутні витрати по охороні та змісту торгових залів, немає потреби витрачати гроші на найм та навчання продавців-консультантів, по-третє, не потрібно оплачувати послуги посередників. 
•Безкоштовна доставка в більшості випадків. Після оформлення замовлення і передачі його в службу доставки, кур'єр безкоштовно привозить покупку додому або в офіс, в найкращий час. У покупців інтернет-мережі «не болить голова» 3 приводу отримання замовлення, їх не тяготить думка про важку сумку від магазину до будинку.

- Свобода вибору. У відвідувачів інтернет-магазинів існує повна, нічим не обмежена свобода вибору. Сформована заявка поступає не на склад рядового роздрібного магазину, а на найбільший оптовий склад, де $\epsilon$ величезний вибір товарів. У Інтернет - магазині можна ознайомитися 3 інструкціями по застосуванню і подивитися фотографії товарів, не покидаючи улюбленого крісла перед монітором комп'ютера. Звичайно, не можна ознайомитися 3 товаром «живцем», відчути його руками, але $\epsilon$ можливість сходити в звичайний магазин, подивитися на уподобаний товар, ще раз зважити все «за і проти», й істотно заощадити значну суму грошей при покупці через Інтернет - магазин.

•Психологічний комфорт. Споживачі онлайн-магазинів не штовхаються в натовпі інших покупців, з нетерпінням чекаючи, коли підійде вільний менеджер. Там ніхто не докучає настирливими порадами і не примушує купити непотрібну річ. Відсутній будь-який тиск з боку продавця. Консультації з будь-якого питання, здійснюються через службу online підтримки: «Бажаєте замовити новинку, що ще не поступила на склад магазину? Залиште заявку і вас проінформують про надходження по електронній пошті».

•Зручність оплати. Клієнти можуть вибрати найоптимальніший спосіб оплати вибраного товару: готівкою при доставці кур'єром, поштовий або банківський переказ, оплата кредитною картою або електронними грошима (Webmoney тощо). Вони можуть відмовитися від покупки, не сплачуючи витрати при доставці.

-Анонімність. Про покупки відвідувачів інтернет-магазинів ніхто не дізнається, якщо тільки вони самі не захочуть поділитися цією інформацією. Тільки інтернет-магазин гарантує повну анонімність покупця, адже реєструватися можна під будь-яким ім'ям. 
Недоліки інтернет-магазинів:

•Недосконала система доставки. Покупці вимагають від онлайн-магазинів швидкої та якісної доставки замовлень. Покупцям дуже зручно, коли покупки доставляють за вказаною адресою прямо на будинок або на роботу. Недосконалість системи доставки виражається в:

•не дотриманні терміну доставки товару;

- Часто саме швидкість доставки $є$ визначальним чинником у вирішенні при виборі товару в Інтернет - магазині. Якщо товар потрібний терміново, то вибирається той магазин, який пропонує швидку доставку.

-дорогій доставці товару;

•Оперативність служби доставки багато в чому визначає імідж магазину. Проте, по визнанню співробітників електронних магазинів, доставка товарів $€$ одним із найслабших місць компаній.

- Не дуже зручна система оплати. Виявилось, що споживачі не раз відмовлялися від здійснення покупки по причині незапропонованої онлайнмагазином, зручної для них форми оплати. Найпоширенішою формою оплати $\epsilon$ оплата кур'єрові готівкою. Він же наголошується як найбезпечніший спосіб.

•Найбільш економним способом оплати можна віднести передоплату банківським переказом.

•Складна система замовлення. Складна система замовлення полягає в довгому і заплутаному процесі оформлення покупки. Покупцеві необхідно заповнити довгу i часто не зовсім зрозумілою форму, внаслідок чого витрачається багато часу в Інтернет, який не завжди дешево стоїть.

-Також можна відзначити повільну швидкість завантаження деяких магазинів, що може послужити причиною відходу з магазину.

•Нестабільний асортимент. Відповідно, отримати конкурентну перевагу зможе той магазин, який запропонує користувачам весь необхідний ним асортимент. 
•Крім того, нестабільний асортимент деяких магазинів, тобто коли після вибору товару і оформлення покупки виявлялося, що потрібного товару немає на складі або просто магазин так і не зв'язався з покупцем.

•Необхідність реєстрації. Деякі магазини примушують покупця проходити дуже довгий покроковий процес реєстрації. Це відлякує потенційних покупців здійснювати покупки в даному магазині, особливо коли покупець цінує час, що витрачається ним.

•Проблема віртуальності. Неможливість відчуття і доторку до товару, що купується (на картинці він може виглядати відмінно, але при отриманні може мати зовсім інший вигляд).

•Невиконання вибору замовлення. Можлива вірогідність переплутаного кольору товару, моделі, вигляду тощо.

-Втрата замовлення.

Комерційна робота роздрібної торгівлі здійснюється наступними напрямками:

• формування необхідного асортименту товарів у рамках купівельного попиту населення;

- розвиток закупівельної діяльності;

- організація господарських зв'язків з постачальниками, посередниками;

• здійснення процесу купівлі-продажу товарів, супроводжуваними комерційними угодами, товарно-грошовим обміном;

• забезпечення стійких конкурентних позицій при вирішенні комерційних завдань.

Комерційна діяльність у роздрібній торгівлі повинна розвиватися 3 урахуванням змін, що відбуваються в економіці перехідного періоду. Для досягнення цієї мети може служити цільова програма стратегічного планування комерційної діяльності роздрібного торговельного підприємства. Вона є економічним обгрунтуванням розвитку підприємства на комерційній основі, дозволяє оцінити власні потенційні можливості, містить контрольні показники у вирішенні комерційних задач, забезпечує формування фінансових ресурсів. 
У сучасному світі неможливо досягти позитивних результатів у торгівлі, поки комерційною діяльністю не буде пронизана вся сфера цієї галузі. Особлива роль у комерційній діяльності належить комерційних операцій, пов'язаних 3 обігом і доведенням товарів до споживачів. Для цього потрібні координація та взаємодія магазину 3 суміжними i територіальними комерційними структурами. На додачу, необхідно також враховувати ситуацію в галузі, регіоні і в цілому по країні.

На основі узагальнення позитивного досвіду можна виділити відправні положення у вирішенні комерційних задач торговим підприємством, до яких належать:

•чітко сформульовано основну мету магазину і відповідна область комерційної діяльності;

• освіта обгрунтованої організаційної структури комерційної служби та забезпечення іiї взаємодії з функціональними службами торгового підприємства;

•здійснення комерційних угод, товарно-грошових і товарно-обмінних операцій з купівлі-продажу з урахуванням попиту споживачів;

•пошук і заповнення суміжних та раніше не охоплених цільових ринків товарів;

•інформаційно-комп'ютерне забезпечення, що дозволяє оперативно приймати рішення і керувати комерційними процесами;

•в умовах нестабільності та непередбачуваності кон'юнктури ринку протистояння комерційним ризикам;

•навчання персоналу комерційної служби, спрямоване на вивчення економіки ринку, основ комерції, ведення комерційної справи;

•аналіз і оцінка проведеної комерційної роботи.

Комерційна діяльність - це невід'ємна умова споживчого ринку, сфери комерційного підприємництва, де відбувається обмін грошей на товари і товарів на гроші. Під нею слід розуміти процеси, пов'язані з купівлею і продажем товарів, задоволенням попиту покупців, розвитком цільових ринків товарів, 
мінімізацією витрат обігу та отриманням прибутку. При закупівлі та постачання товарів вивчається ринок, встановлюються господарські зв'язки 3 постачальниками, здійснюються комерційні операції, спрямовані на комерційні угоди, укладання контрактів та товарно-грошовий обмін. Комерційна робота повинна супроводжуватися комерційними діями і рішеннями виходячи з умов конкретної зовнішнього середовища і кон'юнктури ринку. При виконанні комерційних функцій слід грунтуватися на економічних законах ринку, фінансової політики і комерційному праві.

Торгівля, задовольняючи потреби і запити споживачів, є кінцевою ланкою діяльності суб'єктів ринку. Особлива роль належить комерційній діяльності, пов'язаної з виконанням комплексу заходів щодо доведення товарів від виробника до покупця. Основними ії завданнями є: вивчення запитів і потреб у товарах з орієнтацією на купівельну спроможність; визначення асортиментної політики, формування i регулювання процесів постачання, зберігання, підготовки до продажу та реалізації товарів в ув'язці 3 цілями діяльності підприємства, забезпечення заданого товарообігу матеріальними і трудовими ресурсами.

Отже, основними цілями комерційної роботи в роздрібній галузі, полягають у забезпеченні доведення товарів до покупців i торговому обслуговуванні 3 урахуванням вимог ринку. Цьому сприяють нові умови господарювання підприємств роздрібної торгівлі. Комерційної діяльності повинен бути притаманний динамізм, обумовлений змінами у зовнішному та внутрішному середовищі, ресурсний потенціал, технології торгівлі, фінансовий стан, що є основою функціонування роздрібної торгівлі. 


\section{SECTION 8. INTERNATIONAL ECONOMIC RELATIONS}

DOI 10.46299/ISG.2021.MONO.ECON.II-326-333

\subsection{International corporations as a strong force for economic globalization}

Economic globalization refers to increasing economic interdependence of national economies across the world through a rapid increase in cross-border movement of goods, services, technology and capital. International corporations play a key role in this process.

The global economy has become more competitive as companies of all sizes seek to expand beyond domestic borders. The Internet and information technology are among factors that have made it possible for corporations to venture into foreign markets. Before making an international move, though, it is helpful to understand common reasons why corporations enter the international business arena [337, c. 2].

1. New markets. A saturated domestic industry leaves few opportunities for companies to snap up clients. This drives them to look abroad for new customers and markets. Finding another country where demand for corporate product is higher is a far superior option to simply waiting out the slump in sales. For example, developing countries can provide an ample opportunity for new revenue sources. Discovering resources or creating partnership opportunities may also contribute to corporation's ability to tap into overseas consumer markets. The corporation can quickly establish a strong foreign presence if it has a first-mover advantage.

2. Geographic advantage. Some companies expand internationally to develop synergies in resources and strengths that multiply the value of expansion. Access to new talent pools is a common motive. For instance, some U.S. companies have expanded into Asian markets to leverage the technological expertise of local populations, boosting their own capabilities while expanding their client bases. Distribution efficiency can also be enhanced by establishing effective global systems. This is especially true for companies that source supplies on a global basis.

3. Risk diversification. Operating in multiple countries offers greater insulation from economic downturns in one or two locations. A company doing business in the 
U.S., Asia and Africa may not suffer as much from a U.S. economic slump if it's offset by better conditions in its other locations. In this example, the company can use revenue gained in other markets to sustain and develop its U.S. business.

4. Competitive parity. "Everyone is doing it" is a simple but real motive for many companies that go global. If the corporation's competitors enter foreign markets, it seems logical that this business should do so as well, conditions permitting. If the corporation has a competitive rivalry in the U.S., its competitor could gain increased brand exposure and recognition by entering markets where this corporation doesn't have the presence. By following along or entering before competitors, the corporation maintains parity in activities and exposure.

5. Creating an economy of scale. To put it simply, expanding will enable corporation to produce more units. The more units a corporation produces the lower its' per unit costs. This can increase its profit margins, but the corporation can only get the best of this through selling to more customers, which can only come through expanding to more countries. Such approach helps corporations to maximize on production and sales while effectively minimizing on the average costs.

6. The gig economy. The gig economy is one of the reasons why corporations go global. The Internet has opened the door for companies to trade all over the world. Previously, it was too expensive to do this. Now, you don't even need to have a physical presence in the country in order to do business. You can be an international company from the comfort of your own home. Many companies are now hiring teams they will never meet in person. The freelance economy can help a corporation to get projects done without the need to have employees in the same room as corporation's CEO. It's also cheaper than employing a full-time employer to do the same job. You can easily manage a global empire without visiting the places you are actually doing business in. Solid Wi-Fi connections and software options like Skype allow you to stay connected at all times. Expensive business travel is a thing of the past.

7. Cultures are homogenizing. Again, this is the work of the Internet. Cultures are becoming more and more similar as Western influences are allowed to permeate. Think back to the state of the former Soviet Union. Thirty years ago it would be 
impossible for a Western company to appeal to this audience because they had little exposure to the West. Today they dress the same as the West and they love the same stuff as the West. The corporation's audience has increased without it having to do a thing.

8. Become a trusted brand. The fact of moving internationally will increase corporate prestige as a brand. It will increase corporate overall reach because customers are going to look at an international brand and assume they can be trusted. Expanding globally significantly increases the status quo of a given company and grows its prestige among competitors and further to its consumers as a worldwide trusted brand.

9. Cost-saving reasons. Sometimes it's just a matter of cost. It's cheaper to do business abroad because a corporation can reduce production costs and pay employees in more affordable countries less. There's a reason why Apple outsources the bulk of its iPhone production to Asia. Very often corporations are searching for tax preferences allowing to reduce costs. Tax preferences are a gold mine for major global companies. It's a chance to save most of corporate profits for stakeholders, but this can only happen by expanding internationally.

Let's dwell on domestic market explanation of global corporate expansion. In this case five situations are possible [339]:

1. Domestic markets are saturated and there is pressure to raise sales and profits. When a given product exists in too much surplus in a country, companies opt to find new markets where the product demand is higher. This helps the firms grow favorably the market base as opposed to sticking at the home country where the surplus is too high. Most corporations have very ambitious sales and profit targets. If such figures have to be realized, companies have to move out of their domestic markets.

2. Domestic markets are small. Companies which have ambitions to become big will have to look for bigger markets outside their boundaries.

3. Domestic markets are growing slowly. Most companies are no longer content to grow incrementally. If such companies have to achieve high growth rates, they have to obtain some of their sales from international markets. 
4. Domestic market competition. Even if a company decides to concentrate on its domestic market, it will not be allowed to pursue its goals unhindered. Multinational companies will enter its market and make a dent in its market share and profit. The company has no choice but to enter foreign markets to maintain its market share and growth. Only a company which is internationally competitive can protect its domestic market. No market is or will be protected from incursion by multinational companies. A company's only choice is to go global, even if its prime interest is to protect its domestic turf.

5. High-cost domestic markets. The cost of doing business in certain markets is more favorable compared to other given markets, as such companies opt to expand globally and operate in the given tax heavens or regions with more friendly tax rates, or where the cost of doing business is favorably lower.

If the management of a corporation is thinking about going global, it should follow the step-to-step procedure which is as follows [340]:

1. At the first stage (market entry), companies tend to enter new countries using business models that are very similar to the ones they deploy in their home markets. To gain access to local customers, however, they often need to establish a production presence, either because of the nature of their businesses (as in service industries like food retail or banking) or because of local countries' regulatory restrictions (as in the auto industry).

2. At the second stage (product specialization), companies transfer the full production process of a particular product to a single low-cost location and export the goods to various consumer markets. Under this scenario, different locations begin to specialize in different products or components and trade in finished goods.

3. The third stage (value chain disaggregation) represents the next step in the company's globalization of the supply-chain infrastructure. At this stage, companies start to disaggregate the production process and focus each activity in the most advantageous location. Individual components of a single product might be manufactured in several different locations and assembled into final products 
elsewhere. Examples include the PC industry market and the decision by companies to offshore some of their business processes and information technology services.

4. At the fourth stage (value chain reengineering), companies seek further increase of their cost savings by reengineering their processes to suit local market conditions, notably by substituting capital for lower-cost labor. General Electric's (GE) medical equipment division, for example, has tailored its manufacturing processes abroad to take advantage of low labor costs. The company only uses a more labor-intensive production processes, but also designs and manufactures the capital equipment for its plants locally.

5. Finally, at the fifth stage (the creation of new markets), the focus is on market expansion. The McKinsey Global Institute estimates that the third and fourth stages together have the potential to reduce costs by more than $50 \%$ in many industries, which gives companies the opportunity to substantially lower their sticker prices in both old and new markets and to expand demand. The value of new revenues generated at this last stage is often greater than the value of cost savings at the other stages.

It should be noted that the five stages described above do not define a rigid sequence that all industries follow. As the McKinsey study notes, companies can skip or combine steps. For example, in consumer electronics, product specialization and value chain disaggregation (the second and third stages) occurred together as different locations started to specialize in producing different components (Taiwanese manufacturers focused on semiconductors, while Chinese companies focused on computer keyboards and other components).

Another approach for successful global expansion includes the following stages [341]:

1. Aspirational stage. This stage is marked by the aim, ambition and desire to expand globally. The corporation is ready to respond to the global challenges. This stage is characterized mainly by the following successful factors as efficient investing and well-educated human resources. This is the stage where rational approach is used to see the risk worth taking as the global market is competitive. 
2. Procedural stage. The management has to apply the knowledge acquired at the initial stage. The international research has to be conducted to reveal market conditions and customer preferences. The management has to learn "the rules of the game", develop technical knowledge and legislation knowledge, and to have adaptive learning to operate successfully. It is important to understand different legislative practices and different market characteristics. The first successful factor to be taken into account is conducting a research. The first step in the research is choosing an initial (target) market. Then, it is necessary to decide on such essential criterion as tax breaks. This helps to identify cost manufacturing opportunity and eliminate poor market opportunities. The research can be conducted by attending expert seminars and workshops as a mean to gain expertise in comprehensive information about target country, its market and consumers. The second step is choosing distribution channel. This can be done by hiring a sales representative who, preferably, has to be a native, well-educated, with good interpersonal skills, able to support business organizationally and technically, be personally acquainted with the prospective distributor and be able to evaluate cultural differences. The third step is a selection of financial arrangements. The best way to do business with an overseas buyer is a letter of credit as it keeps all transactions and eliminates worries about payment.

3. Behavioral stage. This stage is marked by awareness of new conditions in which the corporation operates. The sensitivity to environmental demands, cultural appreciation and the empathy are required when exploring a new market. At this stage, the corporation has to have better understanding the people and culture in order to create better business relationships. Companies tend to operate mainly in countries which language is similar to the owners of organization, because language similarity leads to a more thorough understanding and helps to avoid misunderstanding.

4. Conceptual stage. The management has to do a valuation of international business from its experience and observations. An attitude, believes, judgments, opinions, views and ways of thinking have to be included into such an assessment. Therefore, multiple logics have to be applied in order to become a top large company. 
International corporations, MNCs in particular, can contribute to economic development in different ways. When a multinational invests in a host country, the scale of the investment (given the size of the firms) is likely to be significant. Indeed governments often offer incentives to firms in the form of grants, subsidies and tax breaks to attract investment into their countries. These foreign direct investments (FDI) have advantages and disadvantages for the host country.

The possible benefits of a multinational investing in a host country may include [342]:

1. Improving the balance of payments - inward investments will usually help a country's balance of payments situation. The investment itself will be a direct flow of capital into the country and the investment is also likely to result in import substitution and export promotion. Export promotion comes due to the multinational using their production facility as a basis for exporting, while import substitution means that products previously imported may now be bought domestically.

2. Providing employment - FDI will usually result in employment benefits for the host country as most employees will be locally recruited. These benefits may be relatively greater given that governments will usually try to attract firms to areas where there is relatively high unemployment or a good labor supply.

3. Source of tax revenue - profits of multinationals will be subject to local taxes in most cases, which will provide a valuable source of revenue for the domestic government.

4. Technology transfer - multinationals will bring with them technology and production methods that are probably new to the host country and a lot can therefore be learnt from these techniques. Workers will be trained to use the new technology and production techniques and domestic firms will see the benefits of the new technology. This process is known as technology transfer.

5. Increasing choice - if the multinational manufactures for domestic markets as well as for export, then the local population will gain form a wider choice of goods and services and at a price possibly lower than imported substitutes. 
6. National reputation - the presence of one multinational may improve the reputation of the host country and other large corporations may follow suite and locate as well.

7. Source of management experience - the host country's business also gets management expertise from MNCs.

8. Economic liberalization - MNCs break protectionalism, curb local monopolies, create competition among domestic companies and thus enhance their competitiveness.

International corporations contribute to the global economic development significantly. In general, global corporations pay higher wages, increase productivity, are less likely to go out of business, and spur more efficient technological development. 
DOI 10.46299/ISG.2021.MONO.ECON.II-334-351

\section{2 розробка системи економіко-математичного моделювання у дослідженні зони вільної торгівлі України з СС}

Важливою передумовою забезпечення динамічного розвитку національної економіки є іiі інтеграція у світовий економічний простір, що відповідає як сучасним тенденціям глобалізації, так і необхідності поглиблення цивілізованих зовнішньоекономічних відносин України з іншими країнами. Перш за все, це стосується проголошеного нашою державою курсу на інтеграцію до Європейського Союзу (СС), що в перспективі має забезпечити поетапну коінтеграцію входження національної економіки до світової економічної системи, а відтак й підвищення глобальної конкурентоспроможності за умови виваженого державного регулювання.

Важливість вибору правильних орієнтирів зовнішньоекономічної політики набуває особливої уваги в умовах посилення глобалізаційних тенденцій у світі та загострення конкурентного протистояння на світових ринках. Сучасний етап соціально-економічного розвитку України наочно ілюструє, що без правильної, науково обгрунтованої, всебічно зваженої та послідовно здійснюваної зовнішньоекономічної політики не може бути успішно реалізована жодна національна стратегія економічного та соціального розвитку, яка передбачає інтеграцію нашої країни у європейський простір. Водночас зближення нашої держави 3 Євросоюзом неможливе без розробки системи економікоматематичного моделювання, виявленні ризиків, які виникають у процесі створення зони вільної торгівлі (ЗВТ), проблеми виходу українських товаровиробників на європейські ринки, що неодмінно призведе до трансформації більшості секторів національної економіки.

Зона вільної торгівлі України та ЄС передбачає співпрацю за різними напрямами, що переважно містяться у площині питань зовнішньоторговельної сфери (зокрема торгівлі товарами та послугами, митно-тарифного регулювання, інвестиційної та конкурентної політики та врегулювання суперечок).

Для визначення поточного стану, тенденцій та перспектив розвитку ЗВТ можна використовувати різноманітні економіко-математичні методи, які умовно 
можна поділити на дві категорії - неформалізовані (якісні) та формалізовані (кількісні) (дивись табл. 8.2.1).

Таблиця 8.2.1.

\section{Узагальнення системи економіко-математичного моделюванні при}

досліджені зони вільної торгівлі України з СС [343]

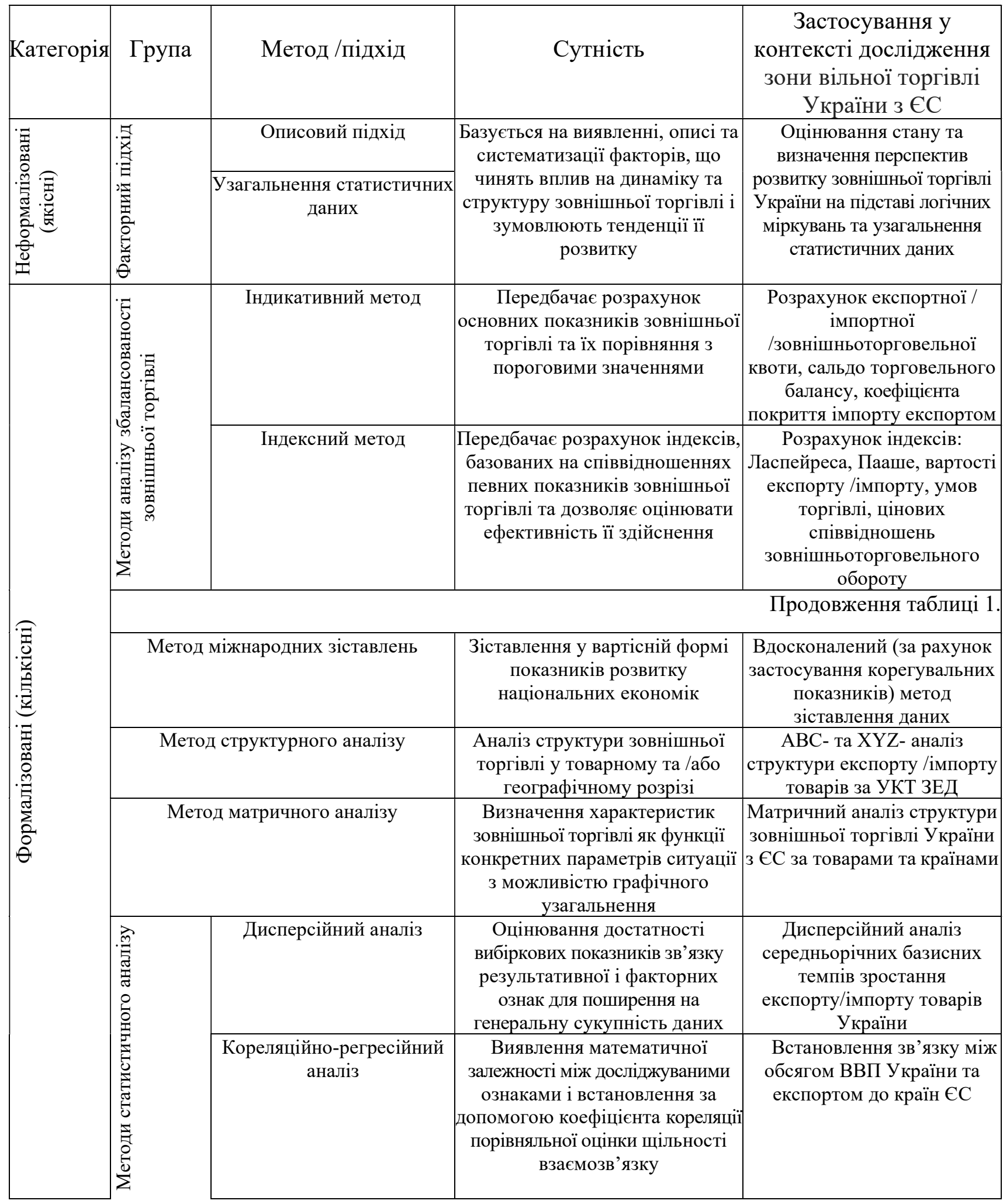




\begin{tabular}{|c|c|c|c|c|}
\hline & \multicolumn{2}{|c|}{$\begin{array}{c}\text { Сценарне планування } \\
\text { (прогнозування) }\end{array}$} & $\begin{array}{c}\text { Конструювання варіантів } \\
\text { розвитку економічного суб'єкта } \\
\text { на основі визначення загальних } \\
\text { факторів впливу }\end{array}$ & $\begin{array}{c}\text { Використання } \\
\text { автоматизованих моделей } \\
\text { загальної економічної } \\
\text { рівноваги та міжгалузевого } \\
\text { балансу, зокрема GTAP }\end{array}$ \\
\hline 鸟 & \multicolumn{2}{|c|}{ Гравітаційне моделювання } & $\begin{array}{c}\text { Базується на ідеї гравітаційного } \\
\text { тяжіння: сила взаємодії між } \\
\text { економічними суб'єктами є } \\
\text { прямо пропорційною добутку } \\
\text { показників їх значущості та } \\
\text { зворотно пропорційною відстані } \\
\text { між ними }\end{array}$ & $\begin{array}{c}\text { Гравітаційна модель торгівлі } \\
\text { України } \\
\text { з країнами Європейського } \\
\text { Союзу } \\
\end{array}$ \\
\hline 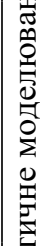 & \multicolumn{2}{|r|}{$\begin{array}{c}\text { Методологія нечіткої } \\
\text { логіки }\end{array}$} & \begin{tabular}{|c|} 
Побудова лінгвістичної моделі \\
кількісно невимірюваних \\
економічних величин 3 \\
подальшою їх трансформацією у \\
числову модель на основі \\
системи правил \\
\end{tabular} & $\begin{array}{c}\text { Модель прогнозування } \\
\text { успішності здійснення } \\
\text { експортно-імпортних } \\
\text { операцій з країнами ЄС }\end{array}$ \\
\hline 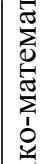 & \multicolumn{2}{|c|}{ Імітаційне моделювання } & $\begin{array}{c}\text { Відтворення в часі } \\
\text { (прогнозування) розвитку } \\
\text { зовнішньої торгівлі за переліком } \\
\text { сценаріїв }\end{array}$ & $\begin{array}{c}\text { Прогнозування розвитку } \\
\text { зовнішньої торгівлі товарами } \\
\text { України з ЄС на } \\
\text { середньостроковий період }\end{array}$ \\
\hline 产 & \multirow[t]{2}{*}{ 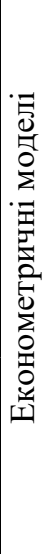 } & $\begin{array}{c}\text { Моделювання } \\
\text { одновимірних часових } \\
\text { рядів } \\
\text { (детерміністський } \\
\text { підхід) }\end{array}$ & \begin{tabular}{|c|} 
Сукупність математико- \\
статистичних методів аналізу, \\
призначених для виявлення \\
структури часових рядів та їх \\
прогнозування, є підгрунтям для \\
побудови детермінованих \\
(зазвичай, трендових) моделей \\
певного функціонального типу \\
\end{tabular} & $\begin{array}{c}\text { Трендові моделі } \\
\text { двосторонньої торгівлі між } \\
\text { Україною та певними } \\
\text { країнами ЄС; економетричні } \\
\text { моделі } \\
\text { зовнішньоторговельного } \\
\text { обороту України загалом та } 3 \\
\text { окремими групами країн } \\
(\mathcal{C}) \\
\end{array}$ \\
\hline & & $\begin{array}{c}\text { Стохастичне } \\
\text { моделювання } \\
\text { (ймовірнісний підхід) }\end{array}$ & 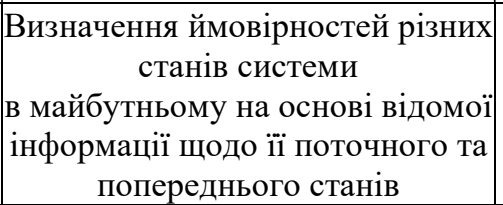 & $\begin{array}{c}\text { Гнучкий інструментарій } \\
\text { аналізу та прогнозування } \\
\text { зовнішньої торгівлі }\end{array}$ \\
\hline
\end{tabular}

Під неформалізованими методами варто розуміти такі, що грунтуються на логічних процедурах узагальнення проявів дійсності i не передбачають підтвердження авторських висновків певною аналітичною залежністю та розрахунками. Формалізований метод передбачає проведення дослідження 3 використанням кількісного аналізу і дозволяє уникнути помилок суб'єктивізму, типових при неформалізованому підході. Саме використання кількісних методів дає грунтовні прогнози тенденцій та динаміки розвитку ЗВТ Україна - СС.

Факторний підхід до аналізу зовнішньої торгівлі України реалізується у роботах науковців як дослідження винятково описового характеру [344] або грунтується на певних статистичних даних [345]. Щодо доцільності використання факторного підходу при аналізі зовнішньої торгівлі за сучасних умов невизначеності важливо те, що встановлені дослідниками передумови розвитку 
зовнішньої торгівлі України здебільшого грунтовні та базуються на виявленні й узагальненні об'єктивних тенденцій.

Неформалізований аналіз фіксує поточний стан та окреслює загальні перспективи розвитку зовнішньої торгівлі, але не дає реальної можливості для прогнозування ii обсягів, динаміки та структури. Додатково придатність результатів неформалізованого аналізу для адекватного прогнозування зовнішньої торгівлі обмежує наявність несподіваних та неочікуваних факторів. Адже стан та тенденції розвитку зовнішньоторговельних відносин України останнім часом визначаються не стільки об'єктивними економічними закономірностями, скільки трансформацією інтеграційних пріоритетів держави через різку зміну геополітичної ситуації.

Отже, неформалізований аналіз на основі факторного підходу - вагома підстава для оцінювання поточного стану та встановлення тенденцій розвитку зовнішньоторговельних відносин держави. Доцільно його використовувати у комплексі 3 формалізованими методами дослідження, що сприятиме підвищенню обгрунтованості прогнозів динаміки та структури зовнішньої торгівлі України.

Формалізований (кількісний) аналіз передбачає проведення дослідження 3 використанням кількісних методів та розрахунків. Найбільш поширені методи аналізу збалансованості зовнішньої торгівлі. Вчені активно застосовують індексний метод, за допомогою якого описують динаміку експортно-імпортних операцій, оцінюють виконання обов'язків за контрактами; аналізують вплив на розвиток зовнішньоекономічних операцій змін цін, кількості товарів, структури постачань; визначають ефективність зовнішньоекономічних операцій.

У роботах науковців використовується індексний метод для розрахунку таких основних показників зовнішньої торгівлі: експортної, імпортної та зовнішньоторговельної квоти, сальдо торговельного балансу, коефіцієнта покриття імпорту експортом. Метод аналізу збалансованості зовнішньої торгівлі, який передбачає розрахунок зазначених показників (індикаторів) та їх 
порівняння $з$ пороговими значеннями, пропонується визначати як індикативний метод.

Використання індексного та індикативного методів аналізу (дивись табл. 8.2.2) дозволяє систематизувати та формалізувати інформацію щодо поточного стану зовнішньої торгівлі, визначати ключові тенденції [346], чинники впливу та ресурси зростання обсягів зовнішньоекономічної діяльності [347]. Водночас, розрахунок індикаторів та індексів зовнішньої торгівлі дає лише статичну картину, не дозволяє формалізувати зв'язки між змінними ситуації та давати грунтовні прогнози динаміки відповідних показників.

Таблиця 8.2.2.

Показники, що застосовуються при індексному та індикативному методі аналізу зовнішньої торгівлі України [346,347]

\begin{tabular}{|c|c|c|}
\hline Показник & Формула розрахунку & Економічна інтерпретація \\
\hline $\begin{array}{c}\text { Експортна } \\
\text { квота }\end{array}$ & $\kappa_{\mathrm{e}}=\frac{\text { Експорт }}{\text { ВВП }} \times 100 \%$ & $\begin{array}{l}\text { Характеризує ступінь відкритості економіки країни. } \\
\text { За критерієм Світового банку економіка країни } \\
\text { вважається відкритою, якщо на макрорівні експортна } \\
\text { квота перевищує } 35 \% \text {, якщо ж ії значення значно } \\
\text { вище, то економіка вважається “надвідкритою”, що } \\
\text { свідчить про залежність від кон’юнктури світових } \\
\text { ринків і вразливість до зовнішніх шоків. }\end{array}$ \\
\hline \multicolumn{3}{|r|}{ Продовження таблиці 2.} \\
\hline Імпортна квота & $\mathrm{K}_{\mathrm{i}}=\frac{\text { Імпорт }}{\mathrm{BВП}} \times 100 \%$ & $\begin{array}{l}\text { Характеризує ступінь імпортної залежності країни. } \\
\text { Безпечним для економіки країни вважається значення } \\
\text { Кі } \leq 15 \% \text {, перевищення свідчить про велику } \\
\text { залежність економіки країни від зовнішніх поставок, } \\
\text { що обумовлюється слабкістю національного } \\
\text { виробництва. }\end{array}$ \\
\hline $\begin{array}{l}\text { Зовнішньотор- } \\
\text { говельна квота }\end{array}$ & ЗТк $=\frac{\text { Експорт }+ \text { Імпорт }}{\text { ВВП }}$ & $\begin{array}{l}\text { Економіка вважається відкритою, } \\
\text { зовнішньоторговельний оборот у відношенні до ВВП } \\
\text { більше за одиницю. } \\
\end{array}$ \\
\hline $\begin{array}{c}\text { Коефіцієнт } \\
\text { покриття } \\
\text { імпорту } \\
\text { експортом }\end{array}$ & $\mathrm{K}_{\text {п }}=\frac{\text { Експорт }}{\text { Імпорт }}$ & $\begin{array}{l}\text { Характеризує співвідношення експорту з імпортом, } \\
\text { що показує ступінь збалансованості зовнішньої } \\
\text { торгівлі. } \\
\text { При активному сальдо торговельного балансу Кп>1, } \\
\text { при пасивному - Кп }<1 \text {. Різниця (1-Кп) характеризує } \\
\text { масштаб його дефіциту }(-) \text { чи профіциту }(+) \text {. }\end{array}$ \\
\hline $\begin{array}{c}\text { Індекс } \\
\text { Ласпейрса }\end{array}$ & $\begin{array}{l}\mathrm{I}_{\mathrm{p}}^{L}=\frac{\sum \mathrm{p}_{1} q_{0}}{\sum p_{0} q_{0}}, \text { де } p_{1} \text { та } p_{0} \\
\text { - ціна товару відповідно в } \\
\text { поточному та базовому } \\
\text { періодах, } q_{1}-\text { кількість } \\
\text { товару в базисному періоді. }\end{array}$ & $\begin{array}{l}\text { Індекс цін за формулою Ласпейреса визначається як } \\
\text { середня гармонічна зважена з відносних цін, де } \\
\text { як ваги використовується вартість окремих товарів за } \\
\text { попередній період. На цей індекс не впливають будь- } \\
\text { які кількісні зміни, бо він характеризує лише цінові } \\
\text { співвідношення по товарах, що реалізовані у } \\
\text { поточному періоді, порівняно } 3 \text { попереднім у } \\
\text { незмінному обсязі базисного періоду. }\end{array}$ \\
\hline
\end{tabular}




\begin{tabular}{|c|c|c|}
\hline Індекс Пааше & $\begin{array}{l}\mathrm{I}_{\mathrm{p}}^{\mathrm{p}}=\frac{\sum \mathrm{p}_{1} q_{1}}{\sum p_{0} q_{1}} \text {, де } p_{1} \text { та } p_{0} \\
\text { - ціна товару відповідно в } \\
\text { поточному та базовому } \\
\text { періодах, } q_{1}-\text { кількість } \\
\text { товару в поточному періоді. }\end{array}$ & $\begin{array}{l}\text { Індекс цін, розрахований за формулою Пааше, } \\
\text { грунтується на поточних вагах і дозволяє порівняти } \\
\text { тільки поточний період з базисним, що не показує } \\
\text { точної зміни ціни від одного періоду до другого, тому } \\
\text { що відображає не тільки зміну ціни, але і зміну } \\
\text { структури ваг. }\end{array}$ \\
\hline $\begin{array}{c}\text { Індекс умов } \\
\text { торгівлі }\end{array}$ & 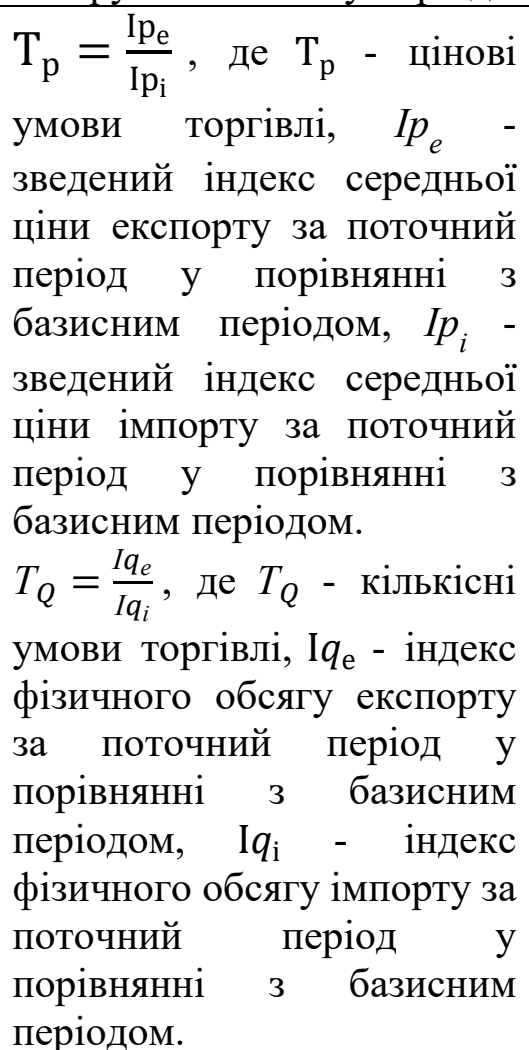 & $\begin{array}{l}\text { Індекси умов торгівлі “цінові” та “кількісні” } \\
\text { характеризують в якій мірі країна виграє (втрачає) за } \\
\text { рахунок зміни цін (кількості) товарів у зовнішній } \\
\text { торгівлі з певною країною (країнами) за відповідний } \\
\text { період часу. } \\
\text { Показник умов торгівлі вимірює відносну динаміку } \\
\text { експортних цін за певний період і розраховується для } \\
\text { проведення аналізу зовнішньоторговельної } \\
\text { діяльності, що вимірюється співвідношенням } \\
\text { середньої виручки від експорту товарів і середніх } \\
\text { витрат на імпорт за певний період часу. }\end{array}$ \\
\hline
\end{tabular}

Встановити тенденції розвитку та проаналізувати структуру зовнішньої торгівлі дозволяє метод міжнародних зіставлень [348], який передбачає аналіз комплементарності двосторонніх відносин між країнами, а саме 3 аналіз іiі мезорівня i мікрорівня. Мезорівень являє собою зовнішньоторговельну комплементарність, тобто комплементарними є товари різних галузей народного господарства, які включені у зовнішньоторговельний оборот країн-партнерів. Мікрорівень характеризує комплементарність на рівні окремих підприємств, фірм, компаній. Високий рівень комплементарності торгівлі свідчить про ефективність здійснення операцій купівлі-продажу товарів партнерами. Основним методом визначення взаємодоповняльності економік на мезорівні $\epsilon$ обчислення індексу комплементарності.

$$
\text { TCI } I_{j}=100-\sum \frac{m_{i k}-x_{i j}}{2}, \text { де }
$$

$T C I_{j}$ - індекс комплементарності торгівлі; $x_{i j}$ - частка експорту і-го товару країни 
j; $m_{i k}$ - частка товару і в загальному імпорті країни к.

Зростання показника свідчить про вище співвідношення експорту в одній країні до імпорту іншої. Якщо країну характеризує високий індекс комплементарності для експорту, це означає, що вона бере участь у розподілі продукції як експортер компонентів. Якщо ж індекс комплементарності торгівлі для імпорту більший, це означає, що ця країна $є$ учасником розподілу виробничих процесів як імпортер компонентів.

У моделі, запропонованій Д. Інь та Д. Лі індекс комплементарності вимірюється з урахуванням товарної специфікації країни [349].

$$
T C I_{i j}^{k}=\frac{x_{i}^{k} / x_{i}}{M_{w}^{k} / M_{w}} \times \frac{M_{j}^{k} / M_{j}}{M_{w}^{k} / M_{w}}, \text { де }
$$

$x_{i}^{k}$ - експорт країни i товару $\mathrm{k} ; x_{i}$ - загальний експорт країни $\mathrm{i} ; M_{j}^{k}-$ імпорт країни ј товарів $\mathrm{k} ; M_{j}$ - загальний імпорт країни $\mathrm{j} ; M_{w}^{k}-$ світовий імпорт товару $\mathrm{k} ; M_{w}$ - загальний світовий імпорт.

Цей показник визначає рівень комплементарності між пропозицією експорту і попитом на імпорт у двох країнах. Якщо індекс дорівнює нулю, країна не експортує жодних товарів або торговий партнер не імпортує жодних товарів, i 100 - коли частки експорту й імпорту збігаються [350]. Індекс TCI може бути розбитий на два індекси RCA (Індекс порівняльних переваг) i RCD (Індекс спеціалізації імпорту). Індекс RCA розраховують підставивши відповідні значення у наступну формулу:

$$
R C A_{i}^{k}=\frac{x_{i}^{k} / x_{i}}{M_{w}^{k} / M_{w}}, \text { де }
$$

де $x_{i}^{k}$ - експорт з країни і товару к; $x_{i}$ - загальний експорт з країни $\mathrm{i} ; M_{w}^{k}-$ світовий імпорт товару к; $M_{w}$ - загальний світовий імпорт.

Індекс RCA дорівнює співвідношенню між часткою продукту в загальному експорті країни і часткою того самого продукту у світовій торгівлі. Цей індекс 
розраховується, щоб визначити, чи має країна конкурентні переваги щодо певного товару. Якщо RCA $>1$, робиться висновок про те, що країна є більш експортно-орієнтованою за даним товаром і має щодо нього конкурентні переваги [350].

Аналогічно індекс RCD (Індекс спеціалізації імпорту) дорівнює співвідношенню частки певного товару в загальному обсязі імпорту країни i відповідної його частки у світовій торгівлі.

$$
R C D=\frac{M_{j}^{k} / M_{j}}{M_{w}^{k} / M_{w}}
$$

де $M_{j}^{k}-$ імпорт країни ј товарів к;

$M_{j}$ - загальний імпорт з країни j;

$M_{w}^{k}$ - світовий імпорт товару к;

$M_{w}$ - загальний світовий імпорт.

Якщо індекс RCD > 2 - висока спеціалізація імпорту; $\mathrm{RCD}<0,75$ спеціалізація імпорту відсутня; $0,75<\mathrm{RCD}<2-$ непевна сфера або відсутня яскраво виражена перевага чи несприятлива позиція.

За допомогою цих індексів можна визначити рівень комплементарності економічних зв'язків між Україною та ЄС.

Для аналізу зовнішньої торгівлі можна також застосовувати структурний аналіз, який передбачає виокремлення складових елементів (підсистем) у структурі об'єкта дослідження і визначення відносин і зв'язків між ними з метою формування комплексного уявлення про об’єкт дослідження в цілому. Різновидом структурного аналізу є АВС-аналіз, який передбачає аналізування структури зовнішньої торгівлі у товарному та/або географічному розрізі з метою визначення значущості певних груп товарів та/або регіонів у забезпеченні загального результату зовнішньоекономічної діяльності. Метод АВС - аналізу здійснюється на основі принципу Парето, тобто у зовнішній торгівлі «20\% товарів дають $80 \%$ результату». АВС-аналіз полягає у тому, що розраховується 
частка кожної товарної позиції в експорті чи імпорті країни, підсумовуються результати методом накопичення та здійснюється розподілення на три групи -3 високим рівнем ефективності експорту чи імпорту (частка - до 80\%), із середнім рівнем ефективності (частка - від 80 до 95\%), з низьким рівнем ефективності (частка - від 95 до 100\%) [351].

XYZ-аналіз використовують для класифікації груп продукції на основі показника стабільності товарної позиції в експорті чи імпорті. Цей показник прийнято вимірювати коефіцієнтом варіації, який показує, яку частину середнє квадратичне відхилення становить від середньої арифметичної величини (у відсотках), тобто наскільки великим є відхилення щодо середнього значення ознаки. У категорію Х попадають товари з коефіцієнтом варіації до 10\% (слабке коливання в часі), в категорію Y - 10-25\% (помірне коливання в часі), в категорію Z - більше 25\% (високе коливання) [351].

Коефіцієнт варіації (V) визначається за формулами [351]:

$$
\begin{aligned}
& V=\frac{\sigma}{\bar{x}} \times 100 \% \\
& \sigma=\sqrt{\frac{\sum_{\mathrm{i}=1}^{\mathrm{n}}\left(\mathrm{x}-\mathrm{x}_{\mathrm{i}}\right)^{2}}{\mathrm{n}}} \quad \text { та } \\
& \bar{x}=\frac{\sum_{i=1}^{n} x_{i}}{n} \quad \text { де, }
\end{aligned}
$$

де $\mathrm{n}$ - кількість товарних позицій, які аналізуються.

Групи AX i BX характеризуються високим рівнем стабільності, ефективності і частки реалізації продукції. Групи АY і ВY за досить високого рівня ефективності реалізації продукції характеризуються середнім рівнем стабільності. Групи AZ i BZ за значної частки реалізації продукції характеризуються низькою стабільністю. Товарна продукція таких груп знаходиться у зоні ризику, що знижує ефективність планування торгівлі і може привести до негативних наслідків (невиконання договірних обов'язків, дефіцит товарів тощо). Низький рівень ефективності і частки реалізації продукції свідчить про недостатній рівень ï якості, неефективне використання ресурсів, що вимагає застосування інноваційного підходу до виробництва, удосконалення 
технології, модернізації і заміни устаткування. Тому групам CX, CY, CZ варто приділяти особливу увагу під час формування політики, спрямованої на модернізацію устаткування, впровадження нових технологій.

Різновидом формалізованого підходу до аналізу зовнішньої торгівлі України є використання матричного аналізу, що, на основі використання правил теорії матриць, дає змогу визначити значення елементів моделі як функцію конкретних параметрів ситуації. Матричний інструментарій надає можливості для аналізу статичного (фіксованого) стану об'єкта дослідження, але не дозволяє достовірно прогнозувати його розвиток.

Наступний метод дослідження зовнішньої торгівлі України - статистичний аналіз - передбачає вивчення й порівняння цифрових даних між собою та 3 іншими. Основне завдання кореляційного і регресійного методів дослідження - аналіз статистичних даних для виявлення математичної залежності між досліджуваними ознаками та встановлення за допомогою коефіцієнта кореляції порівняльної оцінки щільності взаємозв'язку [352].

При використанні даного аналізу необхідно вирішити три основні задачі [353]:

- вибір форми зв'язку;

- визначення параметрів визначення регресії;

- оцінка щільності та надійності зв'язку.

Таким чином, необхідно визначити залежність ВВП України від експорту та імпорту. Про економічну доцільність цих факторів свідчить те, що зовнішньоекономічна діяльсть безпосередньо впливає на ВВП країни.

Аналіз математичної залежності відбувається в декілька етапів:

1. Визначається форма зв'язку між показниками, де $X$ - експорт України (незалежна змінна), а Y - обсяги ВВП країни (залежна змінна) (табл. 8.2.3). 
Таблиця 8.2.3. Дані для розрахунку кореляційно-регресійного аналізу залежності ВВП України від обсягів експорту, млрд. дол.

\begin{tabular}{|c|c|c|c|c|c|}
\hline Роки & $\mathrm{X}$ & $\mathrm{Y}$ & $\mathrm{XY}$ & $X^{2}$ & $Y^{2}$ \\
\hline 2010 & & & & & \\
\hline$\ldots$. & & & & & \\
\hline 2020 & & & & & \\
\hline Всього: & & & & & \\
\hline
\end{tabular}

2. Розраховуються середні показники:

$$
\overline{\mathrm{X}}=\frac{\sum X}{n}, \bar{Y}=\frac{\sum Y}{n}, \overline{\mathrm{XY}}=\frac{\sum X Y}{n}, \overline{X^{2}}=\frac{\sum X^{2}}{n}, \overline{Y^{2}}=\frac{\sum Y^{2}}{n} .
$$

Припустимо, що існуючий зв'язок має лінійну форму, яку можна представити у вигляді рівняння регресії:

$$
Y=\grave{a}_{0}+a_{1} X, \text { де }
$$

$a_{1}$ - коефіцієнт регресії, що показує на скільки зміниться в середньому значенні результативного показника (обсяг ВВП країни) при збільшені факторного (експорт України) на одиницю;

$\grave{a_{0}}$ - виявляє усереднений вплив на результативний показник незазначених факторів.

3. Розраховуються параметри рівняння регресії залежності обсягу ВВП України від експорту:

$$
\begin{aligned}
& \sigma_{x}=\sqrt{\overline{X^{2}}-\bar{X}^{2}}, \\
& \sigma_{y}=\sqrt{\overline{Y^{2}}-\bar{Y}^{2}}
\end{aligned}
$$

4. Далі визначаються $\sigma_{x}^{2}$ й $\sigma_{y}^{2}$, а також $a_{1}=\frac{\overline{X Y}-\bar{X} \bar{Y}}{\sigma_{x}^{2}}$ та $\grave{a_{0}}=\bar{Y}-a_{1} \times \bar{X}$

У підсумку одержуємо рівняння регресії залежності обсягу ВВП України від iï експорту:

5. Для визначення щільності зв'язку в отриманому рівнянні регресії необхідно розрахувати лінійний коефіцієнт кореляції за формулою:

$$
r=\frac{\overline{\mathrm{X} Y}-\bar{X} \bar{Y}}{\sigma_{x} \sigma_{y}}
$$


Якщо розрахований вище коефіцієнт кореляції піднести у квадрат, то отримуємо інший показник тісноти зв'язку, який називається лінійним коефіцієнтом детермінації ( $\left.r^{2}\right)$, що відображає ступінь коливання результативного показника від змін фактору.

6. Далі необхідно оцінити надійність зв’язку за допомогою коефіцієнта Ст'юдента:

$$
t=\frac{|r| \times \sqrt{n-2}}{\sqrt{1-r^{2}}}
$$

7. Для визначення відносних змін результативного показника (у \%) при зміні експорту України на 1\% необхідно розрахувати коефіцієнт еластичності:

$$
K_{e l}=a_{1} \times \frac{\bar{X}}{\bar{Y}}
$$

Для більш детального аналізу впливу зовнішньоекономічної діяльності України на ії обсяг ВВП необхідно провести кореляційно-регресійний аналіз впливу імпорту України на ВВП за схемою, зазначеною вище.

Щодо дисперсійного аналізу, важливим обмеженням при його використанні стає об'єктивна відсутність можливості урахування впливу на результативну ознаку всіх факторів макросередовища внаслідок їх чисельності та складності взаємозв'язку. Наявність неврахованих факторів призводить до того, що в окремих випадках залишкова дисперсія значно завищується та не може виступати адекватним критерієм істотності їхнього впливу. Побудова моделі дисперсійного аналізу передбачає нормальний або близький до нормального розподіл досліджуваних статистичних сукупностей. Якщо ця умова не виконується, то отримані за допомогою дисперсійного аналізу оцінки виявляються перебільшеними.

Значне місце серед методів дослідження зовнішньої торгівлі посідають методи економіко-математичного моделювання. Використання математичних методів для вирішення економічних завдань підвищує рівень обгрунтованості 
висновків щодо тенденцій розвитку зовнішньої торгівлі та рекомендацій, що надаються.

Дуже широким для оцінювання поточного стану та прогнозування тенденцій розвитку зовнішньої торгівлі $\epsilon$ спектр методів економікоматематичного моделювання.

Поширеним інструментом дослідження зовнішньої торгівлі України є сценарне планування, що передбачає варіативне конструювання майбутнього на основі визначення загальних факторів впливу на розвиток об'єкта дослідження. Підгрунтям для використання цього методу зазвичай виступають автоматизовані версії моделей загальної економічної рівноваги та міжгалузевого балансу зокрема, GTAP.

Сценарне планування на основі автоматизованих макроекономічних моделей не $є$ в чистому вигляді інструментом аналізу зовнішньої торгівлі. При використанні цих моделей визначення показників ефективності експортноімпортної діяльності є не метою, а засобом комплексного оцінювання рівня економічного розвитку країни за умови реалізації певних сценаріїв. При цьому отриманим прогнозним значенням макропоказників (у тому числі - обсягів експорту/імпорту) притаманний високий ступінь ймовірності, оскільки вони базуються на врахуванні стійких та однозначних причинново-наслідкових зв’язків між елементами ситуації. Але за сутністю сценарного планування прогнозні значення показників визначаються для обмеженого переліку варіантів майбутнього, вірогідність та вичерпність яких визначається дослідником.

Розвитком ідеї кореляційного аналізу в економіко-математичному моделюванні двосторонньої торгівлі країн є гравітаційна модель.

Гравітаційна модель пов'язує глобальні тенденції виробництва та споживання 3 глобальними тенденціями торгівлі. Популярність моделі зумовлена кількома факторами:

1. Це модель загальної рівноваги глобальної торгівлі. Моделі загальної рівноваги фіксують не тільки безпосередній вплив економічних і 
політичних змін на торгівлю між двома країнами, а й те, як він впливає на інші країни.

2. Ця модель узгоджується зі старими та сучасними теоріями міжнародної торгівлі: модель порівняльних переваг Рікардо, модель монополістичної конкуренції Кругмана, модель гетерогенних фірм на глобальних ринках Меліца.

3. Найважливіше, що вона є найбільш емпірично успішною кількісною економічною моделлю через високу пояснювальну силу: високий $r^{2}$ у регресії логарифму експорту на ВВП експортера, ВВП імпортера та відстань складає близько 0,6-0,7. При аналізі панельних даних 3 повним набором фіксованих ефектів $r^{2} \epsilon$ ще вищим - близько 0,9.

При оцінюванні моделі необіхідно враховувати всі специфічні фактори для кожної країни та кожної пари країн. Різниця, яка залишається (недоторгованість) - це відхилення від глобальних тенденцій торгівлі, що не може бути пояснене виробничою спроможністю експортера, обсягом ринку витрат імпортера, специфічними факторами торгових витрат, такими як відстань, культурні відмінності, угоди про вільну торгівлю, тарифи тощо. Модель пояснює вплив інших країн на двосторонню торгівлю. Наприклад, вона відображає вплив торговельної війни між Китаєм і США на торгівлю між Україною та СС.

Формула гравітаційної моделі є наступною:

$$
X_{i j}=\frac{Y_{i} E_{j}}{Y} \times\left(\frac{\tau_{i j}}{P_{j \Omega_{i}}}\right)^{1-\sigma}, \text { де }
$$

$\mathrm{X}_{\mathrm{ij}}$ - експорт у доларах США з країни i (експортера) до країни ј (імпортера);

$Y_{i}$ - виробнича потужність країни - експортера (ВВП);

$E_{j}$ - розмір споживчого ринку країни-імпортера (витрати в грошовому вираженні);

Y - світовий ВВП;

$\sigma$ - еластичність заміщення між різними товарами, зокрема між місцевими та імпортними товарами. Вона вимірює, наскільки попит на імпортні товари 
зменшиться у відсотковому відношенні, якщо його ціна зросте на $1 \%$. У емпіричних моделях ії величина зазвичай складає близько 4-5;

$\tau_{i j}$ - це торгові витрати між експортером та імпортером, які включають транспортні витрати, витрати на перетин кордону, оплату тарифів, задоволення нетарифних вимог у країнах-імпортерах, оплату страхових послуг;

$P_{j \text { та }} \Omega_{i}$ - це «цінові індекси», які охоплюють всю релевантну інформацію про стан всіх країн світової економіки, їх географічну позицію відносно один одного, всі торгові витрати між усіма країнами, виробництво та витрати у всіх країнах. Ці дві цифри є суттєвими, оскільки вони об'єднують всю релевантну інформацію про глобальну торговельну рівновагу в двох числах. Ці дві цифри називають багатостороннім опором імпорту та експорту.

Необхідно оцінювати гравітаційну модель торгівлі шляхом застосування методу псевдо-максимальної правдоподібності.

$X_{i j}=\exp \left(\gamma_{\text {відст }}\left(\ln\right.\right.$ відст $\left.\left._{i j}\right)+\gamma_{F T A} F T A_{i j}+Z_{i j} \gamma_{Z}+X_{i}+\xi_{j}\right) \times v_{i j}$, де

FTA - це індикатор наявності угоди про вільну торгівлю;

$Z_{i j}$ - фіксує всі змінні, які пояснюють торгові витрати;

Фіксовані ефекти $X_{i}$ та $\xi_{j}$ додані, щоб врахувати багатосторонній опір імпорту та експорту.

Прогнозовані торгівельні потоки обчислюються згідно 3 наступним рівнянням:

$$
\hat{X}_{i j}=\exp \left(\hat{\gamma}_{\text {відст }}(\ln \text { відст } i j)+\hat{\gamma}_{F T A} F T A_{i j}+Z_{i j} \hat{\gamma}_{Z}+\hat{X}_{i}+\hat{\xi}_{j}\right)
$$

А індекс недо- або переторгованості $є$ наступним:

$$
T P_{i j}=X_{i j}-\hat{X}_{i j}
$$

Негативне значення індексу вказує на потенціал зростання експорту, а позитивне - на очікуване зниження експорту в довгостроковій перспективі.

Серед економіко-математичних методів аналізу зовнішньої торгівлі слід виокремити застосування апарату нечіткої логіки. Застосування теорії нечітких 
множин створює великі можливості для оцінювання кількісно невимірюваних економічних змінних, задати які у вигляді аналітичного вираження досить важко (наприклад, «успішність експортно-імпортної діяльності», «зовнішньоторговельний потенціал країни» та ін.). Побудова лінгвістичних моделей таких змінних та подальше використання апарату нечіткої логіки дозволяє перейти від лінгвістичних до числових моделей. Підгрунтям визначення приналежності нечіткій множині (лінгвістичному терму) відповідного елементу універсальної множини зазвичай $\epsilon$ експертне оцінювання. Тому забезпечення узгодженості та неупередженості експертів - одне із очевидних обмежень при використанні методології нечіткої логіки. Другим проблемним питанням $\epsilon$ оптимізація (зменшення) розмірності масиву можливих сполучень лінгвістичних оцінок вхідних змінних моделі.

Існує також досвід імітаційного моделювання зовнішньої торгівлі України. Очевидна перевага імітаційного моделювання - можливість урахування випадкових дій та інших факторів, які створюють труднощі при аналітичному дослідженні. Імітуються елементарні явища, що формують процес, зі збереженням їх логічної структури та послідовності протікання в часі. Ризики застосування імітаційного моделювання полягають у великій ймовірності помилкової імітації. По-перше, реальні економічні процеси мають ймовірнісний характер та піддаються моделюванню тільки при введенні певного роду припущень та обмежень. По-друге, обмеження імітаційного моделювання зумовлюються обмеженою кількістю сценаріїв імітації майбутнього, які вводить до розгляду дослідник.

Окремим великим класом економіко-математичних моделей для аналізу та прогнозування впливу створення зони вільної торгівлі з СС є економетричні моделі. Класичним підходом до економетричного моделювання є розгляд послідовних значень певного показника зовнішньої торгівлі за певний часовий період як одновимірного часового ряду. Аналіз часових рядів являє собою сукупність математико-статистичних методів аналізу (зокрема, методів регресійного аналізу), призначених для виявлення структури часових рядів та їх 
прогнозування. Виявлення структури часового ряду - це підгрунтя для побудови детермінованих (зазвичай, трендових) моделей певного функціонального типу (лінійна, логарифмічна, поліном певного ступеня, експоненційна). Передумовою вибору аналітичного виду функції, що найкраще описує реальний часовий ряд, $\epsilon$ аналіз ключових показників адекватності моделі (критерій Фішера, коефіцієнт детермінації, коригований коефіцієнт детермінації).

Детерміновані моделі за своєю сутністю засновані на врахуванні впливу певних чітко визначених факторів, тоді як на реальну економічну систему впливає велика кількість факторів, які не тільки неможливо ввести до складу моделі в якості іiі параметрів, але й іноді ідентифікувати та перелічити. Це, зокрема, геополітичні трансформації, внутрішньодержавні кризи та зміна влади, локальні військово-політичні та соціальні конфлікти, світові економічні кризи, форс-мажорні обставини, несподівані зміни ринкової кон'юнктури та ін. Наявність цих факторів, напрям і ступінь їх впливу на економічну систему не прогнозована та може варіюватися. Внаслідок впливу таких внутрішніх та зовнішніх факторів поведінка системи може бути передбачена лише ймовірнісно, тобто можна визначити лише можливі вектори іiі розвитку, а не конкретні параметри в певний момент часу. В рамках ймовірнісного підходу до розуміння джерел та передумов розвитку економічних систем в 70 -х роках $\mathrm{XX}$-го сторіччя виникла та активно розвивається методологія стохастичного моделювання.

Метою стохастичного моделювання є визначення ймовірностей різного стану системи в майбутньому на основі відомої інформації щодо ії поточного та попереднього стану. Стохастичне моделювання - це гнучкий інструментарій аналізу та прогнозування зовнішньої торгівлі, використання якого має грунтуватися на об’єктивному факторному аналізі поточної економічної та геополітичної ситуації.

Отже, європейську інтеграцію визнано пріоритетним напрямом державної політики України. Як результат, аналіз структури торгового обміну та прогнозування показників зовнішньої торгівлі України з Євросоюзом (ЄС) 
набувають особливого значення. Водночас виникає потреба у виявленні взаємозалежностей і тенденцій у розвитку вітчизняної торгівлі з $\mathrm{CC}$.

Зовнішньоторговельні відносини є важливою складовою економіки будьякої держави, а для України, яка реалізує експортоорієнтовану модель економіки, їх ефективність $\epsilon$ визначальною для забезпечення іiі динамічного розвитку. Проте аналіз засвідчує, що в Україні сформувалися недостатньо ефективні товарна й регіональна структури зовнішньої торгівлі та недовикористовуються існуючі можливості поліпшення умов товарообміну. Таким чином, в державі відсутні надійні методи і механізми захисту економічних інтересів у сфері зовнішньоторговельних відносин, що дає підстави говорити про недостатню наукову обгрунтованість управлінських рішень в цій сфері. Розв'язати це завдання можна на основі розробки системи економікоматематичного моделювання, застосування якої у процесі прийняття рішень дозволяє уникнути невиправданих (а в деяких випадках i неможливих) практичних експериментів, відобразити багатогранність зв'язків, що характеризують сучасну картину торгового обміну України з $\mathrm{CC}$, а також спрогнозувати шляхом моделювання можливі наслідки реалізації різноманітних заходів. 
DOI 10.46299/ISG.2021.MONO.ECON.II-352-420

\section{3 Розвиток світового та вітчизняного ринків електронної комерції в умовах діджиталізації світової економіки}

На сучасному етапі розвитку економіки особливої актуальності набуває прикладний аспект діджиталізації. Діджиталізація - це глибока і масштабна трансформація бізнесу, що передбачає використання цифрових технологій для оптимізації бізнес-процесів, підвищення продуктивності компанії і поліпшення досвіду взаємодії з клієнтами [354].

Діджиталізація світової економіки - важлива складова економічного розвитку більшості країн і може бути важливою основою стійкого виробництва i гідного рівеня життя людей у майбутньому. За рахунок діджиталізації економіки розвиваються майже всі галузі господарювання. У більшій мірі це проявляється у торговій, фінансовій, виробничій сферах.

Кінець XX ст. - початок XXI ст. стає періодом початку культурної і економічної глобалізації, причиною цього є стрімкий розвиток інформаційних технологій і входження у життя суспільства мережі інтернет. Поява на початку 90-х рр. ХХ ст. інтернету - відправна точка, коли комп'ютерні технології здійснили революцію у всіх сферах соціального життя. Всього за декілька років комерційна діяльність у мережі стає для індустріально розвинених країн, особливо США, ЄС та Азії, реальною і високоприбутковою формою товарногрошових відносин, яка активно впроваджується у всі галузі економіки. Фірми i організації, які найпершими оцінили необхідність запровадження електронної комерції та використання інтернету у своїй роботі, отримали низку конкурентних привілеїв і швидкий доступ до інформації, грошей і товарів [355].

Інноваційні зміни в економіці та суспільстві, стрімка діджиталізація, а останнім часом й умови карантину приводять до зростання попиту на електронний ринок товарів. Електронна комерція - новий і ще не буденний вид комерції з огляду на певний менталітет та ресурсні обмеження. Швидке 
поширення Інтернету впливає на розвиток цього бізнесу та, відповідно, змінює модель споживання i, зрештою, структуру споживчого ринку.

Пандемія COVID-19, змусивши ввести режим суворих обмежень самоізоляцію, дистанційні методи роботи, навчання та інші зміни в звичайному житті населення, тим самим помітно прискорила темпи цифровізації і розвитку діджитал-технологій, що поставило в нові умови діяльності i державні структури, і бізнес. Головним трендом у сфері діджиталізації 2020 року стало максимальне занурення в онлайн комунікації. Це торкнулося не лише зростання електронної комерції, а й масового переходу організацій, компаній на дистанційний режим роботи. За результатами опитування Європейської Бізнес Асоціації, 62\% директорів українських компаній розглядають варіант повної або часткової заміни режиму роботи на віддалений навіть після закінчення карантину . Саме діджиталізація у 2020 році позитивно вплинула як на державу, так і на бізнес. Діджиталізація надає неймовірні можливості для бізнесу, щоб заробити на хвилі зростаючого попиту з боку споживачів, які цікавляться покупками в Інтернеті [356].

Підвищення популярності поняття «електронна комерція» сталося внаслідок його постійного ототожнення з терміном «електронний бізнес». Проте 3 часом науковці почали їх розрізняти. Логічно окремо визначити сутність кожного $з$ понять. Так, спеціалісти компанії IBM дали наступне визначення: «Електронний бізнес - це трансформація головних процесів щодо бізнесу за допомогою інтернет-технологій». Енциклопедія Інтернет-бізнесу дотримується трактовки, що «електронний бізнес представляє собою будь-яку ділову активність, що використовує глобальні інформаційні мережі для перетворення внутрішніх та зовнішніх зв'язків задля того, щоб отримати прибуток». Компанії, які впроваджують інструменти електронного бізнесу у свою діяльність, отримують ряд конкурентних переваг за рахунок зменшення витрат часу і коштів на пошук, збір і обробку інформації. Перед ними відкриваються нові ринки i сфери діяльності, спрощується налагодження збуту та логістики, стають 
доступними високоефективні методи залучення нових та підвищується рівень обслуговування наявних клієнтів з можливістю їх підтримки у режимі 24/7 [357].

Дослідженню електронною комерції, iї розвитку та сучасних трендів у світі та Україні приділені роботи багатьох науковців, а також бізнесменів, підприємців та практиків бізнесу.

Під електронною комерцією майже завжди трактують як застосування комп’ютерних мереж для сприяння транзакціям, які включають виробництво, дистрибуцію, продаж і доставку товарів та послуг на ринку [358]. Водночас визначення терміна «електронна комерція» Комісією Організації Об’єднаних Націй $з$ права міжнародної торгівлі (ЮНІСТРАЛ) $є$ значно глибшим і складається з усіх видів комерційної діяльності, що проводяться за допомогою обміну «інформацією, створеною, надісланою, отриманою i збереженою електронними, оптичними чи схожими засобами, включаючи, але не обмежуючись, електронний обмін даними(EDI), електронну пошту, телеграму, телекс або телефакс» [359].

У законі України про електронну комерцію говориться: «Електронна комерція - зв'язки, які націлені на одержання доходів, що з'являються під час здійснення договорів щодо набуття, змінювання або завершення цивільних прав та обов'язків, які здійснились дистанційно 3 застосуванням інформаційнотелекомунікаційних систем, внаслідок чого в учасників таких відносин 3'являються права та обов'язки майнового характеру» [360].

Так, наприклад, В. Желіховський рекомендує формулювання електронної комерції як сукупність зв'язків у області виконання обміну даними (електронними документами) та інформацією між суб'єктами господарської діяльності із залученням масштабної мережі Інтернет [361].

Демьянец М. В., Елин В. М., Жарова А. вважають, що «електронна комерційна діяльність - це сукупність процесів, спрямованих на перерозподіл товарів, робіт і послуг, суб’єктів господарювання підприємницької діяльності, а 
також процесів, спрямованих на забезпечення такого перерозподілу в мережі Інтернет» [362].

Чучковська А. тлумачить визначення так: «Електронна комерція - це структура взаємопов'язаних правових відносин у сфері здійснення договорів за рахунок обміну електронними документами, що реалізовуються шляхом залучення мереж електрозв’язку, особливо Інтернету» [363].

Борисова Ю. написала у своїй дисертації: «Електронна комерція сукупність дій юридичних i фізичних осіб iз здійснення «електронних» договорів, мета яких - залучення матеріальної користі». Автор доводить, що тлумачення «електронна комерція» ширше від вузького визначення його як підприємницької діяльності [364].

На думку Маєвської А., електронна комерція - це широкий набір інтерактивних методів ведення діяльност 3 надання споживачам товарів та послуг [365].

Хубаєв Г. вважає, що «електронна комерція»- це така форма постачання продукції, при якій вибір і замовлення товарів здійснюється через комп'ютерні мережі, а розрахунки між покупцем і постачальником робляться за допомогою використання електронних документів або засобів платежу [366].

Проаналізувавши висловлювання вчених, можна стверджувати, що «електронна комерція» - це специфічна сфера, яка охоплює усі стадії продажу товару або послуги, від пошуку до його доставки до клієнта, використовуючи Інтернет мережу або соціальні мережі, переважно без особистої зустрічі, а обчислення між покупцем і постачальником виконуються 3 використанням електронних документів або процедур платежу.

Крім того, необхідно розуміти, що електронна комерція і електронна торгівля - це поняття, які не є ідентичними. Електронна комерція є більш ширшою сферою діяльності і включає в себе електронну торгівлю, яка прямо пов'язана з купівлею-продажем та включає не весь процес товарно-грошового 
обміну, а тільки ту його частину. Це стосується саме електронної роздрібної торгівлі [367].

3 вищезазначеного можна сказати, що електронний бізнес включає в себе електронну комерцію, та являє собою найбільш розвинену, втілену у життя його сферу. А інтернет-торгівля - напрямок електронної комерції, її розумінням у самому вузькому значенні - створює принципово нові можливості та орієнтована на торгівлю із застосуванням інформаційних технологій соціальних мереж та мережі інтернет [368]. Після появи терміну "електронна комерція", через те що, вона швидко розвивається, багато дослідників відносять до неї будь-яку бізнесдіяльність і розрізняють електронну комерцію від електронного бізнесу.

Електронна комерція - одна зі складових електронного бізнесу. У свою чергу до електронної комерції входять: управління персоналом, співпраця 3 різними органами влади, постачальниками, фінансовими установами, а також оформлення, виконання та оплата замовлень та інтернет торгівля. До інтернетторгівлі належать електронні магазини, аукціони, електронні моли та телемагазини.

На сьогоднішній час вчені виділяють 5 найбільш популярних видів електронної комерції [370]:

Business-to-Business (B2B)

Включає всі електронні транзакції товарів чи послуг між двома підприємствами. Найчастіше виробники та оптові посередники використовують такий вид електронної комерції. Стрімке зростання В2В-е-ринків розвиває традиційну економію за масштабами на основі витрат, які дуже зменшуються за рахунок е-commerce. По-перше, це скорочення витрат на пошук інформації про постачальників, продуктів та ціни. По-друге, це скорочення витрат на обробку транзакцій. По-третє, онлайн-обробка удосконалює управління запасами i логістикою.

Близько 80\% електронної комерції входить до цього виду, і багато знавців прогнозує, що В2В буде розвиватися швидше ніж В2С. Загальніші В2В приклади й найбільш кращі та практичні моделі: IBM, Hewlett Packard, Cisco тa Dell [371]. 


\section{Business-to-Consumer (B2C)}

Належить до появи ділових взаємовідносин між підприємством та кінцевим споживачем. Тобто це роздрібна торгівля, яка в теперішній період набрала великих обертів через виникнення великого обсягу онлайн - магазинів, які продають різноманітні види товарів широкого використання.

Цей вид електронної комерції включає усі рівні взаємодії електронних засобів між компаніями, які в такий спосіб можуть добре реалізовувати продукцію, самостійно розміщувати замовлення, робити моніторинг їх досягнень за допомогою баз даних постачальників тощо. Приклади В2С моделей - мережні компанії 3 продажу в роздріб: Amazon.com, Drugstore.com, Beyond.com. В2С значно скорочує ціну угод (особливо ціну пошуку), удосконалюючи доступ споживачів до інформації й даючи дозвіл споживачам знайти найбільш конкурентоспроможну ціну за товар або послугу [372].

\section{Consumer-to-Consumer (C2C)}

Виконання електронних транзакцій між фізичними особами. Як правило через третю особу, яка презентує собою онлайн - платформу.

Цей вид електронної комерції входить принаймні в три форми:

1. Аукціони такі, як еВау, що дає дозвіл інтерактивно рекомендувати ціну в теперішньому часі;

2. Однорангові системи, виду моделі Napster (протокол спільного використання файлів між користувачами в системах типу IRC) і пізніші моделі обміну грошей;

3. Оголошення тематичних категорій у портальних сайтах таких, як Тематичних категорій Excite i eWanted (діалоговий, мережний ринок, де покупці і продавці можуть самостійно здійснювати переговори).

Business-to-Government (B2G)

Ця модель електронної комерції охоплює всі транзакції онлайн між компаніями та державними адміністраціями. Складається з фіскальних послуг, 
державних закупівель, соціального забезпечення тощо. Закупівельна політика на веб-сайтах збільшує прозорість процесу закупівель і зменшує ризик порушень.

\section{Consumer-to-Government $(C 2 G)$}

Охоплює транзакції між споживачем та державною адміністрацією. Це може торкатись соціальних виплат, дистанційного навчання, податкових виплат або декларацій тощо.

Також виділять види, але вони не дуже користуються попитом, а саме: [373]

C2B (Користувачі - бізнес) - це приватні послуги, участь в опитуваннях та інших рекламних акціях, участь в партнерських і спонсорських програмах та тому подібне;

$G 2 G$ (електронний уряд) - це вибори системи співробітництва у митних, податкових, правоохоронних сферах та медіа систем;

G2B (електронний уряд у економіці) - це системи розподілення державних замовлень: тендери, забезпечення контакту з податковими, митними органами, органами державної сертифікації та ліцензування, адміністраціями і тому подібне, юридичні та інформаційно-довідкові служби;

G2C (електронний уряд у сфері взаємодіє з громадянами) - це системи соціального обслуговування: пенсії, пільги, системи комунального обслуговування, юридичні та інформаційно-довідкові служби та ін.

Можна зробити висновки, що електронна комерція $\epsilon$ майже у всіх традиційних формах комерційних та державних структур і швидко продовжує розвиватись. Компанії купують товари і послуги в Інтернеті більше, ніж будьколи раніше. В електронній комерції між підприємствами тільки невеликий відсоток онлайн продажів, виражений однозначним числом, здійснюється через торговельні майданчики. Покупці формують замовлення на закупівлю через інші канали цифрових закупівель, такі як програмне забезпечення EDI (електронний цифровий обмін), особливо в секторах роздрібної та оптової торгівлі, де працюють великі компанії. Проте, ринки електронної комерції поступово 
набирають обороти завдяки можливості надавати більш індивідуалізовані i гнучкі пропозиції для підприємств, пристосовуючись до їх попиту і пропонуючи інтерактивний клієнтський досвід.

Розглянемо переваги та недоліки для учасників ринку електронної комерції (табл.8.3.1).

Таблиця 8.3.1

Переваги та недоліки для учасників ринку електронної комерції

\begin{tabular}{|c|c|c|}
\hline $\begin{array}{c}\text { Суб'єкти } \\
\text { ринку }\end{array}$ & Переваги & Недоліки \\
\hline Для покупця & $\begin{array}{l}\text { - мінімізація часу на відвідування } \\
\text { магазину; } \\
\text { - спрощена процедура пошуку } \\
\text { товару; } \\
\text { - доступність електронних } \\
\text { магазинів завдяки режиму їх роботи (24 } \\
\text { годин на добу } 7 \text { днів на тиждень); } \\
\text { - економія часу та коштів при } \\
\text { купівлі товарів і послуг; } \\
\text { - можливість порівняти товар } 3 \\
\text { аналогічними у мережі; } \\
\text { - можна подивтися на відгуки або } \\
\text { написати; } \\
\text { - підприємець змушений через } \\
\text { високу конкуренцію в електронній } \\
\text { комерції робити знижки, проводити } \\
\text { акції та конкурси. Багато банків } \\
\text { пропонують кешбек при оплаті картою. }\end{array}$ & $\begin{array}{l}\text { - недосконалість законодавчої } \\
\text { влади; } \\
\text { - поганий рівень покриття та } \\
\text { доступу до мережі; } \\
\text { - немає можливості побачити } \\
\text { «живий» товар; } \\
\text { - загроза розповсюдження } \\
\text { конфіденційних даних; } \\
\text { - загроза розкрадання платіжних } \\
\text { коштів; } \\
\text { - неякісний сервіс. }\end{array}$ \\
\hline Для продавця & $\begin{array}{l}\text { - зменшення постійних витрат; } \\
\text { - охоплення більшої кількості } \\
\text { клієнтів; } \\
\text { - менше витрат для старту; } \\
\text { - зручність роботи (можна робити на } \\
\text { дому); } \\
\text { - набагато менше паперової роботи; } \\
\text { - підвищується продуктивність } \\
\text { організації: процес запускається, коли } \\
\text { надходить запит від клієнта - ні пізніше, } \\
\text { ні раніше, без зайвих дій і затримок. }\end{array}$ & $\begin{array}{l}\text { - недосконалість законодавчої влади; } \\
\text { - загроза несанкціонованого доступу; } \\
\text { - загроза розкрадання ресурсів; } \\
\text { - низький рівень довіри. }\end{array}$ \\
\hline $\begin{array}{c}\text { Для національної } \\
\text { економіки }\end{array}$ & $\begin{array}{l}\text { - прозорість дій (при г гарній } \\
\text { законодавчій владі); } \\
\text { - можливість володіти п повною } \\
\text { інформацією; } \\
\text { - зручність роботи; } \\
\text { - доступність 24/7; } \\
\text { - контроль. }\end{array}$ & $\begin{array}{l}\text { - велика кількість підприємств у тіні; } \\
\text { - шахрайство; } \\
\text { - загроза хакерських атак; } \\
\text { - складність застосування. }\end{array}$ \\
\hline
\end{tabular}

Складено автором за даними [370, 374] 
Переваги від розвитку електронної комерції є значно суттєвішими, ніж іiі недоліки, а тому виробники, ділові контрагенти, споживачі та суспільство в цілому зможуть перейти на неї завдяки найсучаснішим технологіям, а можливі ризики можна скоротити за рахунок розробки надійних засобів електронної безпеки транзакцій, врегулювання на державному рівні проблем нормативноправового регулювання цієї галуззі.

На сьогодні найбільш прибутковими і помітними сегментами ринку електронної комерції є бізнес для бізнесу (В2В) і бізнес для споживача (В2С).

Розглянемо розвиток ринку електронної комерції за сегментом В2В у світі протягом $2013-2019$ рр. (рис. 8.3.1).

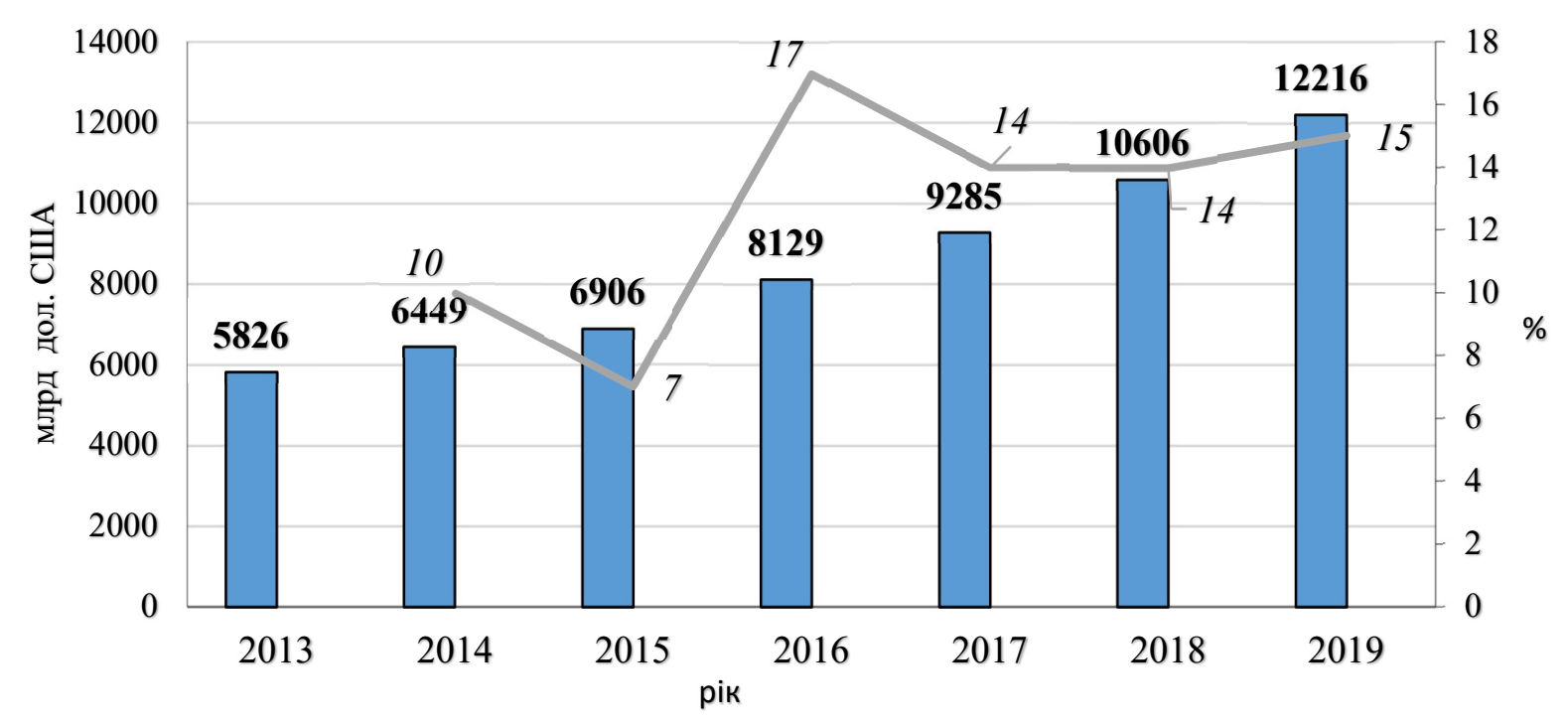

$\square$ Обсяги ринку електронної комерції за сегметом В2В в світі

-3ріст ринку електронної комерції за сегментом В2В в світі

Рисунок 8.3.1. Розвиток ринку електронної комерції за сегментом В2В у світі протягом $2013-2019$ рp. [375]

Сегмент В2В електронної комерції розвивався з кожним роком. 32013 р. по 2019 р. його обсяги збільшилися вдвічі (на 6390 млрд дол. США). 3 точки зору валового товарного обсягу продажу електронної комерції В2В країни Азії займають перше місце у світі, за ним йдуть країни Північної Америки. На Азію припадає приблизно $80 \%$ світового ринку електронної комерції В2В. Китайський ринок оцінюється в 25 трлн юанів, і з 2012 р. він неухильно зростає. 
Стійке зростання також пов'язане 3 торговими платформами В2В малих $\mathrm{i}$ середніх підприємств, доходи яких зростають. У період з 2013 з 2019 р. вартість транзакцій електронної комерції В2В тільки в Китаї зросла в чотири рази [376].

У США як в оптовому, так і у виробничому секторах спостерігається помірне, але стійке зростання транзакцій електронної комерції В2В. Великі або середні компанії В2В зазвичай продають свої товари через комерційні пакети SaaS-компаній, таких як Adobe, SAP або Salesforce. Ці постачальники пропонують набір готових послуг та програмного забезпечення, адаптованого для бізнес-вертикалей. Крім того, у сфері електронної комерції В2В спостерігається сплеск онлайн-ринків у декількох секторах, при цьому Alibaba очолює рейтинг універсальних торговельних майданчиків В2В [377].

Amazon, Alibaba, Rakuten, Mercateo, Global Sources, Walmart i IndiaMART $\epsilon$ основними гравцями на світовому ринку електронної комерції В2В. У 2015 р. Amazon перейменував свої операції електронної комерції В2B з AmazonSupply в Amazon Business, і всього за рік обсяг продажів перевищив 1 млрд доларів США. Alibaba 3 часткою близько 30 \% в Китаї в даний час розширює свою операційну базу на Індію, Свропу і США. Велика мережа недорогих постачальників компанії дозволяє їй домінувати на ринку, за якої слід Global Sources. IndiaMart, Mercateo, Rakuten i Amazon - найбільші компанії електронної комерції В2В в Індії, Німеччині, Японії і США відповідно [378].

В2С - це сегмент електронної комерції, орієнтований на споживача. Це стосується інтернет-транзакцій товарів і послуг, які відбуваються між бізнесом і приватним споживачем. Електронна комерція В2С часто використовується як синонім онлайн-торгівлі. Однак, виступаючи в якості узагальнюючого терміна, електронна комерція В2С відноситься не тільки до онлайн роздрібної, але і до онлайн-ринків, а також до зростаючих ринків електронної комерції безпосередньо споживачеві (D2C) і платного контенту. Оскільки електронна комерція продовжує розвиватися в усьому світі, ринок все більше розширюється 
в більш нішеві категорії, обслуговуючи всі більш і більш конкретні потреби споживачів і бізнесу.

У глобальному масштабі Азія може похвалитися найбільшим ринком електронної комерції В2С, за яким слідують такі ж стійкі, але менші ринки Північної Америки та Європи. Популярність Азії в секторі електронної комерції відбивається в силі таких гравців, як китайська Alibaba Group, яка в даний час $є$ найбільшим онлайн-ринком у світі. Розвиток ринку електронної комерції за сегментом В2С у світі протягом 2014 - 2020 рр. представлена на рис. 8.3.2.

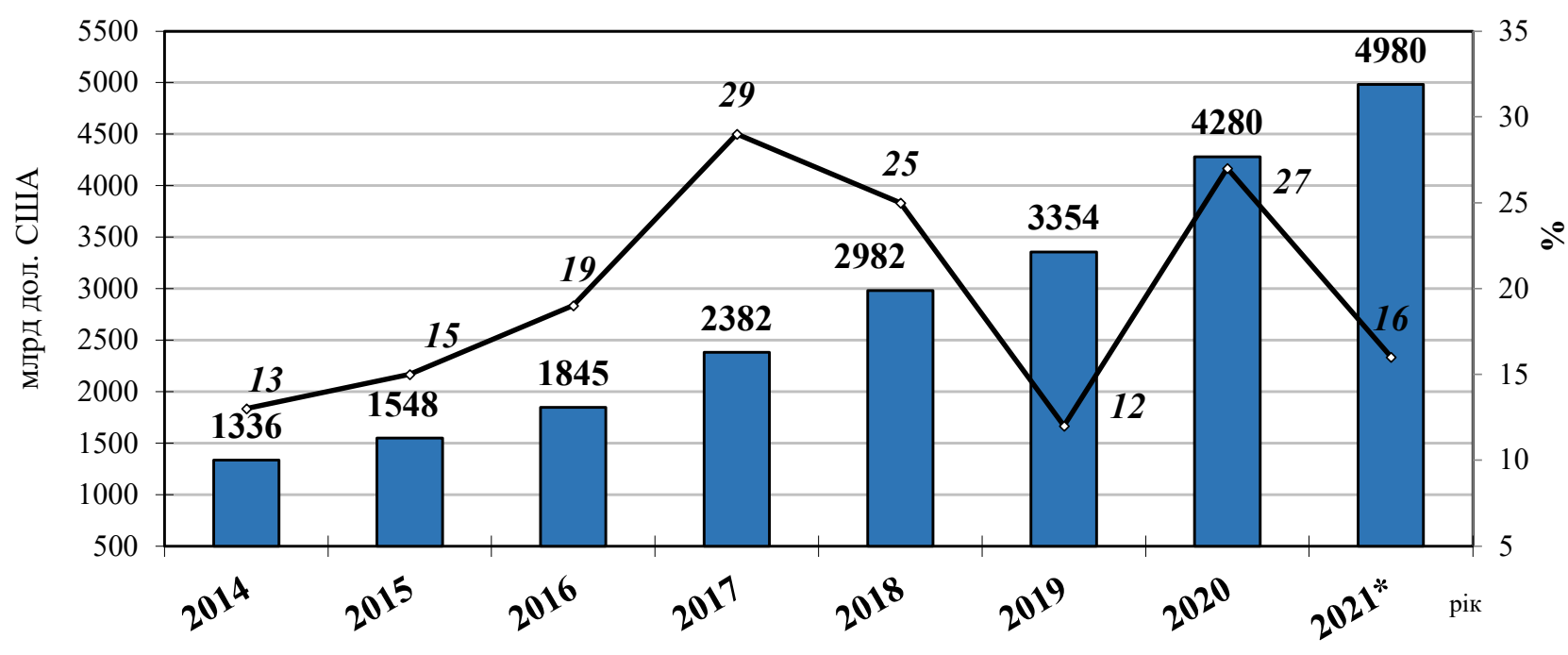

๑ Обсяги ринку електронної комерції за сегментом В2С в світі

$\longrightarrow$ Зріст ринку електронної комерції за сегментом В2С в світі

Рисунок 8.3.2. Розвиток ринку електронної комерції за сегментом В2С в світі протягом $2014-2021$ pp. [379]

На рис. 2 ми можемо простежити 32014 р. по 2020 р. зріст ринку електронної комерції за сегментом В2С в 3 рази або на 2944 млрд дол. США. Щодо прогнозів, то очікується, що в 2021 р. глобальна електронна комерція досягне 4,9 трлн дол. США. Прогнозують, що темпи зростання електронної комерції зменшаться з 2020 року, адже прорив обсягів електронної комерції відбувся у 2020 році і в найближчі роки очікується менші темпи зростання. 
Поштовхом для розвитку електронної комерції $є$ те, що наразі провідні продавці товарів все менше поділяються на офлайн і онлайн-продавців, натомість, намагаючись дотримуватись загального принципу клієнтоорієнтовності. В свою чергу, споживач, одночасно спираючись на важливі переваги офлайну та онлайну, надає перевагу тому чи іншому магазину, враховуючи такі критерії: товар має бути в наявності, оплата зручною та безпечною, отримання та повернення - швидкими, а обслуговування - якісним. Також часто важливу роль відіграють відгуки, які стають в нагоді споживачу при обранні товару чи перевірці добросовісності продавця он-лайн чи офлайн ритейлу.

Варто зауважити, що розвиток електронної комерції спирається на залучення до Інтернету все більшої кількості користувачів, тому не дивно, що частка обороту від електронної торгівлі у ВВП країн та частка електронної складової у роздрібній торгівлі корелює 3 показником рівня проникнення Інтернету, тобто частки населення країни віком від 14 до 74 років, що є регулярними Інтернет-користувачами. Так, рівень проникнення Інтернету у деяких країнах Західної Європи (Люксембургі, Норвегії, Великобританії, Німеччині) наближається до $100 \%$, у той час як в Україні він становить лише близько $63 \%$ [380].

Динаміка обсягів електронної комерції В2С у світі та їх частка у загальних обсягах роздрібної торгівлі за 2015-2021 рр. представлена на рис. 8.3.3. 


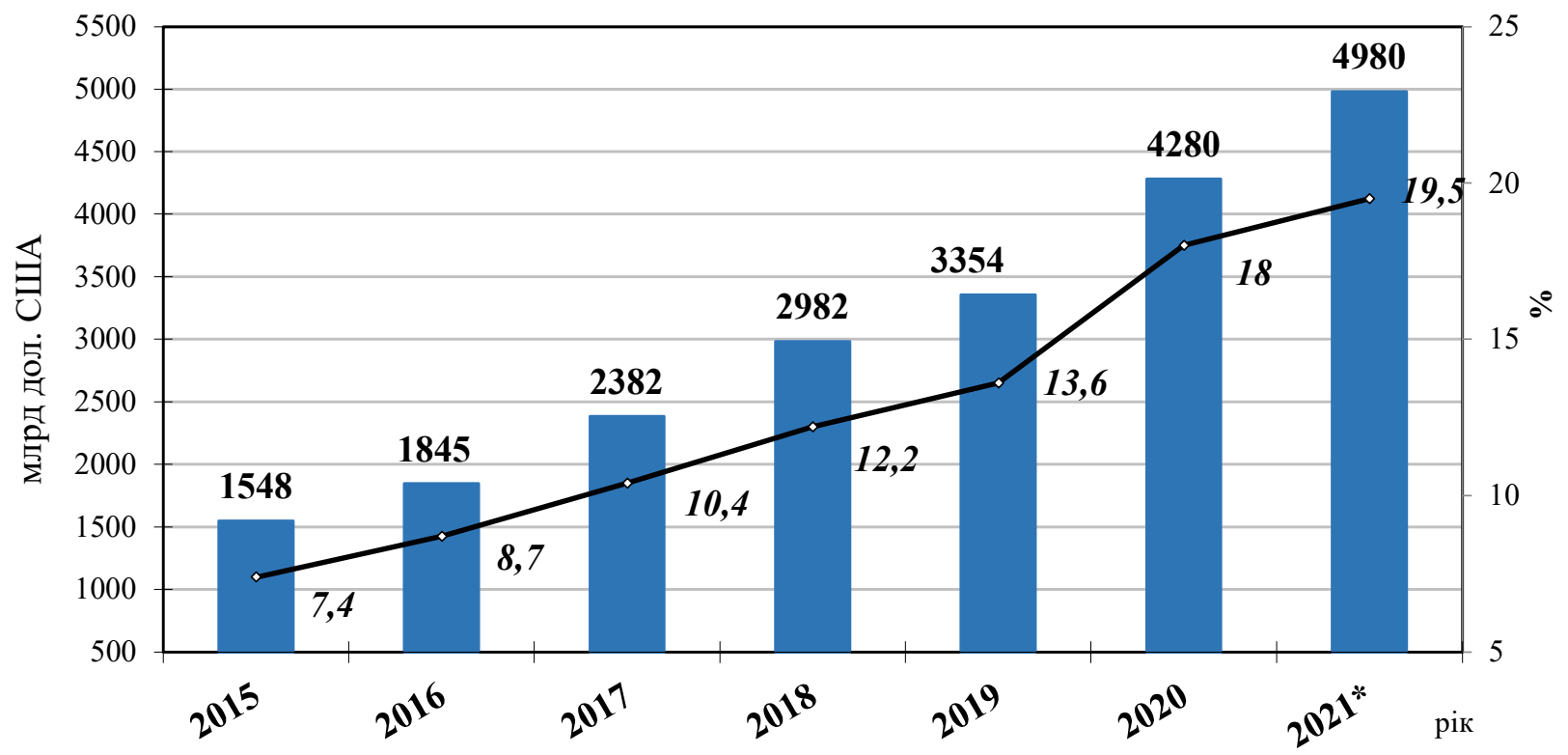

Обсяги ринку електронної комерції за сегментом В2С в світі

$\multimap$ Частка світової електронної комерції за сегментом В2С в загальних обсягах роздрібної торгівлі

Рисунок 8.3.3. Динаміка обсягів електронної комерції В2С у світі та їх частка у загальних обсягах роздрібної торгівлі за 2015-2021рp. [381, 382, 383].

Рисунок 3 нам демонструє зріст як обсягів електронної комерції В2С, так і їх частки в обороті усієї роздрібної торгівлі. Протягом 2015 - 2020 рр. обсяги електронної торгівлі зросли на 2732 млрд дол. США, а частка збільшилася також на 10,6 \%. В 2018 р. обсяги електронної торгівлі у світі не перевищили 3 трлн дол., тоді як у 2020 р. цей показник склав 4 трлн дол. США. В перспективі обсяги електронної торгівлі збільшаться до 5 трлн дол. США до 2022 р. та до 6 трлн дол. США у 2024 р. У 2019 р. частка електронної комерції В2С в обороті усієї роздрібної склала 13,6\%, то вже у 2020 р. 18,0\% всіх роздрібних продажів 
здійснювалося через електоронну комерцію. Очікується, що у 2024 р. цей показник досягне $21,8 \%$.

На всіх 32 національних ринках в 2020 р. зростання електронної торгівлі було як мінімум двозначним числом. По всім регіонам відбувся зріст електронної комерції В2С (рис. 8.3.4).

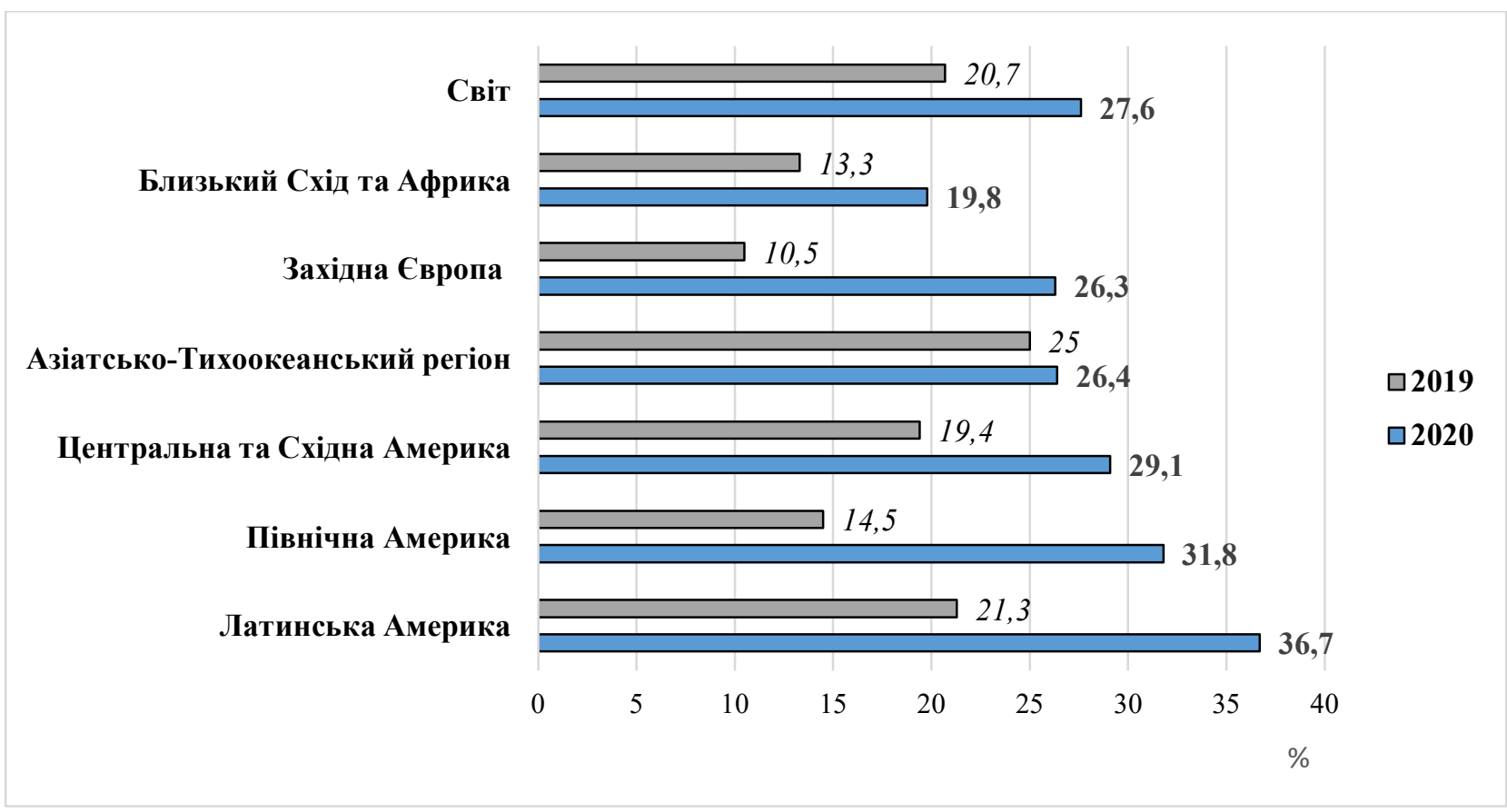

Рисунок 8.3.4. Зріст електронної комерції В2С у світі за регіонами у 2019 -2020 pp. [384, 385]

У Латинській Америці спостерігалося значне зростання на 36,7\%, незважаючи на те, що загальні роздрібні продажі впали нижче середнього (падіння на 3,4\%). Роздрібна електронна торгівля Аргентини зросла на вражаючі 79,0\%, а наприклад в Сінгапурі цей показник наблизився лише до 71,1\%. У 2021 p. зростання електронної тогівлі в усьому світі істотно сповільниться, незважаючи на новознайдений ентузіазм споживачів щодо рішень для цифрових покупок. Прогнозують, що зростання світової електронної торгівлі знизиться до 
14,3\% в 2021 р., частково через звичайного відновлення економіки, а частково через те, що таке значне зростання було перенесено на 2020 рік [384].

Світовим лідером електронної комерції протягом п’яти років є Китай. До світових лідерів належать також США, Франція, Південна Корея, Канада, Індія, Росія, Німеччина (табл. 8.3.2).

Таблиця 8.3.2

Країни з найвищими показниками розвитку електронної комерції за сегментом В2С у 2018 - 2019 р. [385, 386]

\begin{tabular}{|l|c|c|c|c|}
\hline \multicolumn{1}{|c|}{ Країни } & $\begin{array}{c}2018 \text { р., } \\
\text { млрд дол США }\end{array}$ & $\begin{array}{c}2019 \text { р., } \\
\text { млрд дол США }\end{array}$ & $\begin{array}{c}\text { Тепми зросту } \\
2019 / 2018, \%\end{array}$ & $\begin{array}{c}\text { Частка країни у } \\
\text { світових обсягах } \\
\text { електронної } \\
\text { комерції за } \\
\text { сегментом В2С } \\
\text { у 2019 p. }\end{array}$ \\
\hline Китай & 1520,10 & 1934,78 & 27,3 & 57,6 \\
\hline США & 514,84 & 586,92 & 14,0 & 17,5 \\
\hline Великобританія & 127,98 & 141,93 & 10,9 & 4,2 \\
\hline Японія & 110,96 & 115,40 & 4,0 & 3,4 \\
\hline Південна Корея & 87,60 & 103,48 & 18,1 & 3,08 \\
\hline Німеччина & 75,93 & 81,85 & 7,8 & 2,4 \\
\hline Франція & 62,27 & 69,43 & 11,5 & 2,07 \\
\hline Канада & 41,12 & 49,80 & 21,1 & 1,5 \\
\hline Індія & 34,91 & 46,05 & 31,9 & 1,4 \\
\hline Росія & 22,68 & 26,92 & 18,7 & 0,8 \\
\hline
\end{tabular}

У 2019 р. провідним світовим ринком електронної комерції є Китай 3 об'ємом продажів електронної комерції 1935,78 млрд дол. США, що більш ніж у три рази більше, ніж у США, що займає друге місце з 586,92 млрд дол. США. Китай становить 57,6\% світового ринку електронної комерції, що майже вдвічі більше, ніж у наступних п'яти країн разом узятих. Західна Європа володіє двома 3 шести найбільших ринків електронної комерції, на чолі Німеччина $(81,85$ млрд дол. США) і Франція (69,43 млрд дол. США). Це контрастує 3 відносно розвиненим інтернет-ринком Канади, який продовжує демонструвати високі темпи зростання. Незважаючи на загальну цифрову зрілість Канади, електронна 
комерція традиційно відставала від ринку через неефективність логістики. Географічно розосереджене населення Канади від ii західних до східних кордонів зробило створення розподільних центрів електронної комерції $\mathrm{i}$ можливості доставки більш дорогими. Найбільш швидкозростаючим ринком електронної комерції в першій десятці є Індія, обсяг продажів якої в 2019 р. виріс на $31,9 \%$ або до 46,05 млрд. дол. США. Хоча Індія є однією з найбільших економік у світі, але ринок електронної комерції знаходиться не на високому рівні через низький рівень доходів населення та формування інфраструктури для підтримки платежів і доставки [385].

Китай також продовжуватиме бути лідером у світі за кількістю покупців цифрових технологій. На початку 2021 р. цей показник склав 792,5 млн покупців (33,3\% від загальносвітового числа); обсяг продажів електронної комерції- 2,779 трлн дол. США (56,8\% від загальносвітового обсягу); і він стане першою країною в історії, яка буде проводити більше половини своїх роздрібних продажів у цифровому вигляді (52,1\% роздрібної торгівлі становитиме електронна торгівля) [384].

Україна має не такі великі обсяги електронної комерції за сегментом В2С протягом 2018-2019 pр. (2,39 млрд дол.США), як країни 3 найвищим показниками розвитку електронної комерції за сегментом В2С, але темпи зростання з 2018 по 2019 рр. є значними (25,5\%), тобто можна сказати, що рухається Україна досить швидкими темпами. Ринок електронної комерції України зараз є найуспішнішим ринком взагалі в країні. Це лише одна галузь, темпи зростання якої в останні 2 роки є найвищими у Європі, що надає нам позитивні передбачування і заманює все більшу кількість учасників.

Україна продемонструвала значний ріст доходів від електронної комерції В2С за час пандемії. Про це говорять у звіті Payoneer's Global Seller Index [387]. Наша країна зайняла шосту позицію в рейтингу, опередивши В'єтнам, Ізраїль, 
Індію та Японію, але поступившись Китаю, США, Гонконгу, Південнії Кореї та Великобританії (рис. 8.3.5).

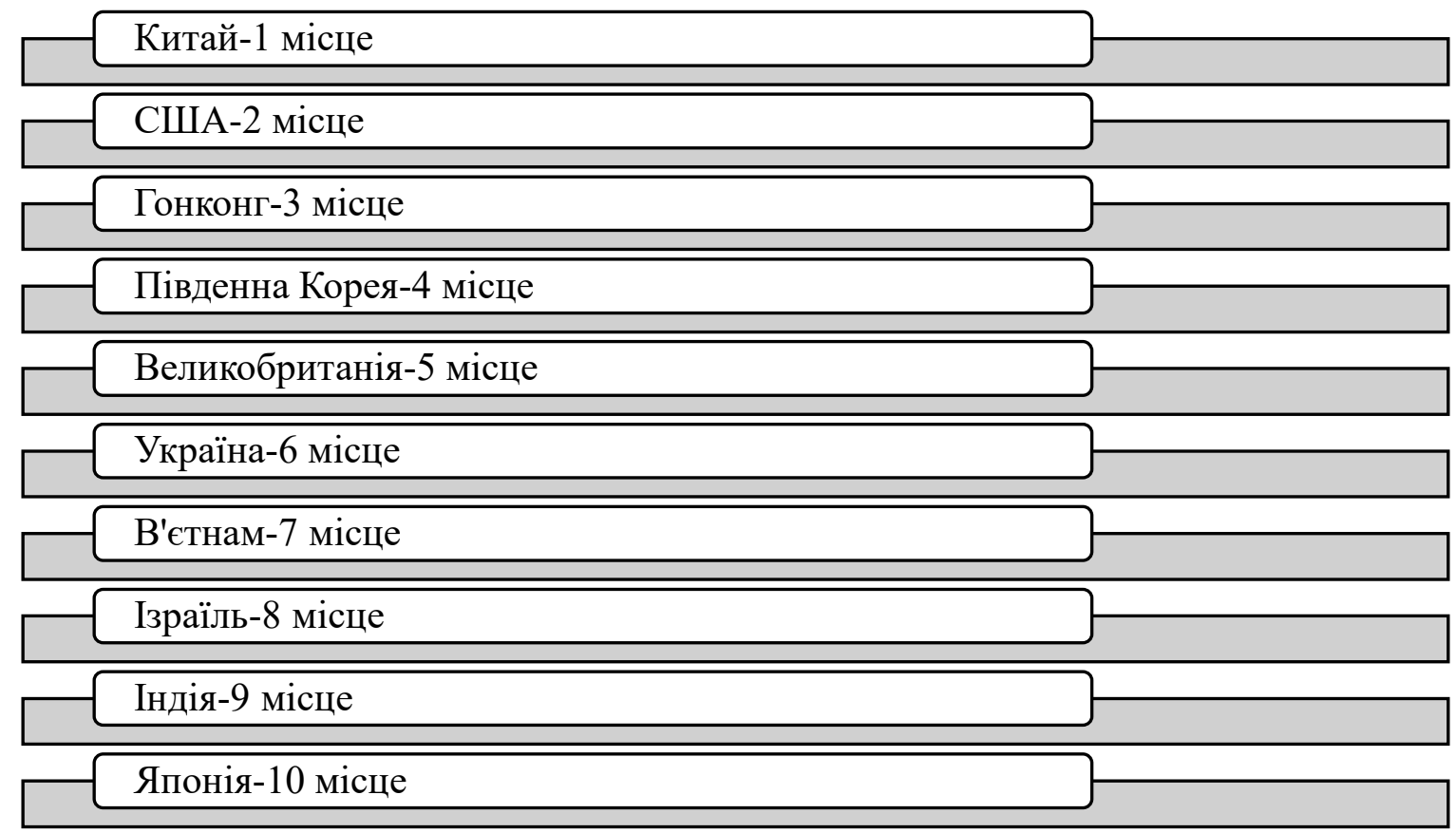

Рисунок 8.3.5. Топ-10 країн з найвищими показниками розвитку електронної комерції у II -III кв. 2020 р. [388]

У світі число відвідувань онлайн-маркетплейсів з січня по червень 2020 р. збільшилася на 37\% або на 6 млрд дол. США (з 16 млрд до 22 млрд дол. США). У другому кварталі 2020 р. світові обсяги продажів зросли на $81 \%$ в річному численні, що майже втричі перебільшує зростання в другому кварталі 2019 р. У третьому кварталі 2020 р. також простежується збільшення на $81 \%$ в річному вирахуванні в порівнянні з 36\% в 3 кварталі 2019 р. [388].

Згідно 3 99firms.com до 2040 року більше 95\% всіх покупок буде здійснюватися через електронну комерцію. Адже зараз починають більше розплачуватися кредитною карткою і $51 \%$ онлайн-покупців роблять покупки через смартфони. Тобто електронна комерція розвивається, у світі налічується 
від 12 до 24 мільйонів сайтів е-commerce. Очікується, що до кінця 2021 року глобальні продажі електронної комерції досягнуть 4,9 трлн дол. США [389].

У 2019 році на електронну роздрібну торгівлю (електронну комерцію В2С) припадало 14,1\% від усієї роздрібної торгівлі у всьому світі. Очікується, що в 2023 році цей показник досягне 22\% [390].

Частка електронної комерції В2С від загального обсягу роздрібних продажів у провідних країнах Свропи у 2015-2020 рр. представлена в табл. 8.3.3.

Таблиця 8.3.3

Частка електронної комерції В2С від загального обсягу роздрібної торгівлі в деяких країнах Свропи у 2015-2020 рр., \% [391, 392, 393, 394]

\begin{tabular}{|l|c|c|c|c|c|c|c|}
\hline \multicolumn{1}{|c|}{ Країни/рік } & 2015 & 2016 & 2017 & 2018 & 2019 & 2020 & $\begin{array}{c}\text { Темпи змін } \\
2020 \text { р. до } \\
2015 \text { p. }\end{array}$ \\
\hline СС (вкл. 2020) & 16 & 16 & 18 & 17 & 18 & 20 & +4 \\
\hline Польща & 16 & 15 & 14 & 14 & 14 & 18 & +2 \\
\hline Італія & 9 & 9 & 101 & 11 & 12 & 13 & +4 \\
\hline Франція & 17 & 17 & 19 & 22 & 22 & 23 & +6 \\
\hline Німеччина & 17 & 14 & 21 & 14 & 15 & 18 & +1 \\
\hline Іспанія & 14 & 16 & 16 & 17 & 17 & 19 & +5 \\
\hline Бельгія & 25 & 29 & 31 & 32 & 33 & 31 & +6 \\
\hline Великобританія & 20 & 19 & 18 & 19 & 21 & 21 & +1 \\
\hline Нідерланди & 13 & 14 & 15 & 15 & 15 & 17 & +4 \\
\hline Фінляндія & 21 & - & 21 & 121 & 21 & 23 & +2 \\
\hline Ірландія & 37 & 35 & 33 & 35 & 33 & 44 & +7 \\
\hline Угорщина & 19 & 16 & 20 & 23 & 24 & 23 & +4 \\
\hline Португалія & 17 & 14 & 16 & 18 & 19 & 20 & +3 \\
\hline Австрія & 16 & 15 & 14 & 14 & 14 & 17 & +1 \\
\hline Швеція & 19 & 21 & 19 & 24 & 24 & 24 & +5 \\
\hline Чехія & 30 & 31 & 31 & 29 & 31 & 31 & +1 \\
\hline Україна & 1,7 & 2,5 & 3,2 & 4 & 7 & 9 & $+7,3$ \\
\hline
\end{tabular}

3 табл. 8.3.2 можна простежити, що протягом 2015-2020 pр. кожна країна збільшила відсоток продажу електронної комерції. Найбільший вісоток електронної комерції В2С у загальному обсязі роздрібної торгівлі в Ірландії, Чехії, Бельгії, Швеції, Франції, Угорщині. Щодо України, то електронна комерція В2С розвивається з кожним роком. Протягом 2015-2020 рр. частка електронної комерції В2С від загального обсягу в Україні зросла на 7,3\%, тобто це найбільший показник серед країн, зазначених у таблиці. Отже, можна зробити 
висновок, що електронна комерція все більше і більше проникає в життя населення.

Електронна комерція В2С у регіонах розвивається швидкими темпами: методи онлайн-платежів стають все більш поширеними, все більше людей починають робити покупки за допомогою своїх мобільних телефонів. У 2020 р. у всьому світі більш ніж 4/5 споживачів купують товари через Інтернет. 3 моменту появи вірусу в березні 2020 року у всьому світі з'явилося значне число інтернет-покупців незалежно від віку. Але тенденція до переходу в інтернетмагазини у значній мірі негативно впливає на фізичні та місцеві роздрібні магазини.

На рис. 8.3.6 представлені країни, у яких найчастіше купували онлайн товари європейці протягом 2014-2020 pр.

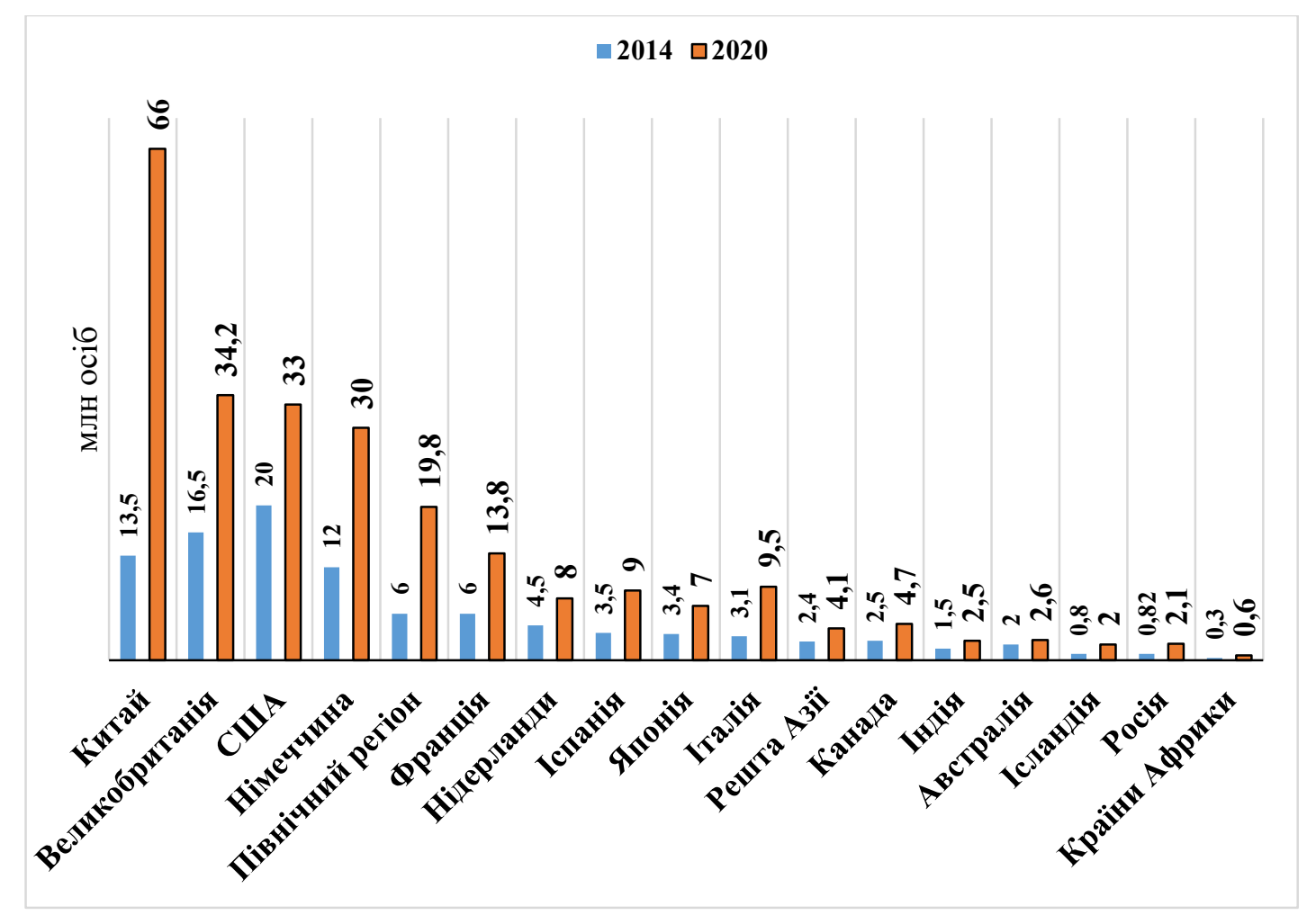

Рисунок 8.3.6. Країни, в яких найчастіше купували онлайн товари європейці протягом 2014-2020 pp. [395]

Рис. 8.3.6 нам демонструє, що кількість осіб, які замовляли товари онлайн протягом 2014-2020 рр., зросла. Європейці найчастіше купували товари у Китаї 
- кількість покупців збільшилась з 2014 р. до 2020 р. на 52,5 млн осіб (у 5 разів). Майже у всіх країнах у 2-3 рази збільшилась кількість покупців, які робили покупки в Інтернеті.

Частка користувачів країн Свропи, яка купувала в Інтернеті протягом 2020 року на сайтах Wish, Zalando, Amazon, Ebay, Etsy, Alibaba / Aliexpress, JD.com та Allegr, представлена на рис. 8.3.7.

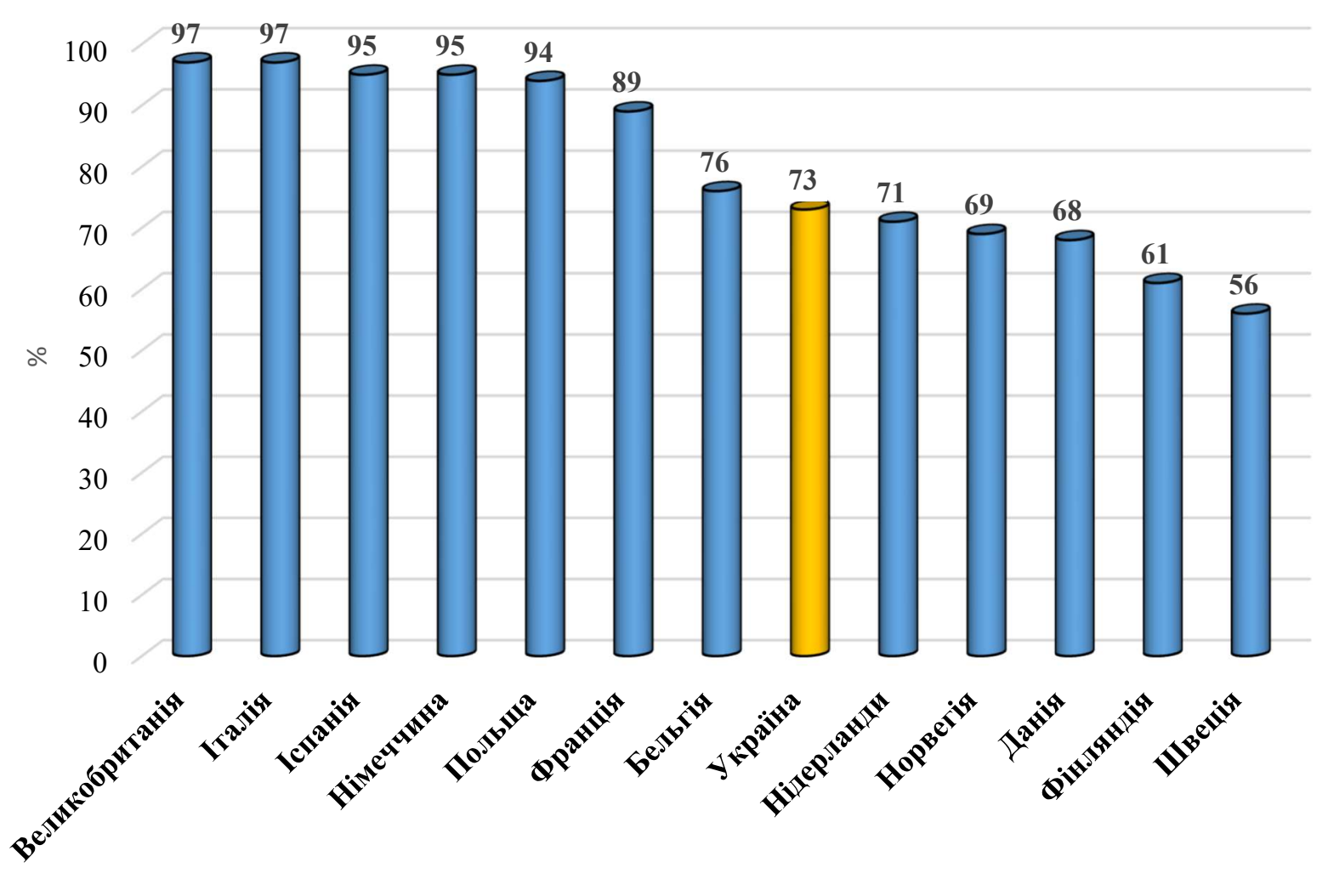

Рисунок 8.3.7. Частка користувачів країн Свропи, яка купувала в Інтернеті протягом 2020 року [395, 396]

У таких країнах як Великобританія, Італія, Іспанія, Німеччина, Польща та Франція частка користувачів склала від 89 до 97\%, яка купувала в Інтернеті протягом 2020 року на таких сайтах: Wish, Zalando, Amazon, Ebay, Etsy, Alibaba / Aliexpress, JD.com та Allegro. Порівняно з іншими країнами Свропи, у Бельгії, Україні, Нідерландах, Норвегії, Данії, Фінляндії та Швеції частка користувачів 
складає від 56 до 76\%. Отже, у 2020 році закупівля та продаж товарів та послуг в інтернеті $є$ дуже популярною.

Користувачі інтернету можуть вибирати з різних онлайн-платформ для перегляду, порівняння та покупки необхідні їм товари або послуги. Деякі вебсайти спеціально націлені на клієнтів В2В (business-to-business), але й індивідуальним споживачам також надається величезна кількість цифрових можливостей.

Двома найбільшими гравцями на світовому ринку електронної комерції $є$ Amazon i Alibaba. Незважаючи на приголомшливу частку ринку США в 52\%, в глобальному масштабі Amazon становить всього 13\% ринку електронної комерції. 3 іншого боку, китайська Alibaba Group управляє двома найбільшими платформами електронної комерції в світі. У сукупності роздрібні продажі на Taobao.com i Tmall.com становлять 30\% ринку електронної комерції [397].

У списку десяти провідних світових компаній електронної комерції в даний час домінують американські компанії, причому п'ять 3 десяти мають головні офіси в США. Це не дивно, враховуючи, що США - один з найбільших ринків електронної комерції у світі (рис. 8.3.8).

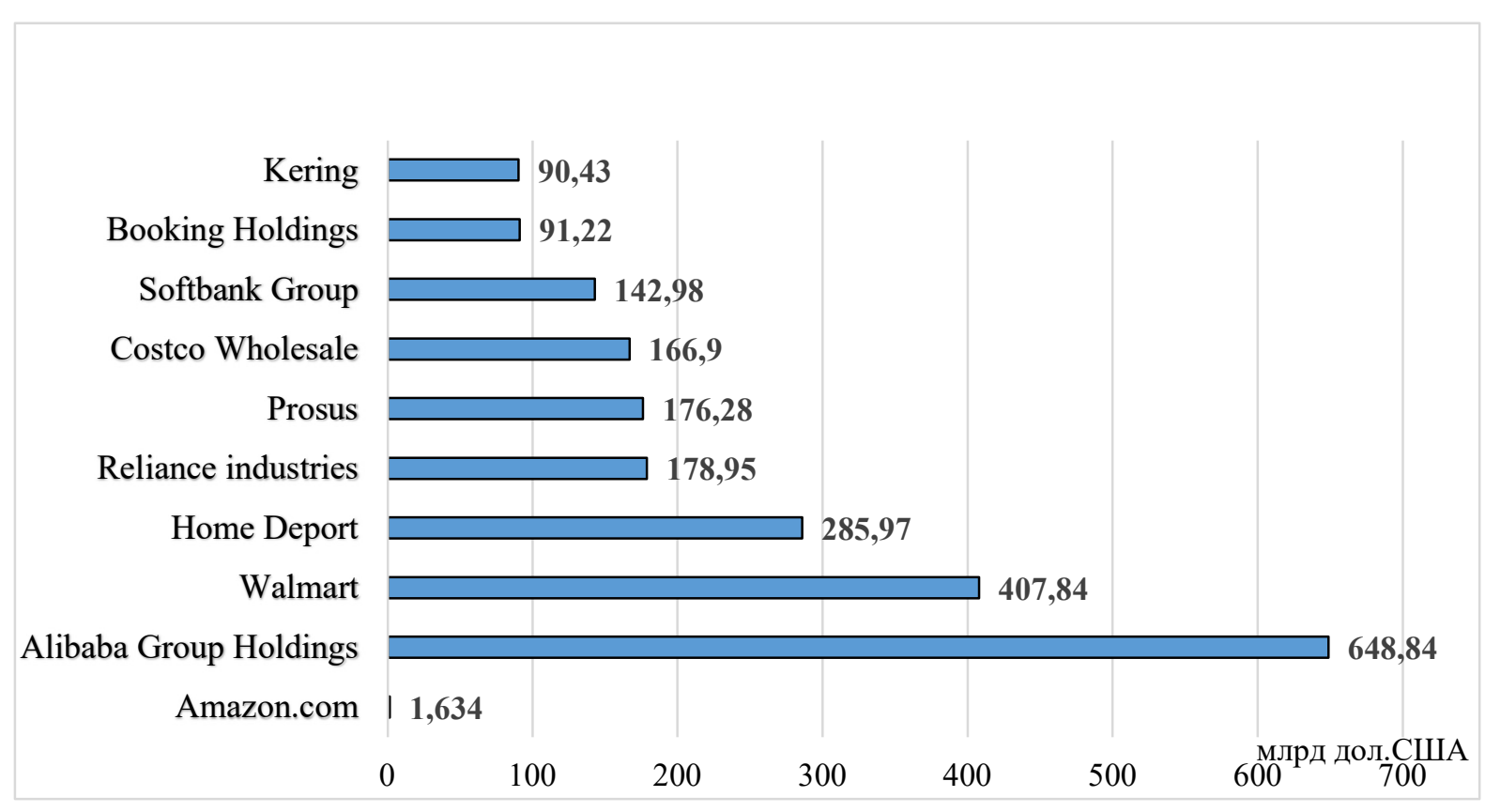

Рисунок 8.3.8. Кращі світові компанії електронної комерції (на січень 2021 р.) [398] 
3 рис. 8.3.8 ми можемо спостерігати, що список провідних компаній електронної комерції очолює гігант електронної комерції Amazon. Станом на січень 2021 року його ринкова вартість становить 1,634 трлн дол. США. Це вражаюче зростання на 73,6\% в порівнянні з попереднім роком, що пов'язано 3 пандемією коронавируса і та обмеженнями по всьому світу, оскільки споживачі проводять більше часу в приміщенні і в Інтернеті. Поточна ринкова капіталізація Amazon більш ніж удвічі перевищує капіталізацію найближчого конкурента та сукупну вартість наступних чотирьох найбільших інтернет-магазинів в списку. Виручка компанії, що займається електронною комерцією, неухильно зростає вже більше десяти років. За 2020 р. виручка компанії досягла 386,1 млрд дол. США, що на 37,6\% більше ніж у 2019 р. Другою за величиною компанією електронної комерції є китайська Alibaba з ринковою вартістю 648,32 млрд дол. США. Хоча їй, безумовно, ще треба буде пройти довгий шлях, перш ніж вона наздожене Amazon, але показує досить вражаючу траєкторію зростання. Фактично з 2018 по 2020 рік Alibaba майже удвічі подвоїла чистий виторг - 36 млрд дол. США до 74 млрд дол. США. Сумарна ринкова вартість двох найбільших інтернет-магазинів Amazon i Alibaba перевищує 2,2 трлн дол. США. Це становить понад 40 \% від загальної ринкової вартості 10 провідних світових компаній електронної комерції. Третя і четверта в списку провідних компаній електронної комерції в 2021 році також мають штаб-квартири в США. На третьому місці Walmart з ринковою вартістю 407,84 млрд дол. США, за ним йде Home Depot 3 285,97 млрд дол. США. Сдина компанія 3 п'яти найбільших інтернет-магазинів, яка не базується в США або Китаї, - це індійська Reliance Industry. Ï̈ї ринкова вартість у даний час складає 178,95 млрд дол. США. Десять провідних світових компаній електронної комерції розкидані по трьох різних континентах: половина з Північної Америки, три з Азії і дві з Свропи [398].

Що стосується найпопулярніших сайтів електронної комерції за кількістю відвідувачів, аmazon.com впевнено посідає перше місце. Останні дані показують, 
що у 2020 році, в розпал пандемії коронавіруса, кількість відвідувань найбільшого в світі інтернет-магазину перевищила 5,2 млрд осіб (рис. 8.3.9).

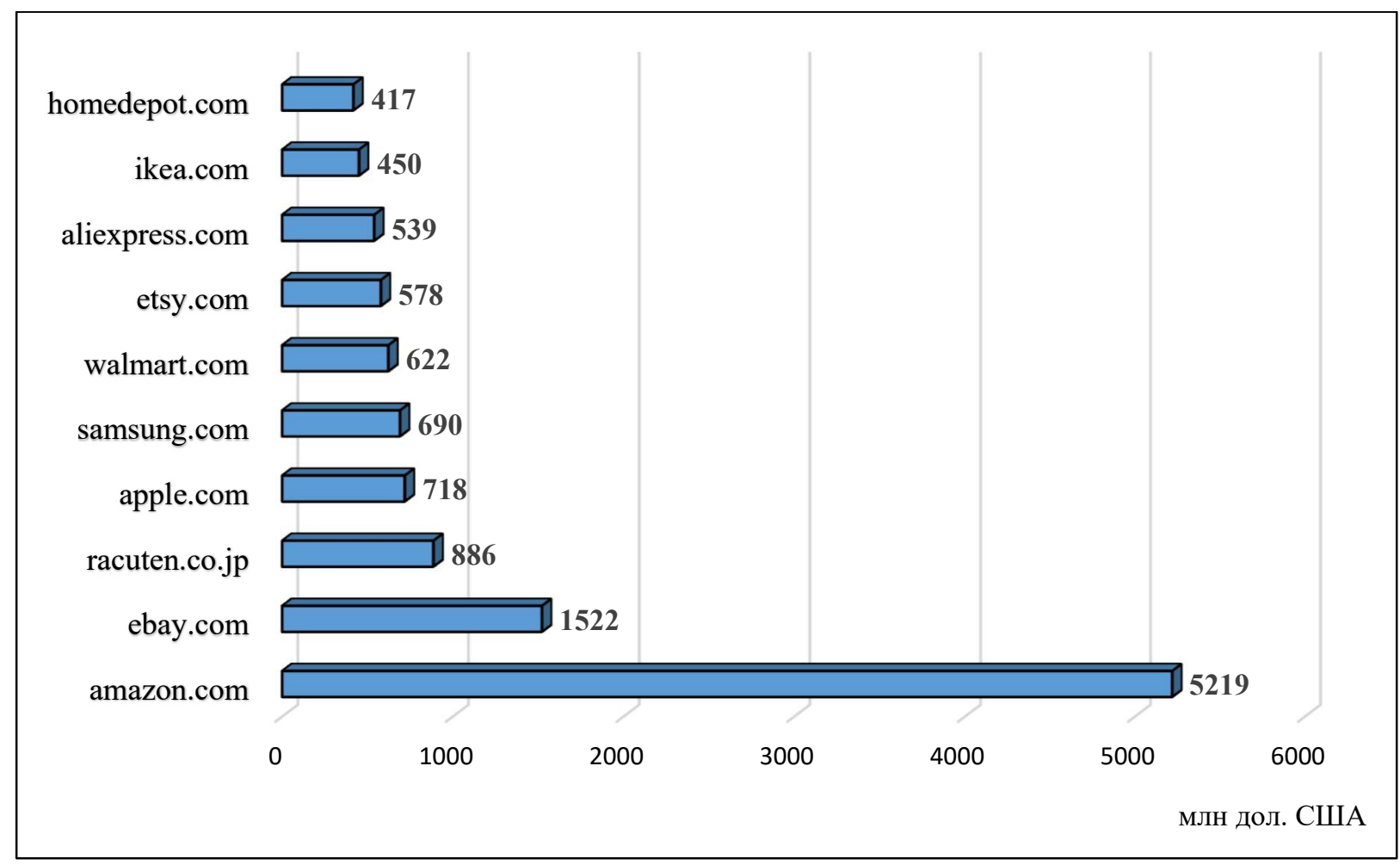

Рисунок 8.3.9. Кращі світові сайти електронної комерції, 2020 р. [399]

Amazon домінує над рештою групи. Його кількість відвідувань веб-сайту майже в 3,5 рази більше, ніж у другого за величиною інтернет-магазину і одного 3 його найближчих конкурентів, еВау. У тому ж місяці ebay.com відвідали більше ніж 1,5 мільярда споживачів по всьому світу. У 2020 р. річний чистий виторг еВау склав понад 10 млрд дол. США, що перевищує 8,6 млрд дол. США в 2019 p. [400].

Разом ці два провідних веб-сайти онлайн-покупок зареєстрували в цілому 6,741 мільярда відвідувань. Це становить 57\% від загальної кількості відвідувань десяти провідних сайтів електронної комерції і більше, ніж інші вісім у списку разом узяті.

Третій у списку найпопулярніших сайтів електронної комерції за кількістю відвідувачів займає rakuten.co.jp, японський сайт електронної комерції, який привернув 886 мільйонів відвідувачів. 
Четвертий і п'ятий за величиною інтернет-магазини йдуть від звичайних магазинів електронної комерції, що продають широкий спектр товарів, у більш конкретну категорію - електроніку. Четверте місце в списку займає сайт apple.com 3718 мільйонами відвідувачів. Далі слід сайт samsung.com, який привернув увагу 690 мільйонів відвідувачів. Між іншим, Apple i Samsung також $€$ двома найбільшими виробниками смартфонів у світі. Однак їх асортимент не обмежується тільки смартфонами. Інші електронні товари, такі як розумні годинник, планшети і побутова техніка, також продаються на їх веб-сайтах. Оскільки електроніка - одна з провідних категорій онлайн-покупок у всьому світі, не дивно, що Apple i Samsung є провідними інтернет-магазинами.

Розташовані в США компанії walmart.com i etsy.com $€$ шостим і сьомим за величиною інтернет-магазинами у світі. Walmart, відомий своїми величезними гіпермаркетами, відвідало 622 мільйона відвідувачів, a Etsy, ринок товарів для рукоділля та креативних товарів, привернув 578 мільйонів відвідувачів вебсайту. Восьме місце в списку кращих сайтів електронної комерції за кількістю відвідувачів займає AliExpress, зазвичай званий «китайською Амазонкою», з 539 мільйонами відвідувачів. Завершують десятку найбільших інтернет-магазинів ikea.com 3450 мільйонами відвідувачів i homedepot.com 3417 мільйонами відвідувачів [399].

Під електронною комерцією С2C розуміються онлайн-транзакції, що проводяться між двома приватними споживачами через онлайн-торговельні майданчики, веб-сайти аукціонів або тематичні рекламні оголошення без участі третьої сторони. Діяльність С2С здійснюється через онлайн-торговельні майданчики, такі як eBay, Etsy або Taobao, а також через аукціонні сайти i форуми, такі як Craigslist. Ці платформи дозволяють споживачам продавати i перепродавати як нові товари, так і колишні у вживанні. Перехід на мобільний зв'язок в останні роки привів до появи роздрібних і торгових платформ, які спонукають споживачів продавати і купувати у інших споживачів без необхідності створювати бізнес або звертатися до третьої сторони. Що стосується додатків, то електронна комерція С2С особливо сприятлива для 
індустрії моди і популярна серед молодого покоління. Прикладом цієї тенденції $\epsilon$ додаток для соціальних покупок Dерор, яке дозволяє мільйонам продавців $\mathrm{i}$ реселерів створювати магазини і зв'язуватися зі споживачами. Електронна комерція від споживача до споживача - це менший сегмент на більш великому ринку електронної комерції з меншою кількістю гравців у порівнянні з гігантами електронної комерції В2С. Як і в інших сегментах ринку, для продажу і покупки товарів широко використовуються як веб-сайти, так і додатки, що допускають транзакції С2С. У Сполучених Штатах у 2020 році понад 100 мільйонів відвідувань провідних торгових майданчиків С2С і покупки / продажу [401].

Мобільний зв’язок збільшує світовий трафік електронної комерції. Одна 3 значних тенденцій у світі електронної комерції - це використання мобільних пристроїв. У 2019 р. на смартфони припадало понад 67\% усіх відвідувань роздрібних веб-сайтів в усьому світі. Оскільки впровадження мобільних пристроїв відбувається швидкими темпами, особливо в регіонах, де відсутня інша цифрова інфраструктура, мобільна інтеграція буде, як і раніше, визначати купівельний досвід у майбутньому. M-commerce (Mobile commerce - мобільна комерція) особливо популярна в країнах Азії: там генерується до 65 \% загального обсягу онлайн-транзакцій через мобільний трафік. Продажі мобільної роздрібної торгівлі як відсоток від роздрібних продажів електронної комерції у всьому світі з 2016 по 2021 роки представлені на рис. 8.3.10.

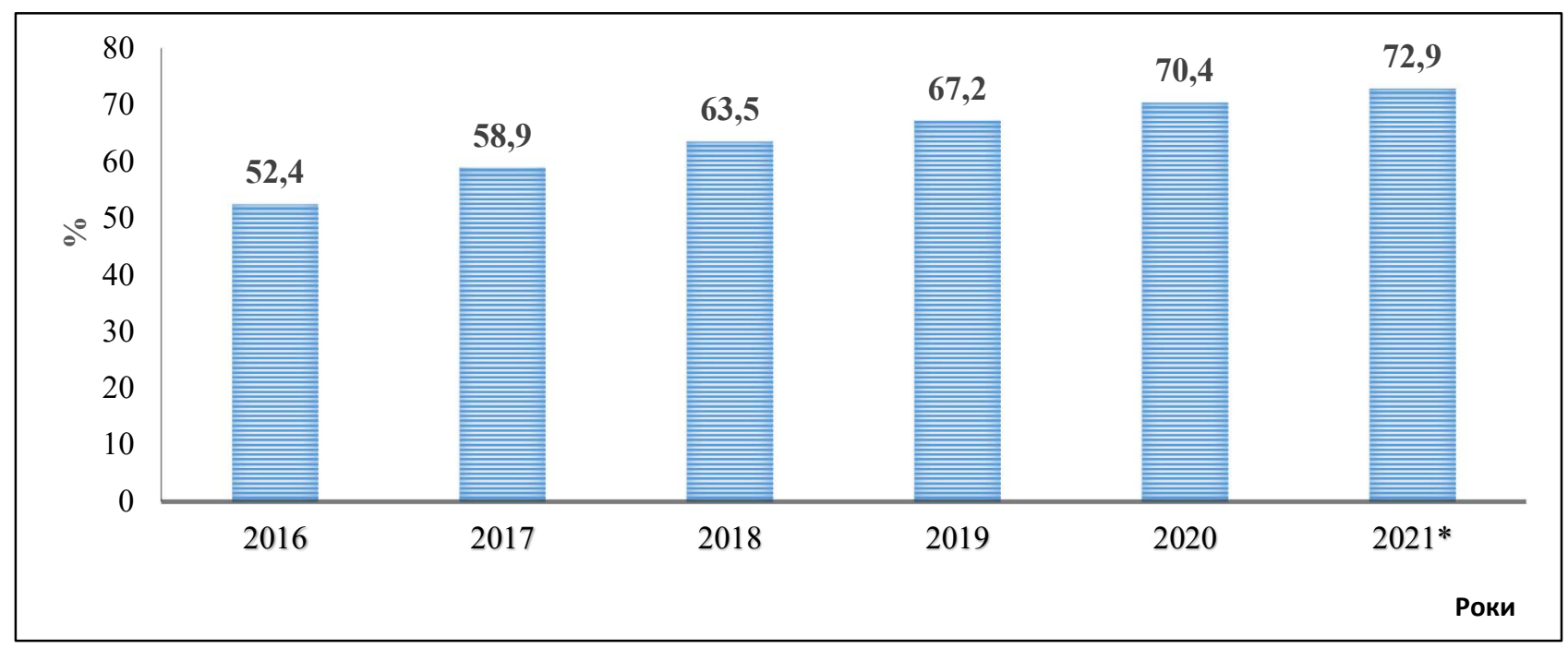

Рисунок 8.3.10. Продажі в м-соmmerce як відсоток від е-соmmerce в усьому світі з 2016 по 2021 роки [389] 
32016 по 2020 рр. продажі в м-сommerce як відсоток від е-commerce в усьому світі збільшилися на 18\%. Очікується, що в 2021 році 72,9 \% всієї роздрібної електронної торгівлі буде генеруватися через мобільну комерцію, в порівнянні з 58,9 \% в 2017 році. Ринки електронної комерції в країнах, що розвиваються, орієнтовані насамперед на мобільні пристрої.

Зміна поведінки онлайн-покупців позитивно вплинуло на деякі ніші. Багато хто не вірив, що можна купити свіжі продукти через інтернет. Людям поки складно звикнути до такого способу доставки, тому що їжа є головною потребою і до неї пред'являються підвищені вимоги.

Розподіл онлайн-покупців за віковими категоріями у регіонах Європи 2019 р. представлено на рис. 8.3.11.

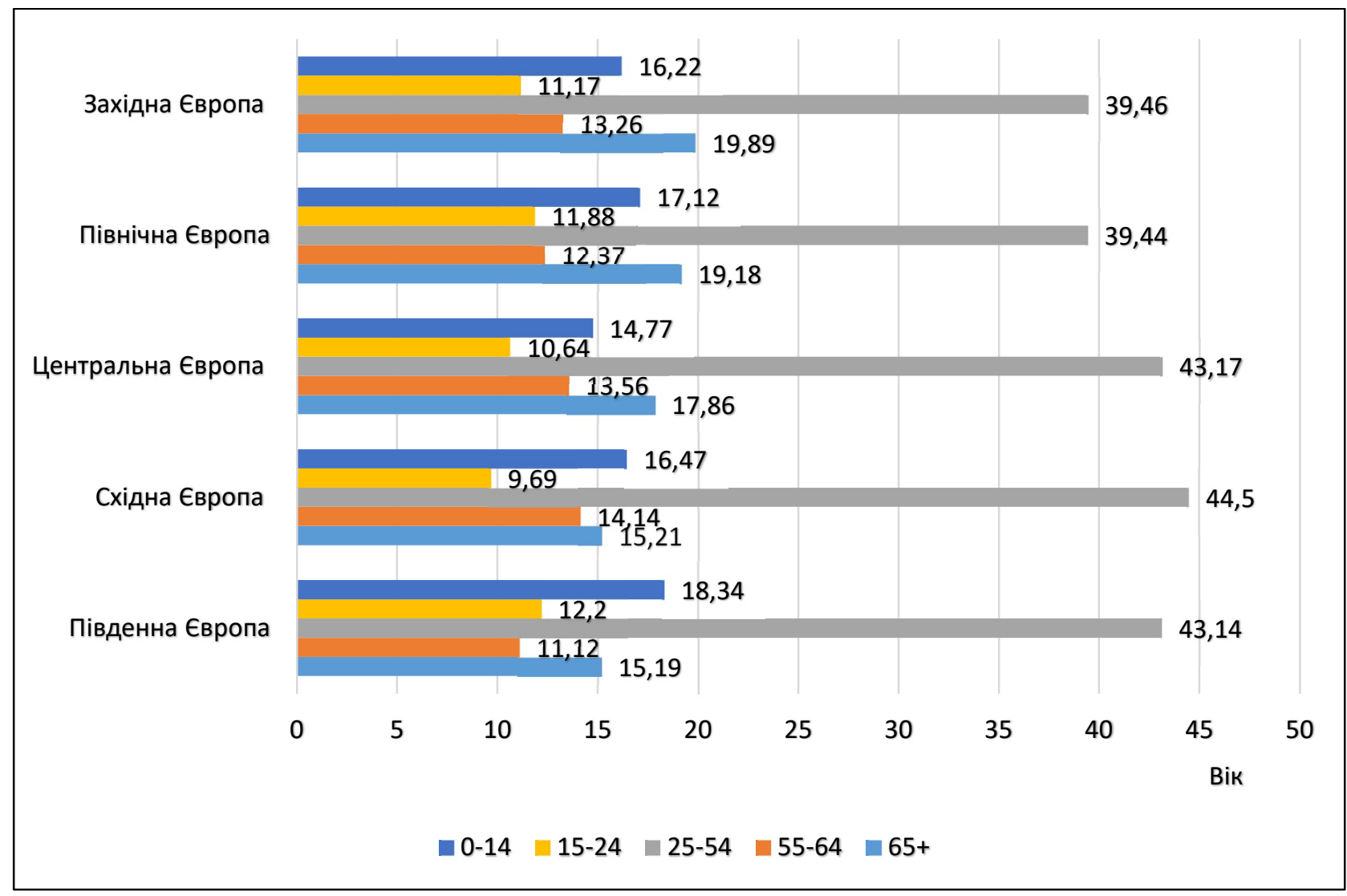

Рисунок 8.3.11. Розподіл онлайн-покупців за віковими категоріями у регіонах Свропи, 2019 р. [402]

3 рис. 8.3.11 видно, що переважають в усіх регіонах Європи онлайн-покупці вікової категорії - 25-54. У Південній та Східній Європі на другому місці - вікова категорія - 0-14, а на третьому місці - 65+, у Центральній, Північній та 
Центральній Свропі навпаки, на другому місці йде вікова категорія - 65+, а на третьому місці - 0-14. Далі на четвертому місці розташова вікова категорія - 5564. та на п’ятому місці - 15-24, крім Південної Європи, в цьому регіоні навпаки.

На рис. 8.3.12 можна спостерігати, які товари електронної комерції за сегментом В2С найчастіше купували онлайн у США:

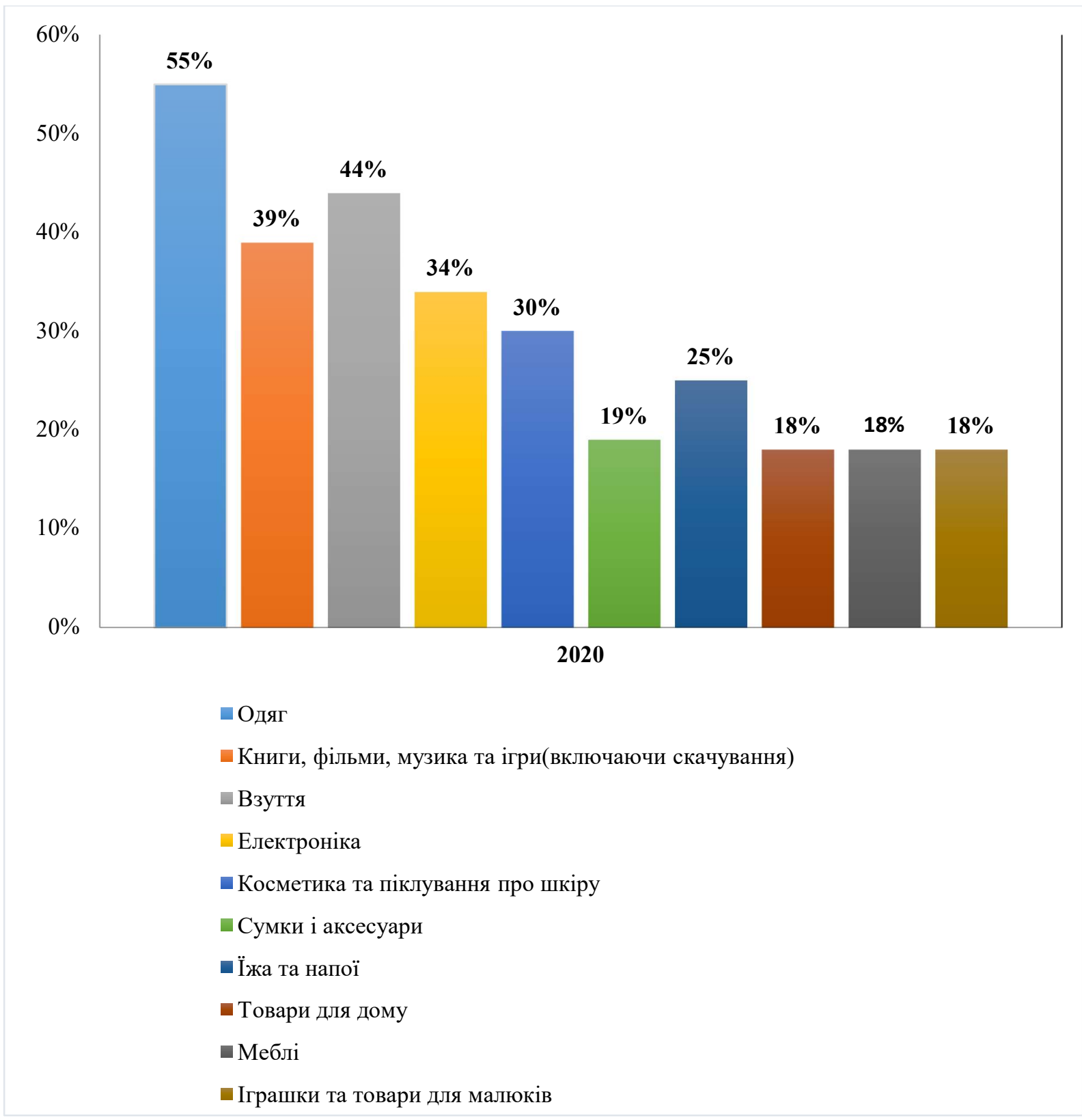

Рисунок 8.3.12. Провідні товари електронної комерції за сегментом В2С у США у 2020 p. [403] 
За сегментом В2С у США у 2020 році найбільше купували одяг (55\%), взуття (44\%), книги, фільми, музику (включаючи скачування) (39\%), електроніку (34\%), косметику та засоби догляду за шкірою (30\%). Найменш - їжу та напої (25\%), сумки та аксесуари (19\%), товари для дому, меблі та іграшки та товари для малюків (18\%).

Але пріоритети у 2020 році у споживачів змінилися. У першу чергу це зумовлено пандемією й тривалими періодами часу, упродовж яких співробітники компаній і споживачі перебували вдома. Галузі моди (одяг, взуття, аксесуари), побутової електроніки, фітнесу й товарів для дому і ремонту у 2020 р. досягли гарних показників, що частково пояснюється їхньою придатністю до життя вдома. Утім, зростання в цих галузях має продовжитися аж до наступного десятиліття. За прогнозами, світовий ринок електронної комерції в індустрії моди зростатиме на 8,6 \% на рік до 2025 р., і стимулюватиме це зростання Китай зі щорічним показником 9,8 \%.Такими темпами його обсяг удвічі перевищить обсяг ринку США до 2025 р. Очікується, що коефіцієнти окупності підвищаться до $20 \%$, тому що споживачі замовляють по декілька розмірів, що призведе до підвищення вимог до складської площі, робочої сили й логістичних ланцюжків. Одяг, сумки й аксесуари належать до найбільш швидкозростаючих категорій. До 2025 р. зростання прибутку в цих категоріях має досягти 54 \%. Слідом іде взуття зі зростанням на рівні $36 \%$ [404].

Витрати споживачів у сфері електронної комерції різко зросли в результаті викликаних пандемією сейсмічних змін у попиті на певні товари й послуги. Перше місце за споживчими витратами посідає США. У перерахунку на душу населення вони в 11 разів вище, ніж у Китаї. Далі йдуть Великобританія, Німеччина, Франція, Італія та Іспанія. Однак до 2021 р., у міру того як розвиток економіки стимулюватиме підвищення стандартів життя, очікується, що Індія матиме найбільший щорічний приріст споживчих витрат [404].

Частка провідних товарів, які купували онлайн у деяких країнах Європи у 2020 р., представлена на рис. 8.3.13. 


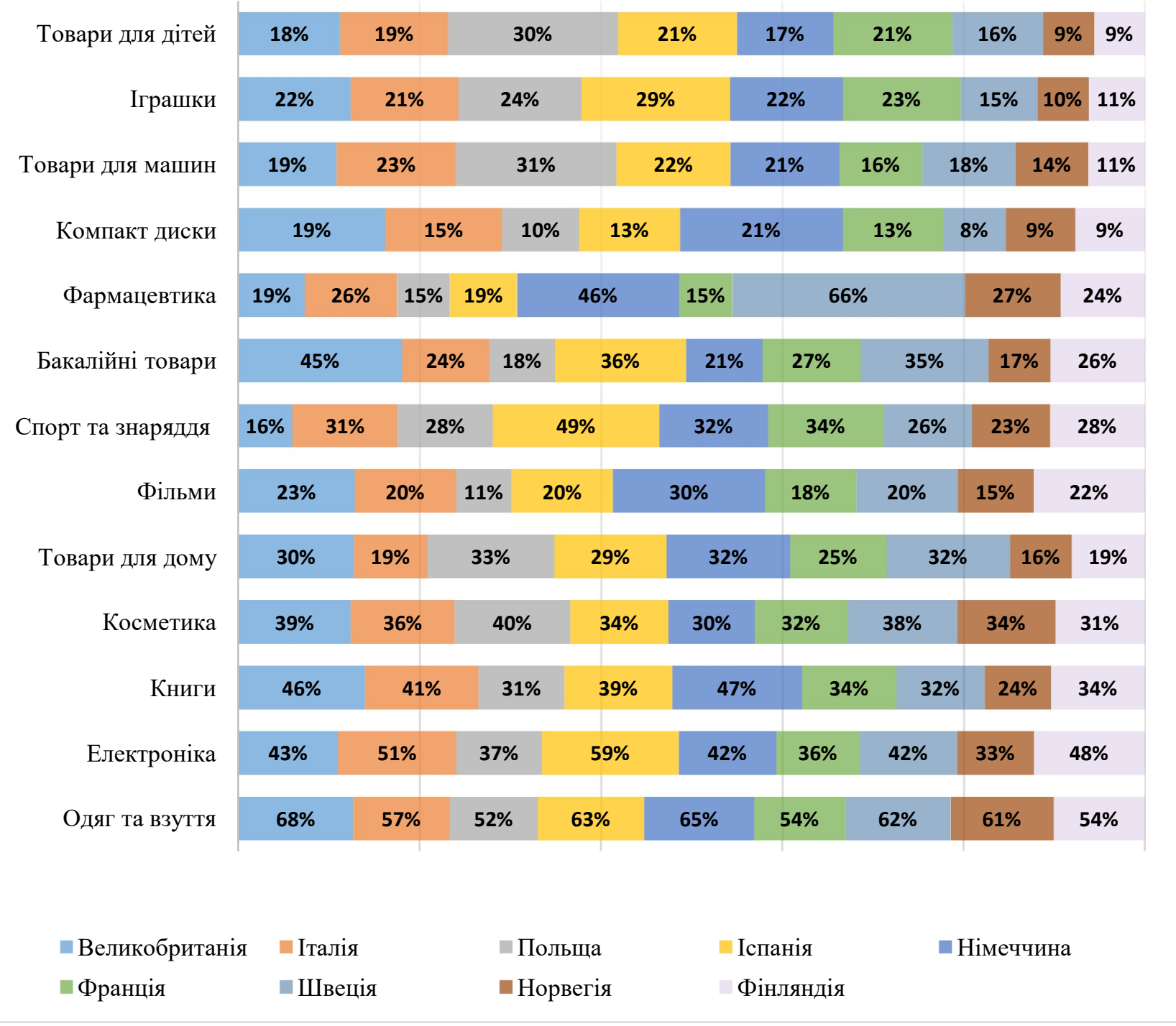

Рисунок 8.3.13. Частка провідних товарів, які купували онлайн у деяких країнах Свропи у 2020 р. [395]

Отже, проаналізувашви рис. 8.3.12 та рис. 8.3.13, можна зробити висновок, що більше в країнах Європи онлайн купували такі товари (по країнам Європи взяті середні дані), ніж у США: одяг та взуття (на 10\%), електроніку (на 9\%), косметику та засоби по догляду за шкірою (на 4\%) та товари для дому (на 8\%). Менше в країнах Європи купували такі товари (по країнам Європи взяті середні дані), ніж у США: книги, фільми, музику та ігри (16\%), іграшки та товари для малюків (13\%).

Частка провідних товарів, які купували онлайн за кордоном у провідних країнах Європи у 2020 р., представлена на рис. 8.3.14. 


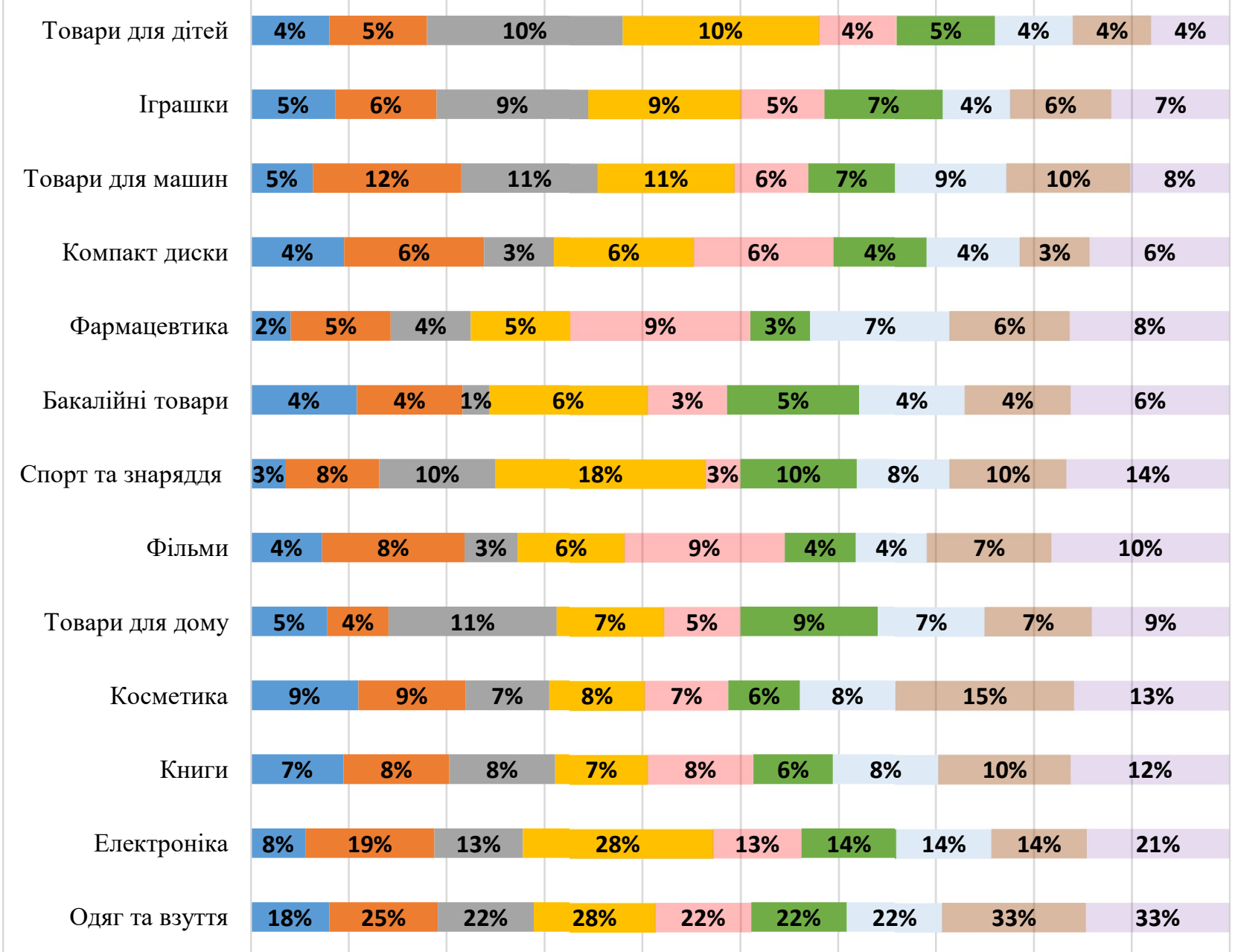

$\square$ Великобританія $\square$ Італія $\square$ Польща $\square$ Іспанія $\square$ Німеччина $\square$ Франція Швеція $\square$ Норвегія $\square$ Фінляндія

Рисунок 8.3.14. Частка провідних товарів, які купували онлайн за кордоном у провідних країнах Європи у 2020 р. [395]

Проаналізувавши частку провідних товарів, які купували онлайн за кордоном у провідних країнах Європи у 2020 р., можна зробити висновок, що найбільше європейці купують онлайн у Великобританії косметику (9\%), одяг та взуття (18\%), книги (7\%) та електроніку (8\%); в Італії - одяг та взуття (25\%), електроніку (19\%), косметику (9\%) та товари для машин (12\%); у Польщі найбільше купували онлайн одяг та взуття (22\%), електроніку (13\%), товари для дітей та спортивні товари та знаряддя (10\%), товари для машин (11\%); в Іспанії - електроніку, одяг та взуття (28\%), спортивні товари та знаряддя (18\%); у Німеччині - одяг та взуття, електроніку (22\% та 13\% відповідно); у Франції - 
одяг та взуття (22\%), електроніку (14\%), спортивні товари та знаряддя (10\%); у Швеції - одяг та взуття (22\%), електроніку (14\%); у Норвегії - косметику (15\%), одяг та взуття (33\%), електроніку (14\%) та у Фінляндії - одяг та взуття (33\%), спортивні товари та знаряддя, косметику (14\%) та електроніку (21\%). Такі товари як книги, фільми, товари для дітей, іграшки, компакт-диски, фармацевтика, бакалійні товари купуються за кордоном не так часто, адже більшість покупців віддають перевагу купувати у себе в країні.

Найпопулярніші методи оплати онлайн-покупок у регіонах світу представлені на рис. 8.3.15.

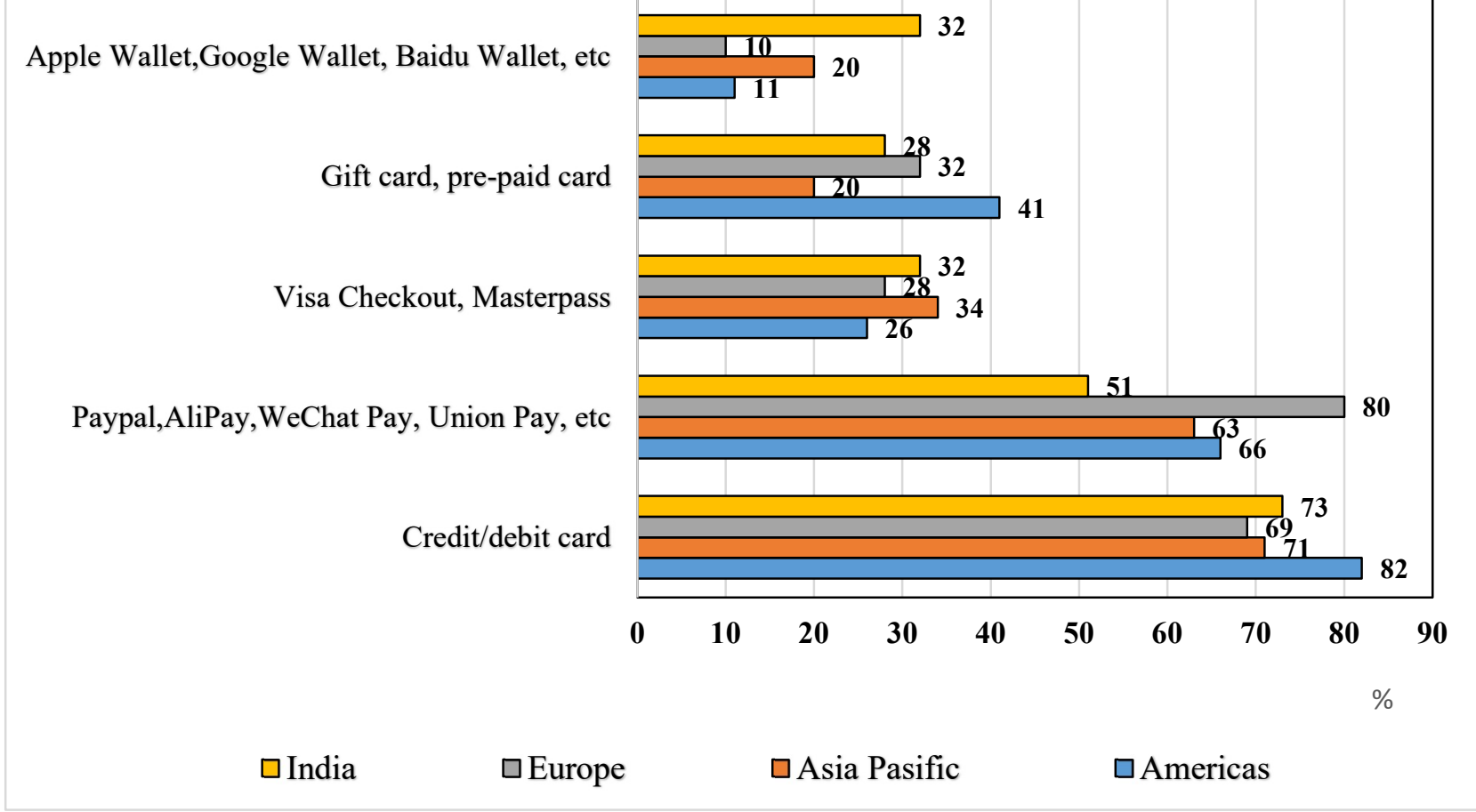

Рисунок 8.3.15. Найпопулярніші методи оплати онлайн-покупок у регіонах світу [405]

На рис. 8.3.15 можна простежити, що у Індії, Азійсько-Тихоокеанському регіоні та Америці найчастіше користувалися методом credit/debit card (73\%,71\% та 82\% відповідно) та методом Paypal, AliPay, WeChat Pay, Union Pay, etc (51\%, $63 \%$ та 66\% відповідно). У Європі на першому місці за методами оплати розташований метод Paypal, AliPay, WeChat Pay, Union Pay, etc (80\%), а на другому місці метод credit/debit card (69\%). В Індії менш використовують онлайн-покупці методи Visa Checkout, Masterpass, AppleWallet, Google Wallet, 
Baidu Wallet, etc (32\%) та метод Gift card, pre-paid card (28\%). В Америці на третьому місці за методом оплати є метод Gift card, pre-paid card(41\%), на четвертому та п'ятому - Visa Checkout, Masterpass (26\%) та AppleWallet,Google Wallet, Baidu Wallet, etc (11\%) відповідно. У Свропі менш роблять оплату онлайн методами Gift card, pre-paid card (32\%), Visa Checkout, Masterpass (28\%) та AppleWallet, Google Wallet, Baidu Wallet, etc (10\%). Та у АзійськоТихоокеанському регіоні менше користуються методами Visa Checkout, Masterpass (28\%) Visa Checkout, Masterpass (34\%) та AppleWallet,Google Wallet, Baidu Wallet, etc, Gift card, pre-paid card (20\%).

Поштовхом для розвитку електронної комерції в Україні є те, що провідні продавці товарів все менше поділяються на офлайн і онлайн-продавців, натомість, намагаючись дотримуватись загального принципу клієнтоорієнтовності. У свою чергу, споживач, одночасно спираючись на важливі переваги офлайну та онлайну, надає перевагу тому чи іншому магазину [406].

На позитивну градацію зростання електронної комерції за сегментом В2С вплинули карантинні обмеження у зв'язку з пандемією COVID-19. Необхідність самоізоляції та соціального дистанціювання, тимчасове припинення діяльності офлайн-магазинів непродовольчих товарів та закладів у різних сферах послуг (розважальні центри, заклади громадського харчування) на підставі вимог уряду, стало результатом не лише збільшення популярності уже наявних маркетплейсів та соціальних мереж, а й змусило багатьох ритейлерів поряд з традиційними точками продажу започатковувати або розвивати наявні онлайн-магазини.

Розвиток та темпи зростання електронної комерції за сегментом В2С в Україні представлені на рис. 8.3.16. 


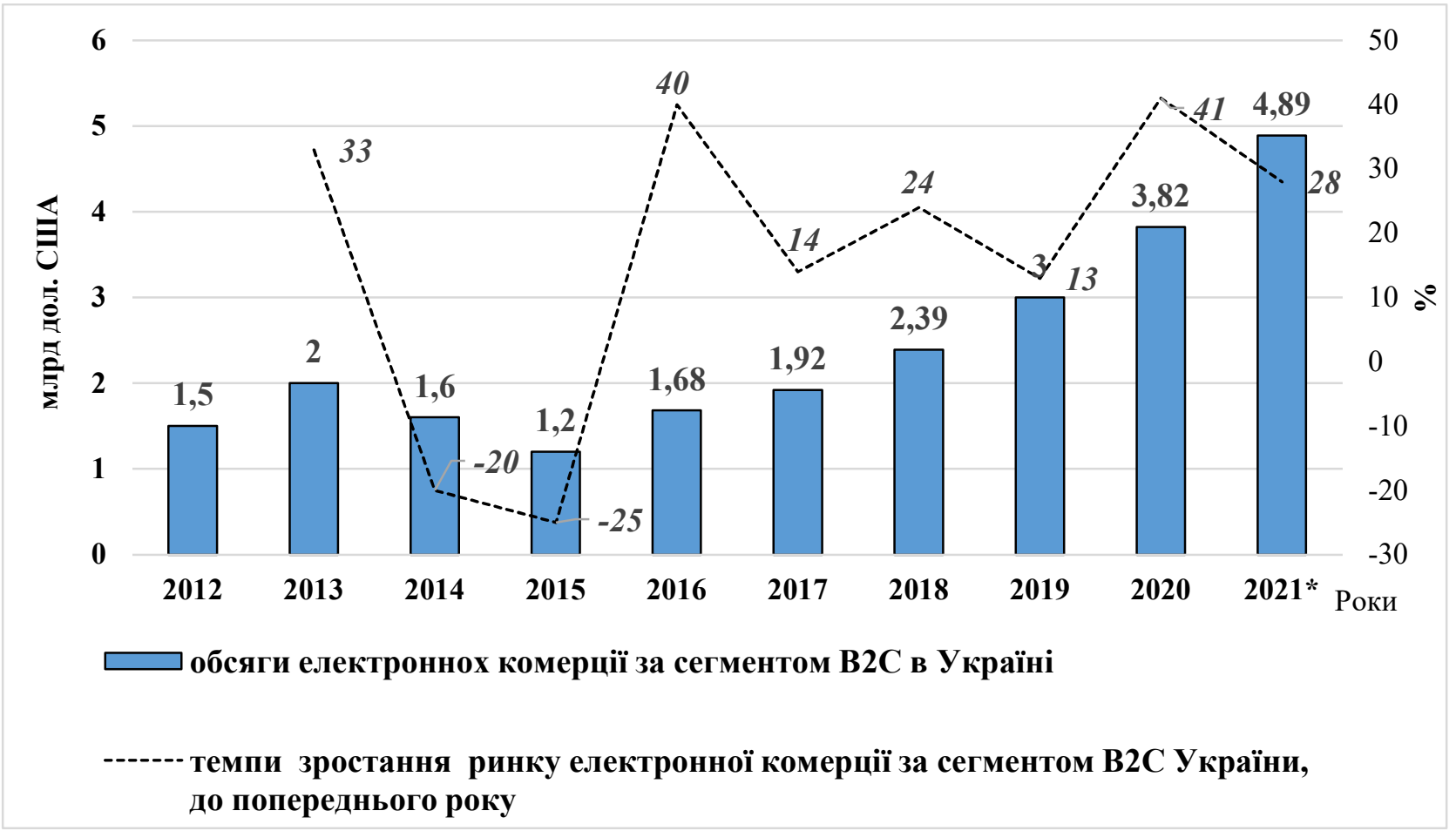

Рисунок 8.3.16. Розвиток та темпи зростання електронної комерції за сегментом В2С в Україні протягом 2012-2021 pp. [386, 394, 407]

Протягом 2012-2020 pp.p інтернет-торгівля збільшилася більше ніж удвічі або на 2,46 млрд дол. США. В 2020 р. онлайн торгівля в Україні склала 3,82 млрд дол. США або 107 млрд грн., що на 41\% більше ніж у 2019 р. (2019 р. 76 млрд дол. США). 32013 р. до 2015 р. відбувся різкий спад в обсягах електронної торгівлі, обсяги зменшилися на 60\%, причиною стала деокупація Криму та Донбасу у 2014 році. Коли економіка почала відновлятися, у 2016 р. зросли обсяги електронної торгівлі на 40\%, порівняно з 2015 р. У 2017-2020 рр. обсяги зросли удвічі або на 1,9 млрд дол. США. У 2021 р. очікується обсяг електронної торгівлі 4,89 млрд дол. США, що на 28 \% більше ніж попереднього року.

На рис. 8.3.17 ми можемо спостерігати зростання електронної комерції у 2020 р., порівняно з 2019 р. у різних країнах світу. 


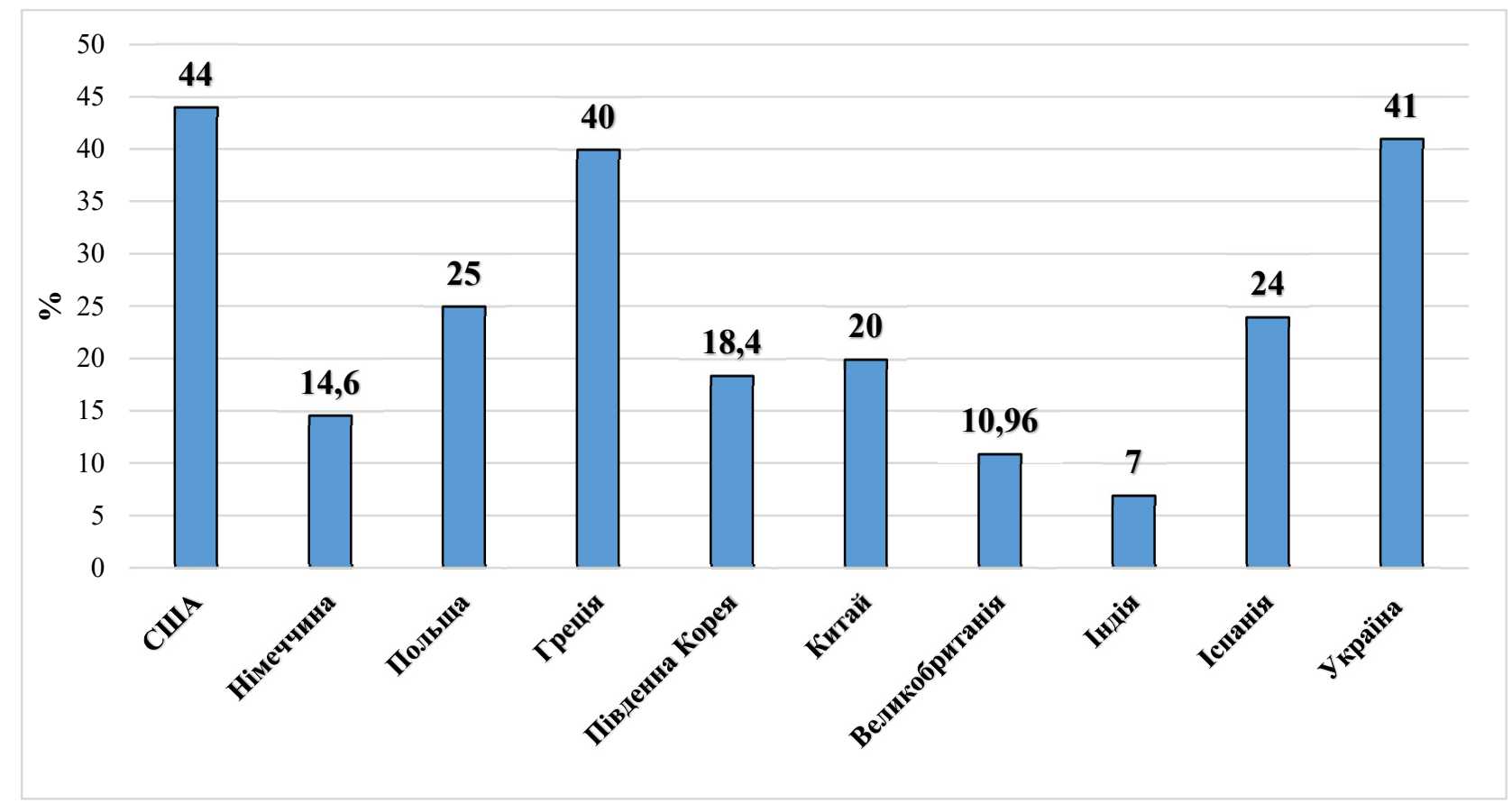

Рисунок 8.3.17. Зростання електронної комерції у 2020 р., порівняно з 2019 р. у різних країнах світу [408-412]

Вибухове зростання онлайн-продажів через пандемію i карантинні обмеження по-різному проявилися в країнах з різним рівнем розвитку інтернетторгівлі. Найбільше зростання електронної комерції у США (44\%), Греції (40\%) та Україні (41\%). Греція відставала від інших країн-членів $\mathrm{CC}$, але в останні місяці зробила значні кроки в напрямку цифрової трансформації своєї економіки, і споживачі частіше роблять покупки в електронному вигляді.

Частка електронної торгівлі у ВВП України має позитивну тенденцію, яка протягом 2010-2020 рр. зросла на 1,56\% (рис. 8.3.18). Грунтуючись на передбаченні, що подальше зростання відбуватиметься у тому числі шляхом перерозподілу коштів з ринку звичайної торгівлі (оптової та роздрібної) у бік онлайн-торгівлі, цей ринок стає перспективною складовою у структурі економіки України. 


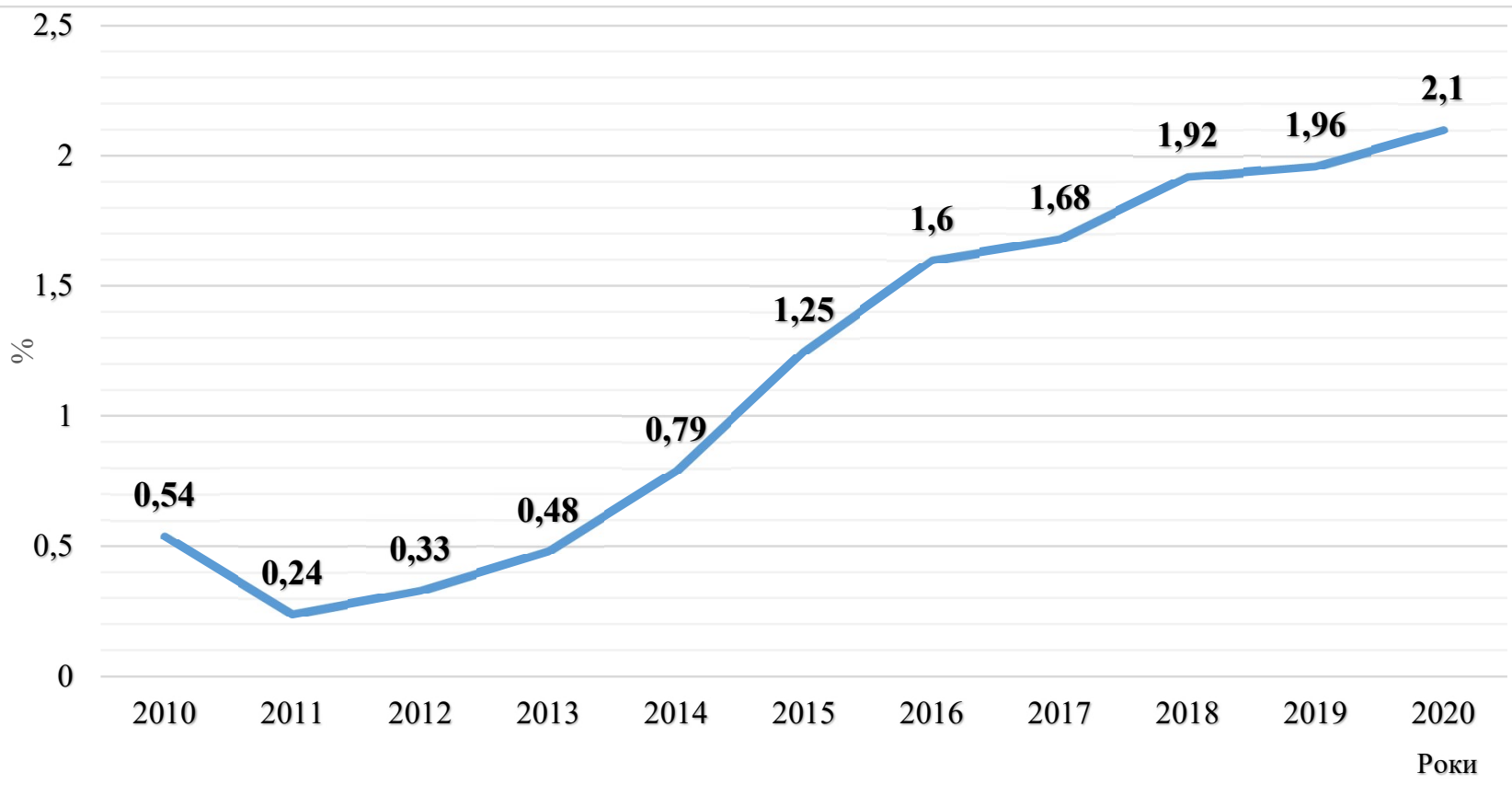

Рисунок 8.3.18. Динаміка частки електронної комерції за сегментом В2С у ВВП України [413, 414]

Світ стає цифровим. I електронна комерція - це важлива складова такого перетворення. Чим більше розвинена економіка країни, тим більше стає обсяг ринку онлайн-торгівлі. Це дуже добре простежується в багатьох країнах Європи, а також в Україні (рис. 8.3.19).

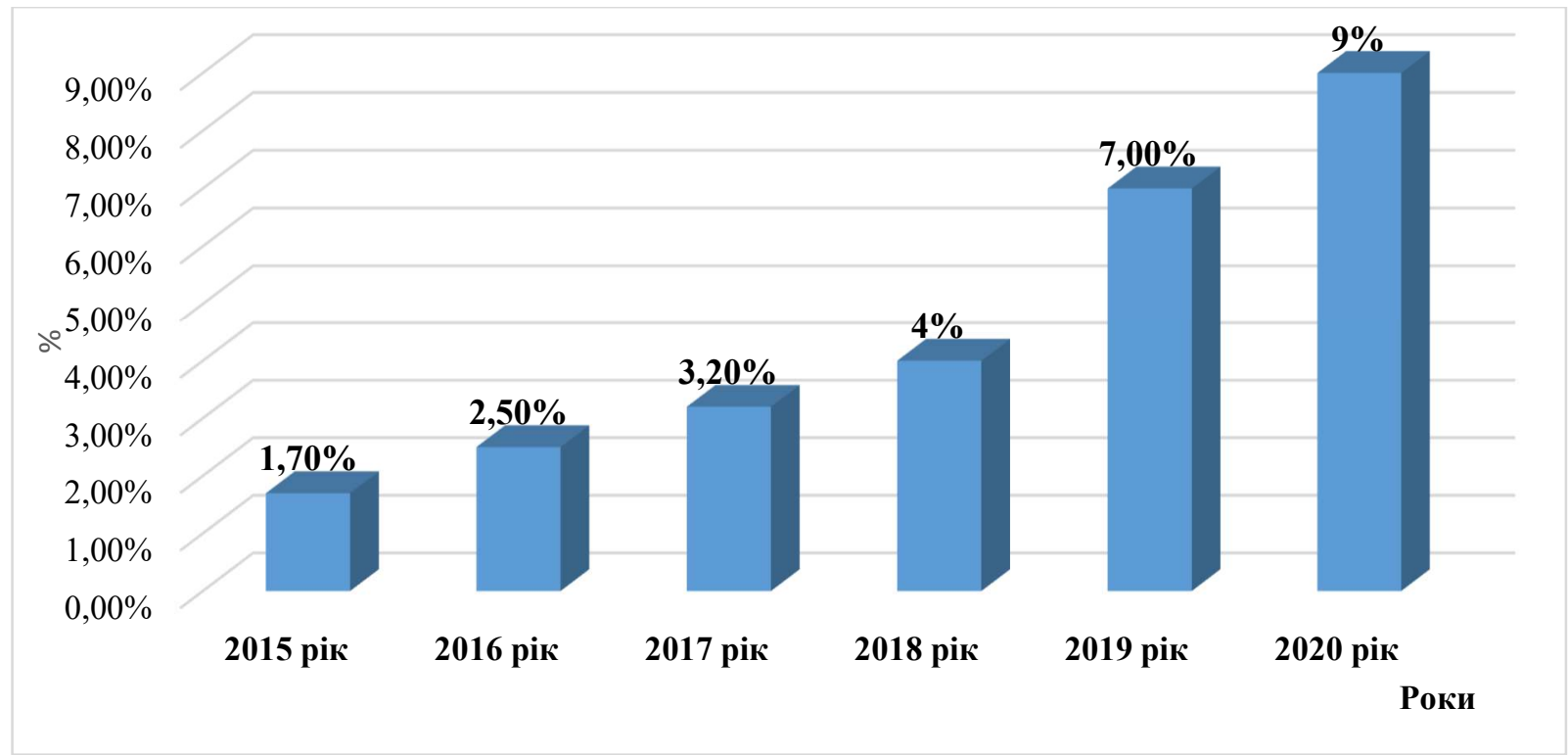

Рисунок 8.3.19. Частка електронної за сегментом В2С у роздрібній торгівлі комерції України [394, 415, 416] 
Протягом 2015-2020 pр. частка електронної торгівлі у роздрібній торгівлі України збільшилася на 7\%. В умовах COVID-19 аналітики відзначили активне зростання онлайн-продажів. За 2020 рік в Україні частка е-commerce зросла на 41\% і становить тепер 9\% від загальної кількості продажів. Порівняно з іншими країнами світу, це дуже маленький відсоток, згідно з даними Eurostat, у Свропейському Союзі на сегмент електронної торгівлі припадає $20 \%$ усіх роздрібних продажів, [417] але Україна не стоїть на одному місці, а робить прогрес у цій сфері. Зростання обороту електронної торгівлі в Україні пов'язане з тим, що для значної кількості наших співгромадян інтернет перетворюється на природне середовище існування, в межах якого задовольняється все більше потреб. За допомогою інтернету почали торгувати багато нових учасників - від міні-виробництв до кав'ярень. Великі онлайн і офлайн-магазини і маркетплейси в більшій мірі покращили свої позиції.

За підрахунками групи компаній EVO, в 2020 році українці придбали за допомогою інтернету товарів і послуг на суму 107 млрд грн. Це на 41\% більше, ніж у 2019 р. Як у наслідок зростання українського ринку електронної комерції перебільшило прогнозування експертів майже втричі. Також зросла і кількість онлайн-оплат - мінімум на 50\%. Зараз майже 9\% всіх покупок в Україні здійснюється онлайн - на маркетплейсах, в онлайн-магазинах і соціальних мережах. До Китаю, де більше $30 \%$ всіх покупок здійснюється онлайн, ще далеко, але приріст за рік позитивний. Для порівняння, в 2019 р. частка елетронної комерції в ритейлі України розглядалася в 7\%, а зріс ринок тоді на $13 \%$ за рік [418].

В Україні AlixExpress був найбільш відвідуваним міжнародним інтернетмагазином серед інтернет-користувачів у 2018 році - 24,7\%, Amazon - 4,9\% i Ebay $-4,6 \%$. 


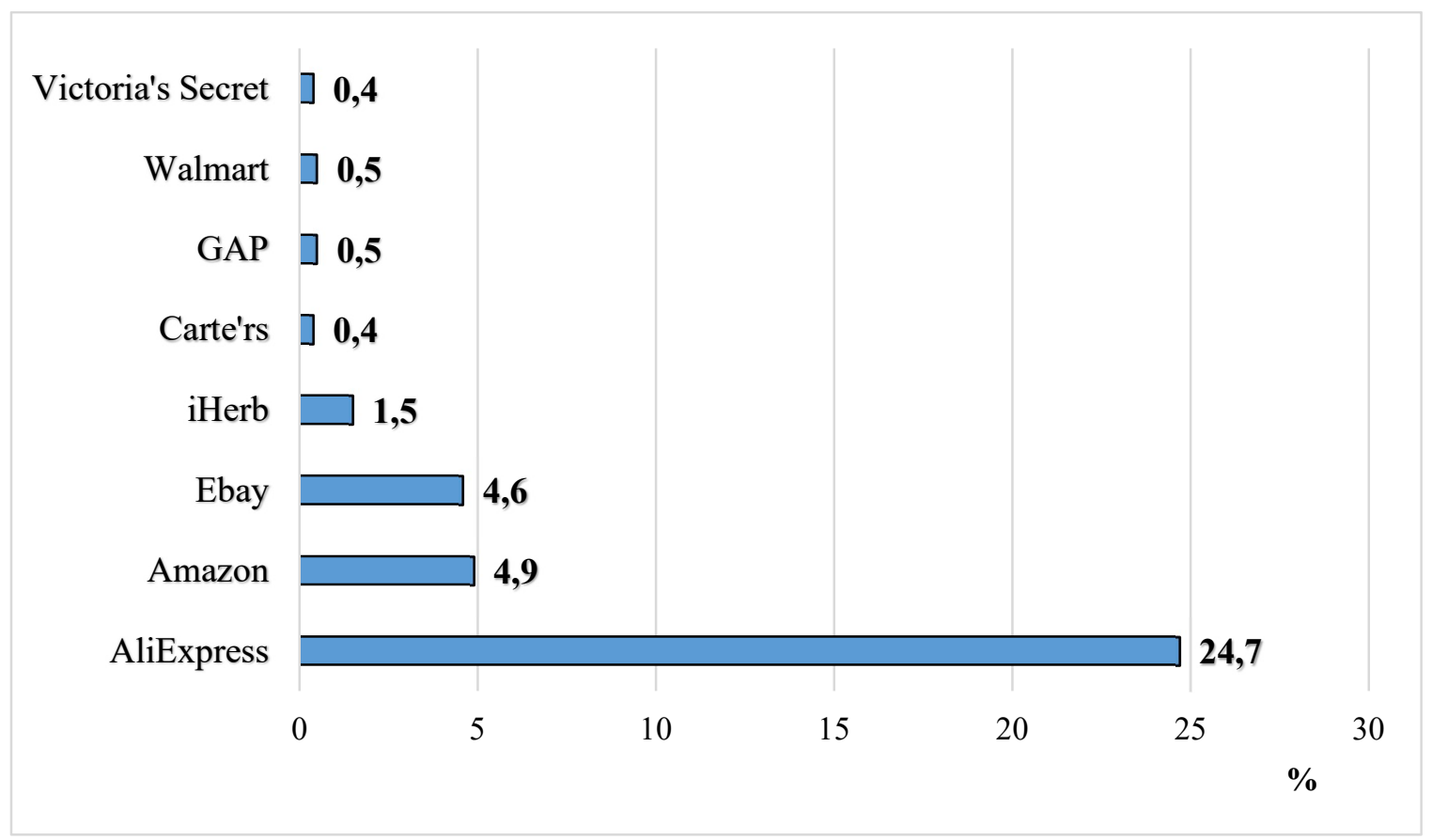

Рисунок 8.3.20. Рейтинг найбільш відвідуваних міжнародних інтернетмагазинів в Україні у 2018 р. [419]

Компанія «Нова пошта» у 2020 році опублікувала список найпопулярніших іноземних сайтів інтернет-магазинів серед своїх клієнтів: Aliexpress, iHerb, eBay, Amazon, 6p.m. Більше купували на таких іноземних сайтах українці у 2020 році, ніж у 2019 році: Aliexpress та iHerb, а менше Carter`s, Victoria`s Secret, H \& M. Все це пояснюється тим, що у 2020 році не було великої потреби замовляти одяг, взуття та засоби догляду за шкірою таких брендів. У 2020 році Nova Poshta Global доставила понад 1000 тонн товарів 3 Китаю та США лише по повітрю. В середньому клієнти замовляють близько 2,6 тонн товару на день виключно на Aliexpress. Загалом кількість замовлень із веб-сайту зросла на 28\% порівняно з 2019 роком [420].

Рейтинг найбільш відвідуваних інтернет-магазинів в Україні в червні 2020 року впевнено очолила Rozetka, також вутоп-5 найбільш відвідуваних інтернет-майданчиків також увійшли Epicentrk.ua, Allo.ua, Makeup.com.ua i Foxtrot.com.ua (рис. 8.3.21). 


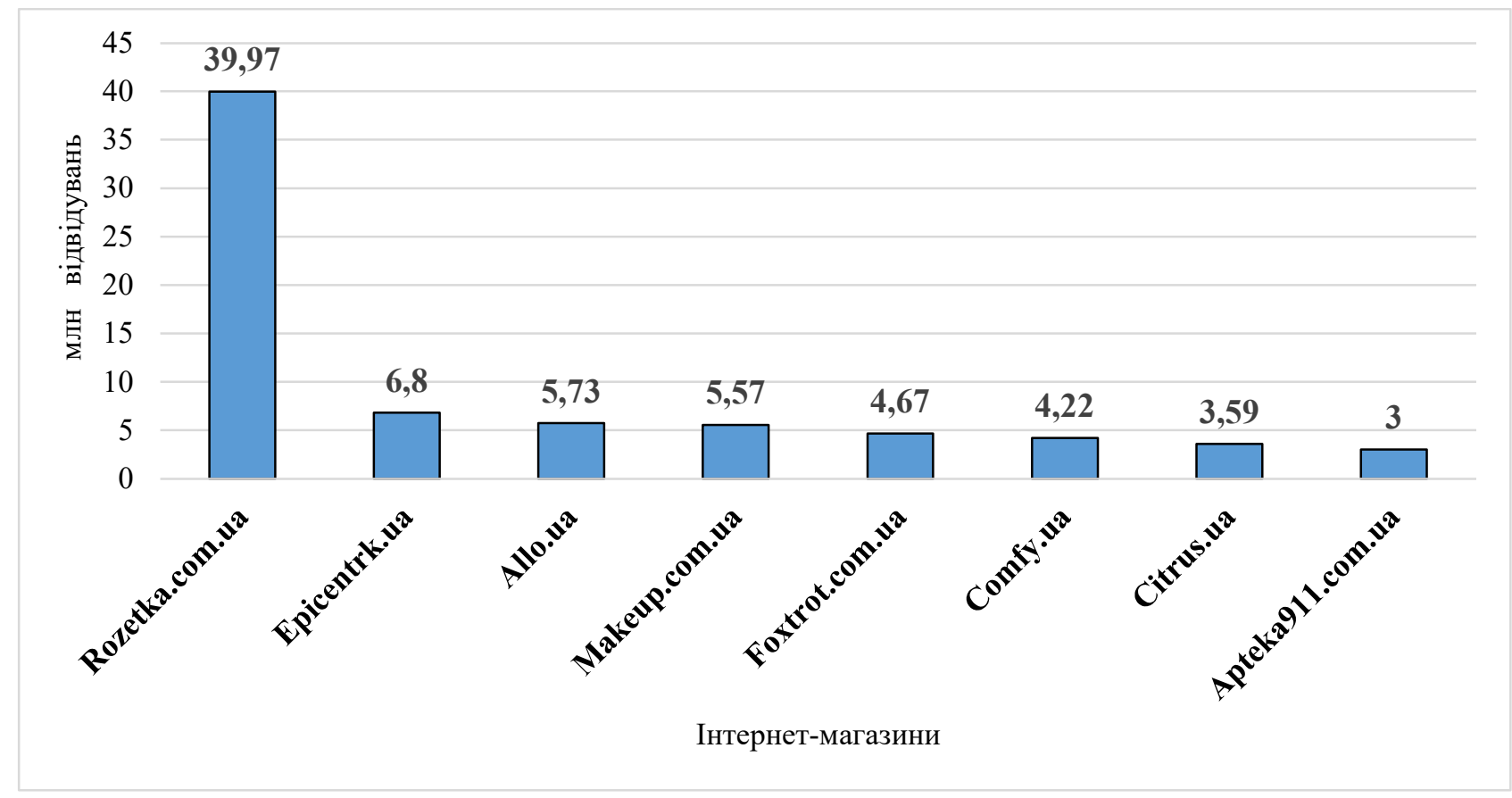

Рисунок 8.3.21. Рейтинг найбільш відвідуваних інтернет-магазинів України, червень 2020 р. [421]

Треба відзначити, що в червні сайт Rozetka досяг показника майже в 40 млн відвідувань - щоденна відвідуваність інтернет-магазину перевищила 1,3 млн. Всі інші інтернет-магазини мають не таку велику кількість відвідувань, як Rozetka.

В 2020 р. електронна торгівля в Україні зазнала істотних змін. Якщо розглядати вітчизняну електронну комерцію в цілому, то найпопулярніша частина інтернет-магазинів залишається незмінною: універсальні портали, на яких можна придбати все - від рушників до комп'ютерів, а також багато різноманітних товарів, включаючи автотранспорт. Так у 2019-2020 pp. практично не змінилася кількість користувачів на універсальних порталах 62,48\% та 62,55\% відповідно (рис. 8.3.22). 


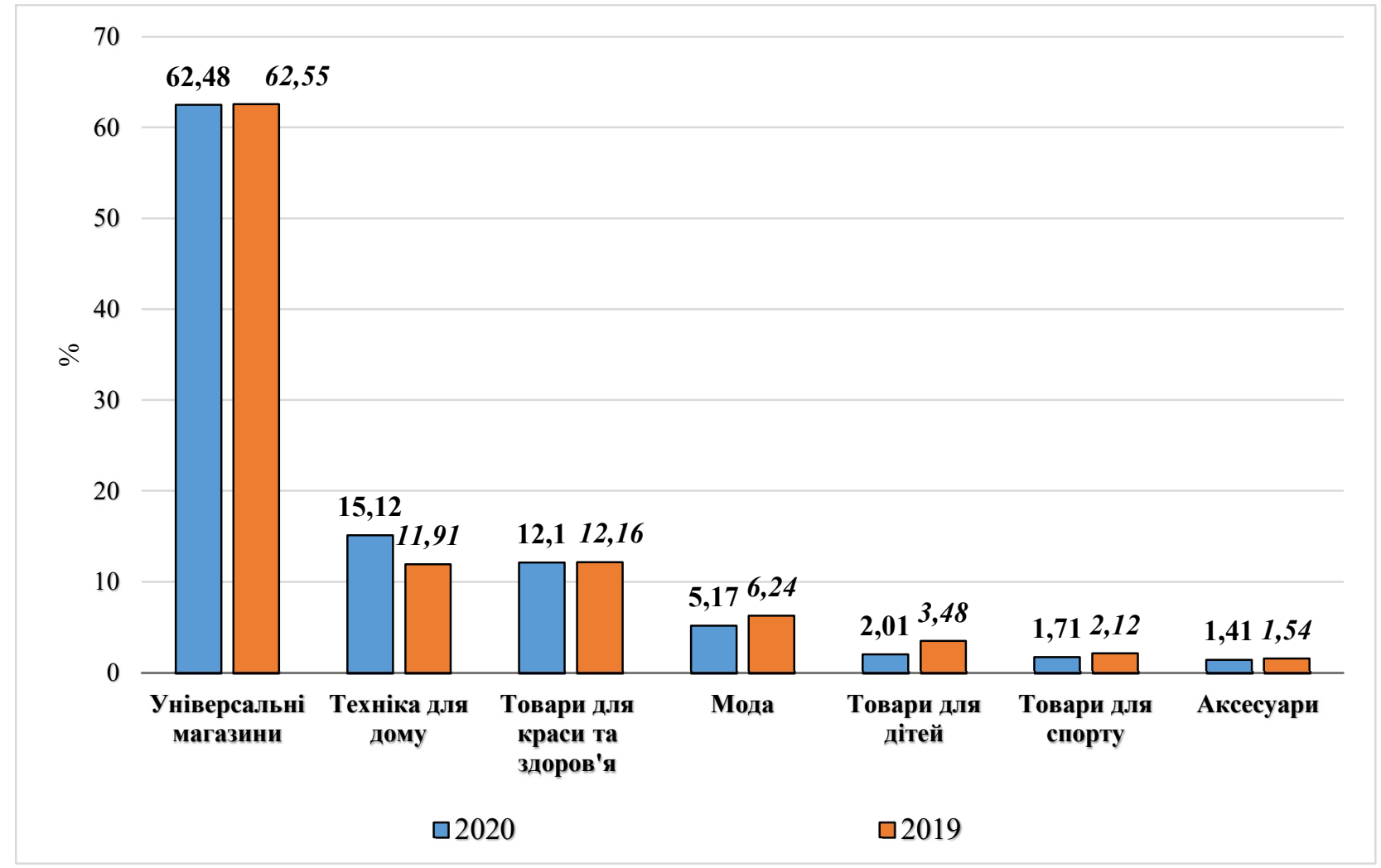

Рисунок 8.3.22. Сегменти української електронної торгівлі у 2019-2020 pp. [422]

* Універсальні магазини (Rozetka, Epicentr, АЛЛО, MOYO, F.UA)

Товари для дому та електроніка (Comfy, Citrus, Foxtrot, Eldorado, TTT)

Товари для краси та здоров'я (Makeup, EVA, Brocard, Parfums.ua, Watsons.ua)

Мода - Fasfion (Intertop, Next.ua, Bonprix, Lamoda, Answear)

Товари для дітей (Panama, BI. UA, Babyplus, Pampik, Antoshka)

Товари для спорту (Мегаспорт, Спорт Мастер, VELIKI.COM.UA, DECATHLON, VELOONLINE)

Найбільших успіхів досягли інтернет-магазини товарів для дому, які збільшили охоплення клієнтів на чверть - 3 11,91 \% до 15,12 \%. В результаті магазини побутової техніки (Foxtrot, Comfy, Citrus та ін.) знову виграли за популярністю сегмент товарів для краси і здоров'я. Це визначається тим, що під час карантину люди стали залишатися більше часу вдома і менше купувати товари для краси.

Решта категорії втратили свої позиції в порівнянні з 2019 роком. Так, в абсолютних показниках зменшився сегмент товарів для дітей (зменшення більше 
40\%). За ним слідують товари для спорту і категорія мода (fashion). Якщо просідання fashion-рітейлерів можна продемонструвати послабленням товарів модниками, які стали рідше залишати дім і змінювати одяг, то товари для спорту, навпаки, почали користуватися підвищеним попитом. Можливо, через те, що ці два напрямки електронної комерції змогли досягти високої конверсії, і спад охоплення не впливає на зростання продажів.

За 2020 р. кількість замовлень на маркетплейсах EVO - Prom.ua, Bigl.ua, Crafta.ua, Shafa.ua, IZI.ua i сайтах компаній Prom.uа зросла на 42\%. Середній чек впав на 10\%. Компанія пов'язує це з тим, що люди стали купувати онлайн значно частіше і дешевші товари - одяг, товари повсякденного вжитку, їжу, маски. Експерти EVO очікують, що в 2021 році темпи зростання онлайн-торгівлі частково збережуться і електронна комерція виросте до 137 млрд грн. Цьому сприятимуть поява безпечних способів онлайн-оплат на маркетплейсах, здешевлення доставки (в тому числі акції безкоштовної доставки від маркетплейсов 3 логістами), швидкість і поліпшення якості обслуговування продавцями У 2020 р. на Prom.ua та Bigl.ua найбільше купували продукти харчування та медичні товари (причина - масштабний карантин). У 2020 р. найбільший приріст на платформах Prom.ua, Bigl.ua склали медичні товари + $225 \%$, товари для домашніх тварин $+69 \%$, сількосподарські товари (насіння, обладнання для саду й городу) $+83 \%$ та продукти харчування $+49 \%$. Значно більшим попитом також користувалися зоотовари - корм та аксесуари для домашніх тварин [423].

В 2020 р. основними постачальниками трафіку залишаються YouTube 42,54\% та Facebook - 40,86\%. У порівнянні з 2019 роком скоротилася частка Vkontakte - 3 10,20\% до 8,19\%. Решта соцмережі залишаються малозначними для залучення користувачів в інтернет-магазини (рис. 8.3.23). 


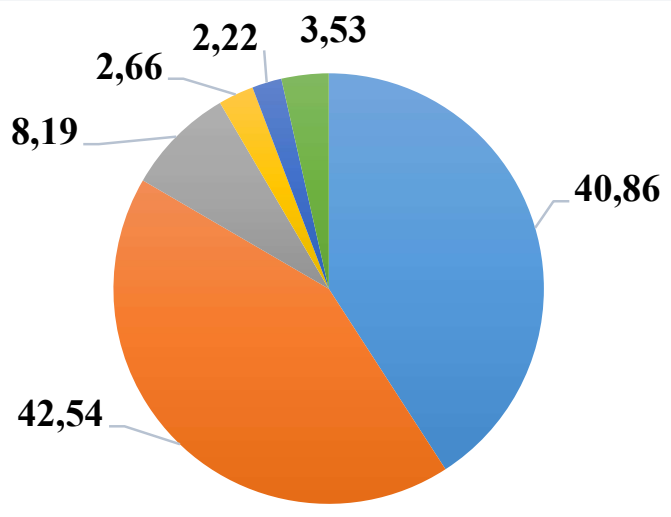

Facebook $\square$ Youtube $\quad$ Vk $\square$ Odnoklassniki $\quad$ Instagramm $\quad$ Iнші

Рисунок 8.3.23. Основні постачальники трафіку в Україні у 2020 р. [424]

Загальний віковий зріз користувачів залишився приблизно колишнім, більше 50\% клієнтів інтернет-магазинів - люди від 25 до 44 років, ще 36\% вікові категорії 18-24 і 45-54 роки. Старше покоління (більше 55-ти) забезпечує українським онлайн-рітейлерам трохи більше 12\% (для порівняння - в 2019 р. ця категорія користувачів становила рівно 10\% трафіку інтернет-магазинів). Варто відзначити, що люди старшого віку стали частіше користуватися інтернетом, у тому числі в силу карантинних обмежень. Це позначилося на зростанні аудиторії користувачів старше 45 років і скорочення частки категорій користувачів молодого і середнього віку (рис. 8.3.24).

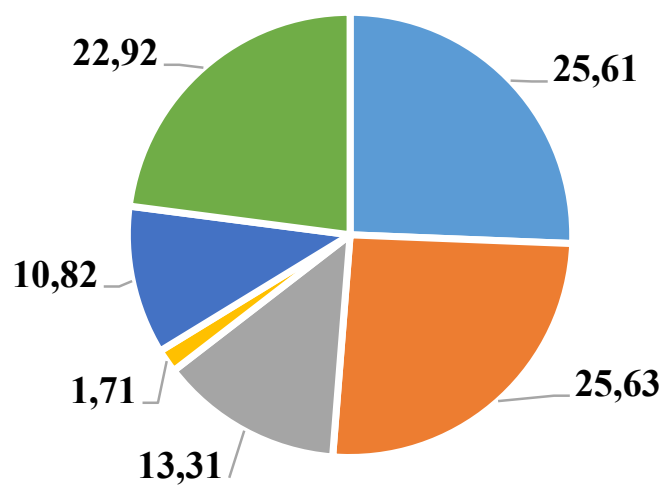

$$
-35-44 \quad-25-34 \quad-18-24 \quad-65+\quad-55-64 \quad-45-54
$$

Рисунок 8.3.24. Розподіл покупців за віковими категоріями в Україні у 2020

$$
\text { p., } \%[424]
$$


Попри всі переваги електронної комерції, не треба забувати і про проблеми, які з'явились із розвитком даного ринку. Основними проблемами можна виділити низьку інформованість людей про мережу, випадки шахрайства на ринку електронної комерції, кіберзагрози, нерозвинену технологічну інфраструктуру, недосконалість законодавчої бази тощо. Розглянемо деякі з них.

По-перше, в Україні сьогодні існують ряд юридичних проблем, які ускладнюють застосування електронної комерції. В нашій країні, крім методів системи розрахунків за товари та послуги, немає необхідної нормативноправової бази електронної комерції, яка б задовольняла та зважалася на рекомендації та правила міжнародних організацій. В українському законодавстві не існує стійких стандартів щодо регулювання ринку електронної комерції, що призводить до низки проблем при використанні мережі.

По-друге, на шляху розвитку електронної комерції в Україні заважає низка перешкод, таких як шахрайські транзакції, які виникли внаслідок викрадених реквізитів карт, інтернет-магазини, що безслідно зникають 3 ринку після позитивного досягнення та виконання афер, несправжні магазини, розроблені для зберігання інформації про карти клієнтів, психологічний фактор тощо. Найнебезпечнішими, звичайно, є шахрайства. За рахунок інтернету реалізується більше тридцяти видів шахрайських злочинів. Причиною недостатньої безпеки даних споживачів є неефективна реалізація права на інформаційну приватність, тобто захист персональних даних під час здійснення онлайн-покупок. В свою чергу, персональні дані відповідно до Директиви 95/46 / ЄС Європейського парламенту та Ради Свропейського Союзу від 24 жовтня 1995 року про захист прав приватних осіб стосовно обробки персональних даних та про вільне переміщення таких даних, означають будь-яку інформацію, пов'язану 3 ідентифікацією фізичної особи («суб’єкта даних») [425]

Найбільш характерними типами шахрайства через інтернет є: 
- транзакції, зроблені шахраями з застосуванням дійсних реквізитів картки (номер картки, термін їі дії і т. п.);

- компрометація даних (отримання інформації про клієнта через злом бази даних торгівельних підприємств через перехоплення повідомлень покупця, що включають його особисті дані) з метою їх використання у шахрайських діях;

- магазини, що з’являються, як правило, на малий проміжок часу для того, щоб зникнути після отримання від покупців коштів за фіктивні товари чи послуги;

- недобросовісне вживання торгівельних підприємств, пов'язані 3 приростом вартості товару відповідно до ціни, яка рекомендована покупцям, або повторенням списань з рахунка клієнта;

- магазини і торгові агенти (Acquiring Agent), потрібні для збирання даних про реквізити карт та іншої особистої інформації клієнтів.

Коли почав розвиватися інтернет та почали з'являтися «віртуальні магазини», стало реальним купувати товари 3 персонального комп'ютера. У зв’язку з цим збільшилось і місце для шахрайств з пластиковими картками, адже для оплати товару, який був замовлений, треба позначити лише реквізити картки. Тобто, будь-які дані про картку для власника може стати значними втратами. А варіантів “виманювання” реквізитів карток їх у власників існує дуже багато.

Незважаючи на багатостраждальну історію розвитку 4G в Україні, в країні вже $є 4$ повномасштабних мережі, які швидко розвиваються. Три з них належать GSM-операторам великої трійки: Vodafone Україна, Київстар та lifecell. Четверта побудована на технології CDMA і належить оператору Інтертелеком. Але інформація, яку вони надають на своїх картах, не завжди достовірна, і іноді ми не можемо отримати гарний зв'язок навіть у місті. Інфраструктура доступу до інтернету в нашій країні не дуже гарно розвинена, коли інший світ, зокрема Японія, вже використовує 5G, в нас по країні не завжди ловить і $3 \mathrm{G}$.

На тепершній час більш широко використовується міжбанківська система електронних платежів та взаєморозрахунків - комп'ютерна система електронного зв'язку, яка, зрозуміло, не може бути на $100 \%$ надійною. 
Складається ситуація, що дає поштовх злочинцям мати несанкціонований доступ до комп’ютерних банків даних для здійснення протиправних маніпуляцій 3 корисливою ціллю.

Також існує загроза електронній комерції від діяльності хакерів. Вони мають змогу через спеціальне програмне забезпечення отримувати, а потім розпродавати номери існуючих рахунків кредитних карток, а також поширювати паролі, ідентифікаційні номери, кредитні та інші персональні дані за рахунок комп'ютерних мереж, які допомагають злочинцям отримати протизаконний доступ до кредитних бюро та комп’ютерних систем фінансових установ.

Треба зауважити, що шахраї - це, майже завжди, розумні системні програмісти, спеціалісти в галузі телекомунікаційних систем, рідше - банківські працівники. Вторгнення в комп'ютерні системи - це не просто гра, це чіткі та продумані дії. На практиці підготовка до злому комп'ютерних систем триває кілька місяців і пов'язана з такими кримінальними діями, як шантаж, хабар персоналу, таємний вхід у службове приміщення, аналіз відкритої та крадіжка службової інформації, підслуховування розмов та перехоплення службових повідомлень на лініях зв'язку.

В Україні є альтернативна інтернет-мережа FIDOnet. Для FIDO немає загальних законів, тому шахраї і захоплюють мережі. Так би мовити, “заломлюють” різні найсучасніші комп’ютерні програми охорони американського банку, що захищається не одним рівнем захисту. Потім “скидають” в інтернет-мережу, і з цієї миті іiї починають використовувати всі. Наприклад, деякий час модно було замовляти квіти з Голландії. Свіжі троянди будуть наступного ранку, а розраховуватись не потрібно: є програма - екулятор кредитної картки. Для багатьох саме інтернет є джерелом існування.

Основними порадами задля уникнення шахрайства можна виділити наступні:

1. Не реагувати на яскраву рекламу і банери, що пропонують незаконні послуги. 
2. Ніколи не відповідати на повідомлення «видішліть SMS», за не зрозуміло що, та не зрозуміло кому.

3. Не намагатися шукати «скачати безкоштовно».

4. Не звертати увагу на різні пропозиції щодо пожертвування.

5. Уникати онлайн казино і тому подібне.

За даними НБУ, кожен день закріплюються сотні намагань несанкціонованого доступу до електронної системи міжбанківських розрахунків. Обсяги цих проступків малі, але не слід їх применшувати, адже злочинність розвивається паралельно з самою галуззю. Крім того, треба зазначити, що це найбільш “тіньовий” вид злочину.

Існують проблеми, які негативно впливають на розвиток українського ринку саме online-торгівлі: недосконалість законодавчої бази; відсутність Інтернету в регіонах або часткове покриття їх території; неузгодженість рівня розвитку торговельних підприємств, якості обслуговування запитам споживачів. 3 цієї точки зору, учасники ринку спроможні прийти до висновку, що рівень обслуговування і репутація стануть їх конкурентними перевагами в порівнянні 3 суб'єктами, що пропонують такі ж товари або послуги. Зараз споживачі віддають перевагу зручності при здійсненні покупок і бажають комфортних умов для покупок. Як стверджує практика, основним інструментом заохочення клієнтів у найближчі роки повинні стати: ефективний маркетинг і робота над створенням гарної репутації (бренду) [426].

У Internet-торгівлі є великий потенціал розвитку, оскільки використати Internet-магазин може користувач будь-якого міста i селища України. Обмеженням доступу до Internet-магазину є тільки відсутність виходу в Інтернет. Адже продавець в мережі не несе витрат на оренду приміщення, організацію вітрин і штат продавців, особливо важливим для розвитку електронного бізнесу $\epsilon$ зацікавлення споживачів, що хочуть пізнавати нові технології, що і $є$ фактором для підйому обсягу online-продажів. Серйозною проблемою, що асоціюється 3 
електронною комерцією в Україні, є неякісний сервіс в українських Інтернетмагазинах.

У Інтернет-компаній немає часу, щоб думати про перспективи бізнесу і потреби споживачів. Більшість компаній формуються наспіх, бізнес-плани не містять таких ключових для бізнесу моментів, як логістика та платіжні системи. Ще однією проблемою Інтернет магазинів є доставка оплаченого товару покупцеві. Ідеальний онлайновий продавець повинен не тільки зберігати на складі велику кількість одиниць товару і оперативно організовувати свій Інтернет каталог у відповідність зі станом складу, але і швидко робити доставку товар за вказаною клієнтом адресою. У пошуках вирішення проблеми доставки більшість Інтернет-магазинів дійшло до висновку: необхідно створювати власний склад, де б зберігався оперативний запас товарів, представлених у прайс-листі. Наявність складу дозволить багато в чому гарантувати асортимент.

Також на розвиток електронного бізнесу в Україні негативно впливають наступні фактори: мало розвинена система електронних платежів, недовіра клієнтів. Низький рівень зарплат українців сильно впливають на розвиток $\mathrm{i}$ зростання онлайн торгівлі. Слабка економіка країни також гальмує процес розвитку на 2-3 роки, в порівнянні з іноземними колегами. Але в Україні є передумови для ефективної роботи ринку електронної комерції. Швидке збільшення рівня проникнення Інтернет технологій в торгівлю говорить про вигідність електронної комерції в бізнесі [427].

Однією з проблем є високі ціни на доставку оплаченого товару покупцем. Оскільки в Україні ринок послуг на доставку формують декілька монополістів (Укрпошта та Нова пошта), це веде до завжди зростаючої вартості послуг доставки. Така ситуація $є$ наслідком того, що споживачі не бажають витрачати зайві гроші на доставку, надаючи перевагу офлайн-магазинам. Незважаючи на недоліки та загрози, ринок електронної торгівлі в Україні має всі перспективи розвитку. Актуальними будуть тенденції, що вже набули розвитку в США, Європі, Китаї та інших країнах та стосуються посилення клієнтоорієнтованості в 
торгівлі, дотримання безпечності та доступності в умовах пандемії Covid-19 [428].

Незважаючи на складний 2020 рік для роздрібної торгівлі, світові роздрібні продажі електронної комерції показали зростання на 27,6 \% за рік, при цьому обсяг продажів перевищив 4 трлн дол. США, коли в 2019 р. зростання відбулося лише на 20,2%. Це являє собою істотний стрибок у порівнянні з минулими роками, але вже у 2021 р. за прогнозами зростання світової електронної торгівлі сповільниться до 16,5 \% [429]. Таке зростання покупок в Інтернеті можна пояснити рядом факторів. Один з основних - пандемія COVID-19. Також рівень комфорту, який надається онлайн-покупцям, зростання довіри онлайн-покупців при здійсненні покупок в Інтернеті, поліпшення досвіду роботи з веб-сайтами, які стали більш зручними для клієнтів.

Експерти прогнозують, що вплив коронавірусу буде не тільки короткостроковим стимулом для електронної комерції, але і збережеться навіть після COVID-19. Це пов'язано з тим, що люди будуть почувати себе комфортно 3 комфортом і зручністю, які він пропонує, а також з перевагами безконтактних платежів, які, ймовірно, викличуть постійний зсув поведінки в бік цифрових покупок. Фактично, ринкові аналітики прогнозують, що індустрія електронної комерції отримає найбільші вигоди від пандемії коронавіруса. Очікується, що рівень проникнення, який в даний час складає $15 \%$, до 2025 року зросте до $25 \%$ (MarketWatch, 2020). Це на 67 \% більше за п'ять років. На жаль, позитивний вплив COVID-19 на електронну торгівлю завдає великої шкоди звичайним магазинам. За прогнозами, протягом наступних п'яти років буде закрито близько 100000 підприємств. За оцінками, найбільшою мірою будуть закриті 24000 магазинів одягу, потім 12000 магазинів побутової електроніки і по 11000 магазинів товарів для будинку і продуктових магазинів [430].

Більше половини (54\%) споживачів збільшили свої витрати в Інтернеті після удару коронавірусу. Але навіть незважаючи на те, що перехід до онлайнпокупок спостерігається серед споживачів різного віку, в основному за цю тенденцію електронної комерції відповідає молоде покоління. Результати 
опитування показують, що двоє 3 трьох (67\%) молодих споживачів у віці від 18 до 34 років витрачають більше грошей на покупку товарів в Інтернеті зараз, ніж до пандеміï (Shopify, 2020). Для старших вікових груп зростання дещо менше. Споживачі у віці від 35 до 54 років збільшили свої витрати на покупки в Інтернеті на 57 \%, в той час як для споживачів у віці 55 років і старше цей показник становить всього $41 \%$ [431].

Кількість соціальних покупців також швидко збільшується. 3 появою кнопки «Купити» в Facebook i Instagram Checkout соціальні мережі стали відігравати значну роль у світі електронної комерції. Соціальні мережі змінили наш спосіб життя, в тому числі те, як ми купуємо речі. Це відмінна можливість для брендів задуматися про те, як поліпшити свої позиції в соціальних мережах, які $\epsilon$ відмінною платформою для відкриття брендів. Оскільки споживачі проводять більше часу в різних типах соціальних мереж, компанії електронної комерції можуть отримати допомогу від впливових осіб Instagram, щоб підвищити свої шанси бути виявленими своєю цільовою аудиторією. Крім того, 3 такими платформами, як Shopify, компанії можуть легко пов'язати свої інтернет-магазини з сайтами соціальних мереж, щоб люди могли купувати у них безпосередньо через соціальні мережі. Наприклад, Instagram i Facebook постійно оновлюють свої функції, щоб задовольнити потреби онлайн-покупців у комфорті.

Ці платформи соціальних мереж діють як канали для натхнення i дозволяють дізнаватися про бренди, поки люди переглядають свої канали. Оскільки соціальні мережі продовжують ставати постійною частиною нашого повсякденного життя, їх здатність впливати на тенденції електронної комерції буде тільки зростати. Ось чому бренди повинні використовувати підхід, орієнтований на покупки, в своїй стратегії в соціальних мережах.

Крім уваги до стійкості і екологічним практикам, велика кількість споживачів також стають більш відкритими для покупок у незалежних компаній. Більше половини (57 \%) заявили, що вперше готові здійснювати покупки 3 новими брендами (Shopify, 2020). Збільшення підтримки було викликано 
пандемією, яка торкнулася багато малих підприємств і спонукала багатьох купувати у них і підтримувати їх. Фактично, більше однієї третини (37\%) споживачів, які роблять покупки в незалежних компаніях, кажуть, що вони роблять це зараз більше, ніж за часів до COVID-19. Штучний інтелект i доповнена реальність поліпшать досвід взаємодії в е-commerce. До 2022 року онлайн-продавці витратять на розробки в галузі штучного інтелекту 7,3 млрд дол. США [432].

Також з’ являться нові способи оплати. Якщо ви не зможете запропонувати клієнтам потрібний їм варіант, то вони не будуть здійснювати покупки у вашому інтернет-магазині. На даний момент більшість онлайн-магазинів, крім дебетових і кредитних карт, беруть цифрові гаманці (наприклад, Google Pay, Samsung Pay, Apple Pay або PayPal). Криптовалюта, особливо біткоіни, також мають багато переваг для власників інтернет-магазинів, наприклад, низькі комісії за проведення платежів і відсутність зворотних транзакцій. Наприклад, онлайнрітейлер Overstock інтегрувався з кріптовалютной біржею Coinbase, щоб клієнти могли оплачувати покупки біткоіни. Можна очікувати, що в 2021 році все більше онлайн-магазинів почнуть приймати криптовалюту.

Екологізація впливатиме на продаж, адже рух за споживання екологічно чистої продукції набирає обертів. Брендам потрібно діяти швидко, щоб залишатися актуальними і конкурентоспроможними. Екологізація споживання це ситуація, в якій клієнти шукають товари, вироблені екологічно чистим способом, що зберігає навколишнє середовище або дозволяє переробку. 65\% споживачів кажуть, що хочуть купувати товари у тих брендів, які виступають за екологізацію. Великі бренди електронної комерції вже почали планувати впровадження більш екологічних методів у свій бізнес. Наприклад, Amazon, провідна світова компанія в електронній торгівлі, взяла на себе зобов'язання до 2040 року звести викиди вуглецю до нуля [432].

До 2022 року більше 120000 магазинів будуть використовувати технології доповненої реальності (AR), пропонуючи набагато багатший купівельний досвід (Prnewswire, 2018). Поширення доповненої реальності в цьому секторі буде 
залежати від роздрібної торгівлі та онлайн-покупців. Одна з основних проблем, 3 якими люди стикаються при здійсненні покупок в Інтернеті, - це неможливість побачити товар на власні очі. Технологія AR допомагає подолати цю прогалину i дозволяє онлайн-покупцям краще візуалізувати цікаві для них продукти [432].

Деякі бренди електронної комерції вже почали експериментувати з AR, що допоможе їм виділитися серед конкурентів. Надання споживачам більш персоналізованого досвіду дозволить підвищити якість покупок в Інтернеті. Компанії використовують доповнену реальність не тільки для поліпшення якості обслуговування клієнтів, але і для того, щоб дати покупцям можливість тестувати і досліджувати продукти так само, як вони це робили б при особистому здійсненні покупок.

Персоналізація покупок в Інтернеті - ключ до задоволення клієнтів. Люди, які здійснюють покупки в Інтернеті, хочуть допомогти знайти потрібні їм продукти і цінують більш індивідуальний підхід. Через погані рекомендації по продуктам онлайн-покупці можуть взагалі уникати певних магазинів.

Сайти електронної торгівлі підтримують цю тенденцію і вкладають кошти в тактику персоналізації, щоб зробити покупки в Інтернеті краще. Це може включати персоналізацію повідомлень, що відправляються електронною поштою, або надання потрібної інформації зацікавленої групи споживачів. Пропонуючи персоналізоване спілкування 3 клієнтами, надаючи відповідні знижки і взаємодіючи з клієнтами, наприклад, за допомогою відеоконтенту, ви зможете зробити покупки більш зручними і зміцнити зв'язок з вашими клієнтами. Одна з багатьох проблем, пов'язаних з управлінням інтернет-магазином, - це необхідність продавати ваш продукт споживачам, у яких немає шансів на фізичну взаємодію з вашим продуктом. Ось де в гру вступає візуальна комерція.

Отже, візуальна комерція - це наступне покоління звичайних статичних візуальних елементів. Він виводить маркетинг на зовсім інший рівень, оскільки замість простого використання фотографій продуктів для просування вашого бізнесу на ринок візуальної комерції він робить ще один крок вперед, включаючи інші типи візуальних елементів, такі як медіа, створені споживачами, 
інтерактивний контент, привабливі відео i, як згадувалося раніше, доповнена реальність. Візуальна комерція повільно, але вірно стає невід'ємною частиною електронної комерції, про що свідчить зростання стоїть за нею технології глибокого навчання. Сюди входить ринок розпізнавання зображень, який повинен вирости з 20,19 млрд дол. у 2018 р. до 81,88 млрд дол. до 2026 р., що означає сукупний річний темп зростання в 19,6 відсотка (MarketWatch, 2020) [432].

Очікується, що використання розпізнавання зображень буде найбільш поширеним на ринку Північної Америки, що фактично корелює з популярністю i попитом на візуальний контент серед споживачів у США. В даний час приблизно 75 \% інтернет-користувачів у США регулярно шукають візуальний контент, перш ніж зробити покупку [431].

Під час карантину постраждали майже всі бізнес-процеси, особливо ринок торгової нерухомості в усьому світі, пише фінансовий портал Finance.ua.

Обмеження урядів, відносно роботи торгових центрів, пунктів обслуговування, громадського харчування, розваг і дозвілля спричинили динамічне зростання продажів в е-соmmerce та зміни у поведінці споживачів. Прослідковується стрімке збільшення активності споживачів в електронній комерції, яке фундаментально здійснює вплив на трансформацію ритейлу, яка пов'язана з удосконаленням технологій і змін у поведінці споживачів. Також дуже зріс відсоток населення старше 55 років, які тепер йдуть від офлайн покупок в інтернет-магазини.

Більше половини $(55,4 \%)$ онлайн-споживачів купують товари за допомогою мобільних телефонів. Проте, не дивно, що онлайн-продажі, як очікується, будуть зростати, оскільки споживачі відчувають себе більш комфортно, роблячи покупки за допомогою мобільних пристроїв.

На рис. 8.3.25 показано прогноз розвитку ринку електронної комерції за сегментом В2С у світі протягом 2021-2024 pp. 


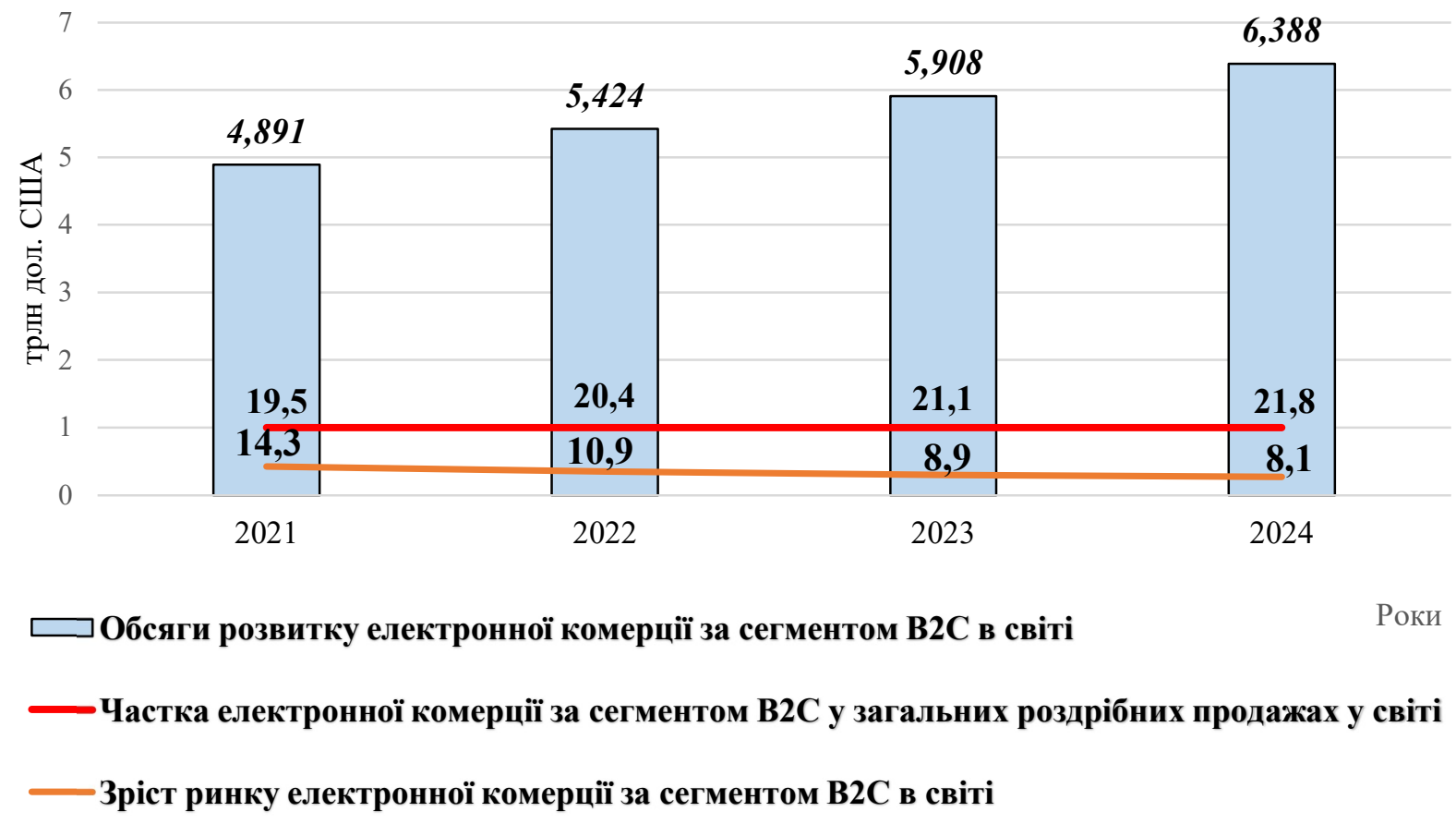

Рисунок 8.3.25. Прогноз розвитку ринку електронної комерції за сегментом В2С у світі протягом 2021-2024 pp. [433]

Очікується, що в 2021 р. глобальні продажі електронної комерції у всьому світі складуть 4,891 трлн дол. США. Ця цифра зростатиме протягом наступних декількох років і досягне в 2024 р. 6,388 трлн дол. США, що доводить, що електронна комерція стає все більш прибутковим варіантом для бізнесу. Крім того, очікується, що в 2021 р. 19,5 \% від загального обсягу світових роздрібних продажів припаде на онлайн-покупки, а в 2024 р. досягне 21,8\%. Тобто майже п'ята частина кожного долара, витраченого на роздрібні товари, буде здійснюватися через Інтернет. Темпи зростання світової електронної комерції на 2021 рік прогнозуються на рівні 14,3 \%, в результаті чого глобальні продажі електронної комерції в усьому світі досягнуть 4,891 трлн дол. США. Однак це зростання становить менше половини в порівнянні з 2020 р.

Оскільки деякі частини світу все ще знаходяться в ізоляції (станом на 3 квартал 2021 р.), продажі електронної комерції в цьому році повинні зрости, хоча і більш повільними темпами, i в найближчі роки прогнозується уповільнення зростання. Наприклад, світове зростання продажів електронної комерції очікується на рівні 10,9 відсотка у 2022 році, що на 3,4 процентних 
пункти нижче, ніж у 2021 році. Цей показник впаде до 8,9 відсотка в 2023 році і $8,1 \%$ в 2024 році. Незважаючи на падаючі темпи зростання, очікується, що частка роздрібних продажів в електронній торгівлі буде збільшуватися. У 2021 році цей показник прогнозується на рівні 19,5 \%, а в 2022 році він збільшиться до 20,4 \% (рис. 8.3.25).

На рис. 8.3.26 представлено середні темпи росту електронної комерції в роздрібній торгівлі в окремих країнах з 2020 р. по 2024 р.

Згідно з прогнозами Statista Digital Market, Туреччина буде займати перше місце з точки зору розвитку роздрібної електронної комерції із середнім річним темпом росту 20,2 в період з 2020 по 2024 рік. Покупки в Інтернеті є одним 3 найпопулярніших видів діяльності в Інтернеті в усьому світі, причому деякі категорії товарів користуються більшою популярністю, ніж інші. Середній показник розвитку продажів світової електронної комерції у роздрібній торгівлі за той же період складе $8,1 \%$.

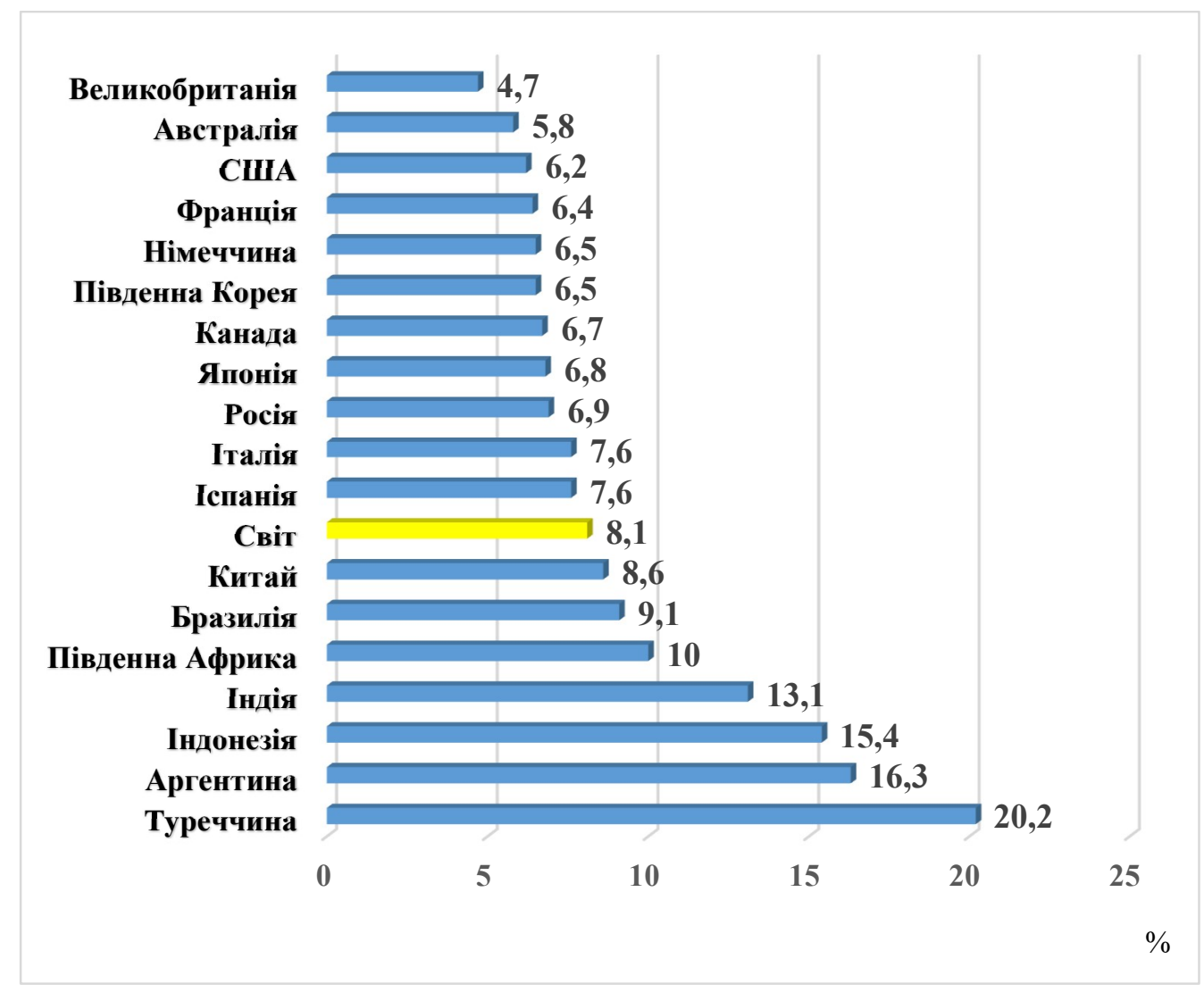

Рисунок 8.3.26. Прогнози розвитку електронної комерції за сегментом В2С у роздрібній торгівлі в окремих країнах з 2020 по 2024 р. [434] 
Китай на сьогоднішній день - найбільший ринок електронної комерції у світі. В 2019 р. обсяг продажів електронної комерції в країні становив 826,6 млрд дол. США і за прогнозами цей показник збільшиться вдвічі до 2024 р. Це означає, що за 4 роки в Китаї може бути витрачено близько 2 з 5 доларів електронної комерції. Проте ринки за межами Європи, Китаю та США вже зростають швидше, ніж китайський ринок. Залежно від того, наскільки швидко зменшиться чисельність населення та робочої сили в майбутньому, це може означати, що китайський ринок може втратити частину своєї популярності далі. Очікується, що в Свропі та США за п'ять років електронна комерція зросте приблизно на 50 \% порівняно з 80 \% в Китаї [435].

На рис. 8.3.27 представлені провідні товари електронної комерції за сегментом В2С у 2021 p.

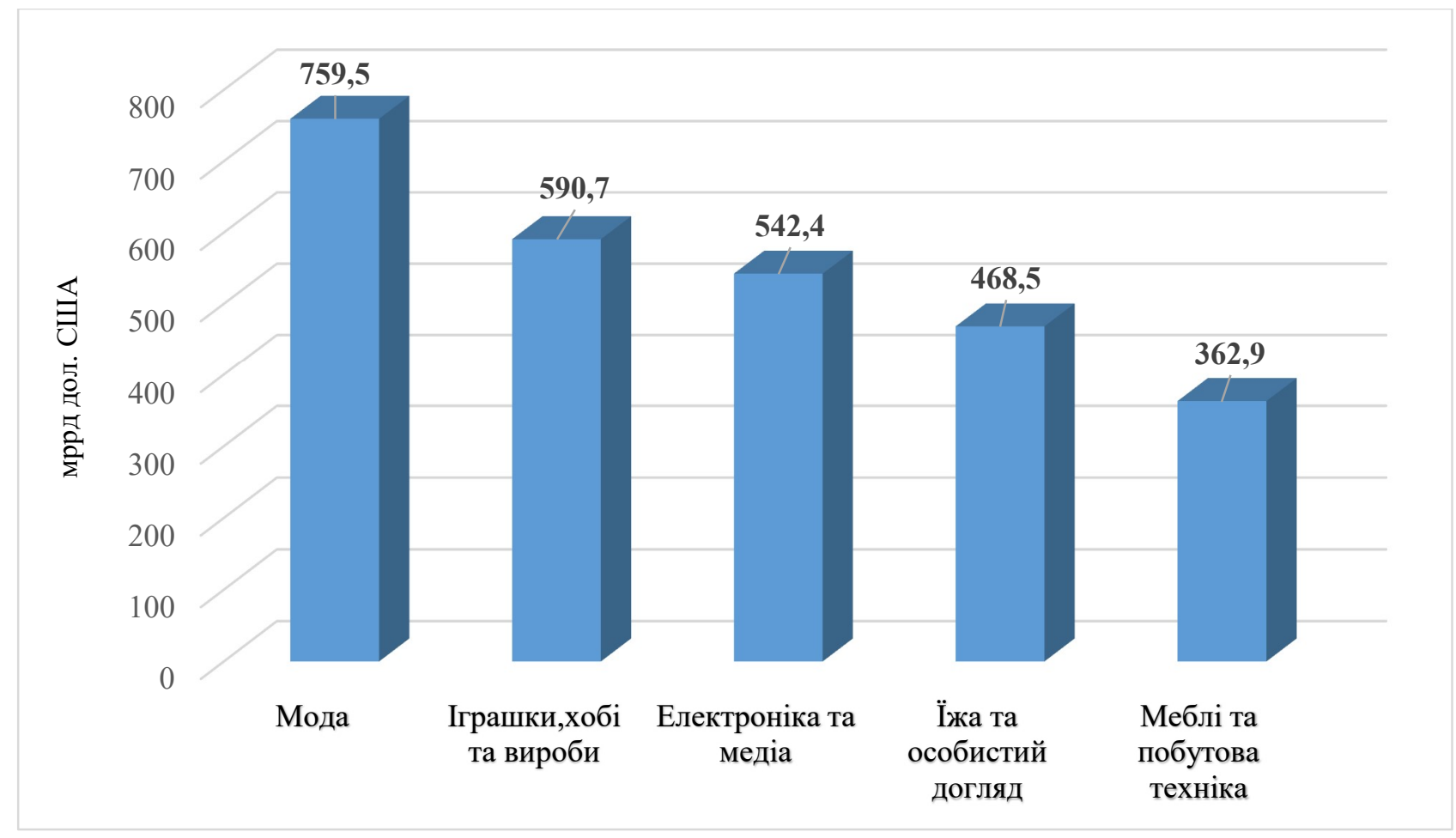

Рисунок 8.3.27. Провідні товари електронної комерції за сегментом В2С

$$
\text { у } 2021 \text { p. [436] }
$$

Згідно з останніми даними, по топовим категоріям покупок в Інтернеті мода - найпопулярніша категорія всіх покупок в Інтернеті. Прогнозується, що із загальних витрат на електронну торгівлю в усьому світі в 2021 р. споживачі витратять 759,5 млрд дол. США на товари, пов'язані з модою (аксесуари, одяг та 
взуття). Це 27,9 \% від очікуваного світового доходу від електронної торгівлі в 2021 р., який складе 2,7 трлн дол. США. Інакше кажучи, більше 13 кожних 4 доларів, витрачених споживачами в Інтернеті в цьому році, витрачається на моду. Це становить значну частину світових продажів електронної комерції і на $15 \%$ більше, ніж 2020 р., в покупках модного одягу в Інтернеті. Однак це відносно повільні темпи зростання в порівнянні зі збільшенням на 26,5\% з 2019 по 2020 рік і на 20,3\% з 2018 по 2019 рік. Аналітики кажуть, що це результат пандемії коронавіруса, яка значно знизила споживчі витрати [436].

Друга за популярністю категорія онлайн-покупок - це іграшки, хобі та вироби. Очікується, що на ці продукти буде витрачено більше 590 млрд дол. США. Разом $з$ модними товарами витрати в цих двох категоріях електронної комерції, за прогнозами, перевищать 1,35 трлн дол. США в 2021 р. Електроніка та медіа стануть третьою за популярністю категорією онлайн-покупок в 2021 р., а обсяг продажів очікується на рівні 542,4 млрд дол. США. Навіть швидкопсувні продукти стають популярним товаром для продажу в Інтернеті. За прогнозами, цього року на продукти харчування та засоби особистої гігієни буде витрачено 468,5 млрд дол. США. 3 очікуваною виручкою в 362,9 млрд дол. США, категорія «Меблі та побутова техніка» займає п'яте місце в списку найбільш популярних категорій покупок в Інтернеті [436].

Впровадження технологій 4G і 5G для забезпечення зв'язку позитивно впливає на зростання ринку, оскільки забезпечує безперебійну роботу користувача. Більш того, використання смартфонів швидко набирає обертів, тим самим збільшуючи доступність покупок в Інтернеті для покупця. Таким чином, очікується, що зростання використання смартфонів буде стимулювати зростання ринку протягом прогнозованого періоду.

Збільшення кількості малих і середніх підприємств також призведе до ескалації попиту. Малий і середній бізнес зростає швидкими темпами, особливо в Індії, Південній Африці та Росії. Такі ініціативи, як Make in India i Start-up India, привели до збільшення числа стартапів в країні, які переходять на онлайн-ринок для бізнесу, тим самим сприяючи зростанню ринку. Більш того, збільшення 
споживчого добробуту також буде стимулювати зростання ринку електронної комерції.

Великі підприємства та організації схиляються до онлайн-бізнесу через менші витрати на зв'язок та інфраструктуру. Електронна комерція пропонує більш легкий доступ до клієнтів, i, отже, також досягається необхідна взаємодія з бізнесом. Електронна комерція також розвивається через зростаючу важливість інструментів онлайн-маркетингу, таких як реклама Google i Facebook. В даний час існує безліч варіантів маркетингу через популярність додатків для соціальних мереж, які допомагають направити ринок електронної комерції до траєкторії зростання.

Через тривалу пандемію COVID-19 схильність клієнтів до покупок в Інтернеті зростає, оскільки звичайні магазини закриті. Серйозно постраждала від пандемії економіка США, Китаю, Індії та Італії. Отже, очевидний вплив на ринок прогнозується в таких регіонах, як Європа і Північна Америка. Наприклад, згідно 3 даними, наданими Emarsys i GoodData, виторг зріс на 37\%, а замовлення - на $54 \%$ в США. Але відсутність впровадження технічної інфраструктури в сільських районах таких країн, як Індія, Китай і Бразилія будуть перешкоджати зростанню ринку [437].

Зростаюче визнання технологій дозволяє сектору електронної комерції бути більш ефективним і доступним. Зростаюче населення середнього класу $\mathrm{i}$ інтенсивне використання соціальних мереж також загострюють попит на онлайн-покупку різних продуктів і послуг, тим самим позитивно впливаючи на зростання сегмента «Бізнес для споживача» (В2C). Інтернет змінив спосіб продажу та купівлі товарів і послуг. Електронна комерція або онлайн-торгівля змінюють купівельний досвід. Банки та інші гравці в індустрії електронної комерції надають безпечну і надійну онлайн-платформу для простої оплати через платіжний шлюз. Учасники ринку зосереджуються на унікальних змінах своїх бізнес-моделей, щоб дозволити продавцям і споживачам укладати угоди в Інтернеті. Провідні роздрібні торговці на ринку намагаються доповнити свою 
традиційну роздрібну торгівлю онлайн-торгівлею і налагодити зв'язки з іншими великими гравцями електронної комерції.

Сегмент «Бізнес для бізнесу» (В2B) в 2019 році домінував на ринку електронної комерції з часткою $63,1 \%$ i, як очікується, стане свідком найшвидшого зростання з 2020 по 2027 рік. Це пояснюється зростаючою схильністю компаній до онлайн-продажів та купівлі товарів і послуг. Крім того, очікується, що зростання проникнення смартфонів в поєднанні з використанням Інтернету буде стимулювати сегмент електронної комерції В2В протягом прогнозованого періоду [437].

Електронна комерція між бізнесом включає в себе купівлю та продаж товарів і послуг між бізнес-компаніями. Більш того, платформи електронної комерції В2В пропонують компаніям нові можливості для покупки і продажу продуктів, тим самим знижуючи як операційні, так і складські витрати. Саме це підтримає зростання сегмента протягом останніх років. Зростання спеціалізованих або вертикальних торгових майданчиків в електронній комерції В2В відкриває нові можливості для ринку. Вертикальні торгові майданчики пропонують широкий асортимент продуктів у товарній категорії. Так само спеціалізовані торгові майданчики надають додаткові послуги, такі як оптові знижки і кілька варіантів оплати.

Схильність компаній до продажу та купівлі товарів і послуг через платформу електронної комерції В2В чітко простежується в усьому світі. Компанії, які віддають перевагу платформи електронної комерції В2В, слідують або моделі ринку, або прямий моделі для ведення свого бізнесу. Модель торгового майданчика передбачає, що компанії продають свої продукти на загальній платформі разом зі своїми конкурентами, в той час як пряма модель передбачає, що компанії створюють свої приватні платформи В2В і продають безпосередньо покупцям.

Аналітики медіа та дослідницької організації digital Commerce 360 представили прогноз розвитку електронної комерції в 2021 році [438]: 
1. Можливість трансформації і зростання електронної комериії.

Через кризу вартість компаній традиційної торгівлі буде падати. Це дозволить технологічним гігантам викупити ці підприємства і вийти в офлайн. Зокрема, Amazon цілеспрямовано завойовує ринок розкоші, може зацікавитися збанкрутілими ритейлерами преміум-сегмента Neiman Marcus, Saks Fifth Avenue та ін.

Нові споживчі звички вплинуть на продуктовий ритейл. Популярність онлайн-замовлень продуктів знизить трафік у магазини, в результаті чого багато хто 3 них закриються або будуть переформатовані в центри виконання замовлень. Так, наприклад, нещодавно надійшов Walmart.

Також інтернет-гіганти можуть викупити таких продавців, як JC Penney Co. Inc. або Sears Holdings Corp. і використовувати їх магазини в якості зручних пунктів отримання інтернет-замовлень.

Все більше немережевих магазинів стануть підключатися до сервісів доставки. Ситуація в цілому прискорить розвиток великих мереж: Amazon стане стрімко розширювати географію мультиканального магазинів Fresh, a Walmart збільшить кількість ПВЗ і ЦІЗ на базі своїх торгових точок.

2. Технологічні та операційні поліпшення електронної комериії.

Розвиток технологій також змінить індустрію. Самоізоляція удесятерила популярність спілкування онлайн. Тому багато хто 3 рітейлерів будуть інвестувати в поліпшення клієнтського досвіду на базі сучасних технологій, у тому числі в навчання персоналу роботі з покупцями по відеозв'язку. Також велике значення надаватиметься функціоналом продають сайтів, щоб максимально нівелювати різницю між онлайн та офлайн-покупками.

Крім того, пандемія довела ритейлерам необхідність автоматизації складської діяльності для прискорення i спрощення збору замовлень. Робототехніка та штучний інтелект стануть основними драйверами прискорення цих процесів, але крім цього вони стануть працювати і на диверсифікацію 
ланцюжків поставок, необхідність якої також проявилася під час тотальних локдаунів.

Окремим каналом продажів стануть месенджери і соціальні мережі, причому з'являться роздрібні торговці, орієнтовані виключно на соціальну комерцію, вважає контент-менеджер і аналітик Табіта Кессіді. За ії словами, роздрібні торговці змінять свої ланцюжки поставок.

\section{3. Нові випробування.}

У той же час, все це значно ускладнить в нинішньому році електронну торгівлю. Конкурентні переваги в цій ситуації отримають найбільш гнучкі, легко адаптовані та інноваційні компанії. Все більше компаній заявляють про дії, спрямовані на збереження навколишнього середовища і сталий розвиток, і в 2021 році їх кількість буде тільки зростати.

Невеликі компанії, які торгують на Amazon та інших маркетплейсах, зможуть успішніше конкурувати на цих майданчиках за рахунок консолідації в рамках інвестиційних фірм. Таких агрегаторів останнім часом з'являється все більше, і все важче виживати тим дрібним брендам, які не потрапляють у сферу ïx інтересів. У той же час, конкуренція загострюється за рахунок великих брендів, також розширюють свої продажі на маркетплейсах.

Однак слід враховувати, що, коли тривала самоізоляція після масової вакцинації буде знята, люди, втомлені від самотності і комп'ютерів, масово вирушать в магазини. Люди будуть прагнути до соціального, емоційного та фізичного досвіду покупок у магазині. Їм так набридло сидіти за екранами своїх комп'ютерів, що в магазинах буде великий сплеск відвідувачів. Традиційним роздрібним продавцям потрібно бути готовими до цього, а компаніям електронної торгівлі заздалегідь вжити заходів до того, щоб зберегти всіх своїх покупців [438].

На сьогоднішній день торговельні компанії цілком конкурентоздатні тільки при використанні Інтернету і різних інструментів електронної комерції. Цей метод користується великою популярністю у продавців насамперед через доступну вартість створення електронної вітрини, яка дозволяє вибудувати 
особисті стосунки з кінцевим споживачем за допомогою системи зворотного зв'язку. Це створення особистого кабінету і надання технічної підтримки, яка сприяє швидкому пошуку товарів завдяки вбудованій системі фільтрів. Слід зазначити, що можливості розвитку в цій сфері мають хороші перспективи. Більшість українських компаній це розуміють і активно вивчають цей сегмент, незважаючи на те, що інфраструктурна складова електронної комерції в Україні не настільки розвинена (головним чином через нерівномірність заселення, недорозвиненість дорожньої інфраструктури, кліматичну складову). Але останнім часом спостерігається позитивна тенденція у вирішенні цього питання завдяки успішному досвіду [439].

Розвиток електронної комерції в Україні є вкрай важливим, адже це результативний спосіб, який дозволяє вийти на міжнародний рівень багатьом українським компаніям, особливо, фірмам, що мають комерційні послуги, i фірмам - розробникам програмного забезпечення. Електронна комерція дає стимул до наступного розвитку в нашій державі як Інтернет-технологій, так і всій фінансовій інфраструктурі.

Кожен рік електронна комерція займає все помітніше місце та відіграє роль не лише як засіб пошуку нових ринків збуту, а й, що істотно важливіше, веде до нових способів виробництва, перерозподілу та збуту товарів і послуг. Комплексне вирішення всіх проблем та ліквідування причин перешкод розвитку електронної комерції в Україні може зменшити різницю у темпах зростання ролі Інтернет-торгівлі у світі та нашій державі, при цьому саме країні слід найбільше дбати про вирішення проблем електронної комерції.

В умовах зростаючого ринку електронної комерції і все більшої конкуренції, що посилюється, необхідно постійно бути в курсі тенденцій даної галузі, щоб збільшувати продажі і забезпечувати кращі результати роботи. Задля успішного ведення електронного бізнесу треба розуміти, чим зацікавити клієнта, де він частіше буває та як донести до нього свій товар.

Очікується, що розширення ринку електронної комерції в Україні триватиме протягом найближчих кількох років, як вказує Статистичний прогноз 
цифрового ринку. Передбачається, що річний темп приросту (CAGR 2020-2024) протягом наступних чотирьох років становитиме $13 \%$. Порівняно із зростанням у 2020 році на $41 \%$, це зменшення свідчить про помірне збільшення обсягів ринку електронної комерції [440].

За прогнозами EVO.Business outlet розмір українського ринку електронної комерції в 2021 р. становитиме 137 млрд грн. (4,89 млрд дол. США), що на 28\% більше порівняно з 2020 р. У той же час, враховуючи, що вакцинація в Україні розпочалася з кінця лютого і триватиме протягом усього року, можуть бути додаткові карантинні обмеження. Оскільки тільки 73\% користувачів Інтернету роблять покупки в Інтернеті, є достатньо місця для того, щоб індустрія електронної комерції зросла ще вище [407].

За прогнозами EVO очікується, що в 2021 р. темпи зростання онлайнторгівлі частково залишаться на одному й тому ж місці і е-соmmerce збільшиться ще на третину. Зокрема, цьому слугуватимуть: [394]

$\checkmark$ поява надійних способів онлайн-оплати на торгових онлайн-площадках;

зменшення ціни доставки (в тому числі знижки безкоштовної доставки від маркетплейсів);

$\checkmark$ швидкість і зростання якості обслуговування продавцями. Споживачі стають більш вибагливими і продавці почали шукати підхід: швидке оброблення замовлень, відправлення якнайшвидше, простіше повернення;

$\checkmark$ карантин витиснув в онлайн традиційно офлайнові продукти, особливо ліки та харчі. У кілька разів збільшився попит на доставку з магазинів і кафе. Навіть після пандемії, маленька ймовірність, що покупці захочуть відмовитися від цих зручностей.

Покупці стали більш вибагливими, а саме продавцям треба підлаштуватися: моментальна обробка замовлень, відправлення сьогодні, просте повернення товарів вже стали звичними. Пандемія виштовхнула в онлайн традиційно офлайнові сегменти, зокрема ліки та продукти. У кілька разів зріс 
попит на доставку з магазинів і ресторанів. Навіть після пандемії, малоймовірно, що покупці відмовляться від цих зручностей.

3 одного боку, керівники українських компаній електронної комерції дають позитивні прогнози на 2021 рік. Це пов'язано із глобальною інтернаціоналізацією, переходом на Інтернет-магазини та зростаючою популярністю інтернет-магазинів та ринків. Тому швидкість та якість обслуговування стали виробниками або рушіями компаній у боротьбі за клієнтів. 3 іншого боку, якщо друге блокування або «карантин вихідних» виявиться довшим, ніж перший, ще один відсоток малого бізнесу обов'язково закриється. I цей відсоток $є$ величезним та найбільш цікавим сегментом для ринку, оскільки $є$ ключовими початковими розробниками, що вигадують нетрадиційні ідеї, підходи та рішення завдяки обмеженим фінансовим ресурсам для просування товарів та послуг [441].

Згідно з прогнозами, до 2022 року $67 \%$ усіх онлайн-покупок у світі будуть здійснюватися через маркетплейси. За останні 3 роки в Україні всі лідери ринку частково або повністю стали маркетплейсами (кожна п'ята з першої двадцятки еcommerce вітрин) [442].

Перспективні напрями та подальші тенденції розвитку електронної комерції в Україні: [443]

1. Розвиток персональних брендів. Дослідження показують, що споживачам сьогодні більш цікаві товари, що пов'язані 3 окремими особистостями, чим з компаніями. Так, Ілон Маск, Стівен Кінг, Євгенія Гапчинська - це скоріше бренди, ніж просто відомі особи в бізнесі, мистецтві, культурі.

2. Спрощення покупок через використання гаджетів. Здійснення покупок через мобільні додатки, соціальні мережі, месенджери через смартфони та інші пристрої допомагають зробити процес купівлі зручним та легким, натиснувши лише одну кнопку. Мобільна комерція з використанням популярних додатків Google Shopping, Facebook Marketplace i Checkout на Instagram прискорює процес купівлі й залишатиметься актуальною для малого i середнього бізнесу. 
Інноваційним є використання «розумних девайсів», які контролюють потребу в покупках.

3. Ріст торгівлі за підпискою (Subscription shopping). Набуває розвитку такий вид електронної торгівлі, як купівля наборів товарів, які мають стабільний попит, за підпискою. Найчастіше до товарів Subscription shopping входять продукти харчування, корм для тварин, товари категорії Droggery. Такий вид електронної торгівлі дозволяє покупцям зекономити час на замовлення комплектів періодично потрібних продуктів. Лише за 2019 рік пропозиції підписки зросли на 40\%. Лише на Amazon є більше 150 варіантів наборів товарів (shopping boxes). Використання підписних наборів буде актуальним для клієнтів старшого віку, а використання персональних наборів товарів стане зручним способом купівлі для покупців, які не мають вільного часу на періодичний шопінг.

4. Удосконалення логістики через поширення послуг фулфілменту. Фулфілмент сервіс (fulfillment) - це послуги аутсорсингу 3 передачі всіх процесів, пов'язаних з обробкою замовлень та відправленням їх кінцевим споживачам. Фулфілмент-компанії беруть на себе повну відповідальність не лише за прийом, обробку замовлень, а й отримання оплати, зберігання товарів, укомплектування, пакування, транспортування, повернення товарів тощо. Перспективним напрямом $є$ автоматизація фулфілменту.

5. Розвиток інструментів та технологій в електронній торгівлі / Сучасний ритейл, тим більше електронний, потребує інноваційних бізнесмоделей. Стратегічно важливим стає використання інструментів та технологій, які дозволятимуть:

$\checkmark$ швидко обрати потрібний товар 3 одночасним порівнянням ціни i характеристик різних виробників;

рекламувати продукцію цільовим споживачам на основі автоматичного відбору, геолокації та пошукових запитів; 
будувати рейтинг продавців за обраними критеріями (ціна, технічні характеристики, доставка,сервіс, відгуки покупців тощо);

$\checkmark$ ефективно управляти запасами на основі діджиталізації, роботизації, використання складського обладнання з RFID датчиками;

$\checkmark$ розширювати канали електронної комерції.

Виділені перспективні напрями розвитку електронної торгівлі в Україні вимагають використання цифрового маркетингу, перегляду та оптимізації діючих стратегій торгівельних підприємств, адаптації їх до нових викликів та потреб.

Останнім часом простежується тренд на впровадження інноваційних технологій з онлайн-продажу. Бізнес не просто тестує, а активно використовує $\mathrm{VR}$, створюючи 3D-фото і відеоогляди. Збільшується частота використання штучного інтелекту та учнів роботів. Створюються чат-боти i віртуальні помічники, які в листуванні з живою людиною замінюють консультанта. Якісно налаштований робот практично не відрізняється від живої людини і закриває до 90\% потреб клієнтів в автоматичному режимі [444].

Цікавий світовий і вітчизняний досвід електронної комерції у секторах G2B та G2C. Ці сектори представлені електронними порталами, що надають послуги для представників бізнесу й окремих громадян. Наприклад, в Естонії 3 2000 року працює система X-tee, яка забезпечує громадян країни такими послугами, як е-вибори (голосування через Інтернет), eRik (центр реєстрів у режимі реального часу), е-комерційний регістр (послуги для юридичних осіб), енотаріус, е-поліція, е-школа, е-пенсія та ін. Цікавий у цьому питанні і досвід Данії. Там у 2003 році був запущений портал Borger.dk, який включає національний реєстр ідентифікаційних номерів, міжвідомчий документообіг, онлайн-оплату податків, мит та зборів.

Для українців з 2015 року доступний портал iGov. Головним завданням порталу засновники бачили перенесення якомога більшого числа послуг в електронну форму. Пересічні українці мають можливість оформити на сайті субсидію, персональні документи, акти одруження та розлучення, документи про 
соціальний захист, зміну місця проживання та ін. Власники бізнесу можуть зареєструвати в електронній формі своє підприємство чи ФОП, оформити документи, пов'язані з отриманням ліцензії, будівництвом або переоформленням нерухомості та ін. Усі послуги, що надаються порталом, - безкоштовні.

У 2020 році для українців став доступний державний портал «Дія» та відповідний мобільний додаток. «Держава в смартфоні», як називають проєкт розробники з Мінцифри, наразі пропонує 27 публічних послуг. Серед них: відкриття або закриття ФОП; оформлення різного роду довідок; оформлення допомоги при народженні дитини; оформлення ряду ліцензій; завантаження студентського квитка, водійського посвідчення та ін. До 2024 року розробники планують оцифрувати 100 \% публічних послуг для громадян і бізнесу [446].

Важливий напрям економічного розвитку України - сфера електронної торгівлі - вимагає державного стимулювання. Спочатку дає можливість отримати додаткові надходження до Державного бюджету України, тому державі прибутково удосконалити регулювання електронної комерції.

Сфера електронної комерції в Україні не сходиться в стандартах Євросоюзу та найкращих міжнародних моделях. Від цього потерпають, насамперед, вітчизняні споживачі. Чи не наймасштабніша проблема української е-торгівлі - реальність схем шахраїв з передоплатою споживачами недійсних товарів чи послуг. Такі кримінальні дії почалися під час пандемії COVID-19. Шахраї багатьом українцям пропонували "повітря" замість медичних масок $\mathrm{i}$ дезінфекторів, а ті у відповідь купували.

У ЄС, США та Ізраїлі є правова норма, яка застерігає споживачів від шахрайства. Відповідно до неї, інтернет-продавці повинні позначати на своїх сайтах лише ті номери телефонів, що офіційно зареєстровані оператором на юридичну особу або прив'язані до паспортних даних приватного підприємця. [448].

Вітчизняне законодавство нерозвинене, а ефективного контрольного органу щодо захисту споживачів у сфері е-комерції немає - як і окремого розділу 
щодо інтернет-торгівлі в законі "Про захист прав споживачів". В законодавстві про електронну комерцію не існує ефективних заходів захисту онлайн-покупців.

На сьогоднішній день у Євросоюзі захист прав споживачів у сфері еторгівлі контролюється директивою 2000/31/ЄС "Про електронну комерцію" та директивою 97/7/ЄС "Про захист прав споживачів у дистанційних контрактах". У нашій країні ще немає, як наприклад у країнах СС, розгалуженої громадянської системи захисту споживачів i реєстру добросовісних продавців. Україна використовує європейську систему захисту споживачів е-комерції, у якій інструменти ефективно впливають на рівні "третього сектору". Такі центри самостійні від держави, проте у них є правові повноваження і загальнодоступні громадянам ЄС і у селах.У США та інших країнах британського права існує перевага засобам вільного підприємницького саморегулювання й дієвому судовому захисту [448].

Щоб вітчизняна торгівля була ефективним руслом, слід підписати закон про захист прав споживачів у сфері інтернет-торгівлі. Він повинен мати такий перелік ефективних норм, що існують в країнах Євросоюзу: [448]

1. Заборона онлайн-торгівлі суб'єктам, які не показують реєстраційну інформацію. Передусім це стосується інтернет-магазинів, телефони яких не верифіковані або не прив'язані до паспортної інформації фізичної собипідприємця.

2. Право за рішенням суду перешкоджати шлях сайтам інтернет-магазинів, які не дотримуються вимог щодо ідентифікації. Слід законодавчо зробити більш прискорену процедуру судового розгляду таких звернень. Подібні норми містив законопроєкт, поданий до Верховної Ради у 2017 році, проте він був скасований. Нова влада не бажає до нього повертатися.

3. Механізм депонування коштів банківськими установами або онлайнмагазинами. Такий спосіб добре застосовується, зокрема, в Китаї. Продавець може здобути гроші від споживача лише після повноцінного проведення своїх зобов'язань. Держава повинна використати потужну інформаційну компанію: роз'яснити плюси депонування коштів на окремому рахунку та позначити мінуси 
оплати за товари чи послуги у форматі Р2Р (переказ коштів від однієї фізичної особи до іншої).

4. Розподіл ролі формування державної політики i захисту прав споживачів. Створити першу функцію Мінекономіки, другу Держпродспоживслужби. Дійсна модель регулювання торгівлі Мінекономіки і Мінцифри, а захисту споживачів Держпродспоживслужбою не ефективно регулює.

5. Офіційний реєстр добросовістних онлайн-магазинів на сайті регулятора. Такий спосіб переплітається 3 європейською моделлю захисту споживачів. Прикладом є введення та створення Німеччиною, Францією та Швейцарією загальнодоступного реєстру старанних продавців у податкових органах.

Електронна комерція в Україні ще тільки починає зароджуватися. Слід зазначити, що прагнення до легітимізації відповідних їй податкових процедур, по суті, не опрацьовується взагалі. 3 метою спрощення податкового адміністрування у сфері електронної комерції, а також організації ефективного контролю за додержанням суб'єктами економічної діяльності національного податкового законодавства треба організувати спеціальну інфраструктуру, що зможе дати безпечний та безперешкодний обмін документами електронної звітності, а також функціонування на високому рівні механізму погашення податкових зобов'язань платниками податків завдяки здійсненню електронних розрахунків.

Деякі рекомендаації щодо удосконалення та розвитку електронної комерції в Україні:

забезпечення відповідної нормативно-правової бази:

- врегулювати питання щодо відповідальності власників маркетплейсів перед споживачем за недоброякісні дії сторонніх продавців;

- запровадити механізм швидкого блокування недобросовісних суб' єктів електронної комерції;

- визначити чіткі правила розміщення інформації про продавця 3 можливістю підтягування даних 3 Сдиного державного реєстра 
юридичних осіб, фізичних осіб, підприємців та громадських формувань;

- запровадити механізми досудового врегулювання спорів між споживачами та продавцями та створити відповідний реєстр електронної комерції з обов'язвовою реєстрацією у ньому суб'єктів еcommerce впровадження екологізованого споживання;

$>$ підписання закону про захист прав споживачів у сфері інтернет-торгівлі;

$>$ запровадження нових способів оплати;

$>$ започаткування персоналізації покупок, доповненої реальності (AR) та штучного інтелекту;

$>$ забезпечення захисту об'єктів інтелектуальної власності та прав їх власників в мережі Інтернет;

$>$ забезпечення захисту персональних даних;

> сприяння зростанню візуальної комерції: великі рітейлери, наприклад, як Bose вже використовують візуальну торгівлю, щоб підштовхнути відвідувачів до покупки. Вони розміщують якісні зображення на своїй стартовій сторінці разом з посиланнями на пряму купівлю товару;

$>$ швидке застосування базових інструментів, комп'ютерів та телекомунікацій, у тому числі й у сільській місцевості, що гарантує збільшення комп'ютерної грамотності населення і відповідний рівень розвитку інфраструктури;

прискорення стрімкого розвитку інфраструктури мережі: розвиток онлайнмагазинів, мережних бізнес-структур, операторів в мережах та складання декількох масштабних вітчизняних Інтернет-порталів;

запровадження е-урядування з е-послугами;

спрощення покупок через використання гаджетів;

розвиток інструментів та технологій в електронній торгівлі; 
> забезпечення фінансування державних проектів (національної програми інформатизації, фінансувати поширення систем електронної комерції);

$>$ розробити Національний план дій 3 регулярного ознайомлення та впровадження систем е-комерції різних типів.

Інтенсивна діджіталізація у всьому світі робить електронну роздрібну торгівлю елементом всесвітньої системи комерції. Прискорений темп сучасного життя отримав значні переваги завдяки можливості проводити онлайнтранзакції. Доступ до Інтернету в усьому світі швидко розширюється, цифрові технології у багатьох галузях викликають суттєві зрушення і нововведення, тому стрімко зростає кількість покупців в сфері електронної торгівлі.

Пандемія COVID-19 поставила людей в умови, коли багато чого потрібно робити не виходячи 3 дому. Таким чином був прискорений процес розширення електронної торгівлі, і покупцям було надано доступ до широкого вибору різноманітних товарів. У той же час, торговельні компанії отримали можливість продовжити роботу в умовах жорстких обмежень і зробити ії більш ефективною. В багатьох країнах транзакції Е-commerce дозволили здійснювати продаж не тільки предметів розкоші і послуг, але й предметів щоденного попиту, необхідних великій кількості людей. Завдяки зручності нових способів торгівлі, ці зміни можуть придбати довгостроковий характер та стимулювати торговельні компанії вкладати кошти в розвиток нових каналів продажів.

Можна констатувати, що криза, спровокована пандемією, прискорила застосування діджитал-технологій і розширила можливості E-commerce, сприяла виникненню нових фірм, типів товарів і збільшенню кількості покупців.

Отже, електронна комерція - це світ, який постійно розширюється. 3 посиленням купівельної спроможності світових споживачів, розповсюдженням користувачів соціальних мереж та постійно розвивающою інфраструктурою, та технологіями, майбутнє електронної комерції стає більш перспективним. 


\section{SECTION 9. MANAGEMENT}

\section{DOI 10.46299/ISG.2021.MONO.ECON.II-421-428}

\subsection{New technologies of personnel management in customs authorities}

Митна служба України є складовою частиною системи органів виконавчої влади України і складається 3 митних органів, митних організацій, а також спеціалізованих навчальних закладів та науково-дослідної установи митної служби України.

Призначенням митної служби України є створення сприятливих умов для розвитку зовнішньоекономічної діяльності, забезпечення безпеки суспільства, захист митних інтересів України.

Служба в митних органах України є державною службою, яка полягає у професійній діяльності придатних до неї за станом здоров'я, освітнім рівнем та віком громадян України, пов'язаний із створенням сприятливих умов для розвитку законної зовнішньоекономічної діяльності, забезпеченням безпеки суспільства та захистом митних інтересів України [449, с.20].

Структура митних органів України включає: 25 митниць (по кількості областей), 49 митних постів; 29 автомобільных пунктів пропуску; 14 залізничних пунктів пропуску; 4 авіаційних пунктів пропуску, 17 морских и річних пунктів пропуску [450, с.31].

Система управління персоналом є комплексом взаємопов'язаних елементів (підсистем), що складаються з органів управління, принципів, методів, форм і засобів і спрямованих на досягнення цілей, що стоять перед колективом (організацією).

Управління персоналом митниці, як і управління персоналом в системі держслужби, має свої особливості. За останні кілька років кадрова робота в митних органах розвинулася в політику кадрів. Вищі органи митниці проводять політику кадрів на всіх рівнях митної системи. Це дуже важке завдання, оскільки 3 правоохоронної сутності органів митниці та особливого службового становища, випливають певні особливості проведення політики кадрів. Головна 
3 таких обумовлена бюрократизмом з численними приписами і правилами, які $є$ обов'язковими для будь-якої державної служби. Митники повинні уживатися 3 безліччю обмежень, дотримуватися суворих процедур.

Митна структура досить розгалужена. Система при наявності 30 підрозділів стає роз'єднаною, трудноуправляемой, схильна до взаімодублірованію. Начальнику митної служби важко забезпечити реалізацію принципу єдиноначальності і реалізації єдиної митної політики. Наслідком такої ситуації є нераціональна розстановка кадрів [450, с.37].

Оскільки митна система $є$ багаторівневою, значить в ній багато начальників і заступників, крім них ще є головні інспектори та керівники груп, які часто виконують роль заступника начальника відділу.

Частина керівництва всіх рівнів замість раціональної перебудови технології митного контролю як i раніше орієнтується на підвищення ефективності за рахунок збільшення чисельності кадрового складу. Але на даний момент необхідно виходити 3 того, що додаткового штату не буде. Шлях вирішення такої проблеми - це ефективне використання наявного кадрового потенціалу.

У кожній організації повинен бути власний вибір способів реформування кадрових служб. Один із способів - це об'єднання всіх служб організації, які пов'язані з формуванням складу кадрів, з організацією і плануванням резерву кадрів, його стимулюванням. Така нова служба повинна мати комп'ютерну техніку. У складі служби, крім інспекторів з підготовки кадрів і персоналу, повинні бути соціологи, юристи, фізіологи, психологи, працівники зі зв'язків із засобами масової інформації.

Об'єктом управління персоналом є всі виконавці управлінських рішень: персонал організації (підрозділу), окремі працівники.

Суб'єкти управління персоналом - це фахівці, працівники кадрової служби, керівники всіх рівнів, що виконують функції управління по відношенню до підлеглих. Об'єктивною основою вимог до системи і технології управління персоналом митного органу є не тільки загальні закони і закономірності теорії 
управління, а й закономірності, притаманні цьому процесу. Система управління персоналом повинна відповідати цілям, особливостям, станом і тенденціям розвитку митної служби. Необхідно враховувати всі можливі взаємозв'язки всередині системи управління персоналом, між ії підсистемами і елементами, між системою управління персоналом і системою управління митним органом в цілому, а також митним органом і зовнішнім середовищем, необхідність пропорційного вдосконалення всіх підсистем і елементів системи управління персоналом для недопущення і виключення диспропорцій в цілісній системі управління. На всіх рівнях і у всіх частинах повинна бути пропорційність системи управління. Співвідношення чисельності працівників системи управління персоналом і кількісного складу митних органів в цілому повинно носити оптимальний характер, а число ступенів управління персоналом повинно бути мінімальним, так як ефективність системи управління персоналом безпосередньо залежить від кількості рівнів управління.На різних щаблях управління повинно відбуватися зростання ролі одних і зниження інших функцій управління персоналом і зміна їх змісту в зв'язку з розвитком і вдосконаленням митної служби. Закономірності управління персоналом взаємодіють, впливають один на одного і підвищують результативність всього процесу управління персоналом.

Система управління персоналом митного органу включає підсистему лінійного керівництва і функціональні підсистеми.

До підсистемі лінійного керівництва відносять управління митним органом і управління окремими функціональними підрозділами. Ї̈і функції виконують: керівник митного органу, його заступники, керівники функціональних підрозділів і їх заступники.

У підсистему функціонального керівництва входять безліч підсистем, які перераховані нижче.

Управління відбором і обліком персоналу включає організацію співбесіди, оцінки , відбору і прийому персоналу, а також переміщення, заохочення та звільнення персоналу; професійну орієнтацію та організацію раціонального 
використання персоналу та документальне забезпечення системи управління персоналом.

В управління розвитком персоналу входить навчання, перепідготовка та підвищення кваліфікації, введення в посаду і адаптація нових працівників, оцінка кандидатів на вакантну посаду, реалізація ділової кар'єри і службово Професійне просування, організація роботи 3 кадровим резервом.Управління трудовими відносинами включає аналіз і регулювання групових і особистісних взаємин, аналіз і керівництво відносин керівництва, управління виробничими конфліктами і стресами, соціально-психологічна діагностика.

В наші дні особливої актуальності набувають питання щодо соціальної захищеності членів трудового колективу. Забезпечення соціальних гарантій в системі митних органів, грунтуються на прогнозуванні та аналізі соціальних процесів, своєчасного виявлення соціально нужденних працівників, надання їм необхідної моральної та матеріальної підтримки, організації робіт з надання допомоги ветеранам.

Особливе місце в процесі щодо реформування кадрових служб повинно відводитися керівнику, який повинен володіти, крім спеціальної психологопедагогічної підготовки та вищої освіти, досвідом керівної і кадрової роботи, повинен мати розвинені комунікаційні, пізнавальні та організаційні здібності.Керівник повинен володіти технікою з управління кадрами, методами оцінки ділових, особистісних якостей співробітників і результатів роботи колективу, питаннями практичного застосування законодавчих основ в роботі 3 кадрами, методами і техніками публічних виступів, способами впливу на трудовий колектив, ведення переговорів при виникненні трудових суперечок. Основними завданнями щодо вдосконалення управління персоналом митних органів в даний час є наступне.

Створення гнучкої, науково-обгрунтованої системи організаційно штатної роботи на основі економного структурної побудови, здатного забезпечити ефективність діяльності митної системи та максимальне використання іiі кадрового потенціалу при обмежених ресурсах. Визначення оптимальної 
потреби митних органів, комплектування їх професійними кадрами необхідної спеціальності і кваліфікації.

Впровадження сучасних методик підбору та визначення професійної придатності кандидатів на службу в митні органи; планове переміщення кадрів по службі на основі сучасних підходів до роботи з резервом.

Створення системи безперервної професійної підготовки кадрів, перехід до інтенсивних методів i форм навчання та підвищення кваліфікації співробітників, держслужбовців, що дозволяє отримати позитивні результати як у професійній сфері, так і в сфері особистісного розвитку кожного митника.

Створення необхідних умов і ефективності системи роботи з резервом на висування, що дозволяє висувати на керівні посади найбільш гідних, професійно підготовлених співробітників.

Розробка i реалізація комплексу правових, оперативних i виховно профілактичних заходів щодо забезпечення законності в діяльності митних органів та їх персоналу, вихованню дисципліни і високої відповідальності кадрів.

Підвищення мотивації до ефективної службової діяльності, у тому числі вдосконалення системи правового регулювання і правових гарантій в митній службі, що забезпечують у зможності професійного i кар'єрного росту, здійснення заходів щодо соціального захисту працівників (держслужбовців, працівників) митних органів.

За своїм змістом процес управління є досить складним. Він ідентичний для управління будь-якими соціальними системами. Крім того, він залишається незмінним до будь-яких умов.

Стосовно до управління оперативно-службовою діяльністю в митних органах загальні функції управління реалізуються через: аналіз і оцінку митної оперативно-службової обстановки і прогнозування; прийняття управлінських рішень 3 проблеми і планування, організацію виконання рішень і планів; регулювання; облік, контроль і оцінку результатів робіт) та утворює цикл управління оперативно-службовою діяльністю.

Аналіз і оцінка митної оперативно-службової обстановки і прогнозування 
нерозривно пов'язані 3 вивченням, пізнанням і передбаченням розвитку сукупності умов на тій чи іншій ділянці митної діяльності і визначенням їх впливу на результати митного справи, а також з метою прийняття обгрунтованих рішень і складання планів.

Під митної оперативно-службової обстановкою розуміється сукупність взаємопов'язаних елементів, 3 розташованими в діалектичному розвитку економічними, політичними, соціальними, правовими, регіональними і іншими умовами (факторами), що суттєво впливають на митну діяльність [450, с.35].

Оцінка митної оперативно-службової обстановки (далі ТОСО) є ядром, стрижнем інформаційного забезпечення управління митною діяльністю і в цій якості логічно входить в систему функцій управління.

В процесі оцінки ТОСО суб'єкт управління вирішує такі завдання забезпечення постійного інформаційного стеження i контролю за станом i розвитком ТОСО; виявлення та усвідомлення характеру виникаючих проблем в процесі розвитку ТОСО; визначення ступеня реальної або потенційної загрози 3 боку противника, а також можливостей, шляхів і засобів іiї усунення.

Як процес, оцінка ТОСО включає в себе наступні етапи: визначення мети і завдання оцінки; вивчення банку даних, що містять відомості про ТОСО (елементи, чинники, умови, конкретні подіі); аналіз елементів і синтез аналітичних даних; формування на основі критеріїв і їх показників оціночних суджень і прогностичних висновків про стан і тенденції розвитку ТОСО, ii динаміці.

Основними завданнями щодо вдосконалення управління персоналом митних органів в даний час є.

Створення гнучкої, науково-обгрунтованої системи організаційно штатної роботи на основі економного структурної побудови, здатного забезпечити ефективність діяльності митної системи та максимальне використання ऑiі кадрового потенціалу при обмежених ресурсах. Визначення оптимальної потреби митних органів, комплектування їх професійними кадрами необхідної спеціальності і кваліфікації. 
Впровадження сучасних методик підбору та визначення професійної придатності кандидатів на службу в митні органи; планове переміщення кадрів по службі на основі сучасних підходів до роботи з резервом.

Створення системи безперервної професійної підготовки кадрів, перехід до інтенсивних методів i форм навчання та підвищення кваліфікації співробітників, держслужбовців, що дозволяє отримати позитивні результати як у професійній сфері, так і в сфері особистісного розвитку кожного митника.

Створення необхідних умов і ефективності системи роботи з резервом на висування, що дозволяє висувати на керівні посади найбільш гідних, професійно підготовлених співробітників.

Розробка і реалізація комплексу правових, оперативних і виховно профілактичних заходів щодо забезпечення законності в діяльності митних органів та їх персоналу, вихованню дисципліни і високої відповідальності кадрів.

Підвищення мотивації до ефективної службової діяльності, у тому числі вдосконалення системи правового регулювання і правових гарантій в митній службі, що забезпечують можливості професійного і кар'єрного росту, здійснення заходів щодо соціального захисту працівників (держслужбовців, працівників) митних органів.

Вивчення матеріалів дозволяють зробити наступні висновки.

Проблеми, які переживають митні органи сьогодні, принципово пов'язані з ускладненням і загостренням проблем їх інституційного розвитку. Своєрідність процесів формування митної системи як найважливішого економічного інституту державного управління зовнішньоекономічною діяльністю на попередніх етапах зумовило виникнення диспропорцій і розривів, внаслідок чого екстенсивно розвиваються митні органи стали відчувати загострюється дефіцит організованості і керованості. Необхідні зміни в управлінні нерідко здійснювалися безсистемних, методом проб і помилок. Всі ці фактори зумовили необхідність наукового обгрунтування, організації та розгортання робіт 3 перетворення митниці в соціальний інститут, який відповідає сучасним характером і тенденціям розвитку зовнішньоекономічних відносин в світі. 
Розвиток системи митних органів тісно пов'язане 3 рішенням управлінських проблем, що передбачає розробку оптимальної організаційної структури управління митними органами.

Всі функції з вироблення державної політики в галузі митної справи знову передаються безпосередньо митній службі. Сподіваємося, що найближчим часом ми побачимо суттєві зміни в системі управління митними органами.

Серед різноманіття видів управлінських структур, описаних в теорії, в митній системі $\epsilon$ кілька їх різновидів: лінійно-функціональна, лінійно-штабна, програмно-цільова .

Організаційна структура управління в митних органах не є завершеною, вона постійно розвивається, вдосконалюється, створюються нові види організаційних структур. Сутність проведених робіт по ії вдосконаленню зводиться до наступного:

- розробці комплексу заходів щодо створення та оформлення типових і конкретних структур управління митними органами;

- здійснення роботи по встановленню категорій митним органам;

- ведення аналітичної і довідкової роботи з організаційно-структурним питань. 
DOI 10.46299/ISG.2021.MONO.ECON.II-429-436

\subsection{The determination method of required modernization level of production's technical means at an enterprise}

Abstract. The determination method of required modernization level of production's technical means at an enterprise, which provides an opportunity to formulate requirements for means of production when equipping an enterprise with means of production.

Key words: means of production, modernization, specifications, life in service.

\section{INTRODUCTION}

In order to maintain the level of its market share (or even increasing it) an industrial enterprise may employ several efforts, such as modernization. Only after modernization is it possible to expand production, increase efficiency, update technical means (TM) of production that are obsolete morally or physically, and so on. However, the decline in competitiveness is not the only factor that encourages renewal, in particular, the TM modernization. Also a significant factor is the financial income forgone, as it is impossible to be financially viable using the obsolete TM [451]-[453].

Modernization of modern production can be done in two ways: extensive and intensive. Extensive methods of modernization include increasing the number of shops, production lines, workers, machines, and so on. At the same time, the technology of production remains obsolete; new innovations are not implemented into a production process. Intensive ways of modernization include the improvement of the technological process through the introduction of modern technologies and methods of work, changes in the structure of the production enterprise [451].

In the practice of the TM of production development exist several methodological approaches to determine the required level of the TM modernization [454] - [457]. The most prevalent methods, which relay on the economic capabilities of the enterprise, are: based on known analogues or based on an available budget dedicated to modernization. In fact, the level of modernization should be determined based on the tasks inherent to the technical means, and the ability to effectively perform their own most important functions. Accordingly, the definition of the required level of modernization of TM 
should depend on the production potential of the enterprise and the ability of the enterprise to successfully perform its own task in the course of production activities.

\section{SUBSTANTIVE PROVISIONS}

The potential of production $\Pi$ of an enterprise is determined by a number

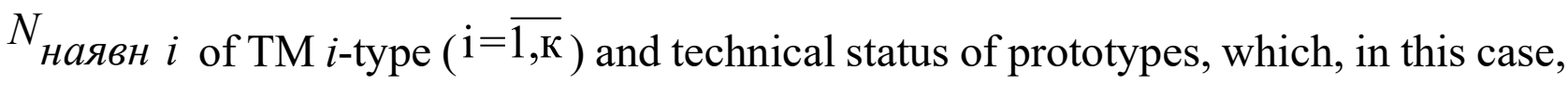
will be characterized by indicators of the technical level of TM of the enterprise, which to some extent depend in addition on their technical characteristics (TCh). The level of production capacity $\theta^{B U M}$ of an enterprise, associated with production potential through expression:

$$
\Pi_{O}^{B u M}=\Pi_{O} \cdot\left(\theta^{\text {Buм }}+\beta_{O} \cdot T\right)
$$

or

$$
\frac{\Pi_{O}^{\text {Buм }}}{\Pi_{O}}=\theta^{\text {Buм }}+\beta_{O} \cdot T \square \frac{N_{O}^{B u м}}{N_{o}},
$$

where $\theta^{\text {BuM }}$ :

$$
\theta^{\text {Buм }}=\frac{\Pi_{O}^{\text {Buм }}}{\Pi_{O}}-\beta_{O} \cdot T
$$

The initial value of the production potential $\Pi_{o i}$ is calculated as follows:

$$
\Pi_{\text {oi }}=N_{\text {наявн } i} K_{e i} K_{\mathrm{Tp} i}
$$

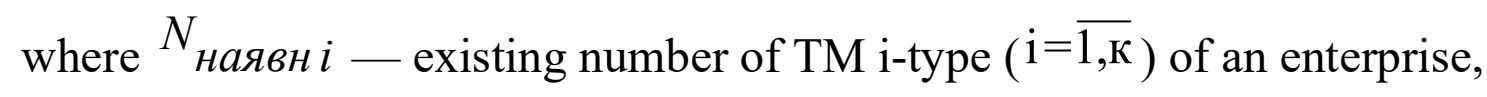
$K_{e i}$ - generalized operating factor of TM i-type of an enterprise:

$$
K_{e i}=K_{y \kappa i} \cdot K_{\text {тГ } i} \cdot K_{p e c} i
$$

In expression (5) ${ }^{K}{ }_{\text {pec }} i$ - resource stock ratio of TMT3 i-type of an enterprise,

$$
K_{\text {pec } i}=\frac{\sum_{\mathrm{s}=1}^{n} N_{i s} \cdot R_{i s}}{N_{\text {наявн } i}},
$$


where $N_{i s}$ - the number of TM of the i-type with the resource reserve factor $R_{i s \text { from existing }} N_{\text {наявн } i \text {; }}$

coefficient of technical readiness of TM of the i- type of the enterprise:

$$
K_{\mathrm{T \Gamma} i}=\frac{N_{\text {тГ } i}}{N_{\text {наявн } i}}
$$

$N_{\text {TГ } i}$ - the number of technically ready TM of the i- type;

$K_{y \kappa} i$ - the coefficient of staffing of the enterprise of the TM of the i-type

$$
K_{y \kappa i}=\frac{N_{\text {наявн } i}}{N_{\text {шт } i}}
$$

If $K_{y \kappa i}=1$, this means that the company has a 100 percent staffing of TM of the i- type.

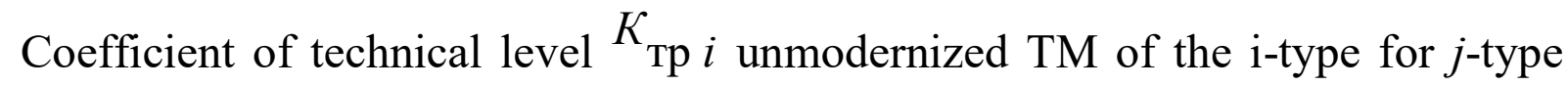
TCh $(\mathrm{j}=\overline{1, \mathrm{n}})$, of one or another, $z$-type, group $(\mathrm{z}=\overline{1, \mathrm{~m}})$ TCh given TM i-type in anticipation of modernization TCh given TM by comparing this characteristic with the corresponding characteristic TM, approved as standard E (for example, the best in the World):

$$
K_{\mathrm{Tp} j z i}=\frac{A_{j z i}}{A_{j z E}},
$$

where ${ }^{A} z i$ - numerical value $j$-type TCh of $z$-type group TCh TM $i$-type;

$A_{j z E}$ - numerical value of similar $j$-type TCh of $z$-type group TCh of standard TM.

Coefficient of technical level $K_{\text {Tp } z i}$ of all j-types $(\mathrm{j}=\overline{1, \mathrm{n}})$ TCh of $z$-type group of TCh of TM $i$-type is equal to:

$$
K_{\text {тр } z i}=K_{\text {тр } 1 i}=\sum_{\mathrm{j}=1}^{\mathrm{n}} K_{\operatorname{Tp} j 1 i} \cdot M_{j 1 i}=\sum_{\mathrm{j}=1}^{\mathrm{n}} \frac{A_{j 1 i}}{A_{j 1 E}} \cdot M_{j 1 i},
$$


wher ${ }^{M} j z i$ - coefficient of importance $j$-type $(\mathrm{j}=\overline{1, \mathrm{n}})$ TCh of $z$-type group TCh of TM of $i$-type, which is determined by an expert survey, in this case $\sum_{\mathrm{j}=1}^{\mathrm{n}} M_{j z i}=1$.

Thus, to ensure a given coefficient $\theta^{B u M}$ production capacity of the enterprise requires the value of potential $\Pi_{O}^{B u M}$ it is necessary to compare with the existing potential $\Pi_{O}$ of this enterprise before the beginning of a cycle of production activity in the conditions of average daily for the period $T$ relative losses $\beta_{O}$ TM of an enterprise.

In the future, it is assumed that the technical level of all TM of an enterprise with non-modernized TCh characterized by a generalized coefficient of technical level $K_{\mathrm{Tp}}$, which is defined as follows:

$$
K_{\mathrm{Tp}}=\frac{\sum_{\mathrm{i}=1}^{\mathrm{K}} K_{\mathrm{Tp}} i \cdot N_{\text {наявн } i}}{\sum_{\mathrm{i}=1}^{\mathrm{K}} N_{\text {наявн } i}}=\frac{\sum_{\mathrm{i}=1}^{\mathrm{K}} K_{\mathrm{Tp}} i \cdot N_{\text {наявн } i}}{N_{\text {наявн }}},
$$

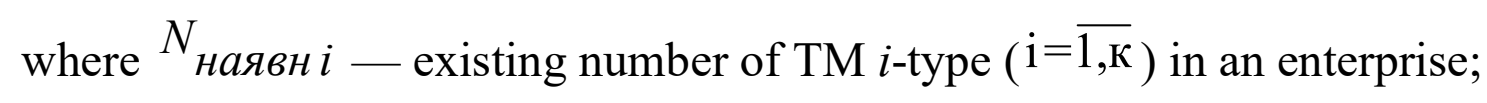

$N_{\text {наявн }}=\sum_{\mathrm{i}=1}^{\mathrm{K}} N_{\text {наявні }}$ - the total number of non-modernized TM of the enterprise, which consists of the number $N_{\text {наявн } i \text { TM } i \text {-type, some TCh which could }}$ be upgraded;

$K_{\mathrm{Tp}} i-$ coefficient of technical level of non-modernized TM of the i- type.

Even with the same amount $N_{\text {наявн } i \text { TMs of } i \text {-type the production potential of an }}$ enterprise will depend on the coefficient of the technical level $K_{\mathrm{Tp}}$ all its TMs, in particular, from the coefficient of the technical level $K_{\text {тр } i}$ ТМ of $i$-type. In turn, the

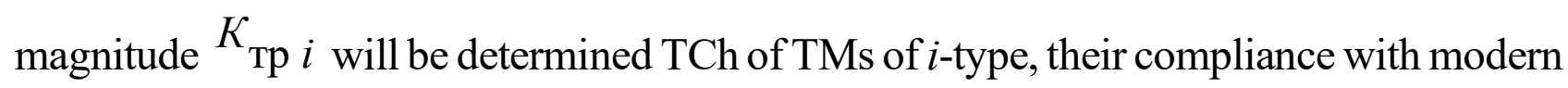
requirements, the degree of moral aging, which may necessitate the modernization of these TMs. 
The TMs modernization is performed by improving the technical characteristics. However, of course, not all TChs should improve, but only certain that can bring the greatest effect. Choosing the right set of characteristics is almost a separate task, as technical means can be characterized by a large number of TChs. Usually, a small amount (not more than 10) of TChs is selected for modernization, which characterizes the most important properties of the TMs, based on the planned (typical) method of TMs application. For example, a forklift truck is designed for truck work, but it is often used for short-distance transportation. When studying the effectiveness of each of these tasks, the appropriate list of TChs is selected.

In addition, to reduce the number of TChs, the full list of TChs can be divided into groups in quantity $\mathrm{m}(\mathrm{z}=\overline{1, \mathrm{~m}})$, based on the properties and functional purposes of the TM. Thus, for a forklift truck, the following groups can be considered separately $(\mathrm{z}=\overline{1, \mathrm{~m}}=1 \div 3)$ :

$\mathrm{z}=1$ - means of mobility;

$\mathrm{z}=2$ - means of loading;

$\mathrm{z}=3$ - means of transportation.

In each such group there may be several (for example, 5-6) the most significant TCh of the technical means.

We assume that each j-th TCh from the z-type group of TCh of the i- type has a numerical value ${ }^{A} j z i$ (measured in absolute units), and a similar j-type TCh with z-type group TCh of technical means of the i-type, which is conventionally taken as a standard, has a numerical value ${ }^{A} j z E$.

Then the coefficient of the technical leve $1 K_{\text {Tp } j z i}$ can be calculated according to the $\mathrm{j}$-type TCh $(\mathrm{j}=\overline{1, \mathrm{n}}) A_{j} z i$ from one or another, $\mathrm{z}$-type, group $(\mathrm{z}=\overline{1, \mathrm{~m}})$ TCh of a certain unmodernized TM of the i- type by comparing this characteristic with the corresponding characteristic ${ }_{j z} E$ of the TK taken as standard E:

$$
K_{\text {тр } j z i}=\frac{A_{j z i}}{A_{j z E}} .
$$


If we enter into consideration the coefficient of importance ${ }^{M} j i$ of the j-type $(\mathrm{j}=\overline{1, \mathrm{n}})$ of technical characteristic ${ }_{j} z i$ in relation to the selected TCh of the z-type group $(\mathrm{z}=\overline{1, \mathrm{~m}})$ of the TCh unmodernized TM of the $\mathrm{i}$ - type $(\mathrm{i}=\overline{1, \mathrm{~K}})$, which is determined by experience or expert survey, with $\sum_{\mathrm{j}=1}^{\mathrm{n}} M_{j z i}=1$, then for all $\mathrm{j}$-type $(\mathrm{j}=\overline{1, \mathrm{n}})$ TCh from the z-type group of technical characteristics of this TM, the coefficient of the technical level $K_{\mathrm{Tp} z} i$ will be equal to:

$$
K_{\text {тр } z i}=\sum_{\mathrm{j}=1}^{\mathrm{n}} K_{\mathrm{Tp}} z_{z i} \cdot M_{j z i}=\sum_{\mathrm{j}=1}^{\mathrm{n}} \frac{A_{j z i}}{A_{j z E}} \cdot M_{j z i}
$$

Note that the relationship $\frac{A_{j z i}}{A_{j z E}}$, taking into account the importance $M_{j z i \text { can be }}$ considered as conditional efficiency ${ }^{W} j i$ (due only to the characteristics of the TM of the i- type, which are selected for future modernization)

$$
W_{j z i}=K_{\mathrm{Tp} j z i} \cdot M_{j z i}=\frac{A_{j z i}}{A_{j z E}} \cdot M_{j z i}
$$

$j$-type TCh ${ }^{A} j z i$ of $z$-type group TCh of TM of the $i$-type relatively similar characteristics $A_{j z E}$ of standard TM, therefore it can be written as follows:

$$
K_{\text {тр } z i}=\sum_{\mathrm{j}=1}^{\mathrm{n}} K_{\mathrm{Tp}} j z i \cdot M_{j z i}=\sum_{\mathrm{j}=1}^{\mathrm{n}} \frac{A_{j z i}}{A_{j z E}} \cdot M_{j z i}=\sum_{\mathrm{j}=1}^{\mathrm{n}} W_{j z i} .
$$

It is possible to determine the importance of expert surveys $G_{z i}$ of selected $z$-type group from all $m$ groups of characteristics $(\mathrm{z}=\overline{1, \mathrm{~m}})$ of TM of the i-type, at the same time $\sum_{\mathrm{z}=1}^{\mathrm{m}} G_{z i}=1$.

Then the coefficient of the technical level $K_{\text {тр } i \text { for all z-type groups of TCh }}$ $(\mathrm{z}=\overline{1, \mathrm{~m}})$ of unmodernized TM of the i-type, calculated relative to the standard TM, will be equal to: 


$$
\begin{aligned}
& K_{\mathrm{Tp} i}=\sum_{\mathrm{z}=1}^{\mathrm{m}} K_{\mathrm{Tp} z i} \cdot G_{z i}=\sum_{\mathrm{z}=1}^{\mathrm{m}}\left(\sum_{\mathrm{j}=1}^{\mathrm{n}} K_{\mathrm{Tp}} j z i \cdot M_{j z i}\right) \cdot G_{z i}= \\
& =\sum_{\mathrm{z}=1}^{\mathrm{m}}\left(\sum_{\mathrm{j}=1}^{\mathrm{n}} \frac{A_{j z i}}{A_{j z E}} \cdot M_{j z i}\right) \cdot G_{z i}=\sum_{\mathrm{z}=1}^{\mathrm{m}} \sum_{\mathrm{j}=1}^{\mathrm{n}} W_{j z i} \cdot G_{z i}
\end{aligned}
$$

Thus, the coefficient of the technical level ${ }^{K}$ тр $i$ of every TM $i$ type is determined only by those selected to upgrade his TCh from all $z$ group $(z=\overline{1, m})$ given the importance of ${ }^{M}$ zi $j \mathrm{TCh}(\mathrm{j}=\overline{1, \mathrm{n}})$.

Similarly, the coefficient of the technical level can be determined $K_{\text {тр } i E \text { for all }}$ $\mathrm{z}$ groups of TCh $(\mathrm{z}=\overline{1, \mathrm{~m}})$ reference TM of the $\mathrm{i}$ type. But in this case, in relation to such vehicles can be considered, that ${ }_{j z i}={ }_{j z E}$. Then, taking into account the previously accepted values $M_{j z i}\left(\sum_{\mathrm{j}=1}^{\mathrm{n}} M_{j z i}=1\right), G_{z i}\left(\sum_{\mathrm{z}=1}^{\mathrm{m}} G_{z i}=1\right)$ it follows that

$$
K_{\text {тр } i E}=1 \text {, }
$$

that in the accepted conditions naturally.

For TM of all types $(i=\overline{1, K})$ the enterprise is determined by the generalized coefficient of the technical level of $K_{\mathrm{Tp}}$ unmodernized TM of all types, calculated relative to the reference $\mathrm{TM}$, considering:

$$
\begin{aligned}
& K_{\text {тр }}=\frac{\sum_{\mathrm{i}=1}^{\mathrm{K}} K_{\text {тр } i} \cdot N_{\text {наявн } i}}{\sum_{\mathrm{i}=1}^{\mathrm{K}} N_{\text {наявн }} i}=\frac{\sum_{\mathrm{i}=1}^{\mathrm{K}} N_{\text {наявн }} i \cdot \sum_{\mathrm{z}=1}^{\mathrm{m}} K_{\mathrm{Tp} z i} \cdot G_{z i}}{\sum_{\mathrm{i}=1}^{\mathrm{K}} N_{\text {наявн }} i}= \\
& =\frac{\sum_{\mathrm{i}=1}^{\mathrm{K}} N_{\text {наявн }} i \cdot \sum_{\mathrm{z}=1}^{\mathrm{m}}\left(\sum_{\mathrm{j}=1}^{\mathrm{n}} K_{\mathrm{Tp} j z i} \cdot M_{j z i}\right) \cdot G_{z i}}{\sum_{\mathrm{i}=1}^{\mathrm{K}} N_{\text {наявн } i}}= \\
& =\frac{\sum_{\mathrm{i}=1}^{\mathrm{K}} N_{\text {наявн }} i \cdot \sum_{\mathrm{z}=1}^{\mathrm{m}}\left(\sum_{\mathrm{j}=1}^{\mathrm{n}} \frac{A_{j z i}}{A_{j z E}} \cdot M_{j z i}\right) \cdot G_{z i}}{\sum_{\mathrm{i}=1}^{\mathrm{K}} N_{\text {наявн } i}}= \\
& =\frac{\sum_{\mathrm{i}=1}^{\mathrm{K}} N_{\text {наявн }} i \cdot \sum_{\mathrm{z}=1}^{\mathrm{m}} \sum_{\mathrm{j}=1}^{\mathrm{n}} W_{j z i} \cdot G_{z i}}{\sum_{\mathrm{i}=1}^{\mathrm{K}} N_{\text {наявн }} i}=\frac{\sum_{\mathrm{i}=1}^{\mathrm{K}} N_{\text {наявн }} i \cdot \sum_{\mathrm{z}=1}^{\mathrm{m}} \sum_{\mathrm{j}=1}^{\mathrm{n}} W_{j z i} \cdot G_{z i}}{N_{\text {наявн }}} .
\end{aligned}
$$


In this case, the coefficient of the technical level $K_{\mathrm{Tp}} \mathrm{TM}$ of all types and potential of the enterprise depends not only on TCh, but also from the available quantity of TM.

Similarly, the coefficient of the technical level is determined $K_{\mathrm{Tp}} i E$ reference TM of all types $(i=\overline{1, K})$ for all $\mathrm{z}$ groups of TCh $(\mathrm{z}=\overline{1, \mathrm{~m}})$ of enterprises, but taking into account:

$$
K_{\mathrm{Tp} E}=\frac{\sum_{\mathrm{i}=1}^{\mathrm{K}} N_{\text {наявн } i} \cdot K_{\mathrm{Tp} i E}}{\sum_{\mathrm{i}=1}^{\mathrm{K}} N_{\text {наявн } i}}=\frac{\sum_{\mathrm{i}=1}^{\mathrm{K}} N_{\text {наявн }} i}{\sum_{\mathrm{i}=1}^{\mathrm{K}} N_{\text {наявн }} i}=1 \text {, }
$$

which is also natural.

\section{CONCLUSIONS}

The article proposes a method for determining the required level of modernization of technical means of production at the enterprise, which provides an opportunity to formulate requirements for technical characteristics of means of production when equipping the enterprise with means of production. Among the advantages of the method is that, first, with its use it becomes possible to take into account the probable type of promising technical means of production equipment of the enterprise; secondly, the accuracy of the method allows to obtain correct forecast terms of TM replacement. 
DOI 10.46299/ISG.2021.MONO.ECON.II-437-444

\subsection{Theoretical and methodological aspects of research and development of the enterprise management system}

The current stage of development of Ukraine's economy requires a systematic approach to personnel management in industrial enterprises. Under the personnel management system is understood the multi-vector activity of the relevant personnel management services of the enterprise, which cover a number of functional subsystems of the production organization.

The personnel management system consists of six subsystems: subsystems of personnel management, subsystems of personnel marketing, subsystems of personnel development, subsystems of motivation of personnel, subsystems of management of communications, subsystems of creation and development of corporate culture. Depending on the size of the organization, the composition of the subsystem varies: in small and medium enterprises in one subsystem include the functions of several subsystems, and in large - the functions of each subsystem are performed by separate units. The combination of these subsystems is unique to each organization and determines its specificity.

Generalization of the experience of Ukrainian industrial enterprises (PJSC "Dnipro Metallurgical Plant", PJSC "Interpipe", PJSC "Evraz DMZ named after Petrovsky", etc.) allows to form the main goal of the personnel management system: ensuring the needs of the production process by employees of the required quality their effective use, professional and social development (Fig. 9.3.1).

This goal reflects the economic aspect of personnel management. In the social aspect, the purpose of personnel management is to meet the needs of employees. 


\section{Level 1 goals}

ensuring the needs of the production process by employees of the required quality, quantity and in a timely manner, the organization of their effective use, professional and social development

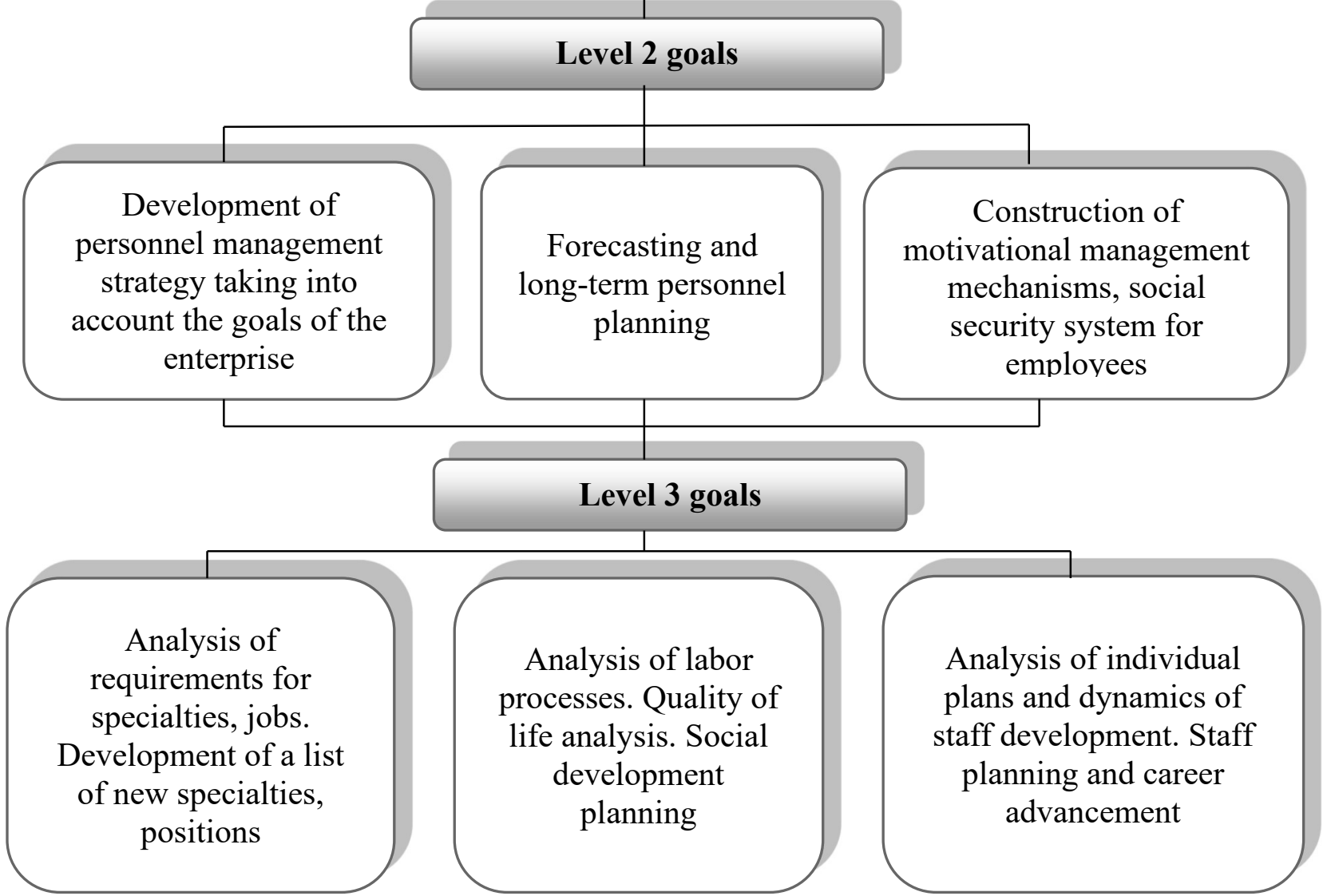

Figure 9.3.1. Tree of goals of the personnel management system of an industrial enterprise

Developed by the author based on sources [458-461]

The modern management of the enterprise is characterized by an adequate response to changes in market conditions, the development of new markets, areas of business. Therefore, research and development of personnel management system should take place through the use of sound principles, research methods, changes in management approaches, the choice of new forms and methods of implementing personnel policy, and so on.

The methodology of research of personnel management systems consists of theoretical provisions, principles, methods that most accurately reflect the features of 
this system. Knowledge of methodology is necessary for successful research and reliable results, which are the basis for the design, construction, organization and improvement of management systems.

In accordance with the objectives of the personnel management system is formed, and as a basis for its construction are used principles, ie rules and methods developed by science and tested in practice.

The principles of the study, being the most important category of methodology, are the basic rules, basis for action, essence and starting points used in the study.

Ignoring the principles of the study leads to unpredictability of results, errors and loss of time. As a result of the analysis of scientific and theoretical sources concerning management systems [462] the basic principles of research of a personnel management system are underlined and shown in fig. 9.3.2.

The principle of systematization

study of personnet management systems as a single, holistic phenomenon that is part of the system of the organization (enterprise) and consists of subsystems, elements and connections

The principle, of obiectivity
research of personnel management systems should be carried out on the basis of scientific correctness and conformity of reality, justice and impartiality, selection of executors of necessary qualification

The nrincinle of science

research is conducted on the basis of modern achievements of science and practice taking into account modern approaches and methods, laws and laws of management of cognitive processes

The principle of functionality

compliance with market relations, features and levels of management

The principle of economic feasibility

research should be cost-effective and increase the efficiency of the personnel management system

The principle of consistency

ensures consistency between the various parts of the management system and with the main goals, objectives, strategy and tactics of the organization, its functioning

The principle of optimality

multivariate elaboration of proposals and selection of the most rational variant of research

Figure 9.3.2. Principles of research of the personnel management system

Developed by the author based on sources [458-461] 
The principles of research of personnel management systems are interconnected, complementary and together constitute a certain system of rules that determine the reliability of research results.

The study of personnel management systems always has a goal, which is divided into sub-goals and objectives. Depending on the goal and objectives of the study are divided into theoretical, empirical and applied. In essence and the need for research aimed at planning, construction, strengthening, development, improvement and operation of personnel management system.

It should be noted that the method of diagnostics of the control system, as well as any other system, should be performed in stages.

The main stages of diagnostics of the personnel management system are shown in Fig. 9.3.3.

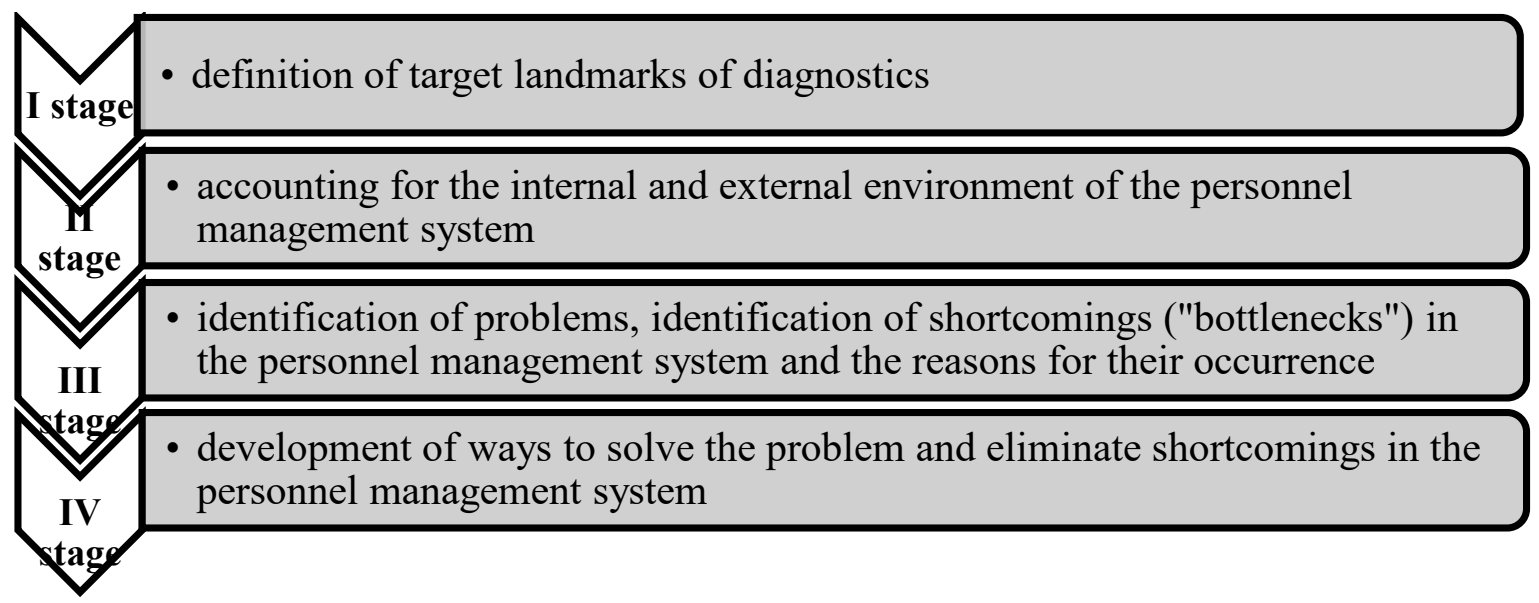

Figure 9.3.3. The main stages of diagnostics of the personnel management system Developed by the author based on sources [464]

I stage "Definition of target landmarks of diagnostics". This stage involves the establishment of goals and objectives that the company should focus on when diagnosing the personnel management system and developing measures to improve the situation.

Stage II "Accounting for the internal and external environment of the personnel management system" involves the analysis of the actual personnel management system and compare it with the desired results. In the course work in the study of personnel 
management system will be used such methods as: express questionnaire; survey of managers; study of documentation; analysis of the external and internal environment of the enterprise. Stage II is the basis for the implementation of stage III "Identification of problems, identification of shortcomings ("bottlenecks") in the personnel management system and the reasons for their occurrence." This stage makes it possible to determine the needs of the personnel management system and set priorities for this process.

Stage IV "Development of ways to solve the problem and eliminate shortcomings in the personnel management system" involves determining the methods and forms of development of the personnel management system that most effectively meet the needs of the enterprise.

When implementing the IV stage of diagnostics of personnel management system, it should be borne in mind that in the modern period of operation of industrial enterprises there is a gradual change of the classical approach to personnel management and the creation of a modern approach to personnel management based on humanistic approach. Comparative characteristics of the classical and modern approach to management are presented in table 9.3.1.

The implementation of such changes in the personnel management system is based on changes in three main important characteristics and functions of personnel policy, which together constitute a new concept of transformation and ensure its competitiveness - changes in staff motivation, development and corporate culture.

These three components (corporate culture, training and development of personnel and their motivation), along with finding ways to improve efficiency, can be considered as the main areas of improvement, development of personnel management. 
Table 9.3.1

Comparison of classical and modern approaches to management

personnel according to the concept of V.R. Vesnina

\begin{tabular}{|c|c|c|}
\hline $\begin{array}{l}\text { The name of the } \\
\text { criterion }\end{array}$ & The classic approach & Modern (humanistic) approach \\
\hline Management style & Authoritarian & $\begin{array}{c}\text { Democratic, welcome initiative, staff } \\
\text { involvement in the personnel management } \\
\text { process }\end{array}$ \\
\hline Personnel & $\begin{array}{l}\text { As a factor of } \\
\text { production }\end{array}$ & As a value, a factor of success \\
\hline Object of management & Staff & Resources, capital, staff \\
\hline $\begin{array}{l}\text { Costs for attracting staff } \\
\text { training, solving social } \\
\text { issues }\end{array}$ & $\begin{array}{l}\text { Minimum; are } \\
\text { considered as "extra" } \\
\text { costs }\end{array}$ & $\begin{array}{l}\text { Maximum; a significant part of the costs is } \\
\text { aimed at the organization of medical care, } \\
\text { creating conditions for recreation, meeting } \\
\text { the needs and development of employees; } \\
\text { costs are considered as investments in the } \\
\text { main source of further income }\end{array}$ \\
\hline Stimulation & Material & $\begin{array}{c}\text { Active application of conditional-intangible } \\
\text { and intangible methods }\end{array}$ \\
\hline $\begin{array}{l}\text { Form of labor } \\
\text { organization }\end{array}$ & Individual & Collective - team work, group \\
\hline $\begin{array}{l}\text { Department in the } \\
\text { structure of the } \\
\text { enterprise dealing with } \\
\text { personnel }\end{array}$ & $\begin{array}{l}\text { Human Resources } \\
\text { Department }\end{array}$ & $\begin{array}{l}\text { Personnel department, social services, } \\
\text { psychologists, coaches, HR managers, all } \\
\text { heads of structural departments subordinate } \\
\text { to the head of the senior staff responsible } \\
\text { for personnel }\end{array}$ \\
\hline \multirow[t]{2}{*}{$\begin{array}{l}\text { The main task of the } \\
\text { personnel department }\end{array}$} & $\begin{array}{l}\text { Ensuring the } \\
\text { availability of } \\
\text { personnel in the } \\
\text { required number, }\end{array}$ & $\begin{array}{l}\text { Ensuring the competitiveness of the } \\
\text { enterprise, its long-term stable development } \\
\text { by }\end{array}$ \\
\hline & $\begin{array}{l}\text { required qualifications } \\
\text { according to the } \\
\text { staffing schedule }\end{array}$ & $\begin{array}{l}\text { regulation of relations between the } \\
\text { production organization and personnel } \\
\text { within the strategy of the enterprise }\end{array}$ \\
\hline
\end{tabular}

Developed by the author based on sources [464, 467-469] 
There are many vectors for the development of this system. All of them are aimed at improving the efficiency of the personnel management system and consist in the implementation of external and internal changes.

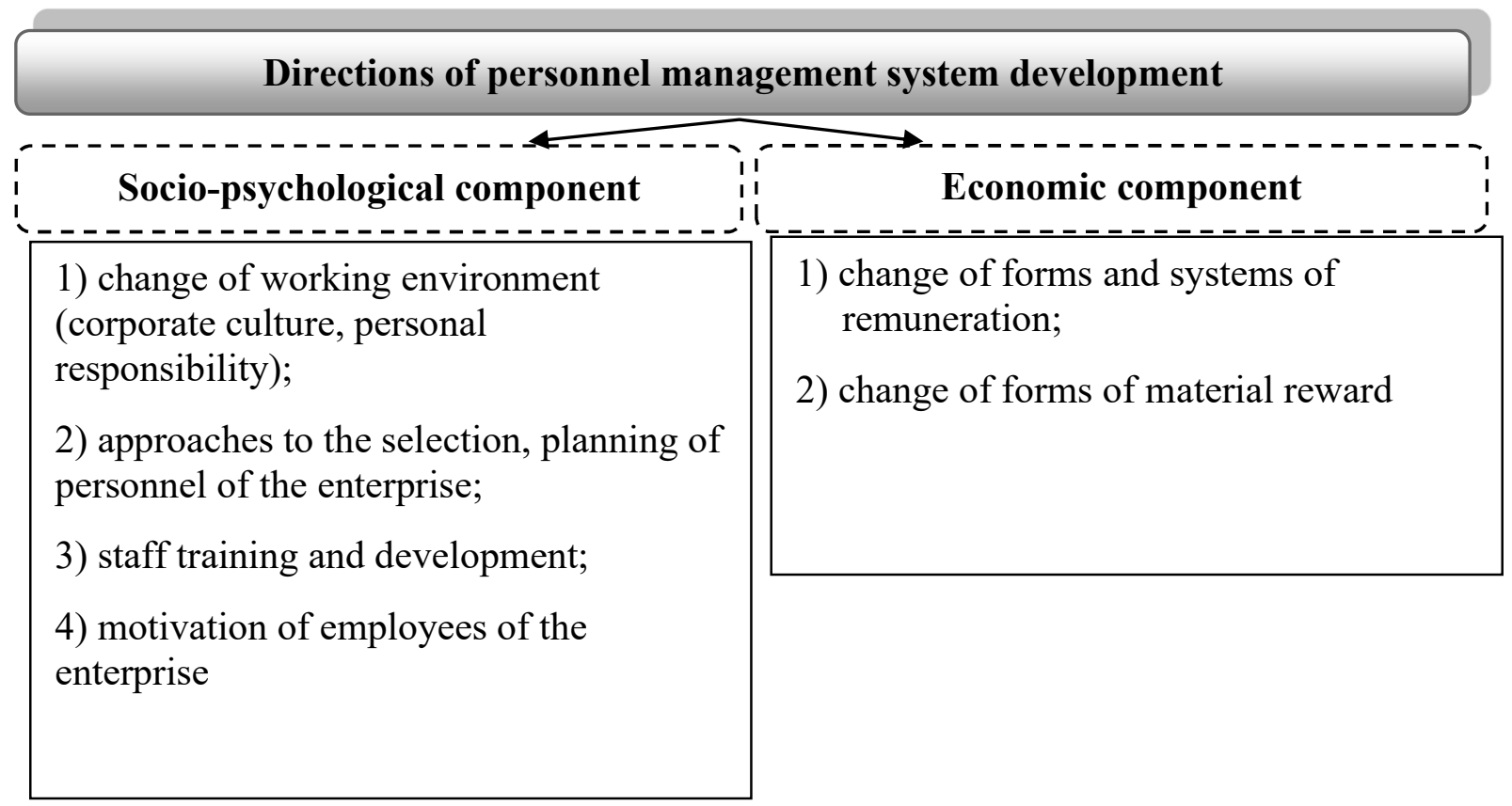

Figure 9.3.5. Directions of development of the personnel management system Developed by the author based on sources [458, 459, 465-469]

External changes include the use of new management systems, a combination of personnel and competitive enterprise development strategy, and so on. Internal changes of the personnel management system - creation of the corresponding corporate culture at the enterprise, training and development of the personnel, increase of its motivation, etc. 
DOI 10.46299/ISG.2021.MONO.ECON.II-445-452

\section{4 Маркетинг в публічному управлінні: стратегія національного бренду}

Глобалізація світової економіки, збільшення міжнародної конкуренції, активізація інноваційних процесів, вимагають нових підходів до розвитку процесів взаємодії маркетингу та публічного управління.

Взаємодія маркетингу та публічного управління має прояв в розвитку маркетингу як управлінської діяльності, концепції та науково-освітнього напряму. Маркетинг сьогодні в розвинених країнах трактується не лише як концепція маркетингу, яка застосовується в сфері публічного управління 3 певним набором притаманних ій специфічних інструментів і технологій, а i осмислюється як філософія публічного управління, творча управлінська діяльність, концептуальний підхід до розроблення загальних орієнтирів і цінностей суспільства. У сучасному науковому дискурсі з питань розвитку маркетингу прийнято виокремлювати два шляхи взаємопроникнення маркетингу та публічного управління. Перший полягає у «дифузії» публічного управління в маркетингові технології. Другий, який відбувається паралельно в історичному контексті, формує практику поступового проникнення маркетингового підходу в практику публічного управління [470].

Зауважимо, що використання технологій маркетингу в публічному управлінні у більшості країн відбувалось саме через комунікації (рекламу, паблік рилейшнз, пропаганду тощо). У кожній країні, в кожний історичний період вони були агресивні чи завуальовані, жорсткі чи гнучкі. Уряди країн застосовували такий інструментарій, який дозволяв швидко та безпомилково досягати чітко визначених цілей - від відвертої пропаганди до використання технологій нейролінгвістичного програмування.

Сьогодні майже всі уряди, публічні діячі, громадськість усвідомлюють необхідність корегування сприйняття, становлення і розвитку бренду країни, вважаючи, що цей процес слід починати зі зміни ставлення самих громадян до своєї країни. 
Так, на жаль, міжнародна спільнота сприймає Україну як країну, де ідуть бойові дії, панує корупція, влада олігархів і відбуваються політичні скандали.

В цій ситуації, просування національних інтересів і бренду “Україна" - це стратегічні інвестиції в наше майбутнє. Успіх економічного зростання та динамічний розвиток відносин з іншими державами багато в чому залежить від того, як буде сформований і як буде просуватися на внутрішньому та світовому ринках бренд країни.

Створення позитивного іміджу країни, розвиток національного бренду, стратегічне позиціонування його на міжнародній арені має стати невід’ємною складовою публічної політики в Україні.

Концепція національного брендингу з'явилась безпосередньо на основі розвитку бізнес брендингу. Саймон Анхольт визначає брендинг країни як систематичний процес узгодження дій, поведінки, інвестицій, інновацій i комунікацій країни для реалізації стратегії конкурентної ідентичності. Бренд країни являє собою ту асоціативну модель, яку містить свідомість індивіда (як мешканця цієї країни, так і громадянина іншої) та до якої він апелює, почувши назву країни [471].

Теорія державного (національного) брендингу бере початок із визначення, аналізу та наукового осмислення чотирьох основних концептуальних категорій, а саме - країна походження, брендинг території, публічна дипломатія та національна ідентичність [472].

За визначення Всесвітньої організації туризму, бренд держави - це сукупність емоційних і раціональних уявлень, що є результатом зіставлення усіх ознак країни, власного досвіду й чуток, що впливають на створення певного образу про неї. Національний брендинг - імідж країни на міжнародній арені у політичному, економічному, культурному вимірах.

Незважаючи на наявність альтернативних підходів до дефініції брендингу, головна його ідея пов'язана 3 продукуванням стійких відмітних властивостей об’єкта або суб'єкта брендингу, а отже, прямо пов'язана з реалізацією стратегії диференціації на конкурентному ринку. Іншими словами, у випадку 
національного брендингу, вона пов'язана зі створенням та розвитком унікального, добре знаного на міжнародній арені національного бренду.

Якщо порівнювати бренд з іміджом, то перше поняття є більш стійким. Імідж держави - це змінна складова бренду, яка означає образ, на який намагаються впливати з метою зміни. Відповідно при згадуванні назви держави (бренду країни) відразу ж виникає цілий ланцюг асоціацій стосовно цієї країни, наприклад: обіцянки щодо очікуваної стабільності, безпеки, гостинності, привабливості для проживання та відпочинку; врахування накопиченого досвід; асоціювання з високим рівнем якості і цінності; провокування встановлення тривалих, що грунтуються на взаємній довірі, відносин; гарантування збільшення доходів країни. Дослідження підтверджують, що країни з сильними брендами здатні ефективніше будувати економічну вартість та експортувати власні продукти; залучати інвестиції, туристів і таланти; змінювати стереотипи і будувати власні конкурентні переваги, такі як: Японія - це високотехнологічний бренд, Франція - бренд країни високої моди та вишуканого смаку, Швейцарія світовий банк, міжнародний сейф, Австрія - країна вальсу, Данія - країна казки і Русалоньки.

Т. Нагорняк вважає, що актуальним для України стане національний брендинг країни через формування іміджу іï регіонів, який включатиме таку послідовність етапів:

• аудит бренду “Україна” та оцінка іміджу іiі регіонів;

- розробка програми формування іміджу регіонів та бренду

«Україна»;

- заходи впровадження програми іміджування регіонів та брендингу країни у межах власних кордонів та у світі [473].

В грунтовному досліджені [474], наразі виділяють сім етапів трансформації концепції брендингу:

1. (1860-1920 pp.) - ідентифікаційний брендинг, що сприяв визначенню продуктової категорії та позиціонуванню товарів та послуг з акцентом уваги на їх якості, складі, цінових характеристиках; 
2. (1920-1930 рр.) - брендинг вигод, що передбачав презентацію не тільки якостей, але і вигод від товару або послуги;

3. (1930-1960 pp.) - «символічний» брендинг, пов'язаний 3 персоналізацією та акцентуванням уваги на іміджі, життєвому стилі, цінностях особистості користувача/покупця;

4. (1960-1980 pp.) - брендинг «досвіду», який передбачає звернення до позитивного досвіду сприйняття та грунтується на технології мультисенсорного (звук, вигляд, смак, запах, тактильні відчуття, навіювання думок) формування та розвитку цього досвіду;

5. (1980-1990 рр.) - «соціальний» брендинг, що акцентував увагу на соціальних факторах, у т. ч. соціальній відповідальності;

6. (1990-2005рр.) - «тотальний» брендинг, який перетворюється 3 маркетингового інструменту в інструмент стратегічного управління та передбачає наявність інтегрованої системи фізичного, психологічного та соціального впливу;

7. (2005 р. - донині) - креативний багатогранний брендинг, що передбачає широке використання нейромаркетингових технологій у процесі брендингу та абсолютний необмежений доступ до застосування будь-яких інновацій та цифрових технологій для формування асоціативного сприйняття будь-якої сфери діяльності, будь-якого об'єкта чи системи з урахуванням еко-, соціо-, кібер- і т.п. пріоритетів у локальному, регіональному, національному, міжнародному або навіть глобальному просторі.

Державний бренд поширюється за допомогою логотипів, слоганів, через інформаційні кампанії, проте цього замало. Важливим є його сприйняття та постійна ретрансляція громадянами усіх верств суспільства.

Так, Саймон Анхольт пропонує поєднувати сили, які формують бренд будь-якої держави, а саме:

•багатство культурної та історичної спадщини;

•ефективність державного управління;

• інвестиційна перспективність країни; 
•якість експортованих товарів;

•населення країни (людський капітал);

•туризм (туристичний потенціал) [471].

Ще один британський дослідник В. Оллінс підкреслює, що в основі національного бренду повинна лежати ключова ідея, яка буде проектувати національні характеристики країни ефективним та привабливим способом. Ця ключова ідея повинна виконувати наступні завдання:

- $\quad$ вона повинна працювати на емоційному і раціональному рівнях, щоб апелювати як «до серця, так і до розуму людей»;

- $\quad$ ключова ідея повинна бути релевантна для всіх аудиторій бренду;

- ключова ідея повинна бути чітко сформульованою;

- $\quad$ ключова ідея повинна бути правдивою, щоб аудиторія визнавала їі як реалістичну [475].

В основі національного бренду можуть лежати ключові ідеї різної спрямованості. Щодо вектору спрямованості бренду держави існують два підходи:

- бренд держави розглядається як зовнішньоорієнтований феномен. Він $€$ носієм або провідником у зовнішній світ ідей, якою є конкретна країна;

- бренд держави є одночасно і внутрішньо- і зовнішньоорієнтованим феноменом.

Незалежно від того, яка ідея буде обрана, слід пам'ятати про те, що важливо цілеспрямовано і систематично просувати ï у світове співтовариство. Навіть одна подія, яка суперечить загальній концепції бренду, може призвести до руйнування цілісного образу країни. Саме тому процесу трансляції державного бренду завжди має передувати аналітична робота, яка дозволить зрозуміти, які уявлення про країну вже існують у світі, визначити основних носіїв даних уявлень та з'ясувати причини формування цих уявлень. Тому сьогодні домінує сприйняття бренду країни , як асоціативної моделі, образу, суми уявлень про країну у свідомості вітчизняних та іноземних споживачів (стейкхолдерів). Водночас, брендинг країни розглядають як процес, спрямований на реалізацію 
стратегії національної безпеки, посилення національної ідентичності, підтримки конкурентоспроможності країни шляхом комунікації зі стейкхолдерами.

Сьогодні існує два впливових міжнародних рейтингів брендів держав Nation Brand Index (Anholft GFK) та Country Brand Index (FutureBrand). Методологія їх складання відрізняється:

- Nation Brands Index розглядає шість критеріїв: туризм, експорт, люди, влада, культура та історична спадщина, інвестиції та імміграція;

- Рейтинг Country Brands Index використовує ієрархічну модель рішень, за допомогою якої бренд оцінюється у таких вимірах:

• обізнаність (чи відомо, що така країна існує),

•знайомство (як добре респондент знає про країну),

•асоціації (туризм, культурний спадок, якість життя, система цінностей),

•повага (наскільки країна викликає пошану),

• міркування (чи розглядалася країна як місце, яке варто відвідати),

• рішення про візит (що спонукає до його прийняття),

•бажання респондента переповідати про країну знайомим.

У процесі порівняння методологій можна визначити, так зване, ядро бренду держави, яке визначають як:

- систему держави: політична, економічна та управлінська.

- національний вимір: ментальність населення, культура та історична спадщина.

До атрибутів бренда можна віднести: назву, логотип, слоган, шрифти, кольори, звуковий ряд.

До основних етапів формування бренду держави відносять:

-визначення цілі та завдань державного брендингу;

-визначення цільової аудиторії та способів просування бренду;

-дослідження щодо існуючих стереотипів про країну у цільової аудиторії;

-визначення переваг, очікувань і вимог цільової аудиторії, оригінальні риси та позитивне сприйняття бренду держави; 
-розробка бренду держави;

-розробка стратегія просування бренду та відповідного плану дій, який, має на меті переведення розробленого макету бренду держави у реальні контексти (візуальний, вербальний, комунікативний);

-контроль за впровадженням програми державного брендингу;

-оцінка проміжних результатів;

-корегування у разі необхідності моделі й стратегії державного брендингу та моніторинг ефективності сформованого бренду держави.

У 2015 році Інститут світової політики провів дослідження щодо іміджу України. Дослідження проводилось у шести найбільших за кількістю населення країнах СС У ході дослідження було встановлено, із чим асоціюється Україна: у цілому в невеликих відсотках (від чотирьох і нижче) негативне сприйняття корелюється 3 позитивним. Серед негативних традиційно залишаються криза (загалом), Чорнобильська катастрофа, соціальна нестабільність, насильство, мігранти, корупція, політичні проблеми, вбивства, анархія, Волинська різня, голод, комунізм, страх, геноцид, економічна криза, падіння літака (Малайзійських авіаліній), анексія Криму тощо. Позитивним - дослідники вважають той факт, що, попри агресивну пропаганду Росії, асоціація України 3 фашизмом практично відсутня.

У 2016 році Brand Finance публікує щорічний звіт про вартість національних брендів світу. За результатами звіту Brand Finance Nation Brands 2016, США продовжують домінувати в рейтингу, збільшивши своє зростання на 4\%. У Японії зафіксовано значне зростання серед найбільших світових економік. Ïї брендова вартість зросла на 18\% внаслідок підвищення курсу національної валюти та зростання конкурентоспроможності робочої сили. Вартість національного бренду України, згідно зі звітом, у 2016 році збільшилась на 39\%. завдяки чому у цьому році він став третім серед тих брендів країни, які зростали найшвидше [476].

У звіті відзначається, що у 2016 році Україна продемонструвала відносну стабільність і користувалась меншою (негативною) увагою засобів масової 
інформації, незважаючи на те, що іiі економіка залишалась вразливою внаслідок подальшого протистояння 3 Росією [477]. При цьому, відзначається, що показники сили бренду для безпеки виросли на 18,2\%, разом з цим відбулось підвищення оцінки якості життя на $11.4 \%$, а також суттєве поліпшення здатності країни зберігати свій найталановитіший кадровий потенціал.

Таким чином, слід зазначити, що в основі публічної політики щодо формування національного бренду повинні лежати ключові ідеї різної спрямованості. Ці ідеї слід цілеспрямовано і систематично просувати у світове співтовариство. На сьогодні такими ідеями можуть бути політика інвестиційної привабливості України, прозорі правила ведення бізнесу і залучення капіталу, просування вітчизняного виробника під слоганом «Купуй Українське», розвиток туризму, розвиток міст «Львів зі смаком шоколаду», гірськолижний курорт «Буковель», участь у популярних музичних конкурсах : « Свробачення - 2021», де справжнім відкриттям і амбасадором українських співочих традицій був виступ гурту «GoA», великий резонанс отримала i нова форма українських футболістів на чемпіонаті Свро-2020 із зображенням мапи України з контурами анексованого Криму і тимчасово окупованих території та гаслом «Слава УкраїніГероям слава!». 
DOI 10.46299/ISG.2021.MONO.ECON.II-453-467

\section{5 Типологія шахрайства у банківській сфері: сутність, умови виникнення та розробка заходів боротьби}

Забезпечення фінансової безпеки банківської установи є актуальною проблемою сьогодення і має здійснюватися на основі розробленої стратегії. Адже низка численних загроз фінансовій безпеці банку як зовнішніх, так i внутрішніх посилює потребу у розробленні комплексного підходу до їх виявлення, аналізу та системної розробки заходів щодо їх запобігання. Тому, погоджуємося з автором [478], що першочерговим завданням є запровадження принципів Базель III, які базуються на принципах управління капіталом та його ліквідністю з метою підвищення стійкості банківського сектору, забезпечення стабільної бази та необхідних резервів з метою протистояти ризикам та кризам. Звідси, фінансова стратегія забезпечення фінансової безпеки банку - це комплекс заходів, які спрямовані на збільшення його вартості, забезпечення платоспроможності, ліквідності та стійкості, ефективної структури капіталу, найбільш прибуткових його вкладень та своєчасне виявлення $\mathrm{i}$ усунення можливих загроз. Метою стратегії $є$ збільшення вартості банку, його прибутковості та розширення позицій на ринку банківських послуг.

Стратегія забезпечення фінансової безпеки банку розробляється відповідно до нормативів НБУ та має узгоджуватися із загально стратегією і розроблятися на основі чинної нормативно-законодавчої бази [478].

Перш за все розглянемо сутність шахрайства 3 правової точки зору, яке згідно ст. 190 Кримінального кодексу України означає «заволодіння чужим майном або придбання права на майно шляхом обману чи зловживанням довірою» [479]. Шахрайство завжди містить прямий умисел на вчинення 
шахрайських дій та корисливі мотиви заподіяння. Крім ст.190 прописано відповідальність за шахрайство, як спосіб вчинення інших злочинів (рис. 9.5.1).

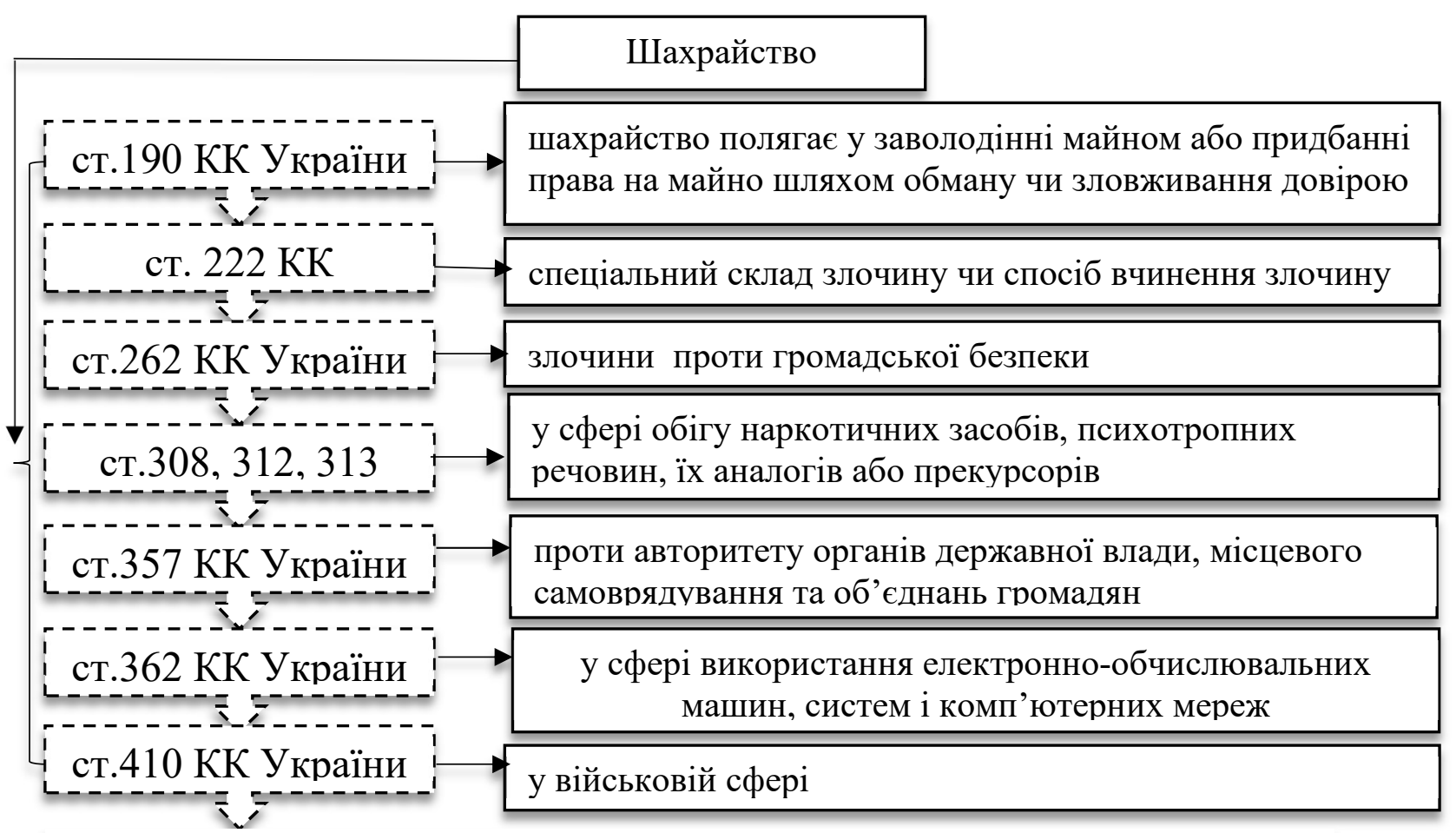

Рис. 9.5.1. Відповідальність за шахрайство

Якщо брати в загальному, то банківська система є однією з основних ланок фінансово-кредитної системи України і є об’єктом, яка приваблює шахраїв та злочинців, використовується платформою для відмивання коштів. Ці факти підривають авторитет банків, як фінансових посередників, що гарантують збереження та накопичення коштів клієнтів: населення, держави та суб’єктів господарювання.

У сучасному світі види та способи вчинення шахрайств змінюються. 3 розвитком новітніх технологій питання шахрайства особливо актуалізувалися. Сьогодні шахрайство проявляється у всіх сферах діяльності, проникає в різні організації та установи, однак особливо вразливою сферою виявився банківський сектор.

Автори [478] зазначають, що шахрайство у комерційному банку $\epsilon$ «сукупністю злочинних дій та маніпуляцій 3 метою заволодіння коштами комерційного банку або його клієнтів»; «Банківське шахрайство - це не 
ситуативний акт, а ретельно спланована та організована діяльність 3 чіткою метою отримати матеріальну вигоду. Фінансове шахрайство характеризується визначенням мети, повторенням дій, послідовністю здійснення та відтермінування прояву тощо» [478, с.104]. При цьому потрібно зазначити, що особливістю шахрайства є те, що власник чи особа, яка зберігає майно, кошти, цінності, добровільно передає їх зловмиснику, не усвідомлюючи наявного обману чи зловживання довірою. Найбільш актуальними, на нашу думку, є такі види шахрайства: зловживання вчинені 3 порушенням кредитування та банківських розрахунків (Г.Матусовський, О.Бушан); розкрадання, хабарі, інші суспільно-небезпечні посилання (В.Попович); поширення інформаційних технологій у банківській сфері (спрощення банківських операцій, поширення шахрайських дій), впровадження банківських карт; фальсифікація документів, використання фіктивних підприємств (О.Кришевич).

Загалом, сьогодні Україна стала плацдармом для вчинення різного виду шахрайств. Тому перш ніж працювати чи підписувати якісь документи потрібно чітко визначити з ким ми працюємо. Для цього потрібно отримати інформацію: про наявність ліцензій займатися певною діяльністю; про розміщення та офіси майбутніх партнерів чи посередників; повну інформацію про власника чи бенефіціара. Другим важливим моментом є те, що потрібно дізнатися - а що саме пропонують нам претенденти на співпрацю, а саме: які пропонуються відсотки та які надаються гарантії; чи виставляються додаткові умови по передоплаті або окремої плати за прискорення процедури вирішення питання; якщо пропонуються інвестиції в проєкти, то чи офіційно зареєстровані останні; чи не створюється фінансова піраміда; чи не поступають пропозиції залучати друзів та родичів тощо.

Стосовно специфіки банківського шахрайства погоджуємося з науковцями, що банк може виступати як жертвою в руках шахраїв, так і інструментом його вчинення [480, с.114]. Як жертвою банк може виступати, коли надаються кредити особам, які заздалегідь планують не віддавати їх; кредити по підроблених документах тощо. Однак це якщо працівники добросовісно 
перевірили позичальника і не виявили ознак підробки чи недоброчесності. Але наявними $є$ факти, коли недобросовісні працівники банку по домовленості 3 третіми особами за певну винагороду приймають сфальсифіковані документи і видають кредити, наносячи збитки банку. Крім того банки можуть слугувати інструментом «липових» переказів на рахунок фірми-постачальника до відвантаження товару (знову ж таки по домовленості осіб), а потім відкликання коштів, як помилково переведених; може банк співпрацювати з групами осіб, компаніями чи фірмами, які займаються відмиванням коштів.

Таким чином можна виокремити зовнішне та внутрішне шахрайство. Зовнішнє шахрайство за даними дослідження KPMG, «у 2018 році 61\% респондентів повідомили про зростання загальної кількості випадків зовнішнього шахрайства, а 59\% заявили про збільшення сум шахрайських операцій. У більшості випадків респонденти вважали, що середня сума кожної шахрайської операції не змінилася (21\%) або зменшилася (38\%). Це можна пояснити великою кількістю шахрайських операцій з картками, сума яких була незначною» [481].

Як зазначено у вищезгаданому дослідженні нова типологія шахрайських операцій (2015-2018рр.), містить як основу «крадіжку персональних даних та використання номера картки для шахрайства / шахрайство від імені принципала, кібератаки, шахрайство з безкартковими операціями та протиправні схеми» [481]. За результатами цього ж дослідження небезпечним для суб'єкта $\epsilon$ внутрішне шахрайство (з боку його працівників). Так, найбільша частка опитаних заявили, що загальна вартість, середня вартість та кількість випадків внутрішнього шахрайства у 2017 і 2018 роках лишилися незмінними або скоротилися. Однак ця інформація може не відображати повну картину впливу внутрішнього шахрайства на фінансову установу, оскільки велика кількість зовнішніх атак є результатом співпраці досвідчених злочинців 3 внутрішніми джерелами, які детально знають банківські системи, процеси та засоби контролю (а також недоліки та слабкі місця систем контролю). Потенційна шкода від шахрайства з боку інсайдерів може бути не меншою, якщо не більшою, за шкоду 
від зовнішнього шахрайства, враховуючи спроможність працівників використовувати слабкі місця засобів контролю з метою привласнення найбільш цінних активів банку. Банкам краще й надалі діяти на випередження 3 метою виявлення шахрайства з боку інсайдерів.

Можна виділити наступні способи шахрайства (рис. 9.5.2):

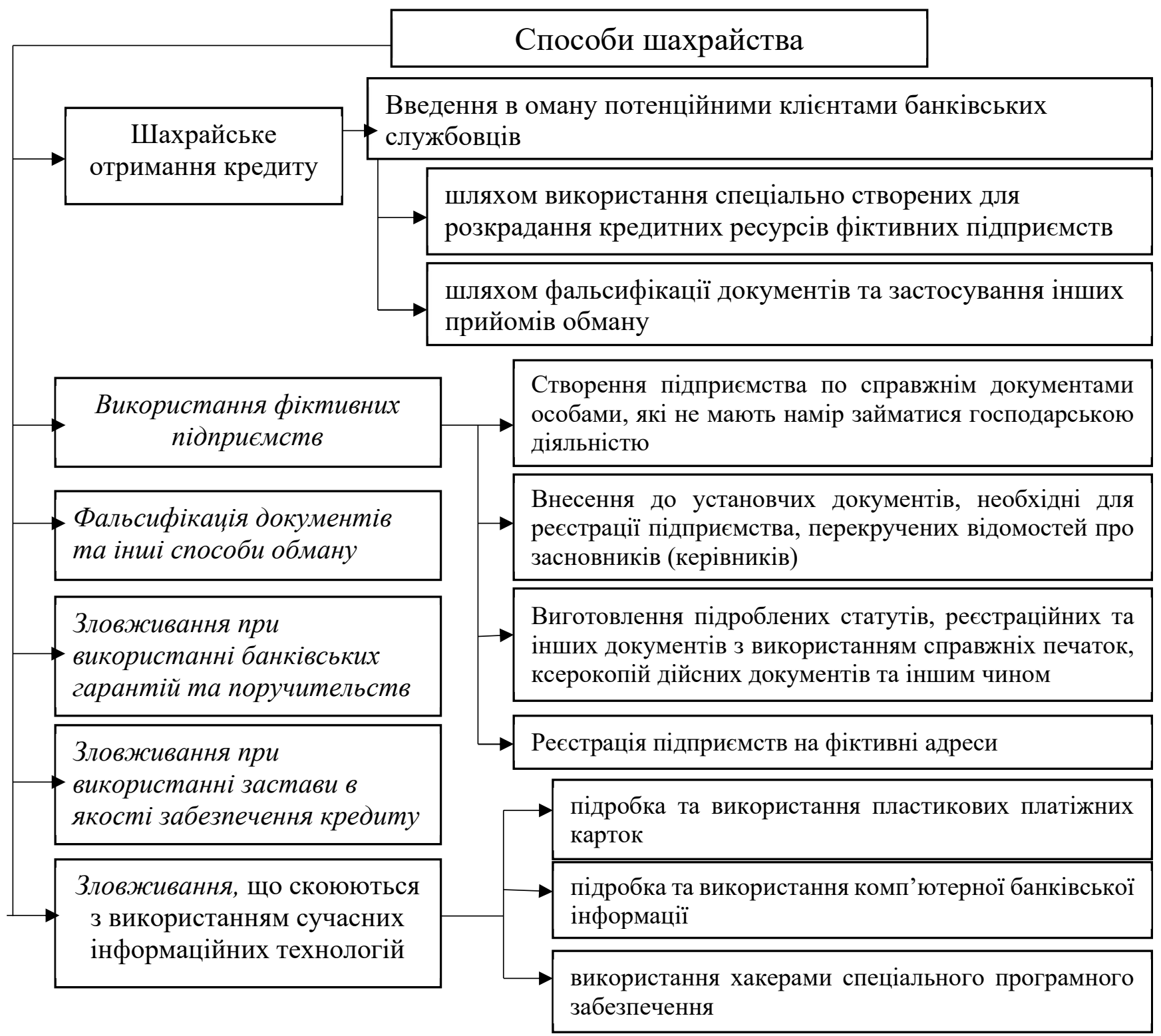

Рис. 9.5.2. Способи шахрайства

О.В. Кришевич виділяє основні чотири способи комп’ютерного шахрайства, a came:

(1) безпосереднє та електромагнітне перехоплення інформації; 
(2) крадіжки програмного забезпечення, крадіжки устаткування, неправомірне отримання кодів;

(3) маніпуляції з інформацією;

(4) несанкціонований доступ до інформації [480, С.591].

Зазвичай, кожна злочинна дія розпочинається 3 отримання контактної інформації, доступу зловмисників до ЕОМ, скачування інформації, зняття коштів та акумулювання їх на «липових рахунках фірм-одноденок» тощо. Такі злочини приховуються через відновлення програмного забезпечення і тому складні у виявленні.

В період 2016-2018 рр. ми спостерігаємо тенденцію зменшення кількості кримінальних злочинів загалом та економічних злочинів, зокрема. Так, експерти зазначають, що спад кількості зареєстрованих злочинів є свідченням зниження активності правоохоронців у цій сфері, а не прямого зменшення даного виду злочинності (рис. 9.5.3).

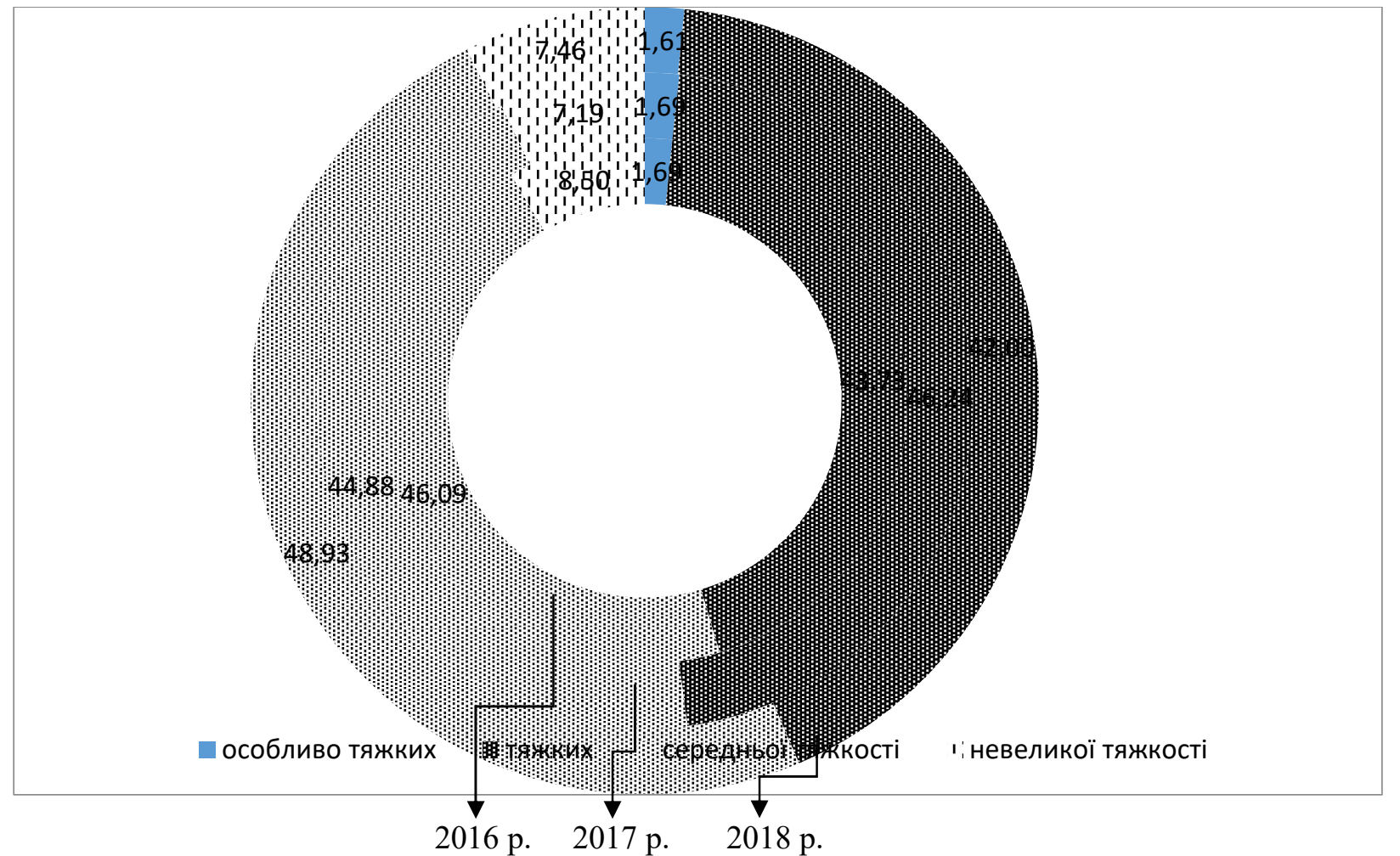

Рис. 9.5.3. Структура злочинів проти власності в Україні за 2016-2018 pp., \% від загальної кількості Складено за даними [482] 
Найбільшу частку в кримінальних злочинах займають злочини проти власності. Водночас, у загальній кількості злочинів найбільшу питома вагу займають тяжкі злочини та злочини середньої тяжкості (табл. 9.5.1).

Таблиця 9.5.1

Динаміка злочинів проти власності в Україні за 2016-2018 pp.

\begin{tabular}{|l|c|c|c|c|}
\hline \multicolumn{1}{|c|}{ Види злочинів } & $2016 \mathrm{p}$. & $2017 \mathrm{p}$. & $2018 \mathrm{p}$. & $\begin{array}{c}\text { Абсолютне } \\
\text { відхилення 2018 } \\
\text { до } 2016 \mathrm{p} .\end{array}$ \\
\hline Злочини проти власності & 405549 & 335910 & 303850 & -101699 \\
\hline Крадіжка & 312172 & 261282 & 238492 & -73680 \\
\hline Грабіж & 27199 & 18130 & 13838 & -13361 \\
\hline Розбій & 3904 & 3006 & 2263 & -1641 \\
\hline Шахрайство & 46019 & 37014 & 33290 & -12729 \\
\hline $\begin{array}{l}\text { Привласнення, розтрата майна або } \\
\text { заволодіння ним шляхом } \\
\text { зловживання службовим становищем }\end{array}$ & 9787 & 10756 & 10713 & 926 \\
\hline $\begin{array}{l}\text { Умисне знищення або пошкодження } \\
\text { майна }\end{array}$ & 3105 & 2714 & 2551 & -554 \\
\hline Інші & 190418 & 191009 & 2703 & -187715 \\
\hline
\end{tabular}

Складено за даними Генеральної прокуратури України [482]

3 табл. 1 видно, що упродовж періоду, що аналізується кількість злочинів проти власності скоротилася на 101699 злочинів. Найбільше упродовж аналізованого періоду здійснювалось крадіжок, шахрайських дій та грабежів.

За результатами дослідження, проведеного компанією $\mathrm{PwC}$, у 2018 році 48\% вітчизняних юридичних осіб постраждали від економічних злочинів та шахрайств, що на 5 \% більше, аніж у 2016 р. [483]. Опитані респонденти зазначили, що найбільш часто вони дотичні із з фактами вимагання, хабарництва i корупції (73\%). Значну частку займають такі злочини, як: незаконне привласнення майна, злочини у сфері публічних закупівель, шахрайство при управління персоналом та кіберзлочини (рис. 9.5.4). 


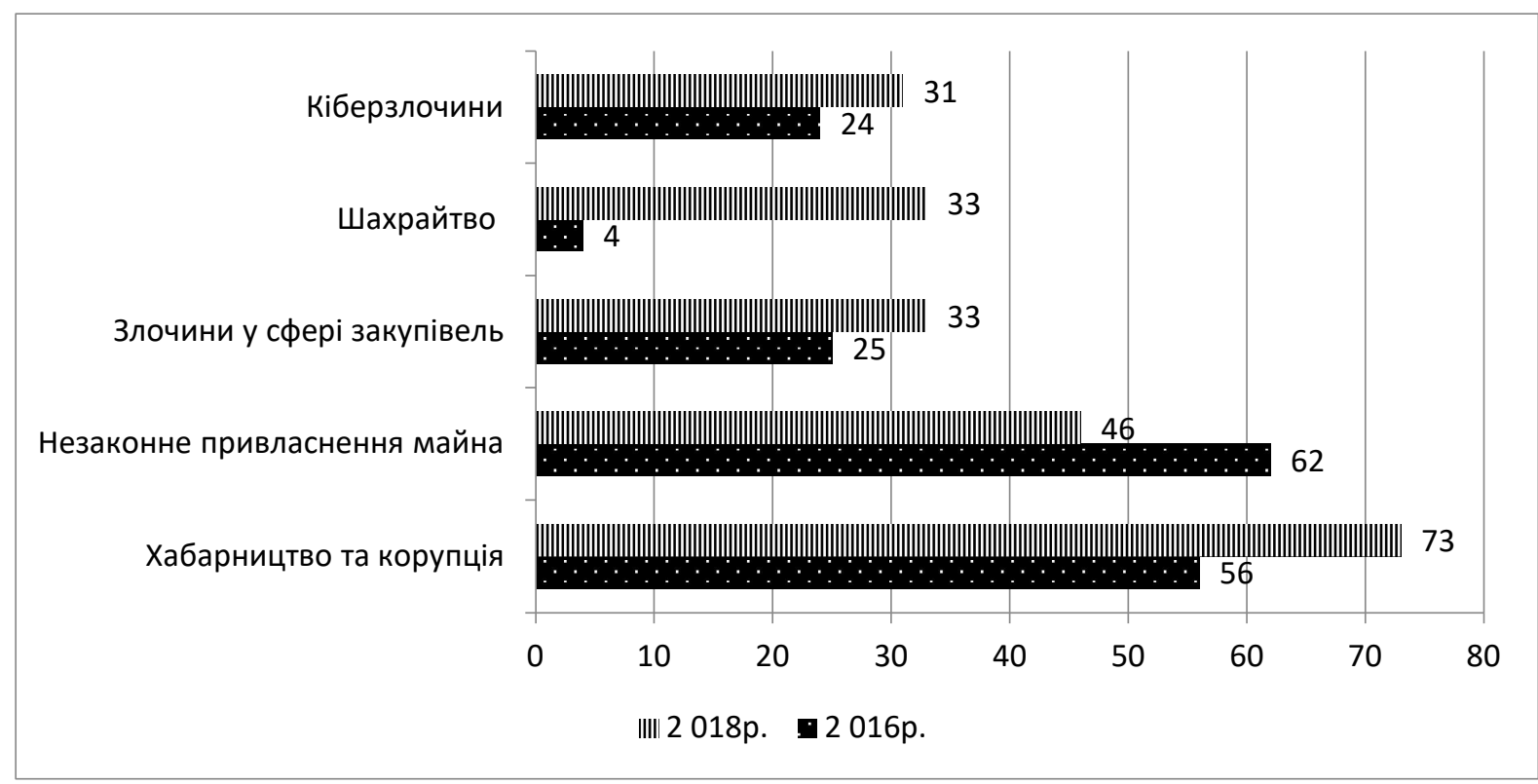

Рис. 9.5.4. Види економічних злочинів в Україні у 2016 р. та у 2018 р., \% Складено за [483]

Аналіз показує, що у 2018 р. в Україні значно знизився індекс сприйняття корупції - до 30 балів. Однак, як бачимо, вказані покращення не знайшли відображення в результатах опитування.

Існує таке твердження, що для того щоб протистояти злочинності ії потрібно вивчити, дослідити умови виникнення та чинники впливу, з чим ми абсолютно погоджуємося. Тому для профілактики та протидії економічним злочинам потрібно з’ясувати причини скоєння таких злочинів та сформувати «портрет» злочинця. Як показали результати опитування, у 2018 р. 36\% шахрайств були скоєні третіми особами [483], що відповідає загальносвітовій практиці. Так рівень шахрайств скоєний третьою стороною у світі становить $40 \%$. Водночас, частка шахрайств вчинених працівниками підприємств перевищила загальносвітовий рівень (52\%) і в Україні цей показник - 56\% [483]. Практика підтверджує, що здебільшого злочини проти своєї ж організації здійснює вище керівництво, частка підприємств, які вказали на це становить 55\%. Важливим $є$ те, що значення цього показника зросло вдвічі, порівняно із 2016 р. ( у 2016 р. - 27\%; у 2018 р. - 55\%). Основною причиною вчинення економічних злочинів $70 \%$ респондентів зазначили про наявність значно більших можливостей скоїти ці злочини, що на 28\% більше, аніж у 2016 р. 
3 метою розробки ефективних заходів боротьби із шахрайством доцільно виокремити основні фактори, що впливають на працівників. Існує три основних чинники, що призводять до здійснення шахрайства з боку працівників:

тиск в середині організації;

можливість вчинення шахрайства;

атмосфера виправдання дій працівників організації.

Для скоєння шахрайських дій працівниками необхідна сукупність всіх трьох чинників. Звідси, для запобігання шахрайству доцільно впливати на працівників та усувати можливі умови для вчинення злочинів. Це можливо шляхом формування атмосфери відкритості на всіх рівнях організації, запровадження ефективних механізмів внутрішньофірмового контролю, формування позитивної корпоративної культури та несприйняття співробітниками шахрайських дій.

Доцільно зазначити, що наслідки від шахрайства є не тільки фінансовими. Розголошення факту шахрайства (не важливо чи організація стала жертвою шахрайських дій, чи їх ініціатором) створює загрозу репутації організації, може підірвати діловий імідж суб'єкта господарювання. Проведене опитування показало, що від економічних злочинів та шахрайства потерпає репутація підприємства, на що вказало $50 \%$ опитаних респондентів. Водночас $42 \%$ опитаних зазначили, що від шахрайських дій постраждали їх відносини із бізнес-партнерами, а 38\% вказали на погіршення відносин із регуляторами (рис. 9.5.5).

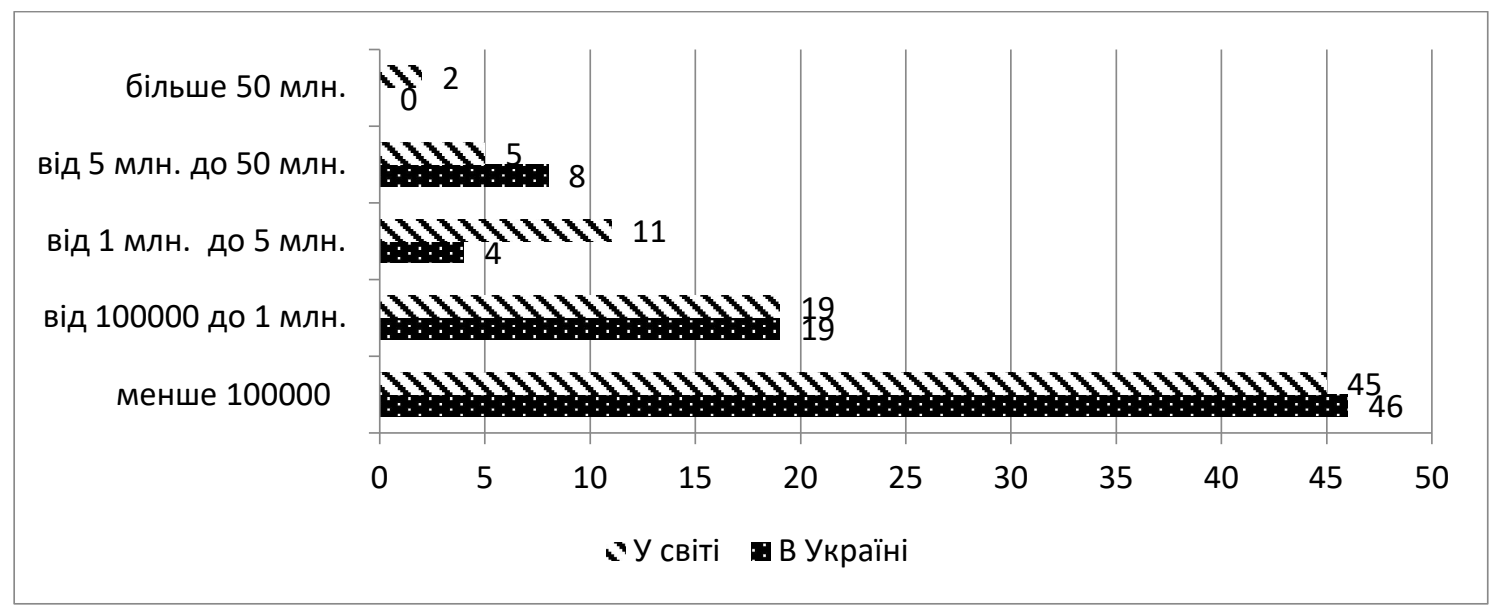

Рис. 9.5.5. Суми фінансових збитків підприємств від вчинених економічних злочинів в Україні і світі, дол. США* [483]

*Не враховані відповіді респондентів, які відповідали «Суму фінансових збитків неможливо оцінити» або «Важко відповісти» 
Вчинені економічні злочини позначаються і на психологічному кліматі в колективі, що проявляється у погіршені професійної етики та поведінки працівників, на що вказали 58\% опитаних.

Отже, банківська система - це одна з основних ланок фінансово-кредитної системи України. Саме тому вона є об'єктом, які приваблюють шахраїв та злочинців. Цей факт підриває авторитет банків, як фінансових посередників, що гарантують збереження та накопичення коштів клієнтів: населення, держави та суб'єктів господарювання. У сучасному світі способи шахрайств змінюються.

Впровадження банківських карт та використання сучасних комп'ютерних технологій у сфері банківських платежів $\epsilon$ характерною особливістю повсякденного життя. Досить швидко розвиваються безготівкові форми розрахунків. Безготівкові платежі мають низку переваг, а саме: сприяють прискоренню оборотності грошових коштів, скороченню кількості готівки, необхідної для обігу. Поширення безготівкових розрахунків призводить до зниження витрат обігу та збільшує прозорість розрахунків [484]. Отже, простота, доступність технологій, швидкість здійснення та дешевизна робить безготівкові розрахунки популярними серед населення та підприємств, а, отже, приваблюють шахраїв. На підтвердження цього факту наведемо такі дані: платіжні сервіси системи Exchange-Online у період з 01.01.2018 по 26.08.2018 зафіксували 12416 підозрілих операцій на загальну суму 3409000 гривень. В підозрілих операціях прийняло участь 7390 банківських карт 135 банків з 53 країн, в тому числі з 67 українських банків. Кошти шахраї намагалися вивести з рахунків клієнтів за допомогою мобільних пристроїв [482].

Ще одним важливим способом шахрайства $є$ використання соціальної інженерії, внаслідок чого зловмисники отримують дані платіжної картки та ідентифікацію іiі, як не дивно основною найбільш вразливою ланкою в цих маніпуляціях є сам клієнт. Шахраї використовують методи інтелектуального аналізу, психологічного впливу та інформаційних технологій, а далі справа швидкої техніки переведення коштів. 
Таким чином банківське шахрайство впливає не лише на банківські установи, уповільнюючи поширення безготівкових операцій, підриваючи довіру населення, але й для держави загалом, порушуючи стабільність банківської системи та ускладнюючи процес протидії шахрайству.

Впровадження банківських карт та використання сучасних комп'ютерних технологій у сфері банківських платежів $є$ характерною особливістю повсякденного життя. Досить швидко розвиваються безготівкові форми розрахунків. Безготівкові платежі мають низку переваг, а саме: сприяють прискоренню оборотності грошових коштів, скороченню кількості готівки, необхідної для обігу. Поширення безготівкових розрахунків призводить до зниження витрат обігу та збільшує прозорість розрахунків [484].

Звідси, простота, доступність технологій, швидкість здійснення та дешевизна робить безготівкові розрахунки популярними серед населення та підприємств, а, отже, приваблюють шахраїв. На підтвердження цього факту наведемо такі дані: платіжні сервіси системи Exchange-Online у період 3 01.01.2018 по 26.08.2018 зафіксували 12416 підозрілих операцій на загальну суму 3409000 гривень. В підозрілих операціях прийняло участь 7390 банківських карт 135 банків 353 країн, в тому числі з 67 українських банків. Кошти шахраї намагалися вивести з рахунків клієнтів за допомогою мобільних пристроїв [482].

Україна займає одне з перших місць серед поширення шахрайських дій у банківській сфері та потрапляє в п'ятірку країн, де банківські платіжні операції $\epsilon$ незахищеними. Зазначимо, що 19\% операцій, які підозрювалися в шахрайстві, виявились дійсно шахрайськими. Це показник перевищує обсяги шахрайств в інших країнах. Так, за допомогою кібершахрайств у 2018 р. 3 карток українців було знято 238955 гривень [482].

Банківські платіжні системи, які мають слабкий захист, можуть втрачати клієнтів, оскільки вони можуть стати об'єктами шахрайства. Залучення широких верств населення до здійснення безготівкових операцій та можливість отримання збитків серед них перетворює банківське шахрайство не тільки у проблему 
банків, але у соціальну проблему. Цю проблему потрібно вирішувати комплексно із залученням держави, населення, банків, інвесторів.

Найбільш поширеними видами банківських шахрайських операцій 3 картками є такі:

- скімінг - шахрайська операція, яка полягає у викраденні інформації 3 магнітної стрічки картки або ПІН-коду клієнта за допомогою спеціальних технічних пристроїв;

- трапінг - шахрайські дії, які полягають у встановленні пасток на шатер банкомату;

- пошкодження банкоматів;

- фішинг - шахрайські операції, що реалізуються із використанням мережі Інтернет;

- вішинг - шахрайство, що використовує мобільний зв'язок;

- вірусні та хакерські атаки, тощо.

На рисунку 9.5.6 наведені групи шахрайських операцій, здійснених у 2018 року та об’єднаних за однаковим способом здійснення, які представлені у відсотках.

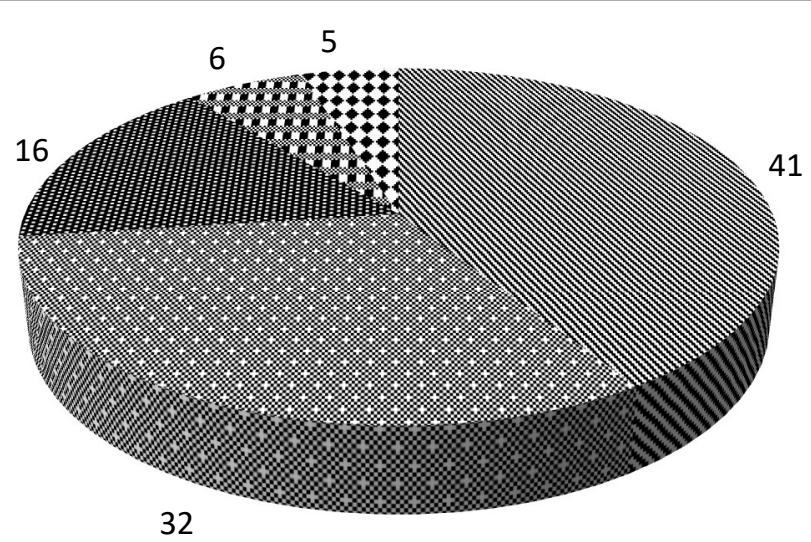

\$ Соціальна інженерія

Крадіжка коштів через банкомат

期 Шахрайські операції через інтернет

- Шахрайські операції через дистанційні мережі обслуговування

₹ Крадіжки через POS-термінали

Рис. 9.5.6. Банківські шахрайські операції за способом вчинення у 2018 р.,\% Складено на основі даних Української міжбанківської Асоціації членів платіжних систем [485] 
Найбільша частка банківських шахрайських операцій, які було здійснено за допомогою методів соціальної інженерії (41\%), реалізувались із використанням вішингу та фішингу. Сутність таких шахрайських дій полягає у виманюванні даних платіжних карток у клієнтів та отриманні доступу до рахунків та викрадені коштів. Жертвами соціальної інженерії, зазвичай, стають люди пенсійного віку (від 55 і старші) - 15\% та особи середнього віку (35-44) $13 \%$.

Як видно з рисунку 6, популярними способом крадіжок коштів у клієнтів банків крадіжки $є$ через банкомат (32\%) та через Інтернет (16\%). 3 огляду на популярність таких видів банківського шахрайства, банки повинні розробити способи захисту операцій.

Заради справедливості необхідно вказати, що банківське шахрайство, що реалізується $з$ використанням соціальної інженерії - це не лише проблема України, а глобальна проблема. Так, на кінець 2018 року шкоди від фішингових атак зазнали більше половини банків світу $-51,70 \%$.

Найбільше від фішингових атак постраждали банківські установи таких країн: Китай (20,87\%), Бразилія (19,16\%), Макао (11,94\%), Російська Федерація (11,29\%), Австралія (10,73\%), Аргентина (10,42\%), Нова Зеландія $(10,18 \%)$, Катар (9,87\%), Казахстан (9,61\%), Тайвань (9,27\%) [482].

Вішинг застосовували банківські шахраї у таких країнах: Росія $(1,2 \%)$, Узбекистан (0,40\%), Казахстан (0,36\%), Таджикистан (0,35\%), Туреччина (0,34\%), Молдова (0,31\%), Україна $(0,29 \%)$, Киргизстан $(0,27 \%)$, Білорусь $(0,26 \%)$ та Латвія $(0,23 \%)$ [482].

У 2018 році на 1 млн. грн. операцій за платіжними картками 92 грн. припадає на незаконні операції, тоді як у 2017 році - 77 грн. [486].

Щодо України, то у 2018 року збитки клієнтів банківських установ від соціальної інженерії склали 509,72 млн. грн. Такий рівень вдвічі перевищив збитки за 2017 рік та у 9 разів за 2016 рік.

Необхідно вказати, що у 2018 р. збільшилася середня сума шахрайської операції, які реалізовувалися з використанням методів соціальної інженерії. 
У 2018 р. вона склала 2543 грн., що в 1,8 разів перевищує даний показник у 2016 році (табл. 9.5.2).

Таблиця 9.5.2

Сума збитків отриманих від банківського шахрайств в Україні за 2016-2018 pp.

\begin{tabular}{|c|c|c|c|c|c|c|c|c|}
\hline \multirow{2}{*}{ Показники } & \multicolumn{2}{|c|}{2016 p. } & \multicolumn{2}{|c|}{2017 p. } & \multicolumn{2}{|c|}{2018 p. } & \multicolumn{2}{|c|}{$\begin{array}{l}\text { Абсолютне відхилення } \\
2018 \text { р. до } 2016 \text { р. }\end{array}$} \\
\hline & $\begin{array}{l}\text { Соціальна } \\
\text { інженерія }\end{array}$ & Інтернет & $\begin{array}{l}\text { Соціальна } \\
\text { інженерія }\end{array}$ & Інтернет & $\begin{array}{l}\text { Соціальна } \\
\text { інженерія }\end{array}$ & Інтернет & $\begin{array}{l}\text { Соціальна } \\
\text { інженерія }\end{array}$ & Інтернет \\
\hline $\begin{array}{l}\text { Середня } \\
\text { сума } \\
\text { збитку від } \\
\text { шахрайськ } \\
\text { ої операції, } \\
\text { грн. }\end{array}$ & 834 & 206 & 1403 & 345 & 2543 & 145 & 1709 & -61 \\
\hline $\begin{array}{l}\text { Загальна } \\
\text { сума } \\
\text { збитків від } \\
\text { шахрайськ } \\
\text { их } \\
\text { операцій, } \\
\text { млн. грн. }\end{array}$ & 51,74 & 32,62 & 275,45 & 63,68 & 509,72 & 159,91 & 457,98 & 127,29 \\
\hline
\end{tabular}

Складено за даними [482]

Найбільша кількість випадків банківського платіжного шахрайства в Україні здійснювались 3 використанням методів соціальної інженерії реалізуються в середовищі Card-Not-Present (операції без наявності картки та фізичної присутності користувача).

\section{Висновки.}

Тобто, найбільш популярними методами вчинення банківського шахрайства є використання соціальної інженерії. Це можна пояснити тим, що зловмисники отримують дані банківської картки та ідентифікаційні дані клієнта. Популярність соціальної інженерії пояснюється й тим, що даний спосіб шахрайства є досить простим у здійсненні. Не дивлячись на те, що банківські співробітники попереджають клієнтів не поширювати інформацію по банківській картці через телефон, проте шахраї мають досить багато способів 
впливу на жертву. Отже, найбільш слабким методом у платіжних системах є сам клієнт. Тут банківські установи $є$ безсилими. Тому для даного випадку шахрайства необхідно використовувати сукупність засобів, які грунтуються на методах інтелектуального аналізу та інформаційних технологій.

Банківське шахрайство має негативні наслідки для стабільності фінансової системи держави в цілому. Негативний вплив проявляється в уповільненні поширення безготівкових розрахунків, поширенні недовіри населення до банків, тонізації фінансових операцій. Необізнаність у механізмах вчинення банківського шахрайства ускладнюють процес його визначення та боротьби 3 ним. Виокремлення ознак шахрайства $€$ необхідним для розробки засобів $\mathrm{i}$ методів захисту від таких злочинів.

В результаті проведеного дослідження виявлено, що збитки від банківського шахрайства щорічно зростають. Клієнти банків самі банківські установи втрачають кошти завдяки різним шахрайським діям. Найбільш популярними методами здійснення банківського шахрайства $є$ соціальна інженерія, фішинг та вішинг. Для боротьби 3 такими видами банківського шахрайства доцільно розробити низку заходів, реалізація яких потребує застосування методів Data Mining та розвинутих інформаційних технологій. 


\section{SECTION 10. MECHANISMS OF REGULATION OF THE ECONOMY}

DOI 10.46299/ISG.2021.MONO.ECON.II-468-475

\subsection{Normative monetary valuation of industrial lands under influence of location factors}

Industrial lands occupy minor area in the structure of the land fund of Ukraine (less than 1\%), but perform a very important function - act as a basis for the placement of the production means.

The normative monetary valuation of industrial lands is carried out in accordance with the Methodology of normative monetary valuation of nonagricultural lands (except for settlements) [487] and the Procedure for normative monetary valuation of non-agricultural lands (except for settlements) [488] and takes into account the metric characteristics of the land plots: (its area), rental income per unit area of the relevant category of land, capitalization period, coefficients that take into account the location, type of use and coefficient that takes into account the land belonging to the lands of environmental, health, recreational, historical and cultural purposes.

The article examines the impact of the coefficients that take into account the regional and local location of the land plot on the indicators of the normative monetary valuation of the industrial lands.

The calculations on the normative monetary valuation of the industrial land plots located on the territory of one cadastral quarter have been made.

It has been established that the indicators of the normative monetary valuation of the industrial land plots located on the territory of the given cadastral quarter are influenced only by the area of the land plot. The valuation indicators do not take into account the local features of the location of a specific land plot. This has advantages in terms of automation of the valuation process of the objects and allows avoiding the subjective interpretation of the manifestation of the local factors on a particular land by the valuator, but makes it impossible to take into account the peculiarities of each specific land plot. 
The economic meaning of the use of the land resources, which are the basis to place the production means, is their ability to make a profit. The indicators of normative monetary valuation of the industrial land plots, which are formed under the influence of the rent-forming factors, local and regional coefficients responsible for the location of the land plot, create the conditions for receiving the revenues to the local budgets in the form of land fees from land tax and rent. The regulation of land valuation for tax purposes is carried out in the context of the procedure of their normative monetary valuation. Some provisions of the normative monetary land valuation, despite the long period of their application, have points that need to be clarified and improved.

Objective of research is to study the current methodological provisions of normative monetary valuation of industrial lands outside the settlements on a specific example in order to determine the areas for improvement.

The object of the researches industrial lands (code 11 according to the Classification of the types of land purpose), which belong to the category of lands industrial lands, transport, communications, energy, defense and other purposes.

In accordance with the provisions of Art. 66 of the Land Code of Ukraine [489] industrial lands include lands provided for the location and operation of the main, subsidiary and auxiliary buildings and structures of industrial, mining, transport and other enterprises, their access roads, utilities, administrative and domestic buildings, other buildings.

Industrial lands can be of state, communal and private forms of ownership.

There is a certain dynamics during 2012 - 2018 regarding a slight increase in the area of industrial land in the overall structure of the land fund of Ukraine and directly in the structure of built-up land (Table 10.1.1). 
Table 10.1.1

Structure of land fund of Ukraine by lands during $2012-2018, \%$ *

\begin{tabular}{|c|c|c|c|c|c|c|c|}
\hline \multirow{2}{*}{$№$} & Main types of land & \multicolumn{2}{|c|}{ As of 01.01.2012 } & \multicolumn{2}{c|}{ As of 01.01.2015 } & \multicolumn{2}{c|}{ As of 01.01.2018 } \\
\cline { 3 - 7 } & $\begin{array}{c}\text { area, } \\
\text { thousand } \\
\text { hectares }\end{array}$ & $\begin{array}{c}\text { specific } \\
\text { weight, } \\
\%\end{array}$ & $\begin{array}{c}\text { area, } \\
\text { thousand } \\
\text { hectares }\end{array}$ & $\begin{array}{c}\text { specific } \\
\text { weight, } \\
\%\end{array}$ & $\begin{array}{c}\text { area, } \\
\text { thousand } \\
\text { hectares }\end{array}$ & $\begin{array}{c}\text { specific } \\
\text { weight, } \\
\%\end{array}$ \\
\hline 1 & Agricultural lands & 42776,9 & 70,9 & 42731,5 & 70,8 & 41489,3 & 68,8 \\
\hline 2 & $\begin{array}{c}\text { Forests and other } \\
\text { wooded areas }\end{array}$ & 10611,3 & 17,6 & 10630,3 & 17,6 & 9365,5 & 15,5 \\
\hline 3 & Built-up lands & 2523,2 & 4,2 & 2550,4 & 4,2 & 3602,1 & 6,0 \\
\hline 4 & $\begin{array}{c}\text { including industrial lands } \\
\text { Open water-logged } \\
\text { lands }\end{array}$ & 223,2 & 0,4 & 224,1 & 0,4 & 224,2 & 0,4 \\
\hline 5 & $\begin{array}{c}\text { Dry open lands with } \\
\text { peculiar vegetation }\end{array}$ & 17,7 & 0,0 & 17,9 & 0,0 & 3,7 \\
\hline & $\begin{array}{c}\text { Open lands without } \\
\text { vegetation or with little } \\
\text { vegetation }\end{array}$ & 1022,9 & 1,7 & 1015,8 & 1,7 & & \\
\hline 6 & Water & 2422,8 & 4,0 & 2426,4 & 4,0 & 2401,4 & 4,0 \\
\hline & Total & 60354,9 & 100 & 60354,9 & 100 & 60354,9 & 100 \\
\hline
\end{tabular}

"Source: formed by the authors according to the data of the State Geocadastre of Ukraine [490]

According to the State Geocadastre of Ukraine for the period from 2012 to 2018, there is a tendency to reduce the area of agricultural lands (by 1287,6 thousand hectares), at the same time, when there is an increase in the area under built-up lands from 2523,2 thousand ha in 2012 to 3602,1 thousand ha in 2018. The area of industrial lands in the overall structure of the land fund of Ukraine increased by 1,0 thousand ha and as of 01.01.2018 amounted to 224,2 thousand ha or $0,4 \%$.

Since industrial lands are the basis for the placement of production means, the basis for determining their normative monetary value is the capitalization of rental income from the use of land.

Rent income ( $\mathrm{Ri}$ ) is defined as the income that can be obtained as a result of land use depending on its quality and location.

The term of capitalization of rental income is set for industrial lands at the level of 33 years.

The coefficient that takes into account the location of land (C) is determined for the cadastral quarter, the boundaries of which are displayed on the index cadastral map 
and is calculated as the product of the coefficient $\mathrm{Cr}$, which takes into account the regional factors of the cadastral quarter location (distance from the administrative center of the district and the nearest settlement, which has highways, entering the suburban area of large cities, etc.) and $\mathrm{Cl}$ (coefficient that takes into account local factors of the location of the cadastral quarter by territorial and planning, engineering and geological, historical and cultural, natural and landscape, sanitary and hygienic and other conditions).

Here is an example of calculating the normative monetary valuation of industrial land on a particular land plot (Table 10.1.2).

Table 10.1.2

Calculation of normative monetary valuation of industrial land plot (cadastral number 6323581700:04:001:0501), located on territory of Kachalivka village council of Krasnokutsk region of Kharkiv oblast, as of 01.01.2021, UAH*

\begin{tabular}{|c|c|c|c|}
\hline № & Indicators & $\begin{array}{l}\text { Order of receipt or } \\
\text { calculation of indicator }\end{array}$ & $\begin{array}{l}\text { Value of } \\
\text { indicator }\end{array}$ \\
\hline 1 & 2 & 3 & 4 \\
\hline 1 & Total area of land plot $(\mathrm{P})$, ha & $\begin{array}{l}\text { Extract from State Land } \\
\text { Cadastre of land plot }\end{array}$ & 0,0004 \\
\hline 2 & $\begin{array}{l}\text { Rent income per } 1 \mathrm{~m}^{2} \text { of the area for the } \\
\text { corresponding category of lands }(\mathrm{Ri}), \mathrm{UAH} / \text { year }\end{array}$ & Annex 1 of Order & 0,6637 \\
\hline 3 & The term of capitalization $(\mathrm{Tc})$, years & Annex 2.2 of Order & 33 \\
\hline 4 & $\begin{array}{l}\text { Coefficient that takes into account the location of } \\
\text { land (C) }\end{array}$ & $\mathrm{C}=\mathrm{Cr} \times \mathrm{Cl}$ & 1,711 \\
\hline 4.1 & $\begin{array}{l}\text { Coefficient that takes into account regional factors } \\
\text { of the location of cadastral quarter }(\mathrm{Cr})\end{array}$ & $\mathrm{Cr}=\mathrm{Cr} 1 \times \mathrm{Cr} 2 \times \mathrm{Cr} 3$ & 1,599 \\
\hline & $\begin{array}{l}\text { Coefficient that takes into account distance of } \\
\text { cadastral quarter from settlements }(\mathrm{Cr} 1)\end{array}$ & Annex 2.5 of Order & 1,23 \\
\hline & $\begin{array}{l}\text { Coefficient that takes into account distance of } \\
\text { cadastral quarter from roads of state } \\
\text { importance }(\mathrm{Cr} 2)\end{array}$ & Annex 2 of Order & 1,30 \\
\hline & $\begin{array}{l}\text { Coefficient that takes into account location of } \\
\text { cadastral quarter in areas of radioactive } \\
\text { contamination due to Chernobyl disaster }(\mathrm{Cr} 3)\end{array}$ & Annex 1 of Order & 1,0 \\
\hline 4.2 & $\begin{array}{l}\text { Coefficient that takes into account local factors of } \\
\text { location of cadastral quarter by territorial and } \\
\text { planning, engineering and geological, historical and } \\
\text { cultural, natural and landscape, sanitary and } \\
\text { hygienic and other conditions (Cl) }\end{array}$ & \multirow[t]{2}{*}{ Annex 6 of Order } & 1,07 \\
\hline & $\begin{array}{l}\text { - Location of cadastral quarter in area of pedestrian } \\
\text { accessibility (not more than } 600 \mathrm{~m} \text { ) to settlements } \\
\text { and community centers }\end{array}$ & & 1,07 \\
\hline
\end{tabular}


Continuation of table 10.1.2

\begin{tabular}{|c|c|c|c|}
\hline 1 & 2 & 3 & 4 \\
\hline 5 & $\begin{array}{l}\text { Coefficient that takes into account type of land plot } \\
\text { use }(\mathrm{Cu})\end{array}$ & $\begin{array}{c}\mathrm{Cu}= \\
\mathrm{Cu} 1 \times \mathrm{Cu} 2 \times \mathrm{Cu} 3 \times \mathrm{Cu} 4\end{array}$ & 1,428 \\
\hline & $\begin{array}{l}\text { Coefficient that takes into account composition of } \\
\text { land }(\mathrm{Cu} 1)\end{array}$ & Annex 7 of Order & 1,2 \\
\hline & $\begin{array}{l}\text { Coefficient that takes into account regional } \\
\text { differences in formation of rental income and is } \\
\text { determined for land for industry, transport, } \\
\text { communications, energy, defense and other } \\
\text { purposes }(\mathrm{Cu} 2)\end{array}$ & Annex 8 of Order & 1,19 \\
\hline & $\begin{array}{l}\text { Coefficient that takes into account the productivity } \\
\text { of forest plantations and is determined for lands } \\
\text { covered with forest vegetation }(\mathrm{Cu} 3)\end{array}$ & paragraph 2.7 of Order & 1,0 \\
\hline & $\begin{array}{l}\text { Coefficient that takes into account the productivity } \\
\text { of water bodies and is determined for lands with } \\
\text { these objects }(\mathrm{Cu} 4)\end{array}$ & paragraph 2.7 of Order & 1,0 \\
\hline 6 & $\begin{array}{l}\text { Coefficient that takes into account the affiliation of } \\
\text { the land plot to the lands of environmental, health, } \\
\text { recreational, historical and cultural purposes (Ce) }\end{array}$ & paragraph 2.12 of Order & 1,0 \\
\hline 7 & $\begin{array}{l}\text { Normative monetary valuation of land in } \\
\text { accordance with Order as of } 01.01 .2013(\mathrm{~V}), \mathrm{UAH}\end{array}$ & $\begin{array}{c}\mathrm{V}=\Pi \text { П } \times \mathrm{P} \times \mathrm{Tc} \times \mathrm{C} \times \mathrm{Cu} \\
\times \mathrm{Ce}\end{array}$ & 214,05 \\
\hline 8 & Indexation coefficient & $\begin{array}{c}\text { Letter of State } \\
\text { Geocadastre } \\
\text { of } 06.01 .2021 \mathrm{p} \text {. } \\
\text { №22-28-0.222-171/2-21 }\end{array}$ & 1,897 \\
\hline 9 & \multicolumn{2}{|c|}{$\begin{array}{l}\text { Normative monetary valuation of land plot taking into account indexation } \\
\text { coefficient as of } 01.01 .2021 \text {, UAH }\end{array}$} & 406,05 \\
\hline
\end{tabular}

* Source: calculated by the authors

The geometrically smallest distance from the boundary of the cadastral quarter, where the valued land plot is located, to the boundary of the settlement, which is the settlement with the status of the district center (Krasnokutsk village) is less than the zone of influence of the settlement (D) $5 \mathrm{~km}$ and makes up respectively 4,5 $\mathrm{km}$ (Df), so the coefficient that takes into account the distance of the cadastral quarter from the settlements $(\mathrm{Cr} 1)$ is determined by calculation.

The basic land value $(\mathrm{Vb})$ of Krasnokutsk village as of 01.01.2021 is $126,71 \mathrm{UAH} / \mathrm{m}^{2}$. The coefficient, which takes into account the degree of urban value of the territories in the area of influence of settlements (Cs), is determined in accordance with Annex 4 of the Order and is for the valued land 0,75 (population of 
Krasnokutsk village according to the Handbook of normative monetary valuation of settlements) official website of the State Geocadastre of Ukraine) is 7928 people).

The capitalization period is 33 years.

The rent income per $1 \mathrm{~m}^{2}$ of industrial land is $0,6637 \mathrm{UAH} /$ year.

The coefficient that takes into account the distance of the cadastral quarter from the roads of state importance $(\mathrm{Cr} 2)$ is determined in accordance with Annex 2 of the Order. The highway of state importance T2106 Krasnokutsk - Stary Merchyk passes through the lands of the cadastral quarter, within which the valued land plot is located, therefore the coefficient $\mathrm{Cr} 2$ is 1,30 .

For the cadastral quarters that do not belong to the areas of radioactive contamination due to the Chornobyl disaster, the coefficient $(\mathrm{Cr} 3)$ is one.

The coefficient, which takes into account the local factors of the location of the cadastral quarter by territorial and planning, engineering and geological, historical and cultural, natural and landscape, sanitary and hygienic and other conditions $(\mathrm{Cl})$, is determined in accordance with Annex 6 of the Order as the result of the coefficient values which correspond to the local factors that are manifested within this cadastral quarter. $\mathrm{Cl}$ is determined in accordance with the Cartogram of the local factors of the location of the cadastral quarter, within which the valued land plot is located, according to territorial and planning, engineering and geological, historical and cultural, natural and landscape, sanitary and hygienic and other conditions.

The cadastral quarter, where the valued land plot is located, is directly adjacent to the border of the settlement - Kachalivka village $(1,07)$.

The Merchyk River flows within the cadastral quarter. A small part of the cadastral quarter is located in the water protection zone. But the given local factor is manifested in a smaller area than the area of half of this cadastral quarter, so this local factor in accordance with the Order is considered to have no manifestation.

The cadastral quarter is located in the zone of exceeding the permissible noise level from the state road T2106 Krasnokutsk - Stary Merchyk. But this local factor of location is manifested in a smaller area than the area of half of this cadastral quarter, so this local factor is considered to have no manifestation. 
The total coefficient, which takes into account the local factors of the location of the cadastral quarter $(\mathrm{Cl})$, is 1,07 .

Since the valued land plot contains land under industrial development, $\mathrm{Cu} 1$ in accordance with Annex 7 of the Order is taken to be 1,2.

The value of the coefficient $\mathrm{Cu} 2$ in accordance with Annex 8 of the Order for Kharkiv region, where the valued land plot is located, is 1,19 .

$\mathrm{The} \mathrm{Cu} 3$ coefficient takes into account the productivity of forest plantations and is determined for lands covered with forest (wood and shrub) vegetation. For the valued land plot of industrial land is equal to 1,0 .

The coefficient $\mathrm{Cu} 4$ takes into account the productivity of water bodies and is determined for lands with these objects: natural watercourses (rivers and streams), artificial watercourses (canals), lakes, ponds, reservoirs and other water bodies. For the valued land plot of industrial land is 1,0 .

The coefficient, which takes into account the affiliation of the land plot to the lands of nature reserve and other nature protection, health, recreational, historical and cultural purpose $(\mathrm{Ce})$ for the valued land plot of industrial lands is 1,0 .

The normative monetary valuation of the land plot as of 01.01.2021 is UAH 406,05, per $1 \mathrm{~m}^{2}$ - UAH 101,51.

But it should be noted that on the territory of the cadastral quarter there are other land plots of industry (cadastral numbers: 6323581700:04:001:0499, 6323581700:04:001:0500, 6323581700:04:001:0502， 6323581700:04:001:0503, 6323581700:04:001:0504, 6323581700:04:001:0505， 6323581700:04:001:0506, 6323581700:04:001:0507, 6323581700:04:001:0508, 6323581700:04:001:0509), normative monetary valuation of which as of 01.01 .2021 is also UAH $101,51 / \mathrm{m}^{2}$. The value of the coefficient, which takes into account the regional factors of the location of the cadastral quarter $(\mathrm{Cr})$ is 1,599 . The coefficient, which takes into account the local factors of the location of the cadastral quarter in terms of territorial and planning, engineering and geological, historical and cultural, natural and landscape, sanitary and hygienic and other conditions $(\mathrm{Cl})$, for the researched land plots is 1,07 . 
The same indicators of the normative monetary valuation of the land plots per 1 $\mathrm{m}^{2}$ indicate the disregard of the particular local factors for each individual land plot, and the adoption of the generalized regional and local factors in the form of the appropriate coefficients for a specific cadastral quarter, within which the valued land plots are located.

The normative monetary valuation of industrial lands is based on the capitalization of rental income. The indicators of monetary valuation of industrial lands are significantly influenced by the coefficients of the location of the land plot, which take into account regional and local factors of the location of the land plot within the cadastral quarter.

During the calculations it was found out that the normative monetary valuation of other industrial land plots located on the territory of one cadastral quarter depends only on the area of the land plot and does not take into account local features of a specific land plot, which, of course, has advantages in terms of automation objects and allows to avoid as much as possible the subjective interpretation of the valuator of the manifestation of the local factors on a particular land plot. But at the same time, this approach to the valuation of objects has the character of averaging the indicators of their valuation and makes it impossible to take into account the unique characteristics of each land plot. 
DOI 10.46299/ISG.2021.MONO.ECON.II-476-551

\section{2 Соціальна політика як елемент ітегрального механізму покращення якості життя населення України}

Підвищення значення соціальної політики сприяє поліпшенню якості життя суспільства. Узгодження інтересів суспільства $є$ складним та багатоаспектним процесом, що охоплює різні процеси, обгрунтовує необхідність використання можливостей соціальної політики. Однією з складових місії $є$ задоволення споживчих потреб суспільства. Лише вивчивши цінності та потреби, можна стверджувати, що соціальна політика має визначені основи $\mathrm{i}$ напрямки, які слід брати до уваги при розробці стратегій соціальної політики на різних рівнях іiі регулювання. Тобто, соціальна політика держави відповідає вимогам населення тільки тоді, коли іiі формування відбулося на основі сформованої соціальної політики регіону, що, у свою чергу, грунтується на досвіді формування соціальної політики підприємств, які належать до різних сфер людської діяльності. Тому, дослідження проблематики формування соціальної політики має актуальне значення.

Проблеми формування соціальної політики розглядаються в працях багатьох вітчизняних та інших визнанених вчених: В. Гриньової, А. Ягідки, В. Пономаренка, В. Скуратівського, Е. Холостової, І. Багрової, І. Григор'євої, М. Дороніної, М. Кизима, Н. Бар'я, Н. Волгіна, Н. Гілберта,Н. Горелова, Н. Лисиці, О. Іванової, О. Новикової, П. Спікера, С. Бульбенюка, С. Гончарової, С. Смирнова, С. Тетерського,Т. Ганслі, Ш. Рамона та інших, а проблемам оцінювання реальних доходів населення й регулюванню соціаль-них стандартів присвятили свої дослідження такі вітчизняні вчені: А. Колот, А. Костишина,
В. Загорський,
В. Литвинов,
В. Мандибура,
Г. Завіновська,
Г. Куліков, Д. Богиня, Е. Лібанова, І. Білоус, І. Гнибіденко, І. Новак, І. Ротчук, К. Ковазіна, Л. Черенько М. Крупка, М. Лазебна, М. Соколик, Н. Коваль, Н. Федірко, О. Базилюк, О. Бистрицька, О. Варецька, О. Жук, О. Мельниченко, П. Герасименко, С. Борлуцький, С. Мірошниченко, та інші. Певні аспекти цієї проблематики досліджували науковці ближнього та дальнього зарубіжжя: Л. Абалкін, А. Аганбегян, М. Волков, М. Мейксін, В. Логінова, А. Ощепков, 
Л. Степанова, Л. Яковлєва та інші, а також Н. Больц, Дж. Гікс, А. Дейтон, С. Клейн, О. Лоренц, Г. Патлер, О. Руф-Фідлер та інші. Разом з тим, є багато питань, які потребують постійного дослідження та уточнення, а саме: недостатньо чітко розділявся зміст соціальної та економічної політики; трактування змісту соціальної політики, як правило, обмежуються рамками проблем щодо забезпечення соціального захисту населення; сфера соціальної політики у більшості випадків, обмежувалася вирішення вузького кола проблем; соціальна політика розглядалася тільки в рамках соціальної відповідальності; наявні проблеми щодо узгодженості нормативно-правового забезпечення даної сфери.

Об’єктом дослідження $є$ процес формування соціальної політики у контексті забезпечення відповідного рівня та якості життя населення, а предметом - теоретичні і методичні аспекти формування соціальної політики України. Теоретичною основою дослідження послужили: законодавчі акти та нормативні документи за темою роботи; базова навчальна література; теоретичні праці вчених, що досліджували дану проблематику; статті в спеціалізованих і періодичних виданнях, які висвітлюють проблеми соціальної політики; довідкова література; статистична інформація; інформаційні бази мережі Інтернет. Обрана для розгляду проблема обумовлена, з одного боку, достатньо високим інтересом до особливостей здійснення соціальної політики у сучасній науці, а $з$ іншого боку - іiі недостатньою розробленістю. Практичне значення дослідження полягає в тому, що здійснено оцінку стану формування та реалізації соціальної політики в контексті забезпечення відповідного рівня якості життя. Дослідження даної теми іï висвітлення у трьох розділах.

Розділ 1. Обгрунтування теоретичних засад формування та здійснення соціальної політики. Вирішення проблем, які пов'язані із функціонуванням соціальної сфери, є прерогативою будь-якої держави. Крім того, соціальна сфера є підсистема національної економіки, тобто це явища, процеси, види діяльності та об'єкти, що мають зв'язок щодо забезпечення життєдіяльності суспільства, 
людини, задоволенням їх потреб та інтересів.

Єдності серед науковців щодо визначення поняття «соціальна політика» не має. Вони трактують дане поняття таким чином:

- «Соціальна політика - діяльність держави щодо створення та регулювання соціально-економічних умов життя суспільства 3 метою підвищення добробуту членів суспільства, усунення негативних наслідків функціонування ринкових процесів, забезпечення соціальної справедливості та соціально-політичної стабільності у країні [543, с. 288]»;

- «Соціальна політика - система правових, організаційних, регулятивноконтрольних заходів держави з метою узгодження цілей соціального характеру із цілями економічного зростання [544, с. 21]»;

- «Соціальна політика - один із видів регулювання держави, яка називається державою загального добробуту та взяла на себе обов'язки забезпечувати певний добробут населення, і включає програми, служби та заходи, що переслідують соціальні цілі, охоплюючи різноманітні сфери життєдіяльності членів суспільства (виробничу, духовну, побутову), регулюючи стосунки між суспільством, колективом, особою не тільки у кожній із цих сфер, але й і в зонах їхньої взаємодії $[559$, с. 10]».

В. А. Скуратівський пропонує розрізняти «вузьке та широке розуміння соціальної політики: у вузькому розумінні соціальна політика - це діяльність суб'єктів соціально-політичного життя, спрямована на формування соціальної безпеки людини й суспільства»; у широкому розумінні - це система інституційних i надінституційних, державних i громадських, суспільних i особистих, індивідуальних способів і форм діяльності, спрямованих на створення умов для всебічної самореалізації соціального потенціалу людини, iї сутнісних сил [538, с. 5]». М. А. Волгін стверджував, що «соціальна політика це взаємини соціальних груп із приводу збереження й зміни соціального стану населення в цілому й складових його класів, шарів, соціальних, соціальнодемографічних, соціально-професійних груп, соціальних общин (родини, народу, селища, міста, регіону й т.п.) [542, с. 14]». С. І. Холостова зазначає, що 
«соціальна політика являє собою проведену державними структурами, громадськими організаціями, органами місцевого самоврядування, а також виробничими колективами систему заходів, спрямованих на досягнення соціальних цілей $\mathrm{i}$ результатів, пов'язаних 3 підвищенням суспільного добробуту, поліпшенням якості життя народу й забезпеченням соціальнополітичної стабільності, соціального партнерства в суспільстві» [556, с. 12].

На рисунку 10.2.1 представлена суть соціальної політики, яка включає в себе зміст і цілі соціальної політики, іiї об’єкти і суб’єкти, функції і завдання, принципи соціальної політики, їі механізми та інструменти.

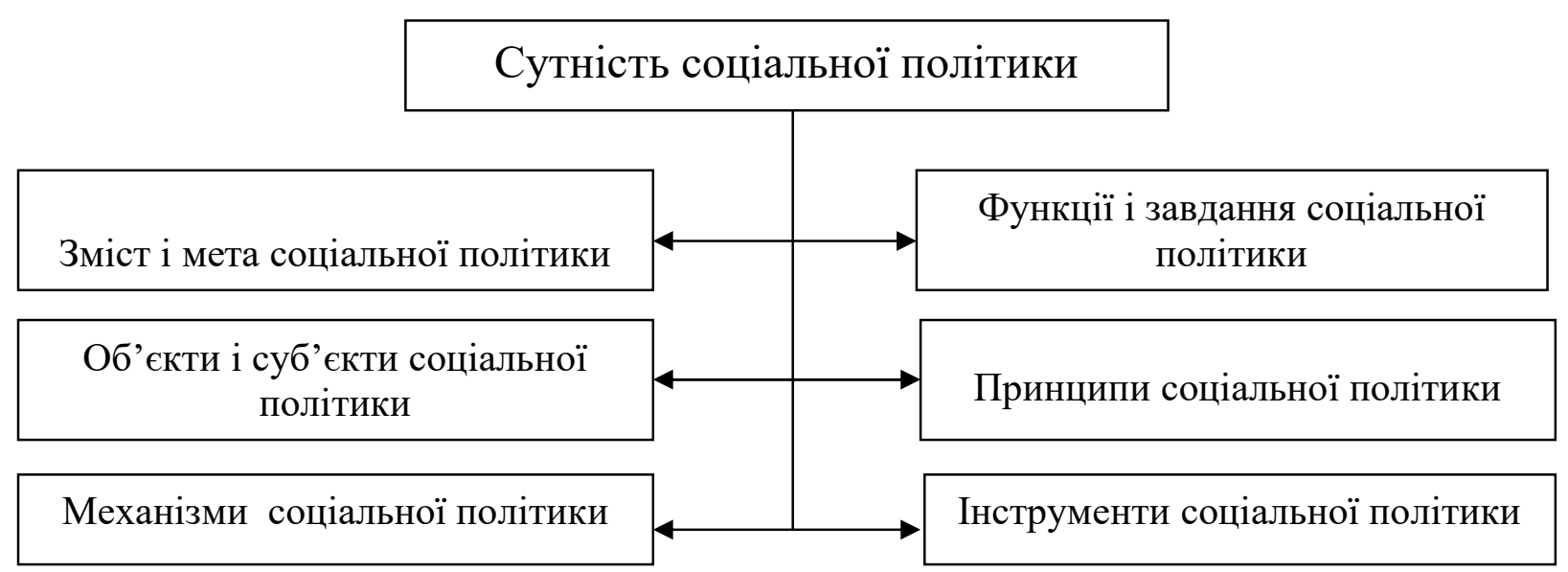

Рис. 10.2.1. Сутність соціальної політики

Джерело: [511], власне узагальнення

Головною метою соціальної політики, перш за усе, $є$ створення передумов для посилення рівня суспільного соціального захисту та соціальної безпеки, досягнення соціальної злагоди, стабільності та соціальної цілісності.

На думку О. Колишкіна О. [511] соціальна політика має передбачати досягнення певної мети. Ми переконані, що нижче наведені напрями досягнення мети мають найактуальніше значення:

- забезпечення стабільного функціонування суспільства, тобто суспільства стабільного, без заворушень і потрясінь, у якому є можливість досягнути суспільної злагоди та цілісності, достойного рівня життєдіяльності населення;

- забезпечення розвитку особистості шляхом можливості вільно розвивати та реалізовувати свої здібності, а також одержувати достойний дохід, 
поліпшувати власний добробут;

- досягнення достойного рівня життєдіяльності людей, а саме - соціального рівня та якості життя, що є прийнятним; соціального захисту категорії малозабезпечене населення та їх безпеки у соціальному плані в суспільстві.

Це означає, що основою соціальної політики має бути максимальне збереження потенціалу людини i країни (фізичного, інтелектуального, духовного-етичного); формування трудової мотивації, виходячи з вимог ринку та соціально-орієнтованої економіки країни; створення та реалізація інституційних та соціально-економічних передумов, які б сприяли розвитку людини, активізували іiї трудову діяльності, гарантували усі ії права та свободи.

У своїй статті О. Іванова [509] сформулювала перелік завдань до соціальної політики. До першочергових завдань, на нашу думку, варто віднести наступні:

- шляхом застосування різних форм компенсації від негативних економічних явищ захисти рівень життя населення;

- надання найбіднішим сім'ям певних допомог;

- надання допомоги при втраті роботи;

- проведення політики соціального страхування;

- встановлення мінімальної гарантованої заробітної плати для працюючих на законодавчому рівні;

- розвиток освітньої, медичної та природоохоронної сфери за рахунок державних коштів;

- здійснення активної політики, яка спрямована на отримання певної кваліфікації громадянами.

На рисунку 10.2..2 окреслене основне коло функцій, тобто головних суспільних завдань та напрямків, соціальної політики. 


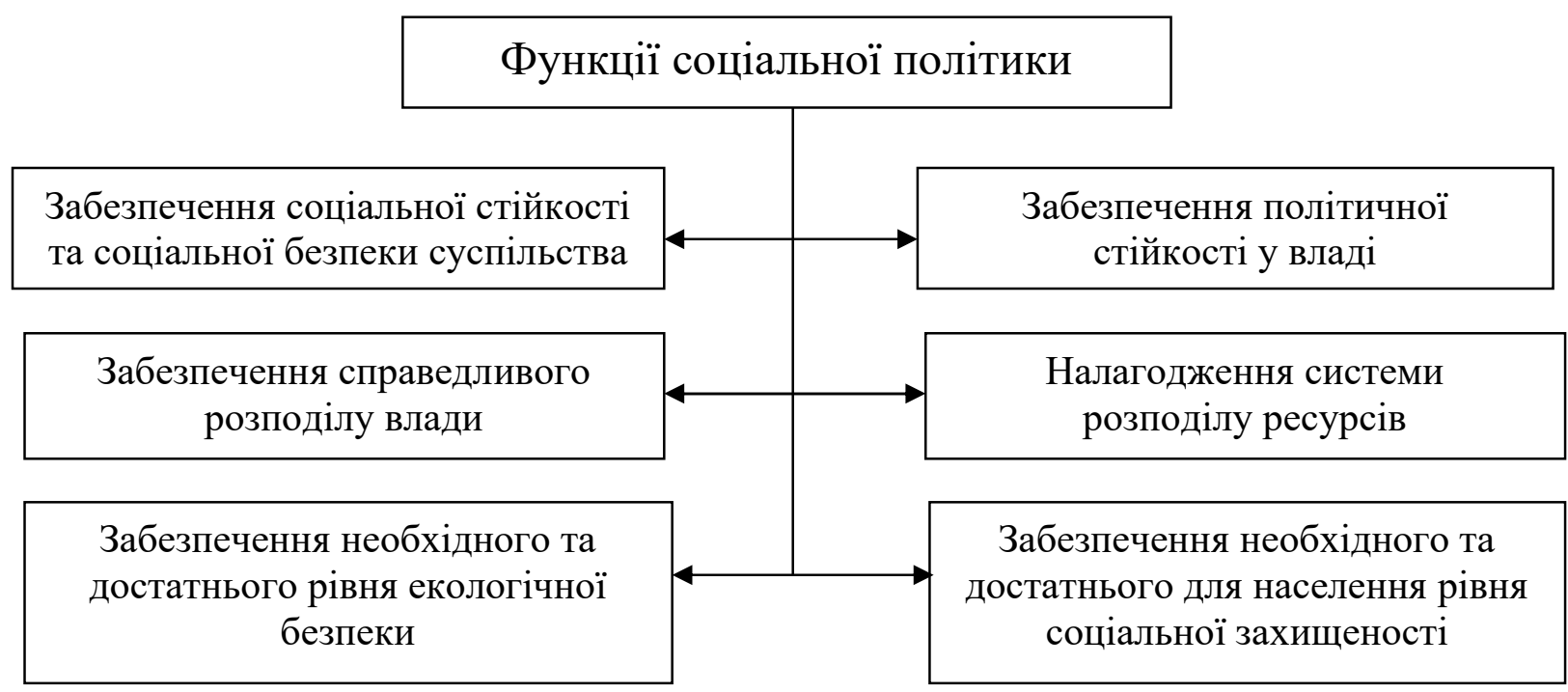

\section{Рис. 10.2.2. Функції соціальної політики}

Джерело: [515], власне узагальнення.

Досліджуючи характеристики основних функцій соціальної політики, ми встановили наступне:

1) функція забезпечення соціальної стійкості суспільства та соціальної безпеки суспільства означає, що соціальна структура може бути різною в різних суспільствах. Крім того, вона є якісно мінливою в історії одного й того ж суспільства в результаті значних революційних нововведень, але вона повинна мати властивості стійкості й динамічного розвитку (інакше дане суспільство руйнується та може припинити існування). Соціальна структура, через свою стійкість, має витримати внутрішні і зовнішні небезпеки іiі руйнування, а також мати перспективу й потенціал якісного відновлення шляхом реформ і революцій;

2) функція забезпечення політичної стійкості у владі означає, що така стійкість може бути досягнута в суспільствах різного типу та у різних індивідуальних історичних умовах по-різному, але суть завжди зводиться до такого - розподіл реальної участі соціальних класів або груп у політичних рішеннях для стримування домінуючого впливу у владі того ж самого панівного класу. Інакше відбувається зміна класового типу влади та можуть настати неминучі революційні перетворення, а серед цих перетворень у пріоритеті має бути забезпечення політичної стійкості, але вже нової влади;

3) функція забезпечення справедливого розподілу влади означає, що 
розподіл владних повноважень має бути справедливим, не потребувати боротьби за його переділ;

4) функція налагодження системи розподілу ресурсів означає, що цей розподіл має влаштовувати переважну більшість населення, оскільки від цього розподілу у певному розумінні залежать умови матеріального забезпечення життя людей у суспільстві, а також можливості рішення проблем різних соціальних груп. До економічних параметрів, які мають соціальний сенс i соціальне призначення, належать такі: інвестиції і їхня структура; рівень i диференціювання доходів; загальний розмір та структура соціальних витрат за річний період; умови й розміри соціальної допомоги й підтримки;

5) функція забезпечення необхідного та достатнього рівня екологічної безпеки належить до актуальних функцій соціальної політики, оскільки пов'язана із забезпеченням суспільством і державою необхідного й достатнього рівня екологічної безпеки;

6) функція забезпечення необхідного та достатнього для населення рівня соціальної захищеності грунтується на тому, що держава, яка виступає як гарант та захисник для громадян країни, повинна створювати певну систему захисту для усього суспільства - як для економічно сильних членів суспільства, так і для слабких та вразливих верств населення.

На рисунку 10.2.3 наведені основні об'єкти соціальної політики.

\begin{tabular}{|c|c|}
\hline Об' & ітики \\
\hline $\begin{array}{c}\text { Ринок праці та зайнятість } \\
\text { населення }\end{array}$ & $\begin{array}{c}\text { Система соціального захисту } \\
\text { населення }\end{array}$ \\
\hline $\begin{array}{l}\text { Трудові } \\
\text { відносини }\end{array}$ & $\begin{array}{l}\text { Елементи соціальної } \\
\text { інфраструктури }\end{array}$ \\
\hline Громадяни як споживачі & $\begin{array}{c}\text { Оплата праці та доходи } \\
\text { населення }\end{array}$ \\
\hline
\end{tabular}

Рис. 10.2.3. Об'єкти соціальної політики

Джерело: власне узагальнення.

Т. Семигіна надала детальну характеристику об'єктам соціальної політики 
[533]. Досліджуючи характеристики основних об’єктів соціальної політики , ми встановили наступне:

1) ринок праці та зайнятість населення: ринок праці належить до факторів виробництва, коли домогосподарства (в ролі найманих працівників) пропонують свою працю, а виробники (працедавці) мають потребу в ній. У результаті згоди встановлюється ціна праці, яка є при цьому ставкою заробітної плати, та обсяг праці, що використовується. Щодо зайнятості населення, то це соціальноекономічна категорія, яка характеризується залученням населення в суспільне виробництво, від якого залежить рівень та якість життя, загальний соціальнопсихологічний стан суспільства та можливості реалізації здібностей людини, трудового потенціалу суспільства в цілому.

2) система соціального захисту населення включає в себе систему заходів, які мають захищати будь-якого громадянина країни від економічної та соціальної труднощів не тільки через втрату роботи (тобто безробіття), а також тоді, коли відбувається втрата чи різке скорочення доходів, або хвороби, виробничі травми чи інвалідність, досягнення похилого віку тощо;

3) як відомо, трудові відносини врегульовані нормами трудового права, а от суспільні відносини, які виникли у результаті впливу норм трудового права на поведінку суб'єктів трудової діяльності через укладання трудового договору, коли виникають правові зв'язки, а також через відносини щодо встановлення умов праці, навчання й перекваліфікації за місцем роботи та відносини, вирішенням конфліктів і трудових спорів та працевлаштуванням;

4) елементи соціальної інфраструктури формуються з тих галузей, які забезпечують нормальні умови життєдіяльності людей: роздрібна торгівля (забезпечує товарами народного споживання); громадське харчування (забезпечує продукцією харчування); житло; дитсадки та інші дошкільні заклади; заклади охорони здоров’я; заклади культури;

5) громадяни як споживачі є суб’єктами ринкової економіки та ключовою фігурою у взаємовідносинах між виробником та продавцем товарів, для якої працюють мільярди людей, створюючи товари різноманітного призначення. 
Громадяни мають право на гарантований рівень споживання, який забезпечується стимулюванням виробництва товарів, виконання робіт та надання послуг - це як споживачі, а також запровадженням компенсаційних виплат, різних допомог та пільг - це як громадянин;

6) оплата праці та доходи населення. Як відомо оплата праці (заробітна плата) являє собою винагороду, що має бути виплачена найманому працівникові роботодавцем за виконану ним роботу, то саме через систему заробітної плати суспільство здійснює мотивацію праці, контролює міру праці та міру споживання матеріальних i духовних благ працівниками. Під доходами населення розуміють суму грошових засобів і матеріальних благ, які були отриманими або створеними громадянами за певний часовий проміжок. Саме доходи є визначальними, оскільки рівень споживання населення прямо залежить від їх рівня.

Держава через відповідальних за формування та реалізацію соціальної політики органи законодавчої та виконавчої влади, до яких відносяться Верховна Рада України та Уряд з його профільними Міністерствами (праці та соціальної політики, охорони здоров'я, освіти і науки - є головним суб'єктом соціальної політики в Україні. Також до суб'єктів соціальної політики належать державні комітети й відомства та органи місцевого самоврядування. Активну роль у здійсненні соціальної політики відіграють громадські та політичні організації, профспілки, фонди та асоціації. Проте, серед інституціональних структур, які здійснюють соціальну політику, головну роль відіграє саме держава. Держава має виконувати координаційні та організаційні дії щодо регулювання процесів функціонування та розвитку соціального життя країни. За величиною потенціалу держава, що є суб'єктом соціальної політики, має значно більше можливостей у порівнянні з іншими суб' єктами цього процесу.

Отже, соціальна політика являє собою таку діяльність держави, яка передбачає створення та врегулювання соціально-економічних умов життя суспільства на засадах підвищення добробуту членів суспільства та усунення або мінімізації впливу негативних наслідків від розвитку ринкових процесів, а також 
забезпечення соцсправедливості та соціальної й політичної стабільності. Соціальна політики визначає суспільно-політичні та макроекономічні орієнтири, де перші визначаються обраною моделлю суспільної політики.

Діяльність держави, яка направлена на створення та регулювання соціально-економічних умов життя суспільства, що ставить за мету підвищення добробуту членів суспільства, мінімізацію або усунення негативних наслідків функціонування ринкових процесів, забезпечення справедливості та стабільності у соціальній та соціально-політичної сферах у країні називається соціальна політика. Соціальна політика повинна базуватися на певних принципах, що наведені на рисунку 10.2.4.

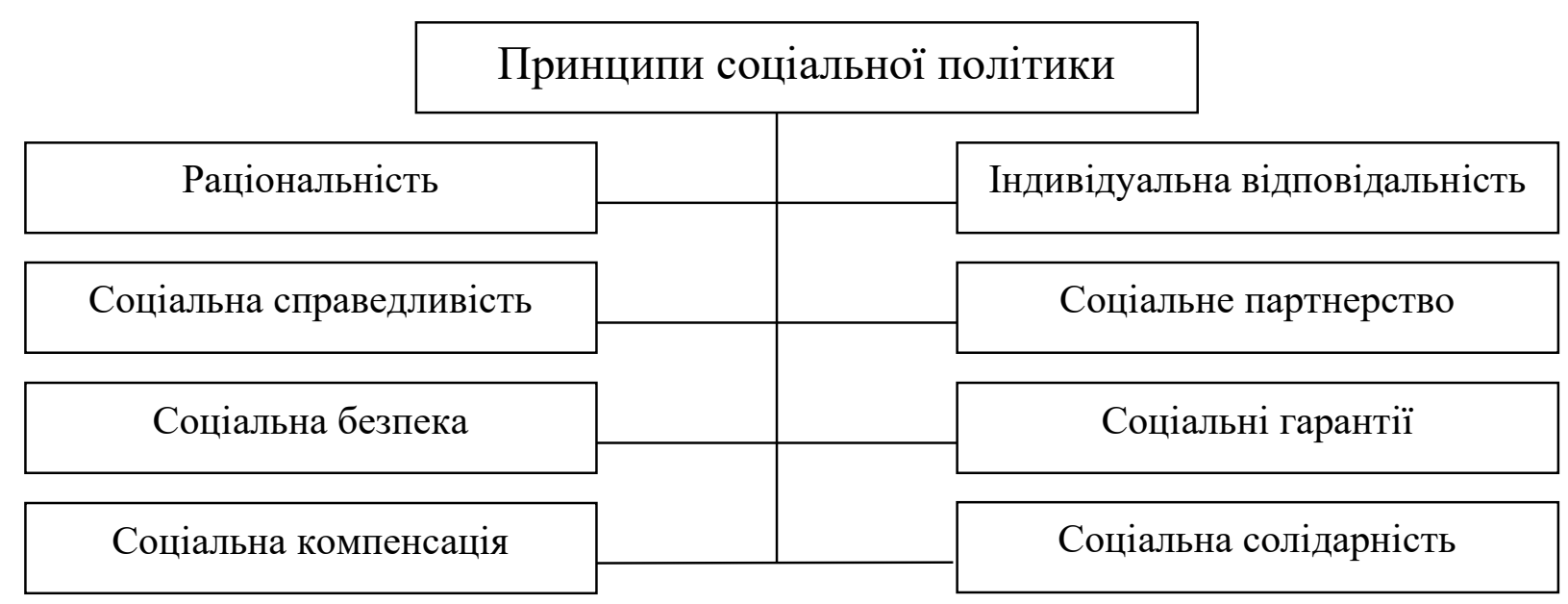

\section{Рис. 10.2.4. Принципи соціальної політики}

Джерело: [509], власне узагальнення.

Дослідимо характеристики даних принципів соціальної політики:

1) принцип раціональності передбачає досягнення найкращого співвідношення між метою соціальної політики та засобами ії реалізації, через адекватний розподіл фінансових засобів, соціальних інвестицій за різними напрямками з урахуванням пріоритетів;

2) принцип соціальної справедливості передбачає однакові можливості для всіх членів суспільства щодо можливостей вільного розвитку, реалізації своїх здібностей, одержання справедливого доходу, поліпшення добробуту, тобто забезпечення рівня та якості життя;

3) принцип соціальної безпеки передбачає наявність такого стану 
державного розвитку, коли держава має спроможна забезпечити гідний та якісний рівень життя населення, а вплив внутрішніх та зовнішніх загроз, при цьому, є мінімальним;

4) принцип соціальної компенсації має забезпечити часткову фінансову компенсацію, яка призначається непрацюючим особам, або соціальні послуги, які мають надаватися громадянам похилого віку, інвалідам, хворим, тобто тим, хто не здатен до самообслуговування й потребують постійної сторонньої допомоги;

5) принцип індивідуальної відповідальності пов’язаний із соціалізацією особистості, оскільки вона утверджується як новоутворення у період соціальної зрілості;

6) принцип соціального партнерства передбачає пом'якшення соціальної напруги та забезпечення узгодження різноманітних, а іноді i протилежних інтересів, соціальних груп та верств населення.

7) принцип соціальних гарантій передбачає досягнення мети щодо гарантування дотримання конституційного права громадян на належний життєвий рівень шляхом встановлення та забезпечення громадянам суспільства мінімум соціальних послуг. «Державні соціальні гарантії - встановленні законами мінімальні розміри оплати праці, доходів громадян, пенсійного забезпечення, соціальної допомоги, розміри інших видів соціальних виплат, встановленні законами та іншими нормативно-правовими актами, які забезпечують рівень життя не нижчий від прожиткового мінімуму [556]».

8) принцип соціальної солідарності має сприяти забезпеченню першочергових пріоритетних суспільних ініціатив щодо їх фінансування. «Серед найважливіших принципів соціальної політики слід визначити принцип солідарності (підтримки), який передбачає пріоритет суспільних ініціатив відносно відповідної діяльності державних органів та інститутів з фінансування соціальних заходів [535, с. 94]».

Як і більшість країн, так і Україна, у результати переходу на засада ринкової економіки, обрала дві основні моделі розвитку соціальної політики: 
континентальна (або бісмарківська) та англосаксонська (або модель Беверіджа).

Саме ці принципи соціальної політики формують у різних країнах або консервативну, або соціально-демократичну, або ліберальну політику.

Розглянемо основні характеристики цих моделей (рис. 10.2.5).

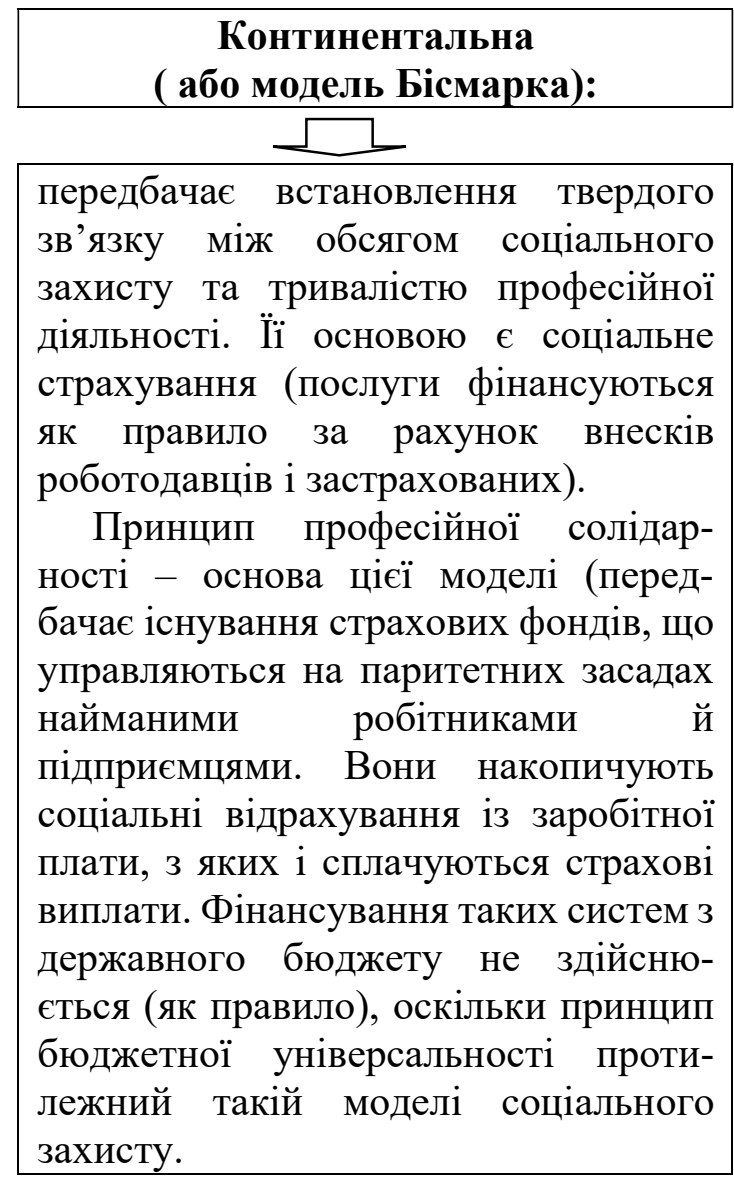

\begin{tabular}{|c|}
\hline $\mathbf{M}$ \\
$\mathbf{O}$ \\
Д \\
$\mathbf{E}$ \\
$\boldsymbol{J}$ \\
$\mathbf{b}$ \\
\\
$\mathbf{C}$ \\
$\mathbf{O}$ \\
$\mathbf{U}$ \\
$\mathbf{I}$ \\
$\mathbf{A}$ \\
$\mathbf{J}$ \\
$\mathbf{b}$ \\
$\mathbf{H}$ \\
$\mathbf{O}$ \\
$\mathbf{I}$ \\
$\mathbf{I}$ \\
$\mathbf{O}$ \\
$\boldsymbol{J}$ \\
$\mathbf{I}$ \\
$\mathbf{T}$ \\
$\mathbf{U}$ \\
\hline
\end{tabular}
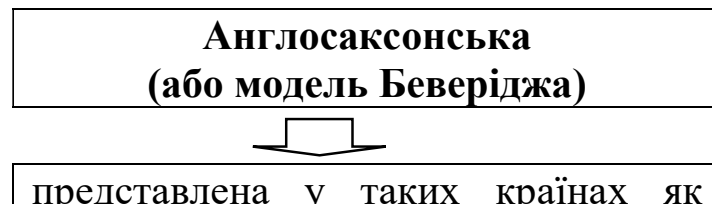

Великобританія та Ірландія.

Модель базується на таких принципах:

1) принцип загальності (універсальності) системи соціального захисту - поширення ii на всіх нужденних у матеріальній допомозі громадян;

2) принцип однаковості й уніфікації соціальних послуг і виплат виражається в однаковому розмірі пенсій, допомог і медичного обслуговування, а також умов їхнього надання;

3) принцип розподільної справедливості - наріжний у даній модель. Тут мова йде не про професійну солідарність як у моделі Бісмарка, а про солідарність на національному рівні.

\section{Рис. 10.2.5. Характеристики континентальної та англосаксонської}

\section{моделі соціальної політики}

Джерело: власне узагальнення.

А. Скуратівським, О. Палій, Е. Лібановою були наведені детальні характеристики основних моделей [538]. Варто зазначити, що ці дві моделі практично реалізуються у наступних 3-х моделях:

1. Консервативна модель. Її ідеологічну основу становить ідея виправдання соціальної диференціації в суспільстві. Майнова нерівність розцінюється як цілком природне і нормальне явище. Головна ж місія держави - через гнучку податкову політику здійснювати перерозподіл доходів, водночас надаючи компенсацію за допомогою трансфертів тим прошаркам, які їі потребують [538].

2. Ліберально-демократична модель. Усі фактори - законодавство, 
власність, ринкова економіка - в державі $€$ механізмами координації індивідуальних інтересів. В ідеалі держава бере на себе функцію стимулятора індивідуальної активності, заохочуючи своїх громадян до пошуку роботи, соціального захисту, підприємницької ініціативи. Правова база ліберальної моделі соціальної політики сфокусована на громадянських правах, зокрема на рівноправності громадян незалежно від расових, етнічних, статевих та інших ознак. Свою головну місію держава вбачає в охороні прав людини, тоді як охорона соціальних прав значною мірою перекладається на громадські організації й саму особистість. Пріоритетними у таких суспільствах $\epsilon$ громадянські, політичні, а лише потім - соціальні права [538].

3. Соціал-демократична модель акцентує увагу на запобіганні різкій диференціації найвищого та найнижчого рівня доходів. Серед управлінських важелів вагомими є самоврядні структури. Соціальні гарантії грунтуються як на державній, так і на недержавній підтримці. У функціональному відношенні державна політика спрямована на забезпечення всіх громадян роботою. Зайнятість утворює стабільну податкову базу. Рівень оподаткування загалом значно вищий, ніж, скажімо, в ліберальній моделі. Це й дає змогу державі здійснювати перерозподіл бюджету, забезпечуючи громадян соціальною допомогою. Правові пріоритети даної моделі зосереджені на соціальних правах як на головній меті соціальної політики [538]».

П. Спікер [548] дійшов висновку про те, що особливу значимість має формування та використання різноманітних й взаємопов'язаних механізмів соціальної політики державою. Механізм соціальної політики має чітке обгрунтування та направленість - гарантувати відповідний рівень життя населенню та дотримання соціальної справедливості щодо розподілу національного доходу через затвердження мінімального гарантованого рівня оплати плати, що повинен забезпечити:

- $\quad$ набір товарів основної групи та послуги для фізіологічних i соціальних потреб; 
- визнання власних доходів джерелом основного благополуччя;

- забезпечення безпеки та рівноваги в екологічному напрямку;

- збереження генофонду нації;

- формуванню системи пільг i компенсацій, що $є$ дієвими та обгрунтованими, а також збільшення розмірів допомоги тих, хто її потребує;

- забезпечення доступної та безоплатної повної загальної середньої освіти, а також професійно-технічної освіти;

- розвиток соціальної інфраструктури за рахунок держави;

- проведення активних заходів політики щодо набуття громадянами нових спеціальностей, підвищенню їх кваліфікації та перенавчанню.

Механізм здійснення соціальної політики держави представлено на рисунку 10.2.6.

\begin{tabular}{|c|c|c|c|c|}
\hline \multicolumn{5}{|c|}{ Механізми соціальної політики } \\
\hline 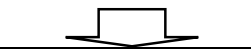 & $\sqrt{2}$ & $\square$ & 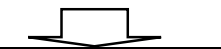 & 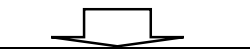 \\
\hline $\begin{array}{l}\text { Нормативно } \\
\text {-законодавче } \\
\text { регулювання }\end{array}$ & $\begin{array}{c}\text { Інструменти } \\
\text { та стимули } \\
\text { податкового } \\
\text { регулювання }\end{array}$ & $\begin{array}{c}\text { Фінансовий } \\
\text { механізм } \\
\text { регулювання }\end{array}$ & $\begin{array}{c}\text { Адміністра- } \\
\text { тивний } \\
\text { ресурсний }\end{array}$ & $\begin{array}{c}\text { Методи } \\
\text { політичного } \\
\text { регулювання }\end{array}$ \\
\hline
\end{tabular}

\section{Рис. 10.2.6. Механізми соціальної політики}

Джерело: власна розробка.

П. Спікер стверджував, що «до основних механізмів соціальної політики належать:

1. Законодавча та нормативна база, яка формується законодавчою владою у суспільстві та визначає загальні напрями соціальної політики;

2. Фінансовий механізм - визначається законодавчою та виконавчою владою та встановлює порядок формування та використання фінансових ресурсів, які необхідні для забезпечення заходів соціальної політики;

3. Податкові інструменти та стимули - використовуються 3 метою зацікавленості роботодавців у сприянні проведенню та реалізації соціальної політики, домогосподарств - у підвищенні рівня економічної самостійності, соціальної захищеності, які забезпечуються власними силами;

4. Адміністративний ресурс або адміністративні рішення, що використовує 
влада різних рівнів для підвищення рівня соціальної підтримки населення поряд із заходами, які передбачені законодавством країни;

5. Політичні методи - спрямовані на організацію та проведення мітингів, страйків, учасники яких висувають соціально-економічні вимоги, лобіювання конкретних рішень із соціальної політики [548, с. 28]».

Держава є головним учасником розробки і реалізації соціальної політики, тому активно використовує державні інструменти. На рисунку 10.2.7 наведені інструменти соціальної політики.

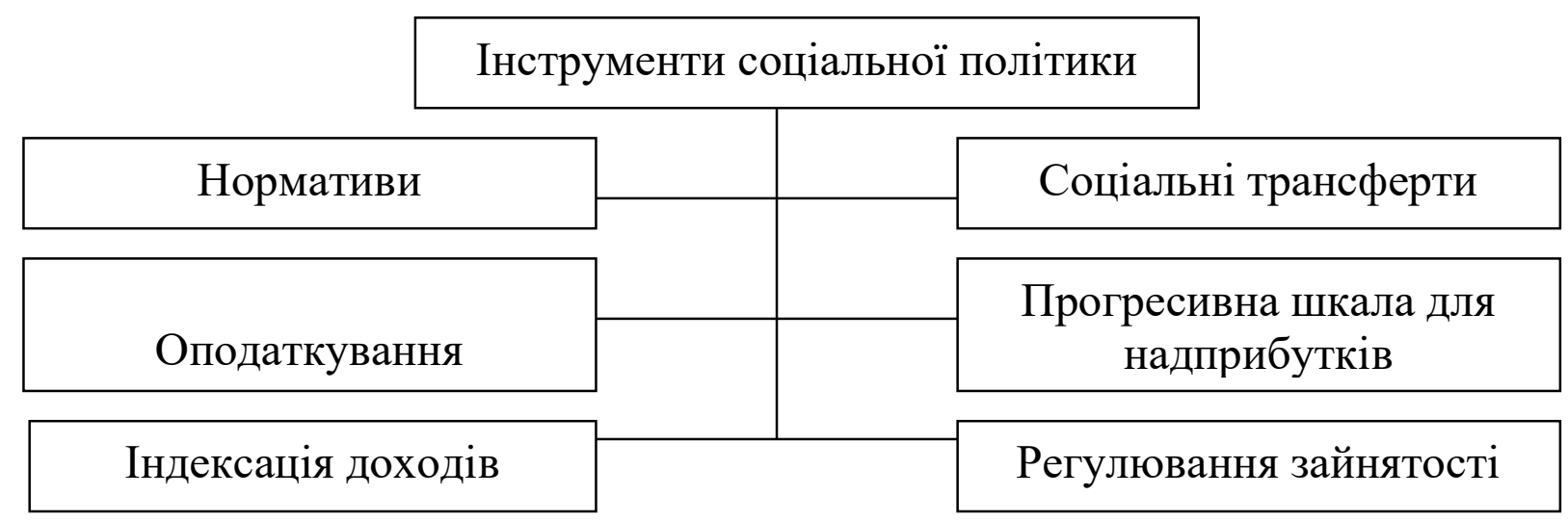

Рис. 10.2.7. Інструменти соціальної політики

Джерело: власна розробка.

О. Сергієнко дійшов висновку, що «серед цих інструментів найважливішу роль відіграють такі:

- нормативи, що визначають мінімальні стандарти споживання і діють як законодавчо встановлені й обов'язкові (величина прожиткового мінімуму, мінімальна зарплата і пенсія, гарантований мінімум послуг охорони здоров'я, житла тощо);

- соціальні трансферти, тобто різні засоби перерозподілу прибутків (регіональні субвенції, соціальні виплати і т. ін.);

- оподаткування, що стимулює створення нових робочих місць;

- уведення прогресивної шкали для надвисоких прибутків;

- індексація доходів - тобто збільшення їхнього номінального обсягу для запобігання зниження реального їхнього рівня. Індексація здійснюється шляхом регулювання номінальної зарплати, прибутків, процентних ставок. Індексація 
може йти за підвищенням цін або випереджати його.

- регулювання зайнятості - це здійснюваний державою за допомогою всіх юридичних засобів владний вплив на суспільні відносини в сфері зайнятості населення з метою їх упорядкування, закріплення, охорони та розвитку [536, с. $35] \gg$.

Отже, соціальна політика має розглядатися як правова політика, що орієнтована на людину, на ії добробут, безпеку та розвиток. Соціальна функція суб'єктів соціальної політики - державних та суспільних інститутів - не має обмежуватися лише турботою про соціально вразливі верстви населення, а бути спрямованою на все суспільство, тобто на усі суспільні потреби та вимоги людини. Оскільки соціальна політика в умовах сьогодення охоплює усі сфери суспільного життя, то вона набуває першочергового значення, а економічна та інші сфери діяльності уряду та державних органів повинні соціальні цілі ставити на перше місце, а не навпаки.

«Реалізація соціальної політики грунтується на основні забезпечення відповідного рівня життя населення і дотримання соціальної справедливості при розподілі національного доходу на основі встановлення мінімального рівня заробітної плати [536, с. 34]». Вона спроможна забезпечити суспільству підтримку економічної конкуренції завдяки соціальній злагоді, стабільності та правовим нормам, а також досягти економічного успіху через підвищення рівня продуктивності, творчу ініціативність та громадську довіру. Формується ефективна соціальна політика за рахунок такого:

- спрямовування на збереження та відтворення трудового потенціалу;

- запобігання високому рівню безробіття;

- запобігання занепаду соціальної сфери (об'єкти соціальної інфраструктури - охорона здоров'я, освіта, культура та інші).

Отже, лише поєднуючи соціальну політику з механізмом економічного зростання, можна посилити її роль у суспільстві.

Особливістю соціальної політики є наявність двох основних етапів:

1) стадії формування соціальної політики передбачає дотримання таких 
основних принципів: обгрунтованості - для забезпечення цілей, напрямів та задач необхідними ресурсами; реалістичності - орієнтація на пріоритетні соціальні проблеми. Перша стадія завершується прийняттям відповідного законодавчо-нормативного документу.

2) стадії реалізації соціальної політики передбачає дотримання таких основних принципів: конкретизації - відповідності соціально-економічних програм соціально-економічному плануванню; результативності - досягне-ння реалістичних результатів у визначений період. Для подолання соціальних проблем у суспільстві потрібна розробка та реалізація соціальної стратегічної програми, яка б була зрозумілою населенню з метою ії підтримки ним та здатної відновити довіру до влади. Основними причинами нереалізованості частини або повного варіанту соціально-економічних програм соціальної політики $є$ необгрунтованість і нереалістичність поставлених завдань.

Формування та реалізація соціальної політики має сприяти створенню середнього класу, забезпечення високих життєвих стандартів та рівня якості життя, а це можливо за умов досягнення довготривалої стратегічної мети соціальної політики. Схема формування та реалізації соціальної політики наступна (рис. 10.2.8):

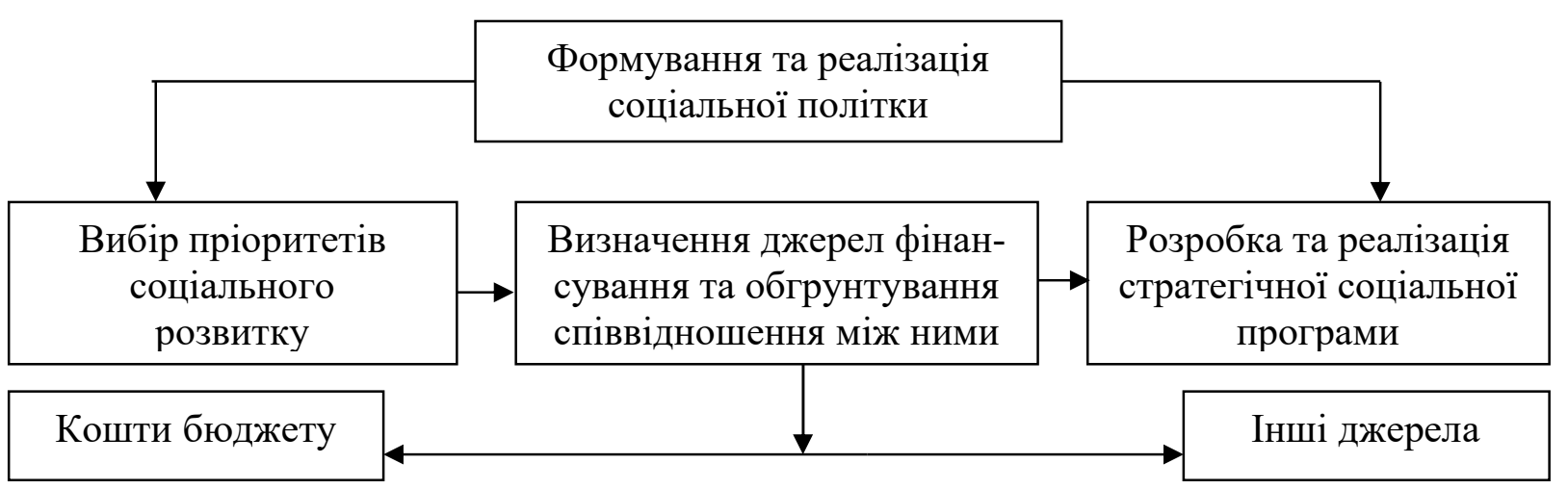

Рис. 10.2.8. Формування та реалізація соціальної політки

Джерело: [556], власне узагальнення.

Поняття «якість життя» значно ширше, ніж поняття «рівень життя», яке визначається, як правило, рівнем споживання благ і послуг матеріального характеру та величиною доходів населення. До якості життя належить таке: обсяг і характер зайнятості; умови праці; рівень освіти; забезпеченість житлом; 
система соціального забезпечення; екологічні умови життя.

Показники якості життя тісно пов'язані з параметрами якості самого населення, становищем генофонду, які включають фізіологічні та соціальноетичні характеристики. Тому, чітке визначення структурних елементів, що характеризують якість і рівень життя, - $є$ початковим пунктом вироблення обгрунтованої соціальної стратегії і політики, яка побудована на програмі подолання різкого зниження якості життя громадян.

До важливих стратегічних орієнтирів соціальної політики відноситься мотиваційне стимулювання активності (економічної) людини, створення передумов для iї ініціативності, розвитку енергій та здібностей, відкриття нових можливостей, що здатні забезпечити через працю гідний рівень життя. Така стратегічна направленість потребує значних зрушень у громадській свідомості і системі цінностей суспільства та подолання багаторічних стереотипів й звичок розраховувати не на свої сили, а на владу.

Не лише рівня та якості життя стосуються соціальні пріоритети. Сфери охорони здоров'я, культури, екології теж відносяться до них. Для їх визначення необхідним $\epsilon$ таке: визначення співвідношення між бюджетними i не бюджетними коштами; розмежування сфер застосування прямих і непрямих методів державного регулювання; розробки соціальних програм, що передбачають структурну переорієнтацію економіки на виробництво для збільшення споживання, розвитку житлового будівництва, охорони здоров'я, природоохоронних заходів.

Після вибору соціальних пріоритетів визначають джерела фінансування та співвідношення між ними. Джерелами фінансування можуть бути бюджетні та позабюджетні кошти: Бюджетні кошти включають кошти державного бюджету, регіональних та місцевих бюджетів, а також ресурси міжбюджетного перерозподілу, які підуть на видатки на соціальний захист і соціально-культурну інфраструктуру.

«Видатки на соціальний захист та соціальне забезпечення включають: виплату пенсій і допомоги; пільги ветеранам війни і праці; допомогу сім'ям 3 
дітьми; інші види соціальної допомоги; пенсії військовослужбовцям та особам начальницького і рядового складу; фінансування дитячих закладів-інтернатів, притулків для неповнолітніх, програм соціального захисту непов-нолітніх, будинків-інтернатів для пристарілих та інвалідів, інших закладів і заходів у галузі соціальної політики, молодіжних програм; кошти з бюджету, що передаються до Фонду соціального захисту інвалідів України [18]».

До державної соціальної допомоги громадянам належить щомісячна адресна готівкова грошова субсидії, що має відшкодувати витрати за плату й користування житлом та витрати на комунальні послуги - водо-, тепло-, газопостачання, водовідведення, електроенергія, вивезення побутового сміття та рідких нечистот, а також раз на рік субсидія на придбання скрапленого газу, твердого чи рідкого пічного побутового палива.

Видатки на соціальну сферу включають виділення коштів на освіту (загальноосвітні школи, школи-інтернати, дошкільні заклади, професійнотехнічні училища, заклади післядипломної освіти); охорону здоров'я (медичні установи, санітарно-епідеміологічна служба); культуру (театри, бібліотеки, музеї, заповідники); ЗМІ - телебачення і радіомовлення, книговидання, преса,та ін.; фізичної культури і спорту.

До позабюджетних коштів належать кошти державних соціальнострахових фондів, регіональних позабюджетних фондів, територіальні займи, кошти недержавних соціальних фондів, кредитні ресурси і грошовий потенціал некомерційних неурядових установ. Ці кошти формуються за рахунок страхових платежів, обов'язкових страхових внесків працюючих громадян, інших джерел (асигнування і дотації з держбюджету). До державних соціальних страхових фондів відносять: Фонд зайнятості, Пенсійний фонд, Фонд соціального страхування, Фонд страхування на випадок травматизму i професійної захворюваності.

Отже, лише після обгрунтованого визначення джерел фінансування соціальної політики та співвідношення між ними, можна розпочати роботу щодо розробки та реалізації соціальної програми. 
Реалізовується соціальна політика вона за напрямами, представленими на рисунку 10.2.9 та у таблиці 10.2.1.

Напрямами формування та реалізації соціальної політики

\begin{tabular}{|c|c|}
\hline $\begin{array}{c}\text { Забезпечення цільового характеру } \\
\text { пільг соціального спрямування }\end{array}$ & Впровадження пенсійної реформи \\
\hline $\begin{array}{l}\text { Посилення впливу держави на розподіл } \\
\text { доходів через фіскальні механізми }\end{array}$ & $\begin{array}{c}\text { Стимулювання розвитку } \\
\text { національного виробництва }\end{array}$ \\
\hline $\begin{array}{c}\text { Активізація державної політики на } \\
\text { ринку праці }\end{array}$ & $\begin{array}{c}\text { Заохочення й розвиток соціальної } \\
\text { відповідальності бізнесу }\end{array}$ \\
\hline $\begin{array}{c}\text { Заохочення підприємств до дій шодо } \\
\text { підвишення продуктивності праці та } \\
\text { збільшення доходів працюючих }\end{array}$ & $\begin{array}{c}\text { Підвишення ефективності } \\
\text { використання бюджетних впдатків на } \\
\text { соціальну сферу }\end{array}$ \\
\hline
\end{tabular}

Рис. 10.2.9. Напрямами формування та реалізації соціальної політики Джерело: [561, с. 89]

Таблиця 10.2.1

\section{Напрями формування та реалізації соціальної політики}

\begin{tabular}{|l|l|}
\hline Напрямам & Характеристика напряму \\
\hline $\begin{array}{l}\text { Забезпечення } \\
\text { цільового } \\
\text { характеру пільг } \\
\text { соціального } \\
\text { спрямування: }\end{array}$ & $\begin{array}{l}\text { виключення користуванням пільг особами, які не мають потреби в їх } \\
\text { отриманні через монетизацію частини пільг; нормування пільг 3 } \\
\text { реєстру пільговиків, єдиного електронного обліку прав на отримання } \\
\text { пільг, дохідного цензу. }\end{array}$ \\
\hline $\begin{array}{l}\text { Впровадження } \\
\text { пенсійної } \\
\text { реформи: }\end{array}$ & $\begin{array}{l}\text { формування механізмів інвестиційного використання коштів } \\
\text { пенсійних фондів, державний нагляд-контроль та гарантуванням } \\
\text { надійності їхніх вкладень. }\end{array}$ \\
\hline $\begin{array}{l}\text { Посилення } \\
\text { впливу держави } \\
\text { на розподіл } \\
\text { доходів через } \\
\text { фіскальні } \\
\text { механізми: }\end{array}$ & $\begin{array}{l}\text { вилучення та перерозподіл частини отримуваних в суспільстві } \\
\text { завдяки продуктивності, а через недосконалість ринків. Це можливе за } \\
\text { рахунок запровадження: прогресивної ставки прибуткового } \\
\text { оподаткування громадян; оподаткування нерухомості; впорядкування } \\
\text { розрахунку величини та сплати рентних платежів за використання } \\
\text { надр, аграрних, природно-кліматичних, рекреаційних ресурсів. }\end{array}$ \\
\hline
\end{tabular}




\begin{tabular}{|c|c|}
\hline $\begin{array}{l}\text { Стимулювання } \\
\text { розвитку } \\
\text { національного } \\
\text { виробництва: }\end{array}$ & $\begin{array}{l}\text { спрощення умов для довгострокового кредитування інвестиційних } \\
\text { проектів; розбудова інфраструктури внутрішнього ринку; підтримка } \\
\text { вітчизняного виробника щодо виробництва того, що потребує } \\
\text { споживач. }\end{array}$ \\
\hline $\begin{array}{l}\text { Активізація } \\
\text { державної } \\
\text { політики на } \\
\text { ринку праці: }\end{array}$ & $\begin{array}{l}\text { забезпечення державного замовлення на підготовку фахівців; } \\
\text { запровадження механізмів перепідготовки працівників; підвищення } \\
\text { територіальної мобільності працівників; розширення мережі } \\
\text { соціальних робіт для вивільнених працівників. }\end{array}$ \\
\hline $\begin{array}{l}\text { Заохочення й } \\
\text { розвиток } \\
\text { соціальної } \\
\text { відповідальності } \\
\text { бізнесу: }\end{array}$ & $\begin{array}{l}\text { запровадження фіскальних засобів заохочення соціальної } \\
\text { відповідальності бізнесу та міжнародних соціальних стандартів } \\
\text { ведення бізнесу; пропагування цінностей та стандартів соціально } \\
\text { відповідального бізнесу; державна підтримка національних і } \\
\text { міжнародних ініціатив щодо соціальної відповідальності. }\end{array}$ \\
\hline $\begin{array}{l}\text { Підвищення } \\
\text { ефективності } \\
\text { використання } \\
\text { бюджетних } \\
\text { видатків на } \\
\text { соціальну сферу: }\end{array}$ & $\begin{array}{l}\text { передбачає модернізацію управління установами соціальної сфери; } \\
\text { запровадження страхових засад в наданні соціальних послуг; } \\
\text { раціоналізацію фінансових установ соціальної сфери; збільшення } \\
\text { інвестиційної складової соціальних видатків для уникнення } \\
\text { непоправних втрат соціальної інфраструктури; диверсифікацію } \\
\text { надавачів соціальних послуг. }\end{array}$ \\
\hline $\begin{array}{l}\text { Заохочення } \\
\text { підприємств до } \\
\text { дій щодо } \\
\text { підвищення } \\
\text { продуктивності } \\
\text { праці та } \\
\text { збільшення } \\
\text { доходів } \\
\text { працюючих }\end{array}$ & $\begin{array}{l}\text { формуванням нового мислення керівників і стилю управління щодо } \\
\text { підвищення ефективності використання усіх видів ресурсів, які задіяні } \\
\text { у виробничому процесі, підвищення якості продукції і зростання } \\
\text { обсягу виробництва на одиницю ресурсів; забезпечення динамічної } \\
\text { рівноваги між результатами праці і винагородою, між потребами } \\
\text { різних груп носіїв інтересів на підприємстві використовуються } \\
\text { принципи системи мотивації праці персоналу підприємства, що } \\
\text { полягають в економічності, соціальному захисті та стабільності, } \\
\text { корпоративності. }\end{array}$ \\
\hline
\end{tabular}

Джерело: власне узагальнення.

Як правило, соціальна політика держави спрямована на соціально вразливі верстви населення. Соціальну роботу здійснюють державні структури, різні громадські організації та церковні громади. Їх діяльність направлені на соціально вразливі верстви населення. До них відносяться:

1) індивіди або соціальні групи, що мають ймовірність зазнати негативних впливів (соціальних, екологічних або дістати хвороби). Серед них виділяють такі категорії:

1.1) бездомні;

1.2) родини з проблемами дитячої занедбаності, сексуальних зловживань 
у родині;

1.3) подружні пари, які мають серйозні подружні конфлікти;

1.4) родини, де дитину виховує лише один із батьків та де є конфлікти;

2) ВІЛ-інфіковані люди та їхні родини;

3) Особи з низькими доходами через відсутність постійної роботи, відсутністю годувальника, фізичними вадами, низький рівень професійної підготовки тощо;

4) особи, які порушили закон, були визнаними винними та несуть покарання;

5) вагітні дівчата-підлітки;

6) сексуальні меншини, які мають особисті або сімейні проблеми;

7) особи, які мають тілесні або психічні захворювання, або мають інвалідність;

8) залежні від алкоголю, наркотиків та їхні родини;

9) іммігранти та національні меншини, жертви расизму та дискримінації;

10) особи із затримками розвитку (інваліди розвитку) та їхні родини;

11) літні люди, які не можуть адекватно функціонувати;

12) мігранти та біженці, які мають недостатні необхідні ресурси;

13) проблемні діти та їхні родини;

14) особи, що перебувають постійному стресі або перенесли травмуючі події (наприклад, вихід на пенсію чи смерть близької людини), а також бездомні діти.

До категорій громадян, що не можуть конкурувати на ринку праці, належать:

1) молодь, яка закінчила чи припинила навчатися у середніх загальноосвітніх школах, професійно-технічних закладах, а також звільненні зі строкової військової;

2) діти-сироти, діти, батьки яких про них не піклуються, а також особи, 
що не досягли 18 років, але змушені працювати;

3) жінки, які мають дітей віком до шести років;

4) матері-одиначки, що мають малолітніх дітей або дітей інвалідів;

5) багатодітні сім'ї;

6) неповні сім’ї та сім'ї з дітьми;

7) інваліди;

8) особи передпенсійного віку тощо.

Соціальна політика не повинна визначатися лише підтримкою малозабезпечених прошарків населення, але має передбачати і захист осіб, що беруть участь у суспільному виробництві - людей, що працюють за наймом, тобто економічно активне населення. Соціальний захист економічно активного населення має формуватися як багаторівнева та організована система заходів, які спрямовані щодо мінімізації соціальної напруги, конфліктів і суперечностей соціального характеру в суспільстві, i, як наслідок, на забезпечення ефективного розвитку економіки. Ефективний захист та якісна підтримка населення соціального характеру $є$ основою економічного зростання. Соціальний захист економічно активного населення має передбачати такі дії держави, які спрямовані на гарантії у сфері зайнятості населення через регламенти праці у формі законів: тривалість робочого тижня, охорони праці, тривалості та порядку надання відпусток; оплату праці працівників через установлення мінімальних ставок заробітної плати; гарантування прав працівників при прийомі на роботу $\mathrm{i}$ звільненні. Ця сторона соціальної політики теж обумовлена рівнем економічного розвитку країни, співвідношенням політичних сил i рівнем суспільної самосвідомості.

Соціальний захист забезпечують і підприємства (або підприємці), і самі наймані робітники через систему соціального страхування - пенсійного, медичного, від безробіття, від нещасливих випадків на виробництві. Крім того, важливою ланкою соціального захисту населення є програми працевлаштування і перекваліфікації.

Отже, наявність дієвої та ефективної системи соціального захисту - це 
головні ознаки рівня розвитку держави, ії відповідності вимогам сьогодення. Вищий рівень життя членів суспільства підтверджує розвиток самого суспільству. Прагнення України інтегруватися в Європейську співдружність країн не може мати перспектив без розробки комплексу правових, економічних, організаційних заходів як державних, так і недержавних організацій, що спроможні впливати та сприяти підтриманню соціальної стабільності в суспільстві, зростанню добробуту населення, забезпеченню належного рівня та якості життя населення.

Соціальною політикою прийнято вважати діяльність різних суб'єктів соціальної політики, яка спрямована на задоволення соціальних потреб як суспільства, так і окремої людини. При цьому, реалізація соціальних потреб, які мають забезпечити життєдіяльність та розвиток соціальної сфери, мають грунтуватися на безкомпромісному дотриманні основних громадянських прав та свобод, а також здійснюватися на засадах соціальної справедливості.

У Конституції України зазначено:

«Стаття 46. Громадяни мають право на соціальний захист, що включає право на забезпечення їх у разі повної, часткової або тимчасової втрати працездатності, втрати годувальника, безробіття з незалежних від них обставин, а також у старості та в інших випадках, передбачених законом.

Стаття 47. Кожен має право на житло. Громадянам, які потребують соціального захисту, житло надається державою та органами місцевого самоврядування безоплатно або за доступну для них плату відповідно до закону. ... Ніхто не може бути примусово позбавлений житла інакше як на підставі закону за рішенням суду.

Стаття 48. Кожен має право на достатній життєвий рівень для себе і своєї сім'ї, що включає достатнє харчування, одяг, житло.

Стаття 49. Кожен має право на охорону здоров'я, медичну допомогу та медичне страхування. Охорона здоров'я забезпечується державним фінансуванням відповідних соціально-економічних, медико-санітарних і 
оздоровчо-профілактичних програм. 1

Стаття 50. Кожен має право на безпечне для життя і здоров'я довкілля та на відшкодування завданої порушенням цього права шкоди. Кожному гарантується право вільного доступу до інформації про стан довкілля, про якість харчових продуктів і предметів побуту, а також право на ï поширення.

Стаття 53. Кожен має право на освіту. Повна загальна середня освіта $€$ обов'язковою. Громадяни мають право безоплатно здобути вищу освіту в державних і комунальних навчальних закладах на конкурсній основі.

Стаття 56. Кожен має право на відшкодування за рахунок держави чи органів місцевого самоврядування матеріальної та моральної шкоди, завданої незаконними рішеннями, діями чи бездіяльністю органів державної влади, органів місцевого самоврядування, їх посадових і службових осіб при здійсненні ними своїх повноважень [513]».

Державне управління соціальною політикою здійснюють Кабінет Міністрів України «Пункт 3 ст. 116 Конституції України фіксує функцію Кабінету Міністрів України по забезпеченню проведення фінансової, цінової, інвестиційної та податкової політики; політики у сферах праці й зайнятості населення, соціального захисту, освіти, науки і культури, охорони природи, екологічної безпеки і природокористування [513]». А також іiі здійснюють місцеві державні адміністрації, органи місцевого самоврядування та їх виконавчі й розпорядчі органи та інші.

Держава в реалізації соціальної політики виступає гарантом соціального й законодавчого порядку та способів їх забезпечення. Зокрема, Конституція України гарантує вище згадані права на свободу думки, працю, добровільного вибору професії та роду трудової діяльності, отримання якісної освіти та медичної допомоги. Держава не лише гарантує соціальні права, а й несе відповідальність перед населенням за їх забезпечення та формування гідного рівня життя.

Конституція України детально відображає гарантії, які стосуються соціального розвитку держави та рівня життя іï населення, можемо сюди 
віднести наступні закони: «Кодекс законів про працю України»; «Про допомогу сім'ям 3 дітьми»; «Про зайнятість населення»; «Про колективні договори та угоди»; «Про межу малозабезпеченості»; «Про основи соціальної захищеності інвалідів в Україні»; «Про основні засади соціального захисту ветеранів праці та інших громадян похилого віку в Україні»; «Про охорону праці»; «Про пенсійне забезпечення військовослужбовців та осіб начальницького та рядового складу»; «Про сприяння соціальному становленню і розвитку молоді в Україні»; «Про статус і соціальний захист громадян, які постраждали внаслідок Чорнобильської катастрофи» і т.д. [508].

Систему уповноважених структур, які наділені компетенцією щодо вирішення питань соціального захисту, утворює Міністерство праці та соціальної політики України. Його функції прописані у Положенні про Міністерство праці та соціальної політики України (затверджено Указом Президента України від 30 серпня 2000 р. №1035/2000 (з наступними змінами i доповненнями)). Діяльність Міністерства праці та соціальної політики України координується Кабінетом Міністрів України. Основними завданнями даної структури є:

- формування та забезпечення реалізації державної соціальної політики у сферах, що визначені;

- забезпечення «реалізації права громадян на соціальний захист» шляхом надання соціальної підтримки;

- участь у розробленні «Проектів Державної програми розвитку України», «Державного бюджету України»;

- проведення різних моніторингів у соціальній сфері (праці, зайнятості, соціального захисту, соціального страхування, пенсійного забезпечення, соціального обслуговування);

- нагляд 3 боку держави щодо загальнообов'язкового державного соціального страхування, а також за додержанням вимог законодавства 3 питань 
призначення і виплати пенсій;

- розроблення соціальних стандартів і нормативів на рівні державних.

Органи місцевого самоврядування мають теж повноваження у сфері соціального захисту населення, а саме:

- можуть за рахунок власних коштів та благодійних надходжень встановлювати додаткові гарантії до вже встановлених гарантій у відповідності до законодавства щодо соціального захисту населення;

- вирішувати питання із наданням допомог соціально незахищеним верствам населення, які були визначені на рівні законодавства України.

Місцеві Ради депутатів та їхні виконавчі органи крім власних повноважень здійснюють і низку повноважень у сфері соціального захисту, які їм делеговані державою (ст. 34 Закону України «Про місцеве самоврядування в Україні»).

До державних страхових фондів передусім належить Пенсійний фонд України (ПФУ). ПФУ не відноситься до центральних органів виконавчої влади. Бюджет ПФУ затверджує КМУ. Питаннями щодо призначення різних пенсій та соціальних допомог займаються спеціальні відділи системи органів праці та соціального захисту, а також інші установами, діяльність яких врегульована спеціальними нормативно-правовими актами.

У сфері недержавного соціального забезпечення $\epsilon$ також інституції, діяльність яких регулюється Законом України «Про недержавне пенсійне забезпечення», щодо недержавного пенсійного забезпечення та надання соціальних послуг - це: недержавні пенсійні фонди; страхові організації; банківські установи, які уклали договори страхування про відкриття депозитних рахунків пенсійного призначення; недержавні комерційні організації суб'єктів, які надають послуги недержавного пенсійного забезпечення; консультаційні та агентські послуги щодо недержавного пенсійного забезпечення.

Правове регулювання відносин у сфері соціального захисту має певну особливість, яка обумовлена юридичним способом здійснення урегулювання цієї сфери. Мова йде про спеціальний вид соціально-захисної функції держави через затвердження соціальних стандартів та стандартизацію в цілому, які спрямовані 
на реалізацію права людини вимагати встановлення на державному рівні певних мінімальних стандартів як систему базових показників для визначення рівня їх забезпеченості.

Система стандартизації соціальних прав включає:

1) створення каталогу соціальних прав;

2) визначення змісту (елементів) кожного права;

3) встановлення державних гарантій забезпечення прав;

4) встановлення системи контролю за забезпеченням соціальних прав.

Правові основи соціальної стандартизації прописані у Законі України «Про державні соціальні стандарти та державні соціальні гарантії» [34], де, у відповідно до ст. 27, наказом Міністерства праці та соціальної політики України від 17 червня 2002 р. №293 затверджено «Державний класифікатор соціальних стандартів та нормативів». Його розроблено з метою забезпечення соціальних прав та державних соціальних гарантій достатнього життєвого рівня для кожного громадянина у відповідності до Конституції України через законодавчого визначені державні соціальні стандарти і нормативи. «Державний класифікатор соціальних стандартів та нормативів» ураховує диференціацію за соціальнодемографічною ознакою, підходами до визначення нормативів, науковим обгрунтуванням визначення норм споживання, гласністю, громадським контролем.

Головним призначенням затвердження державних соціальних стандартів та нормативів є визначення такого:

- алгоритму реалізації соціальних прав та державних соціальних гарантій громадян (що гарантуються статтями Конституції України);

- пріоритетів державної соціальної політики щодо забезпечення потреб людини (матеріальні блага та послуги, а також фінансові ресурси для їх забезпечення);

- обгрунтованих розмірів потреби в коштах Державного бюджету України, місцевих бюджетів, соціальних фондів на захист і утримання соціальної 
сфери.

Соціальним стандартом у сфері доходів населення, що є державним базовим, є прожитковий мінімум, а його правове регулювання здійснюється відповідним Законом України «Про прожитковий мінімум». На основі соціальних стандартів на визначаються мінімальний розмір заробітної плати, мінімальний розмір пенсії за віком, неоподатковуваний мінімум доходів громадян, розмір державної соціальної допомоги та інших соціальні виплати, що $€$ розмірами основних соціальних гарантій.

Верховна Рада України в 1993 р. затвердила «Концепцію соціального захисту населення» [528]. В документі вказано, що джерелом підвищення добробуту населення є ефективна праця, трудова активність населення та підприємницька ініціатива громадян. Також зазначається, такі зміни $є$ можливими на основі сталого розвитку трудового потенціалу та його ефективного використання й застосування. Однак, не все ж не варто забувати про те, що зростання рівня життя людини прямо пропорційно їі власним доходам. Тому головну роль держава має звертати саме на умови праці людей та винагороду за пророблену роботу, причому саме в державних стандартах та доходних мінімумах криється шлях до забезпечення соціальних гарантій та соціального захисту. Згідно Концепції соціального забезпечення населення України, система соціального забезпечення громадян та населення повинна формуватись так, щоб не породжувати утриманство при розподілі соціальних благ. А також щоб заохочувати і стимулювати до праці, й створювати умови для реалізації цієї концепції.

Отже, головним завданням управління державною соціальною політикою має стати:

- зміна існуючих умов соціального забезпечення на краще;

- створення превентивних засобів щодо упередження негативних соціальних явищ;

- зростання рівня добробуту населення та недопущення зниження індексу людського розвитку (або потенціалу), який є індикатором демографічної 
та соціально-економічної сфери.

Отже, основою для реалізації та здійснення соціальної політики в Україні має стати взаємна та колективна відповідальність, а також державна гарантія щодо забезпечення взаємних соціальних обов'язків: держава-населення, населення-держава. Окрім цього, соціальна політика має постійно коригуватися у відповідності до стану економічного розвитку, постійно забезпечувати позитивні зміни мінімальних стандартів рівня життя населення та сприяти розвитку соціальних та економічних інституцій. Роль держави, як суб'єкта соціальної політики, є визначальною та головною, але має підкріплюватися діяльністю інших інститутів громадянського суспільства, які виконують частину функціональних обов'язків. Головна особливість ролі держави проявляється в відповідальності за безпеку та стабільність в середині суспільства та проведення соціальної політики, оскільки держава володіє широким спектром повноважень, що дозволяють їй виконувати головну формувальну та забезпечувальну роль.

Досліджуючи теоретичні основи формування та реалізації соціальної політики були зроблені такі висновки:

1. Державна соціальна політика являє собою багаторівневу та багатофункціональну систему, яка здатна забезпечити ефективний соціальноекономічний розвиток країни шляхом залучення людського капіталу й трудових ресурсів через реалізації їх потенціалу.

2. Структура соціальної політики держави складається з іï суб'єктів, об’єктів, принципів функціонування та механізмів впровадження (суб'єкти соціальної політики перебувають в постійній взаємодії і ця взаємодія направлена на створення необхідних умов для іiї об'єктів).

3. Інститути соціальної політики сприяють захисту громадян та зростанню людського потенціалу, і для яких перші мають пріоритетне значе-ння через найбільшу близькість до вирішення потреб конкретних людей.

4. Ключовим механізмом реалізації соціальної політики є соціальне страхування, соціальні гарантії та послуг з боку держави та громадських організацій. Але даний механізм має ряд прогалин через його недосконалість та 
неузгодженість, що ускладнює соціальний захист населення.

5. Впровадження та реалізацію соціальної політики здійснює Міністерство соціальної політики, яке є уповноваженим центральним органом виконавчої влади із забезпечення рівних прав та можливостей щодо надання допомоги.

6. На шляху до вдосконалення системи соціального захисту населення одним 3 важливіших моментів має стати розширення його конкретизації та направленості. Але варто зазначити, що тільки на рівнях областей , районів, підприємств можна достовірно визначити на скільки людина, що звернулася за допомогою, насправді іï потребує.

Розділ 2. Оцінка соціальної політики як елемента інтегрального механізму покращення якості життя населення України. Сьогодні Україна знаходиться у відверто складних трансформаційних умовах - військові події на Сході країни, погіршення економічної ситуації, зростання соціальної напруги. Все це зменшує шанси на реалізацію соціальної політики та економічний розвиток. Досягнення економічного та демографічного розвитку $є$ неможливим без потужної та структурно розвиненої соціально-економічної бази.

«Якість життя» відноситься до комплексного поняття, що враховує має враховувати різні аспекти людського життя ,а з точки зору оцінювання - це $\epsilon$ багатовимірна величина. Для забезпечення адекватної оцінки, іï будують шляхом використання національної матриці індикаторів, які максимально адаптовані до державної статистики. Національна матриця індикаторів може включати показники, які даний час не розраховуються, але можуть бути розрахованими. Крім того, вона повинна забезпечити можливість міжнародних порівнянь. Кожен індикатор розглядається $з$ двох боків:

- за джерелом отримання (об'єктивний чи суб'єктивний);

- як характеристика певної середовища життєдіяльності.

Для забезпечення рівня якості життя населення відповідного рівня зусилля спрямовуються $з$ двох боків:

- діяльність держави щодо забезпечення належного рівня якості життя 
населення;

- безпосередні зусилля громадян.

Такий поділ є умовним, оскільки, з одного боку - діяльність держави має обмежені можливості через стан економіки та населення, яке має особливості у його характеристиці: статевовіковій структурі, поведінці на ринку праці тощо; а 3 іншого боку - активність населення суспільно-економічного характеру грунтується на тих «правилах гри», які пропонує держава.

Отже, якість життя забезпечується як державою так i населенням. Ефективність зусиль держави $є$ меншою, ніж самого населення, тобто, економічне зростання та збільшення фінансування певних програм, які мають ефективність не завжди, призводить до певного зростання якості життя, а от зростання доходності громадян - завжди перетворюється у підвищення якості життя. Разом з тим, кожна людина як особистість має свою уяву про якість життя та можливості щодо іiі забезпечення у конкретних умовах існування. Тому, при розробці національної матриці індикаторів якості життя виокремили три блоки показників:

- блок 1: кількісно описує зовнішне середовище, характеризує досягнутий стан, в якому відбувається життя людини, і здійснює оцінку якості життя;

- блок 2: забезпечує оцінку поточного стану якості життя, який має бути сформований як результат спільного впливу держави та населення;

- блок 3: показники, що відбивають суб’єктивну оцінку стану якості життя самим населенням, які характеризують якість життя 3 точки зору індивідуума, його сприйняття доступності різних ресурсів та можливості щодо їх використання.

Лише при оптимальній збалансованості компонентів усіх трьох вказаних блоків можна досягти високого рівня якості життя. Доступність чинників якості життя може забезпечити високу статусність та високу самооцінку досягнутого статусу, а можливі дисбаланси за трьома компонентами вказують на проблеми щодо досягнення високої якості життя. Об'єктивні та суб'єктивні оцінки 
об’єднуються і можуть дати чотири варіанти розвитку подій (табл. 10.2.2):

Таблиця 10.2.2

Матриця стану якості життя населення

\begin{tabular}{|c|c|c|}
\hline Суб’єктивна & \multicolumn{2}{|c|}{ Об’єктивна } \\
\hline оцінка & добре & погано \\
\hline добре & БЛАГОПОЛУЧЧЯ. & $\begin{array}{c}\text { АДАПТАЦІЯ. } \\
\text { («щасливі бідні люди») }\end{array}$ \\
\hline \multirow{2}{\text{погано}}{} & $\begin{array}{c}\text { ДИСОНАНС. } \\
\text { Невідповідність очікуваної і } \\
\text { отриманої якості життя }\end{array}$ & ВІДТОРГНЕННЯ. \\
\hline
\end{tabular}

Джерело: [564].

Залежно від сфер людської життєдіяльності диференціюються характеристики середовища життя. Виділяють природне, соціальне, економічне та суспільно-політичне середовище, а у відповідності до специфіки впливу цих середовищ на якість життя, розрізняють чотири підсистеми якості життя: якість громадського, трудового, сімейного та особистого життя (рис. 10.2.10).

\begin{tabular}{|l|c|c|c|}
\hline \multicolumn{5}{|c|}{ СЕРЕДОВИЩЕ } \\
\hline економічне & природне & суспільно-політичне & соціальне \\
\hline \multicolumn{4}{|c|}{ ЯКІСТЬ ЖИТТЯ } \\
\hline громадського & трудового & сімейного & особистого \\
\hline \multicolumn{2}{|c|}{ ПІДСИСТЕМИ } \\
\hline
\end{tabular}

Рис. 10.2.10. Середовище та підсистеми якості життя населення

Джерело: розроблено автором на основі узагальнення.

Отже, при формуванні національної матриці індикаторів якості життя, виділяють блоки стану, поточної ситуації, суб'єктивної оцінки, а також чотири природне, соціальне, економічне, суспільно-політичне середовища (три останні середовища мають свої субсередовища). Блоки, середовища та їх структурні елементи наведені дозволяють мати чітку уяву про те, чому конкретні особливості життєдіяльності населення, умови проживання та стан населення $є$ саме такими, а не іншими. Оцінка якості життя має грунтуватися на існуючих сучасних концепціях та теоріях, які дозволяють отримати чіткі відповіді та 
пояснити вплив процесу соціально-економічного розвитку та результати.

Таким чином, до основних принципів, які мають застосовуватися до оцінки якості життя населення $\epsilon$ : системність оцінки; комплексність оцінки; динамічність оцінки; підбір універсальних показників оцінки; урахування особливостей минулого періоду; застосування гендерно-вікового підходу для того, щоб краще осмислили специфіку соціального розвитку. Принципи вимірювання якості життя, передбачають, що вимірювання повинно складатися 3 інтегрального індексу та набору субіндексів, які утворюють відповідно до структури системи показників. Тобто, загальна оцінка є інтеграційною від часткових оцінок. Звідси виникає питання - що таке елементарний індекс, який би, по-перше, розраховувався на основі визнаного набору показників, а, подруге, слугував складовою для розрахунку субіндексів та інтегрального індексу. «Розрахунок індексу структурного елементу матриці має свою послідовність передбачає три етапи: нормування показників; визначення ваг показників; розрахунок індексу [564]».

«Індекс структурного елементу матриці розраховується за формулою:

$$
\mathrm{I}=\Sigma\left(\mathrm{Z}_{\mathrm{i}} \times \mathrm{W}_{\mathrm{i}}\right)
$$

де, $\mathrm{Z}_{\mathrm{i}}$ - нормоване значення i-го показника; $\mathrm{W}_{\mathrm{i}}$ - вага $\mathrm{i}-$-го показника [564]».

В Україні сформована своя національна матриця індикаторів для визначення якості життя (табл. 10.2.3). 
Таблиця 10.2.3

Національна матриця індикаторів якості життя населення в Україні

\begin{tabular}{|c|c|c|c|}
\hline \multicolumn{4}{|c|}{ ЯКІСТЬ ЖИТТЯ } \\
\hline \multirow{3}{*}{$\begin{array}{c}\text { Середовище } \\
\text { (субсередовище) }\end{array}$} & \multicolumn{3}{|c|}{ Блоки } \\
\hline & \multicolumn{2}{|c|}{ Об’єктивна оцінка } & Суб’єктивна \\
\hline & стан & поточна ситуація & оцінка \\
\hline \multicolumn{4}{|c|}{ Природне середовище } \\
\hline Екологія & Природне середовище & Екологічна ситуація & $\begin{array}{c}\text { Оцінка екологічної } \\
\text { ситуації }\end{array}$ \\
\hline \multicolumn{4}{|c|}{ Соціальне середовище } \\
\hline Здоров'я & $\begin{array}{l}\text { Система охорони } \\
\text { здоров'я }\end{array}$ & Здоров’я населення & $\begin{array}{c}\text { Оцінка системи охорони } \\
\text { здоров'я та власного } \\
\text { здоров’я }\end{array}$ \\
\hline Освіта & Система освіти & Освіта населення & $\begin{array}{c}\text { Оцінка системи освіти та } \\
\text { власної освіти }\end{array}$ \\
\hline Безпека & $\begin{array}{l}\text { Криміногенне } \\
\text { середовище }\end{array}$ & $\begin{array}{l}\text { Криміногенна } \\
\text { ситуація }\end{array}$ & $\begin{array}{c}\text { Оцінка особистої } \\
\text { безпеки }\end{array}$ \\
\hline $\begin{array}{l}\text { Культура, } \\
\text { мистецтво, } \\
\text { відпочинок }\end{array}$ & $\begin{array}{c}\text { Сфера культури, } \\
\text { мистецтва, туризму }\end{array}$ & $\begin{array}{l}\text { Активність населення } \\
\text { у сфері культури, } \\
\text { мистецтва, туризму }\end{array}$ & $\begin{array}{c}\text { Ставлення до культури, } \\
\text { мистецтва, туризму }\end{array}$ \\
\hline Житло & Ринок житла & Житлові умови & $\begin{array}{c}\text { Оцінка благоустрою та } \\
\text { умов проживання }\end{array}$ \\
\hline Транспорт & $\begin{array}{c}\text { Транспортна } \\
\text { інфраструктура }\end{array}$ & Безпека на транспорті & $\begin{array}{c}\text { Оцінка роботи } \\
\text { транспорту }\end{array}$ \\
\hline \multicolumn{4}{|c|}{ Економічне середовище } \\
\hline Економіка & Стан економіки & Добробут & $\begin{array}{c}\text { Оцінка матеріального } \\
\text { становища }\end{array}$ \\
\hline Зайнятість & Ринок праці & $\begin{array}{c}\text { Зайнятість та умови } \\
\text { праці }\end{array}$ & $\begin{array}{c}\text { Оцінка ситуації } 3 \\
\text { зайнятості }\end{array}$ \\
\hline \multicolumn{4}{|c|}{ Суспільно-політичне середовище } \\
\hline $\begin{array}{c}\text { Громадянська } \\
\text { активність }\end{array}$ & $\begin{array}{l}\text { Розвиток громадян- } \\
\text { ського суспільства }\end{array}$ & $\begin{array}{c}\text { Суспільно-політична } \\
\text { ситуація }\end{array}$ & $\begin{array}{c}\text { Оцінка суспільно- } \\
\text { політичної ситуації }\end{array}$ \\
\hline $\begin{array}{c}\text { Суспільне } \\
\text { середовище }\end{array}$ & $\begin{array}{c}\text { Стан суспільного } \\
\text { середовища }\end{array}$ & Соціальне уособлення & Соціальне самопочуття \\
\hline
\end{tabular}

Джерело: [564].

Подальша робота з інтегральним індексом і субіндексами зводиться до, розрахунку або сумарного, або середнього показника. Перші дають змогу визначити внесок кожного індексу в узагальнюючий індекс, а другі - тоді, коли кількість складових сукупностей при порівнянні відрізняються.

У дослідженнях за різними програмами використовують 9 факторів для оцінки якості життя для визначення оцінки країни. Опис показників, які враховувалися при складанні рейтингу, представлено у таблиці 10.2.4. 
Таблиця 10.2.4

Основні індикатори оцінки якості життя

\begin{tabular}{|c|c|c|c|}
\hline $\begin{array}{l}\text { № } \\
\text { П/II }\end{array}$ & Індикатор & Показник індикатора & Джерело \\
\hline 1. & Здоров’я: & очікувана тривалість життя (в роках) & US Census Bureau \\
\hline 2. & Сімейне життя: & $\begin{array}{l}\text { рівень розлучень на } 1 \text { тисячу осіб. } \\
\text { Ставиться оцінка від } 1 \text {, що означає мало } \\
\text { розлучень, до } 5 \text { - багато розлучень. }\end{array}$ & $\mathrm{OOH}$; Euromonitor \\
\hline 3. & Громадське життя: & $\begin{array}{l}\text { значення на рівні 1, якщо високий рівень } \\
\text { відвідування церков або кількість } \\
\text { профспілкового членства. }\end{array}$ & World Values Survey \\
\hline 4. & $\begin{array}{l}\text { Матеріальний } \\
\text { добробут: }\end{array}$ & $\begin{array}{l}\text { ВВП на душу населення, Паритет } \\
\text { купівельної спроможності. }\end{array}$ & $\begin{array}{l}\text { Economist } \\
\text { Intelligence Unit }\end{array}$ \\
\hline 5. & $\begin{array}{l}\text { Політична стабіль- } \\
\text { ність та безпека: }\end{array}$ & $\begin{array}{l}\text { Рейтинги політичної стабільності та } \\
\text { безпеки. }\end{array}$ & $\begin{array}{l}\text { Economist } \\
\text { Intelligence Unit }\end{array}$ \\
\hline 6. & $\begin{array}{l}\text { Клімат } \\
\text { географія: }\end{array}$ & $\begin{array}{l}\text { Широта, що розділяе холодних та } \\
\text { жарких клімати. }\end{array}$ & CIA World Factbook \\
\hline 7. & Гарантія роботи: & Рівень безробіття (у \%). & $\begin{array}{l}\text { Economist } \\
\text { Intelligence Unit }\end{array}$ \\
\hline 8. & $\begin{array}{l}\text { Політична } \\
\text { свобода: }\end{array}$ & $\begin{array}{l}\text { Значення від 1, якщо повністю вільна, } \\
\text { до } 7 \text { - невільна. }\end{array}$ & Freedom House \\
\hline 9. & Статева рівність: & $\begin{array}{l}\text { визначається діленням } \quad \text { середньої } \\
\text { заробітної плати чоловіків на заробітну } \\
\text { плату жінок. }\end{array}$ & $\begin{array}{l}\text { UNDP Human } \\
\text { Development Report }\end{array}$ \\
\hline
\end{tabular}

Джерело: власна розробка.

Наведемо основні результати таких досліджень. «ООН визнало наш рівень розвитку як високий. На основі отриманих показників країнам присвоюються певні індекси щодо людського розвитку, за якими їх поділяють на 4 групи: $з$ дуже високим (увійшли такі як Чехія, Польща, Словаччина, Угорщина, Румунія та інші); високий (увійшли такі як Україна, Болгарія, Грузія, Туреччина та інші); середній (Молдова та інші); низьким [563]».

Науковці інституту демографії та соціальних досліджень імені М. В. Птухи НАН України, стверджували, що «впродовж останньої чверті сторіччя Україна зіткнулася 3 абсолютно новими для себе викликами, зумовленими набуттям незалежності й розривом традиційних зв'язків у межах колишнього СРСР та формуванням нових міжнародних контактів. Ми долучи-лися до нового глобалізованого світу, що спричинило глибоку економічну кризу перехідного періоду. I відійшовши від задекларованої за радянських часів рівності для всіх, 
виявили поміж себе кричущу нерівність Таку глибоку, що, нині вона може навіть спричинити розподіл суспільства на касти [563]».

За звітними даними середня тривалість життя в Україні обох статей нині становить у середньому 71,1 року. Це, на жаль, нижче, ніж середній показник у світі - 71,7. І лише на 1,3 року більше, ніж було у 1990-му. Для порівняння - у країнах з дуже високим рівнем розвитку: у Чехії - 78,8, у Польщі - 77,6, в Угорщині - 75,3. У країнах нашої групи: в Туреччині - 75,5, в Грузії - 75 років, в Болгарії - 74,3. І навіть у Молдові, яка належить до країн із середнім розвитком, - 71,7. I це попри те, що в середині 1990-х середня тривалість життя в Україні та Польщі була однаковою.

Середня тривалість життя жінок в Україні - 76 років, чоловіків - 66,2 року. Трохи менша вона лише в жінок у Молдові - 75,9 років, а чоловіки там живуть в середньому довше - 67,6 року. Але, порівняймо з країнами 3 дуже високим розвитком: у Чехії жінки живуть 81,6 року, чоловіки - 75,9; у Словаччині жінки - 80, чоловіки - 77,2 року; майже такі самі показники і в Румунії; з Польщею відставання на 5,5 року - жінок і 7,5 року чоловіків.

«В Україні з’явилося абсолютно нове поняття «раптова бідність», з яким нам раніше стикатися не доводилося. Вплинули на це анексія Криму, бойові дії на сході й майже 2 мільйони вимушених переселенців. Більшість із них ще вчора мали все необхідне - житло, роботу, чітко визначений соціальний статус і були самодостатніми. Та миттєво втратили все й перетворилися фактично на біженців. I це ще більше загострило соціальні проблеми, яких й до того в нас було чимало $[563] \gg$.

На рисунку 10.2.11 наведені дані щодо забезпечення мобільними телефонами та Інтернетом, задоволеністю власним та суспільним життям. 


\begin{tabular}{lcc}
$\begin{array}{l}\text { Tаблиця 1. Забезпеченість мобільними } \\
\text { телесронами та інтернетом }\end{array}$ \\
\hline & Інтернет-користувачі, \% & Мобільні телефони, на 100 осіб \\
\hline Чехія & 81,3 & 129,2 \\
\hline Польща & 68,0 & 148,7 \\
Словаччина & 85,0 & 122,3 \\
\hline Угорщина & 72,8 & 118,9 \\
\hline Румунія & 55,8 & 107,1 \\
\hline Болгарія & 56,7 & 129,3 \\
\hline Грузія & 45,2 & 129,0 \\
\hline Туреччина & 53.7 & 96.0 \\
\hline Україна & $\mathbf{4 9 , 3}$ & $\mathbf{1 4 4 , 0}$ \\
\hline Молдова & 49,8 & 108,0 \\
\hline
\end{tabular}

\section{Таблиця 2. Задоволеність власним життям, \%}

\begin{tabular}{l|c|c|c|c|c|c|c|c|}
\hline & Освітою & $\begin{array}{c}\text { Охороною } \\
\text { здоров'я }\end{array}$ & $\begin{array}{c}\text { Рівнем } \\
\text { життя }\end{array}$ & Роботою & Безпекою & Свободою вибору & Загальний \\
індекс
\end{tabular}

\section{Таблиця 3. Задоволеність суспільним життям, \%}

\begin{tabular}{|c|c|c|c|c|c|c|}
\hline & $\begin{array}{c}\text { Місцевим } \\
\text { ринком праці }\end{array}$ & $\begin{array}{l}\text { Можливостями } \\
\text { дозвілля }\end{array}$ & $\begin{array}{l}\text { Місцевоюо } \\
\text { владою }\end{array}$ & $\begin{array}{l}\text { Правовоюо } \\
\text { системою }\end{array}$ & $\begin{array}{l}\text { Захистом } \\
\text { довкілля }\end{array}$ & $\begin{array}{l}\text { Центральною } \\
\text { владою }\end{array}$ \\
\hline Чехія & 39 & 14 & 89 & 45 & 67 & 44 \\
\hline Польща & 25 & 9 & 86 & 42 & 51 & 21 \\
\hline Словаччина & 12 & 11 & 81 & 26 & 38 & 28 \\
\hline Угорщина & 23 & 9 & 80 & 42 & 46 & 28 \\
\hline Румунія & 22 & 7 & 80 & 40 & 28 & 25 \\
\hline Болгарія & 13 & 4 & 77 & 19 & 22 & 14 \\
\hline Грузія & 5 & 18 & 74 & 37 & 30 & 25 \\
\hline Туреччина & 31 & 5 & 75 & 43 & 44 & 49 \\
\hline Україна & 9 & 16 & 76 & 4 & 13 & 8 \\
\hline Молдова & 9 & 17 & 71 & 22 & 24 & 17 \\
\hline
\end{tabular}

Джерело: Інститут демографрії та соціальних досліджень ім. М. В. Птухи НАНУ

\section{Рис. 10.2.11 Результати дослідження ІД та СД ім. М. В. Птухи НАНУ}

Джерело: [563].

Найкращий індекс людського розвитку світового рейтингу у 2017 р. зафіксований в Норвегії. Такий висновок зробили аналітики Програми розвитку 
ООН (ПРООН) щодо оприлюдненого глобального рейтингу індексу людського розвитку. Згідно рейтингових, індекс людського розвитку в Норвегії має значення 0,953; Швейцарія - 0,944; Австралія та Ірландія - 0,939 та 0,938 відповідно, а на п'ятому місці - Німеччина $з$ індексом 0,936. До десятки потрапили Ісландія, Гонконг, Швеція, Сінгапур, Нідерланди. У країнах колишнього радянського союзу найкращий показник у Естонії, де індекс становить 0,871. Він відповідає 30 місцю у загальному рейтингу. Наші західні сусіди України, до яких належать Польща, Словаччина та Угорщина, посіли 33, 38 та 45 місця рейтингу, відповідно. Росія потрапила на 49-ту позицію, а Білорусь - на 53-ту. Щодо України, то автори індексу визначили ії розвиток у 0,751. Через такий показник Україна опинилася на 88-му місці у переліку з 189 країн. На останньому місці - Нігер. Визначальними критеріями є такі показники, як тривалість життя, рівень освіти та доходів громадян [521].

Отже, усе вищевикладене дозволяє зробити висновок, що сьогодні перед Україною постали серйозні виклики, які вона має вирішити, серед яких найбільш значимими $\epsilon$ : наростаюча диспропорція між бідними та багатими; падіння довіри населення до влади різних рівнів управління, а також в особистих стосунках; прогресуюче небажання працювати легально та намагання приховати свої справжні доходи; відсутність моральних принципів щодо намагання отримати від держави соціальний захист та пільги, якщо реальне фінансове становище цього не передбачає.

Оцінювання задоволеності людини за різними сторонами іiі життєзабезпечення для визначення якості життя має безліч складнощів через наявність об’єктивних та суб’єктивних причин. Через військово-політичну обстановку в Україні постає завдання щодо оновлення існуючих методик вимірювання якості життя населення. Крім того, якість життя людина напряму пов'язана 3 рівнем соціально-економічного розвитку країни. Тому, діяльність держави у сфері соціального забезпечення має не допустити погіршення ситуації щодо рівня якості життя населення своєї країни.

Аналіз реальної ситуації із забезпечення якості життя населення України 
свідчить про наявність позитивних зрушень у частині наближення до європейських значень вітчизняних державних соціальних стандартів. Але ці зміни відбуваються надто повільний. Державні соціальні гарантії, до яких відносяться встановлені законами та іншими нормативно-правовими актами, мінімальні розміри оплати праці та пенсійного забезпечення, доходів громадян, соціальної допомоги, медичне обслуговування, розміри інших соціальних послуг не спроможні задовольнити потреби українського суспільства та створити умови для комфортного та гідного життєвого рівня. Крім того, вони слабо спрямовані щодо стабілізації процесу збіднення громадян та запобігання незахищеності й соціальної ізоляції. Особливу складність відчувають більшість пенсіонерів, вразливе населення у працездатному віці у сільській місцевості та в містах, некваліфікована робоча сила, особи 3 інвалідністю й хронічними захворюваннями та багатодітні родини.

Номінальна заробітна плата середнього та мінімального форматів дає змогу оцінити загальну кількість коштів, яку виплачують за результати праці, $\epsilon$ та залишається головним джерелом доходів працюючого населення. В Україні впродовж 2004-2019 рр. номінальна середня заробітна плата (надалі НСЗП) постійно зростала, і лише у 2000 р. вона була нижчою за прожитковий мінімум для працездатних осіб (темпи їі зростання у гривневому еквіваленті становили, відповідно, 17,3 та 17,6 рази, але у валютному - лише 3,7 і 4,0 рази). Реальна заробітна плата дає змогу визначити спроможність виплачених коштів. Для неї найбільш чутливим до падіння був період з 2009 р. до 2015 р., а причиною цього були світова фінансова криза на тлі політичної й економічної кризи у країні. У 2019 р. і середня заробітна плата, і мінімальна зросли у 2,08 та 2,9 рази, відповідно.

Зростання середньої і мінімальної заробітних плат були нижчими від рівня інфляції: у 2014 р. інфляція становила 24,9\%, а мінімальна заробітна плата (надалі МЗП) не змінювалась з 2013 р.; у 2015 р. - 43,3\%, а рівень мінімальної заробітної плати було підвищено лише на 13,1\%. Це означає, що при зростанні цін у 2013-2015 рр. у межах 68-69\% держава підвищила прожитковий мінімум 
тільки на 160 грн., а це суттєво вплинуло на купівельну спроможність реальної заробітної плати. Найнижчих рівень інфляції був у 2012 р. (становив він 99,8\%), і тоді, середня та мінімальна заробітні плати становили 274,6\% та 100,1\%, відповідно, величини прожиткового мінімуму для працездатних осіб (наділі ПМдПО), а рівень середньої та мінімальної пенсій перебував на рівні 170,4\% і 104,7\% прожиткового мінімуму для непрацездатних осіб (надалі ПМдНО).

В Україні до 2009 р. були значно нижчі за величину ПМдПО, що суперечить європейській практиці та вимогам економічної безпеки: у 2004 р. та 2005 р. розмір мінімальної заробітної плати становив лише $61,0 \%$ та $65,8 \%$, а у 2008 р. - 84,87\% рівня прожиткового мінімуму для працездатних, відповідно; у період 2017-2019 рр. це співвідношення стало відповідати 190,0\%, 211,0\% та 217,0\%, відповідно, що свідчить про скерування до європейських стандартів (ще у 2008 р. для Великої Британії та Франції становили 6,4:1 та 4,7:1, відповідно [514]).

Пенсійне забезпечення у своїй величині на початку 2000 р. було мізерне. Так, мінімальна пенсія у 7 разів була меншою від прожиткового мінімуму для непрацездатних осіб. Постановою КМУ «Про підвищення рівня пенсійного забезпечення» № 1215 від 18.09.2004 р. разом з доповненням Постановою КМУ від 27.10.2004 р. рівень виплат усім категоріям пенсіонерів мінімальної величини зрівнялася $з$ прожитковим мінімумом для непрацездатних осіб та подальших змін на зниження не зазнавав.

Різке підвищення валютного курсу в країні у 2015-2016 рр., коли долар подорожчав у 3 рази по відношенню до гривні та порівняно з початком 2014 р., рівень заробітної плати у доларовому еквіваленті «відкатився» до рівня 20042005 рр., а середня та мінімальна пенсія - зменшилась практично у 2 рази. Уповільнене зростання рівня мінімальної пенсії зберігається до середини 2019 р., і це за умов проведення пенсійної реформи.

Аналіз динаміки зміни величини ПМдПО за період 2013-2019 рр. у національній валюті та за офіційним курсом євро до гривні дозволив вияви-ти, що ПМдПО за цей період (було здійснено 6 підвищень) зріс від 1210 грн. до 1921 
грн. (перше півріччі 2019 р.), а от у валютному обчисленні - падіння із 104,3 євро (кінець 2013 р.) до 64,3 євро (перше півріччі 2019 р.), тобто, загальне зменшення становить майже 1,6 рази.

Розмір прожиткового мінімуму у цінах травня 2019 р. у розрахунку на місяць на одну особу становить 4236,85 грн., але без урахування виплат -податку на доходи фізичних осіб та військового збору, становить 3690,49 грн. А для працездатних осіб фактичний прожитковий мінімум становив 4744,71 грн., без відрахувань 3819,49 грн., для непрацездатних осіб - 3144,16 грн. [519]. Це означає, що законодавчо визначений на цей місяць загальний прожитковий мінімум у розмірі 1853 грн. занижено у 2,3 рази (або на 2384 грн.), у порівнянні 3 його фактичним значенням; для працездатних осіб зниження у 2,5 рази (або на 2824 грн.); для непрацездатних - 2,1 рази (або 1647 грн.). Такий стан свідчить про значне «недоврахування» офіційних прожиткових мінімумів для цих, а також для інших, соціальних та демографічних категорій населення. Варто відзначити, що рівень прожиткового мінімуму для України $\epsilon$ «певним компромісом» між «можливостями економічного характеру держави» та соціальними потребами іï населення, а у дійсності, величина прожиткового мінімуму повинна відображати рівень мінімального доходу, який би дозволив працівникам забезпечити середній рівень життя та нормальні умови для відтворення робочої сили (структура прожиткового мінімуму містити елементи: фізіологічний та соціальний у співвідношенні $85 \%$ до 15\%).

Необхідно зауважити, що серед головних функцій МЗП (посеред відтворювальної, стимулюючої, регулюючої, оптимізаційної) досить важливою $€$ критеріальна, що слугує формуванню базового орієнтиру у встановленні рівня державної соціальної підтримки та пенсійного забезпечення населення [512]. Як відомо, мінімальна заробітна плата є основною державною гарантією, а іiі вартісне значення спрямоване на забезпечення прожиткового мінімуму. Тому, не маємо права залишати без уваги мінімальний розмір оплати праці в погодинному обчисленні. Станом на першу половину 2019 р. в Україні вона становила 25,13 грн. (або 0,90 євро) за годину роботи. Ця величина оплати є меншою за оплату 
погодинної праці в острівній державі Полінезійського архіпелагу Самоа (одна із найнижчих і становить лише 1,04 євро за годину). Так, наприклад, у Люксембурзі вона становить 12,41 євро за годину, Ірландії - 9,78 євро за годину, Німеччині 9,73 євро за годину. Щодо інших розвинених держав, то в Австралії, Новій Зеландії, Канаді, Японії та США - 11,83; 9,77; 7,55; 7,51 та 6,4 євро за годину [516].

Основною статтею споживчих витрат українців, як працездатних, так i непрацездатних, складають витрати на продукти харчування, які протягом останніх понад 10 років становили в середньому 51,4\% (у 2004 р. - 57,5\%; у 2007 p. - 58,3\%; у 2015 р. - 53,1\%). Але, відповідно до українського законодавства, «порогове» значення цього показника має становити на рівні $60 \%$, тобто досягнуті рівні витрат є близькими до критичних. Більшість країн Європи на харчування спрямовує менше $20 \%$ споживчих витрат. «На сьогодні найменше на придбання продуктів харчування витрачають у Великобританії (8,6\%), Ірландії (9,7\%) та Австрії (9,8\%), а найбільше - у країнах Балтії (Естонії, Латвії і Литві) 20,6\%; 20,4\% та 23,3\%, відповідно [507]». Варто відзначити, що показник рівня витрат на продукти харчування $є$ індикатором оцінки продовольчої безпеки держави та матеріальної забезпеченості іiі населення (за законом Енгеля: рівень життя особи - обернена залежність від частки витрат на продукти харчування). Навіть певні відчутні зростання середніх заробітних плат і пенсій у період 20172019 рр. не змінили цієї ситуації на краще, і витрати на продукти харчування цих категорій українського суспільства надалі залишились на рівні 86-94\%. Відповідь на це потрібно шукати у розбалансованості міжгалузевих відносин.

Протягом останніх років статистичні дані фіксують одноманітне харчування населення України [499], коли енергетична цінність раціону, що є реальним, забезпечується вуглеводами та рослинними жирами, і свідчить це про харчову незбалансованість (суттєво менше споживається м'яса (майже 25\%), фруктів і ягід (понад 50\%), а риби і морепродуктів (майже 80\%), що позначалося на загальній калорійності споживаних продуктів, порівняно з 1990 р., менше на 
$18 \%)$.

Постановою КМУ «Про затвердження наборів продуктів харчування, наборів непродовольчих товарів та послуг для основних соціальних i демографічних груп населення〉 № 780 від 11.10.2016 р. були затверджені переглянуті та нові норми споживчого кошика (старі діяли з квітня 32000 р.) [525]. Так, мінімальний продуктовий кошик за новими нормами для працездатних осіб у 2018 р. та 2019 р. становив 1662,0 і 1787,0 грн., відповідно (або 90,0\% та 93,0\% величини ПМдПО); для непрацездатних осіб - 1326,0 грн. та 1466 грн. (або 93,0\% та 93,7\% ПМдНО). Щодо енергетичної цінності «середньодобового набору продуктів харчування» непрацездатних осіб, то вона зросла лише на 63,9 ккал. Це означає, що пересічний пенсіонер може «збільшити» свій щоденний раціон на таке - додаткових 18 г макаронів, або 25 г вареної ковбаси, або 24 г пшеничного хліба, або 100 г молока. Фактично вибір припадає на більшу кількість споживання хліба і картоплі при зменшенні в м'яса та риби й морепродуктів - на 0,34 кг та 0,5 кг, відповідно.

Українською владою у попередні роки здійснювалося адміністрування рівня цін на обмежений перелік соціально захищених продуктів харчування. Але у вересні 2016 р. (Постанова КМУ № 656) були «відпущені» ціни на вищеозначені «регульовані» продукти, що спричинило суттєве зростання цін на них - від 17\% до 21\% [530]. Причиною цього стало подальше здешевлення національної валюти, посилення фіскального тиску, неефективність системи державного контролю. У червні 2017 р. відбулося зростання цін на 19 позицій соціально захищених продовольчих товарів (із 23). Але Уряд з 1 липня 2017 р. своєю Постановою $з$ метою «створення «нормальних умов для вітчизняних виробників та подальшого розвитку бізнесу агропромислової галузі» остаточно скасував регулювання їх ціноутворення, навіть не зваживши на готовність України до того, чи зможуть економічні закони реально диктувати правила на ринку продуктів харчування.

Аналіз вартості житлово-комунальних послуг за період 2004-2019 рр. вказує, що вони зросли майже у 30 разів, а найбільше зростання відбулося після 
2014 р. Так, вартість природного газу у 2013 р. за умов середньорічного споживання до $2500 \mathrm{~m}^{3}$ [504] (найбільш властиве для домогосподарств пенсіонерів) становила 0,7254 грн. за $1 \mathrm{~m}^{3}$ та 1 кВт. год. електроенергії коштувала 0,2802 грн. Така вартість енергоносіїв дійсно була у 8 разів меншою за європейські ціни [507]. Але, починаючи з 2014 р., їхнє зростання почалось шаленими темпами. Крім того, Урядовими рішеннями були переглянуті норми споживання для населення у випадку відсутності лічильників обліку, законодавчо забезпечено комерційний облік послуг із постачання теплової енергії, гарячої води, централізованого водопостачання. Усе це та фінансова неспроможність населення призвели до заборгованості за надані житловокомунальні послуги на початку 2019 р. у сумі 69,4 млрд. грн., яка липня цього ж року зменшилась до 57,2 млрд. грн.

Державні витрати на охорону здоров'я 3 кожним наступним роком знижуються, а приватні навпаки - зростають. «На пацієнтів вже накладено неймовірний тягар витрат на власне лікування (понад 60\% загальних витрат), унаслідок чого пролонгується не лише подальше зубожіння значної частини населення, але й відбуваються суттєві втрати людського потенціалу, які вражають увесь цивілізований світ - щорічно через низькі якість та доступ-ність медичної допомоги українців фізично меншає на 200-300 тис. осіб [499]»

Середня і мінімальна пенсії у гривневому еквіваленті за період 2004-2019 pp. зросли у 15,9 рази та 10,9 рази, відповідно, а от за приведенням за обмінним курсом НБУ до євро зростання становило лише 3,4 рази та 2,4 рази, відповідно. Порівнюючи зміни цих двох видів пенсій у 2012-2013 рр. та рівнем 2019 р., бачимо, що відбулось фактичне їх знецінення в 1,37 рази та 1,73 рази, відповідно.

Важливим економічним показником $є$ коефіцієнт заміщення доходу, тому що саме на його основі Міжнародна організація праці, а не на прожитковому мінімумі, рекомендує будувати свої пенсійні системи при нормативному значенні не нижче 40\% [541]. Так, середнє значення цього коефіцієнта в країнах ЄC становить 70,9\%, а в Україні - 35\%. Негативна динаміка його зниження відбулася з 2015 р. і до нині. Навіть заходи щодо стабілізації пенсійної реформи 
2017 р. зниження не зупинило. Це означає, що практично відсутня можливість на загальнодержавному рівні компенсувати втрачені працівниками заробітки на мінімально необхідному рівні. Ситуація щодо наповнення пенсійного бюджету свідчить про невтішні прогнози, і не лише щодо його постійного зменшення, але і щодо загроз функціонування чинної системи пенсійного забезпечення.

Якщо порівняти результати, які досягла Україна у соціальній сфері, із вимогами Стратегії Міжнародної організації праці щодо соціального забезпечення для всіх», то «Україна в горизонтальному вимірі - «швидке впровадження мінімальних рівнів соціального захисту...»- формально їх досягла [550]. А от такі основні гарантії, як доступ до першочергових необхідних видів медичних послуг та основні гарантовані доходи для осіб похилого віку i осіб, що мають економічно активний вік, і не здатних одержувати достатній дохід через хворобу, безробіття, вагітність та пологи чи інвалідність так і не забезпечуються повною мірою.

У 2020 р. Україна посіла 63 місце у загальному рейтингу за величиною індексу соціального прогресу (Social Progress Index). Усього оцінені 163 країни. Показник цього індексу України становив 73,38 бали проти 66,97 білів та 80 позиції рейтингу у 2019 р. (середнє значення індексу серед усіх досліджуваних країн - 64,24 бала). «У 2019 р. група країн із дуже високим рівнем життя i помірно високою якістю життя скоротилася з 104 до 71. Проте Україна показала значно гірші результати порівняно з іншими країнами за показниками очікуваної тривалості життя після 60 років (117-те місце серед 163 країн), а також відстає за низкою інших показників. Для довідки: індекс соціального прогресу розробив професор Гарвардської школи бізнесу та Массачусетського технологічного інституту. Даний індекс вимірює ступінь забезпеченості країни соціальними $і$ екологічними потребами населення за 54 індикаторами. Дослідження публікується щорічно некомерційною організацією [568].

Отже, аналіз ситуації щодо забезпечення рівня та якості життя населення України свідчить про наявність позитивних зрушень в частині наближення значень українських державних соціальних стандартів до європейських. Але це 
відбувається досить повільно. Державні соціальні гарантії (мінімальні розміри оплати праці, пенсійного забезпечення, доходів громадян, соціальної допомоги, доступу до основних медичних послуг, розміри інших соціальних послуг» не спроможні задовольнити потреби щодо створення комфортного й гідного життєвого рівня та слабо спрямовані на запобігання збіднення, незахищеності та соціальної ізоляції через відсутність належного фінансового бюджетування.

Однією з головних функцій держави щодо проведення соціальної політики має бути іï спрямовання на забезпечення умов життєдіяльності людини, реалізацію та розвиток її як інтелектуального так і професійного потенціалу. Реалізувати це можлива за рахунок системи соціального захисту та відповідного фінансове забезпечення, що здійснюється за рахунок державних бюджетних коштів.

Найбільше державних витрат на соціальний захист та сферою охорони здоров'я спрямовується на рівні 58,9\% у Данії, 58,8\% у Німеччині, 57,3\% у Фінляндії, 56,3\% у Норвегії. По країнах СС у загальному, то на соціальний захист направляється до 54,9\% усіх державних коштів [565]. Світові тенденції вплинули на економіку європейських держав, але скорочення видатків торк-нулося інших сфер, а щодо соціальної сфери, то тут спостерігається динаміка зростання державних видатків на соціальні потреби. Це має логічне пояснення, бо у період кризи зростає кількість населення, яке потребує соціальної допомоги, а також уряди через соціальну допомогу намагаються збільшити внутрішній споживчий попит для покращення економічної ситуації в країні.

Україна має розгалужену систему соціального захисту населення. За роки незалежності ця система була доповнена різноманітними соціальними програмами та допомогами. Це дало змогу охопити більшість населення країни різними формами соціального захисту, але при цьому збільшило навантаження на державні фінанси. Але варто зазначити, що в умовах економічних та фінансових криз ці фінанси не спроможні забезпечити бездефіцитне фінансування потреб системи соціального захисту. Розмір соціальних виплат в Україні, як свідчать попередні дослідження, є низькими, а сама система 
соцзахисту перестала бути ефективною щодо іï головного призначення зменшення рівня бідності та скорочення нерівності у доходах, а також щодо підвищення якості життя населення. Усе це може створити реальні загрози для національної безпеки України через можливість соціальних вибухів.

Соціальні видатки у державних витратах завжди посідали провідне місце, а основним джерелом фінансування системи соціального захисту є бюджет країни (державний та місцевий). В Україні спостерігається динаміка зростання видатків держбюджету на соцзабезпечення та охорону здоров'я (табл. 10.2.5).

Таблиия 10.2.5

\section{Динаміка та структура соціальних видатків у Зведеному бюджеті України}

\begin{tabular}{|c|c|c|c|}
\hline \multirow{2}{*}{ Piк } & \multicolumn{3}{|c|}{ Видатки } \\
\cline { 2 - 4 } & загальні & $\begin{array}{c}\text { на соціаль- } \\
\text { ний захист } \\
\text { та забезпе- } \\
\text { чення }\end{array}$ & $\begin{array}{c}\text { на } \\
\text { охорону } \\
\text { здоров'я }\end{array}$ \\
\hline 1996 & 7284,8 & 4105,6 & 3179,2 \\
\hline 1997 & 9529,0 & 5607,7 & 3921,3 \\
\hline 1998 & 8094,0 & 4227,0 & 3867,0 \\
\hline 1999 & 7955,8 & 4147,1 & 3808,7 \\
\hline 2000 & 10873,4 & 5985,2 & 4888,2 \\
\hline 2001 & 16030,7 & 8332,8 & 7697,9 \\
\hline 2002 & 22657,5 & 12643,9 & 10013,6 \\
\hline 2003 & 23090,3 & 12219,7 & 10876,6 \\
\hline 2004 & 30194,5 & 18113,1 & 12081,4 \\
\hline 2005 & 54055,2 & 38674,9 & 15380,3 \\
\hline 2006 & 58337,4 & 39985,2 & 18352,2 \\
\hline 2007 & 72881,8 & 47892,1 & 24989,7 \\
\hline \multicolumn{3}{|c}{ Джерело: }
\end{tabular}

\begin{tabular}{|c|c|c|c|}
\hline \multirow{2}{*}{ Рік } & \multicolumn{3}{|c|}{ Видатки } \\
\cline { 2 - 4 } & загальні & $\begin{array}{c}\text { на соціаль- } \\
\text { ний захист } \\
\text { та забезпе- } \\
\text { чення }\end{array}$ & $\begin{array}{c}\text { на } \\
\text { охорону } \\
\text { здоров'я }\end{array}$ \\
\hline 2008 & 107629,6 & 74069,7 & 33559,9 \\
\hline 2009 & 115339,9 & 78775,4 & 36564,5 \\
\hline 2010 & 149280,2 & 104534,7 & 44745,3 \\
\hline 2011 & 154396,4 & 105434,7 & 48961,7 \\
\hline 2012 & 183760,8 & 125306,9 & 58453,9 \\
\hline 2013 & 206631,3 & 145062,6 & 61568,7 \\
\hline 2014 & 195038,3 & 137993,6 & 57044,7 \\
\hline 2015 & 247331,2 & 176339,8 & 70991,4 \\
\hline 2016 & 333739,2 & 25830,7 & 75408,5 \\
\hline 2017 & 388154,1 & 285761,7 & 10292,4 \\
\hline 2018 & 425215,6 & 309363,6 & 115852,0 \\
\hline 2019 & 450147,2 & 321141,6 & 129005,6 \\
\hline
\end{tabular}

1) [495] - Бюджетний моніторинг (період 1996-2016 pp.) : сайт. URL: https://www.ibser.org.ua/publications/monitoringcategories/richnyy (дата звернення: 20.05.2021);

2) [518] - Міністерства фінансів України (період 2017-2019 рp.) : сайт. URL: https://mof.gov.ua/uk/statistichnij-zbirnik (дата звернення: 20.05.2021).

Дані таблиці 10.2.5 свідчать про те, що соціальні видатки за період, що аналізувався, зросли 31996 р., коли становили 7284,8 млн. грн., до 2019 р. до величини 450147,2 млн. грн., тобто зростання становить 62 рази. Частки видатків, які направляються на фінансування програм соціального захисту та 
соціального забезпечення, зазнають поступового зростання з кожним роком, так, якщо у 1996 р. вони становили 56,4\% загальної величини соціальних видатків, то вже у 2019 р. вони становили 71,3\%.

Також спостерігається щорічне зростання витрат на охорону здоров'я, але їх частка зменшилася з 43,6\% у 1996 р. до 28,7\% у 2019 р. Витрати на соціальний захист у 1996 р. становили 21,3\% усіх державних видатків, а у 2019 р. - 32,80\%. У 2013 р. була найвища частка соціальних видатків, яка склала 40,85\%. Крім того, слід зазначити, що спостерігається нерівномірність у темпах зростання витрат, і пов'язано це зі змінами у системі соціального захисту, насамперед, через зростання мінімальної заробітної плати та пенсії.

В Україні фінансування соціальних видатків розподілено між державним бюджетом та місцевими бюджетами. Частина фінансових коштів, що виділяється на соціальні потреби через місцеві бюджети, формуються через міжбюджетні трансферти з Державного бюджету України. У загальній сумі трансфертів вони складають близько 36,0-42,0\%, а це означає, що є великий дефіцит місцевих бюджетів при виконанні соціальних функцій, які є делегованими їм державою. Частка фінансових ресурсів, що акумулюється у Державному бюджеті України, за своїм показником є значно. У 2002 р. 73,51\% усіх державних коштів України з врахуванням міжбюджетних трансфертів перерозподілявся через державний бюджет. У 2015 р. ця величина склала 84,86\%. Під впливом реформ останніх років, у першу чергу через процес децентралізації, можемо спостерігати зменшення частки фінансових ресурсів, що перерозподіляються саме через державний бюджет України, так у 2019 р. ця частка становила 77,39\%. Це означає, що система формування місцевих фінансів характеризується хронічним дефіцитом та слабкістю.

В Україні спостерігається щорічне зростання витрат на соціальний захист з державного бюджету України (табл. 10.2.6). 
Таблиця 10.2.6

\section{Видатки Державного бюджету України за 2008-2019 роки}

\begin{tabular}{|c|c|c|c|c|c|c|}
\hline \multirow[b]{2}{*}{$\begin{array}{c}\text { Видатки згідно з } \\
\text { функціональною класифікацією }\end{array}$} & \multicolumn{2}{|c|}{2009 p. } & \multicolumn{2}{|c|}{2011 p. } & \multicolumn{2}{|c|}{2013 p. } \\
\hline & $\begin{array}{l}\text { млн. } \\
\text { грн. }\end{array}$ & $\begin{array}{c}\text { частка, } \\
\%\end{array}$ & \begin{tabular}{l|} 
мЛн. \\
грн.
\end{tabular} & $\begin{array}{c}\text { частка, } \\
\%\end{array}$ & $\begin{array}{l}\text { млн. } \\
\text { грн. }\end{array}$ & $\begin{array}{c}\text { частка, } \\
\%\end{array}$ \\
\hline Загальнодержавні функції, з них: & 24850,4 & 10,25 & 39996,6 & 11,99 & 50101,1 & 12,4 \\
\hline обслуговування боргу & 9038,7 & 3,73 & 23134,4 & 6,94 & 31677,1 & 7,9 \\
\hline оборона & 9663,3 & 3,99 & 13241,1 & 3,97 & 14843,0 & 3,7 \\
\hline $\begin{array}{l}\text { громадський порядок, безпека та } \\
\text { судова влада }\end{array}$ & 24159,2 & 9,97 & 32514,3 & 9,75 & 39190,9 & 9,7 \\
\hline охорона навкол. середовища & 1824,3 & 0,75 & 3008,4 & 0,90 & 4595,0 & 1,1 \\
\hline житлово-комунальне господар. & 270,6 & 0,11 & 324,2 & 0,10 & 96,9 & 0,0 \\
\hline охорона здоров'я & 7534,9 & 3,11 & 10223,9 & 3,07 & 12879,3 & 3,2 \\
\hline духовний та фізичний розвиток & 3216,7 & 1,33 & 3830,4 & 1,15 & 5111,9 & 1,3 \\
\hline освіта & 23925,7 & 9,87 & 27232,7 & 8,17 & 30943,1 & 7,7 \\
\hline $\begin{array}{l}\text { соціальний захист та соціальне } \\
\text { забезпечення, з них: }\end{array}$ & 51517,6 & 21,25 & 63540,2 & 19,05 & 88547,3 & 21,9 \\
\hline - соціальний захист пенсіонерів & 47912,8 & 19,76 & 58317,1 & 17,49 & 83233,6 & 20,6 \\
\hline економічна діяльність & 33294,3 & 13,73 & 44771,6 & 13,43 & 41299,2 & 10,2 \\
\hline міжбюджетні трансферти & 62180,1 & 25,65 & 94875 & 28,45 & 115848,3 & 28,7 \\
\hline Усього & 242437,2 & 100,00 & 333459,5 & 100,00 & 403456,0 & 100,00 \\
\hline \multirow{2}{*}{$\begin{array}{c}\text { Видатки згідно } 3 \\
\text { функціональною класифікацісю }\end{array}$} & \multicolumn{2}{|c|}{2015 p. } & \multicolumn{2}{|c|}{2017 p. } & \multicolumn{2}{|c|}{2019 p. } \\
\hline & $\begin{array}{l}\text { млн. } \\
\text { грн. }\end{array}$ & $\begin{array}{c}\text { частка, } \\
\%\end{array}$ & $\begin{array}{l}\text { млн. } \\
\text { грн. }\end{array}$ & $\begin{array}{c}\text { частка, } \\
\%\end{array}$ & $\begin{array}{l}\text { мЛн. } \\
\text { грн. }\end{array}$ & $\begin{array}{c}\text { частка, } \\
\%\end{array}$ \\
\hline Загальнодержавні функції, з них: & 103116,7 & 17,9 & 142492,7 & 17,0 & 164358,1 & 15,3 \\
\hline обслуговування боргу & 84505,4 & 14,6 & 110456,1 & 13,2 & 119231,2 & 11,1 \\
\hline оборона & 52005,2 & 9,0 & 74346,2 & 8,9 & 106624,1 & 10,0 \\
\hline $\begin{array}{l}\text { громадський порядок, безпека та } \\
\text { судова влада }\end{array}$ & 54643,4 & 9,5 & 87850,5 & 10,5 & 142375,9 & 13,3 \\
\hline охорона навкол. середовища & 4052,9 & 0,7 & 4739,9 & 0,6 & 5841,2 & 0,5 \\
\hline житлово-комунальне господар. & 21,5 & 0,0 & 16,9 & 0,0 & 106,9 & 0,0 \\
\hline охорона здоров'я & 11450,4 & 2,0 & 16729,4 & 2,0 & 38518,0 & 3,6 \\
\hline духовний та фізичний розвиток & 6619,2 & 1,1 & 7898,1 & 0,9 & 10007,1 & 0,9 \\
\hline освіта & 30185,7 & 5,2 & 41297,3 & 4,9 & 51624,3 & 4,8 \\
\hline $\begin{array}{l}\text { соціальний захист та соціальне } \\
\text { забезпечення, } 3 \text { них: }\end{array}$ & 103700,9 & 18,0 & 144478,9 & 17,2 & 218665,6 & 20,4 \\
\hline - соціальний захист пенсіонерів & 94811,6 & 16,4 & 133458,6 & 15,9 & 181800,0 & 17,0 \\
\hline економічна діяльність & 37135,4 & 6,4 & 47000,1 & 5,6 & 72400,9 & 6,8 \\
\hline міжбюджетні трансферти & 173979,9 & 30,2 & 272602,9 & 32,5 & 260339,7 & 24,3 \\
\hline Усього & 576911,2 & 100,0 & 839452,9 & 100,0 & 1070861,8 & 100,0 \\
\hline
\end{tabular}

Джерело:

1) [495] - Бюджетний моніторинг (період 1996-2016 pp.) : сайт. URL: https://www.ibser.org.ua/publications/monitoringcategories/richnyy (дата звернення: 20.05.2021);

2) [518] - Міністерства фінансів України (період 2017-2019 рp.) : сайт. URL: https://mof.gov.ua/uk/statistichnij-zbirnik (дата звернення: 20.05.2021).

Протягом 2004-2009 рр. витрати на соціальний захист та соціальне 
забезпечення збільшилися майже у 4,3 рази (або на 36360,1 млн. грн.): з 12157,5 млн. грн. у 2004 р. до 51517,6 млн. грн. у 2009 р.; протягом 2009-2019 рр. - ще у 4,3 рази (з 51517,6 млн. грн. до 218665,6 млн. грн. у 2019 р.). Значне зростання спостерігається тоді, коли відбувалися зміни у законодавстві України щодо «розширення видів соціальних допомог або збільшення їх розмірів, так частка цих витрат збільшилася з 18,0\% у 2015 р. до 24\% у 2019 р. у державному бюджеті України. Особливістю фінансування цього напряму у нашій державі $є$ те, що майже усі вони спрямовується на виплату пенсій та покриття дефіциту Пенсійного фонду України, а це має негативний вплив на розмір виплат на фінансування інших соціальних функцій держави, які є гарантованими.

Витрати, що спрямовуються на фінансування Пенсійного фонду України, у 2003 р. складали 28,4\% усіх видатків на соціальний захист та соціальне забезпечення. У 2014 р. він досяг рівня 94,1\%, а у 2019 р. - 83,1\%. Отже, 3 позицій фінансування на даний час головним пріоритетом у соціальній політиці держави є підвищення рівня життя пенсіонерів, але витрати на соціальний захист досягли такої величини, коли їх збереження на досягнутому рівні $\epsilon$ серйозною фінансовою проблемою для бюджету країни. Це негативно позначається на перерозподілі фінансових ресурсів для інших соціальних цілей, які теж мають значимість - це соціальне фінансування сфер охорони здоров'я, освіти, культури та економічне фінансування розвитку економіки країни.

Протягом 2002-2019 рр. частка соціальних видатків через фінансування за рахунок Державного бюджету України коливається у межах 40-65\%, а 3 місцевих бюджетів - у межах 35-60\%. А от у розрізі функціонального фінансування соціальних видатків, то спостерігаються структурні зміни: у 2019 р. найбільшу частку займає «Соціальний захист пенсіонерів», яка становить 83,1\% (проти 92,4\% у 2018 р.) усіх фінансових ресурсів. При цьому структура соціальних видатків місцевих бюджетів $є$ більш рівномірною.

Протягом 2000-2019 рр. склалася тенденція стійкості до зниження питомої ваги власних та закріплених доходів місцевих бюджетів: частка доходів місцевих бюджетів без урахування міжбюджетних трансфертів у 2000 р. становила 76,6\%; 
у 2003 р. вона зменшилась до 65,8\%. у 2012 р. до рівня 44,7\%. у 2015 р. до рівня $41,4 \%$, а у 2018 р. до рівня 46,8\%. Це означає, що значна частина податкових надходжень спрямовується саме до державного бюджету, а джерела фінансових ресурсів, що є закріпленими за місцевими бюджетами, $\epsilon$ незначними $\mathrm{i}$ покривають лише 50\% усіх видатків. У результаті цього місцеві бюджети та процес фінансування повноважень, що покладені на місцеві громади, занадто залежить від дотримання графіків переказу коштів та від повноти обсягів надходжень міжбюджетних трансфертів.

Загальний розмір коштів, які виділяються місцевим бюджетам, зростає: у 2002 р. вони становили 9039 млн. грн., то у 2019 р. вже 260174,2 млн. грн. Тобто, місцеві бюджети є сильно залежними від коштів, що надходять 3 державного бюджету України,. Крім того, ці суми зростають з кожним роком. Це зростання пов'язано 3 щорічним зростанням розміру соціальних допомог та кількості їх одержувачів через наявність об'єктивних причини. У першу чергу, через зменшення кількості народжених дітей та значну кількість переселенців 3 окупованих територій, які не оформили та не отримують соціальні допомоги. Варто відзначити, що з 2015 р. спостерігається зменшення кількості отримувачів соціальних виплат за більшістю видами соціальних допомог. Такі зміни відбулися через збільшилася кількість малозабезпечених домогосподарств, яким надавалася соціальна допомога. У 2013 р. кількість таких домогосподарств становила з 453376 одиниць, у 2015 р. вона зросла до 826131, а у 2018 р. до 874753 одиниці [546]. Це свідчить про зростанням показників бідності у наслідок погіршення соціально-економічного становища населення в останні роки.

За рахунок власних коштів місцевих бюджетів у 2008 р. покривалися потреби на соціальний захист та соціальне забезпечення (без врахування витрат на охорону здоров'я) з часткою $21,45 \%$, то у 2018 р. вона склала лише 14,28\%. Основними витратами $\epsilon$ : допомоги сім'ям 3 дітьми, малозабезпеченим домогосподарствам, інвалідам 3 дитинства, дітям-інвалідам та тимчасова допомога дітям, а також надання пільг та житлових субсидій населенню. Отже, удосконалення міжбюджетних відносин та посилення адресності соціальної допомоги на засадах підвищення ефективності ії використання - це пріоритетні 
напрями для підвищення ефективності фінансової забезпеченості соцсфери.

Оцінка соціальної політики як елемента інтегрального механізму покращення якості життя населення дозволила зробити такі висновки:

1. Головним засобом реалізації цілей державної політики у галузі покращення якості життя населення має стати збалансований розвиток України, оскільки у регіонах країни склалися різні умови щодо формування засад відтворення і розвитку населення через відмінності в рівнях розвитку інфраструктури, ступеня реалізації інноваційного та підприємницького потенціалу, сприятливості екологічної обстановки, рівнях і тенденціях соціального й культурного розвитку. Крім того, розробки і затвердження нових соціальних та екологічних стандартів у формуванні якості життя людей в регіонах країни не викликає сумнівів.

2. Надання пріоритету економічному зростанню над соціальним призводить до збідніння людей та погіршення стану суспільства, а от заходи соцзахисту можуть стати дієвим фактором для сприяння сталого економічного зростання через пряму підтримку працюючого населення, розширення його можливостей, підвищення внутрішнього попиту та продуктивності праці.

3. Соціальний захист та соціальне забезпечення в Україні в умовах сьогодення є найбільшою видатковою статтею зведеного бюджету України, а загальний обсяг фінансування за нею перевищує сукупні видатки на такі соціальні сфери як охорона здоров'я, освіта та економічна діяльність.

4. Відсутність фінансових ресурсів на місцях примушує органи місцевого самоврядування фінансувати освіту, охорону здоров'я, соціальний захист, через зменшення розмір коштів, які направлені на розвиток місцевої громади, що негативно позначається на економіці громади, регіону, країни. Крім того, фінансування більшості соціальних програм покладено теж на них. Тому, 3 огляду на дефіцитність фінансових ресурсів, має особливу важливість щодо чіткого оцінювання рівня та ефективності даних програм.

Розділ 3. Стратегія формування та регулювання соціальної політики в Україні. Світові тенденції щодо інтеграції країн та формування єдиного 
соціального простору передбачають орієнтацію багатьох країн світу на використання міжнародних норм та стандартів 3 метою забезпечення економічних та соціальних прав людини. Соціальні політики різних країн суттєва відрізняються одна від другої залежно від рівня економічного розвитку, соціально-економічної кон'юнктури та національних традицій країни. На практиці виділяються три найбільш розповсюджувані моделі соціального розвитку - ліберальна, консервативна та соціально-демократична [553].

Держави, які обрали ліберальну модель соціального розвитку, намагаються забезпечити рівними можливостями всіх громадян і гарантувати мінімальний рівень достатнього існування, але при цьому знімають з себе відповідальність щодо якісного розвитку громадянина та за його перспективу соціального характеру. Фінансування соціальних витрат, у більшій ії частині, здійснюється за державний кошт. Ліберальна модель соціального розвитку реалізується в США, Великобританії, Канаді, Австралії, Японії тощо.

Основними напрямами соціальної політики США є реалізація заходів соціального характеру для унеможливлення соціального вибуху та встановлення в суспільстві соціальної справедливості, які втілюються через боротьбу держави з бідністю та здійснюється шляхом надання соціальної допомоги громадянам для задоволення своїх основних первинних потреб у результаті відсутності власних. Соціальне забезпечення США є децентралізованим і реалізується через соціальні федеральні, штатні та місцеві програми.

Державна система соціального забезпечення США складається з системи соціального страхування та системи державної допомоги: перша - передбачає фінансування соціальних програм, які націлені на відшкодування втрати заробітної плати у зв'язку з виходом на пенсію та 3 непрацездатністю або 3 безробіттям. Програми соціального страхування складаються з двох програм:

- програми соціального забезпечення: націлена на відшкодування втрати заробітної плати. Вона фінансується за рахунок податку на заробітну плату зі ставкою 7,5\% і стягується з перших 48 тис. дол. доходу. Повний розмір допомоги отримується лише тоді, коли відбувається вихід на пенсію (у випадку смерті іiі 
отримують утриманці робітника).

- програми страхування по безробіттю: отримання допомоги має право застрахований робітник, що втратив роботу з фінансуванням виплат за рахунок сплати податкового збору у розмірі 3,5\%. Ї̈̈ сплачує працедавець 3 перших 7 тис. дол. заробітку. Розмір допомоги не перевищує 50\% від заробітку робітника.

Система соціального страхування діє на державному та на рівні штатів. Федеральний уряд здійснює загальне керівництво програмами соціального страхування, а от адресності допомоги (питання щодо розмірів та строків) вирішує штат. Паралельно, на рівні штатів, функціонують програми страхування на випадок виробничого травматизму та професійних захворювань. Метою роботи системи державної допомоги є забезпечення соціально незахищеним верствам населення гарантованого доходу у «межах малозабезпеченості». На рівні штатів розмір гарантованого доходу передбачає збільшення за рахунок бюджетних коштів штатів.

Система державної допомоги складається з 4 видів програм: додаткової програми соціального забезпечення (встановлює єдиний загальнонаціональний мінімальний рівень доходу для престарілих та непрацездатних); програми допомоги неповним сім'ям 3 дітьми; програми продовольчих талонів (забезпечення населення 3 низьким рівнем доходу допомогою у вигляді продуктів); програми медичної допомоги (фінансова допомога особам, що беруть участь у першій та другій програмах). Обгрунтування соцсправедливості в США базується на вирівнюванні рівнів соціально-економічного розвитку штатів шляхом трьохрівневого регулювання: загальнодержавного, відомчого, регіонального. На першому здійснюється формування національної політики регіонального соціально-економічного розвитку держави шляхом координації та прийняття законодавчих актів; на другому - розподіл федеральних коштів, що були виділені на проведення програм соціально-економічного розвитку регіонів; на третьому - втілюються у життя напрями соціально-економічного розвитку [567].

Характерними рисами соціальної політики Великобританії є жорстка 
перевірка потреб у соціальній допомозі, обмеженість соціальних трансфертів, спрямованість на згладжування соціальної нерівності при одночасному стимулюванні трудової активності населення, посилення децентралізації управління соціально-економічним розвитком країни, перенесення значимості соціальної політики на регіональний рівень, забезпечення та підтримка мінімальних умов життєдіяльності населення як граничної межи цивілізованого існування. Особливістю соціальної політики Великобританії є гарантування своїм громадянам мінімального рівня цивілізованого існування [570]. Засобом забезпечення належного рівня життєдіяльності населення є метод прямого перерозподілу доходів (більш 40\% рівень перерозподілу ВВП через бюджетну систему держави). Соціальна допомога населенню надається через системи соціальних трансфертів (пенсії за віком, за непрацездатністю, спадкоємцю; систему пільг (при цілковитій непрацездатності, для спадкоємців та ін.); виплати за хворобу, узаконені лікарняні та декретні; компенсації тимчасової та постійної непрацездатності, у разі виробничої травми; виплати безробітним; допомога багатосімейним та ін. Фінансову базу системи створюють національні страхові внески.

Загальне управління соціальної сфери у Великобританії здійснює Департамент соціального захисту, функціональним завданням якого $\epsilon$ дослідження процесів соціального розвитку, оцінка їх тенденцій, вдосконалення заходів щодо вирішення соціальних проблем, управління наданням грошової допомоги через центральні, регіональні та міські бюро. Управління конкретних соціальних проблем здійснюють відповідні департаментами - Департамент охорони здоров'я, Департамент 3 питань зайнятості, Департамент винагород соціального захисту тощо. Держава лише здійснює контроль за діяльністю місцевих органів влади та за потреби коригує їх діяльність.

Отже, державна система соціального забезпечення держав, що обрали ліберальну модель соціального розвитку, забезпечує високий рівень обліку соціальних потреб населення у кожному регіоні країни. До переваг можна віднести повну та оперативну реалізацію програм соціальної забезпеченості, 
захист громадян від негативних соціальних ризиків, сприяння у вирішенні найгостріших соціальних проблем, що позитивно впливає на підтримку соціальної стабільності у державі. Разом з тим є певні недоліки, а саме: створення великого апарату управління; можливість використання коштів за нецільовим напрямком використання; регіональні відмінності у реалізації програм соціальної допомоги через фінансові можливості штатів; послаблення стимулу до праці через можливість отримання допомоги за декількома соціальними програмами; посилення соціальної роз'єднаності між працюючими та тими, хто отримує соціальну допомогу.

Центристський підхід грунтується на консервативній моделі соціаль-ного розвитку держави, де велика роль приділяється сім’і як базовій соціаль-ній одиниці. Фінансування відбувається за рахунок страхових внесків, що формуються на підприємців. На основі консервативної моделі здійснюють свою соціальну політику Франція, Німеччина, Австрія, Бельгія, Італія та ін.

Французька соціальна політика спрямована на задоволення потреб громадян у гідних умовах життєдіяльності, зростання рівня зайнятості населення, гарантування соціально-економічної стабільності, забезпечення рівних можливостей громадян у реалізації своїх громадянських прав, зменшення диференціації у доходах між багатими та бідними [569]. Завдання соціальної політики вирішуються через системи систем соціального забезпечення та соціального страхування: перша - передбачає дію соціальних програм, спрямованих на відшкодування втрати заробітної плати, пов’язаної з виходом на пенсію та непрацездатністю (фінансуються за рахунок податку на заробітну плату, який сплачується робітниками); друга - передбачає відшкодування втрат заробітної плати у зв’ язку з виходом на пенсію, непрацездатністю та безробіттям, але це відбувається завдяки дії соціальних програм (фінансування здійснюється через фонди соціального страхування, за які відповідають підприємці). Тобто, спрацьовує принцип децентралізації управління соціально-економічним розвитком держави.

Виділяють три рівні управління: державний (здійснюється контроль за 
дотриманням місцевими органами влади чинного соціального законодавства); регіональний (фінансування планується 3 урахуванням інтересів та потреб департаментів та комун, які дають погодження на реалізацію плану регіонального соціально-економічного розвитку); місцевий (управління соцзабезпеченням і охороною здоров'я, житлове будування, початкове та професійне навчання, охорона навколишнього середовища та ін.; фінансування за рахунок муніципальних бюджетів, які формуються доходами від муніципальної власності, податкових надходжень, державних дотацій та кредитів).

Завданням державної політики у Франції є забезпечення для регіонів держави однакового рівня соціально-економічного розвитку. Це досягається через надання державних дотацій (основною є загальна дотація функціонування. «Вона складається з трьох частин: базової (40\%), яка залежить від кількості населення регіону; урівнювальної (37,5\%), яка залежить від рівня фінансового благополуччя території; компенсаційної (22,5\%), що залежить від специфічних характеристик регіону та його ресурсних можливостей [540, с.42]».

«Поліпшення демографічної ситуації у країні, знищення абсолютної бідності, вирівнювання соціально-економічного становища населення нових $\mathrm{i}$ старих федеральних земель - це пріоритетні завдання соціальної політики у Німеччині [537, с. 271]». Вирішення цих питань опирається на систему соціальної допомоги, що регулюється Федеральним законом про соціальну допомогу. Система соціальної допомоги складається такого: допомога по бідності, допомоги різного забезпечення. «Надання соціальної допомоги у Німеччині здійснюється за федеральним принципом. Згідно 3 ним за фінансування і управління соціальною допомогою відповідають місцеві органи влади $[498$, с. 137]». Федеральне міністерство праці та соціальних питань (загальнодержавний рівні регулювання) розробляє загальнодержавні напрями соціальної політики; виконує розробку заходів, надає практичних рекомендацій, здійснює нагляд за дотриманням чинного законодавства. Для вирівнювання життєвих можливостей населення система соціальної допомоги доповнюється 
механізмом перерозподілу коштів між територіями.

Системи соціальної допомоги країн із консервативною моделлю соціального розвитку є достатньо гнучкі та спроможні адаптуватися до потреб суспільства в умовах змін соціально-політичного становища. Соціальна політика цих держав грунтується на забезпеченні рівноваги між патерналістськими заходами та адресними соціальними програмами підтримки населення. До недоліків цієї системи можна віднести поширення певної залежності населення від соціальної підтримки держави, яке призводить до зростання витрат соціального характеру та виникнення фінансових проблем щодо їх покриття. Вирішення фінансової проблеми потребує здійснення пошуку нових джерел фінансування соціальної сфери та стимулювання розвитку системи благодійної допомоги. Соціальна політика у цих країнах направлена на подолання залежності населення від соціальної допомоги та активізації щодо включення у суспільне життя. Для соціально-демократичної моделі розвитку держави у пріоритеті $є$ досягнення рівності та соціальної справедливості, яка реалізується через рівний розподіл доходів, який забезпечує усім громадянам (без урахування трудового внеску) рівень життя. Визначальна роль щодо фінансування соціальних витрат належить державі. За такою моделлю здійснюється соціальна політика у Норвегії, Фінляндії, Швеції, Ісландії, Данії та деяких інших країнах. Економіка цих країн серед інших країн Європейського Союзу (СС) є «найбільш соціально орієнтованою за критерієм частки соціальних витрат у державному бюджеті, який коливається у межах 26-39\%. За цим показником аутсайдерами є Данії та Швеції. Витрати на соціальні цілі у відсотках до ВВП становлять 39,0 та 32,8\%, відповідно. Винятком є Ісландія, де відповідний показник є значно нижчим, ніж в інших країнах Північної Свропи, та дорівнює 19,1\% [492, с. 23-24]». Особлива увага щодо вирішення соціальних проблем громадян приділяється у Норвегії. Фінансування соціальної сфери та сфери охорони здоров'я в цій країні складає третю частину від загального доходу держави.

Управління соціальним напрямом у Норвегії здійснюється на трьох рівнях: державному, регіональному та муніципальному. Міністерство здоров'я та 
соціальних справ формує основні напрями національної соціальної політики, де у межах державного регулювання соціального розвитку виконуються: «Програма регіонального розвитку Норвегії, Програми виплат пенсіонерам (після 67 років), вдовам, дітям (до 18 років), непрацездатним, по хворобі, по вагітності та пологам, щотижневі виплати по безробіттю, за виробничі травми та ін. Виконання Програм регіонального розвитку щодо вирішення соціальних проблем покладаються на обласні ради. Реалізація державних соціальних програм здійснюється соціальними службами на муніципальному рівні [566]».

Система соціального забезпечення Фінляндії спрямована на профілак-тику виникнення соціальних проблем та на забезпечення гарантованого рівня доходу й підвищення рівня добробуту іï громадян. Система управління соціальними процесами у Фінляндії має теж три рівні, але: загально-державний, провінційний та місцевий. Керівним загальнодержавним органом управління є Міністерство 3 соціальних справ і охорони здоров’я, яке визначає основні напрями соціального розвитку держави, розробляє заходи щодо їх реалізації, готує соціальні реформи, забезпечує їх виконання та здійснює координацію соціального розвитку. Провінційне управління здійснюється структурами з соціального забезпечення й охорони здоров'я, які розподіляють державні субсидії, координують i контролюють відповідну соціальну роботу місцевих органів. На місцевому рівні управління здійснюється місцевими управліннями соціального забезпечення, які розподіляють кошти та визначають регіональну соціальну політику, збирають податки та координують надання соціальних послуг громадянам.

Отже, аналіз міжнародного досвіду щодо державного регулювання соціальної безпеки в різних країнах на засадах використання різних моделей соціального розвитку держави дає змогу визначитися 3 можливостями його використання в України. Досвід ефективного соціального управління у США, скандинавських країнах, країнах Європи визначає відповідність соціальних стратегій держави офіційно затвердженій моделі соціальної держави, а це дозволяє визначити шляхи вирішення першочергових соціальних проблем та 
гармонійний розвиток суспільства.

Проблеми, що пов'язані 3 покращення якістю життя населення слід розглядати комплексно та в системі інтересів різних рівнів. Системний розгляд синтезує інтегральну ідею покращення якості життя населення та пов’язує 3 визначеними обмеженнями та перевагами розвитку у соціальній, економічній та екологічній цілісності.

Розглянемо інтереси покращення якості життя на різних рівнях:

- світовий рівень - вирішити глобальні проблеми, які пов'язані щодо такого: боротьби з бідністю; усуненням проблем гендерної нерівності; зменшенням темпів поширення соціальних хвороб; використанням енергії і ресурсів за умов збереження навколишнього середовища; забезпеченням якісною питною водою і т. і.;

- національний рівень - вирішення державницьких питань щодо такого: зростання конкурентоспроможності держави; інтелектуальний розвиток та інформованість суспільства; перетворення потенціалів, що є у наявності (серед яких інтелектуальні, транзитні, природно-ресурсні та інших), на стратегічний ресурс розвитку України;

- міжрегіональний рівень - досягнення збалансованості у розподілі валового внутрішнього продукту у результаті впливу використання природного фактору;

- регіональний рівень - формуються напрями соціально-економічного розвитку, але без урахування корпоративних механізмів розвитку.

Держава має регулювати соціальний механізм шляхом визначення певних обмежень для непередбачених процесів, які можуть відбутися у суспільстві через процеси трансформації, глобалізації та інших. Крім того, непередбачувані процеси держава теж має спрямовувати в напрямку покращення якості життя в цілому, а не окремих соціальних груп. У галузі якості життя населення функціями державної політики є:

- розробка комплексних Концепції і Стратегії покращення якості життя 
в Україні;

- визначення регіональних пріоритетних напрямів соціальноекономічного розвитку щодо поліпшення умов життя і стану населення;

- підтримка держави досліджень, які спрямовані на визначення еталонів якості життя населення на короткостроковий та довгостроковий період запровадження;

- забезпечення державного функціонування системи контролю та прогнозування змін якості життя населення;

- упровадження єдиної та обгрунтованої системи моніторингу щодо визначення якості життя населення;

- державна експертиза на відповідність стратегічній меті щодо покращення якості життя України розроблених проектів законів, державних i регіональних програм розвитку.

Владні інститути, органи регіонального і місцевого самоврядування, громадські організації та саме населення мають реалізувати Концепцію покращення якості життя в Україні. Значна увага має бути направлена на населення, оскільки його здатність, як колективу людей, працювати, у першу чергу, у напрямку покращення власних або сімейних інтересів індивідуально, а потім і спільного життя обумовлено рівнем його соціально-психологічного потенціалу (визначальним цього потенціалу $\epsilon$ прагнення до соціальних й позитивних досягнень, які повинні отримувати підтримку суспільства).

Є декілька причин, чому ідея покращення якості життя населення має бути винесена на рівень національної ідеї, це такі:

1. Формування якості життя населення на території на засадах системності (якість життя населення спільності людей певної території $\epsilon$ системним поняттям, що передбачає формування і управління процесами, які впливають на неї та не здійснюється в межах чогось одного (галузі чи сфери);

2. Репутація держави в питаннях якості життя населення (важливий фактор оскільки пов'язаний 3 конкурентоспроможністю та інвестиційною привабливості країни. Саме через це Концепція покращення якості життя 
населення має стати основою соціально-економічної політики України).

3. Ефективне використання та розвиток людського потенціалу (затребуваність науковців, освітян та інтелектуальної еліти).

Отже, в царині покращення якості життя населення метою соціальноекономічної політики України має стати формування і відтворення людського потенціалу, характеристики якого дозволять сприяти модернізації економіки і суспільства країни.

Серйозні та значні ринкові перетворення в Україні стали причиною того, що держава не може здійснювати соціальне забезпечення усіх категорій населення через обмежені фінансові можливості. Конституцією України проголошено, що Україна $є$ соціальною державою, для якої пріоритетом $є$ соціальне забезпечення осіб. В останні два десятків років ми спостерігаємо нестабільність економічної ситуації як в Україні, так і у світі. Через це нарізними проблемами сфери соціального страхування є:

1) низький рівень охоплення збіднілого населення соціальною підтримкою;

2) низька адресність допомог при наданні соціальної підтримки.

Не через збільшення державного фінансування, а шляхом трансформації політики доходів населення має вирішуватися проблема соціального захисту. Маємо змінювати Концепцію соціальної політики - від політики встановлення системи державного захисту до політики зростання доходів, оскільки спрямованість цієї політики направлена на зростання індивідуальних доходів населення, у результаті чого кожна працююча людина може за рахунок власних коштів забезпечити себе необхідними соціальними послугами. Чинне законодавство України визначило значно більше різних видів соціальних пільг, виплат та послуг, ніж це зазначено у Конституції України чи у міжнародноправових зобов'язаннях України. Це означає, що держава бере на себе додаткові зобов'язання соціального захисту та забезпечення, які не завжди мають соціальну чи економічну доцільність (за винятком привілеїв для представників певних професій або окремих соціальних груп), а також потрібного ресурсного 
забезпечення.

Отже, фінансування соціальної сфери в Україні супроводжується значною кількістю проблем й недоліків та вимагають обов'язкового втручання. Вирішення даної проблем вимагає інноваційного реформування соціальної політики. Нестабільність економічної ситуації та наявність бюджетного дефіциту стали поштовхом для керівництва країни щодо активного пошуку підходів до розв'язання проблем фінансування соціальної сфери: встановлюються й оцінюються альтернативні доходні джерела бази державного бюджету; аналізуються різні варіанти ефективного співставлення витрат i результатів фінансування видатків. Серед основних підходів до вдосконалення бюджетного наповнення та оптимального фінансування соціальної захищеності та соціальної забезпеченості є:

- розширення сфер застосування ринкових інструментів соціального захисту: підтримка діючого обов'язкового та запровадження добровільного страхування; упровадження та розвиток накопичувальних систем страхування; диференційований підхід щодо задоволення попиту на різні соціальні послуги, через механізм діяльності державних пенсійних фондів, інститутів медичного страхування;

- нетрадиційні форми залучення коштів як суб'єктів господарювання так і домогосподарств;

- розширення сфери надання оплатних соціальних послуг, що диференційовані за ознаками якості;

- стимулювання та залучення некомерційного сектора до реалізації соціальних програм.

В Україні значний рівень фінансування для забезпечення соціальних видатків не свідчить про те, що система соціального захисту населення в Україні має ефективність з точки зору доступності та якості надання соціальних послуг та допомог. Тому, постає питання щодо створення ефективної системи фінансового забезпечення соціального захисту населення шляхом її подальшого реформування. Розроблені заходи мають зменшати навантаження на бюджет й 
сприяти нормальному забезпеченню соціальних виплат з відповідних джерел належною фінансовою підтримкою.

В Україні саме від фінансових можливостей держави залежить планування бюджетних коштів на фінансування пільг окремим категоріям громадян. А через відсутність достовірної інформації про кількість осіб, які мають право на пільги, а також про їх вартість, відсутня можливість запровадження уніфікованих підходів до визначення загального обсягу видатків державного бюджету. На сьогодні відшкодування вартості наданих пільг на протязі року знаходиться у межах фінансових можливостей держави за відповідний рік. Через це якість послуг, що надаються на пільгових умовах, знижується та відбувається порушення порядку їх надання. Ці видатки плануються не на рівні органів місцевого самоврядування, яким делеговано повноваження щодо фінансування пільг, а державними органами виконавчої влади. Органи місцевого самоврядування безпосередньо здійснюють призначення та надання пільг громадянам, але подаються розраховані показники державними органами виконавчої влади. Це призводить до того, що вони не зацікавлені у будь-якій оптимізації та економії, оскільки «кінцева визначена» сума на фінансування кожного виду пільг планується через призму наявних коштів державного бюджету та практично не залежить від реальної потреби для громади.

Варто відзначити, що система пільг і соціальних виплат, які домінує у сфері соціального захисту та соціального забезпечення, $є$ непрозорою. Замість реального соціального обслуговування населення утримується потужна розгалужена структура з державних і комунальних закладів соціального захисту та соціальних служб. Складність системи соціального захисту у сфері адміністрування пільг та обліку сприяє можливим зловживанням. Громадяни мажуть без належних підстав отримати документи, що надають їм право користуватися пільгами, на які вони не мають права. Такі порушення і з боку отримувача пільги, і з боку того, хто надав такий документ, як правило, лишаються безкарними. $€$ і інша сторона цього питання, коли особи, які мають усі підстави для отримання пільг, ними не користуються з різних об'єктивних та 
суб’єктивних причин.

Система надання пільг створює проблеми для підприємств, які надають такі послуги. 3 організаційної точки зору надання пільг зводиться до звичайного відшкодуванні витрат підприємствам, які надають певні послуги пільговим категоріям громадян. При чому, вартість наданих таких послуг, як правило, залежить від політики тарифного формування надавачів послуг без урахування державного регулювання розрахункової вартості пільги.

Реалії сьогодення передбачать, що соціальну політику не можна розглядати окремо від глобальних змін і глобальних викликів. Оскільки від таких викликів залежить загальний соціальний та економічний прогрес і безпека держави. Поглибленням соціальної нерівності, ризики бідності й соціального відторгнення, соціальні та військові конфлікти, погіршенням стану довкілля, є глобальними проблеми розвитку, які неможливо розв’язати без об’єднання зусилля всього суспільства. Створюючи власну стратегію розвитку, яка полягає в інтеграції до ЄС, Україна повинна ясно усвідомлювати як свої можливості, так і зовнішні загрози. В таких умовах, головною ідеєю соціальної політики має залишатися прагнення до більшої справедливості суспільства та забезпечення сталого розвитку економіки. Для іï створення необхідна грамотна та дієва соціальна політика. Саме завдяки реалізації заходів соціальної політики проходить затвердження принципів соціальної рівності та справедливості в рамках соціально-орієнтованої ринкової економіки.

Отже, головним та важливим кроком на шляху до вдосконалення системи соціального захисту населення має бути:

1) конкретизація та направленість. А можливо зробити тільки на локальних рівнях управління, до яких відносяться рівні областей та районів, де реально можна визначити реальну потребу людини;

2) запровадження прогресивних економічних реформ як внутрішніх так i зовнішніх змін. Прогресивні зміни економічного характеру $\epsilon$ важливим фактором розвитку держави. До них можна віднести рівноправне існування різних форм власності; лібералізація цін; свобода підприємницької діяльності; 
вільний вибір виду прикладання трудових зусиль; урегулювання оплати праці, яка має стати базою для формування зовсім нової соціально-економічної та демографічної ситуації;

3) вироблення адекватного та ефективного механізму соціального забезпечення населення;

4) соціальна політика має розглядатися у контексті глобальних змін і глобальних викликів. Це пов'язано з тим, від цих викликів напряму залежить загальний соціальний й економічний прогрес, а також безпека держави. Соціальна нерівність, ризики бідності та соціального відторгнення, соціальні та військові конфлікти, погіршення стану довкілля, які поглиблюються, відносяться до глобальних проблем розвитку, але їх не можна розв'язати без спільних зусиль всього світового суспільства;

5) розробка власної Стратегії соціального розвитку України, яка грунтується на засадах інтеграції до Європейського Союзу, має ураховувати чітке усвідомлення своїх можливостей та зовнішніх загроз;

6) головною ідеєю соціальної політики має бути визнано прагнення до справедливості у суспільстві та забезпечення сталого економічного розвитку (сьогодні Україна перебуває у складних умовах, що пов'язані з військовими дії на Сході країни, у результаті чого відбувається погіршенням економічної ситуації та зростання соціальної напруги. А це зводить нанівець шанси на реалізацію соціальної політики та економічний розвиток).

Отже, будь-які проблеми щодо урегулювання соціального захисту громадян - це прерогатива державної політики. Держава має вжити заходи для урегулювання питань економічного становища та гарантій соціального захисту громадян. Але маємо визнати, що сьогодні держава не готова, у першу чергу, через економічні обставини забезпечити виконання програм соціальноорієнтованого напряму. Цей «тягар ліг на плечі» органів місцевого самоврядування, які змушені вирішувати проблеми, що пов'язані з соціальним захистом населення, та шукати джерела фінансування для міських програм соціальної допомоги громадянам. Тому, першочерговим завданням є пошук 
оптимальних шляхів на місцевому рівні щодо надання соціальної допомоги та послуг. Запровадження нових соціальних програм і вдосконалення діючих спроможні забезпечити оптимізацію управлінням системою соціального захисту населення на різних рівнях та забезпечити високу якість й оперативність надання.

Оскільки якість життя населення та соціальна сфера мають взаємну узгодженість, то забезпеченість напрямів формування соціальної політики розділимо на дві складові: заходи підвищення якості життя населення та заходи удосконалення соціальної політики.

Заходи підвищення якості життя населення. Ми вже наголошували, що покращення якості життя населення в Україні має враховувати регіональні і місцеві специфіки розвитку країни. До інструментів покращення якості життя населення, які мають пріоритетне застосування, має входити

1) територіальний маркетинг. Такий вид маркетингу означає персоніфікований спосіб мислення і дій регіональних органів управління щодо взаємодії з власниками й підприємцями та спрямований на задоволення виявлених потреб населення регіону. Для цього потрібно системно вивчати стан і тенденції розвитку територій, налагодити збір достовірної інформації разом 3 соціологічними опитуваннями, яка ототожнює специфіку якості життя населення у регіоні;

2) розробка та затвердження Концепція покращення якості життя населення в Україні. Україна має вирішити складні завдання, які пов'язані 3 процесами інтегрування у різні міжнародні організації, а через це проблематика підвищення якості трудового життя відходить на задній план. Але, слід усвідомити і таке: без осмислення якісних характеристик життя людей в Україні будь-яке амбіційне соціальне, економічне та геополітичне завдання вирішити просто не можна;

3) забезпечення збалансованого розвитку регіонів у контексті покращення якості життя населення. Тут доцільно, окрім розробки Концепції 
покращення якості життя населення в Україні, вжити таких заходів:

3.1) розробка і реалізація «Регіональних програм покращення якості життя населення〉 через формування організаційно-управлінського механізму для забезпечення збереження і покращення якості життя населення в регіоні; (завдання - зростання і покращення демографічної ситуації; створення сприятливих умов для проживання та збереження здоров'я, сприяння самореалізації людей);

3.2) паспортизація та уніфікація регіонів і населених пунктів України за показником інтегральної оцінки якості життя населення для урахування в схемах розселення населення і розміщення продуктивних сил;

3.3) удосконалення методологій i методик регіональної соціальної статистики щодо обстеження домогосподарств для отримання достовірної інформації;

3.4) удосконалення міжбюджетних відносин 3 метою адекватного фінансового забезпечення;

3.5) актуалізація та розширення ролі місцевих органів влади.

На практиці реалізувати ці завдання є можливість через створення регіональних центрів, Координаційно-методичних рад 3 дослідження регіональних проблем розвитку (використати науково-дослідні та освітні установи), регіональні управління статистики і громадські об'єднання різних напрямів діяльності (соціальні, правові, екологічного та інших).

Заходи удосконалення соичіальної політики. Для досягнення європейських стандартів життя в Україні важливо здійснити виважені заходи щодо підвищення ефективності послуг соціальної сфери:

1) виконання економічно-обгрунтованих державних соціальних програм (ці програми мають бути спрямовані на вирішення найважливіших та найпріоритетних соціальних проблем регіонів на засадах забезпечення збалансованості, координації, організації належного контролю за їх виконанням);

2) поліпшення якості розробки «Стратегій регіонального розвитку»;

3) пошук новітніх нетрадиційних механізмів подолання соціальних 
проблем на територіях, які відносяться до депресивних, з метою зростання ефективності;

4) організація соціального моніторингу діяльності владних структур різних рівнів (державних органів, регіональних органів та органів місцевого самоврядування);

5) удосконалення міжбюджетних відносин шляхом розширення повноважень місцевих громад при розрахунку потреби у фінансових ресурсах для соціального захисту населення (поліпшення фінансування соціальної сфери на місцевому рівні без зміцнення фінансової бази та підвищення фінансової незалежності місцевих бюджетів малоймовірне. Цьому сприятиме розширення самостійності місцевих органів самовряднування шляхом побудови адекватної системи формування бюджетів;

6) посилення адресності соціальної допомоги та підвищення ефективності iii використання (можна досягли через розвиток інституту державних соціальних інспекторів);

7) удосконалення критерії визначення майнового стану сім’і;

8) достовірне формування на локальному рівні бази одержувачів усіх видів соціальних допомог 3 метою ii передання до загального Державного реєстру осіб, які користуються або мають право на відповідні соціальні виплати, допомоги та пільги;

9) залучення громадських організацій до соціального захисту окремих категорій населення;

10) створення ефективних систем моніторингів витрачання коштів на соціальний захист та визначення ефективності відповідного виду соціальної допомоги, послуги чи пільги.

11) реформування системи пільг через їх заміну на інші механізми соціального захисту (розв’язання має бути у законодавчій площині. Потрібно розділити поняття «пільга» на дві складові: перша - пільга, що надаються громадянам за життєвих обставин та зумовлюють необхідність особливої уваги до людини (є частиною державної системи соціального забезпечення); друга - 
пільга, що пов’язана зі службовим статусом особи чи видом її трудової діяльності);

12) проведення аудиту системи пільг, соціальних і компенсаційних виплат та їх одержувачів, що є чинними, для визначення обсягу фінансування;

13) розширення адресності надання пільг за критерієм доходності родини/особи та впорядкувати кола осіб, на яких ця пільга поширюється;

14) вилучення $з$ нормативно-правових документів положень про пільги за професійною ознакою (ці пільги не передбачають механізмів їх реалізації та визначення джерел фінансування та не відповідають принципам ринкової економіки. До таких пільг, на нашу думку, належать пільги для: народних депутатів, та членам їхніх сімей; кандидатам у Президенти України; депутатам місцевих рад; держслужбовцям; суддям; працівникам прокуратури та інші);

$15)$ розробка пропозицій для внесення змін до законодавчих актів з питань надання пільг найменш захищеним верствам населення та особам, які мають особливі заслуги перед Батьківщиною, опираючись на єдність принципів та критеріїв для визначення законодавчих нормам та нормативів споживання;

16) трансформація соціальних пільг в умовні трансферти (переведення субсидій за користування комунальними послугами на ваучери на придбання певних послуг комунальних підприємств (прямі грошові платежі у якості субсидій себе фінансово не виправдали);

17) застосування науково-обгрунтованих підходів до розрахунків державних мінімальних стандартів;

18) терміновий перегляд «Методики визначення розміру прожиткового мінімуму на одну особу та осіб, що належать до основних соціальних i демографічних груп населення» та приведення іiі у відповідність до вимог законодавства європейських держав;

19) відмовитися від використання показника «рівня забезпечення прожиткового мінімуму», оскільки він необгрунтовано занижує державні соціальні гарантії;

20) розширити види відповідальності для припинення практики 
невиконання правових норм;

21) запровадження правил підвищення мінімальної пенсії шляхом ii «ув'язки» з індексом споживчих цін для груп населення з різними доходами;

22) визначення нових правил щодо перегляду структури та вмісту споживчого кошика для його адаптації до потреб населення;

23) продовження реформування пенсійної системи шляхом розробки нормативних, організаційних та контролюючих механізмів регулювання запровадженого другого рівня;

24) запровадження нових видів джерел фінансування охорони здоров'я, які базуються на державно-приватному партнерстві, обов'язковій страховій медицині та легалізації інших джерел оплати наданих медичних послуг;

25) збільшення інвестування освіти, професійної підготовки та навчання національних трудових ресурсів протягом усього життя шляхом залучення як державних джерел фінансування, так і недержавних за узгодженими програмами професійної підготовки;

26) адаптації досвіду з реалізації соціальних регулювання країн $Є С$ в умовах України (не просте перенесення моделі, методу чи технології, а упровадження за умов доцільності, обгрунтованості, виконаної підготовки та належного фінансового забезпечення) та інші.

Отже, на сучасному етапі розробка та реалізація ефективної системи соціального захисту населення як складової соціальної політики у контексті забезпечення зростання рівня та якості життя населення є визначальним завданням для розбудови соціально-економічної моделі суспільства в Україні. Головних завданням державної соціальної політики України має бути забезпечення виваженого та якісного державного управління усіма сферами життя суспільства,а кінцевою метою побудови соціальної держави - політичного устрою, який би дозволив кожній людині відчувати себе комфортно сьогодні та упевнено завтра. Ми переконані, що вирішення цього завдання без продуманої, 
виваженої, обгрунтованої та ефективної соціальної політики неможливо.

Для розробки шляхів удосконалення соцполітики було встановлено:

1. Позитивний досвід щодо забезпечення ефективного соціального регулювання у світі дозволяє зробити висновок про те, що в Україні назріла необхідність здійснити зміни у розбудові соціальної направленості нашої держави шляхом забезпечення соціально-орієнтації економіки, підвищення значення держави у вирішенні соціальних проблем та розробці системи профілактичних заходів для унеможливлення соціальних небезпек. Застосування у системі національної безпеки України важелів унеможливлення соціальних небезпек потребує обгрунтованого визначення механізму регулювання соціальної безпеки.

2. Соціальна політика $є$ визначальним елементом внутрішньої політики держави, яка є значимою складовою загальної політики, та реалізується через соціальні програми та інші заходи соціально-економічного розвитку. В їі основі мають бути враховані відповідний рівень економічного розвитку та стану економіки, а от нехтування соціальними проблемами може причиною «соціальних вибухів», що призведуть до суттєвих економічних втрат.

3. Дослідження дозволило виявити тенденції формування, реалізації та розвитку соціальної політики в Україні, яка має зазнати інноваційного розвитку саме на регіональному рівні управління в умовах трансформаційних процесів в українському суспільстві. Департаменти соціального захисту населення обласних державних адміністрацій мають стати головним суб’єктом, через який реалізується соціальна функція держави.

4. Запропоновані зами шляхи удосконалення соціальної політики у контексті забезпечення покращення якості життя населення, на нашу думку, $є$ найвагомішими та спроможними підвищити соціальну направленість та рівень $і 1$ ефективності.

\section{ЗАГАЛЬНІ ВИСНОВКИ}

Виконане дослідження на тему «Соціальна політика як елемент інтегрального механізму покращення якості життя населення України» 
дозволило зробити наступні узагальнення:

1. Найважливішою функцією будь-якої держави світу є іï соціальна політика. Ця політика здійснюється як найрозвиненішими країнами (країнами загального добробуту або соціальними державами), так і країнами, які на початковій стадії розвитку (країни третього світу). Порівнюючи рівень соціального забезпечення в цих країнах, можемо впевнено сказати, що він діаметрально протилежний. Це свідчить про те, що моделі соціальної політики у цих країнах різні. Ці моделі не є ідентичними і у державах, що мають ефективну економіку. Тому, актуальне значення має з'ясування суті соціальної політики, iї функцій, принципів, моделей, інструментів тощо.

2. Важливість державної соціальної політики засвідчує перелік іiі напрямів: політика розподілу i перерозподілу суспільного продукту; демографічна політика; політика зайнятості та охорони праці; політика соціального забезпечення і соціального страхування; політика гармонізації соціально-економічних інтересів і забезпечення соціального діалогу. Кожен 3 зазначених напрямів має свою структуру з додаткових складових напрямів. Таким чином, перелік основних напрямів соціальної політики з його складовими свідчать про необхідність грунтовного аналізу потреб суспільства та відповідального ставлення державних органів влади до своїх обов'язків.

3. Соціальна політика є визначальним напрямком внутрішньої державної політики, мета якої формування гідних умови життя всім членам суспільства. Її завдання має бути - постійне покращення добробуту людей. Тому, і було створено систему соціального захисту та соціальних гарантій.

4. Результативність соціальної політики можна визначити за таким критерієм як рівень життя населення. Даний критерій характеризує спроможність задоволення духовних та матеріальних потреб громадянами. В Конституції України визнано, що найвищою соціальною цінністю держави $\epsilon$ людина, iї честь та гідність, життя й здоров'я, безпека та недоторканність називаються.

5. Державі реформи ігнорують практично усі найважливіші соціальні 
процеси. Крім того, досить часто приймаються популістські рішення, що посилює недовіру людей до влади.

6. Фактично зруйновані головні галузі соціального захисту людини, до яких відносяться охорона здоров’я, освіта та культура. У результаті цього населення втратило можливість отримувати соціальні послуги через їх їх переведення на платну основу. Матеріально-технічна забезпеченість за залишковим принципом призвела до ліквідації та зупинки більшості підприємств і систем життєзабезпечення.

7. Демографічна ситуація в Україні є критично. Це підтверджується погіршенням показників смертності та народжуваності, зниженням прогнозів очікуваної тривалості життя, загостренням ситуації на ринку праці через масову міграцію, посиленням нерівності у розподілі прибутків, масштабами бідності через постійне зростання цін на продукти харчування та комунальні послуги. Ситуація на Сході країни та пандемія теж внесли свій негативний внесок на демографічну ситуацію.

8. Прожитковий мінімум по факту більш ніж у 2 рази від встановленого на законодавчому рівні. Причино цього є те, що до його величини «підв’язано» понад 180 різноманітних видів виплат. До пошуку додаткових джерел видатків 3 бюджетів усіх рівнів та до перерахунку значної кількості виплат призводить будь-яке збільшення прожиткового мінімуму.

9. Першочерговими завданнями у сфері соціального захисту та соціального забезпечення мають стати - підвищення ефективності управління бюджетними коштами, що направляються на підтримку соціально збіднілих верств населення з боку держави, та подальше реформування сфери надання соціальних послуг і соціального захисту.

10. Необхідність реформування системи пенсійного забезпечення $\epsilon$ незаперечною. Це реформування має створити належні умови для такого: підвищення рівня пенсій; перерозподілу функцій між державою, роботодавцями й працюючими щодо соціального захисту громадян похилого віку на засадах раціональності; залучення нагромаджуваних пенсійних коштів для реалізації 
політики економічного зростання.

11. Реалізація стратегічного курсу України до європейських стандартів життя має грунтуватися на такому: підвищенні ефективності та якості надання соціальних послуг; створення та впровадження, у першу чергу, правових, а також організаційних умов недопущення зниження рівня життя населення.

12. Україна має намір інтегруватися у світове суспільство в умовах розвитку нових підходів до змісту соціальних відносин, яких вона має теж розвивати та дотримуватися. Свропейський Союз затвердив соціальні критерії, дотримання яких мають формувати та реалізовуватися у соціальній політиці держав:

- розширення свободи вибору способу життя, життєвих благ, можливостей отримати освіту та творчих здібностей;

- підвищення рівня матеріального добробуту та якості життя;

- покращення здоров’я та збільшення тривалості трудової активності;

- збільшення тривалості життя, посилення національної та соціальної безпеки.

У відповідності до статусу соціально-ринкової держави, дані показники мають реалізуватися через соціальні стандарти, які повинні забезпечити виконання основних соціальних завдань - задоволення потреб населення, збереження єдиного соціального простору, забезпечення соціальної рівності, концентрація матеріальних ресурсів тих напрямів соціальної політики, які $\epsilon$ пріоритетними.

13. Шляхи удосконалення соціальної політики у контексті забезпечення покращення якості життя населення, які були нами запропоновані мають, на нашу думку, мають найвагоміше значення на даному етапі соціальноекономічного розвитку України та спроможні підвищити соціальну направленість та рівень ефективності соціальної політики. 


\section{SECTION 11. MICRO AND MACRO ECONOMY}

DOI 10.46299/ISG.2021.MONO.ECON.II-552-564

\section{1 Державна підтримка стратегічних напрямів розвитку малого та середнього підприсмництва}

Україна, як i будь-яка інша держава, зацікавлена у розвитку підприємництва. Вважається, що в силу певних причин великі корпорації не можуть швидко реагувати на зміни ринкової ситуації, в результаті чого не справляються 3 потребами населення, а збільшення числа активних малих підприємств сприяє поліпшенню якості життя громадян країни та, відповідно, зростанню економічних показників в цілому. При цьому малі підприємства не являють панацеєю, а ефективно можуть діяти лише в сукупності 3 активним розвитком всієї структури бізнесу.

Існуючі програми підтримки малого та середнього підприємництва (МСП) як на державному так і регіональному рівнях мають недосконалу методологічну базу, а також недостатньо ефективну систему оцінки результатів програмних заходів.

Аналіз динаміки частки малих підприємств в Україні у загальній кількості підприємств - суб’єктів підприємницької діяльності за період 2010-2020 pp. свідчить, що цей часовий відрізок характеризується зростанням їх кількості. Так, за статистичними даними, на початок 2020 р. в Україні налічувалось 380079 суб’єктів МСП, з яких 313380 - мікропідприємства, а також 1561028 фізичних осіб - підприємців. У 2010 році ці показники становили відповідно 378224 суб’єкта МСП, з них 300445 - мікропідприємства та 1328743 фізичних осіб підприємців. За цей час кількість середніх підприємств зменшилось з 20983 до 17751 суб’єкта, проте відбулося незначне збільшення суб'єктів малого підприємництва на 5087 одиниць, що свідчить про недостатню ефективність інструментів стимулювання їх розвитку. Найбільша кількість МСП традиційно зосереджена в м. Києві - 101699, Дніпропетровській - 31128, Харківській 25031, Львівській - 20451, Київській - 21040, Одеській - 25848. Це обумовлено 
географічними чинниками щодо розташування регіонів, особливостями економічного розвитку, видами економічної діяльності та великою кількістю зареєстрованих підприємств. На МСП працює значна частина працездатного населення країни. Так, у 2010 році на цих підприємствах було зайнято 8372452 особи, а на початок 2020 року в цьому бізнесі працювало 7409466 осіб, тобто на $11 \%$ зменшилась кількість працюючих.

Статистичні дослідження діяльності МСП в деяких країнах-членах $\mathrm{CC}$ підкреслюють їх важливу роль у досягненні соціально-економічного розвитку держави. За рахунок МСП створюється значна частина ВВП у країнах світу. Так, у країнах - членах ЄС мале підприємництво створює 39,3 \% доданої вартості та надає майже 50,0 \% робочих місць [571]. Статистичні дані свідчать про превалювання мікропідприємств у країнах СС (93,2 \%) серед усіх МСП нефінансового сектора. Однак серед зайнятих у нефінансовому секторі вони займають лише 29,8 \% [572].Частка малого підприємництва у загальній чисельності зайнятих становить понад половину у США та Франції - 54,0 \%, в Італії - 73,0 \%, в Японії - 78,0 \% [573]. В Україні цей показник протягом 20002019 рр. складав 9,0-11,0 \%, що свідчить про повільні тенденції процесу формування та розвитку малого підприємництва в країні.

Дослідження зайнятості населення на МСП свідчить про послаблення ролі малого підприємництва у вирішенні питання створення нових робочих місць. На думку 3. Варналія, «Причиною негативних тенденцій щодо кількості зайнятих на малих підприємствах України $є$ зміни в державній політиці відносно регулювання малого підприємництва, брак державної підтримки суб’єктів малого підприємництва, що призвело до зменшення їх активності у виробничих секторах економіки, що, своєю чергою, призвело до скорочення кількості їхніх працівників» [573].

За даними щорічної оцінки ділового клімату (ABCA, Annual Business Climate Assessment), що проводиться 3 метою виявлення бар'єрів на шляху розвитку МСП та кількісному визначенні «ціни» дотримання регуляторних вимог для МСП, основними перешкодами для діяльності та зростання МСП в 
Україні є: нестабільна політична; низький попит на продукцію; високі ставки податків; складне податкове адміністрування; часті зміни економічного законодавства; інфляція; високий регуляторний тиск; перевірки, корупція; недостатність кваліфікованих працівників; війна на сході України; низька доступність кредитів; високий рівень конкуренції; проблема ліквідності - брак обігових коштів; високі ставки кредитів; неефективність державного апарату; обтяжливе валютне регулювання; обмежувальне трудове законодавство; застарілі технології; проблеми з енергопостачанням [574].

Починаючи з 2016 р., Україна вжила важливих заходів, спрямованих на покращення середовища для розвитку малих та середніх підприємств. У травні 2017 р. Кабінет Міністрів затвердив першу в Україні Стратегію розвитку МСП на період до 2020 р. Наступного року при Міністерстві розвитку економіки, торгівлі та сільського господарства України був створений Офіс розвитку МСП з повноваженнями сприяти в реалізації Стратегії розвитку МСП, особливо в плані інфраструктури підтримки бізнесу. Проте, незважаючи на всі ці заходи, нещодавній аналіз МСП продемонстрував, що адміністрування податків, регуляторний тиск та корупція й надалі залишаються найбільшими проблемами для МСП. У таблиці 11.1.1 наведено загальні якісні характеристики сценаріїв розвитку МСП в Україні: передумови здійснення, можливі дії, результати та ймовірність реалізації.

Загальними передумовами розвитку МСП у країні на макроекономічному рівні $є$ такі: схильність населення до підприємницької діяльності; рівень цін на енергоносії; інвестиційний клімат у країні; розвиток інфраструктури; рівень конкуренції; рівень інноваційної активності; розвиток фінансово-кредитної системи; рівень інфляції; рівень безробіття або неповної зайнятості та рівень корупції у країні. 
Таблиця 11.1.1.

Якісні характеристики сценаріїв розвитку МСП в Україні

\begin{tabular}{|c|c|c|c|}
\hline Передумови & Можливі дії & Результати & $\begin{array}{c}\text { Імовірність } \\
\text { реалізації }\end{array}$ \\
\hline $\begin{array}{l}\text { - Схильність } \\
\text { населення до } \\
\text { підприємницької } \\
\text { діяльності } \\
\text { • Ціни на енергоносії } \\
\text { - Інвестиційний клімат } \\
\text { у країні } \\
\text { • Розвиток } \\
\text { інфраструктури } \\
\text { • Рівень конкуренції } \\
\text { • Рівень інноваційної } \\
\text { активності } \\
\text { • Розвиток фінансово- } \\
\text { кредитної системи } \\
\text { • Рівень інфляції } \\
\text { • Рівень безробіття або } \\
\text { неповної зайнятості } \\
\text { • Рівень корупції у } \\
\text { • Країні } \\
\text { • Якість державних } \\
\text { інститутів } \\
\text { •Спрямованість } \\
\text { реалізації державних } \\
\text { реформ } \\
\text { •Рівень державної } \\
\text { ініціативи щодо } \\
\text { дерегулювання та } \\
\text { підтримки розвитку } \\
\text { МСП }\end{array}$ & $\begin{array}{l}\text { •Створення єдиного } \\
\text { інформаційного } \\
\text { ресурсу МСП } \\
\text { • Стимулювання } \\
\text { впровадження } \\
\text { енергозберігаючих } \\
\text { технологій } \\
\text { • Створення рівних } \\
\text { умов для розвитку } \\
\text { конкуренції } \\
\text { • Заохочення } \\
\text { інновацій МСП } \\
\text { • Спрощення } \\
\text { ведення бізнесу на на } \\
\text { законодавчому рівні } \\
\text { • Усунення } \\
\text { надмірного } \\
\text { регуляторного тиску } \\
\text { держави } \\
\text { (податкового, } \\
\text { валютного, } \\
\text { земельного, цінового } \\
\text { тощо } \\
\text { • Підготовка та } \\
\text { впровадження } \\
\text { державної стратегії } \\
\text { підтримки та } \\
\text { розвитку МСП за } \\
\text { участю } \\
\text { представників } \\
\text { бізнесу }\end{array}$ & $\begin{array}{l}\text { - Рівень розвитку } \\
\text { підприємництва в } \\
\text { країні } \\
\text { • Обсяг та інноваційність } \\
\text { виробництва товарів / } \\
\text { послуг МСП } \\
\text { - Рівень } \\
\text { конкурентоспроможн } \\
\text { ості МСП на } \\
\text { внутрішньому } \\
\text { зовнішніх ринках } \\
\text { - Рівень залучення МСП в } \\
\text { ланцюги створення } \\
\text { доданої вартості } \\
\text { - Рівень прийнятності } \\
\text { фінансово-правового } \\
\text { законодавства } \\
\text { - Зміна нормативно } \\
\text { правової бази щодо } \\
\text { МСП }\end{array}$ & $\begin{array}{l}\text { Висока } \\
\ldots . \\
\text { Середня } \\
\text {... } \\
\text { Низька }\end{array}$ \\
\hline
\end{tabular}

Песимістичний сценарій розвитку МСП в Україні, який може бути реалізований за низької ймовірності внаслідок виникнення низки несприятливих передумов та низької спроможності економіки та держави до їх нівелювання. Так, за песимістичним сценарієм розвитку МСП у країні на макроекономічному рівні будуть спостерігатися такі передумови: низька схильність населення до підприємницької діяльності; шокове зростання ціни на енергоносії; несприятливий інвестиційний клімат у країні; занепад 
інфраструктури; низький рівень конкуренції; низький рівень інноваційної активності; збої у роботі фінансово-кредитної системи; зростання рівня інфляції; зростання рівня безробіття або неповної зайнятості; посилення корупції у країні; призупинення реалізації державних реформ і формальний рівень державної ініціативи щодо дерегулювання та підтримки розвитку МСП.

Результатами реалізації песимістичного сценарію розвитку МСП в Україні на макроекономічному рівні можуть бути такі: зниження рівня розвитку підприємництва у країні; зниження обсягу та інноваційності виробництва товарів та послуг МСП; низький рівень конкурентоспроможності МСП на внутрішньому та зовнішніх ринках; низький рівень залучення МСП у ланцюги створення доданої вартості.

За базовим сценарієм розвитку МСП в Україні, який може бути реалізований з високою ймовірністю внаслідок створення низки прийнятних передумов і певного рівня спроможності економіки та держави до їх нівелювання. Так, за базовим сценарієм розвитку МСП у країні на макроекономічному рівні будуть спостерігатися такі передумови: незначне зростання схильності населення до підприємницької діяльності; помірне зростання ціни на енергоносії; певне покращення інвестиційного клімату в країні; поступове відновлення інфраструктури; помірний рівень конкуренції; зростання рівня інноваційної активності; покращення роботи фінансовокредитної системи; помірний рівень інфляції; незначне зростання рівня безробіття або неповної зайнятості; незначне зниження корупції в країні.

Виходячи з передумов і можливих дій результатами базового сценарію розвитку МСП в Україні з високою ймовірністю на макроекономічному рівні буде: незначне зростання рівня розвитку підприємництва в країні; незначне зростання обсягу та інноваційності виробництва товарів та послуг МСП; зростання рівня конкурентоспроможності МСП на внутрішньому та зовнішніх ринках; зростання рівня залучення МСП у ланцюги створення доданої вартості.

Оптимістичний сценарій розвитку МСП в Україні, який може бути реалізований з ймовірністю нижче середньої внаслідок створення сприятливих 
передумов та високого рівня спроможності економіки та держави до їх нівелювання. Так, за оптимістичним сценарієм розвитку МСП у країні на макроекономічному рівні будуть спостерігатися такі передумови: зростання схильності населення до підприємницької діяльності; відносно стабільні ціни на енергоносії; покращення інвестиційного клімату в країні; висока якість інфраструктури; високий рівень конкуренції; високий рівень інноваційної активності; стабільна робота фінансово-кредитної системи; нормальний рівень інфляції; нормальний рівень безробіття; відчутне зниження корупції у країні.

Виходячи 3 передумов і можливих дій результатами оптимістичного сценарію розвитку МСП в Україні з ймовірністю нижче середнього на макроекономічному рівні буде: постійне зростання рівня розвитку підприємництва в країні; значне зростання обсягу й інноваційності виробництва товарів та послуг МСП; високий рівень конкурентоспроможності МСП на внутрішньому та зовнішніх ринках; високий рівень залучення МСП у ланцюги створення доданої вартості в промислових кластерах.

Отже, за результатами проведеного дослідження щодо можливих сценаріїв розвитку МСП в Україні можна зробити висновок, що воно буде з високою ймовірністю розвиватися за базовим сценарієм, що характеризується незначним покращенням показників розвитку на макроекономічному та загальнодержавному рівнях.

Для реалізації стратегій і програм розвитку МСП у країні необхідний відповідний інструментарій.

У тлумачному словнику під інструментарієм розуміється сукупність інструментів, які використовуються в якій-небудь галузі. Водночас інструмент це засіб, який використовується для досягнення чого-небудь [575].

Виділяють такі основні види підтримки МП у промислово розвинутих країнах світу: адміністративно-правову, фінансово- кредитну й інвестиційну, податкову, залучення МП до виконання державних заказів, кадрову, консультаційну та інформаційну, експортної діяльності, регіонального розвитку. 
Кожний 3 видів підтримки МП, своєю чергою, складається 3 певного інструментарію.

Із інструментів державної підтримки малого інноваційного бізнесу в закордонних країнах найчастіше використовувалися такі: гранти на виконання НДДКР - 17 випадків (15,9 \% від загальної кількості); співфінансування контрактних робіт університетів, державних дослідницьких організацій, що виконуються для підприємств малого бізнесу - 15 випадків (14,0 \%); створення інфраструктури підтримки малого інноваційного бізнесу- 13 випадків (12,1%); програми підтримки МСП на основі кластерно- мережевого підходу - 12 випадків (11,2%). Найбільшу кількість інструментів державної підтримки малого інноваційного бізнесу використовували країни: США і Франція - по 9; Японія - 7; Австрія, Німеччина, Фінляндія - по 6 [576].

Види державної підтримки розвитку МСП в Україні наступні.

Інфраструктурна: здійснюється в рамках державних, регіональних і місцевих програм розвитку малого і середнього підприємництва (бізнес-центри, бізнес-інкубатори, інноваційні бізнес-інкубатори, науково-технологічні центри, центри трансферу технологій, фонди підтримки малого підприємництва, лізингові компанії, консультативні центри, інші підприємства, установи та організації, основним завданням яких є сприяння розвитку малого і середнього підприємництва).

Фінансова: часткова компенсація відсоткових ставок за кредитами, що надаються на реалізацію проектів суб’ єктів малого і середнього підприємництва; часткова компенсація лізингових, факторингових платежів та платежів за користування гарантіями; надання гарантії та поруки за кредитами суб’єктів малого i середнього підприємництва; надання кредитів, у тому числі мікрокредитів, для започаткування і ведення власної справи; надання позик на придбання і впровадження нових технологій; компенсація видатків на розвиток кооперації між суб’єктами малого і середнього підприємництва та великими підприємствами; фінансова підтримка впровадження енергозберігаючих та екологічно чистих технологій; інші види не забороненої законодавством 
фінансової державної підтримки.

Інформаційна: створення та забезпечення функціонування державних, регіональних і місцевих інформаційних систем, інформаційнотелекомунікаційних мереж, сприяння започаткуванню підприємницької діяльності за допомогою Інтернету; надання інформації: про стан виконання державних, регіональних і місцевих програм розвитку малого і середнього підприємництва та рівень ефективності державної підтримки; про стан розвитку малого і середнього підприємництва; про об'єкти інфраструктури підтримки малого і середнього підприємництва; іншої інформації (економічної, правової, статистичної, виробничо-технологічної, з питань маркетингу), необхідної для забезпечення розвитку суб'єктів малого і середнього підприємництва.

Консультаційна: сприяння утворенню об'єктів інфраструктури підтримки малого і середнього підприємництва, які надають консультаційні послуги суб'єктам малого і середнього підприємництва, та забезпечення їх діяльності; спрощення доступу до інформації в режимі реального часу.

Державна підтримка у сфері інновацій, науки та промислового виробництва: надання фінансової підтримки для утворення об’єктів інфраструктури підтримки малого i середнього підприємництва у сфері інновацій, науки та промислового виробництва, у тому числі бізнес-інкубаторів, інноваційних бізнес-інкубаторів, науково- технологічних центрів, центрів трансферу технологій; сприяння розвитку венчурного підприємництва; створення системи економічних стимулів для розвитку економіки на основі технологічних інновацій; передачі наукової продукції, створеної за рахунок бюджетних коштів, для іiі впровадження у виробництво; створення умов для залучення суб'єктів малого і середнього підприємництва до укладення договорів субпідряду у сфері інновацій та промислового виробництва; стимулювання залучення іноземних інвестицій i розвитку взаємовигідної міжнародної інноваційної співпраці; створення умов для поширення кооперації між суб'єктами малого і середнього підприємництва та великими підприємствами.

Державна підтримка у сфері підготовки, перепідготовки і підвищення 
кваліфікації управлінських кадрів та кадрів ведення бізнесу: створення та розвитку мережі бізнес-інкубаторів; розроблення та виконання освітніх програм, спрямованих на підготовку, перепідготовку і підвищення рівня кваліфікації кадрів для суб'єктів малого і середнього підприємництва на основі державних освітніх стандартів; створення умов для підвищення рівня професійних знань $\mathrm{i}$ ділових якостей фахівців з числа соціально незахищених верств населення; надання навчально-методологічної, науково-методичної допомоги суб'єктам малого і середнього підприємництва; сприяння участі у програмах обміну міжнародним досвідом 3 метою запровадження передових технологій та підвищення рівня кваліфікації персоналу суб'єктів малого і середнього підприємництва.

Державна підтримка МСП, що провадять експортну діяльність: сприяння просуванню на ринки іноземних держав продукції вітчизняного виробництва (товарів, робіт і послуг), об'єктів інтелектуальної власності та створення сприятливих умов для українських учасників експортної діяльності; співпраці 3 міжнародними організаціями та іноземними державами у сфері розвитку малого i середнього підприємництва; утворення об'єктів інфраструктури підтримки малого і середнього підприємництва, що сприяють експортній діяльності, зокрема шляхом надання фінансової підтримки (кредитування, гарантування, страхування експортних операцій, часткова компенсація частки відсоткових ставок за кредитами для провадження експортної діяльності, часткове покриття витрат суб'єктів малого і середнього підприємництва, пов'язаних із здійсненням маркетингових заходів на зовнішньому ринку, вивченням кон'юнктури зовнішнього ринку, пошуком партнерів, просуванням товарів на нові ринки, участю у виставково- ярмарковій діяльності за кордоном, відрядженням спеціалістів для вивчення ринків іноземних держав, підготовкою, перепідготовкою та підвищенням кваліфікації персоналу суб'єктів малого і середнього підприємництва з питань експортної діяльності); сприяння участі суб'єктів малого i середнього підприємництва у виставково-ярмарковій діяльності за кордоном для представлення продукції вітчизняного виробництва, 
у тому числі шляхом надання фінансової підтримки, надання в оренду виставкових площ, часткового покриття витрат суб'єктів малого і середнього підприємництва, пов’язаних з участю у виставково-ярмарковій діяльності за кордоном; сприяння поширенню за кордоном інформації про потенційні можливості вітчизняного малого і середнього підприємництва та забезпеченню доступу до іноземних інформаційних мереж для пошуку ділових партнерів.

Мале та середнє підприємництво в Україні проходить складний шлях становлення. Корисним на цьому шляху може стати врахування досвіду провідних країн світу у створенні сприятливих умов ведення підприємницької діяльності. В економічно розвинених країнах світу розвиток МСП йде більш швидкими темпами, ніж в Україні, через розуміння державними органами влади його значення для економічного зростання країни та підвищення якості життя іiі населення. Малі та середні підприємства, згідно з Євростатом, виступають «основою європейської економіки, що $є$ потенційним джерелом праці та економічного зростання» [571].

«У країнах із розвиненою ринковою економікою, де мале підприємництво забезпечує 60-70 \% ВВП, на його підтримку щорічно спрямовується 2-3 \% видаткової частини бюджету» [576]. Пояснюється це тим, що, незважаючи на соціально-економічну значущість МСП, вони мають значні ризики функціонування та є найбільш вразливими до інфляції, значної конкуренції, обмеженості фінансових ресурсів тощо. Політика Європейської Комісії щодо МСП зосереджена переважно у п’яти пріоритетних сферах: сприяння підприємництву та навичкам; поліпшення доступу МСП до ринків; скорочення бюрократії; поліпшення потенціалу зростання МСП; зміцнення діалогу та консультації з зацікавленими сторонами МСП. Відрізняються тенденції розвитку МСП у країнах з різними методами державного регулювання, а саме США, СС та Японії.

Державна підтримка МСП у СС здійснюється на наднаціональному та національному рівнях: європейські програми фінансової допомоги; національні програми спрощення процедур створення підприємств; європейська програма 
розвитку вторинного ринку цінних паперів EASDAQ, європейська програма розвитку мереж «бізнес-ангелів»; європейська та національні програми підвищення інноваційного потенціалу МСП; програма управлінської інтеграції в ЄC [577]. Також у СС функціонує Свропейський фонд регіонального розвитку, обсяг фінансування програм надання допомоги МСП з якого складає близько 140 млрд. дол. на період з 2014 р. по 2020 р. відповідно до Багаторічної програми фінансового розвитку СС на період 2014-2020 pp. [577].

Таблиця 11.1.2.

Інституційно-правова підтримка МСП в країнах ЄС

\begin{tabular}{|c|c|c|}
\hline Органи у справах МiCП & Напрями підтримки & Форми підтримки \\
\hline $\begin{array}{l}\text { Міністерства } \\
\text { економіки }\end{array}$ & $\begin{array}{l}\text { Зміцнення єдиного } \\
\text { внутрішнього ринку ЄС }\end{array}$ & $\begin{array}{l}\text { Пряме субсидування через } \\
\text { бюджетне фінансування фондів; } \\
\text { гарантії по кредитах, пільгові } \\
\text { кредити, участь в капіталі МСП }\end{array}$ \\
\hline $\begin{array}{l}\text { Міністерства } \\
\text { промисловості і торгівлі; } \\
\text { зайнятості }\end{array}$ & $\begin{array}{l}\text { Усунення адміністративних } \\
\text { бар'єрів для ведення МСБ } \\
\text { Уніфікація законодавчої бази } \\
\text { Посилення взаємодії країн ЄС } \\
\text { для більш глибокого } \\
\text { економічного } \\
\text { співробітництва з іншими } \\
\text { країнами } \\
\text { Пряма фінансова підтримка }\end{array}$ & $\begin{array}{l}\text { Державні установи, зокрема } \\
\text { торгово-промислові палати, } \\
\text { займаються навчанням і } \\
\text { підвищенням кваліфікації, } \\
\text { технологічним консультуванням } \\
\text { кадрів, задіяних на МСП, } \\
\text { стимулюванням міжнародної } \\
\text { торгівлі та співпраці, видачою } \\
\text { сертифікатів якості, наданням } \\
\text { ділової інформації представникам } \\
\text { МСП }\end{array}$ \\
\hline $\begin{array}{l}\text { Мережа державних і } \\
\text { приватних організацій } 3 \\
\text { регулювання розвитку і } \\
\text { підтримки МСП } \\
\text { Європейський фонд } \\
\text { регіонального розвитку }\end{array}$ & $\begin{array}{l}\text { Непряма державна допомога: } \\
\text { законодавче регулювання, } \\
\text { податкова політика, цільові } \\
\text { кредити }\end{array}$ & $\begin{array}{l}\text { Наднаціональні та національні } \\
\text { програми підтримки МСП: } \\
\text { EASDAQ, «бізнес-ангели» тощо. } \\
\text { Система взаємодії МСП через } \\
\text { мережі: Interprise, Europartenariat, } \\
\text { BC-Net, BRE, СвроIнфоЦентри }\end{array}$ \\
\hline
\end{tabular}

Джерело [577, с. 8]

У США у 1953 р. на правах федерального відомства було створено Адміністрацію у справах малого бізнесу (АМБ), у програмні функції якої входить: забезпечення МСП доступу до капіталу; надання інформаційної, 
технічної, навчальної (для стартапів) допомоги МСП; допомога МСП в укладанні контрактів з урядом щодо федеральних закупівель (щорічно понад 200 млрд. дол.); відділ АМБ захисту інтересів МСП проводить аналіз впливу законодавства на їх інтереси, захищає його права на слуханнях, проводить наукові дослідження [578].

Регіональні представництва АМБ у штатах взаємодіють 3 Центрами розвитку підприємництва, або/та з адміністрацією штату та співфінансують на 50,0 \% за рахунок власних коштів університетів, бюджету штату, приватних спонсорів.

Центри розвитку підприємництва - це «мережа громадських організацій, до складу якої входять АМБ, університети, торгово-промислові палати, влади штатів і місцева адміністрація, неурядові організації та приватний бізнес», індекс дохідності яких складає 2-19 дол. залежно від штату [578].

У табл. 11.1.3 представлено напрямки та форми інституціонально-правової підтримки МСП в США.

Таблиця 11.1.3

Інституціонально-правова підтримка МСП в США

\begin{tabular}{|c|c|c|}
\hline $\begin{array}{c}\text { Органи у справах } \\
\text { МСП }\end{array}$ & Напрями підтримки & Форми підтримки \\
\hline $\begin{array}{l}\text { Адміністрація у справах } \\
\text { малого бізнесу } \\
\text { Відділ захисту інтересів } \\
\text { МСП } \\
\text { Центри розвитку } \\
\text { підприємництва в } \\
\text { штатах }\end{array}$ & $\begin{array}{l}\text { х Стійка державна система } \\
\text { регулювання і підтримки } \\
\text { підприємств МСБ } \\
\text { Розвинена система держаних } \\
\text { замовлень; } \\
\text { надання державних гарантій щодо } \\
\text { забезпечення кредитів } \\
\text { для МСП } \\
\text { Інвестиційне кредитування МСП } \\
\text { Гарантування позик }\end{array}$ & $\begin{array}{l}\text { Відповідно до «Закону про } \\
\text { малий бізнес», для МСП } \\
\text { надається доступ до } \\
\text { фінансових ресурсів, } \\
\text { розміщення в секторі не } \\
\text { менше } 23 \% \text { державного } \\
\text { замовлення, надання } \\
\text { фінансової, } \\
\text { консультаційної, технічної } \\
\text { та організаційної допомоги }\end{array}$ \\
\hline
\end{tabular}

Джерело [577, с. 8]

Таким чином, аналіз світової практики та напрямів розвитку МСП дозволив зробити висновки про наступні тенденції:

спостерігається сприяння розвитку МСП як основи державної економічної політики, що забезпечується розробкою державних програм розвитку та 
підтримки МСП, цілями яких є створення нових підприємств і нових робочих місць у країні, впровадження інновацій та використання новітніх технологій, підвищення конкурентоспроможності національних товаровиробників на світових ринках, розвиток галузей, регіонів, територіальних одиниць;

головною тенденцією майже всіх розвинутих країн $є$ дерегулювання підприємницької діяльності, що проявляється у зниженні адміністративних бар'єрів ведення бізнесу, проведенні активної антимонопольної політики, подоланні недобросовісної конкуренції по відношенню до МСП, розробці антикорупційного законодавства;

інструментами та напрямами державного регулювання МСП в країнах світу в основному є фінансові, інфраструктурні, консалтингова та інформаційна підтримки;

спостерігається тенденція до кооперації великих, малих і середніх підприємств, наприклад, в інноваційних розробках, окремих виробництвах тощо.

В України МСП розвиваються менш стрімко через відсутність виваженої державної політики підтримки та стимулювання їх розвитку, брак бюджетних коштів і відсутність визначених державою пріоритетів розвитку та підтримки.

Основними очікуваними заходами державної підтримки перешкодам для діяльності та зростання МСП в Україні є: зменшення кількості документів, необхідних для ведення підприємницької діяльності; спрощення податкового адміністрування; створення єдиного інформаційного ресурсу, де можна дізнатися про правила та умови ведення бізнесу, зміни законодавства тощо; створення рівних умов для всіх суб'єктів бізнесу при веденні господарської діяльності; перетворення податкової на сервісну службу для платників податків; переведення надання адміністративних послуг в електронний формат; створення дієвого механізму виконання законодавчих актів [6]. 


\section{SECTION 12. THEORY AND HISTORY}

DOI 10.46299/ISG.2021.MONO.ECON.II-565-570

\section{1 Тимбілдинг як один із інноваційних методів в управлінській діяльності керівника}

В сучасних умовах надзвичайно важливого значення набуває проблема формування конкурентоздатної управлінської команди. Все частіше досвідчені керівники прагнуть не просто сформувати колектив, а побудувати команду, яка є чимось більшим, ніж просто група спільно працюючих людей. Вона повинна бути ефективною і результативною, i при цьому працювати на перспективу, оскільки якість і результативність діяльності будь-якої організації визначається не зусиллям окремих працівників, а результативністю праці усього колективу. Ефективність і результативність в довгостроковій перспективі - це і $є$ успішний командний менеджмент.

Теоретичні питання формування та розвитку команд розроблені у концепціях Дж. Адайра, М. Белбіна, Р. Кон, Р. Лайкерта, Ч. Маргерісона, Д. МакКена, Е. Портера, Б. Такмена та інших зарубіжних учених. Проблематика командного менеджменту вивчається також на базі наукових праць Т.Ю. Базарова, Ю.М. Жукова, А.Л. Журавльова, Ю.В. Синягіна. Одним із сучасних напрямів досліджень є наукові розвідки у сфері командної інтердисциплінарної науки (Б. Джонес, С. Кіслер, Д. Стоколс, Б. Уззі, С. Уочті, В. Хагстром, К. Хол). Проведено аналіз ціннісного змісту організаційної культури ( Л.М. Карамушка, O.I. Бондарчук ) [581]. Окремі аспекти формування команд на матеріалі діяльності українських організацій досліджували О. А. Філь, В. І. Барко, Л. М. Карамушка, М. Коваленко, Г. В. Ложкін, С. Д. Максименко, Л. Слободянюк та iH. [582].

Широкого розповсюдження в управлінні організаціями займає формування команд (team building), що зумовило виокремлення самостійного напрямку в управлінні - менеджменту команд. Даний підхід передбачає пошук спільних цінностей, відкритий доступ до інформації, заохочення командної роботи, 
співробітництво і партнерство, колективну відповідальність за результати роботи, розвиток творчого групового та індивідуального потенціалів, адаптацію організацій до раптових змін зовнішнього середовища [583].

Сучасні керівники організацій відчувають особливу потребу в побудові систем управління, здатну швидко реагувати на зміни факторів динамічного зовнішнього і внутрішнього середовища, а це не є можливим без ефективного управління персоналом, який, безсумнівно, $\epsilon$ стратегічно важливим та унікальним ресурсом організації, що забезпечує успішне функціонування, конкурентне процвітання і позитивний імідж компанії. У зв'язку з цим виникає пряма необхідність впровадження максимально ефективних способів, методів та інструментів впливу на персонал.

Сьогодні існує безліч методів, які спроможні підвищити ефективність організаційних перетворень, якість прийнятих рішень та адаптивність до змін. Відповідно до мотиваційної характеристики у складі методів управління виділяють три групи: 1. Економічні методи управління об'єднують усі методи, за допомогою яких здійснюється вплив на економічні інтереси колективів i окремих їхніх членів. Цей вплив здійснюється матеріальним стимулюванням окремих працівників і колективів у цілому. 2. Організаційно-розпорядчі методи, спрямовані на використання таких мотивів трудової діяльності як почуття обов'язку, відповідальності. 3. Соціальні методи грунтуються на використанні соціального механізму, що діє у колективі (неформальні групи, роль і статус особистості, система взаємовідносин у колективі, соціальні потреби).

Подібні технології повинні забезпечити, по-перше, повне розкриття трудового потенціалу, реалізацію професійних якостей і досягнення високих результатів кожного співробітника, а подруге - єдність поглядів та дій співробітників, згуртованість та відданість організації, націленість на досягнення особистих й організаційних цілей. Іншими словами, ефективність діяльності сучасної організації може забезпечити стабільний i високорезультативний кадровий склад. Головною загрозою стабільності персоналу організації $\epsilon$ плинність кадрів. В такому випадку особливої актуальності набуває 
застосування командного менеджменту, як однієї з інноваційних технологій стабілізації трудових колективів [584].

В основі розуміння поняття командного менеджменту закладено зміст такої категорії як «команда». Дане поняття нині є досить поширеним, однак воно не має однозначного визначення. В літературі існують чисельні підходи до трактування поняття «команда». Команда - це група 3 двох або більше осіб, які регулярно взаємодіють та координують свою роботу для досягнення спільної мети. Команда - це група людей, що працюють разом для досягнення конкретної цілі. Команда - це спосіб побудови організації з урахуванням реальних якостей iii співробітників, заради максимально ефективного досягнення цілей організації і т. д. [585, с. 55]. Згідно тлумачення в енциклопедії, команда в організаційному контексті (від лат. commando - «доручаю», «наказую») - це об'єднання однодумців, які керуються спільною метою [586].

Ідея командних методів активно впроваджувалася в практику менеджменту в 60-70 роки XX століття. Так, у Великобританії був презентований так званий «Мотузковий курс» - тренінг, покликаний забезпечити психологічну підготовку та командну сумісність військовослужбовців спецпідрозділів королівства [587]. Курс виявився настільки вдалим, що його тут же взяли на озброєння «акули бізнесу» США. Маючи прикладний характер, цей тренінг міг вирішити головну проблему американського бізнесу - зростаючу конкуренцію 3 боку японців, ділова культура яких відрізнялася від американської і західноєвропейської. Японці, виховані в дусі колективізму і орієнтовані на командні дії, зуміли за короткий термін зробити величезний економічний стрибок - «японське диво» чим поставили в глухий кут світове співтовариство [588]. Це стало першим поштовхом, який допоміг усвідомити ефективність командного підходу до роботи.

На сьогодні тимбілдинг є однією з перспективних моделей корпоративного менеджменту, що забезпечує повноцінний розвиток організації. Взагальному, тимбілдінг - термін, що часто використовується в широкому діапазоні дій для створення і підвищення ефективності роботи команди. Дослівний переклад 3 
англійської мови дозволяє нам зрозуміти, що по суті тимбілдинг - це "будівництво команди".

Існують також різноманітні визначення щодо тимбілдингу та умов його застосування. Тимбілдинг (англ. team building - побудова команди) становить одну з перспективних моделей корпоративного менеджменту, що забезпечують повноцінний розвиток компанії та є одним із найбільш ефективних інструментів управління персоналом. Командне будівництво спрямоване на створення груп рівноправних фахівців різної спеціалізації, які спільно несуть відповідальність за результати своєї діяльності та на рівній основі здійснюють розподіл праці в команді [589, с. 39].

Заходи для створення колективу та оптимізації управління ним (тимбілдинг) сприяють не лише об'єднанню, але й, в свою чергу, позитивно впливають на діяльність організації в цілому. Складність завдань, які виникають у сучасних умовах, обумовлюють об'єднання людських ресурсів, необхідність їх згуртованості та взаємопідтримки під час розв'язання різного роду професійних ситуацій. Сьогодні тимбілдинг дозволяє торкнутися таких аспектів роботи 3 колективом: розвиток командного духу, можливість виявляти і реалізовувати особистісний потенціал співробітників; знайти варіанти вирішення конфліктних ситуацій; розвиває здатність швидко приймати рішення в критичних i нестандартних ситуаціях; виховує в колективі довіру до організації і один до одного; є вагомим методом нематеріальної мотивації персоналу, який дозволяє співробітникам відчути увагу керівництва до кожного іiі співробітника, що, в кінцевому результаті, дозволяє створити згуртований та креативний колектив однодумців [590].

Можна виділити такі складові процесу тимбілдінгу: 1. Формування й розвиток навичок командної роботи (team skills), які $є$ основою системи впровадження тимбілдингу (гармонізація спільної мети 3 особистими цілями; прийняття відповідальності за результат команди; ситуаційне лідерство (лідерство під завдання) 2. Формування командного духу, тобто сукупності психологічних феноменів, що характеризують неформальне ставлення 
співробітників до колег й організації (посилення почуття згуртованості, формування стійкого відчуття «ми»; розвиток довіри між співробітниками, розуміння та прийняття індивідуальних особливостей одне одного; створення мотивації на спільну діяльність; створення досвіду високоефективних спільних дій; підвищення неформального авторитету керівника). 3. Формування команди - механічні дії 3 підбору, оптимізації структури команди й функціонально-рольового розподілу [591].

Цікавим фактом $є$ те, що кожен співробітник вважає свою роботу самою важливою, пріоритетною та тією, що вимагає найбільшої уваги. Через це серед колег інколи виникають суперечки, адже люди рідко намагаються зрозуміти суть роботи інших відділень. У таких випадках, під час тимбілдингу можна спланувати заходи, які дозволять колегам спробувати, як це працювати в тому чи іншому відділі. Таким чином, співробітники краще зрозуміють тонкощі роботи один одного, а у команді з'явиться більше розуміння й поваги до праці інших.

Для досягнення поставлених цілей, під час тимбілдингу має бути достатньо взаємодії між його учасниками. Заходи потрібно планувати з ціллю активізувати всіх учасників, змусити їх разом працювати та розв'язувати поставлені задачі. Результатом такої взаємодії повинні бути нові побудовані комунікаційні зв'язки між їі членами [592].

Ефективну команду можна охарактеризувати загальноприйнятими критеріями ефективності будь-якої організаційної структури, однак є специфічні риси, властиві тільки команді. Перш за все, це націленість всієї команди на кінцевий результат, ініціатива і творчий підхід до вирішення завдань. Висока продуктивність та орієнтованість на кращий варіант рішення, активне i зацікавлене обговорення виникаючих проблем доповнюють їі характеристику.

Але необхідно пам'ятати, що проведення таких заходів допомагає збільшити поле довіри в колективі, колеги відкриють нові сторони й можливості вербальної та невербальної комунікації, але це не вирішить усіх існуючих проблем. Важливим завданням менеджера є вміння підібрати людей. Але все це не означає, що, набравши необхідних людей за знаннями, уміннями, навичками, 
особистісними якостями команда вже готова. При цьому найбільш важливою функцією менеджера $\epsilon$ вміння створити командний дух, що $\epsilon$ важливою складовою частиною тимбілдингу (тімспіріт - від англ. «team spirit» «командний дух»), яка вибудовує партнерські ділові і особистісні відносини між усіма членами команди. Тімспіріт, в першу чергу, спрямований на формування емоційної зв'язки між співробітниками організації, яка згодом стане основою взаємодопомоги і взаєморозуміння. Саме командний менеджмент допомагає стабілізувати трудовий колектив, розвивати потенціал кожного співробітника.

3 урахуванням зазначених переваг командного менеджменту можна стверджувати, що він стає основою сучасних технологій, здатний забезпечити корисний економічний і соціальний ефект у підтримці динамічної стабільності персоналу організації. Безумовно, при побудові команди, необхідно враховувати особливості самої організації, iï цілі, місію, стратегію розвитку, масштаб і специфіку діяльності. І не менш важливо пам'ятати про особливу роль керівника в процесі командоутворення.

Отже, можна зробити висновок, що тимбілдинг є одним із найбільш ефективних методів управління, який дозволяє об'єднати кожного окремого працівника в колектив для налагодження відносин всередині організації та успішної роботи кожної ії ланки. У разі об'єднання колективу підвищується працездатність, персонал більш мотивований та зацікавлений в успішній роботі. Якісна система корпоративного управління, а саме заходи тимбілдингу, виступає умовою ефективної роботи. В результаті керівник отримує згуртовану команду, яка готова працювати ефективніше, в якій налагоджуються комунікаційні зв’язки і підвищується усвідомлення відповідальності ролі кожного в колективі [593]. 


\section{REFERENCES}

1. Bondarenko T. Accounting and control of overhead costs (on the example of mining and processing enterprises): author's ref. dis. Cand. econ. Science: special. 08.00.09 - accounting, analysis and audit. K.2009. 23 p.

2. Butynets F., Voynalovich O., Tomashevskaya I. Organization of accounting: a textbook for students. special «Accounting and Auditing». Zhytomyr:. «Ruta». 2005. $448 \mathrm{p}$.

3. Drobiazko S. Management of enterprise costs based on the budgeting process: author's ref. dis. Cand. econ. Sciences: special 08.00.04 - economics and management of enterprises. K. 2011. 19 p.

4. Kostyakova A. Accounting for the production of crop products: author. dis. Cand. econ. Science: special. 08.00.09 - accounting, analysis and audit. K. 2010. 19 p.

5. Marx K., Engels F. Capital: op. in 23 vols. M .: Politizdat. T. 1-2. 1961.

6. Methodical recommendations on planning, accounting and calculation of the cost of products of agricultural enterprises № 132. URL: http://zakon.nau.ua/doc.

7. Pogorelov Y. The choice of substantiation of methods of management of expenses of the enterprise: author's ref. dis. Cand. econ. Sciences: special 08.06.01 Economics, organization and management of enterprises. Donetsk. 2006. 32 p.

8. UAS 16 «Costs». Ministry of Finance of Ukraine of December 31. 1999. № 318.

9. Ricardo D. The beginnings of political economy and taxation. M .: State Publishing House of Political Literature. T. 1. 1955. p. 116-123.

10. Smith A. A study of the nature and causes of the wealth of peoples. M .: Sotsekgiz. 1962. p. 23-25.

11. Suk L., Suk P. Accounting: textbook. manual (2nd ed., revised. and add.). K .: Knowledge. 2008. 507 p.

12. Chertkova N. Economic significance of industrial enterprises costs. State and regions. 2006. № 6. p. 444-447.

13. https://dspace.uzhnu.edu.ua > jspui > bitstream > lib

14. Про бухгалтерський облік та фінансову звітність в Україні : Закон України від 16.07.1999 р. № 996-XIV / Верховна рада України. URL: http://zakon2.rada.gov.ua/laws/show/996-14\#Text

15. Нові вимоги подання фінансової звітності за 2020 рік. URL: https://medoc.ua/blog/novi-vimogi-podannja-finansovo-zvitnosti-za-2020-rik 
16. Фінзвітність на основі таксономії: регуляторам рекомендовано подовжити строки подання звітності до центру іiі збору та не застосовувати санкції протягом 2021 року. Офіційно про податки. URL: http://surl.li/uoki

17. Меморандум про взаєморозуміння щодо розробки і запровадження системи фінансової звітності від 18.12.2017 р. № 102/15 / Верховна рада України. URL: https://zakon.rada.gov.ua/laws/show/v0102201-17\#Text

18. Про внесення змін до Закону України «Про бухгалтерський облік та фінансову звітність в Україні» щодо удосконалення деяких положень : Закон України від 05.10.2017 р. № 2164-VIII / Верховна рада України. URL: https://zakon.rada.gov.ua/laws/show/2164-19\#Text

19. Про затвердження перекладу Таксономії фінансової звітності за міжнародними стандартами фінансової звітності: Наказ Міністерства фінансів України від 13.11.2020 р. № 709 / Міністерство фінансів України. URL: https://cutt.ly/xneawfC

20. Складання фінансової звітності у форматі / Офіційний сайт Nexia DK. URL: https://cutt.ly/wnep6jc

21. Парокіна А., Таран I. Підходи до створення звітності у форматі iXBRL: переваги та недоліки 2021. № 4. С. $56 . \quad$ URL: https://ibuhgalter.net/ru/material/1129/22660

22. Ареф'єва О. В., Мягких I. М., Росумака Т. Г. Власний капітал підприємства та проблеми його формування. Інтелект-XXI. 2016. № 6. С. 161169. URL : http://nbuv.gov.ua/UJRN/int_XXI_2016_6_18

23. Бутинець Ф. Ф. Бухгалтерський фінансовий облік: підручник. Житомир, 2009. $912 \mathrm{c}$.

24. Вівчар О. Й., Саварин В. М. Власний капітал як фінансове джерело функціонування підприємства. Науковий вісник НЛТУ України. 2009. Вип. 19.5. C. 146-150. URL : http://nvunfu.esy.es/Archive/19_5/146_Wiwczar_19_5.pdf

25. Горбатенко А. А. Особливості формування власних фінансових ресурсів підприємств в Україні. Економічний вісник Переяслав-Хмельницького ДПУ імені Григорія Сковороди. 2016. Випуск № 15/1. С. 195-201.

26. Іщенко Я. П., Галайда Л. В. Теоретичні основи формування власного капіталу підприємства. Науковий вісник Херсонського державного університету. 2015. Вип. 15. Ч. 1. С. 146-148. URL : http://www.ej.kherson.ua/journal/economic_15/1/39.pdf

27. Олександренко I. В. Управління власним капіталом підприємства. Економічний форум. 2016. №3. С. 211-216. URL http://nbuv.gov.ua/UJRN/ecfor_2016_3_32 
28. Хмелевська А. В., Незборецька Г. М. Власний капітал за атрибутами об'єкту бухгалтерського обліку. Сталий розвиток економіки. 2011. № 2. С. 192 194.

29. Щербань О. Д., Струкова М. О. Визначення категорії «власний капітал підприємства». Економіка і суспільство. 2017. №9. С. 736-739. URL : http://www.economyandsociety.in.ua/journal/9_ukr/126.pdf

30. Загальні вимоги до фінансової звітності: Національне положення (стандарт) бухгалтерського обліку 1 від 07 лют. 2013 р. № 73. URL : http://zakon4.rada.gov.ua/laws/show/z0336-13

31. Концептуальна основа фінансової звітності. URL : http://zakon2.rada.gov.ua

32. Назарова I. Сутність та структуризація власного капіталу для потреб обліку. Вісник Тернопільського національного економічного університету. 2017. № 3. C. 117-126. URL : http://nbuv.gov.ua/UJRN/Vtneu_2017_3_12

33. Ловінська I. Г. Сутність власного капіталу підприємства 3 позицій обліку. Фінанси, облік і аудит. 2012. № 20. С.328-333. URL : http://nbuv.gov.ua/UJRN/Foa_2012_20_41

34. Сук Л. К., Сук П. Л. Фінансовий облік: навч. посіб. Київ, 2012. 647 с.

35. Хом’як Р. Л. Бухгалтерський облік в Україні: навч. посіб. Львів, 2004. $912 \mathrm{c}$.

36. Сопко В. В. Бухгалтерський облік капіталу підприємства (власності, пасивів) : монографія. Київ: Центр навчальної літератури, 2006. 312 с.

37. Івченко Л. В., Удовик Н. Л. Власний капітал: джерела формування та функції. Молодий вчений. 2016. № 1(28). C.55-59. URL : http://molodyvcheny.in.ua/files/journal/2016/1/13.pdf

38. Цюцяк І. Л. Аналіз наукових підходів до трактування категорії «власний капітал». Науково-інформаційний вісник Івано-Франківського університету права імені Короля Данила Галицького: Економіка. 2014. № 9. C.271-280. URL : http://nbuv.gov.ua/UJRN/Nivif_2014_9_42

39. Малярець Л. М., Пономаренко Н. М.Управління процесом росту власного капіталу підприємства: монографія. Харків: ХНЕУ, 2011. 227 с.

40. Бутинець Ф. Ф., Горецька Л. Л. Бухгалтерський облік у зарубіжних країнах : навч. посіб. Житомир, 2002. 544 с.

41. Кадацька А. М. Сутність власного капіталу підприємства: Вісник Сумського національного аграрного університету. Серія : Економіка i менеджмент. 2014. Вип. 4. C. 153-156. URL : http://nbuv.gov.ua/UJRN/Vsna_ekon_2014_4_34 
42. Бухгалтерський облік і фінансова звітність в Україні: навч.-практ. посіб. / за ред. С. Ф. Голова. Дніпропетровськ, 2000. 768 с.

43. Варічева Р. В. Аналіз оптимальності структури власного капіталу акціонерних товариств: проблеми та перспективи. Вісник соціальноекономічних досліджень. 2012. Вип. 4(47). С. 155-167. URL : http://nbuv.gov.ua/UJRN/Vsed_2012_4_26

44. Ефимова О. В. Финансовый анализ. Москва, 2002. 528 с.

45. Бернадзіковська Л. О., Мукоїд І. В. Особливості формування власного капіталу підприємства у вітчизняній та міжнародній економіці. URL : http://www.sworid.com.ua/index.php/uk/economy-411/business-economics-andproduction-management-411/11299-411-1069

46. Коваль Л. В. Горбатюк В. В. Власний капітал: облік та представлення в звітності, в контексті національних та міжнародних стандартів. Економічні науки. Сер.: Облік і фінанси. 2013. Вип. 10(3). С. 310-318. URL : http://nbuv.gov.ua/UJRN/ecnof_2013_10\%283\%29_53

47. Коркушко О.Н. Класифікаційні види власного капіталу, як об'єкта обліку. Сталий розвиток економіки. 2013. №4. С.262-265. URL : http://nbuv.gov.ua/UJRN/sre_2013_4_57

48. Міщук Є. В. Особливості системи управління власним капіталом підприємства та шляхи її вдосконалення. Агросвіт. 2015. № 24. C. 46-49. URL : http://www.agrosvit.info/pdf/24_2015/10.pdf

49. Микитенко А. М. Формування системи управління власним капіталом підприємства. Наукові праці Національного університету харчових технологій. 2015. Том 21. № 1. C. 93-101. URL : http://dspace.nuft.edu.ua/jspui/bitstream/123456789/19489/1/13.pdf

50. Подольська В. О, Яріш О. В. Фінансовий аналіз: навч. посіб. Київ, 2007. $488 \mathrm{c}$.

51. Про Рекомендації парламентських слухань на тему: "Стан i перспективи забезпечення в Україні безпеки дорожнього руху" Схвалено Постановою ВР України від 13 квітня 2016 року № 1091-VIII. URL:http://zakon5.rada.gov.ua/laws/show/1091-19

52. Варивода В. І., Свдокимов Д. А., Сюравчик В. Г., Жук О. М., Риндюк І. I. Забезпечення Національною поліцією безпеки дорожнього руху: правові та організаційні аспекти : метод. рек. Київ : Нац. акад. внутр. справ, 2019. 110 с.

53. Досвід країн Європи щодо управління безпекою дорожнього руху : вебсайт. URL: http://www.pishohid.org.ua/news/dosvid-krayin-yevropy-shchodoupravlinnya-bezpekoyu-dorozhnogo-ruhu

54. Дослідження MBC щодо основних причин ДТП : веб-сайт. URL: http://forinsurer.com/public/06/03/02/2196 
55. В Україні відклали запуск системи фото-відео фіксації правопорушень. Gazeta.UA : веб-сайт. URL: http://gazeta.ua/articles/business/_v-ukrajini-vidklalizapusk-sistemi-foto-video-fiksaciji-pravoporushen/534237

56. Товстуха С. Застосування Європейського досвіду державного управління безпекою дорожнього руху України : веб-сайт. URL: http://www.dridu.dp.ua/vidavnictvo/2011/2011_02(9)/11tsodru.pdf

57. Заліван О.В. Роль програмно-цільового методу при підготовці місцевих програм з підвищення безпеки дорожнього руху. - Стандарти ЄС щодо захисту пішоходів та практичні аспекти їх застосування в Україні. - Харків, 2013.

58. Лях М.А. Основи керування автомобілем та безпека дорожнього руху / Лях М.А. Дем'янюк О.С., Бешун О.А. : Навч. посібник: для ВНЗ - К.: ВІКНУ, $2011-368 \mathrm{c}$.

59. Кодекс України про адміністративні правопорушення. URL: https://zakon.rada.gov.ua/laws/show/80731-10\#Text

60. Review of Maritime Transport 2019. Доступ до електронного ресурсу: https://unctad.org/system/files/official-document/rmt2019_en.pdf

61. Transhipment Port Selection and Decision-making Behaviour, December 2009 International Journal of Logistics 6(4):229-244

62. Container Transshipment and Logistics in the Context of Urban Economic Development 2015. 4-8.

63. Сухоставець А. І. Інноваційні аспекти підприємницької діяльності в соціальній сфері сільських територій. Макроекономічне регулювання інвестиційних процесів та впровадження стратегії інновативно-інноваційного розвитку в Україні : мат. між нар. наук.-практ. конф. (м. Київ, 23-24 жовтня 2008 р.) : У трьох част. РВПС України НАН України. К. : РВПС України НАН України, 2008. Ч. 3. C. 261.

64. Господарський кодекс України № 436-IV 16.01.2003 р. Відомості Верховної Ради України (ВВР). 2003. № 18, № 19-20, № 21-22, ст.144. UR1: https://zakon.rada.gov.ua/laws/show/436-15\#n2582.

65. Королев В. И. Предпринимательство - дело новое или хорошо забытое? В. И. Королев. М. : Изд-во «Знание». 1992. - С. 6-22.

66. Гальчинський А. С. Основи економічної теорії : підручник К. : Вища школа, 1995. $567 \mathrm{c}$.

67. Cantillon R. Essai sur la nature du commerce en g'en'eral.. Londres, 1959. URL: https://oll.libertyfund.org/title/higgs-essay-on-the-nature-of-trade-in-generalhiggs-ed.

68. Смит А. Исследование о природе и причинах богатства народов. Антология экономической класики. М. : МП «Эконом», «Ключ», 1993. 475 с. 
69. Turgot A.R.J. The Economics of The Hague: Martinus Nijhoff. 1977. 152p.

70. Шумпетер Й. Теория экономического развития: исследование предпринимательской прибыли, капитала, кредита, процента и цикла конъюнктуры. М. : Прогресс, 1982. 231 с.

71. Хайек Ф. Конкуренция как процедура открытия. Мировая экономика и международные отношения. 1989. № 12. С. 14-19.

72. Долан Э. Дж. Рынок: микроэкономическая модель. СПб., 1992. 496 с.

73. Амигуд М. Общественные связи и развитие предпринимательства в Украине. Предпринимательство, хозяйство и право. 1999. № 6. С. 45-49.

74. Вороніна Л. І. Розвиток підприємництва в економіці України. Вісник Київського університету. Економіка. К., 1994. Вип. 1. С. 39-42.

75. Економічний словник-довідник. За ред. С. В. Мочерного. К. : Феміна, $1995.368 \mathrm{c}$.

76. Лагутін В. Д. Людина і економіка: Соціоекономіка : навч. посібник для вузів. К. : Просвіта, 1996. 336 с.

77. Дынкин А. Зачем экономике предприниматель? Мировая экономика и международные отношения. 1991. № 1. С. 115-120.

78. Кретов С. И. Предпринимательство: сущность, директивы и перспективы. М. : Изд-во «Знание», 1992. 64 с.

79. Гордеева Ю. Психологические предпосылки успешного предпринимательства. Предпринимательство, хозяйство и право. 2000. № 3. С. 61-63.

80. Основи економічної теорії : підручник : у 2-х кн. Кн. 2 : Підприємництво, маркетинг, менеджмент. Відтворення в національному та світовому господарстві / за ред. Ю. В. Ніколенка. К. : Либідь, 1998. 421 с.

81. Лагутін В. Д. Людина і економіка: Соціоекономіка : навч. посібник для вузів К. : Просвіта, 1996. 336 с.

82. Малік М.Й., Шпикуляк О.Г., Супрун О.М. Розвиток підприємницької діяльності в аграрному секторі: макроекономічний аспект. Науковий вісник Ужгородського університету 2017. Серія Економіка. Випуск 1 (49). T.2. URL: http://www.visnykekon.uzhnu.edu.ua/images/pubs/49_2/49_32-37.pdf

83. Охота Ю. В. Підприємницька діяльність в аграрному секторі: сутність, організаційно-правова форма та інші основні аспекти. URL: http://www.economy.nayka.com.ua/pdf/3_2018/153.pdf

84. Сичова М. О., Шевченко Н. О. Особливості розвитку підприємництва в аграрному секторі регіону. URL: http://www.agrosvit.info/pdf/13_2010/2.pdf. 
85. Тридід О. М. Організаційно-економічний механізм стратегічного розвитку підприємства: [Монографія] / О. М. Тридід. - Харків. : Вид-во ХДЕУ, 2002. $-364 \mathrm{c}$.

86. Транченко Л. В. Проблеми удосконалення організаційно-економічного механізму управління підприємством / Л. В. Транченко, Л. О. Баластрик // Теоретичні та прикладні питання економіки. зб. наук. праць - К.: Київський університет, 2005. - Вип. 7. С. 188-195.

87. Малицький А.А. Організаційно-економічний механізм управління підприємством: сутність та структура [Електронний ресурс] / А.А. Малицький // Рубрика: Соціум. Наука. Культура. Економіка. - Режим доступу: http://intkonf.org.

88. Про внесення змін до Закону України "Про туризм" та деяких інших законодавчих актів щодо основних засад розвитку туризму. URL: http://search.ligazakon.ua/__doc2.nsf/link1/J103317A.html

89. Інфраструктура туризму: конспект лекцій. Для здобувачів вищої освіти, які навчаються за спеціальністю 242 «Туризм» за усіма формами навчання / Укладачі: О. В. Поступна, Н. А. Леоненко - Х.: НУЦЗУ, 2020. - 233 с.

90. Мельниченко О. А. Особливості розвитку індустрії туризму в Україні: монографія / О. А. Мельниченко, В. О. Шведун. - Х. : Вид-во НУЦЗУ, 2017. $153 \mathrm{c}$.

91. Гайдук А. Формування туристичної ринкової інфраструктури як фактор підвищення ефективності функціонування ринку туристичних послуг / А. Гайдук // Регіональна економіка. - 1999. - №2. - С. 172-178.

92. Організація туризму: підруч. / за заг. ред. д.е.н., проф. В. Я. Брича. Тернопіль: ТНЕУ, $2017-448$ с.

93. Турецька компанія зацікавилася модернізацією аеропорту в Херсоні Мінінфраструктури / InterfaxУкраїна. 30.11.2020. URL: https://ua.interfax.com.ua/ news/economic/706690.html

94. Власова В.П. Державно-приватне партнерство як механізм розвитку транспортної інфраструктури Херсонської області / В. Власова // Бізнес-інформ. - №12 - 2020. - C. 217 - 224.

95. Презентовано перші 6 ділянок доріг для реалізації потенційних пілотних проєктів ДПП, - Владислав Криклій / Міністерство інфраструктури України. 29.10.2020. URL: https://mtu.gov.ua/news/32322.html

96. Залізничний транспорт. URL: https://khoda.gov.ua/zaliznichnij-transport

97. Херсонський річковий порт URL: http://www.sifservice.com/index.php/informatsiya/porty-ukrainy/rechnyeporty/item/48-khersonskij-rechnoj-port 
98. Пасажирські перевезення. URL: https://investinkherson.gov.ua/proregion/transportnij-hab/

99. Сертифіковані та категоризовані заклади розміщення в Херсонській області. URL: https://khoda.gov.ua/sertif\%D1\%96kovan\%D1\%96-takategorizovan\%D1\%96-zakladi-rozm\%D1\%96shhennja-v-hersonsk\%D1\%96j-oblast

100. Херсонщина - приваблива цілий рік і це справжня перлина степової України. URL: https://khoda.gov.ua/hersonshhina-\%E2\%80\%93-privablivac\%D1\%96lij-r\%D1\%96k-\%D1\%96-ce-spravzhnja-perlina-stepovo\%D1\%97ukra\%D1\%97ni-\%E2\%80\%93-dmitro-butr\%D1\%96j

101. Саганюк Ф. В. Сектор безпеки і оборони України: теорія, стратегія, практика: монографія / Саганюк Ф. В., Фролов В. С., Устименко О. В., Лобко М. М. та ін. // Київ: Академпрес - 2017. - 180 с.

102. Єдиний перелік (каталог) спроможностей Міністерства оборони України та Збройних Сил України. Київ: МОУ. - 2017. - 75 с.

103. Snyder D. Capabilities and Risks in Air Force Programming: Framework, Metrics, and Methods / Snyder D., Mills P., Resnick A., Fulton D. [Electronic resourse]: https://www.rand.org/pubs/monographs/MG815.html.

104. Iancu D. Perspectives on the Risk in Military Capabilities Management. International conference / Iancu D., Gabriel A. [Electronic resourse]: DOI: 10.2478/kbo-2019-0040.

105. Army Modernization Strategy [Electronic resourse]: https://www.army.mil/e2/downloads/rv7/2019_army_modernization_strategy_final.p df.

106. Trewin N. Risk management and its practical application: Lessons from the British Army / Trewin N., Johnson U. [Electronic resourse]: DOI: 10.1080/13669870903551670.

107. Jason A. A Risk Assessment Methodology for Divesting Military Capabilities Allied Nations / Jason A. [Electronic resourse]: https://scholar.afit.edu/cgi/viewcontent.cgi? article $=4438 \&$ context $=$ etd.

108. Correia J. Military capabilities and the strategic planning conundrum [Electronic resourse]: DOI 10.35467/sdq/108667.

109. Kerr C. A Framework for strategic Military capabilities in Defense. Transformation Centre for Technology Management University of Cambridge [Electronic resourse]: https://pdfs.semanticscholar.org/daaf/76a4ab4b6bf10e7bad04442b5d91c55f7a36.pdf.

110. Кулинич Р. О. Статистична оцінка чинників соціально-економічного розвитку: монографія / Кулинич Р. О. // Київ: Знання. - 2007. - 311 с. 
111. Васьківський Ю., Галімук Ю. Специфічні особливості функціонування регіональних видань. Соціально-компетентне управління корпораціями в умовах поведінкової економіки: [матеріали Міжнар. наук.-практ. конф. (18 лютого 2021 р.)] / відп. ред. О.М. Павлова, К. В. Павлов, Л. В. Шостак, А. М. Лялюк - Луцьк, 2021. С. $402-404$ (565 с.)

112. Гібридна війна на Сході України в міждисциплінарному вимірі: витоки, реалії, перспективи реінтеграції: збірник наук. пр. / За заг ред. В. С.Курило, С. В. Савченко, О. Л. Караман. Старобільськ: ДЗ «ЛНУ імені Тараса Шевченка», 2017. 432 с.

$\mathrm{BBC}$

113. «Європарламент у резолюції закликав переглянути відносини з Росією. https://www.bbc.com/ukrainian/news_in_brief/2015/06/150610_rl_eu_russia (дата звернення: 21.02.2019)

114. Ярочкин В. И. Секьюритология: Наука о безопасности жизнедеятельности. М. : Ось-89, 2000. 400 с.

115. Власюк О. С. Національна безпека України: еволюція проблем внутрішньої політики : вибр. наук. праці. К. : НІСД, 2016. 528 с.

116. Про національну безпеку України : Закон України. Документ 2469VIII від 21.06.2018. Чинний 3 08.07.2018. URL: https://zakon5.rada.gov.ua/laws/show/2469-19/page (дата звернення: 12.06.2021).

117. Верхоглядова Н. І., Олініченко I. В. Принципи забезпечення економічної безпеки регіону. Ефективна економіка. 2013. № 9. URL: http://www.economy.nayka.com.ua/?op=1\&z=2296 (дата звернення: 12.06.2021).

118. Економічна безпека / О. Є. Користін, О. І. Барановський, Л. В. Герасименко та ін. ; за ред. О. Джужі. К. : Алерта ; КНТ ; Центр учбової літератури, 2010. 368 с.

119. Шуршин В. О. Принципи формування системи індикаторів i показників економічної безпеки України : збірник наукових праць Кіровоградського національного технічного університету. Серія : Економічні науки. 2007. Вип. 12, ч. 2. С. 376-380.

120. Шнипко О. С. Економічна безпека багаторівневих систем: регіональний аспект. К.: Генеза, 2006. 288 с.

121. Головня Ю. І. Стратегічні пріоритети забезпечення економічної безпеки в регіоні. Теоретичні і практичні аспекти економіки та інтелектуальної власності : зб. наук. пр. : у 2-х вип. Маріуполь : ПДТУ, 2013. Вип. 2, т. 1. С. 294 298.

122. Основи економічної безпеки / О. М. Бандурка, В. Є. Духов, К. Я. Петрова, І. М. Черв'яков. Харків: Вид-во Нац. ун-ту внутр. справ, 2003. 236 с. 
123. Ляшенко О. М. Концептуалізація управління економічною безпекою підприємства: монографія / Луганськ : Вид-во СНУаб. В. Даля, 2011. 400 с.

124. Ляшенко О. М. Концептуалізація управління економічною безпекою підприємства: монографія. 2-ге вид., переробл. К. : НІСД, 2015. 348 с.

125. Бреус С. В. Принципи управління економічною безпекою закладів вищої освіти в сучасних умовах. Східна Європа: економіка, бізнес та управління. 2018. Вип. 6 (17). С. 56-63. URL: http://www.easterneuropeebm.in.ua/journal/17_2018/12.pdf (дата звернення: 12.06.2021).

126. Бреус С. В. Проблеми та перспективи забезпечення економічної безпеки вітчизняних вищих навчальних закладів. Актуальні проблеми економіки. 2015. № 8 (170). C. 144-149.

127. Денисенко М. П., Бреус С. В. Економічна безпека вищих навчальних закладів: основні тенденції на ринку праці. Інвестиції: практика та досвід. 2016. № 14. C. 10-14.

128. Денисенко М. П., Бреус С. В. Економічна безпека ВНЗ у регіональному розрізі: дослідження сутності ризику, безпеки та економічної небезпеки. Бізнес-навігатор. 2017. Вип. 4-1 (43). С. 79-85.

129. Бреус С. В. Управління економічною безпекою системи вітчизняних закладів вищої освіти: моногр. / С. В. Бреус. - Київ : КНУТД, 2019. — 400 с.

130. Филин С. А., Якушев А. Ж. Формирование условий и стратегического инструментария мобилизации экономики. Национальные интересы: приоритеты и безопасность. 2016. № 9. С. 61-74.

131. Артьомов I. В. Український вимір європейської та євроатлантичної інтеграції : навчальний посібник. У 2-х кн. Ужгород : Ліра, 2008. кн. 2. 324 с.

132. Баятова И. М. Зарубежный опыт финансового обеспечения работ по мобилизационной подготовке и государственной поддердке организаций, которым установлены мобилизационные задания. URL : https://cyberleninka.ru/article/n/zarubezhnyy-opyt-finansovogo-obespecheniya-rabotpo-mobilizatsionnoy-podgotovke-i-gosudarstvennoy-podderzhke-organizatsiykotorym/viewer (дата звернення 03.02.2020).

133. Executive Order 12742 of January 8, 1991 : National Security Industrial Responsiveness. URL : file://D:/User/Downloads/463152.pdf (дата звернення 03.02.2020).

134. 10 U.S. Code $\S 2535$ Defense Industrial Reserve. URL : https://www.law.cornell.edu/uscode/text/10/2535 (дата звернення 03.02.2020).

135. Чеканова I. В., Лисенко О. І., Ткач I. М. Аналіз досвіду мобілізаційних економік в провідних країнах світу. Збірник наукових праць Центру воєнностратегічних досліджень Національного університету оборони України імені Івана Черняховського. 2014. № 1(50). С. 20-27. 
136. Балтина А. М., Волохина В. А., Попова Н. В. Финансовые системы зарубежных стран. Москва : Финансы и статистика, 2014. 304 с.

137. Wehrpflichtgesetz (WPflG). Ausfertigungsdatum: 21.07.1956. URL : https://www.gesetze-im-internet.de/wehrpflg/WPflG.pdf (дата звернення 03.02.2020).

138. Амрин Г., Ричи Дж., Моди И. Организация производства и управления в американских корпорациях.- М.: Экономика, 1991, 284 с.

139. Беллман Р. Динамическое программирование. «ИЛ», 1960. $552 \mathrm{c}$.

140. Вентцель Е.С. Исследование операций. - М.: Советское радио, 1972,

141. Гетьман О.О., Шаповал В.М. Економічна діагностика: [навчальний посібник для студентів вищих навчальних закладів]- К.: Центр навчальної літератури, 2007, 307 с.

142. Дзюбан І. Ю., Жиров О. Л. Охріменко М. Г.Методи дослідження операцій - Київ : «Політехніка», 2005, 160 с.

143. Зайченко О.Ю., Зайченко Ю.П. Дослідження операцій. Збірник задач — К.: Видавничий Дім "Слово", 2007, 472 с.

144. Іваницька О. В., Рощина Н. В., Сербул Р. С. Транспортна задача лінійного програмування. Агросвіт, 2015, № 14, С. 35-40.

145. Карімов Г.І. Моделювання та прогнозування в управлінні: навч. посібник/ Г.І. Карімов - Кам’янське: ДДТУ, 2018, 163 с.

146. Листопад В.В. Некоторые методы решения задась дробно-линейного програмиования. Информационные технологии в образовании, науке и производстве: IV Международная научно-техническая интернет-конференция, 18-19 ноября 2016 г. Секция Информационные технологии в производстве и научных исследованиях [Электронный ресурс]. - Минск : БНТУ, 2016.

147. Ложковський А. Г. Теорія масового обслуговування в телекомунікаціях / А. Г. Ложковський. - Одеса : ОНАЗ ім. О. С. Попова, 2010, $112 \mathrm{c}$.

148. Льюс Р., Райфа Х. Игры и решения (пер. с англ.). - М.: Изд-во иностранной литературы, 1961. -- 642 с.

149. Олешко Т.І., Лобанов М.О. Економічні задачі в теорії ігор. Проблеми системного підходу в економіці, 2018, Вип. 3(2). -С. 120-124.

150. Тютюнник Ю.М. Особливості застосування теорії массового обслуговування в економічному аналізі. Економіка і підприємництво: організаційно-методологічні аспекти обліку, фінансів, аудиту та аналізу. Збірник науко-вих праць. Випуск 4. Т. 2. Полтава: ПДАА, 2006. С. 19-27. 
151. Шиян А.А. Теорія ігор: основи та застосування в економіці та менеджменті. Навчальний посібник. - Вінниця: ВНТУ, 2009, 164 с.

152. Blizzard Arena. Official website. Retrieved from: https://eu.battle.net/login/en/?ref=https://eu.battle.net/oauth/authorize?response_type \%3Dcode\%26client_id\%3D057adb2af62a4d59904f74754838c4c8\%26scope\%3Dacc ount.full $\% 2520$ commerce.virtualcurrency.full $\% 2520$ commerce.virtualcurrency.basic \%26state\%3DeyJzdGF0ZUVudHJvcHkiOiJYV0hRMTdTSmdPOWIzQ2s2RElFYm 9pV2RSR0VjNHZsWHI0OHZrdXJndVJzPSIsInJIZmVycmVyIjoiL292ZXJ2aWV3I n0\%253D\%26redirect_uri\%3Dhttps://account.blizzard.com/login/oauth2/code/accou nt-settings\%26registration_id\%3Daccount-settings\&app=oauth

153. PUBG Corporation // офіційний сайт URL: https://www.pubg.com/

154. Sokolovska Z.M., \& Yatsenko N. V., Khortiuk M. V. (2019) Imitation Models of Activity of IT Firms on the Anylogic Platform. Business Inform, 6, 61-76 [in Ukrainian].

155. Valve Corporation // офіційний сайт URL: https://www.valvesoftware.com/uk/

156. Sztrik J. Basic Queueing Theory. Hungary : University of Debrecen, Faculty of Informatics, 2012, 193 p.

157. Korecz`ky`j B. (2005) Diagnosty`ka ty`piv dy`versy`fikaciyi diyal`nosti u sub'yektiv gospodaryuvannya ( $\mathrm{Zb}$. nauk. pracz' kafedry' ekon. analizu Ternopil`s ‘koyi akademiyi nar. gosp-va №14( pp.53-55.

158. Korin`ko M. D. (2009) Dy`versy`fikaciya yak strategiya rozvy`tku ( Aktual`ni problemy` ekonomiky №5( pp. 12-17.

159. Lemishko O.O.(2001) Dy`versy`fikaciya - najvazhly`vishy`j faktor pidpry`yemny`cz`koyi diyal'nosti u sil's'kogospodars 'ky`x pidpry`yemstvax Lugans`koyi oblasti ( Ekonomika APK №4] pp. 106-110.

160. Stepanenko N.I. (2010) Mexanizm formuvannya strategiyi dy`versy`fikaciyi agroservisny`x pidpry`yemstv (Vseukrayins`ky`j naukovovфy’robny`chy`j zhurnal №1(15)] pp.18-21.

161. Tomilin O.O. (2012) Dy`versy`fikaciya agrarny`x pidpry`yemstv yak diyeva strategichna oriyentaciya $\mathrm{v}$ agropromy`slovij sferi ( $\mathrm{zb}$. nauk. pr. VNAU / Seriya «Ekonomichni nauky» №3(69) ] pp. 205-2011.

162. Castro Rui, Clementi Gian Luca and MacDonald Glenn. 2004.Investor protection, optimal incentives and economic growth, The Quarterly Journal of Economics, August 2004, 1131-1175. USA.

163. Bachevskyi B.Ye., Zablodska I.B. and Reshetnyak O.O. 2009. Potential and development of the enterprise. - K .: Center for Educational literature, 400. Ukraine. 
164. Peshko A.B. and Nazarenko A.B. 2005. International experience in attracting foreign investment and intensifying investment activities. Stateand Regions Journal, № 5, 196-199. Ukraine.

165. Ludchenko Ya.O. 2004.Evaluation of economic efficiency of investment projects.Kyiv: Nika-Tsentr, Elga, 208. Ukraine.

166. Postil I.I. 2002.The mechanism of formation of investment resources. Regional perspectives. № 6, 59 - 61. Ukraine.

167. Burenin A.N. 1996. Financial derivatives markets. Moscow: INFRA, 368. Russia.

168. Krushvits L. 2000. Financing and Investment / Translated from German under the general editorship of V.V. Kovalyov and Z.A. Sabov. S.-Petersburg: Peter. 400. Russia.

169. Khoma I.B., Alekseyev I.V., Trevogo L.S. and Andrushko N.I. 2012. Financial services market. Lviv: Lviv Polytechnic Publishing House, 248. Ukraine.

170. Khoma I., Alekseyev I, Shpak N. 2013. Modelling of an impact of investment maintenance on the condition of economic protectability of industrial enterprises. Econtechmod. An international quarterly journal on economics of technology and modelling processes. Poland, Lublin-Rzeszow - 2013. - Vol. 2, No. 2. - P. 3-9. Polish.

171. Калетнік Г.М. Стратегіко-інституційні засади ефективності використання потенціалу аграрного сектору економіки. Економіка, фінанси, менеджмент: актуальні питання науки і практики. 2015. № 1. С. 5-9.

172. Загребельний P. 7 міфів про пальмову олію. URL: https://www.deltawilmar.com/7-mifiv-pro-palmovu-oliyu/

173. Oilseeds and oilseed products. FAO. 2020. URL: http://www.fao.org/3/ca8861en/Oilseeds.pdf

174. Маслак О., Ільченко В., Ільченко О. Економіка процесів: збирання зернових. Пропозиція. 2016. URL: https://propozitsiya.com/ua/ekonomika-procesivzbyrannya-zernovyh

175. Агрохолдинги-лідери за обсягами інвестицій в новітні технології. URL: $\quad$ https://superagronom.com/news/6773-nazvano-agroholdingi-lideri-zaobsyagami-investitsiy-v-novitni-tehnologiyi

176. Guidance document on the implementation of procedures based on the HACCP principles, and on the facilitation of the implementation of the HACCP principles in certain food businesses. URL: http://ec.europa.eu/food/food/biosafety/hygienelegislation/guidance_doc_haccp_en.p df. 
177. Офіційний сайт сертифікаційної компанії GMP+, URL: https://www.gmpplus.org/en/certification/find-gmp-certified-companies/

178. Політика сталого розвитку і корпоративної соціальної відповідальності, Компанія Кернел, URL: https:/www.kernel.ua/wpcontent/uploads/2019/08/SDCSR-Policy_UKR.pdf

179. Блуммарт Тью, Стефан ван ден Брук, Четвертая промышленная революция и бизнес. Как конкурировать и развиваться в эпоху сингулярности, «Альпина Паблишер». 2018.

URL: http://www.management.com.ua/qm/qm258.html

180. State Statistics Service of Ukraine (2019), available at: http://www.ukrstat.gov.ua/.

181. Bilorus O. and Rohach V. (1992). Menedzhment: poshuk i obgruntuvannia stratehichnykh tsilei pidpryiemstva. Ekonomika Ukrainy, №7, pp. 40-47.

182. Rui Wang, Zhongying Qi and Yumin Shu (2020), Multiple relationships between fixed-asset investment and industrial structure evolution in China-Based on Directed Acyclic Graph (DAG) analysis and VAR model. Structural Change and Economic Dynamics, vol. 55, pp.222-231, URL: https://doi.org/10.1016/j.strueco.2020.09.001

183. Afanasev S. A. (2014), Amortyzatsyia kak vnutrennyi ystochnyk ynvestytsyi dlia obnovlenyia osnovnykh sredstv. Molodoi uchenyi, № 4.2 , pp. 13-15. — URL: https://moluch.ru/archive/63/10154.

184. Tarasiuk H. M. and Valinkevych N.V. (2016), Financial and economic mechanism for ensuring the modernization of enterprises. Problemy teorii ta metodolohii bukhhalterskoho obliku, kontroliu i audytu : mizhnarodnyi zbirnyk naukovykh prats, Zhytomyr, № 2-3 (35) pp. 448-457.

185. Petrovych Y.M. (2016). Rozvytok promyslovykh pidpryiemstv shliakhom modernizatsii. Visnyk Natsionalnoho universytetu «Lvivska politekhnika». Seriia «Problemy ekonomiky ta upravlinnia», 847, pp. 3-9.

186. Koleshchuk, O., Prokhorova., V., Korzh, R., Mrykhina, O. and Mirkunova, T.(2019). Evaluation of innovative technologies in conditions of the digital economics. International Journal of Recent Technology and Engineering, 8 (3), rp. 230-236.

187. Kyfiak V. F. (2010) Stratehiia rozvytku terytorialnykh rekreatsiinykh system: teoriia, metodolohiia, praktyka: monohrafiia [Strategy of development of territorial recreational systems: theory, methodology, practice: monograph]. Kyiv; Chernivtsi: Knyhy-KHKHI. (in Ukrainian)

188. Melnychenko, O., Shvedun, V. (2017). Osoblyvosti rozvytku industriyi turyzmu v Ukrayini [Features of the tourism industry in Ukraine]. Kharkiv: NUTSZU [in Ukr]. 
189. Mochernyi S. V. (2006) Internatsionalizatsiia vyrobnytstva i suchasni tendentsii rozvytku svitovoho hospodarstva [Internationalization of production and modern trends in the world economy]. Ekonomika Ukrainy. No. 5. pp. 47-55.

190. Zaitseva, V.M. (Eds.) (2021). Turystychna haluz' Ukrayiny v period Yevrointehratsiyi: teoretychnyy aspekt [Tourist branch of Ukraine in the period of Eurointegration: theoretical aspect]. Zaporizhzhia: NU "ZP" [in Ukrainian].

191. Zaitseva, V., Tsviliy, S., Gurova, D. (2020). Development of wellnessdirection in business of tourist enterprises of the region at the expense of digitalization. Visnyk L'vivs'koho instytutu ekonomiky i turyzmu - Bulletin of the Lviv Institute of Economics and Tourism, 15, 30-39 [in English].

192. Zhuravlova S. (2019) Development of ecological competence in modern specialists. Proceedings from XIX International Multidisciplinary Scientific GeoConference SGEM 2019. Available at: https://www.iaeg.info/event/xixinternational-multidisciplinary-scientific-geoconference-sgem-2019/

193. Tsviliy S., Vasylychev D., Gurova D. (2020) Improvement of the qualification of small\& micro-enterprise staff in the crisis conditions of business transformation. Ekonomichnyy visnyk UDKHTU. № 1(11)/20, pp. 50-60. (in Eng.)

194. Derzhavna sluzhba statystyky Ukrayiny [State Statistics Service of Ukraine]. ukrstat.gov.ua. Retrieved from:http://www.ukrstat.gov.ua [in Ukrainian].

195. Stratehiya rozvytku turyzmu Zaporiz'koyi oblasti na 2021-2027 roky [Tourism development strategy of Zaporizhzhia region for 2021-2027]. (n.d.). berga.gov.ua. URL: http://www.berda.gov.ua/files/admin/Tourism_development_strategy_Zp.pdf.

196. Tsviliy, S., Gurova, D., Zhuravlova, S. (2021). Coronavirus priorities in marketing management of microenterprises in the hospital field. Infrastructura rynku Market infrastructure, 52, 120-125[in English].

197. Zaitseva V.(ed.) (2017) Industriia hostynnosti v Ukraini: stan, tendentsii rozvytku [Hospitality industry in Ukraine: state and trends], Zaporizhzhia: Prosvita. (in Ukr.).

198. Zaitseva, V., Tsviliy, S., Bublei, G. (2019) Innovation facilities of the tourist business of small and medium enterprises of the region. Roczniki Ekonomiczne KPSW w Bydgoszczy. № 12. P. 201-212. [in Eng.].

199. Zaitseva V. M. (ed.) (2018) Stratehichne upravlinnia hotelnymy pidpryiemstvamy $\mathrm{v}$ umovakh hlobalizatsiii [Strategic management of hotel enterprises in the context of globalization]. Zaporizhzhia: ZNTU. (in Ukrainian)

200. Strashynska L.V. (2011) Marketynh hotelnoho i restorannoho hospodarstva [Marketing of hotel and restaurant economy]. Kyiv: NUKHT. (in Ukrainian)

201. Durovych A. P. (2003) Marketing v turizme: uchebnoe posobie [Marketing in tourism: a textbook]. Minsk: Novoe znanie. (in Russian). 
202. Halasyuk, S., Nezdoyminov. S. (2019). Orhanizatsiya hotel'noho hospodarstva [Organization of the hotel industry]. Kyiv: FOP Hulyayeva V.M. [in Ukrainian].

203. Korniienko O., Kuklina T. (2019) Mizhnarodnyi hotelnyi biznes: problemy ta perspektyvy [International hotel business: problems \& prospects]. Infrastruktura rynku (electronic journal). No. 31. pp. 27-30. Available at: http://www.marketinfr.od.ua/journals/2019/31_2019_ukr/6.pdf. (accessed 10 February 2021).

204. Kotler F. (eds.) (2003) Marketynh menedzhment [Marketing management]. Sankt-Peterburh: Pyter (in Russian)

205. Kuklina, T.S. (2017). Vykorystannya informatsiynykh tekhnolohiy v diyal'nosti turystychnykh pidpryyemstv [The use of information technology in the activities of tourism enterprises]. Prychornomors'ki ekonomichni studiyi - Black Sea Economic Studies, 13/2, 217-221 [in Ukrainian].

206. Tsviliy S., Vasylychev D., Gurova D. (2020) Innovative potential of the tourist territory in the strategy of sustainable development of the domestic region. Trends, prospect and challenges of sustainable tourism development. L'viv : L'vivs'kyy torhovel'no-ekonon. Universytet, pp. 51-66. (in English)

207. Tsviliy S., Gurova D., Bulatov S. (2020) Reserves for reduction of labor capacity of hotel and restaurant product and their effective use in the enterprise personnel management system. Infrastruktura rynku (electronic journal). no. 47. pp. 123-128. URL: http://www.market-infr.od.ua/journals/2020/47_2020_ukr/25.pdf.

208. Tsviliy, S., Gurova, D., Korniienko, O. (2020) Postcoronavirus development of the regional tourist destination on the principle of public-private partnership. ZVO «Mizhnar. un.-t biznesu i prava. «Biznes-navihator». № 4 (60). S. 134-138. [in Eng.]

209. Zaitseva, V., Filei, Yu. (2010) Pravove rehulyuvannya turystychnoyi diyal'nosti [Legal regulation of tourism]: navch. pos-k. Zaporizhzhya : Prosvita. $220 \mathrm{~s}$. [in Ukr.]

210. Господарський кодекс України № 436-IV від 16.01.2003. Відомості Верховної Ради України.2003. № 18-22. ст. 144

211. Боярська М.О. Аналіз стратегії розвитку підприємства. Глобальні та національні проблеми економіки. 2015. Вип. 5. С. 306-310.

212. Доброва Н.В., Осипова М.М. Основи бізнесу: навчальний посібник. Одеса: Бондаренко М. О., 2018. 305 с.

213. Калініченко Л.Л., Вєтрова В.В., Константинова К.Г. Фінансове забезпечення старту підприємницької діяльності. Молодий вчений. Вип. № 5.1. (57.1.). 2018. C. $31-36$.

214. Підприємництво і бізнес-культура: навчальний посібник / Укладачі: Лаготюк В.О., Безродна С.М. Чернівці, Видавничий дім «Родовід» 2016. 158 с. 
215. Поддєрьогін А.М. Фінанси підприємств: підручник / Керівник авторського колективу і науковий редактор А.М. Поддєрьогін. - К.: КНЕУ, 2017.

216. Хлістунова Н. Аналіз поточної діяльності підприємства як основа формування стратегічної гнучкості на прикладі «ТДЦ-АВТО». Економічний аналіз. 2012. № 11. Ч. 3. С. 111-114

217. Беляцкий Н. П., Велесько С. Е., Ройш П. Управление персоналом : Учеб. пособие. - Минск : Интерпрессервис; Экоперспектива, 2002. - 352 с.

218. Корчагина А. С, Клочкова М. С. Управление персоналом. Ответы на экзаменационные билеты: Учеб. пособие для вузов. - 2-е изд., стереотип. -М.: Изд-во «Экзамен», 2007. - 288 с.

219. Маслов Е. В. Управление персоналом предприятия : Учеб. пособие / Под ред. П. В. Шеметова. - М.: ИНФРА-М; Новосибирск : НГАЭиУ, 2000. - 312 c.

220. Управление персоналом организации: Учебник. - 2-е изд., доп. и перераб. / Под ред. А. Я. Кибанова. - М. : ИНФРА-М, 2002. - 638 с.

221. Управление персоналом : Учеб. пособие / С. И. Самыгин, Л. Д. Столяренко, С. И. Шило и др.; Под ред. С. И. Самыгина. - Ростов н/Д: Феникс, 2001.-512 c.

222. Столяров Г. В. Кадровая политика инновационной организации // Стратегическое партнёрство бизнеса и образования: Материалы Международной научно-практической конференции / Брянск: ООО Ладомир, 2012. - C. 254-258.

223. Климчук М. М. Вплив ризик-менеджменту на формування стратегії управління бізнес-процесами підприємства в умовах цифрової економіки: міжнародний досвід / М.М. Климчук, І. А. Ачкасов, С. А. Климчук, О. П. Поляк //Бізнес-інформ-2021.-№1.- с. 272 - 278.

224. Klymchuk M. Cognitive Technologies as a Determinant of the Economic Transformation Process and Energy Efficiency of the Economy: Monograph / M. Klymchuk, V. Tkachenko.- Kyiv, 2021.-196 p.- References: P. 173.

225. Klymchuk M. Applied Aspects of Formation of Facilitation-Reflective Methodology of Personnel Motivation Management in the Energy Management System / M. Klymchuk, I. Fedun., I. Novikova, I., Artamonova, G.V.// Lecture Notes in Networks and Systems, 2021, 194 LNNS, pp. 344-354.

226. Klymchuk M. Recursive and convergence methodology of the investment management of the enterprise digitalization processes / M. Klymchuk, V. Tkachenko // Management Systems in Production Engineering, 2020, 29(1), pp. 14-19.

227. Klymchuk M. The Economic-Mathematical Development of Buildings Construction Model Optimization on the Basis of Digital Economy/ M. Klymchuk, A. 
Kwilinski, V. Tkachenko // Management Systems in Production Engineering, 2019, 27(2), pp. 119-123.

228. Klymchuk M. Risk management system references in construction / V. Tkachenko, M. Klymchuk, I. Tkachenko, T. Ilina // Research Papers in Economics and Finance.- 4 (1) - 2020.- C.21-30. ttps://doi.org/10.18559/ref.2020.1.2

229. Klymchuk M., Tkachenko V. Theoretical and methodological basis of cognitive economics formation. Abstracts of V International Scientific and Practical Conference. Oslo, Norway 2020. pp. 69-74pp. Available at : DOI: 10.46299/ISG.2020.II.V URL: https://isg-konf.com.

230. Susannah Hammond \&Mike Cowan Thomson Reuters: Cost of Compliance $2021 \mathrm{https}: / / \mathrm{www} . c 0 r p o r a t e c o m p l i a n c e i n s i g h t s . c o m / c o g n i t i v e-g o v e r n a n c e-r i s k-$ framework

231. Enterprise Risk Management - Integrated Framework. Committee of Sponsoring Organizations of the Commission Treadway. URL: https://www.coso.org/Pages/ erm-integratedframework.aspx

232. Risk Management Standard. Risk Institute Management (IRM) / Association of Insurance and Risk Managers (AIRMIC) / National Management Forum risks in the public sector of the economy (Alarm). 2002. URL: https://www.slideshare.net/luisvitiritti/risk-management-standard

233. Данилишин Б. Світова фінансова криза - тест для України. Дзеркало тижня. 2008. No38. С. 17-18.

234. Трусова Н.В. Боргові зобов'язання підприємств: процедура банкрутства та визнання вимог кредиторів. Збірник наукових праць ТДАТУ (економічні науки).2018. № 1 (36). С.169-178.

235. Сакун А. Ж., Пантюк І.П. Системний підхід до організації та управління виробничо-збутовою діяльністю підприємств промисловості. Вісник Бердянського університету менеджменту і бізнесу. 2017. № 2 (38). С. 55-59

236. Маренич Т.Г. Трансформація та механізми економічного регулювання агроформувань: питання теорії, методології, практики: монографія. Харків: ТОВ «ЕДЕНА», 2006. 413c

237. Чернявський А. Д. Антикризове управління підприємством. Київ: МАУП, 2006. $256 \mathrm{c.}$

238. Трусова Н.В., Пристемський О.С., Сакун А.Ж. Фінансовий механізм та інструменти забезпечення стійкого розвитку аграрних підприємств. Облік і фінанси. 2019. No4(86). С. 114-123.

239. Пристемський О.С., Логінова А.О. Методи антикризового управління підприємством . II Всеукраїнська науково-практична інтернет конференція «Актуальні проблеми та перспективи розвитку обліку, аналізу та контролю в 
соціально-орієнтованій системі управління підприємством». 23 квітня 2019 р., Полтава.: ПДАА, 2019.С.212-214.

240. Шершньова 3. Є. Стратегія управління. Київ: КНЕУ, 1999. 384 с.

241. Gryshova I., Sakun A. Influence of the Commercialization of Innovations on Leadership Positions of the Agro-Industrial Sector. Proceedings of the 5th International Conference on Social, Economic, and Academic Leadership (ICSEALV 2019), Advances in Social Science, Education and Humanities Research, Vol. 386, pp.39-44, https://doi.org/10.2991/assehr.k.191221.175

242. Аграрна політика та земельні відносини: підручник / Г.М. Калетнік, I.В. Гончарук, Т.В. Смчик, С.М. Лутковська - Вінн. нац. аграр. ун-т. - Вінниця: BHAУ, 2020. - $307 \mathrm{c}$.

243. Venture impact 2004. Venture capital benefits for the U.S. economy, Global Insight.

244. Иванов В.В. Национальные инновационные системы: опыт формирования и перспективы развития. Инновации №4, 2002, с.14-26.

245. Дагаев А.А. Венчурный бизнес: управление в условиях кризиса. Проблемы теории и практики управления, 2003, №3, с.74-80.

246. Грозний I.С. Стратегія виводу венчурного капіталу з інноваційного проекту. Вісник Львівської комерційної академії. Серія економічна. Львів: Видавництво Львівської комерційної академії, 2005. Випуск 18. Частина 1. С. $160-165$

247. Маковеев П. С. Венчурное инвестирование малого и среднего бизнеса в экономике Украины. Труды Одесского политехнического университета .2003. Вып.1. С.254-258

248. Analiz hozyaystvennoy deyatelnosti v promyishlennosti: Uchebnik / Pod obsch.red. V.I. Strazheva.- Mn.: Vyish.schk., 1996.

249. Чалдаева, Л. А. Экономика предприятия : учебник и практикум для среднего профессионального образования / Л. А. Чалдаева. - 5-е изд., перераб. и доп. - Москва : Издательство Юрайт, 2019. — 435 с.

250. Analiz finansovogo sostoyaniya predpriyatiya. Spravochnoe posobie. Sankt-Peterburg, Auditorskaya firma «Ekselsior», 2004.

251. Dontsova L.V., Nikiforova N.A. Analiz finansovoy otchetnosti: Uchebnoe posobie. - M.: Izdatelstvo «Delo i Servis», 2004.

252. Dontsova L.V., Nikiforova N.A. Godovaya i kvartalnaya buhgalterskaya otchetnost. Metodicheskoe posobie po sostavleniyu. - M.: Izdatelstvo «Delo i Servis», 1998. 2002.

253. Efimova O.V. Finansovyiy analiz. - M.: Izd-vo «Buhgalterskiy uchet», 
254. The concept of trust in research by P. Sztompka, electronic source available at the link: http://ecsocman.hse.ru/rubezh/msg/19034149.html

255. Electronic source available at the link: https://nonews.co/directory/lists/countries/public-trust-politicians

256. electronic source available at the link: https://www.hse.ru/data/2014/03/05/1332915183/\%D0\%94\%D0\%BE\%D0\%B2\%D0 \%B5\%D1\%80\%D0\%B8\%D0\%B5\%20\%D0\%B8\%20\%D0\%BD\%D0\%B5\%D0\%B4 $\% \mathrm{D} 0 \% \mathrm{BE} \% \mathrm{D} 0 \% \mathrm{~B} 2 \% \mathrm{D} 0 \% \mathrm{~B} 5 \% \mathrm{D} 1 \% 80 \% \mathrm{D} 0 \% \mathrm{~B} 8 \% \mathrm{D} 0 \% \mathrm{~B} 5 \% \mathrm{D} 0 \% 98 \% \mathrm{D} 0 \% 9 \mathrm{D} \% \mathrm{D}$ $0 \% \mathrm{~A} 2 \% \mathrm{D} 0 \% 95 \% \mathrm{D} 0 \% \mathrm{~A} 0 \% \mathrm{D} 0 \% 9 \mathrm{D} \% \mathrm{D} 0 \% 95 \% \mathrm{D} 0 \% \mathrm{~A} 2 . \mathrm{pdf}$

257. Efimova O.V. Finansovyiy analiz. - M.: Izd-vo «Buhgalterskiy uchet», 2002.

258. Savitskaya G.V. Analiz hozyaystvennoy deyatelnosti predpriyatiya. - Mn.: IP «Ekoperspektiva»; «Novoe znanie», 1999.

259. Ekonomicheskiy analiz: Uchebnik dlya vuzov / Pod red.L.T.Gilyarovskoy. - M.: YuNITI-DANA, 2004.

260. Sheremet A.D. Sayfulin R.S. Metodika finansovogo analiza. - M.: Infra M, 1996.

261. Oleynik O. Ways of defining the level of trust: how do semiotics and hermeneutics influence such notions as trust and confidence, belief? // Євроінтеграційний вибір України та проблеми макроекономіки: XXVII Міжнародна науково-практична конференція молодих вчених і студентів: тези доповідей, Дніпро, 5 грудня 2019 р. [Електронний ресурс]. - Дніпро: Університет імені Альфреда Нобеля, 2019. - 476 с. ISBN 978-966-434-469-9

262. Electronic source available at the link: https://nonews.co/directory/lists/countries/global-competitiveness-index

263. Electronic source available at the link: https://nonews.co/directory/lists/countries/gdp-pp

264. Electronic source available at the link: http://mba.susu.ru/info/news/onlayn-vstrecha-doverie-kak-faktor-i-instrumentsotsialno-ekonomicheskogo-razvitiya/

265. Electronic source available at the link: http://www.rabe.ru/upload/files/20_02_2021/\%D0\%9F\%D1\%80\%D0\%B5\%D0\%B7 $\% \mathrm{D} 0 \% \mathrm{~B} 5 \% \mathrm{D} 0 \% \mathrm{BD} \% \mathrm{D} 1 \% 82 \% \mathrm{D} 0 \% \mathrm{~B} 0 \% \mathrm{D} 1 \% 86 \% \mathrm{D} 0 \% \mathrm{~B} 8 \% \mathrm{D} 1 \% 8 \mathrm{~F} \% 20 \% \mathrm{D} 0 \% 90$ $\% \mathrm{D} 1 \% 83 \% \mathrm{D} 0 \% \mathrm{~B} 7 \% \mathrm{D} 0 \% \mathrm{~B} 0 \% \mathrm{D} 0 \% \mathrm{BD} \% \mathrm{D} 0 \% \mathrm{~B} 0 \% 20-\% 20 \% \mathrm{D} 0 \% 94 \% \mathrm{D} 0 \% 9 \mathrm{E} \% \mathrm{D} 0$ $\% 92 \% \mathrm{D} 0 \% 95 \% \mathrm{D} 0 \% \mathrm{~A} 0 \% \mathrm{D} 0 \% 98 \% \mathrm{D} 0 \% 95$.pdf

266. Electronic source available at the link: https://cyberleninka.ru/article/n/doverie-kak-faktor-ekonomicheskogo-razvitiyaissledovaniya-s-pozitsiy-institutsionalnoy-ekonomicheskoy-teorii 
267. Tkachenko N. (2009). Financial stability of insurance companies: theoretical approaches // Finance of Ukraine. № 6. P. 104-122.

268. Pavlovskaya O., Prytulyak N., Nevmerzhytska N. (2007). Financial analysis, 2d ed.. Kyiv: Ministry of Education and Science of Ukraine, KNEU [in Ukrainian].

269. Kramarenko H. (2003). Financial analysis and planning. Kyiv: Center for Educational Literature [in Ukrainian].

270. Bilyk M. (2005). Financial analysis. Kyiv: KNEU [in Ukrainian].

271. Kotlyar M. (2005). Assessment of financial stability of the enterprise on the basis of analytical coefficients // Finance of Ukraine. № 1. P. 113- 117 [in Ukrainian].

272. Martsyn V. (2008). Reliability, solvency and financial stability - the main components of the financial condition of the enterprise // Economics. Finance. Law. № 7. P. 26-28.

273. Антонюк О.І. Особливості розвитку банківської системи України на сучасному етапі. Вісник Університету банківської справи Національного банку України. 2013 № 1 (16).С.145-147

274. Арбузов С.Г. Банківська енциклопедія / С.Г. Арбузов, Ю.В. Колобов, B.I. Міщенко, С.В. Науменкова. К.: Центр наукових досліджень Національного банку України: Знання, 2011. С. 63.

275. Банківська система України URL: https://aub.org.ua

276. Блащук Ю. Соціальний капітал банківської системи URL:https://www.epravda.com.ua

277. Витяг зі статуту асоціації “Український кредитно-банківський союз” URL: http://kbs.org.ua

278. Доходи і витрати банків України URL: http://www.bank. gov.ua

279. За рік прибуток банківської системи впав на третину URL: ttps://www.unian.ua

280. Зрозуміти та відпустити: причини і результати «великого банківського . очищення» URL: . https://badbanks.bank.gov.ua

281. Кількість комерційних банків в Україні з 2008 по 2019 pp. URL: . https://index.minfin.com.ua/ua/banks/stat/count/

282. Комплексна програма розвитку фінансового сектору України до 2020 року URL:http://www.bank. gov.ua

283. Національний банк залишив без змін критерії розподілу банків на групи на 2021 рік URL: https://bank.gov.ua 
284. Національний банк удосконалив вимоги щодо організації системи управління ризиками в банках та банківських групах URL: https://bank.gov.ua

285. Основні показники банківської діяльності в Україні URL: . https://index.minfin.com.ua

286. Пурій Г.М. Сучасний стан та перспективи розвитку банківської системи України. Фінансовий простір.2017. №3. С. 41-47.

287. Система ризик-менеджменту в банках: теоретичні та методологічні аспекти: монографія / За ред. В. В. Коваленко. Одеса: ОНЕУ, 2017. С. 304.

288. Статут АУБ URL: http://aub.org.ua

289. Статут НАБУ URL: http://www.nabu.ua

290. Українська міжбанківська асоціація членів платіжних систем "СМА" https://www.ema.com.ua

291. Частка непрацюючих кредитів (NPL) висока, але поступово скорочується. URL: http://www.bank. gov.ua

292. Юрків Н.Я., Гладких Д.М. Розвиток банківського кредитування господарюючих суб'єктів як умова забезпечення сталого економічного зростання в Україні. URL: https://niss.gov.ua

293. Structure and economic contribution of the banking sector. URL: . https://www.ebf.eu

294. Єдиний Реєстр наявності кредитної історії (СРНКІ) позичальника. [Електронний ресурс]. - Режим доступу: https://uchba.co/services/ernki/

295. Офіційний сайт ТзОВ «Українське бюро кредитних історій». [Електронний ресурс]. - Режим доступу: https://www.ubki.ua/

296. Офіційний сайт ПрАТ «Перше всеукраїнське бюро кредитних історій». - [Електронний ресурс]. - Режим доступу: http://main.pvbki.com/

297. Офіційний сайт ПрАТ «Міжнародне бюро кредитних історій». [Електронний ресурс]. - Режим доступу: https://credithistory.com.ua

298. Офіційний сайт ТзОВ «Бюро кредитних історій «Українське кредитне бюро». - [Електронний ресурс]. - Режим доступу: https://creditua.com/

299. Обсяги активних операцій та частка непрацюючих активів в цілому по банківській системі України за 2018-2020 роки. - [Електронний ресурс]. - Режим доступу: https://bit.ly/3xn7p0k

300. Згруповані балансові залишки за звітністю банків України за 20182020 роки. - [Електронний ресурс]. - Режим доступу: https://bit.ly/3gluHOD

301. Upravlenie po rezul'tatam / obshh. red. i. pred. Ja. A. Lejmana ; [per.s finn.]. - M. : Nauka, 1993. - 315 s. 
302. Tokar M. (2020). Hromadski orhanizatsii Ukrainy v systemi rozvytku publichno-upravlinskykh vidnosyn: monohrafiia. Lvivskyi rehionalnyi instytut derzhavnoho upravlinnia NADU pry Prezydentovi Ukrainy Lviv: LRIDU NADU.

303. Gorshkov A. S. Principy upravlenija po rezul'tatam v dejatel'nosti organov vlasti / A. S. Gorshkov, A. L. Kirillov // Upravlencheskoe konsul'tirovanie. - 2008. № 1. - S. 5-13.

304. KMU (2019), Polozhennya pro Ministerstvo tsyfrovoyi transformatsiyi Ukrayiny [Regulation on the Ministry of Digital Transformation of Ukraine], the order of the Cabinet of Ministers of Ukraine dated September 18, 2019 №. № 856. URL: https://zakon.rada.gov.ua/laws/show/856-2019-\%D0\%BF\#Text [in Ukrainian].

305. Suchasni kontseptsiyi publichnoho upravlinnya / V. O. Berezhnyy // Aktual'ni problemy derzhavnoho upravlinnya. - 2013. - № 2. - S. 31-38. URL: http://nbuv.gov.ua/j-pdf/apdy_2013_2_6.pdf

306. Adizes I. Na poroge upravlencheskoj revoljucii//Harvard Business Reviev -2017 s.7-9.

307. Taler R. Novaja povedencheskaja jekonomika M.: Izdatel'stvo «Je», 2017. $225 \mathrm{~s}$.

308. Gohberg L. Innovacionnye processy: tendenciyi problemy//Jekonomist.2016.-No2- S. 50-59.

309. Komov M. S. Rol' innovacij v antikrizisnom upravlenii // Molodoj uchenyj. - 2016. - No 19. - S. 458-459.

310. Kozachenko V.H. Tekhnolohizatsiya upravlins'koyi diyal'nosti: zmist ta pryznachennya // Ekonomika i rehion \# 3 (58) - 2016 - PoltNTU. - S. 37-40.

311. Babchyns'ka O. I. Komunikatsiynyy protses v upravlinni: osnovni polozhennya. Efektyvna ekonomika. 2018. \# 9. URL: http://www.economy.nayka.com.ua/?op=1\&z=6539

312. Tokar M. Didzhytalizatsiia yak optymizatsiia vzaiemodii publichnoi vlady i hromadskykh orhanizatsii / Aspekty publichnoho upravlinnia. Tom 8. Spetsvypusk. № 1.2020 . S. $130-132$.

313. Асоціація Рітейлерів України 2019. Топ-20 найбільш інноваційних компаній України: з рітейлу до списку увійшов тільки Сільпо. [online]. Режим доступу: <https://rau.ua/novyni/top-20-innovation/> .

314. Всесвітній економічний форум, 2021. Звіти «The Global Competitiveness Index за 2017-2020 pp.»< <https://www.weforum.org/reports>.

315. Світова організація інтелектуальної власності, 2021. Звіти «The Global Innovation Index за 2017-2020 pp.». [online]. Режим доступу: $<$ https://www.globalinnovationindex.org/analysis-indicator $>$. 
316. Світовий банк, 2021. Звіти «Doing business за 2017-2020 pp.». [online]. Режим доступу: <http://edclub.com.ua/analityka/doing-business-2018-ukrayina-vreytyngu-svitovogo-banku-legkosti-vedennya-biznesu>.

317. Фарат, О.В., 2019. Теоретико-методологічні основи забезпечення конкурентоспроможності підприємницьких структур на засадах розвитку інноваційних кластерів у системі національної економіки. Львів: Видавництво Львівської політехніки, с. 224.

318. Kinash, I., Andrusiv, U., Golovnia, O., and Popadynets, I., 2019. Aspects of the formation and development of innovation infrastructure in Ukraine. Management Science Letters, 9 (Special Issue 13), 2403-2414.

319. Sherifi, I., Andrushchenko, H., Vankovych, D., Solokha, D., Malyshenko, I., Yavorska, N., 2020. Strategic management of industrial enterprise innovation potential development. Academy of Strategic Management Journal. Vol. 19, iss. 6. P. $1-8$.

320. ATKINSON, S. (2016): 10 Mega Trends that are (re)shaping our world. Ipsos. 2016. [online]. [Cited 5.05.2021.] Available online: https://www.ipsos.com/sites/default/files/10-Mega-Trends-That-are-Reshaping-TheWorld.pdf

321. BHASIN, S. C. (2018): Interview : Defining the Power of Megatrends People Matters. People Matters. 2018. [online]. [Cited 25.04.2020.] Available online: https://www.peoplemattersglobal.com/article/diversity/defining-the-power-ofmegatrends-19001

322. DUFVA, M. (2020a): The metatrends behind the megatrends Sitra. Sitra. 06.03.2020. [online]. [Cited 25.04.2020.] Available online: https://www.sitra.fi/en/articles/the-metatrends-behind-the-megatrends/

323. DUFVA, M. (2020b): The big picture of the megatrends Sitra. Sitra. 06.03.2020. [online]. [Cited 25.04.2020.] Available online: https://www.sitra.fi/en/articles/the-big-picture-of-the-megatrends/

324. EFRAT, Z. (2018): World's top Global mega trends to 2020 and implications to business, society and cultures. Executive Summary. Frost Sullivan. [online]. [Cited 19.04.2020.] Available online: https://fdocuments.in/document/worlds-top-global-mega-trends-to-2020-andimplications-to-business-society.html

325. HORX, M. (2020): The Power of the Megatrends. About the turbulence of the future. Zukunftsinstitut Horx GmbH. [online]. [Cited 19.04.2020.] Available online: https://www.horx.com/en/speeches/the-power-of-the-megatrends/

326. KLEIN, F., BANSAL, M., \& WOHLERS, J. (2017): Beyond the Noise : The Megatrends of Tomorrow's World. Deloitte. [online]. [Cited 19.04.2020.] Available

online: 
https://www2.deloitte.com/content/dam/Deloitte/n1/Documents/public-sector/deloittenl-ps-megatrends-2ndedition.pdf

327. MELNYK, L., KUBATKO, O., DEHTYAROVA, I., MATSENKO, O., \& ROZHKO, O. (2019): The effect of industrial revolutions on the transformation of social and economic systems. Problems and Perspectives in Management, 17(4), 381391. [online]. [Cited 5.05.2021.] Available online: https://doi.org/10.21511/ppm.17(4).2019.31.

328. MITCHELL, G. (2020): 20 Metatrends To Blow Your Minds - The Manufacturing Connection. The Manufacturing Connection. All Rights Reserved. 10.01.2020. [online]. [Cited 19.04.2021.] Available online: https:/themanufacturingconnection.com/2020/01/20-metatrends-to-blow-your-minds/

329. RIFKIN, J. (2015): Zero Marginal Cost Society: The Internet of Things, the Collaborative Commons, and the Eclipse of Capitalism. New York : St. Martin's Griffin Publisher.

330. Штангрет А.М. Антикризове управління підприємством: [навч.посіб.]. К.: Знання, 2007. 335c.

331. Спіріна М.В. Стратегія управління конкурентоспроможністю підприємства // Актуальні проблеми економіки. 2004. №8. С. 176-181.

332. Карпенко Л. М. Методичні підходи до оцінювання рівня конкурентоспроможності підприємства // Вісник соціально-економічних досліджень. 2013. Вип. 3(2). С. 24-31.

333. Коненко В.В., Кліщенко А.О. СТРАТЕГІЯ ФОРМУВАННЯ КОНКУРЕНТНИХ ПЕРЕВАГ ПІДПРИЄМСТВА // СУчасний рух науки: тези ІІІ міжнародної науково-практичної інтернет-конференції, 1-2 жовтня 2018 р. Дніпро, 2018. С. 310-312.

334. Довгань Л. Є. Стратегічне управління: навч. посіб. 2-гевид. К. : Центр учбової літератури, 2011. 440 с.

335. Балабанова Л. В. Оптова торгівля: маркетинг та комерція. Навчальний посібник. 2013. 432 с.

336. Памбухчіянц О. В. Організація та технологія комерційної діяльності. Навчальний посібник. 2006. 284 с.

337. Global cooperation \& delegation development [Electronic resource]. Available at : http://www.wevio.com/solution/global-cooperation-delegationdevelopment/

338. Agrawal A.J. Ten Reasons Why Businesses Are Going Global [Electronic resource]. - Available at: https://www.huffingtonpost.com/aj-agrawal/ten-reasonswhy-businesse_b_11512636.html. 
339. Chand S. 8 reasons why most companies prefer to go global - explained! [Electronic resource]. - Available at : http://www.yourarticlelibrary.com/business/8reasons-why-most-companies-prefer-to-go-global-explained/13176.

340. Cornelis de Kluyver. Fundamentals of global strategy [Electronic resource]. - Available at : https://saylordotorg.github.io/text_fundamentals-of-globalstrategy/s04-the-globalization-of-companies.html.

341. International Corporations : lecture notes / compilers I. S. Marekha, V. O. Shcherbachenko. - Sumy : Sumy State University, 2019. - 150 p.

342. Impact of multinational companies on the host country. [Electronic resource]. Available at: http://textbook.stpauls.br/Business_Organization/page_144.htm.

343. Калюжна Н. Зовнішня торгівля України: методологія дослідження // Зовнішня торгівля: економіка, фінанси, право. 2017. № 1. стр.18-19. URL: http://zt.knute.edu.ua/files/2017/01(90)/ZT_01_2017_st_02.pdf

344. Сидяга Б. Проблеми розвитку торговельного потенціалу України. Соціально- економічні проблеми і держава. 2014. Вип. 1 (10). С. 250-256. URL: http://sepd.tntu.edu.ua/images/stories/pdf/2014/14sbvtpu.pdf.

345. Кисельова О. М. Структурні особливості зовнішньоекономічної діяльності України. Економіка і прогнозування. 2012. № 4. С. 93-101. URL: http://nbuv.gov.ua.

346. Александрова Р. А., Платошина Г. М., Платошин А. С. Статистичне дослідження зовнішньої торгівлі товарами України. Вісн. Приазов. держ. техн. ун-ту. 2009. № 19. С. 362-365.

347. Мазаракі А. А. Сучасні тенденції та чинники розвитку зовнішньої торгівлі України. Вісн. Київ. нац. торг.-екон. ун-ту. 2011. № 2. С. 5-14.

348. Мельник Т. М. Іллегалізація сфери зовнішньої торгівлі товарами в Україні. Екон. часопис-XXI. 2014. № 7-8 (1). С. 4-7.

349. Yin J. Explosion of Trade Disputes? URL: www.wto.org/wto/ dispute/dsu.htm.

350. Calfat G. Junior The EU-Mercosul free trade agreement: Quantifying mutual gains / German Calfat, Renato Flores // Ensaios Economicos. - 2004. - № 575. - P. 1-38.

351. Лапшин B.I., Кузніченко B.М. Товарна структура міжнародної торгівлі України в 2016 році. / Глобальні та національні проблеми економіки. №17. - 2017. - C. 914. URL: http://global-national.in.ua/archive/17-2017/183.pdf

352. Гусев Н.Ю. Статистика: основы методологии /Н. Ю. Гусев. - М.: Издво АСB, 2000. - стр.172 
353. Ефимова М.Р. Общая теория статистики / М.Р. Ефимова, Е.В. Петрова, В.Н. Румянцев. - [2-е изд., испр. и доп.]. - М.: ИНФРА-М, 2005. - стр. 299.

354. Фомичев K. Go digital or die. Диджитализация как неизбежность // Ассоциация профессиональных директоров. 26.12.2017. URL: https://nand.ru/professional-information/news/20566/ (дата звернення 23.04.2021)

355. Макарова М. Електронна комерція: навч. посібник. Київ: Академія. 2002. $269 \mathrm{c}$.

356. Діджиталізація влади: чи зможуть депутати піти в онлайн. ЛІГА:ЗАКОН. БІЗНЕС. 13.01.2021. URL: https://biz.ligazakon.net/news/200378_ddzhitalzatsya-vladi-chi-zmozhut-deputati-ptiv-onlayn (дата звернення 27.05.2021)

357. Клюка А. Исследование рынка электронной коммерции в Украине // Украинский интернет-журнал. 11.04.2013. URL: http://ain.ua/2013/04/11/120835 (дата звернення 13.04.2021)

358. Крегул Ю., Батрименко В., Батрименко В. Правове регулювання міжнародної електронної комерції // Зовнішня торгівля: економіка, фінанси, право. 2018. № 2. C. 136-147. URL: http://zt.knute.edu.ua/files/2018/02(97)/16.pdf

359. Дяченко Я. Електронна комерція в зовнішньоекономічній діяльності: матеріали наукової конференції, м. Полтава. 2010. URL: http://oldconf.neasmo.org.ua/node/2085 (дата звернення 25.02.2021)

360. Закон України «Про електронну комерцію» від 3 вересня 2015 року № 675-VIII. Відомості Верховної Ради. 2015. № 45. Ст. 410. URL: https://zakon.rada.gov.ua/laws/show/675-19\#Text (дата звернення 03.03.2021)

361. Желіховський В. М. Правові засади електронної комерції в Україні. : Дис... канд. юр. наук: Київський національний університет внутрішніх справ, Київ. 2007.

362. Демьянец М. В., Елин В. М., Жарова А. К. Предпринимательская деятельность в сети Интернет: Монографія: ЮРКОМПАНИ. 2014. 440 с.

363. Чучковська А. В. Правове регулювання електронної комерції в Україні: навч. посібник. Київ: Центр учбової літератури, 2007. 224 с.

364. Борисова Ю. О. Цивільно-правове регулювання відносин у сфері електронної комерції. Дисертація канд. юрид. наук: 12.00 .03 , Київ. нац. ун-т ім. Тараса Шевченка. К., 2012. 190 с.

365. Маєвська А. А. Електронна комерція і право: навч. - метод. посібн. Харків: 2010. 256 с.

366. Хубаев Г. Маркетинг информационных продуктов и услуг: Ростов-наДону: РГЭУ «РИНХ», 2005. 224 с. 
367. Електронна торгівля. Навчальні матеріали онлайн. URL: https://pidru4niki.com/18641210/marketing/elektronna_torgivlya (дата звернення 29.03.2021)

368. Мокроносов А. Г. Конкуренция и конкурентоспособность : учебное пособие / А. Г. Мокроносов, И. Н. Маврина. Екатеринбург : Изд-во Урал ун-та, 2014. $194 \mathrm{c}$.

369. Дунська А. Р. Зовнішньоекономічна діяльність:теорія та практика. Навчальний посібник. К.: Кондор-Видавництво, 2013. 688 с.

370. Береза А. М., Козак I. А., Левченко Ф. А. та ін. Електронна комерція: навч. посібник : Київ.: КНЕУ. 2002. 326 с.

371. Електронна комерція. Види електронної комерції: Бізнес-до-бізнесу (B2B). URL: https://sites.google.com/site/elektronnakomercia05/vidi-elektronnoiekomerciie/biznes-do-biznesu-b2b (дата звернення 29.03.2021)

372. Електронна комерція. Види електронної комерції: Бізнес-доспоживача (B2C). URL: https://sites.google.com/site/elektronnakomercia05/vidielektronnoie-komerciie/biznes-do-spozivaca-b2c (дата звернення 29.03.2021)

373. Шалева О. Основні категорії і класи електронної комерції. 2021. URL: https://pidru4niki.com/14100821/informatika/elektronna_komertsiya (дата звернення 05.05.2021)

374. Що таке електронна комерція? E-commerce для початківців. Interkassa. Платформа для приймання платежів. URL: https://www.interkassa.com/ua/blog/chto-takoe-elektronnaya-kommerciya-ecommerce-dlya-nachinayushchih/ (дата звернення 10.03.2021)

375. Global B2B e-commerce gross merchandise volume (GMV) from 2013 to 2019. STATISTA. URL: https://www.statista.com/statistics/705606/global-b2b-ecommerce-gmv/ (дата звернення 02.04.2021)

376. B2B E-Commerce. STATISTA. 2021. URL: https://www.statista.com/markets/413/topic/458/b2b-e-commerce/\#overview (дата звернення 09.04.2021)

377. What is the growth region for B2B e-commerce? STATISTA. 2021. URL: https://www.statista.com/markets/413/topic/458/b2b-e-commerce/\#statistic1 (дата звернення 09.04.2021)

378. In-depth: B2B e-Commerce 2019. STATISTA. 2021. URL: https://www.statista.com/study/44442/statista-report-b2b-e-commerce/ (дата звернення 10.04.2021)

379. B2C E-Commerce. STATISTA. 2021. URL: https://www.statista.com/markets/413/topic/457/b2c-e-commerce/\#overview (дата звернення 10.04.2021) 
380. Гліненко Л. К., Дайновський Ю. А. Стан і перспективи розвитку електронної торгівлі України. Маркетинг і менеджмент інновацій. 2018. o 1. С. 87.

381. B2C E-Commerce. $\quad$ STATISTA. 2021 URL: https://www.statista.com/markets/413/topic/457/b2c-e-commerce/\#statistic1 (дата звернення 17.04.2021)

382. eMarketer Editors. Global Ecommerce Update. EMARKETER 2021. URL: https://www.emarketer.com/content/worldwide-ecommerce-will-approach-5-trillionthis-year (дата звернення 17.04.2021)

383. Интересные факты об интернет-торговле в мире в 2020 году. LEMARBET. 2021. URL: https://lemarbet.com/razvitie-internetmagazina/interesnye-fakty-ob-internet-torgovle/ (дата звернення 17.04.2021)

384. Cramer-Flood E. Global Ecommerce Update EMARKETER. 2021. URL: https://www.emarketer.com/content/global-ecommerce-update-2021 (дата звернення 17.04.2021)

385. Lipsman A. Global Ecommerce 2019. EMARKETER. URL: https://www.emarketer.com/content/global-ecommerce-2019 (дата звернення 17.04.2021)

386. Рынок интернет-торговли в Украине. Z-Украина: рынок ИТ, торговля. 2019. URL: https://zet.in.ua/statistika-2/rynok-it/rynok-internet-torgovli-v-ukraine/ (дата звернення 23.03.2021)

387. Report 2020:Leap Giant: e-E of Growth c 19-COVID. Payoneer. C. 8 URL: https://pubs.payoneer.com/docs/q1_q2_seller_report_2020.pdf C. 8.

388. Украина вошла в ТОП-10 стран по росту доходов от е-соmmerce. MMR. 2021. URL:https://mmr.ua/show/ukraina-voshla-v-top-10-stran-po-rostu-dohodov-ote-commerce (дата звернення 24.03.2021)

389. Юдін А. СВITOВИЙ Е-COMMERCE I M-COMMERCE СТАТИСТИКА I ФАКТИ ЕЛЕКТРОННОЇ КОМЕРЦІЇ 2020. МАRКЕТЕR. 2021. URL: https://marketer.ua/ua/e-commerce-worldwide-statistics-facts/ (дата звернення 10.04.2021)

390. E-commerce share of total global retail sales from 2015 to 2024. STATISTA. 2021. URL: https://www.statista.com/statistics/534123/e-commerceshare-of-retail-sales-worldwide/ (дата звернення 27. 04.2021)

391. The statistical office of the European Union. EUROSTAT. 2021. URL: https://ec.europa.eu/eurostat (дата звернення 22.04.2021)

392. Кліщук Л. В Україні оприлюднили тренди ринку е-commerce за 2018 рік. 2018. URL: https://nachasi.com/2018/12/06/pokaznyky-rynku-e-commerce/ (дата звернення 29.03.2021) 
393. Яким був український еcommerce у 2019 році. EVO-business: українська продуктова IT-компанія. 2021. URL:https:/evo.business/lyudikupuvali-bilshe-serednij-chek-zmenshivsya-vartist-dostavki-zrosla-yakim-buvukra\%D1\%97nskij-ecommerce-u-2019-roci/ (дата звернення 30.03.2021)

394.

395. E-commerce in Europe. 2020. PostNord. C.14. URL: https://www.postnord.se/siteassets/pdf/rapporter/e-commerce-in-europe-2020.pdf (дата звернення 27.03.2021)

396. Edwards K. Key takeaways from E-commerce Region Report: Europe 2020. E-commerce Germany news. URL: https://ecommercegermany.com/blog/keytakeaways-from-e-commerce-region-report-europe-2020 (дата звернення 27.03.2021)

397. B2C E-Commerce. STATISTA. 2021. URL: https://www.statista.com/markets/413/topic/457/b2c-e-commerce/\#statistic1 (дата звернення 17.04.2021)

398. TOP ECOMMERCE COMPANIES IN 2021. OBERLO. URL: https://www.oberlo.com/statistics/top-ecommerce-companies (дата звернення 04.04.2021)

399. TOP ECOMMERCE SITES BY VISITORS. OBERLO. 2021. URL: https://www.oberlo.com/statistics/top-ecommerce-sites-by-visitors (дата звернення 04.04.2021)

400. Annual net revenue of eBay from 2013 to 2020. STATISTA URL: https://www.statista.com/statistics/507881/ebays-annual-net-revenue/ (дата звернення 26.04.2021)

401. C2C E-Commerce. 2021. URL:https://www.statista.com/markets/413/topic/983/c2c-e-commerce/\#overview (дата звернення 26.04.2021)

402. European Ecommerce Report. 2019. URL: European_Ecommerce_report_2019_freeFinal-version.pdf C. 17

403. Which of these items have you bought online in the past 12 months? STATISTA. 2021. URL: https://www.statista.com/forecasts/997093/onlinepurchases-by-category-in-the-us (дата звернення 29.03.2021)

404. Звіт FedEx про тенденції в торгівлі на 2021 рік: Виявлення можливостей в умовах невизначеності. FedEx 2021. 12 с. URL: https://www.fedex.com/content/dam/fedex/eu-europe/campaigns/h1-2020/trendsreport/fedex_trade_trends_report_uk-ua.pdf (дата звернення 07.04.2021)

405. Most popular payment methods of online shoppers in selected regions as January 2019. STATISTA. URL: https://www.statista.com/statistics/676385/preferred-payment-methods-of-onlineshoppers-worldwide-by-region/ (дата звернення 25.04.2021) 
406. Сак Т. В., Ховхалюк Д. О. Електронна торгівля в Україні: стан, тенденції, перспективи розвитку. Маркетинг і цифрові технології. 2020. Том 4, №3. C. 73-85. URL:https://mdt-opu.com.ua/index.php/mdt/article/view/112/105 (дата звернення 13.04.2021)

407. RYBAK V. Pandemic Boost: How Ukraine's E-Commerce Sphere Developed in 2020. UkraineWorld: multimedia project. 2021. URL: https://ukraineworld.org/articles/ukraine-explained/how-ukraines-e-commercesphere-developed-2020 (дата звернення 21.04.2021)

408. Савчук К. На підйомі: як у 2020 році зростали ринки е-соmmerce в різних країнах світу. 2021. Електронний журнал el news. URL: https:/elnews.com.ua/uk/na-pidjomi-yak-u-2020-roczi-zrostaly-rynky-e-commercev-riznyh-krayinah-svitu/ (дата звернення 21.04.2021)

409. Ecommerce in UK to reach $€ 222$ billion in 2020. Ecommerce news Europe. 2020. URL: https://ecommercenews.eu/ecommerce-in-uk-to-reach-e222-billion-in2020/ (дата звернення 09.04.2021)

410. 2020 E-commerce Payments Trends Report: China. JPMorgan Chase sites. 2021 URL: https://www.jpmorgan.com/merchant-services/insights/reports/china2020 (дата звернення 09.04.2021) paper.

411. Peermohamed A. India's e-commerce sector sees big growth in 2021. EURL:https://economictimes.indiatimes.com/tech/technology/indias-e-commercesector-sees-big-growth-in-2021/articleshow/80055318.cms (дата звернення 11.04.2021)

412. The eCommerce market in Spain. EcommerceDB. 2021. URL: https://ecommercedb.com/en/markets/es/all (дата звернення 01.05.2021)

413. Гліненко Л. К., Дайновський Ю. А. Стан і перспективи розвитку електронної торгівлі України. Маркетинг і менеджмент інновацій: Львів. 2018. №1. C. 83-102. URL: https://mmi.fem.sumdu.edu.ua/sites/default/files/mmi2018_1_83_102.pdf (дата звернення 02.05.2021)

414. Edwards K. Key takeaways from E-commerce Region Report: Europe 2020. URL: https://ecommercegermany.com/blog/key-takeaways-from-e-commerce-regionreport-europe-2020 (дата звернення 19.04.2021)

415. Кліщук Л. В Україні оприлюднили тренди ринку е-соmmerce за 2018 рік. 2018. URL:https://nachasi.com/2018/12/06/pokaznyky-rynku-e-commerce/ (дата звернення 29.03.2021)

416. Яким був український еcommerce у 2019 році. EVO-business: українська продуктова IT-компанія. 2021. URL: https://evo.business/lyudikupuvali-bilshe-serednij-chek-zmenshivsya-vartist-dostavki-zrosla-yakim-buvukra\%D1\%97nskij-ecommerce-u-2019-roci/ (дата звернення 30.03.2021) 
417. The statistical office of the European Union. EUROSTAT. 2021. URL: https://ec.europa.eu/eurostat (дата звернення 22.04.2021)

418. Нагорский В. Рынок е-соmmerce в Украине в 2020 году вырос на 40\% - до 107 млрд грн (+инфографика) //Ассоциация ритейлеров Украины. 2021. URL: https://rau.ua/ru/news/e-commerce-v-ukrayini-2020/ (дата звернення 19.04.2021)

419. Ranking of most visited international online stores in Ukraine in 2018, by share of audience. The statistic portal for market data. URL: https://www.statista.com/statistics/1029319/most-visited-international-online-storesukraine/ (дата звернення 21.04.2021)

420. Ukrainians order 2.6 tons of goods on Aliexpress via Nova Poshta per day. Ain.ua: інтернет-журнал. 2020. URL: https://ain.ua/en/2020/05/05/ukrainiansorders-on-aliexpress-via-nova-poshta/ (дата звернення 12.04.2021)

421. 10 самых посещаемых интернет-магазинов в Украине в июне 2020 года. EVO-business. 2020. URL: https://evo.business/10-samyx-poseshhaemyxinternet-magazinov-v-ukraine-v-iyune-2020-goda/ (дата звернення 13.04.2021)

422. Топ-10 найбільш відвідуваних інтернет-магазинів України в червні. EVO-business. 2020. URL: https://rau.ua/ru/analytics/top-10-ynternet-magazynovjune/ (дата звернення 17.04.2021)

423. Нагорский В. Рынок е-сommerce в Украине в 2020 году вырос на 40\% - до 107 млрд грн (+инфографика) //Ассоциация ритейлеров Украины. 2021. URL:https://rau.ua/ru/news/e-commerce-v-ukrayini-2020/ (дата звернення 19.04.2021)

424. Спецпроект «E-commerce UA»: Как изменились за год показатели работы ключевых интернет-магазинов Украины. Ассоциация Ритейлеров Украины. 2021. URL:https://rau.ua/ru/news/spetsproekt-e-commerce-ua-2020/2/ (дата звернення 17.04.2021)

425. Директива Європейського парламенту та Ради Європейського Союзу про захист прав приватних осіб стосовно обробки персональних даних та про вільний рух таких, від 24 жовтня 1995 року No 95/46 / EC. URL: https://zakon.rada.gov.ua/laws/show/994_242 (дата звернення: 01.06.2021).

426. Кобелев О. Актуальные проблемы электронной коммерции Украины. Маркетинг. 2010. № 4. С. 3-15.

427. Зосімов В. Проблеми та перспективи розвитку електронної торгівлі в Україні. Геометричне моделювання та інформаційні технології. 2018. № 1. С. 5157. URL:http://nbuv.gov.ua/UJRN/gmtit_2018_1_10 (дата звернення 03.05.2021)

428. Синявська О. О. Електронна торгівля в Україні: тенденції та перспективи розвитку. Міжнародні відносини. Економіка. Країнознавство. Туризм: Збірник ХНУ імені В. Н. Каразіна. 2019. No 9. С. 127. URL: http://www.irbis-nbuv.gov.ua/cgi- 
bin/irbis_nbuv/cgiirbis_64.exe?I21DBN=LINK\&P21DBN=UJRN\&Z21ID=\&S21RE $\mathrm{F}=10 \& \mathrm{~S} 21 \mathrm{CNR}=20 \& \mathrm{~S} 21 \mathrm{STN}=1 \& \mathrm{~S} 21 \mathrm{FMT}=\mathrm{ASP} \_$meta\&C21COM=S\&2_S21P03= FILA=\&2_S21STR=VKhMv_2019_9_18 (дата звернення: 20.06.2020).

429. eMarketer Editors. Global Ecommerce Update. EMARKETER. 2021. URL: https://www.emarketer.com/content/worldwide-ecommerce-will-approach-5-trillionthis-year (дата звернення 17.04.2021)

430. GLOBAL ECOMMERCE SALES GROWTH (2019-2024). OBERLO. 2021. URL: https://www.oberlo.com/statistics/global-ecommerce-sales-growth (дата звернення 10.05.2021)

431. Mohsin M. 10 ecommerce trends that you need to know in 2021. OBERLO. URL: https://www.oberlo.com/blog/ecommerce-trends (дата звернення 10.09.2021)

432. Бхаттачарья Д. Восемь трендов е-соmmerce, которых стоит ожидать в 2021 год. Менеджмент Дейджест. 2020. URL: http://www.management.com.ua/tend/tend1251.html (дата звернення 10.05.2021)

433. GLOBAL ECOMMERCE SALES GROWTH (2019-2024). OBERLO. 2021 URL: https://www.oberlo.com/statistics/global-ecommerce-sales-growth (дата звернення 10.05.2021)

434. Retail e-commerce sales CAGR forecast in selected countries from 2021 to 2025. STATISTA. 2021 URL: https://www.statista.com/statistics/220177/b2c-ecommerce-sales-cagr-forecast-for-selected-countries/ (дата звернення 10.05.2021)

435. Where E-Commerce is Growing Fastest. STATISTA. 2021. URL: https://www.statista.com/chart/22729/e-commerce-sales-growth-by-region/ (дата звернення 13.05.2021)

436. Top online shopping categories. OBERLO. 2021. URL:https://www.oberlo.com/statistics/top-online-shopping-categories (дата звернення 11.05.2021)

437. E-commerce (2020 - 2027). Market analysis report. Grand wiew research. 2020. 108c. URL: https://www.grandviewresearch.com/industry-analysis/ecommerce-market (дата звернення 11.05.2021)

438. Электронная торговля в 2021 году: прогноз Digital Commerce 360. Belretail. 2021. URL: https://belretail.by/article/elektronnaya-torgovlya-v-goduprognoz-digital-commerce (дата звернення 11.05.2021)

439. Нікітенко К. С. Роль електронної торгівлі в підвищенні якості взаємодії держави, бізнесу та суспільства. Економіка та суспільство. №24. 2021. URL: https://economyandsociety.in.ua/index.php/journal/article/view/191/183 (дата звернення 12.05.2021)

440. The eCommerce market in Ukraine. EcommerceDB. 2021. URL: https://ecommercedb.com/en/markets/ua/all\#: :text=The\%20eCommerce\%20market 
\%20in \%20Ukraine,rate $\% 20$ of $\% 2026 \% 25 \% 20$ in $\% 202020$ 12.05.2021)

(дата

звернення

441. STOROZHUK A. New Face of Ukrainian E-Commerce Market: What Changes 2020 Has Caused. Interfax Ukraine: Ukraine news agency. 2020. URL:https://en.interfax.com.ua/news/blog/703877.html (дата звернення 10.05.2021)

442. Регулювання інтернет-торгівлі: міжнародний досвід. DEGA: law firm. 2020.

URL:

https://eba.com.ua/wpcontent/uploads/2020/08/Regulyrovanye_ynternet_torgovly_m ezhdunarodnyj-opyt_KG_12082020.pdf (дата звернення 11.05.2021)

443. Сак Т. В., Ховхалюк Д. О. Електронна торгівля в Україні: стан, тенденції, перспективи розвитку. Маркетинг і цифрові технології. 2020. Том 4, №3. C. 73-85. URL: https://mdt-opu.com.ua/index.php/mdt/article/view/112/105 (дата звернення 11.05.2021)

444. Рынок интернет-торговли Украины: динамика e-commerce и перспективы роста. Liga.tech. 2020. URL: https://tech.liga.net/all/novosti/rynokinternet-torgovli-ukrainy-dinamika-e-commerce-i-perspektivy-rosta (дата звернення 11.05.2021)

445. Гудзь М. В. Українські реалії та перспективи формування та функціонування біржової та електронної торгівлі. Електронне фахове видання «Ефективна економіка». 2017. http://www.economy.nayka.com.ua/?op=1\&z=6093 (дата звернення 12.05.2021)

446. Ковтун Т. Д., Матвієнко А. П. Сучасний стан і перспективи розвитку світового та вітчизняного ринків електронної комерції. БІЗНЕСІНФОРМ. № 4. 2020. C. 295-303. URL: business-inform-2020-4_0-pages-295_303.pdf (дата звернення 13.05.2021)

447. Лакіза В.В., Бала Р.Д. Особливості застосування електронної торгівлі суб'єктами господарювання в умовах міжнародної економічної діяльності. Електронне фахове видання «Ефективна економіка». 2020. № 11. URL: http://www.economy.nayka.com.ua/pdf/11_2020/55.pdf (дата звернення 01.06.2021)

448. Тітамир О. Що заважає українській електронній торгівлі стати цивілізованою Економічна правда: онлайн редакція. 2020. URL: https://www.epravda.com.ua/columns/2020/06/22/662046/ (дата звернення 13.05.2021)

449. Митний кодекс України від 11.07.2002 N92-IV (із змінами i доповненнями, внесеними Законами України від 01.08.2009). - С.20.

450. Дьомін Ю.М. Перспективи щодо розширення повноважень митних органів України // Митна справа. - 2019. - №3. - С.30-39. 
451. Velizhanskaya S.S. Ways to increase production efficiency // "Planning and Economic Department", 2019, №7. URL: https://www.profiz.ru/peo/7_2019/effektivnost_proizvodstva/

452. Pashchenko I.V. Modernization in the system of reproduction of technical means of agro-industrial complex: author's ref. dis. ... Cand. econ. Sciences, 08.00.05 / Moscow: 2006. 20 p.

453. Khlynin E. B. Determining the basic needs and reasons for updating the fixed capital of the enterprise // Finance and Credit, 35 (467), 2011. P. 38-43.

454. Demidov B.A., Velichko A.F., Voloshchuk I.V. System-conceptual foundations of activity in the military-technical field: Book. 2. Organizational and methodological foundations of activities in the military-technical field: ed. B.A. Demidova / Kyiv: Technology Park, 2006. 1152 p.

455. Kovtunenko A.P., Zubarev V.V. Fundamentals of analysis of complex technical systems. Theory and applications: Kyiv: CNDI OVT ZSU, SPD Bogdanov V.O., 2009. 496 p.

456. Romanchenko I.S., Shuienkin V.O., Khomchak R.B., Tregubenko S.S., Marko I.Yu, Zakusylo P.S., Khazanovych O.I. Development of the theory of logistics of troops : monograph / Lviv: NALF, 2019.650 p.

457. Garifullin R.F. Algorithm of technical re-equipment based on innovation planning methods. Bulletin of Economics, Law and Sociology. 2012. № 2. 22-27p.

458. Bazarova T. Y. Personnel management [Text]: a textbook for universities / ed. T.Y. Bazarova, B.L. Eremina. - M.: UNITI, 2000. - 423 p.

459. Hmil F.I. Personnel management: a textbook / F.I. Hmil. - K.: Akademvidav, 2006. $-488 \mathrm{p}$.

460. Egorshin A.P. Personnel management/ A.P. Egorshin.- 4th ed., Corrected. - N. Novgorod: 2003. - 720 p.

461. Makarova IK Personnel management: student / IK Makarova. - M.: Jurisprudence, 2002.- 304 p.

462. Lysenko Y. R. Strategic personnel management / Y. R. Lysenko, Art. N. Andriunko, T. Y. Bulikova. - View. friend, rerun. and additional - Donetsk: TOV "Yugo-Vostok, Ltd", 2005. - 201 p.

463. Gruzina I.A. Problems of personnel development in the system of strategic management of the enterprise: monograph / I.A. Gruzina, V.I. Derikhovska. - H .: Type. KhNEU them. S. Kuznets, 2014. - 252 p.

464. Yankovskaya L.A. Personnel management. Training and retraining of employees of the enterprise: textbook. manual. / L.A. Yankovskaya. - Lviv: Ed. Lviv Polytechnic National University, 2005. - 196 p. 
465. Vinogradsky M.D. Personnel management: textbook. manual./ M.D. Vinogradsky, A.M. Vinogradskaya, O.M. Shkanova. - Kind. second, rework. and add. - Kyiv: Center for Educational Literature, 2009. - 502 p.

466. Slanchenko L. I. Improvement of the personnel management system as a necessary condition for the successful functioning of an enterprise and a factor in increasing its competitiveness / L. I. Slanchenko, M. P. Gakame // Society: politics, economics, law. - 2013. - No. 2. - P. 42-45

467. Voronina A.V. Prerequisites and features of enterprise personnel development / A.V. Voronina, K.M. Nikolaeva // Electronic scientific professional publication "Eastern Europe: Economics, Business and Management".- №4 (04) .2016. - P.196-200

468. Voronina A.V. Methodology of development strategy of personnel development of production organization / A.V. Voronina, K.M. Nikolaeva// Electronic scientific professional publication "Economy and Society". - 2017. - № 8. - P. 208-214

469. Voronina A.V. Improving the quality control system of training of personnel of the production organization / A.V. Voronina, K.M. Nikolaeva // Electronic scientific professional publication "Global and national problems of the economy" - Mykolaiv: MNU. VO Sukhomlinsky.- Issue 16.- 2017. - P.294-298

470. Kaplan A.M., Haenlein M. The increasing importance of public marketing: Explanations, applications and limits of marketing within public administration. European Management Journal. 2009. № 27. P. 197-212.

471. Анхольт С. Создание бренда страны. Бренд- менеджер. 2007. №1. С. $36-44$.

472. Fan, Y. Branding The Nation: Towards A Better Understanding. Place Branding and Public Diplomacy. 2010. Vol. 6, 2. P. 97-103.

473. Нагорняк Т.Л. Бренди країн світу. Імідж українських регіонів у контексті розбудови бренда "Україна". URL: http://www./ social-science.com.ua.

474. Мазараки А., Пятницкая Г., Григоренко О. Идентификация контента национального брендинга. Вісник КНТЕУ. 2019. № 2. С. 5-33.

475. Olins W. Branding the nation - the historical context. Journal of Brand Management. 2002. Vol. 9. Is. 4. P. 241-248.

476. Brand Finance 2016. URL: http://brandfinance.com/knowledgecentre/reports/brand-finance-nation-brands-2016

477. Вартість національного бренду України збільшилась на $39 \%$. Економічна правда 10.12.2016. URL: https://www.epravda.com.ua/news/2016/12/10/614032/

478. Родченко С.С., Живко З.Б. Фінансове шахрайство у фінансовій сфері: сутність, види та сучасний стан. Науковий вісник Ужгородського національного 
університету. №31, 2020. 103-107. DOI: https://doi.org/10.32782/2413-9971/2020$31-16$

479. Кримінальний кодекс України. поточна редакція від 30.12.2020, підстава - 1074-IX Відомості Верховної Ради України (ВВР), 2001, № 25-26, ст.131 URL: https://zakon.rada.gov.ua/laws/show/2341-14\#Text

480. Кришевич О.В. Способи шахрайств в банківській сфері: кримінальноправовий аспект. Юридичний вісник. № 2 (23), 2012. - С.112-116

481. Глобальне дослідження 3 питань шахрайства у банківській сфері. Багатостороння загроза шахрайства: чи готові банки гідно протистояти виклику? KPMG International 2019. 24 c. https:/assets.kpmg/content/dam/kpmg/ua/pdf/2020/01/Global-Banking-FraudSurvey.pdf (дата звернення: 21.07.2020)

482. Fraud Digest. Украинская межбанковская ассоциация членов платежных систем EMA. 2018. URL: https://ema.com.ua/fraud-digest-. (дата звернення 21.07.2020)

483. Офіційний сайт Генеральної прокуратури України. URL: https://old.gp.gov.ua/ua/stst2011.html?dir_id=112661\&libid=100820(дата звернення 14.03.2021)

484. Кривошапова С. В., Литвин Е. А. Оценка и способы борьбы с мошенничеством с банковскими картами. Международный журнал прикладных и фундаментальных исследований. 2015. № 4. С. 116-120.

485. Сайт Української міжбанківської Асоціації членів платіжних систем. URL: https://www.ema.com.ua/citizens/cyber-safety-school/top-5-shahrajskih-shem2019/

486. У 2018 році частка шахрайських операцій із платіжними картками в Україні зросла - НБУ. URL: https://gordonua.com/ukr/news/money/u-2018-rotsichastka-shahrajskih-operatsij-z-platizhnimi-kartkami-v-ukrajini-zrosla-nbu819441.html

487. Resolution of the Cabinet of Ministers of Ukraine "Methodology of normative monetary valuation of non-agricultural lands (except for settlements)" №1278 (2011). Available at: http:// rada.gov.ua.

488. Resolution of the Cabinet of Ministers of Ukraine "Procedure for normative monetary valuation of non-agricultural lands (except for settlements)" №508 (2013). Available at: http:// rada.gov.ua.

489. Land Code of Ukraine: Adopted 25.10.2001 № 2768-III // Bulletin of the Verkhovna Rada of Ukraine. - 2002. - № 3-4. - Art. 27.

490. The structure of the land fund of Ukraine and the dynamics of its changes. Available at: https://land.gov.ua/info/struktura. 
491. Андрианова В. Особенности управления процессом воспроизвод-ства человеческого капитала. Экономика и управление. 1999. №2. С. 12-13.

492. Антюшина Н.M. Социальные государства Европы и пути их развития / Антюшина Н.М // Труд за рубежом. 2005. №1. С. 22-40.

493. Берданова О. Розвиток соціальної інфраструктури регіону (опорний конспект дистанційного курсу навчальної дисципліни) : навч. посібник / О.В. Берданова, М. К. Орлатий, Н. А. Сич. К.: Центр навчальної літератури, 2005.

494. Болюбах В. Соціальний захист працівників на підприємствах. Актуальні проблеми екноміки. 2006. №3. С. 154-157.

495. Бюджетний моніторинг (період 1996-2016 pp.) : сайт. URL: https://www.ibser.org.ua/publications/monitoringcategories/richnyу (дата звернення: 20.05.2021);

496. Валлерстайн И. Анализ мировых систем: современное видение мирового государства благосостояния и его социально-экономические основы. СПб.: Экономика, 1998.

497. Введення в соціальну роботу : навч. посібник / Т.В. Семигіна, I.M. Грига, О.С. Шевчук. К.: Фенікс, 2001. С. 188-193.

498. Гриценко Е.В. Немецкие концепции о соотношении местного самоуправления и государства: история и современность / Гриценко Е.В. Журнал российского права. 2001. № 6. С. 137-144.

499. Державна служба статистики України. URL : http://www.ukrstat.gov.ua/(дата звернення: 10.05.2021).

500. Державна служба статистики України.. URL : http://www.ukrstat.gov.ua/(дата звернення: 15.05.2021).

501. Державна служба статистики. Головне управління статистики в Житомирській області. Статистичний щорічник Житомирської області за 2019 р. / за редакцією Г. Пашинської. Житомир: 2020. 455 с.

502. Державне регулювання економіки : навч. посібник / за ред. C.I. Архієреєва, Н.Б. Решетняк. Харків: НТУ «ХПІ», 2004. С. 67-69.

503. Державні соціальні гарантії. URL: https: //www.msp.gov.ua/content/socialni-standarti.html (дата звернення 19.05.2021р.).

504. Динаміка цін на природний газ для споживачів України. URL : http:// www.naftogaz.com/files/Dostup/Dynamika (дата звернення: 15.05.2021).

505. Дядкова Н. Про заходи щодо підвищення результативності роботи міністерства праці та соціальної політики. Україна: аспекти праці. 2005. №2. С. 79-82. 
506.

Свростат.

URL

:https

epp.eurostat.ec.europa.eu/portal/page/portal/publications/recently_published (дата звернення: 10.05.2021).

507. Свростат URL : https://ec.europa.eu/eurostat (дата звернення: 15.05.2021).

508. Законодавство у сфері соціального захисту. Уповноважений Верховної Ради України 3 прав людини URL: https://zakon.rada.gov.ua/laws/show/776/97-\%D0\%B2\%D1\%80\#Text (дата звернення : 16.05.2021 р.).

509. Іванова О. Соціальна політика: теоретичні аспекти / О.Л. Іванова. К.: Академія, 2003. С. 56-63.

510. Кодекс законів про працю України (Затверджується Законом № 322VIII від 10.12.71 ВBР, 1971, додаток до № 50, ст. 375). URL: https://zakon.rada.gov.ua/laws/show/322-08\#Text. (дата звернення : 11.05 .2021 p.).

511. Колишкін О. Теорія і практика соціального управління / O.M. Колишкін. Х.: Живе слово, 2004. С. 202-206.

512. Колот А. М. Дослідження проблем оплати праці: порівняльний аналіз. Україна та країни ЄC : монографія / [кол. авт., за заг. ред. А. М. Ко-лота, Г. Т. Кулікова]. Київ : КНЕУ, 2008. 274 с.

513. Конституція України [Електронний ресурс] // Відомості Верховної Ради України (ВВР). - 1996. - № 30. - с. 141. - Режим доступу: http://zakon5.rada.gov.ua/laws/show/254\%D0\%BA/96-\%D0\%B2\%D1\%80 (дата звернення : 25.05.2021р.).

514. Максимчук $€$. Особливості реалізації соціальних гарантій в Україні // Наукові праці НДФІ. 2008. Вип. 3(44). С. 53-62.

515. Мельник А. Державне регулювання економіки / А.Ф. Мельник. $\quad$ К.: Знання, 1999. С. 35-38.

516. Минимальные зарплаты по странам мира. URL : http://web.archive.org/ web/20140819082548/https://hmbee.ru/info/zarplaty (дата обращения: 10.05.2021).

517. Михальченко М. Україна як нова історична реальність: запасний гравець Свропи / М.І. Михальченко. Дрогобич: ВФ “Відродження”, 2000. С. 8-9.

518. Міністерства фінансів України (період 2017-2019 pp.) : сайт. URL: https://mof.gov.ua/uk/statistichnij-zbirnik (дата звернення: 20.05.2021).

519. Міністерство соціальної політики України. Головні новини. URL : https://www.msp.gov.ua (дата звернення: 05.05.2021).

520. Наливайко А. Теорія стратегії підприємства. Сучасний стан та напрямки розвитку: Монографія / А.П. Наливайко. К.: КНЕУ. 2001. С. 18-20. 
521. Новини та аналітика про Германію, Росію, Європу, світ. URL: https://www.dw.com/uk/\%D1\%83\%D0\%BA\%D1\%80\%D0\%B0\%D1\%97\%D0\%BD $\% \mathrm{D} 0 \% \mathrm{~B} 0-\% \mathrm{D} 0 \% \mathrm{BD} \% \mathrm{D} 0 \% \mathrm{~B} 0-$

88-\%D0\%BC\%D1\%83-\%D0\%BC\%D1\%96\%D1\%81\%D1\%86\%D1\%96-\%D0\%B2$\% \mathrm{D} 0 \% \mathrm{~B} 3 \% \mathrm{D} 0 \% \mathrm{BB} \% \mathrm{D} 0 \% \mathrm{BE} \% \mathrm{D} 0 \% \mathrm{~B} 1 \% \mathrm{D} 0 \% \mathrm{~B} 0 \% \mathrm{D} 0 \% \mathrm{BB} \% \mathrm{D} 1 \% 8 \mathrm{C} \% \mathrm{D} 0 \% \mathrm{BD} \%$ D0\%BE\%D0\%BC\%D1\%83-\%D1\%80\%D0\%B5\%D0\%B9\%D1\%82\%D0\%B8\%D0 \%BD\%D0\%B3\%D1\%83-\%D1\%8F\%D0\%BA\%D0\%BE\%D1\%81\%D1\%82\%D1\%9 6-\%D0\%B6\%D0\%B8\%D1\%82\%D1\%82\%D1\%8F/a-45497261

522. Новіков В. Потенціал стабільної соціальної політики / В. Новіков. Україна: аспекти праці. 2005. № 1. С. 17.

523. Про внесення змін у додаток до Постанови Кабінету Міністрів України від 25 грудня 1996 р. № 1548 та визнання такими, що втратили чинність деяких постанов Кабінету Міністрів України : Постанова Кабінету Міністрів України № 394 від 07.06.2017 p. URL : https://zakon.rada.gov.ua/laws/show/3942017-\%D0\%BF (дата звернення: 15.05.2021).

524. Про державні соціальні стандарти та державні соціальні гарантії : Закон України (Відомості Верховної Ради України (ВВР), 2000, № 48, ст.409). URL: https://zakon.rada.gov.ua/laws/show/2017-14\#Text (дата звернення : 16.05.2021 p.)

525. Про затвердження наборів продукті в харчува ння, наборі в непродовольчих товарів та наборів послуг для основних соціальних i демографічних груп населення : Постанова Кабінету Міністрів України № 780 від 11.10.2010 p. URL : https://zakon.rada.gov.ua/ laws/show/780-2016-\%D0\%BF (дата звернення: 16.05.2021).

526. Про колективні договори і угоди : Закон України (Відомості Верховної Ради України (ВBP), 1993, № 36, ст.361). URL: zakon.rada.gov.ua/cgibin/laws/main.cgi?nreg=3356-12 (дата звернення : 15.05.2021р.).

527. Про підвищення соціальних гарантій для трудящих : Закон УКРАЇНСЬКОЇ РАДЯНСЬКОЇ СОЦІАЛІСТИЧНОЇ РЕСПУБЛІКИ (Відомості Верховної Ради України (ВВР), 1991, $\mathrm{N}$ 42, ст.549). URL: https://zakon.rada.gov.ua/laws/show/1280-12\#Text (дата звернення : 26.05.2021 p.)

528. Про проект Концепції соціального забезпечення населення України : постанова Верховної Ради України (Відомості Верховної Ради України (ВВР), 1994, N 6, ст. 31). URL: https://zakon.rada.gov.ua/laws/show/3758-12\#Text. (Дата звернення : 20.04.2021 р.).

529. Про професійні спілки, їх права та гарантії діяльності : Закон України (Відомості Верховної Ради України (ВВР), 1999, № 45, ст.397). URL: https://zakon.rada.gov.ua/laws/show/1045-14\#Text (дата звернення : 20.05.2021 p.)

530. Про реалізацію пілотного проекту щодо тимчасового обмеження застосування постанови Кабінету Міністрів України від 25 грудня 1996 р. № 1548 
та постанови Кабінету Міністрів України від 17 жовтня 2007 р. № 1222 : Постанова Кабінету Міністрів України № 656 від 22.09.2016 р. // Урядовий кур’єр. 2016. № 183. 29 верес.

531. Ромашов О. Социология труда : учеб. пособ. / О.В. Ромашов. М.: 2001. C.123-129.

532. Савчук, Л. XVI Всесвітній конгрес з питань безпеки та гігієни праці / Л.В. Савчук. Інформаційний бюлетень з охорони праці. 2002. №4. С. 27-28.

533. Семигіна Т. Порівняльна соціальна політика : навч. посіб. / Т.В. Семигіна. К.: МАУП, 2005. С. 67-71.

534. Семигіна Т. Словник із соціальної політики / Т.В. Семигіна. К.: Видавництво Києво-Могилянської академії, 2005. С. 114-115.

535. Семигіна Т. Соціальна політика у глобальному вимірі / Т.В. Семигі-на. К.: Пульсари, 2004. С. 93-96.

536. Сергієнко О. Соціальна політика в сучасному світі та в Україні / О. Сергієнко. Україна: Аспекти праці. 2002. №1. С. 31-37.

537. Ситник Г. Державне управління національною безпекою України: монографія / Г. Ситник. К.: Вид-во НАДУ, 2004. 408 с.

538. Скуратівський В. Соціальна політик: Навч. посібник для слухачів, аспірантів, докторантів спеціальності «Державне управління» / А.В. Скуратівський, О.М. Палій, Е.М. Лібанова. К.: УАДУ, 1997. С. 5-34.

539. Смирнов С. Региональные аспекты социальной политики / С.Н.Смирнов. М.: Гелиос, 1999. С. 65-66.

540. Снігова О.Ю. Механізми державного та регіонального управління соціальною безпекою: дис. на здобуття наук. ступеня канд. екон. наук: 08.02 .03 / О.П. Снігова. Донецьк, 2006. 272 с.

541. Соловьев А. К. Коэффициент замещения трудовой пенсии: конфликт макроэкономических и социальных целей. URL : https://cyberleninka.ru/article/n/ koeffitsient-zamescheniya-trudovoy-pensii-konflikt-makroekonomicheskih-isotsialnyhtseley (дата обращения: 15.05.2021).

542. Социальная корпоративная политика: проблемы, опыт, перспективы : Учебное пособие / Под общ. ред. Н.А. Волгина, В.К. Егорова. М.: Издательскоторговая корпорация «Дашков и Ко», 2004. С. 14-18.

543. Социальная политика, уровень и качество жизни: Словарь. М.: ВЦУЖ, 2001. C. $288-289$.

544. Социальная політика : Учебник / Под общ. ред. Н. А. Волгина. М.: Изд-во «Экзамен», 2002. С. 21-22. 
545. Соціальна відповідальність бізнесу як складова соціальної політики України. Економіка \& держава. 2007. №5. С. 71-73.

546. Соціальний захист населення України : стат. збірник / Відп. за вип. I. В. Сеник. Київ :Державна служба статистики України, 2019. 124 с.

547. Соціальний захист як ознака цивілізаційного суспільства. Віче. 2007. №5. C. 56-59.

548. Спікер П. Соціальна політика: теорії та підходи / П. Спікер. К.: Фенікс, 2000. C. $17-34$.

549. Стратегія економічного і соціального розвитку України (2004-2015 роки) “Шляхом Європейської інтеграції” / Авт. кол.: А.С. Гальчинський, В.М. Геєць та ін.; Нац. ін-т стратег. дослідж., Ін-т екон. прогнозування НАН України, М-во економіки та 3 питань європ. інтегр. України. К.: ІВЦ Держкомстату України, 2004. С. 216-217.

550. Стратегія Міжнародної організації праці. Соціальне забезпечення для всіх: побудова мінімальних рівнів соціального захисту та встановлених систем соціального забнзпечення: узагальнений виклад / Міжнародна організація праці ; Бюро МОП для країн Центральної та Східної Свропи. Будапешт : МОП, 2013. 78 c.

551. Теренс М. Соціальна політика та соціальне забезпечення за ринкової економіки: Пер. $з$ англ. О. Перепадя / М. Г. Теренс. К.: Основи, 1996. С. 10-18.

552. Территориальные проблемы социальной политики / Под ред. Э.Б. Гилинской, С. Н. Смирнова. М., 2000. С. 131.

553. Торлопов В. Основные модели социального государства / Торло-пов В. Человек и труд. 1998. №6. С. 4-8.

554. Україна посіла 35 місце за Індексом соціально-економічної захищеності. Соціальний захист. 2005. №4. С. 14-25.

555. Фирсов М. Теория социальной работы : Учеб. пособие для студ. высш. учеб. заведений / М.В. Фирсов, Е.Г. Студенова. М.: Гуманит. изд. центр ВЛАДОС, 2001. С. 136-137.

556. Холостова Е. Социальная політика : Учеб. пособие / Е.И. Холостова. М.: ИНФРА-М, 2001. С. 12-22, 42.

557. Четверикова Л. Суть соціальної політики та аналіз ії моделей / Л. Четверикова. Соціогуманітарні проблеми людини. 2005. №1. С. 67-75.

558. Шаронов А. Формирование системы государственных минимальных социальных стандартов / А. Шаронов, И. Ильин. Экономист. 1999. № 1. С. 48-56.

559. Шевчук П. Соціальна політика / П.І. Шевчук. Львів: Світ, 2005. С. 1013. 
560. Щодо необхідності внесення змін до Типового положення про управління праці та соціального захисту населення. Соціальний захист. 2005. №3. C. 33-35.

561. Щокін Г. Закони соціального розвитку і управління / Г.В. Щокін. К.: МАУП, 2006. С. 80-82, 89-90.

562. Ягідка І. Соціальна інфраструктура і політика: Навч. посіб. / I.C. Ягідка. К., 2000. С. 56-57.

563. Якість життя оцінка експертів. URL: https://ukurier.gov.ua/uk/articles/yakist-zhittya-v-ukrayini-ocinki-ekspertiv/ (дата звернення 10.05.2021р.).

564. file:///C:/Users/DELL/Downloads/\%D0\%AF\%D0\%BA\%D1\%96\%D1\% $81 \% \mathrm{D} 1 \% 82 \% \mathrm{D} 1 \% 8 \mathrm{C} \% 20 \% \mathrm{D} 0 \% \mathrm{~B} 6 \% \mathrm{D} 0 \% \mathrm{~B} 8 \% \mathrm{D} 1 \% 82 \% \mathrm{D} 1 \% 82 \% \mathrm{D} 1 \% 8 \mathrm{~F} \% 20 \% \mathrm{D}$ 0\%B2\%20\%D0\%A3\%D0\%BA\%D1\%80\%D0\%B0\%D1\%97\%D0\%BD\%D1\%96.pdf

565. General government expenditure by function.Eurostat : website. URL: $\mathrm{http}: / /$ ec.europa.eu/eurostat/data/database (дата звернення 19.05.2021р.).

566. Julian Tupay. Germany's New Security Strategy / Режим доступа: http://blog.ic(ds.ee/article/89/germanys(new(security(strategy

567. National Security Council. The National Security Strategy of the United States of America. Washington, DC: US Government Printing Office, 2002.

568. Social Progress Imperative. URL: https://ua.interfax.com.ua/news/general/728532.html (дата звернення 12.05.2021p.)

569. The French White Paper on defence and national security URL: http:/ /www.globalsecurity.org/military/library/report/ 2008/livre(blanc_france_2008.pdf (дата звернення 19.05.2021р.).

570. The National Security Strategy of the United Kingdom. A Strong Britain in an Age of Uncertainty. London, October 2010. P. 27.

571. Annual report on european SMEs 2012/2013. URL:http://ec.europa.eu/enterprise/policies/sme/factsfiguresanalysis/performance review/files/supporting-documents/2013/annual-report-smes-2013_en.pdf.

572. Что сдерживает развитие малого бизнеса в Украине? // Финансовый пульс. URL: http://finpuls.com/ru/industry/business/news/CHto-sderzhivaet-razvitiemalogo-biznesa-v-Ukraine-.htm

573. Варналій 3.С. Основи підприємницької діяльності. URL: http://westudents.com.ua/glavy/23325-3-osoblivost-rozvitku-malogo-pdprimnitstvav-ukran-za-kordonom.html.

574. Максимов В. И. Аналитические основы применения когнитивного подхода при решении слабоструктурированных задач. Труды Ин-та пробл. упр. им. В. А. Трапезникова РАН. 1999. Т. 2. С. 95-109. 
575. Байдаков А. Н., Назаренко А. В, Запорожец Д. В. Прогнозные сценарии как необходимый компонент системы риск-менеджмента. Вестник АПК Ставрополья. 2011. №3(3). С. 55-58.

576. Индекс экономической политики в сфере МСП : станы восточного партнерства (2016) - оценка соответствия принципам европейского акта о малом бизнесе. URL: http://www.oecd.org/globalrelations/SME_Policy_Index_Eastern_Partners_2016_Russian.pdf

577. Стоянова М.М., Журавльова Т. О., Добровольський О. І. Адаптація закордонного досвіду стимулювання розвитку малого та середнього підприємництва. Економічні інновації. 2014. Вип. 57. С. 394-399.

578. Мортаза А.Я. Механизмы фінансового стимулирования и кредитной поддержки малого предпринимательства в мировой экономике. МИР (Модернизация. Инновации. Развитие). 2017. Т.8. №1. С. 51-59.

579. Макогон Ю. В. Малыйбизнес в Украине в условиях глобализации мировой экономики. Економічний вісник Національного технічного університету України "Київський політехнічний інститут". 2013. № 10. С. 94-

580. URL: http://nbuv.gov.ua/UJRN/evntukpi_2013_10_17

581. Голентовська О.С. Огляд зарубіжних та вітчизняних підходів до проблеми командотворення / О.С. Голентовська // Наука і освіта: науковопрактичний журнал Південноукраїнського національного педагогічного університету ім. К.Д. Ушинського. - 2014. - № 5. - С. 24-30.

582. Калинець К. С. Сутність та особливості формування управлінської команди[Електронний pecypc]. Pecypc доступу: https://essuir.sumdu.edu.ua/bitstreamdownload/123456789/42707/1/Kalynets_management_team.pdf

583. Там же.

584. Марина Єщенко, Ангеліна Гречко ISSN 2409-8892. Galician economik journal, No 2 (63) 2020 https://doi.org/10.33108/galicianvisnyk_tntu2020.02

585. Довгань Л.Є., Ведута Л.Л., Мохонько Г.А. Технології управління людськими ресурсами : навч. посібник для здобув. Ступеня маг-ра за ОП «Менеджмент і бізнес-адміністрування» / КПІ

586. Ложкин Г. В., Повякель Н. И. Практическая психология конфликта 2-е издание, стереотипное. - МАУП: Киев, 2002. - 196 с.

587. Шпортько, Г., Карабаш, А. (2021). Дослідження формування ефективної управлінської команди. Економіка та суспільство, (25). [Електронний pecypc]. - Ресурс доступу: https://doi.org/10.32782/2524-0072/2021-25-19. 
588. Нікіфорова Л. О., Білоконь Я. В. Тімбілдинг як основа ефективного розвитку колективу [Електронний ресурс]. - Ресурс доступу: http://ir.lib.vntu.edu.ua/handle/123456789/11942

589. Технології роботи організаційних психологів: [навч. посіб. для студентів вищ. навч. закл. та слухачів ін-тів післядиплом. освіти] / за наук. ред. Л. М. Карамушки. - К.: ІНКОС, 2005. - 366 с.

590. Тімбілдинг як інноваційний метод в управлінській діяльності керівника ДНЗ [Електронний ресурс]. - Ресурс доступу: http://eprints.zu.edu.ua/24714/1

591. Тімбілдінг: як створити команду мpіï. URL: https://www.vinnitsa.info/news/timbildinh-yak-stvoryty-komandu-mriyi.html.

592. Аніщенко А.П., Зайцева М.Н. Тимбілдинг як одна 3 перспективних моделей корпоративного менеджменту в туризмі // Культурологія та соціальні комунікації: інноваційні стратегії розвитку: матеріали Міжнар. наук. конф. (м. Харків, 21-22 листопада 2019 р.). Харків: Харк. держ. акад. культури, 2019.C.104-106.

593. Нікіфорова Л. О., Білоконь Я. В. Тімбілдинг як основа ефективного розвитку колективу [Електронний ресурс]. - Ресурс доступу: http://ir.lib.vntu.edu.ua/handle/123456789/11942. 